Caio Luis Mattei Faggin

\title{
Vilanova Artigas, a casa, modelo de urbanidade
}



Caio Luis Mattei Faggin

\section{Vilanova Artigas, a casa, modelo de urbanidade}

Dissertação apresentada ao Programa de Pós-Graduação em Arquitetura e Urbanismo, Faculdade de Arquitetura e Urbanismo da Universidade de São Paulo, como requisito parcial para a obtenção de grau de Mestre.

Orientadora:

Profa. Dra. Helena Aparecida Ayoub Silva 
Autorizo a reprodução e divulgação total ou parcial deste trabalho, por qualquer meio convencional ou eletrônico, para fins de estudo e pesquisa, desde que citada a fonte.

E-mail do autor: caiofaggin@gmail.com

\begin{tabular}{|l|}
\hline F154V \\
Fagin, Caio Luis Mattei \\
Vilanova Artigas, a casa. Modelo de urbanidade / Caio Luis \\
Mattei Faggin. -São Paulo, 2015. \\
230 p. : il. \\
Dissertação (Mestrado - Área de Concentração: Projeto de \\
Arquitetura) - FAUUSP. \\
Orientadora: Helena Aparecida Ayoub Silva \\
1.Casas 2.Edifícios públicos 3.Pátio 4.Arquitetura(Tipologia) \\
5.Artigas, João Batista Vilanova, 1915-1985 I.Título \\
CDU 728.1
\end{tabular}




\section{AGRADECIMENTOS}

Esse trabalho sempre transitou, como eu também, e para onde levei suas ideias, encontrei acolhimento e entusiasmo. Agradeço a todos que me incentivaram e apoiaram na materialização dessa dissertação, em especial à:

Marlene Yurgel pela receptividade e incentivo primordiais na retomada.

Helena Ayoub pelo acolhimento e confiança.

Antonio Armesto pelo apoio na fundamentação da ideia.

Antiono Barossi e Artur Rozestraten pelo rico debate na qualificação.

Betta Romano e Carlos Faggin, meus pais e colegas, pelo amor pleno e permanente incentivo.

Cada uma das minhas irmãs: Dora, Joana e Marina Faggin, por tantos e tão variados motivos.

Suely Ceravolo, Rogério Calia e novamente aos meus pais, por me mostrarem a riqueza do caminho do ensino, andando por ele.

Cynthia pelo apoio incondicional, incentivo, paciência e pelas conversas-chave sobre arquitetura.

Janaina e Maria pelo carinho e pelas gostosas visitas.

Teo Pastor pela precisa tradução.

Alice Castro pelo pique e dedicação com o design.
Ao Marcos Acayaba, ao Júlio Katinsky, Silvio Macedo e Luiz Munari por celebrarmos nossa amizade também nas disciplinas da FAU velha.

Aos professores e alunos do Ateliê Vertical, da FAU nova.

Aos professores e colegas do Grupo de pesquisa em projeto e do Metrópole Fluvial por me mostrarem que é possível fazer pesquisa em projeto e também desenhar na pós.

Aos meus professores e colegas da EtsaB pela abertura de horizontes.

À Catherine Otondo, César Shundi, Moracy Amaral, José Paulo Gouvêa, José Guilherme P. Leite e tantos outros colegas pela amizade e por irem abrindo o caminho da nossa geração na academia.

Às colegas Denise Invamoto, Giovana Avancini e Paula Dedecca pelo entusiasmo ao trazermos um pouquinho da história da nossa arquitetura pra hoje, projetando ou escrevendo.

Aos meus atuais e ex-colegas de escritório e a todas as equipes que formamos, por me ensinarem a produzir, produzindo junto.

Agradeço muito à Ana Paula Vaz, Ainá Calia, Teté Masetti, Ana Paula Carvalho e Sandra Firmino, pelo apoio, compreensão e por estarem sempre por perto.

Em especial agradeço à Conceição, minha avó, por me mostrar a riqueza do mundo das letras, lendo sempre e à Alessandra e ao Salvatore, meus avós, por viverem intensamente o amor à arte, à ciência e à arquitetura. 


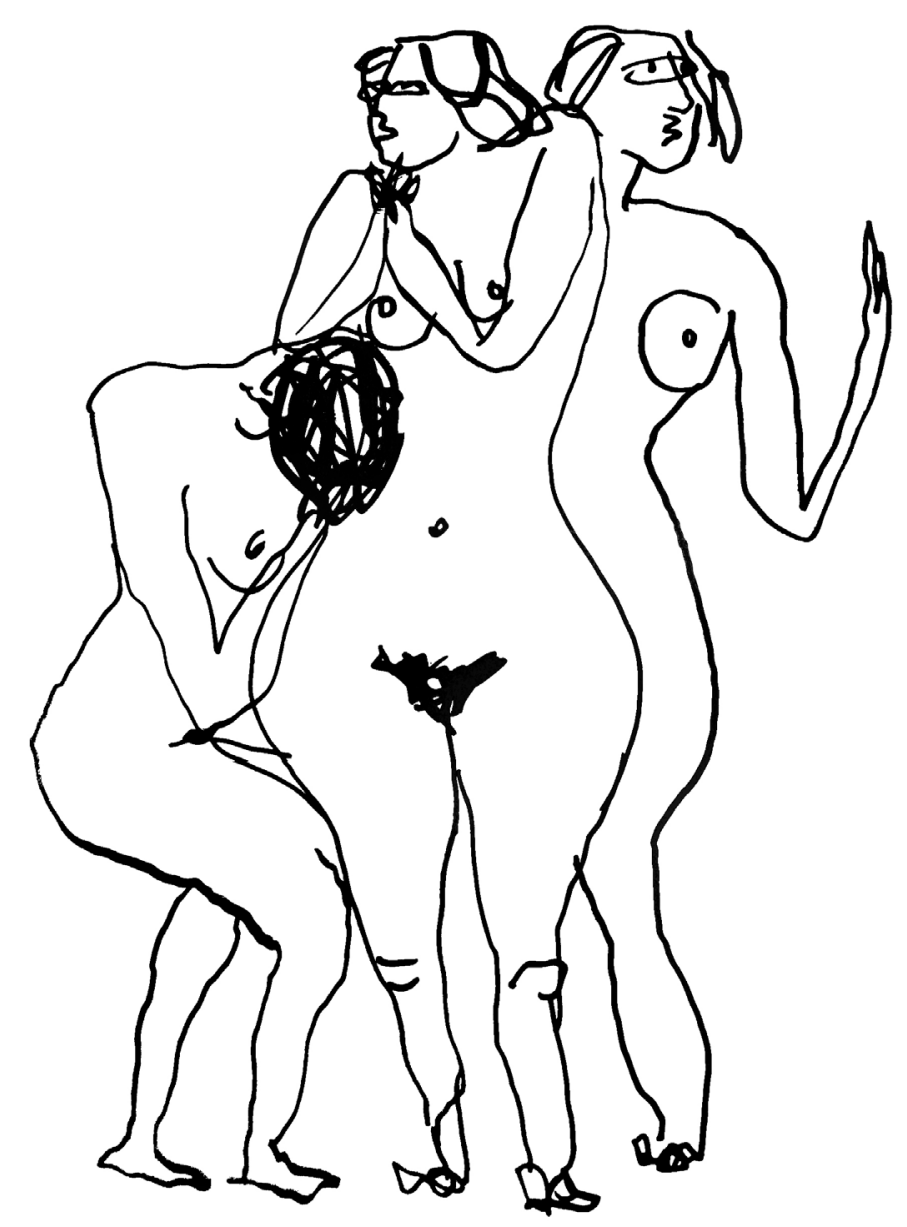


Para falar de arquitetura,

Seria a arquitetura uma terceira pessoa? Outra? Além das duas, teoria e prática?

Ou seria esta, dita terceira, uma reunião que faria das duas uma mesma?

À união carnal entre teoria e prática daríamos um nome novo abrangente e significativo: Arquitetura.

Onde houver arquitetura, haverá pela presença unida entre teoria e prática. Não seriam exatamente três, mas duas, sendo uma, esta sim; outra.

\section{Artur Rozestraten}

Texto manuscrito pelo Professor Doutor em fevereiro de 2014, na folha de rosto do exemplar do Memorial de Qualificação devolvido ao mestrando durante a banca de qualificação, ao ver a imagem ao lado sobre o seguinte texto: "Elas três, a teoria, a prática e a arquitetura, nessa interdependência, entrelaçadas" que abriam o Memorial. 


\section{ABSTRACT}

João Batista Vilanova Artigas (1915-1985) graduated as an architect-engineer in 1937, designing until the 1960 mostly single-family houses in the city of São Paulo. Only thereafter did he have the opportunity to design and construct public buildings, such as clubs, hospitals, universities, stations, etc. Single-family houses, with one or two floors, located in the cite jardin areas of São Paulo, lie on limited lands and are strongly restricted by urbanistic regulation. Artigas turned his starting point as a house architect into a virtue and converted the act of designing habitats into an experimental laboratory. Consequently he ended up mixing a wide range of spatial, constructive and distribution solutions, making his residences emblematic works of art and constituents of a clear speech on the relationship between house and city. The main objective of this dissertation is the consolidation of the house paradigm and formation of types that would soon be applied on projects of collective dimensions and public buildings, works which would dominate the mature architect's agenda until the end of his productions. It is also the opportunity to reflect about the house, the public building and its relations with cities and the urbanity that arises. This dissertation also proposes understanding the change of scale and conservation of meanings and values as an amalgam that gives unity to Artigas production.

Key Words: Architecture; Houses; Type; Public building; João Batista Vilanova Artigas. 


\section{RESUMO}

João Batista Vilanova Artigas (1915-1985) formou-se engenheiroarquiteto em 1937, até a década de 1960 projetou principalmente residências unifamiliares, quase sempre na cidade de São Paulo.

Somente a partir de então teria a oportunidade de projetar e construir também edifícios de uso coletivo ou público como clubes, hospitais, universidades, estações, etc. As casas unifamiliares, de um ou dois pavimentos, localizadas na cidade de São Paulo, nos bairros jardim, se situam em terrenos de dimensões reduzidas e estão fortemente condicionadas pelas normas urbanísticas. Artigas fez de sua condição inicial de arquiteto de casas uma virtude e converteu o ato de projetar o habitat em um laboratório de experimentações. Acabou assim destilando um amplo repertório de soluções espaciais, construtivas e de distribuição, tornando suas residências obras emblemáticas e constituintes de um evidente discurso sobre a relação entre a casa e a cidade. Têm especial interesse, como argumento principal da dissertação, a consolidação dos paradigmas da casa e formação dos tipos, que logo seriam aplicados na produção dos projetos de dimensão coletiva e edifícios públicos, obras que passaram a dominar a pauta do arquiteto da maturidade até o final de sua produção. É também a oportunidade de refletir sobre a casa, o edifício público e suas relações com a cidade e a urbanidade que aí surge. Propõe-se o entendimento desse processo de mudança de escala e permanência de significados e valores, como um amálgama que dá unidade à obra de Artigas.

Palavras Chave: Arquitetura; Casas; Tipo; Edifício Público; João Batista Vilanova Artigas. 



\section{SUMÁRIO}

Introdução

\section{Parte I}

1. Considerações teóricas

1.1. A análise como ferramenta de projeto

1.2. Terminologia

1.3. Ferramentas de análise

2. Modelo e laboratório

2.1. A casa como modelo

2.2. A mudança de escala

\section{Parte II}

3. Relações analógicas

3.1. Desenho

3.2. Tabelas analógicas

4. Elementos da arquitetura.

4.1. Terrapleno

4.2. Ponto de apoio

4.3. Teto

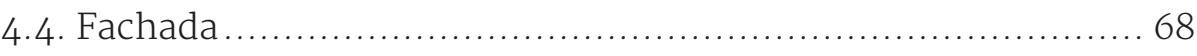

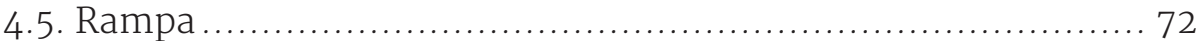

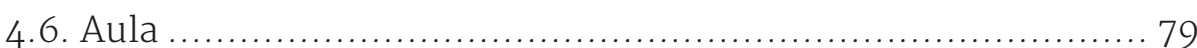

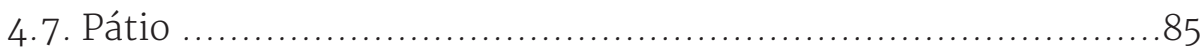

4.7.1. Pátio externo - delimitador .................................. 90

4.7.2. Pátio tangencial e semipátio ............................... 92

4.7.3. Pátio linear - a rua ............................................. 96

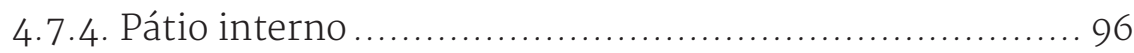

4.7.5. Redução do pátior ….................................... 98

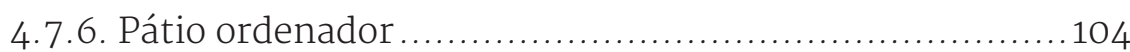

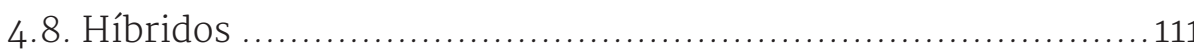

5. Desenhos analíticos........................................... 117

6. Considerações finais ................................................. 135

7. Fichas das obras .................................................139

8. Tabela analítica e de tipos ............................................221

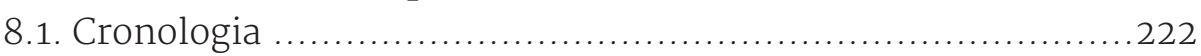

9. Referências bibliográficas ....................................... 224

10. Índice de imagens................................................. 228 
2. Afirmação controversa caso seja entendida como uma questão de causa e efeito, cronológica, mas ao projetar o arquiteto vai destilando um rol de soluções que passam a consolidar, com a sucessão de projetos, seu vocabulário típico.

\section{INTRODUÇÃO}

Essa dissertação de mestrado assume a forma de um percurso analítico que se vale da expressão escrita, de esquemas e desenhos para refletir sobre arquitetura. Como um caderno de notas e croquis que passa a ser compartilhado aqui, pretende conduzir o leitor por um universo de reflexões que se desdobram na identificação de valores da arquitetura delimitados por um processo de análise de projetos concretos e poder explicitar as questões com as quais o arquiteto lida ao projetar e ao concretizar os paradigmas nos objetos arquitetônicos.

O recorte proposto para início do exercício de análise é formado por um conjunto de dez casas projetadas por João Batista Vilanova Artigas $^{1}$, residências unifamiliares na cidade de São Paulo. As onze obras selecionadas foram construídas entre 1942 e 1968, compartilham do mesmo contexto urbano; são residências tipicamente paulistanas em bairros de baixa densidade com características de cidade jardim, ocupam lotes relativamente exíguos e, por isso, tem em comum a marca das condicionantes impostas por tal entorno físico e leis urbanísticas específicas.

Dentro deste elenco de objetos culturais e de suas arquiteturas, transcorro pela decodificação das obras, a partir de sua tipificação procurando estabelecer a conexão desse universo - da arquitetura das casas projetadas por Vilanova Artigas - com a disciplina da arquitetura em si e entender a validade dos tipos e elementos (físicos e espaciais) nos edifícios de maior escala, sendo essa a principal hipótese levantada.

Acredito que a oportunidade de projetar casas tenha sido enfrentada por Artigas como laboratório, onde elaborou modelos para a arquitetura de maior escala e de uso público, tendo nas casas um amplo campo de provas $^{2}$.

A casa urbana paulistana, em sua obra, se torna introspectiva e forma seu próprio microcosmo, mas antes constrói uma sequência clara de espaços, um promenade, que suaviza a transição e estabelece o diálogo com o urbano. Nesse particular a relação casa-cidade se desenvolve nas residências como um ensaio para os projetos de maior escala, processo em que se reconhece os principais paradigmas da casa trabalhados por Artigas e logo reeditados no edifício público.

Paulo Mendes da Rocha comenta sobre a experimentação na obra de Vilanova Artigas: 
3. ROCHA, Paulo Mendes da, in A presença de Artigas, revista

Módulo n ${ }^{\circ}$ especial Vilanova Artigas, Rio de Janeiro, 1985. pág.23.

4. BAROSSI, Antonio Calros, Ensino de projeto na FAUUSP, tese de doutorado apresentada à FAUUSP em 2005. Pg. 10.

5. ROCHA, Paulo Mendes da, ao relatar a resposta dada pelo escritor e crítico literário Edmund Wilson (1985-1972) quando

indagado sobre como chegou a ser tão renomado crítico, resposta

válida também para compreender a arquitetura, segundo o

entrevistado. Em entrevista concedida ao programa Roda Viva

da TV Cultura de São Paulo em 10/06/2013, disponível em:

$<$ https://www.youtube.com/watch?v=pVSg8ZY2V94> (acesso em

25/01/2015). Citação de 1h25'09"

"Não podia fazê-las (as cidades) como queria mas realizava as escolas, as casas, os sindicatos, como quem experimenta o universo num pequeno modelo, que faz com que, na hora de concluir, a poesia domine a linguagem." 3

Propõe-se a análise das casas como ponto de início para um entendimento amplo da obra desse arquiteto, portanto, o objeto da dissertação é iniciado na série de residências e se expande, incluindo também os edifícios públicos que estabelecem algum tipo de relação com as casas.

É possível, nas obras, reconhecer relações diretas entre casas e obras públicas, seja isoladamente em cada uma das obras seja de partes do edifício em relação ao todo - exercício válido quer para a compreensão da escala doméstica da arquitetura quer para a pública.

Para desenvolvimento dessa hipótese a dissertação está organizada em duas partes principais: a primeira procura delimitar alguns conceitos e expor, previamente, as ferramentas de análise utilizadas no processo e, a segunda, trata de aplicá-las para identificar e delinear os tipos presentes de forma mais marcante na obra do arquiteto, estabelecer os vínculos analógicos entre as obras e, simultaneamente, aprofundar
6. Postura crítica defendida pela arquiteta Ruth Verde Zein no fechamento do seu artigo Artigas Pop-cult de 2013.

ZEIN, Ruth Verde, Artigas pop-cult: considerações sobre a cabana primitiva, a casa pátio e quatro colunas de madeira. 2013. pg.14<https://bibliodarq.files.wordpress.com/2012/10/zein-rv-artigas-pop-cult.pdf $>$, acesso em 14 Fev 2015. o entendimento das ferramentas de análise propostas através de sua aplicação

Antonio Carlos Barossi na introdução de sua tese de doutoramento, ao explicar o método de trabalho que aplicou em seu desenvolvimento, diz:

"O trabalho foi desenvolvido à maneira de um projeto, onde planta, cortes, elevações, modelo, perspectivas e memorial se articulam e se completam na materialização da idéia para construção do objeto" 4

Este será também nosso método, porém aplicado às avessas, não teremos como ponto de chegada a construção do objeto se não como ponto de partida. Partimos do objeto construído para com a análise fazermos cortes, plantas, elevações, perspectivas, memorial e no percurso falarmos de projeto e de teoria, enfim, de arquitetura.

Outro mote com o qual nos identificamos e que nos conduz, é saber:

"Porque diabos esse cara fez isso, assim?" 5

Mas mantendo a cautela de acreditar, sempre, mais na arquitetura do que nos arquitetos. ${ }^{6}$ 

PARTE I 

7. Martí coincide com os mesmos termos de Paulo Mendes da Rocha, que diz: "a arquitetura é um discurso sobre o

conhecimento (...) deve ser clara nas suas intenções" em entrev

ista ao Roda Viva citada, ver nota 5, aos 42'30".

8. Martí Aris, Carlos, La cimbra y el arco, Op.Cit, contracapa.

9. Traduzo o termo supeditada utilizado pelo autor para

subordinada, mas o faço com o temor de que assuma uma

condição mais intensa do que C. Martí pretende em seu texto,

proponho que prevaleça a ideia de interdependência entre

arquitetura e teoria e não de subordinação.

\section{CONSIDERAĢ̃̃ES TEÓRICAS}

É necessária uma breve explanação sobre a seleção de conceitos teóricos relacionados à arquitetura utilizados na presente pesquisa, para estruturar os exercícios analíticos propostos. Nesse aspecto, chamam atenção as considerações feitas por Carlos Martí Aris (2005) em seu livro La cimbra y el arco, Martí escreve:

"Todo intento de construcción teórica en nuestro ámbito, debe, de entrada, asumir su papel auxiliar, su condición secundaria, su supeditación a las obras, que son las verdaderas depositarias del conocimeinto ${ }^{7}$, tanto en arquitectura como en cualquier otra actividad artística. Ese carácter auxiliar que le atribuyo a la teoria en el campo del arte, no disminuye en nada su importancia, ni desmiente su valor decisivo. Es, exactamente, como la cimbra que hace posible la construcción del arco: una vez cumplida su misión desaparece y, por tanto, no froma parte de la percepción que tenemos de la obra acabada, pero, en cambio, sabemos que há sido un paso obligado e imprescindible, un elemento necesario para erigir la obra que ahora vemos y admiramos." 8

Portanto, partimos da constatação proposta por Martí que considera a construção teórica subordinada9 às obras, fato que não diminui em nada a sua importância, ao contrário, reforça a ideia de que ha um estreito vínculo de interdependência entre teoria e prática, assim como existe entre a cimbra e o arco. 


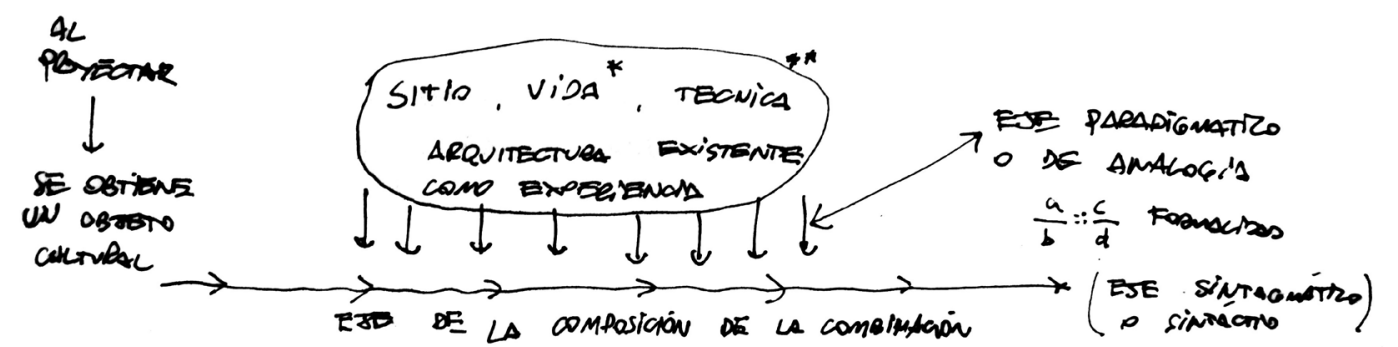

10. ARMESTO Aira, Antonio, op.cit., pg.IV - "A análise separa e decompõe para indagar sobre o fundamento geral que sustenta às obras. Estudam-se os exemplos não por sua capacidade de sugestão e sim em função do quanto possam contribuir a ampliar o saber teórico dentro da arquitetura, a tornar mais claro o campo no qual se dá o projeto e a adquirir uma maior inteligibilidade da realidade." (tradução livre do autor)

2 Esquema feito pelo autor sobre os valores que participam no processo de projeto em arquitetura

\subsection{A análise como ferramenta de projeto}

"El análisis separa y descompone para indagar sobre el fundamento general que sustenta a las obras. Se estudian los ejemplos no por su capacidad de sugestión sino en cuanto pueden contribuir a ensanchar el saber teórico dentro de la arquitectura, a hacer más claro el marco en que se da el proyecto y a adquirir una mayor inteligibilidad de la realidad." 10

Armesto aproxima ainda a produção teórica como uma necessidade que se vincula à prática e a acompanha, perseguindo a clarificação dos objetivos, individualização dos problemas e sistematização analítica da complexidade e da riqueza da arquitetura nos termos que lhe são próprios. Segundo a linha que adota, projeto e análise são ambos capazes de individualizar uma estrutura.

Portanto, o exercício analítico proposto nessa pesquisa pode ser compreendido a partir da decomposição de determinada obra enquanto objeto cultural, ou seja, na qualidade de representantes físicos de um universo paradigmático. Tendo em foco essa ação decompositiva procurei elencar os conceitos presentes nas concepções de Artigas. Não se trata de desvendar as referências presentes no âmago do pensamento desse arquiteto em seu processo de criação, mas, examinar com maior proximidade traços significantes de uma arquitetura que nos foi legada. Uma oportunidade para falarmos da própria disciplina e dos valores que a rodeiam.

Ao projetar, um arquiteto se vale do repertório que acumulou até o momento em que inicia o projeto, utiliza as referências que tem e acessa valores - tanto consciente como inconscientemente - desde as referências propriamente arquitetônicas, espaciais, de construção, etc. (relacionadas ao metier da arquitetura), àquelas trazidas de outros campos artísticos, da cultura e cidadania, que acabam por exprimir os valores culturais individuais e da sociedade da qual faz parte. 

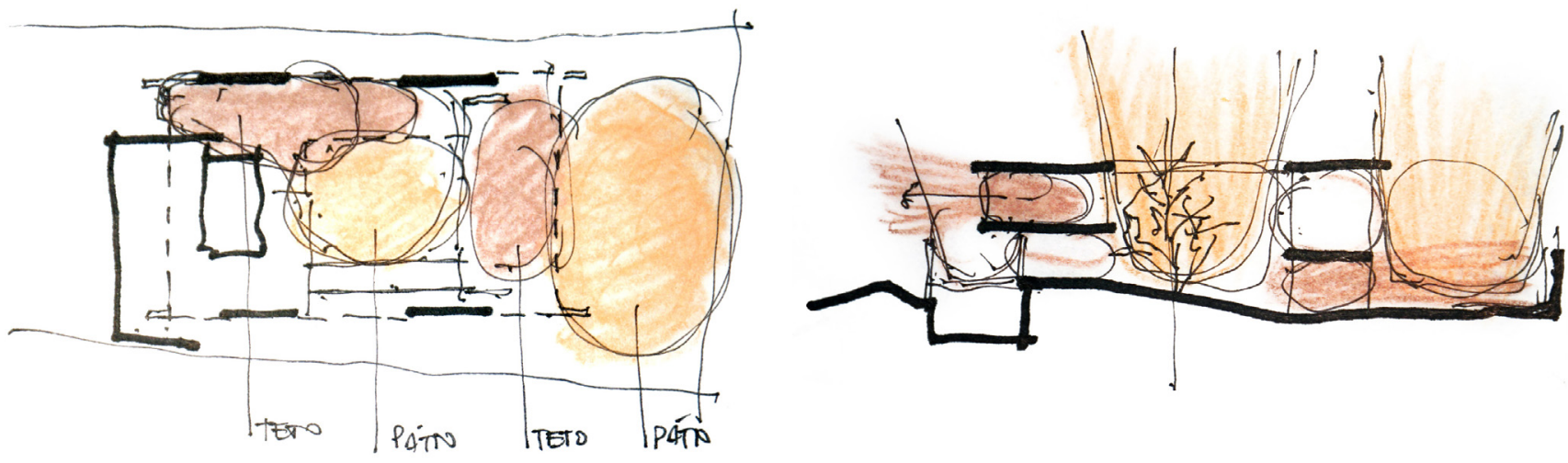

2A Croquis analítico da casa Bittencourt II - 1959 (ver 5. Desenhos Analíticos, pg.117)

Vejo a análise em arquitetura como uma ferramenta eficaz que permite refazermos o percurso traçado por Artigas ${ }^{11}$ ao concebê-la, porém, no sentido inverso, como se invertêssemos o vetor mantendo, entretanto, o seu eixo, partir da obra arquitetônica assumindo-a como objeto uno, a partir do qual é possível manejar diversos elementos: tipos arquitetônicos, a construção, os espaços, as relações entre as partes e o todo, as relações entre a obra concreta e o conjunto da obra ou produção de outros arquitetos e também nos diversos campos da cultura.

Assim, a análise é uma forma de reflexão sobre as obras que nos foram legadas, atuando dentro do campo da teoria do projeto para ampliá-lo, ao restabelecer os vínculos entre a obra (a própria arquitetura) e o tipo (estrutura e decisões lógico-formais que a rodeiam). Entendemos que a análise individualiza uma determinada estrutura ou tipo em uma obra, por sua vez, a ação projetual, individualiza uma obra a partir da análise. Como proposto inicialmente trata-se do mesmo trajeto tomado a partir de suas duas origens, ou seus dois fins, em cada um dos casos. Em
11. Destaco o fato de que o processo criativo artístico pode também ser feito em parceria, por duas ou mais pessoas, ou por equipes, como é notório e crescente no cenário da produção contemporânea. Cabe aqui reafirmar a licença acadêmica que se solicita para incluir no rol de obras analisadas, aquelas que foram projetadas na fase em que João B.Vilanova Artigas foi sócio do Arq. Carlos Cascaldi, sem, entretanto, me referir à dupla de criadores ou mesmo distinguir as obras concebidas pelos dois daquelas atribuídas somente a Artigas. Nenhuma dessas questões pretende diminuir o reconhecimento pela participação de Cascaldi nos processos criativos.

12. Autores como: Josep Quetglas, Antonio Armesto, Giorgio Grassi, Carlos Martí, Artur Rozestraten. consonância com essa visão e nos termos descritos, desenvolvemos a dissertação.

\subsection{Terminologia}

Ao longo do desenvolvimento da pesquisa surgiu a necessidade de delimitar de forma precisa os significados pretendidos para cada um dos termos aplicados, abrindo espaço para um breve ajuste terminológico antecedendo o desenvolvimento da análise. Observouse relações de equivalência entre diversos conceitos tal como desenvolvidos por alguns autores ${ }^{12}$, e o significado que interessa salientar para a composição do discurso analítico dessa investigação. Assim, as considerações a seguir resultam do levantamento de traços terminológicos coletados em definições de tais autores, seguidas por minhas considerações pessoais. 


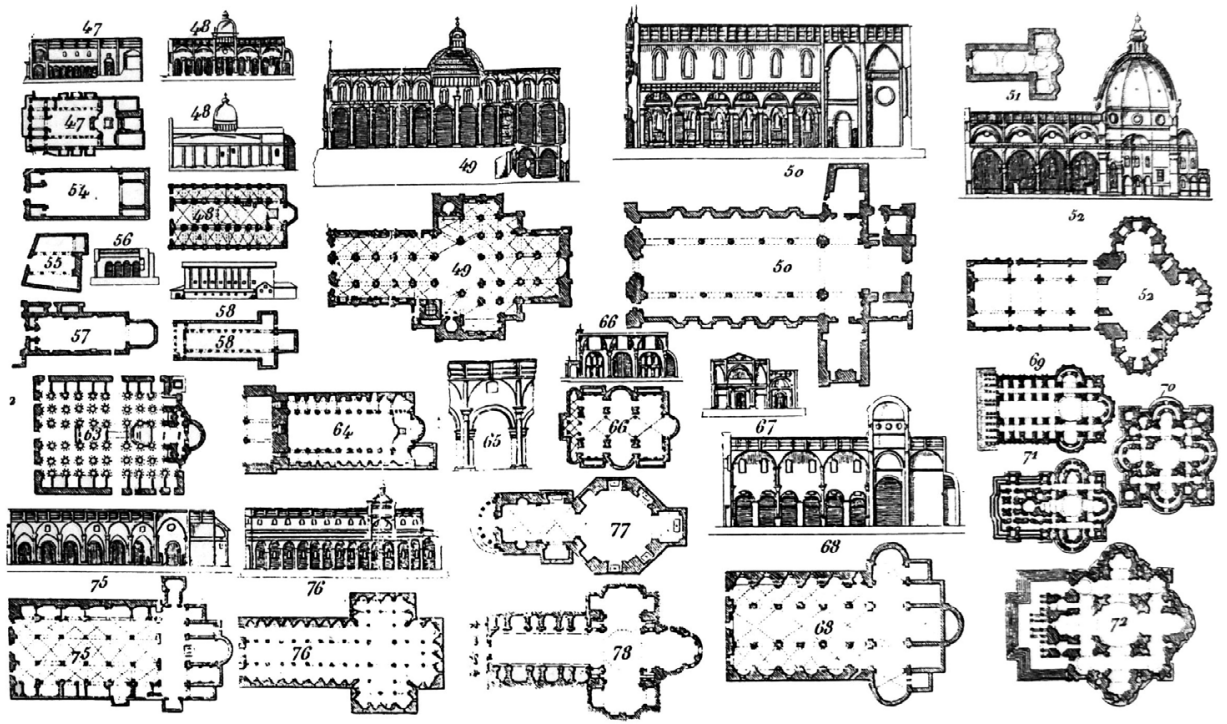

3 Tabela tipológica basilical
13.Terminologia é tanto disciplina como objeto de estudo e compilação de termos especializados (CABRÉ, M. Teresa. La terminologia. Teoría, metodologia, aplicaciones. Barcelona : Editorial Antárdita/Empúries, 1993)

14. Analogia - conceito originário da filosofia grega pode ser entendido como igualdade entre razões. No estabelecimento de analogia fundamenta-se a ação analítica. Uma imagem simples e ilustrativa é a da geometria, quando figuras de distinta escala se relacionam por semelhança.

15. MARTí Aris, Carlos, Las Variaciones de la identidad, 1993, op.cit., pg.29

Importante ressaltar que o objetivo não foi desenvolver um trabalho terminológico de lexicografia ${ }^{13}$, mas, elencar termos que articulam relações entre si ao se pensar na arquitetura. A ideia partiu da possibilidade de estabelecer analogias que por semelhança constroem relações entre objetos analisados ${ }^{14}$; recorro à analogia para um exercício de aproximação de significados.

A seguir discuto o significado de: tipo, arquétipo, classificação e tipificação, lugar, estrutura, urbanidade e modelo.

\section{Tipo (týpos)}

"El tipo arquitectónico se define por la presencia de un invariante formal que se manifiesta en ejemplos diversos y se sitúa al nivel de la estructura profunda de la forma" 15

Carlos Martí faz essa afirmação em Variaciones de la identidad - um ensayo sobre tipo em arquitetura logo no início, para definir tipo arquitetônico o relaciona à estrutura e forma. Aprofundando mais 
a definição, o autor defende que o conceito de tipo transita entre o significado e a ferramenta projetual; a ideia do tipo é o procedimento no qual a arquitetura revela seu conteúdo essencial (significado) e, ao mesmo tempo, um método operativo constitutivo do ato de projetar (ferramenta).

Martí aprofunda ainda o conceito de tipo entendido como similitude estrutural entre diversas obras - dentro de sua máxima acepção genérica, independentemente de épocas ou estilos - no sentido de abstrair-se de aspectos particulares ou individuais dos fenômenos, colocando em maior evidência suas dimensões universais, todas são condições indispensáveis para a compreensão estrutural da forma.

Nos alinhamos à forma com que Martí desenvolve a concepção de tipo principalmente em dois dos aspectos que ele propõe: o primeiro se refere ao vínculo entre tipo e significado, no sentido de signo, de identificação de figura, leitura de uma regra clara, de uma imagem conhecida, a visão de algo que já foi visto, um reconhecimento. O segundo aspecto proprio do tipo está no fato de colocá-lo em estreita relação com o fazer

arquitetônico. Nesse particular, Giorgio Grassi, no prefácio do livro, ao destacar a relevância da obra de Martí, reconhece a proximidade entre o fazer arquitetônico e o estudo do tipo em arquitetura e destaca que teoria da arquitetura se faz projetando. Em suas palavras:

"De ahí la condición expectante, como a la espera, de este texto (más allá de su contribución real en el plano teórico-metodológico): porque la última palabra corresponde a "quien hace". La última palabra no puede ser otra que el propio proyecto" 16

Grassi ressalta que Martí consegue evitar o aparato teórico-sistemático que rodeia o termo tipo na teoria da arquitetura e, ao contrário, destaca seu caráter operativo, sua praticidade, exercita o tipo através da análise da obra de notáveis arquitetos e, assim, atribui-lhe o uso que fazem dele os arquitetos que projetam, em sua acepção prática, evitando o emprego do termo de forma especulativa e fechada de quem apenas observa de fora. Representa assim uma reaproximação possível entre projeto e teoria. 

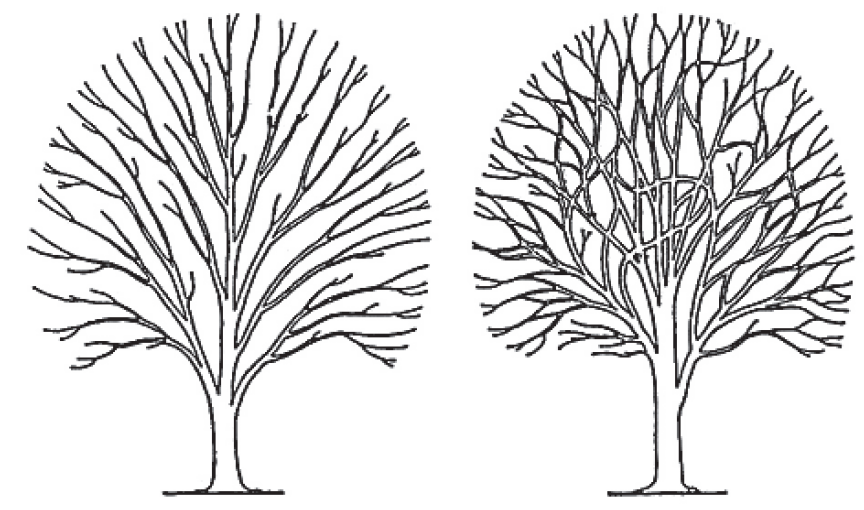

4 Diagrama proposto por Alfred L. Kroeber, ver nota 18

\section{Arquétipo}

O termo arquétipo talvez pudesse ser entendido como um conceito mais preciso do que tipo. Mas, creio que seu emprego usual está ligado a um distanciamento grande entre teoria e prática da arquitetura. Remete aos tratados de arquitetura ${ }^{17}$, contrastando com a leitura proposta por Martí, que proponho prevaleça.

\section{Classificação e tipificação}

A classificação - como na taxonomia - se vale da leitura das diferenças entre os objetos e ou espécies. Por muito tempo a classificação da arquitetura também esteve vinculada diretamente à imagem do edifício, ao visual e fisionômico, compartilhando da mesma lógica que a classificação biológica em classe, ordem, gênero e espécie.

Segundo a análise do arquiteto e crítico Carlos Martí Aris ${ }^{18}$, as espécies, assumindo-se uma visão darwinista, em seu trajeto evolutivo, somente se afastam e diferenciam, sem a possibilidade de se recombinarem. Diferentemente da evolução da cultura, que mostra que a confluência,
17. Tratados elaborados, muitas vezes, por quem olhava de fora. 18. Carlos Martí Aris em Las Variaciones de la identidad, Op.Cit., no capítulo segundo (2.1.) faz um rica análise comparativa entre as ações de classificação, próprias da biologia, e as ações de tipificação, próprias da cultura, cita os estudos de Arthur Koestler sobre a criação de novas ferramentas por combinações de utensílios anteriores e ilustra os conceitos de filogenia biológica e filogenia cultural a partir de teoria desenvolvida pelo antropólogo Alfred L. Kroeber. Reproduz também um diagrama proposto por Kroeber sobre esse tema. pg. 50-58.

19. ARMESTO Aira, Antonio, op.cit., pg. 85. mestiçagem e fusão são indispensáveis para a fertilidade do pensamento criativo. Ações combinatórias estreitamente vinculadas à ideia de tipo e de hibridação.

\section{Lugar (tópos)}

"El concepto de lugar, el topos, (...) es el del mundo constituido por objetos cilíndricos, caracterizados por su autonomia, verdaderos universos que distingen su espacio vectorialmente desde la tierra al cielo y se colocan unos junto a los otros. Cada uno de ellos exhibe su corporiedad como limitación de su extención horizontal."19

Segundo Martí, a arquitetura se diferencia dos objetos artesanais ou industriais, não apenas em escala, mas pelo fato de estar vinculada ao lugar e de toda a especificidade que assume para realizar plenamente seu pertencimento ao sítio. Contrariamente às ferramentas, utensílios e máquinas, que são intercambiáveis entre si e permitem a reprodução indefinida do objeto - seguindo-se determinados modelos e padrões - a arquitetura, ao arraigar-se ao lugar e ser envolvida por sua peculiaridade, resulta literalmente irrepetível. 
19. MARTÍ Aris, Carlos, op.cit., pg.93. "O Tipo representa o genérico, o universal, o abstrato" tradução do autor.

20. Idem. "enquanto o Lugar se aproxima do particular, do concreto" tradução do autor.

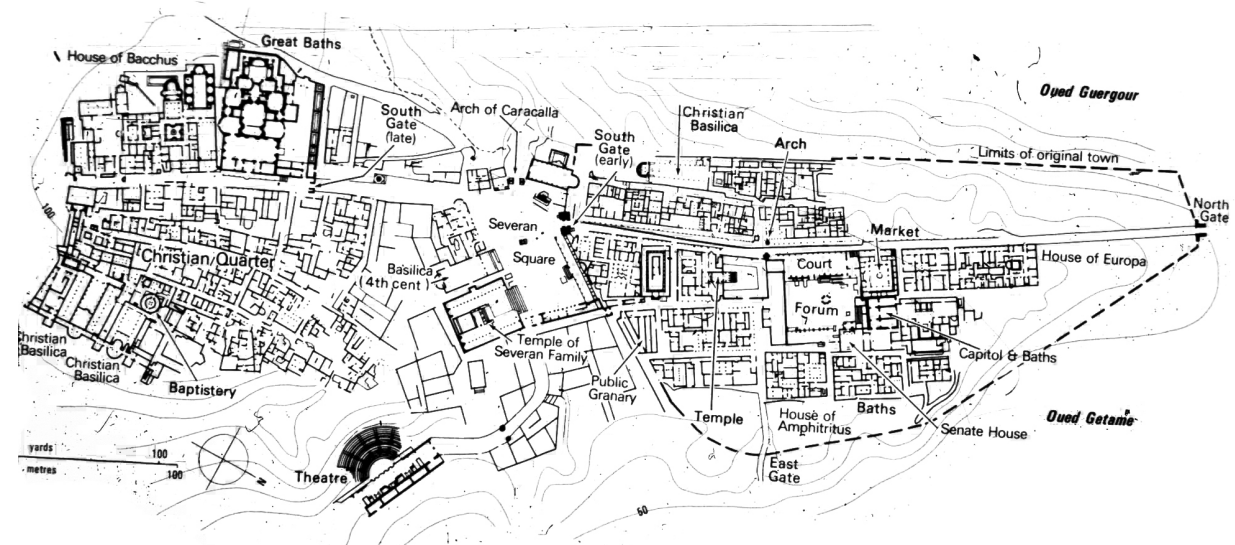

5 Djemila

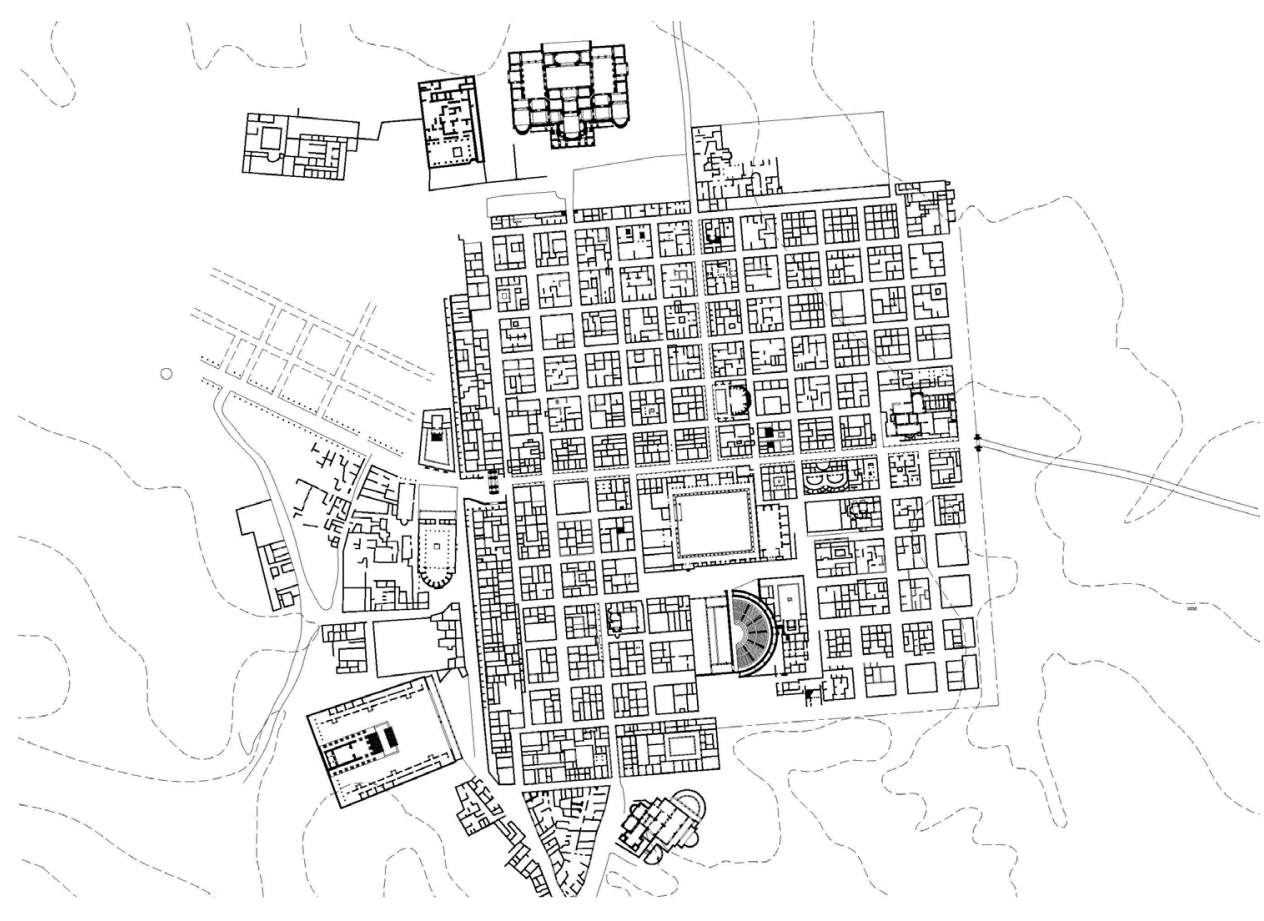

6 Timgad
Ao propormos o viés de irrepetibilidade que a arquitetura assume estamos, aparentemente, nos contrapondo à ideia de repetição da qual o tipo depende. Mas, talvez, esse aparente paradoxo seja a chave para a compreensão do conceito de tipo e de lugar. O tipo é a parcela da arquitetura que não varia, a estrutura profunda da forma que permanece ali, legível. O lugar, melhor dizendo, o pertencimento da arquitetura ao lugar é a parcela da arquitetura que singulariza cada obra.

"El tipo representa a lo genérico, lo universal,"19 Possiblemente represente la parte repetible da arquitetura "mientras el lugar se assimila a lo particular, lo singular, lo concreto."2o e assim se une à parte singular da arquitetura.

Giorgio Grassi em texto sobre as cidades romanas da Argélia, Timgad e Djemila, diz:

"Ciudades famosas (...) ya que en sus formas se expresa gran parte de la teoría de la arquitectura de la ciudad romana (...) En la comparación de esas dos ciudades hallamos la confirmación (...) sobre la diferencia entre orden formal prefijado (...) y orden formal que proviene de las cosas, que surge de su condición particular. Y toda esa densidad teórica y metodológica se debe solo a que una ciudad se encuentra en medio de la llanura y otra sobre 


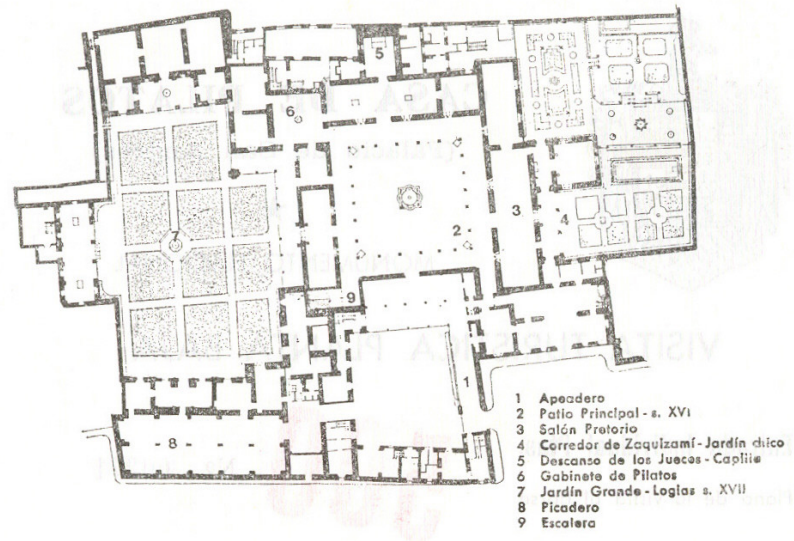

7 Casa de Pilato Sevilha

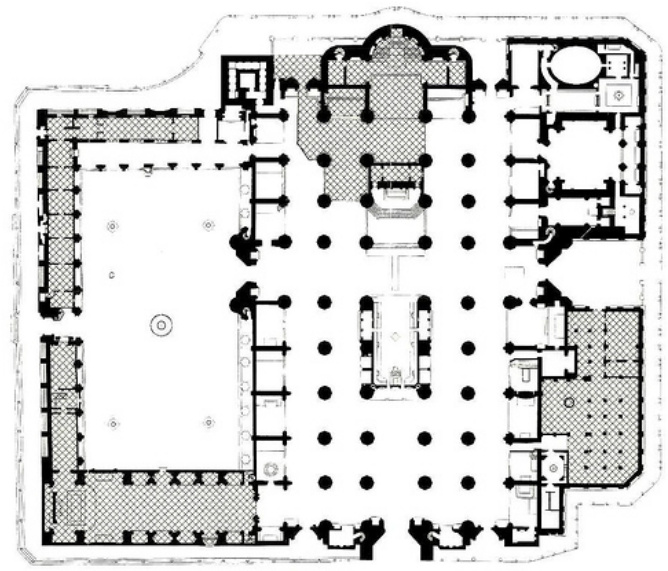

8 Catedral de Sevilha
21. GRASSI, Giorgio di, Questioni di Progetazzione, 1982. in Quaderni di Lotus, Architettura língua morta, Electa, Milão, 1988, pg. 22-33. Apud, MARTí Aris, Carlos, Las Variaciones de la identidad, op.cit., pg.95-96.

22. MARTÍ Aris, Carlos, op.cit., pg.97. "O que dissemos da cidade romana caberia também para as catedrais ou basílicas, templos ou mercados, teatros ou anfiteatros da cultura romana que sempre insistem sobre algum tipo; algumas ideias de arquitetura que ao se materializarem desenvolvem um inesgotável repertório de variáveis. A casa romana está sujeita ao mesmo princípio, mas a repetição no tempo é acompanhada de uma repetição no espaço" tradução do autor.

23. Idem, pg.97

la curva de una cresta montañosa; solo porque la resistencia opuesta por el elemento natural ha sido diversa en ambos casos (...) Se trata de la misma forma de ciudad: porque, en realidad, es la misma ciudad acontecida en lugares diversos." 21

"Lo que hemos dicho de la ciudad romana cabe decirlo también de sus edifícios. Ya sean basílicas o termas, templos o mercados, teatros o anfiteatros, la cultura romana insiste siempre sobre algunos tipos, algunas ideas de arquitectura que, al materializarse, desarrollan un inagotable repertorio de variaciones. La casa romana está sujeta también a esse mismo principio, solo que la repeticion en el tiempo se acompaña, em esse caso, de uma repeticion en el espacio" 22 (em um lugar sempre diverso)

"Es esse um fenómeno recurente em todas las épocas: la casa del hombre, em uma determinada cultura, es siempre semejante, aunque distinta, a las otras casas." 23

Com essa afirmação, estamos falando de tipo e lugar, de geral e 


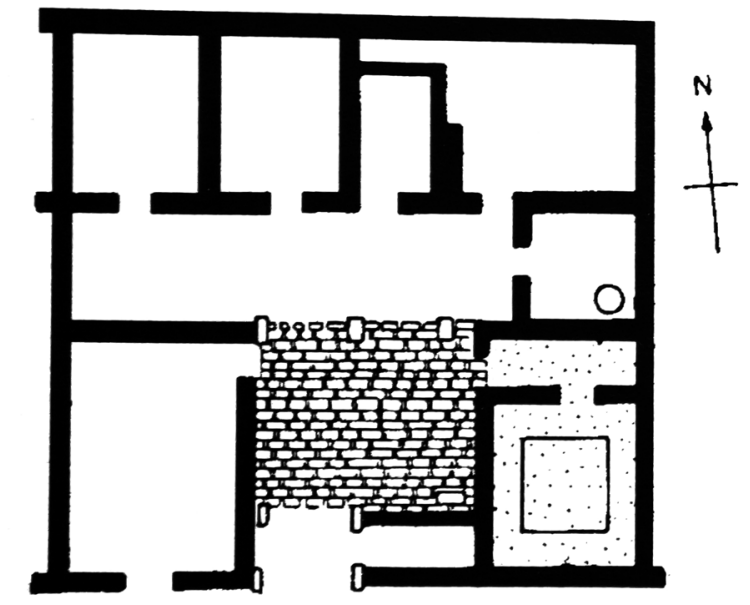

8A Cidade pré-helênica de Olinto, séc. V a.C. - casa tipo e tecido urbano.
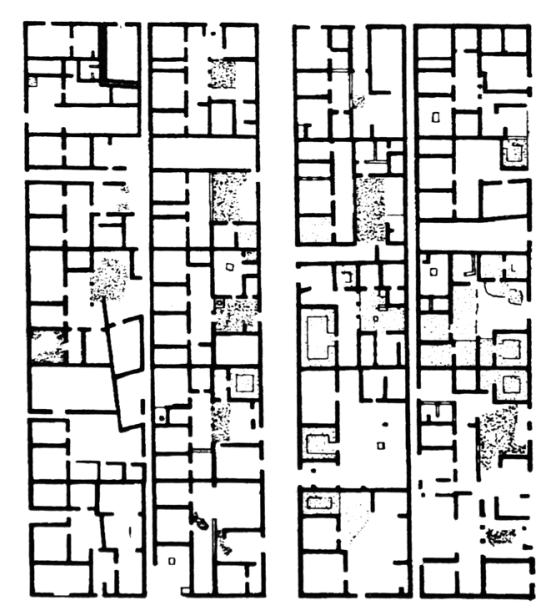

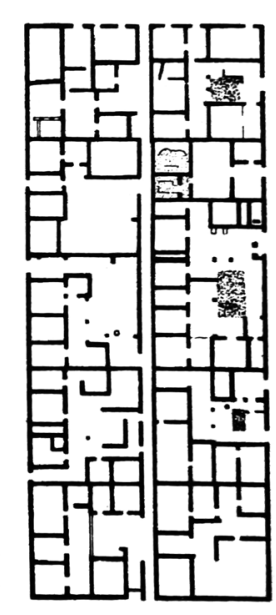

particular, de cultura e identidade.

Martí prossegue suas reflexões com a ideia de que a homogeneidade tipológica frequentemente acaba definindo a formação de um lugar, a ocupação de um território, determinada cidade e os valores nela compartilhados, dessas manifestações coletivas e análogas entre si, que parecem impregnar as formas da arquitetura.

\section{Estrutura}

Pretendemos que estrutural e estrutura tenham maior abrangência do que quando empregados como relacionados à estrutura portante, é aplicado com um significado mais amplo, entendido também como semelhança lógico formal, desde o ponto de vista da estrutura compositiva da arquitetura, não somente da estrutura física de sustentação.

O conceito de estrutura, nos termos que nos interessa nessa dissertação, fica bastante evidente em passagem analítica que Carlos Martí faz ao citar a contribuição de Jean-Nicolas-Louis Durand à discussão sobre a decomponibilidade da arquitetura, Martí utiliza a teoria desenvolvida por Durand para apontar-lhe uma debilidade e ali, nesse ponto de incompletude, esclarecer o conceito de estrutura.

Segundo Martí, Durand parte do princípio de que os modelos do passado já não servem ao arquiteto pra resolver os problemas edificatórios de sua época e propõe um instrumento que lhe permite enfrentar qualquer programa sem a sujeição obrigatória aos modelos.

"Ese instrumento no será outro que la Composición, cuyo manejo requiere un conocimiento sistemático de los Elementos de la Arquitectura." 24

Durand propõe portanto que ao arquiteto possa ser possível combinar adequadamente as partes e elementos que formam o repertório da arquitetura para chegar a um projeto sem a necessidade de recorrer a nenhum modelo. 


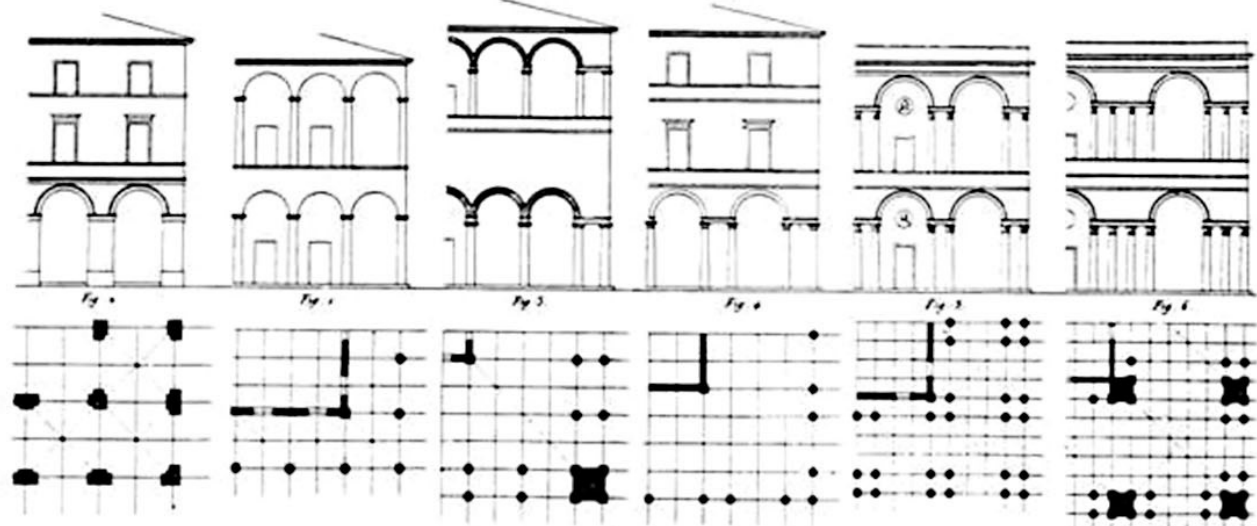

Ht
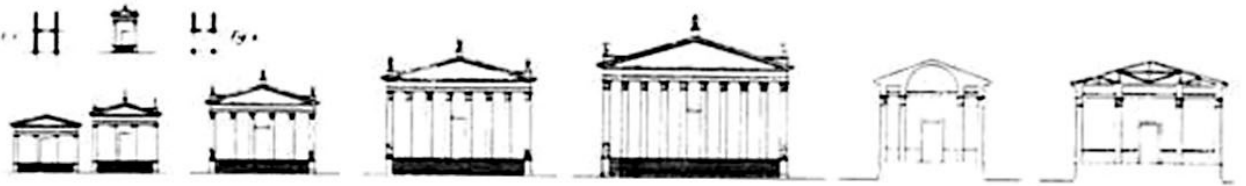

fHat
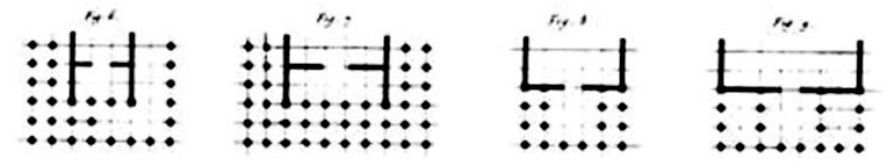

$+1$
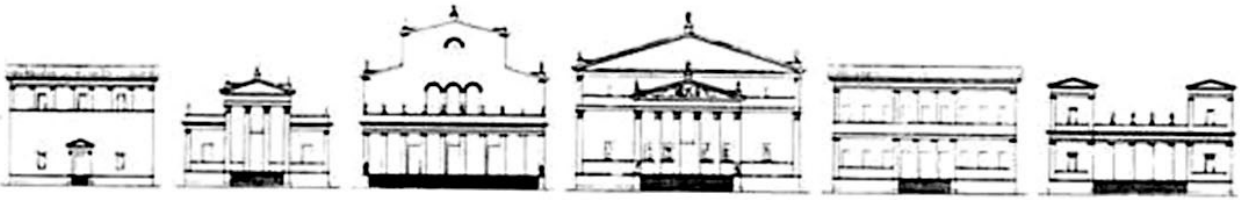

L

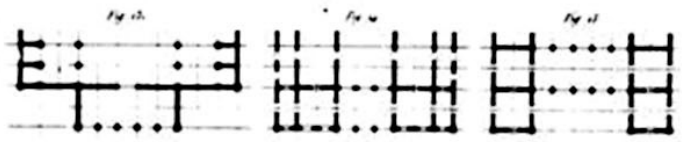

9 JNL Durand
Em rápida definição Martí delineia a teoria de Durand com a seguinte descrição:

"El Compendio de Durand ofrece dichos Elementos desmontados y catalogados y a ello se añade un manual de instrucciones que le permita al arquitecto recomponerlos a su critério que, según Durand, debe ir guiado por la conveniencia y la economía." 25

Martí aponta o papel predominante que Durand atribui aos Elementos como a principal debilidade de sua teoria, então cita una frase atribuída a Durand, que ao falar dos elementos, diz:

“...éstos son a la arquitectura lo que las palavras son al discurso y las notas a la música." 26

Martí prossegue defendendo que do mesmo modo que o discurso não é uma mera combinação de palavras, nem a música mera sucessão de notas, a arquitetura não pode ser vista como um caminho unívoco 
28. Frase colocada na boca de Marco Polo por Ítalo Calvino em

seu Cidades Invisiveis, apud MARTí Aris, Carlos, Las Variaciones de

la identidad, Op.Cit., pg.140

29. FERREIRA, Aurélio Buarque de Holanda. Novo dicionário

Aurélio da língua portuguesa, 1. ed. São Paulo: Ed. Nova

Fronteira, 1987

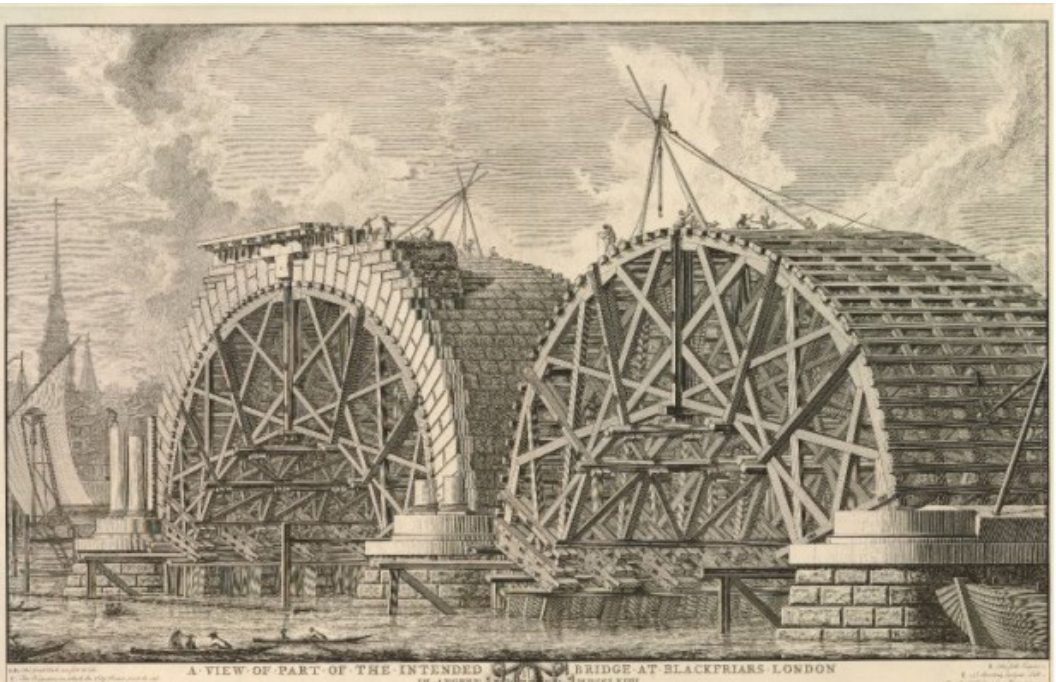

10 "A View of Part of the Intended Bridge at Blackfriars, London, in August MDCCLXIIII", by Giovanni Battista Piranesi, 1766 que vai dos elementos ao todo, sem o risco de empobrecê-la e desnaturalizá-la.

"Para que exista música, discurso o arquitectura no basta con los elementos; se requiere también una estructura, una idea general

que gobierne las relaciones que se dan entre ellos, en función de

determinados objetivos. (...) Es un principio ordenador, capaz de hacer jugar a los elementos el papel que les corresponde (...) estrutura, que en ele caso de la arquitectura coincide com su principio tipológico.

(...) comporta la presencia de un principio constructivo y de unos procesos generativos (...)" 27

Essa é precisamente a acepção que estrutura tem nesse texto, é o conjunto de leis e regras compositivas, não necessariamente explicitadas ou contidas em um manual de instruções, mas expressa na arquitetura, na lógica ordenadora dos elementos que possibilita que a arquitetura não se origine pela mera sobreposição, justaposição ou aglutinação de elementos.
"El puente no esta sostenido por esta o aquella piedra, sino por la línea del arco que ellas forman" 28

Este arco, que de nada depende, construtivamente, é a nossa estrutura.

\section{Urbanidade}

Urbanidade. [Do lat. urbanitate.] S. f. Qualidade de urbano; civilidade, cortesia, afabilidade.

Civilidade. [Do lat. civilitate.] S. f. 1. Conjunto de formalidades observadas entre si pelos cidadãos em sinal de respeito mútuo e consideração. 2. Polidez, urbanidade, delicadeza cortesia.

Polidez. (ê) S. f. 1. Qualidade ou estado de polido. 2. Delicadeza, cortesia, civilidade, urbanidade. ${ }^{29}$ 


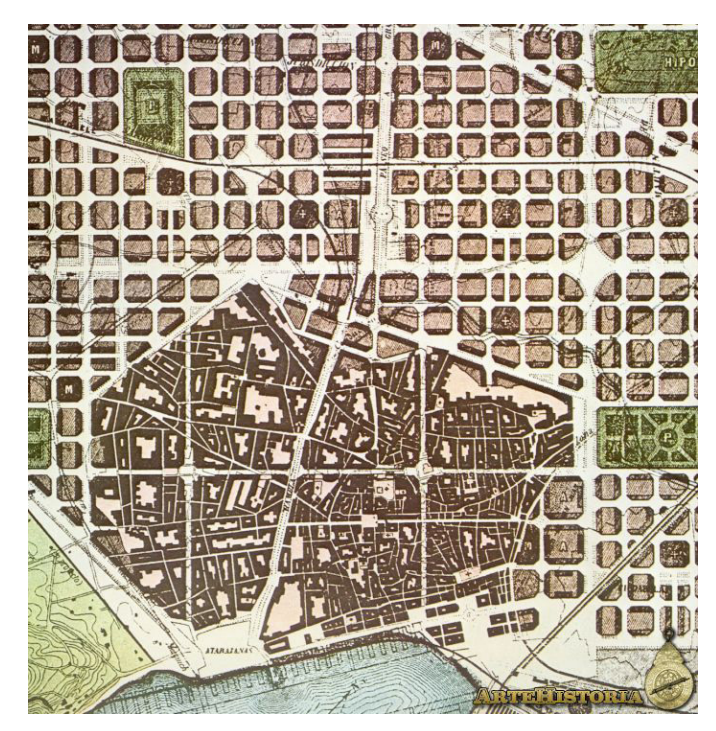

11 Eixample de Barcelona - plano Cerdà 1867

Talvez não seja necessário ressaltar que a cidade une esses três substantivos:

\section{civitas - urbs - polis}

Ao retomarmos o termo urbanidade podemos intuir que junto com civilidade e polidez estejam todos unidos em torno a determinada qualidade positiva, que pode estar presente nas obras analisadas. É esse o significado, esse adjetivo que perseguimos.

O engenheiro de caminhos estradas e pontes Ildefons Cerdà (18151876) na ocasião da realização de seu plano para expansão urbana de Barcelona em 1867 publicou Teoría general de la urbanización. Um amplo estudo sobre urbanismo que além de seu legado físico, urbano, na cidade que se expandiu sob seu desenho, nos deixou um igualmente amplo e rico legado científico, urbanístico (próprio da disciplina) e até etimológico. Cerdà dedica um trecho do terceiro livro da publicação
(Libro III - Examen analítico del estado actual de la urbanización) a discorrer sobre o termo urbano, perseguindo-lhe a raiz etimológica.

Seu discurso menciona uma série de raízes compartilhadas pela cidade (ou pela urbanização, que é o tema central de sua produção), percorre seus diversos sinônimos, transita entre polis, urbs e civitas mencionadas acima - e também burg, medinah, castro, cartach. ${ }^{30}$

Mas é quando aproxima civitas de urbs que surge o vínculo com urbanidade. Cerdà considera que a raiz civitas está sempre vinculada ao cidadão - civis, civitas, civilitas, civil, civilidade, cidadania, cidadão. Enquanto urbs vem vinculada ao espaço, à forma física da cidade - urbe, urbanus, urbano, urbanização - em nossa acepção é nessa dualidade entre espaço e cidadão que surge urbanidade.

"La palavra urbanus (de urbe) se referia á cosas del conjunto material de la urbe: así es, que los ciudadanos nunca se llammaron urbanos, porque 
30. Segundo Cerdà: burg - gôdo/germânico, medinah - árabe, castro - romano (militar), cartach - fenício/púnico e polis - grego, civitas - romano e urbs-uri-ur-urbum-uro-aro - de etrusco/ romano a celta/basco, de cidade a cultivo, com a licença de apresentar as seis últimas raízes em resumo visual-esquemático do autor.

31. CERDÀ i Sunyer, Ildefons, Teoría general de la urbanización, Imprenta Española, Madri, 1867, pgs. 505-6, grifos do autor, urbanidade: grifo meu. acentuação do texto original.

32. DA CUNHA, 1997 apud Rozestraten, A.S. Op Cit. pg.10.

la palabra radical no consentia semejante aplicación. (...) cuando querian espresar simplemente la idea del habitante de la urbe, hecha abstracción de su calidad de ciudadano, (...) empleaban la palabra urbi-cola, es decir, morador de la urbe. Más adelante urbanus y urbanitas, urbano y urbanidad, llegaron a tener una acepción moral, análoga, por no decir idéntica, à civilis y civilitas; pero eso fue por estension, efecto de una comparacion tácita entre costumbres ó cultura de los habitantes del rus (campo), á quienes se llamaba rustici, (...) y los moradores de la urbs que siempre se reputaron mas cultos y mas civilizados: de manera que unbanus asi como urbanitas, (...) se referian essencialmente á cosas y personas concernientes á la parte material del conjunto de edificios." 31

Se admitirmos a dualidade mencionada, entre espaço e cidadão contrariando a Cerdà que considera urbanidade e civilidade como sinônimos - melhor dizer, portanto, que propomos essa dualidade para podermos expressar a intensão de que urbanidade possa significar, dentro dessa dissertação, qualidade cidadã - civilidade, própria da urbe - expressa em um elemento físico, em uma construção. Em outras palavras, que urbanidade possa ser um adjetivo atribuível à arquitetura, como qualidade reconhecível de determinada obra ser portadora de valores de civilidade, é a urbanidade - própria do cidadão: cortesia, polidez, civilidade, afabilidade - expressa, por assim dizer, na arquitetura, no espaço que se materializa pela construção. Urbanidade é a civilidade do objeto.

\section{Modelo}

"Etimologicamente, o termo modelo (séc XVI) tem origem no italiano modèllo, derivado do latim modellus, variação de modulus, que é diminutivo de modus. Modus ou modo significa: maneira, método, disposição, forma” 32 

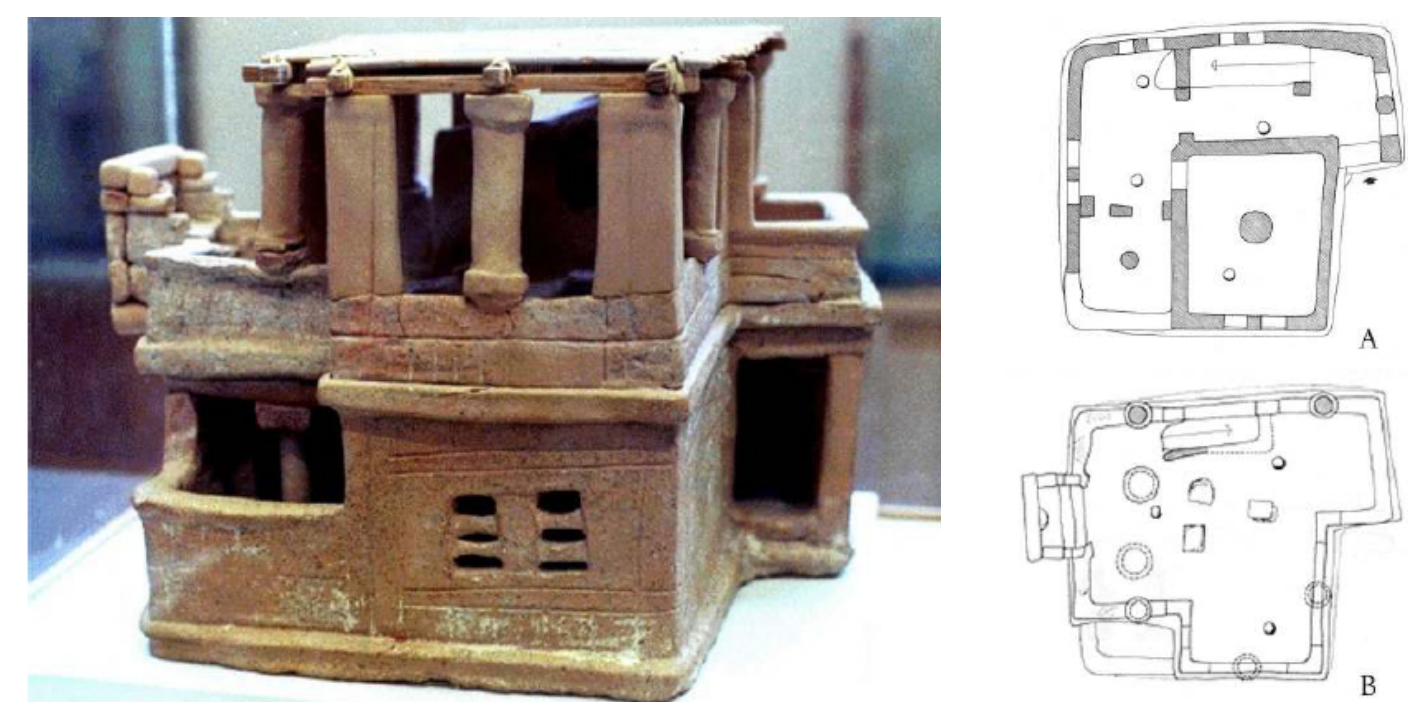

33. ROZESTRATEN, Artur Simões, 2003. Op.Cit.. Pg. 10

34. MARTÍ Aris, Carlos, op.cit., pg. 139.

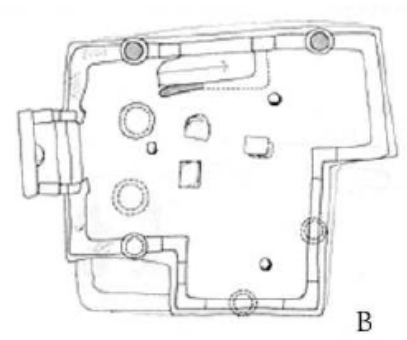

12 Modelo minóico

A acepção pretendida para o termo modelo se entrelaça com a de tipo, pelos traços que carregam a noção de padrão, capaz de reunir características positivas suficientes que lhe permitam ser utilizado na repetição e na mudança de escala. Modelo pode ser também visto como exemplo bem resultante ou a tentativa boa. O modelo é o objeto cujo método generativo é válido - tem valor, valorizado - e esse objeto passa a ser um dos portadores do método. Nesse sentido, Artur Rozestraten, ao conceituar o termo, propõe:

"Modelo, no sentido genérico relaciona-se a exemplo, ideal, referência ou padrão. Já os sentidos específicos do termo parecem conjugar essa noção (...) a certas particularidades de uma determinada área do conhecimento.”
"No universo da arquitetura, (...) encontram-se os seguintes sentidos de modelo:

- Modelo como conjunto de conceitos, premissas e formas (...).

- Modelo como a referência escolhida pelo arquiteto para sua composição, seja uma ideia ou forma material.

- Modelo como sistema experimental (...).

- Modelo de teste pré-série, ou protótipo, (...) feito como "primeiro tipo" para teste de uma produção seriada.

- Modelo como tipo, categoria, gênero de objetos. 


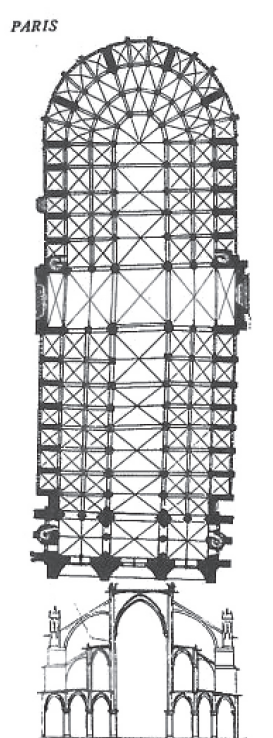

$\therefore \sqrt{n-1}$
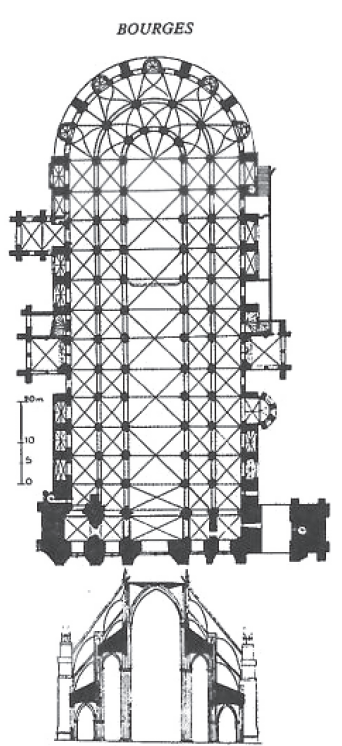

不两

(a)
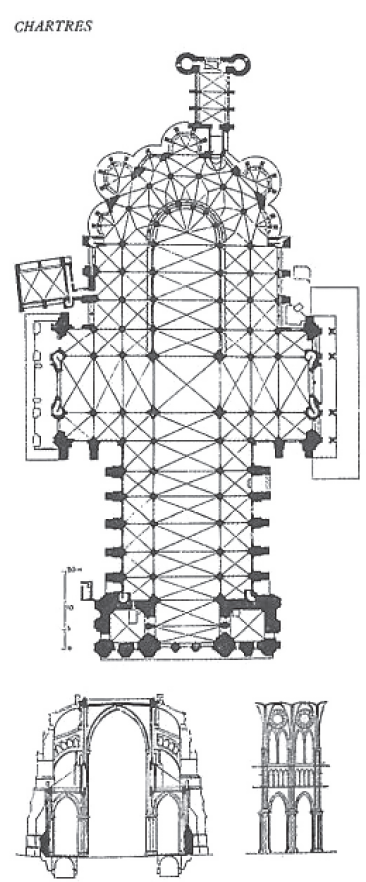

REMS

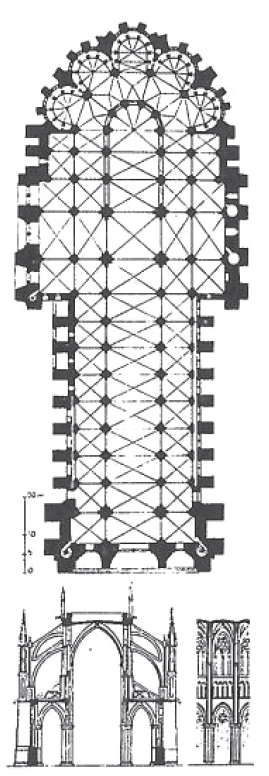

AMIENS
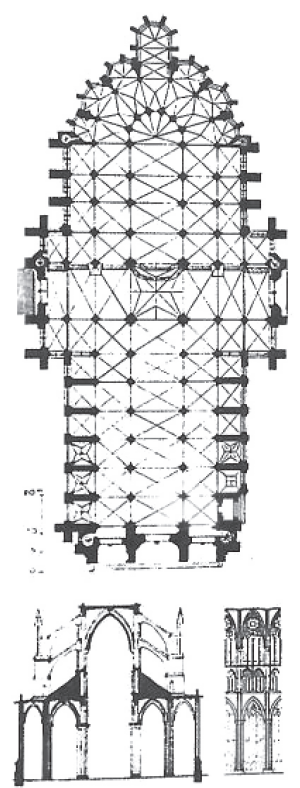

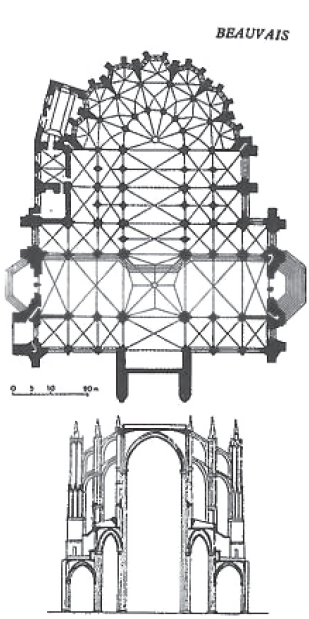

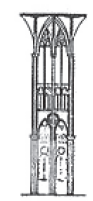

13 Catedrais goticas francesas

- Modelo significando as diversas representações planas da arquitetura (...).

- Modelo como representação tridimensional de um objeto ou arquitetura feita em escala (...)." 33

À exceção dos dois últimos sentidos elencados por Rozestraten, todos os outros encontram alguma presença nas casas projetadas por Artigas.

A intenção de se criar um modelo, em arquitetura, não acontece a priori, um edifício não é concebido para ser modelo ou matriz, eventualmente pode ser reconhecido como experiência bem sucedida e tornar-se assim um modelo, portanto a posteriori. Nesse particular, ao ser entendido como objeto modelo, portador de qualidades reconhecidamente positivas, ele passa também a ser objeto de análise frequente, já que a ação analítica é a que permitirá a extração de suas qualidades e, portanto, a sua afirmação como modelo.

"Así, cuando el maestro de la Catedral de Bourges afronta la construcción del edifício, no parte de unos datos abstractos y carentes de forma; su punto de partida es, por el contrário, un modelo definido, basado en las experiencias inmediatamente precedentes: Senlis, Noyon, Laon...del mismo modo opera el maestro de Chartres con respecto a Bourges: añadiendo un eslabón más a la cadena de los ejemplos anteriores, avanzando por un lento camino de depuración y perfeccionamiento." 34 

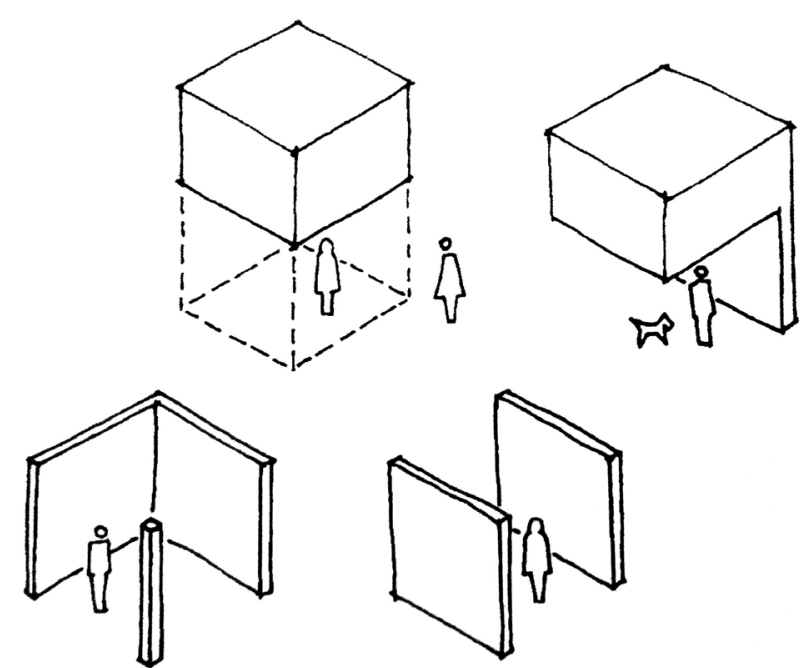

14 Operações arquitetônicas possíveis com planos e volumes (tetos e recintos).

\subsection{Ferramentas de análise}

Como elementos principais de trabalho para o método de aproximação à arquitetura das casas escolhidas e dos edifícios recorrentes, nos propomos a fazer uso de ferramentas analíticas descritas por Antonio Armesto Arias. Em seu El Aula sincronica, un ensayo sobre el analisis en arquitectura (1993), Armesto propõe exercícios de análise a partir de um sistema, sugerindo que toda arquitetura possa ser entendida, analisada e decodificada, a partir de três campos: forma (arquitetura), construção (técnica) e utilidade (não relacionada à função e sim ao significado).

A forma é abordada isoladamente da construção e Armesto propõe que toda arquitetura é constituída por três elementos básicos: aulas, recintos e pórticos, e pelas inicias dos termos batiza o sistema ARP. Com certa liberdade poderiam ser traduzidos em: salas (com fechamentos e com teto), recintos (apenas com fechamentos laterais, sem teto) e tetos (somente a cobertura, sem fechamentos). Para esse autor tratam-se de elementos primitivos e que combinados e dosados são capazes de gerar toda arquitetura.

Invertendo o raciocínio: com a análise se torna possível decompor a arquitetura à esses elementos básicos para melhor entendê-la. E essa é a principal função do sistema proposto que empregamos como ferramenta de análise.

Aprofundando os conceitos Armesto sugere o seguinte:

"El recinto coloca al hombre en relación de restricción respecto a su entorno, de definición primera y localización de un lugar o punto sobre la tierra, que se convierte em un polo axis mundi, de verticalidade, que lo vincula al cielo, en una dimensión religiosa y trancendente."

"El pórtico, como antinomia del recinto, propone un punto de vista sobre la tierra, sobre el paisaje como naturaliza contingente y gozosa, siendo su carácter próprio el ser un elemento transitivo y creador de la relación 
35. ARMESTO Arias, Antonio. El Aula sincronica, un ensayo sobre el analisis en arquitectura, Tese de doutorado apresentada à EtsaB-

UPC em 1993, p.64.

"O recinto coloca o homem em relação de restrição respeito ao seu entorno, de definição primordial e localização de um lugar sobre a terra, que se converte em um polo ou axis mundi, essa verticalidade, o vincula com os céus, em uma dimensão religiosa e transcendente.

O teto, como antinômio do recinto, propõe um ponto de vista sobre a terra, sobre a paisagem como natureza contingente e gozosa, sendo seu caráter próprio o de ser um elemento transitivo e criador de relação "horizontal". Não estabelece um vínculo forte com o solo e tem uma componente de não fixação de abertura. O pórtico representa os caracteres físicos não do espaço religioso e transcendente e sim do espaço civil e cotidiano.

A aula propõe a síntese complexa. Nela se podem graduar os ingredientes do transcendente e o contingente segundo o acento posto no eixo vertical ou na abertura ao terrenal, por isso pode

ser o mais quente dos albergues, o mais severo dos templos ou

lugar por excelência da reunião civil." Tradução do candidato.

"horizontal". No establece un vinculo flerte com el suelo y tiene una componente de no fijeza y de apertura. El pórtico representa los caracteres físicos no del espacio religioso y transcendente sino del espacio civil y cotidiano."

"El aula propone la síntesis compleja. En ella se pueden guardar los ingredientes de lo transcendente y de lo contingente según el acento puesto em el eje verticalo en la apertura a lo terrenal, por eso puede ser el más cálido de los albergues, el más severo de los templos o el lugar por excelência de la reunión civil." 35

Em relação à adaptação dos três termos do castelhano para o português propomos a seguinte aproximação:

Aula utilizado tal como empregada em português leva à ideia de evento mais que à de espaço. Poderíamos usar junto com sala, mas sala de aula é específico, conectada a ambiente e função. Além disso, não é genérico como se pretende para a definição de um espaço simplesmente coberto
36. ARMESTO Arias, Antonio. El Aula sincronica, un ensayo sobre el analisis en arquitectura, Tese de doutorado apresentada à EtsaB-

UPC em 1993, p.64. e fechado. Poderia ser utilizado apenas sala, mas, em português, tem certa conotação hierárquica; é o espaço servido, ambiente principal, lugar vasto e coberto, rodeado de estâncias menores ou de uso complementar, significado também indesejado na análise.

Recorro às próprias explicações de Armesto quando, em uma nota de rodapé do texto, faz referência à Yago Bonet e ao La arquitectura del humo, obra na qual se apoia para resolver a ambiguidade em relação à palavra aula, observa:

"En esa investigación (La arquitectura del humo, de Yago Bonet) las palabras hall, halle, halla, saal, sala y el término latino aula, (...) llegan a ser sinônimos de un único concepto general. Nosotros otorgamos al término aula esse sentido genérico, como punto de partida metodológico, dado el enfoque deductivo que nos hemos propuesto." 36

Respeitando a acepção proposta por Bonet, mantemos aula como no original, vinculando-a a espaço fechado e coberto. 


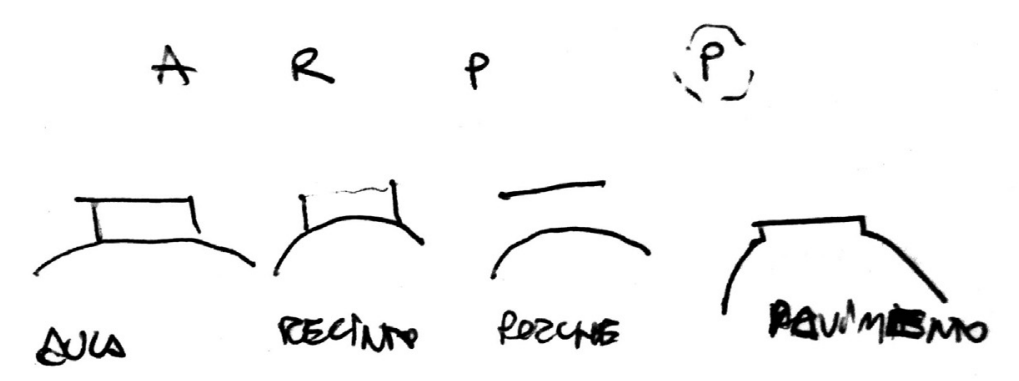

$15 \mathrm{ARP}+\mathrm{P}$
37. SUMMERSON, John. A linguagem clássica da arquitetura. $1^{\mathrm{a}} \mathrm{ed}$. São Paulo: Ed. Martins Fontes, 1982, p. 134, grifo do autor.

38. A relação entre o muro e a vertical é interessante se posta ao lado dos termos elevação e alçado, normalmente usados para designar o desenho das fachadas do edifício, em português brasileiro e protugues de Portugal, respectivamente. Ambos remetem à ideia de elevar, levantar, uma ação que existe fisicamente na construção e encontra sua ação análoga no desenho do projeto, ao traçarmos as linhas verticais a partir da planta.
Recinto, é o que encontra melhor equivalência entre os dois idiomas. Devo fazer uma pequena ressalva: em português pode significar o ambiente dentro de um edifício, um cômodo ou sala.

Entretanto, esse não é o entendimento pretendido. A palavra pode ser compreendida diretamente já que creio prevalecer a ideia ligada à formação do espaço.

Pórtico se traduzido imprecisamente para pórtico chega quase ser um falso cognato, já que pórtico em português pode se referir a um portal de acesso ou a um segmento estrutural.

Em definição por John Summerson está ligado à arquitetura clássica e, portanto, mantém relação direta com presença de colunas.

"PÓRTICO. Passagem abrigada. Em geral este termo é aplicado à projeção apoiada sobre colunas à frente de um templo. Pórticos deste tipo são classificados segundo o número de colunas, a saber: Terastilo (4), Hexástilo (6), Octastilo (8), Decástilo (10) e Dodecástilo (12).” 37

Neste trabalho seu significado corresponde apenas a cobertura, ou plano de cobertura, sem necessariamente ter relação com a presença de pilares ou colunas. Portanto, proponho o uso do termo teto
O sistema analítico ARP, conforme vimos, faz referência ao espaço arquitetônico exclusivamente, deixa de lado toda e qualquer questão construtiva.

Em sua tese Armesto desenvolve também um trinômio relativo à construção, sugerindo que toda obra seja composta fisicamente pelas seguintes lógicas construtivas: muros, entramados e bandejas. Para ele sistema MEB, compreendido da seguinte forma:

Os muros resultam ser uma extrusão axial de uma determinada forma pretendida para a construção, é o desenvolvimento vertical da marca que o edifício faz no terreno, ou seja, a extrusão de sua planta a partir da primeira fiada. Tem como direção definidora a vertical ${ }^{38}$. O relacionamos construtivamente à alvenaria.

O entramado é um sistema de equilíbrio entre as três direções, um universo cartesiano onde há os três eixos, X, Y e Z. Não tem uma direção definidora, já que nenhum dos eixos prevalece sobre os demais; a hierarquia é dissolvida.

A bandeja representada pelo sistema de lajes e pilares corresponde à prevalência do plano horizontal. 
39. ARMESTO Arias, Antonio. El Aula sincronica, un ensayo sobre el analisis en arquitectura, Tese de doutorado apresentada à EtsaB-

UPC em 1993, p.82.

É interessante a constatação de que cada uma das lógicas estruturais propostas tem seu surgimento e sua prevalência em diferentes momentos da história da arquitetura e da técnica: o muro remete à técnicas construtivas milenares. A lógica do entramado, milenar com a madeira, renasceu com a indústria do ferro, no século XIX e a bandeja remete imediatamente a imagem do concreto armado e à planta livre do Movimento moderno.

O sistema analítico proposto por Antonio Armesto e descrito aqui permite uma aproximação interessante às obras de Artigas, parametrizando a análise. Possibilita ir além do tipo e desconstruir, fragmentar mesmo, encontrar outros tipos e lógicas construtivas também em suas partes, tanto a partir da forma (da arquitetura) quanto da construção

Essa afirmação nos conduz à seguinte proposta apresentada pelo autor em seu El aula sincrônica:

"Planteamos aquí el tema de la construcción como una discusión de cierto punto de vista que tiende a separar radicalmente la arquitectura del momento de su ejecución, distinguiendo un momento de ideación sin matéria y outro de materialización sin ideas, como fases que se suceden mecánicamente o, a lo sumo, dialécticamente." 39

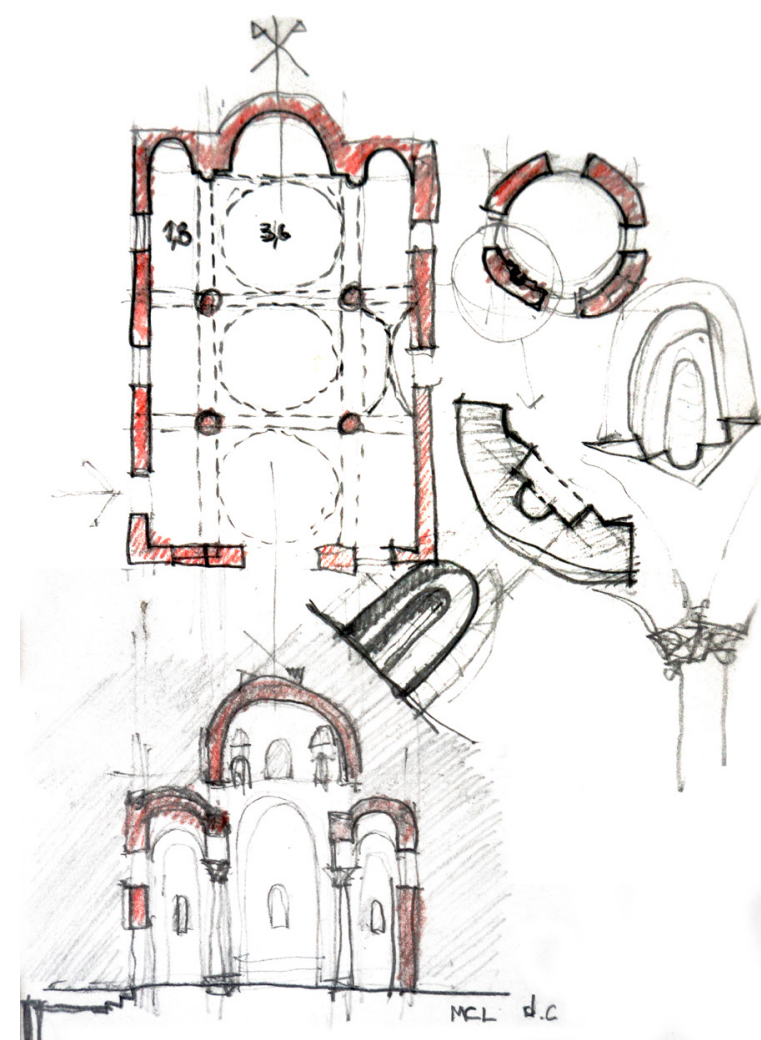

16 Igreja de San Cataldo, Palermo, Itália, 1160 circa - croquis do autor
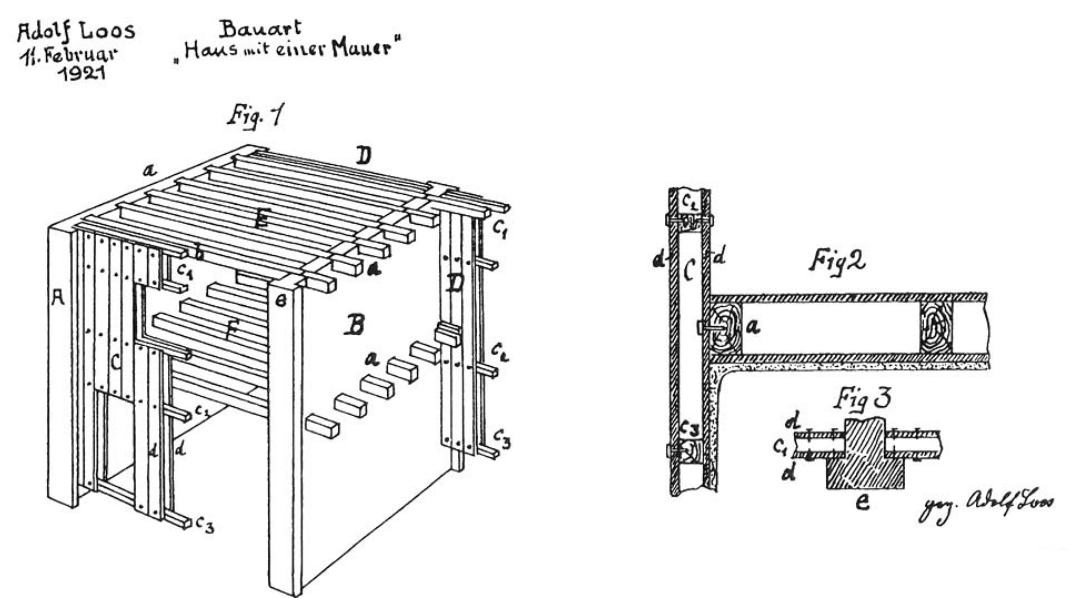

17 Haus mit einer Mauer, a casa de um muro só 


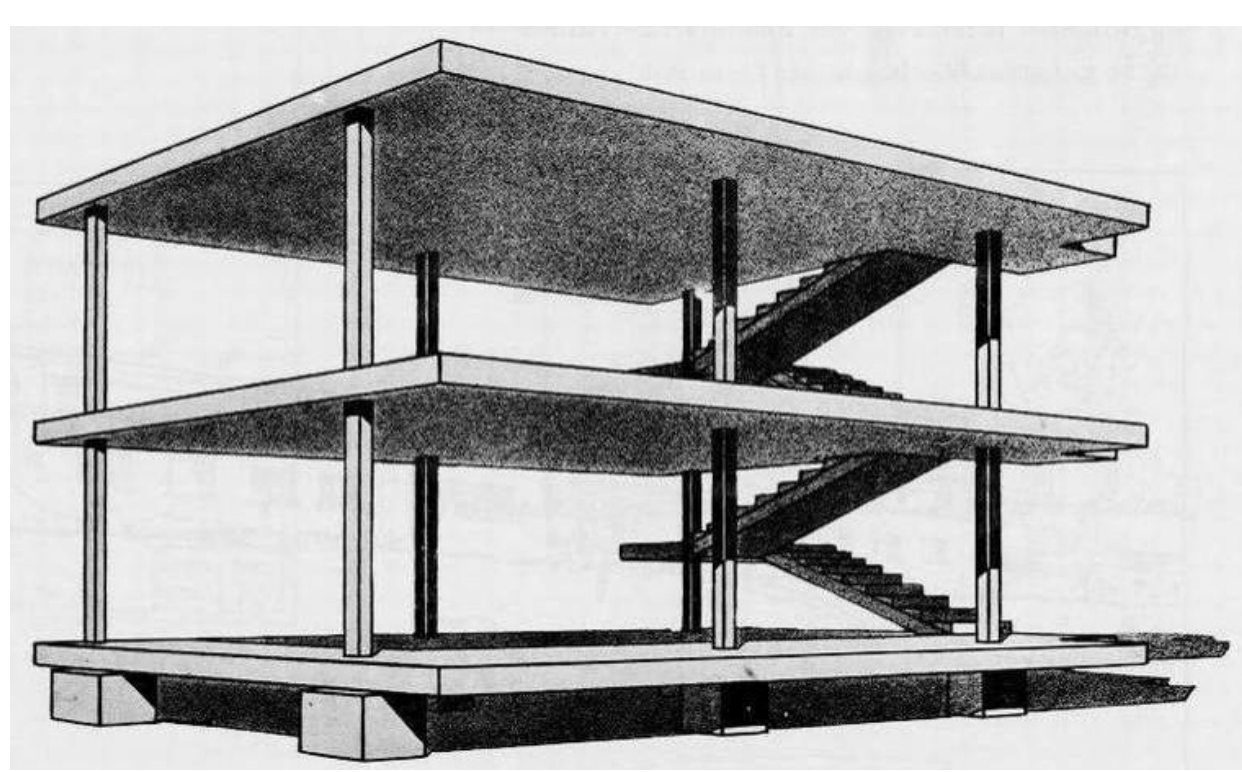

18 Maison domino

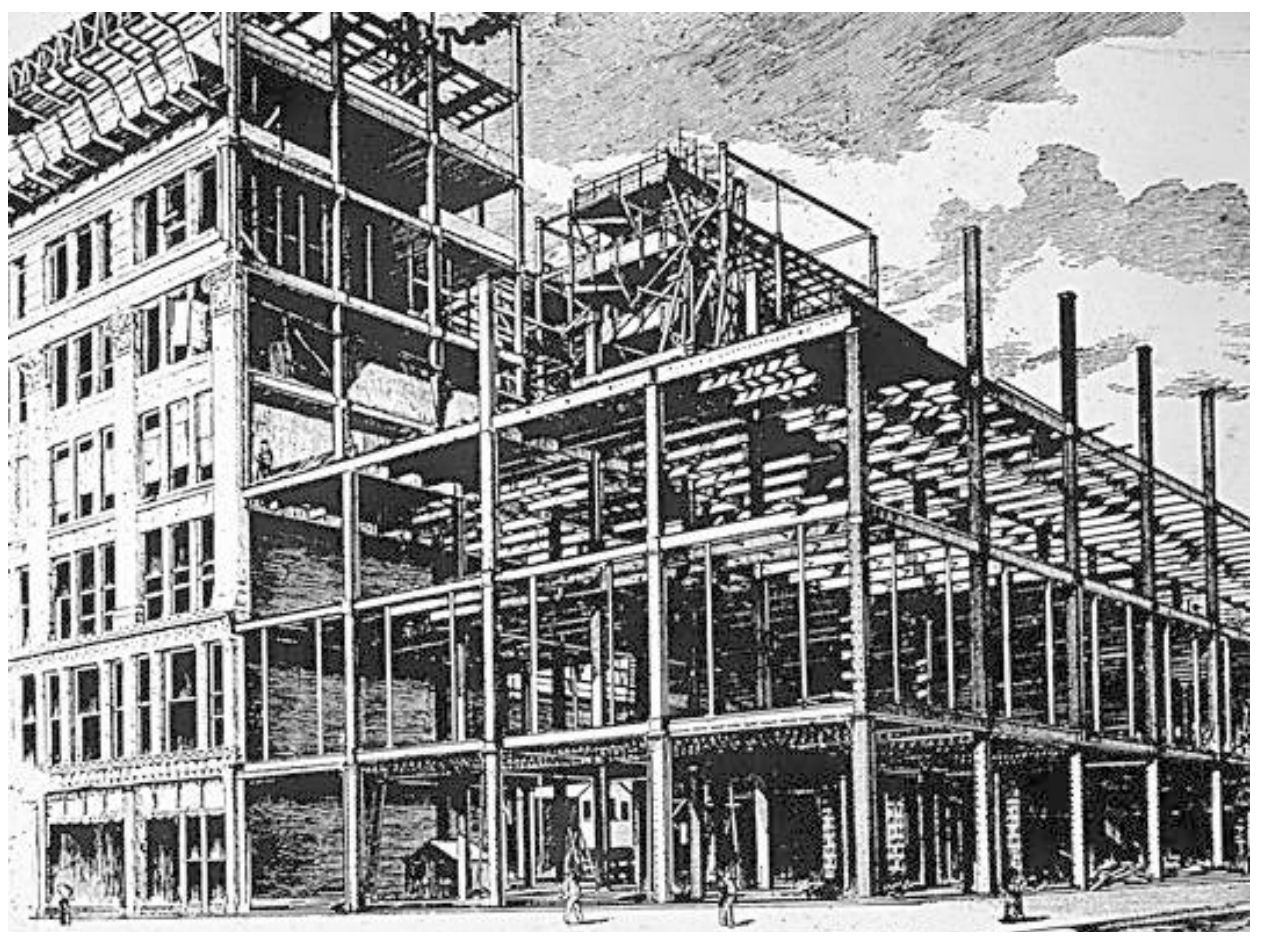

19 Fair Store
40. ROCHA, Paulo Mendes da, 2013, entrevista concedida ao programa Roda Viva da TV Cultura de São Paulo em 10/06/2013, disponível em: <https://www.youtube.com/ watch?v=pVSg8ZY2V94> (acesso em 25/01/2015). Citação de 1 h21'20"

A partir desse, talvez possamos nos propor a fazer uma tentativa de analisar exclusivamente a arquitetura, portanto, deixando de lado a construção.

Essa postura acaba não sendo das mais usuais se comparada com a frequência com que falamos de construção sem necessariamente falarmos de arquitetura. Na presente dissertação pretendemos nos aproximar da primeira alternativa, falar de espaços e do vazio mantendo o foco na arquitetura. Acabaremos inevitavelmente tratando de materiais, sistemas e técnicas, mas parece - assumindo-se os riscos - ser interessante e atraente a ideia de termos o centro gravitacional posto na arquitetura puramente.

"O que a arquitetura pretende é fazer os vazios, os espaços usáveis, desfrutáveis, para amparar a imprevisibilidade da vida." 40

O elenco de elementos da arquitetura que são abordados na parte II, representam justamente a intenção de deslocar o foco da análise para os espaços da arquitetura, para o côncavo, o negativo, para a capacidade de conter que lhe é própria, de abrigar e de não se opor ao uso que recebe,levando assim a técnica e a construção (no sentido físico) para a 
41. ROCHA, Paulo Mendes da, 2013, entrevista concedida

ao programa Roda Viva da TV Cultura de São Paulo em

10/06/2013, disponível em: <https://www.youtube.com/

watch?v=pVSg8ZY2V94> (acesso em 25/01/2015). Citação de

1 h19' $55^{\prime \prime}$

posição de auxiliares, profundamente necessários, mas que cedem seu protagonismo à arquitetura da arquitetura.

Antonio Armesto, em seu El Aula Sincronica na abertura dos dois capítulos nos quais apresenta sua aproximação à arquitetura pelos trinômios ARP e MEB ilustra sua proposta de abordagem de arquitetura e de construção separadamente quando introduz o ARP. O intitula " $L a$ arquitectura de la arquitectura" alertando para o fato que usa o termo duas vezes com significados diferentes: o primeiro com sentido de ordem implícita na construção do pensamento, da mesma forma que o termo é usado em outras disciplinas, já no segundo uso se refere à disciplina da arquitetura propriamente. O capitulo seguinte se intitula "La arquitectura de la construcción" onde aborda a ordem implícita no pensamento sobre a construção.

"A FAU por exemplo é uma distribuição espacial que podia ser abstrata e que se consegue com a construção." 41

Para podermos abrir a pauta para a "distribuição espacial abstrata" será inevitável falar de construção.

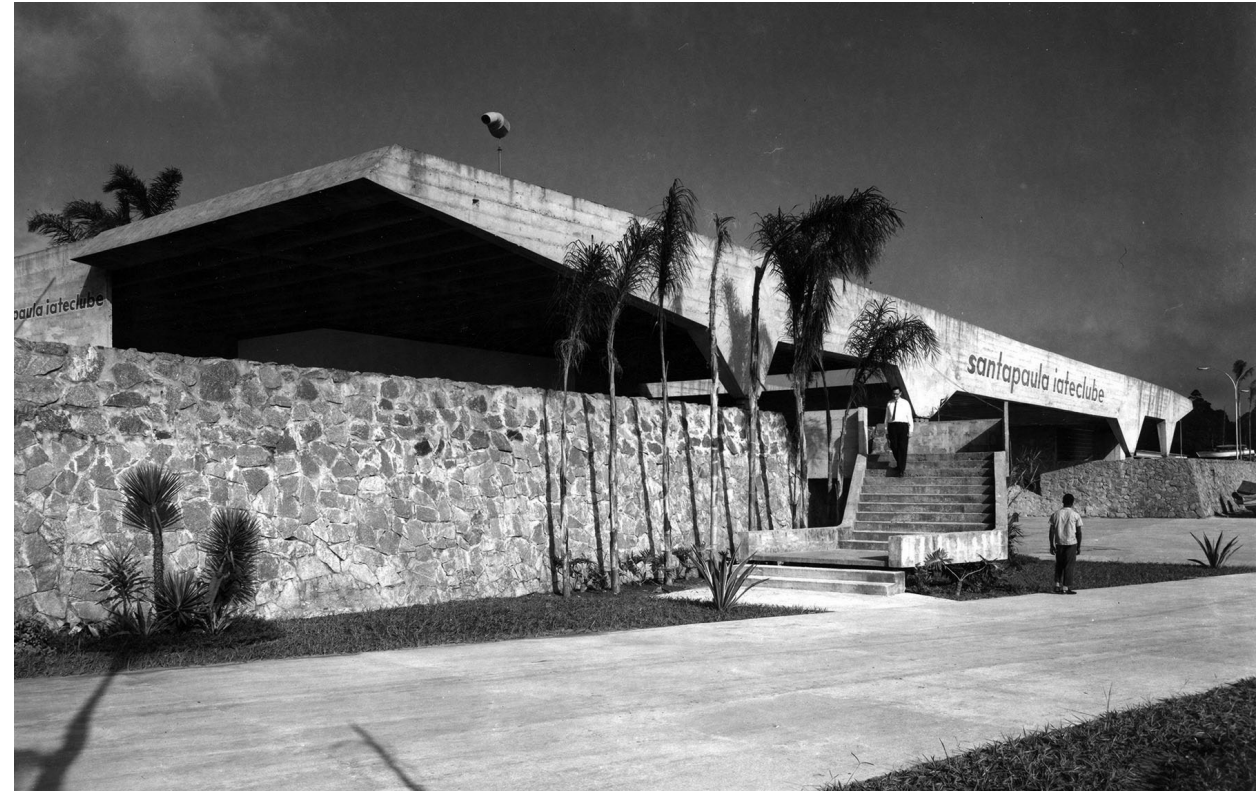

21 Murário e bandeja - Garagem de barcos Santa Paula - 1961

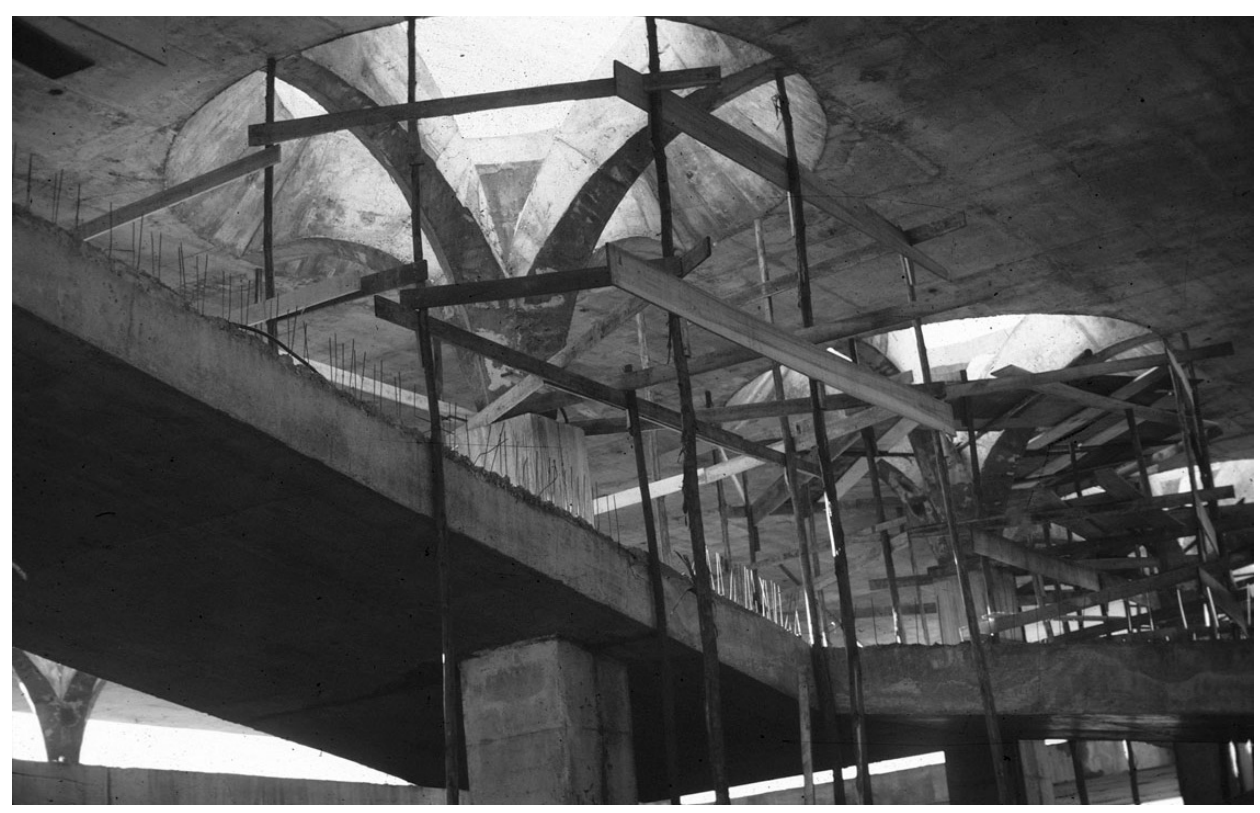

22 Entramado e bandejas - Estação Rodoviária de Jaú, 1973 


\section{MODELO E LABORATÓRIO}

Este capítulo está dividido em duas partes: na primeira (casa e modelo) explora-se o binômio experimentação-aplicação, na segunda tratase da mudança de escala da arquitetura, a validade dos modelos e a permanência de valores. Desenvolvendo a ideia central da dissertação, discorrendo sobre a obra de Vilanova Artigas a partir da casa como modelo de ensaios e das obras complexas como campo de aplicação.

\subsection{A casa como modelo}

Para introduzir a questão da casa como modelo convém retomarmos as sete acepções do termo levantadas por Rozestraten - anteriormente citadas ao tratarmos da terminologia - reproduzindo-as na mesma ordem em que são apresentadas pelo autor, porém numerando-as.

1. Modelo como conjunto de conceitos, premissas e formas (...).
2. Modelo como a referência escolhida pelo arquiteto para sua composição, seja uma ideia ou forma material.

3. Modelo como sistema experimental (...).

4. Modelo de teste pré-série, ou protótipo, (...) feito como "primeiro tipo" para teste de uma produção seriada.

5. Modelo como tipo, categoria, gênero de objetos.

6. Modelo significando as diversas representações planas da arquitetura (...).

7. Modelo como representação tridimensional de um objeto ou arquitetura feita em escala (...). $4^{42}$

Com exceção das de número 4 e 6, todas as demais são válidas como acepções para modelo ao refletirmos sobre a apropriação da oportunidade de projetar casas como momento de experimentação. A questão principal levantada por essa pesquisa, que está inclusive no seu título, guarda proximidade especial com dois dos significados listados acima, os de número 3 e 7, são reproduzimos abaixo na íntegra do texto, como Rozestraten propõe em seu "Estudo Sobre a História dos Modelos Arquitetônicos na Antiguidade" (2003 pg. 10): 
"Modelo como sistema experimental material ou eletrônico, construído com o intuito de auxiliar a formular ou testar uma hipótese relacionada ao desempenho de um ambiente, sistema construtivo ou de material específico."

"Modelo como representação tridimensional de um objeto ou uma arquitetura feita em escala matemática. Essa representação pode se referir a uma arquitetura existente, uma arquitetura em projeto, ou uma arquitetura não mais existente. Quando essa representação é feita em escala reduzida, denomina-se maquete."

Ao resgatar esses dois significados, as outras acepções elencadas relacionadas à modelo (tipo, categoria, gênero de objetos trabalhados no capítulo de terminologia) ficam temporariamente afastadas para centrar-nos naquelas que se aproximam mais da ideia de que o processo projetual para uma casa pode gerar um modelo. Ou dito de outra forma, que este processo pode ser visto como análogo ao processo de criação de uma pequena maquete executada porém em escala matemática de razão 1:1, fato que lhe garante uma série de vantagens; a principal poder ser visitada.

Não podemos ignorar que o processo de criação de um projeto e consequente construção de uma casa sejam longos e complexos e que têm um fim determinado, que é a produção da arquitetura. Mas tampouco é desprezível o efeito que essa obra construída terá como portadora de boas soluções, representante de relações harmônicas entre as partes e o todo, qualquer casa bem sucedida pode chegar a se converter eu um modelo de arquitetura.

Um arquiteto não encontra apenas dentro da própria obra as referências das quais lança mão ao projetar, no entanto, deve-se considerar que suas próprias obras participam como modelos para sua arquitetura, com forte presença. Essa questão certamente está presente em todas as artes e campos da cultura.

O que nos leva a nos aproximar de outra acepção para modelo proposta por Rozestraten (a de numero 2, acima)

modelo como a referência escolhida pelo arquiteto para sua composição, seja uma ideia ou forma material.

Esse processo imaginado como cíclico, em constante repetição e retomada, gerando uma sucessão de eventos, muitos até simultâneos, como pode ter ocorrido no caso de Artigas projetando simultaneamente uma casa e um edifício público, ao longo de sua 
43. ACAYABA, Marcos, entrevista à revista Caramelo, $n^{\circ} 3$, GFAU, outrubro, 1991, op.cit., pg.11, grifo meu.

44. ARTIGAS, João Batista Vilanova, Acrópole, nº 368, dezembro 1969, pg. 13. Apud. ZEIN, Ruth Verde, op. cit., pg, 4.

45. ZEIN, Ruth Verde, Artigas pop-cult: considerações sobre a cabana primitiva, a casa pátio e quatro colunas de madeira. 2013, pg, 4 .

produção no tempo, todo esse cenário nos leva à imagem de um laboratório, um campo fértil de experimentação, dentro do qual foram sendo moldados os edifícios.

"A década de 60 era da arquitetura de testes. (...) onde havia muita experimentação a nível de racionalização da construção, racionalização dos próprios espaços, (...)e cada casa era um ensaio, modelo de organização da família perante a sociedade, a cidade. (...) nos anos 70 os programas mudaram completamente (...) Houve um rápido enriquecimento (...) na área de casas, houveram produções onde essas teses foram um pouco esquecidas e o que se fez foram as grandes estruturas. O que restou foi a perspectiva de ensaiar na casa o edifício público." ${ }^{\text {43 }}$

\subsection{Mudança de escala}

A grande escala em arquitetura necessariamente carrega em sua estrutura primordial, em seu tipo a experiência da casa.

"O repertório de formas que os arquitetos empregam na organização do espaço das habitações é diferente do que empregam para outros programas. Fácil de afirmar, isto. Nem faltam justificativas, todas elas repetidas com freqüência, gastas pelo uso. Entretanto, trata-se de questão que merece maior exame. Construir, foi para o homem, primeiramente, construir sua habitação. Alojar-se no espaço, dominá-lo como parte da natureza. ${ }^{44}$

Segundo Ruth V. Zein (2013) a necessidade de enfrentar novos programas, quase todos nascidos da revolução industrial e da 


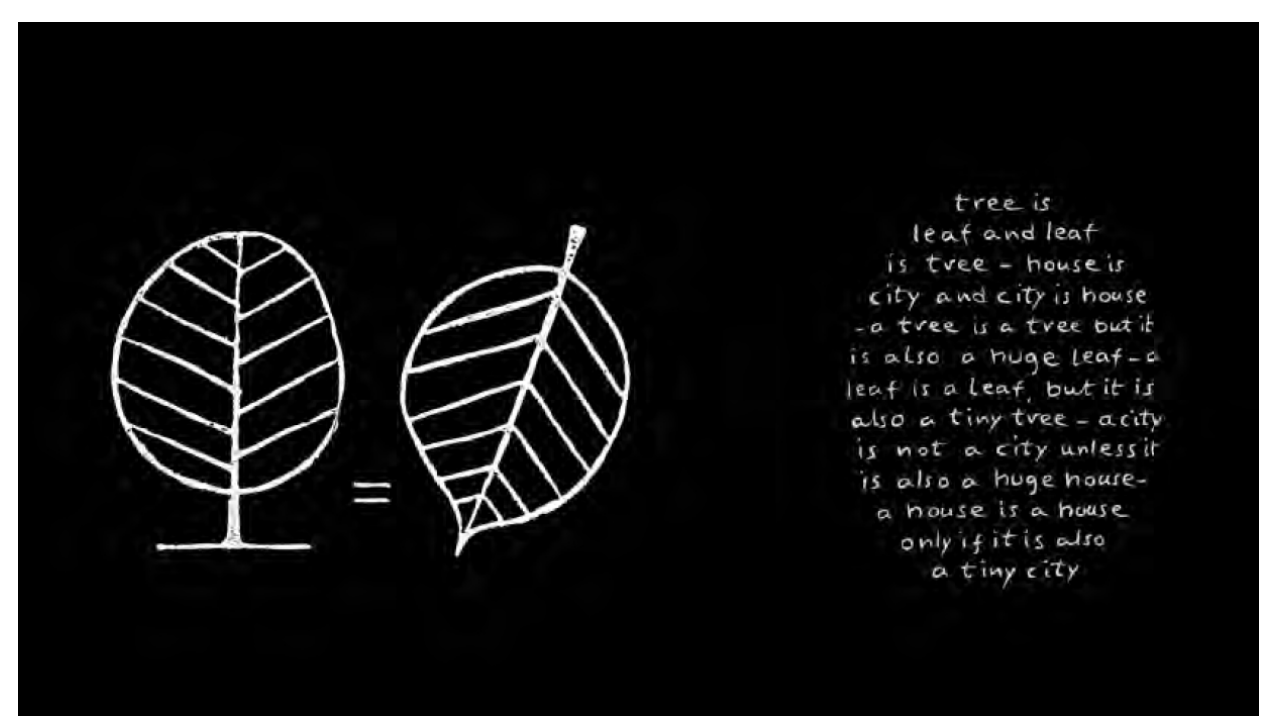

23 "a tree is a leaf", Aldo van Eyck

intensa urbanização nos séculos 19 e 20, e por serem recentes e pouco estabelecidos, exigirá soluções altamente inovadoras. 45 Dentro dessa necessidade de inovar e frente ao fato de que a grande escala não carrega detrás de si a mesmo repertório de soluções que o enfrentamento do programa doméstico, surgem uma série de ações compositivas e projetuais que a arquitetura vai enfrentar, tendo a casa como elemento primordial. Os tipos arquitetônicos primordiais da residência serão revisitados, mesclados, expandidos e justapostos para gerar o edifício complexo, que atenderá aos novos programas do edifício público. Esse é o contexto que encontramos na obra de Artigas quando passa a enfrentar a grande escala, surgem os edifícios mistos, híbridos, politípicos, etc. mas que sempre prezervarão os tipos ancestrais na estrutura profunda de sua forma. 

PARTE II 


\section{RELACÕ̃ES ANALÓGICAS}

Para que a análise ocorra e se possam identificar as analogias, semelhanças e equivalências entre as obras selecionadas nessa abordagem são necessárias duas ações essenciais, a primeira é a de desenhar, depurar, filtrar e percorrer novamente os traços que representam as obras. A segunda é a de dispor os desenhos que representam as obras em igualdade de condições entre si - sejam desenhos instrumentados da arquitetura, sejam os desenhos resultantes da ação primeira analítica - colocados numa situação que possam ser vistos sincronicamente.

\subsection{Desenho}

"No processo dialético entre pensar e construir, entendemos que o desenho é também pensamento espacial, ele se forma na mente e não apenas figura no papel. É aquilo que põe em relação as distintas variáveis de um projeto em curso. É um meio plástico, móvel e flexível que encontra correspondência no manejo do meio espacial." 46

Catherine Otondo ao fazer essa conceituação envolvendo pensamento, espaço e desenho lança luz sobre a interdependência entre o desenho e a formação do pensamento espacial, deixando em evidência que o desenho é ferramenta capaz de por em relação as variáveis de um projeto. Em nosso entender, o desenho também pode nos permitir fazer o caminho contrário, e ao invés de pôr em relação a variáveis o usaremos para isolar os distintos elementos de uma obra. Essa é a grande força que o desenho tem em análise de projetos. 
Ao redesenhar as obras nos obrigamos a exercitar o olhar. A simples ação de colocarmos um papel transparente sobre uma representação gráfica de determinado edifício e começarmos a traçar linhas, nos força, a isolar determinado elemento em relação a todos os outros. Podemos representar apenas a massa construída, só as aberturas, o terreno, o teto, o opaco, o volume, a forma. Estaremos decompondo a obra ao separarmos os elementos, sistemas e proporções que a integram, até que o ato de desenhar nos ajude a entender sua estrutura 47 .

“...muchos(...) coinciden em considerar la abstracción como una operación intelectual que equivale a separar, mentalmente, lo que en realidad resulta inseparable. (...) Cualquier operación analítica, en la medida que comporte el desglose de un todo unitario de sus componentes básicos, implica un cierto grado de abstracción." 48
Mesmo exercitando o olhar e o gesto, e através do processo que o encadeamento dessas duas ações estabelece com a percepção e pensamento, estaremos atados - nessa decomposição a que chamamos física mesmo sendo gráfica - a desenhar os limites, a construção. Um caminho possível para identificar o espaço que estes contém; ler a arquitetura contida na construção.

A partir do método de se colocar em visão sincrônica todas as obras assumidas para a dissertação, surgem duas formas de tabelas analíticas. Uma de agrupamento das obras por tipo e por tamanho, e outra em função dos vínculos que estabelecem entre si, onde se indica também o caráter e o grau de completude desses vínculos. 


\subsection{Tabelas analógicas}

\subsubsection{Tabela analógica}

A visualização sincrônica das obras selecionadas é dada pelo agrupamento por famílias tipológicas (indicados em colunas na tabela) em que se evidenciam as casas e os edifícios classificados em função do tipo em torno ao qual estão estruturados. Representados, portanto, em uma mesma área da tabela. Além dos tipos descritos anteriormente - pátio, teto e aula - também são levantados exemplos de obras que podem ser vistas como tipos híbridos, posicionadas então em zonas intermediárias da tabela.

\subsubsection{Tabela sincrônica}

A tabela sincrônica tem função distinta: deve ser possível nela visualizar objetivamente e comparar, em igualdade de condições, os desenhos das casas e edifícios. A tabela trás para dentro do campo visual do leitor, um conjunto amplo de referências que podem ir desde um par até um grande conjunto delas, e ao trazê-las simultaneamente para dentro do campo visual, facilita o encontro de vínculos entre as obras. Pode apresentar os desenhos na mesma escala, então

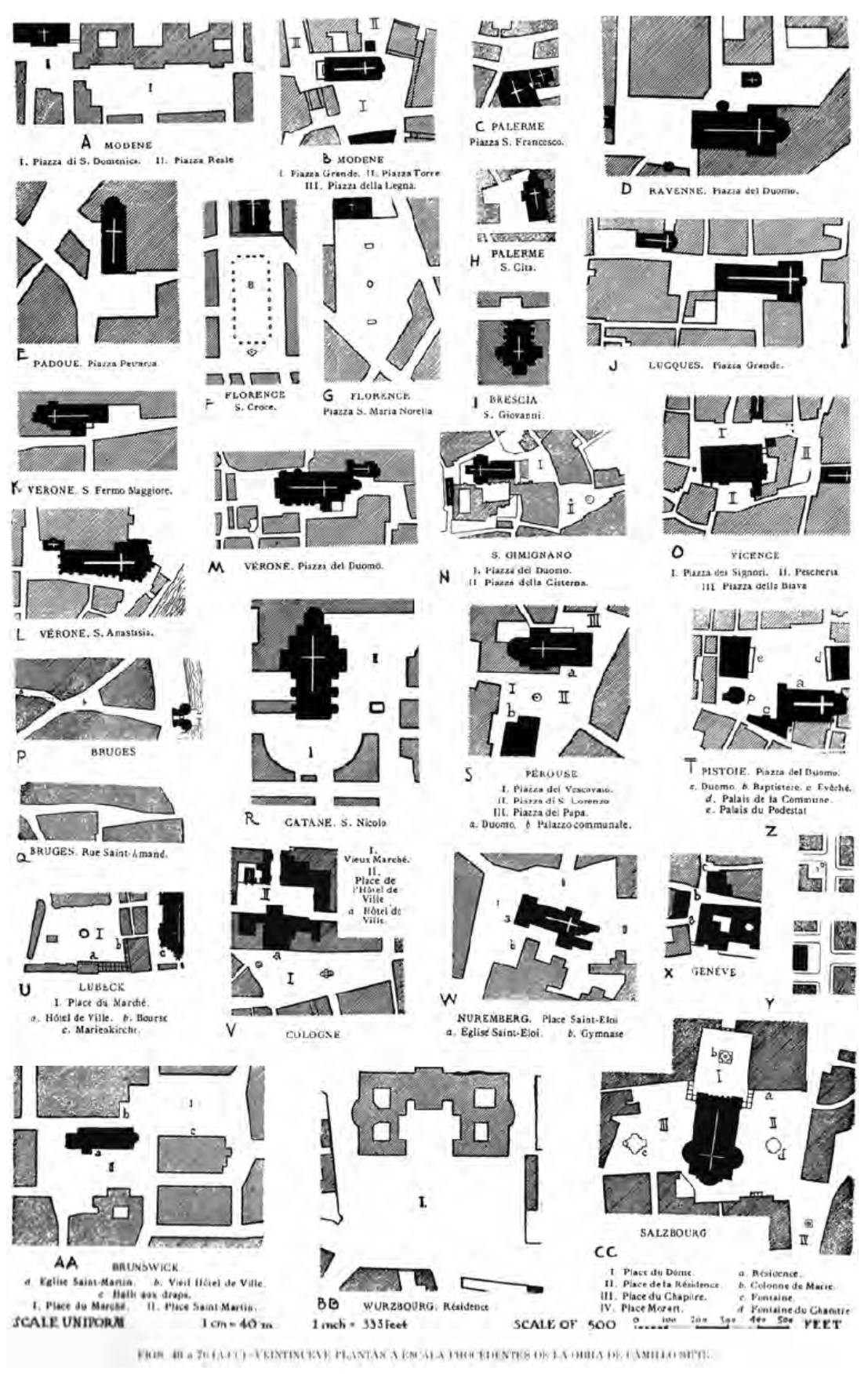

24 Tabela analítica, JNL Duran 
será ferramenta de análise não apenas de da forma mas também de proporções e escala. É análoga às convenções presentes nos desenhos de arquitetura, à planta baixa ou ao corte, que nos permitem ver ao mesmo tempo (em sincronia) fachadas opostas ou pavimentos não adjacentes, uma vez que esses desenhos de arquitetura contam também com a sincronia como parte da convenção.

Foi organizada com lógica cartesiana: no eixo horizontal estão posicionadas as dez casas projetadas por Artigas que são objeto de entrada da análise. No eixo vertical as obras de grande escala e uso público - também de sua autoria. O centro da tabela é campo de livre associação entre elas.

O uso da tabela pressupõe um estudo prévio das obras em análise. Com esse objetivo elaboramos o resumo iconográfico das obras recortadas de Artigas.

As imagens que representam os edifícios são menções visuais 'imagens-lembrete' - de cada obra. Sua leitura/uso ocorre da seguinte forma: a identificação de similaridades ou aspectos em comum em duas obras pode ser conferida cruzando coluna de uma com a linha de outra, e no quadro correspondente ao cruzamento se indicado o tipo de vínculo identificado.

No uso que se faz da tabela nesse exercício propomos a busca por relações analíticas em função de vínculos ligados a cinco temas da arquitetura presentes nas obras de Artigas, principalmente:

\section{terrapleno, cobertura, fachada, pátio e ponto de apoio.}

Feita essa leitura, a partir do elemento vinculante, há a identificação do tipo de vínculo, esses foram classificados em formas de analogia.

Duas obras poderão se relacionar por: afinidade, valores e significado, oposição/negação ou analogia completa. Foi criada uma codificação cromática para indicar estas variáveis

A sistematização representada na tabela não esgota as relações analógicas possíveis, mas permite uma leitura completa das possibilidades de vínculos e analogias entre os edifícios e, a partir dessa rede de relações foi possível definir e decidir os temas, elementos e tipos mais relevantes para os ensaios feitos na segunda parte da dissertação. Cada um dos vínculos possibilita e respalda a abordagem de algum tema próprio da arquitetura, a partir de um fio condutor geral, que é a obra de Vilanova Artigas 


\section{ELEMENTOS DA ARQUITETURA}

O Movimento Moderno negou veementemente os tipos seculares ao representar um momento histórico de ruptura. Afirma-se que foi influenciado pelo deslumbramento por todas as novidades técnicas da época. Conforme Jorge Pessoa de Carvalho destaca em sua dissertação:

"Para Le Corbusier somente uma nova arquitetura poderia exprimir o "espírito novo" da "civilização maquinista" e seria capaz de enfrentar os problemas decorrentes dos processos de industrialização e urbanização assistidos desde a virada do século" 49

Esse anseio pelo novo que Carvalho nos trás encontra ecos nas afirmações de Paulo Mendes da Rocha em seu texto Genealogia da imaginação, carregadas de ruptura e negação.
"A arquitetura contemporânea é essencialmente o desenho da cidade e não sua decoração com uma sucessão hedionda de artefatos esdrúxulos. É preciso desatar o nó da divisão esquizofrênica entre arquitetura e urbanismo, entre arte e técnica, arte e ciência."

"O Arquiteto Vilanova Artigas legou-me essa visão crítica. Minha arquitetura sempre foi inspirada por idéias, não evoca modelos de palácios ou castelos, mas a habilidade do homem em transformar o lugar que habita, com fundamental interesse social, através de uma visão aberta, voltada para o futuro." 50

Ainda que o trecho citado esteja dentro de um contexto no qual Paulo Mendes da Rocha tratava da escala urbana, não deixa de ser emblemática a negação que faz aos palácios e castelos como modelos, aqui, bastante carregada de viés político, já que vinha tratando - no trecho que antecede ao texto citado - da cidade feita de palácios e monumentos, como símbolos da burguesia (dominante [sic]). A postura 
51. RECASENS, Gonzalo Díaz. La tradición del patio en la arquitectura moderna. In: DPA Documents de Projectes d'Arquitectura. Revista del Departament de Projectes Arquitectònics de la Universitat Politècnica de Catalunya (UPC), $\mathrm{n}^{\circ}$ 13, Dezembro 1997. Pág.6.

51. Arquitetura sem arquiteto no sentido antropológico, arquitetura feita pelo homem, quase sem ter a consciência da amplitude da disciplina e de toda a carga de conhecimento que o fazer preserva.

de Mendes da Rocha confirma a negação de modelos do passado, própria dos modernos.

Mesmo que tomemos a liberdade de considerar um período de praticamente cem anos como homogêneo e guardadas as devidas distâncias geográficas, parece evidente que a tônica modernista era a de negação do passado. A despeito do discurso entoado por seus arquitetos, o modernismo produziu obras que respondem a tipos históricos. Ainda que rejeitando os elementos universais e imperecíveis da arquitetura, fizeram bom uso deles.

Gonzalo Díaz Recasens em seu texto La tradición del patio em la arquitectura moderna nos aborda esse fato da seguinte forma:

"Tras los inicios del Movimiento moderno, en que se buscaba la ruptura con la tradición histórica, se recurre al origen y razón de ser de las formas remotas y ancestrales. A mi parecer, esta búsqueda de la esencia de la arquitectura, de lo imperecedero, desemboca en un progresivo reencuentro con las raíces y formas heredadas, y va presentando el patio como una forma labrada por el tiempo, cúmulo de buenas soluciones y valores espaciales, capaz de soportar muchas situaciones e intenciones arquitectónicas." ${ }^{\prime 1}$

A postura de negação das formas clássicas ancestrais entre os modernos talvez tenha durado pouco, no entanto, nunca se assumiu objetivamente esse universo como provedor de modelos. É possível afirmar que a postura de negação estava muito mais presente no ornamento, no decorum, do que no tipo e em sua capacidade estruturadora.

A produção de Artigas, acabou chegando a tipos da arquitetura ancestral, atemporal, arquiteturas sem arquiteto ${ }^{51}$ - talvez tenha partido desses tipos, mais concretamente - fazendo uso portanto de elementos que logo nos foram legados (também) pelos modernos entre os quais pode-se incluir Artigas. Contrariando os princípios fundadores do Movimento, os arquitetos fizeram uso desses elementos 


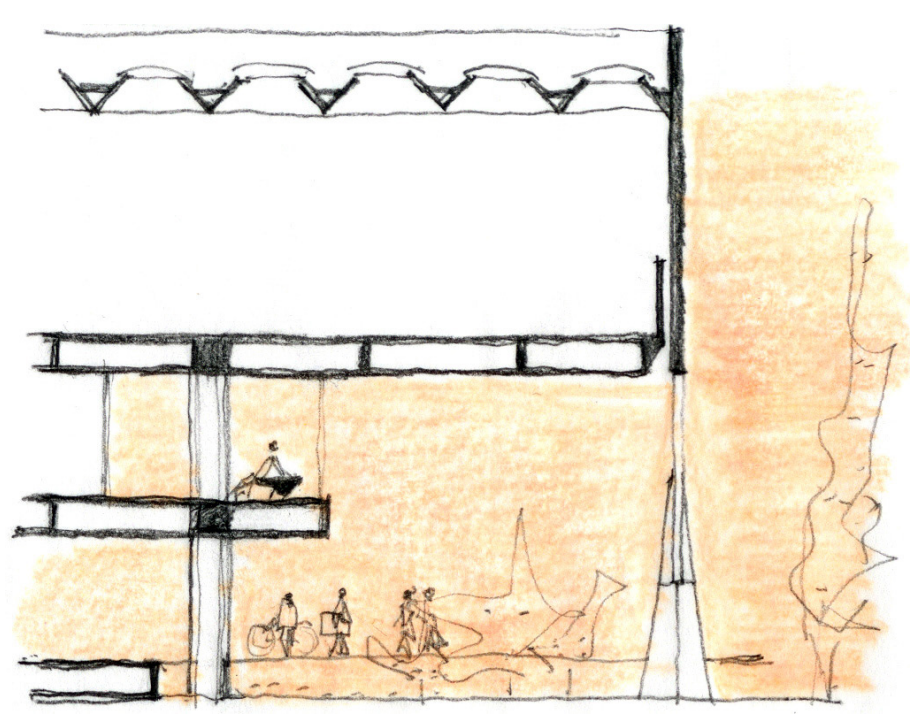

25 Peristilo de entrada da FAU

com tanta propriedade que é difícil se desvencilhar da ideia de que não foram propostos por eles próprios e sim revisitados ao longo do século XX, no sentido antropofágico, como uma reedição e posterior destruição da matriz, sem deixar vestígios da fonte que utilizaram.

Artigas em depoimento dado a Eduardo de Jesus Rodrigues e Fernando Frank Cabral, em 1978, faz a seguinte colocação sobre o projeto do edifício da FAU:

"Morria de medo de arriscar, aquilo tão simples como estava colocado. 0 que eles vão dizer disso? Não chega a ser nada. Não tem porta na entrada.

Eu queria que a entrada fosse como ela é: um peristilo, clássico, grego, e que não tem porta." 52

Essa constatação sugere para o arquiteto contemporâneo uma espécie de sensação de 'tranqüilidade transcendental' ao sentir que tudo na arquitetura está inventado, temos que rever, resgatar, reeditar, mas
52. ARTIGAS, João Batista Vilanova, in RODRIGUES, Eduardo de Jesus CABRAL, Fernando Frank, documentário, de andamento, disponível em <https://www.youtube.com/ watch?v=AbJ4siNjamI>, acesso em 25/01/2015.

53. Gonzalo Díaz Recasens atribui aos modernistas a capacidade de trazer elementos da arquitetura atemporal para a pauta da produção do séc.XX como se tratassem de grandes novidades. Não com o intuito de enganar, mas com naturalidade de quem ampara a arquitetura nos valores universais do homem.

54. Depoimento de Paulo Mendes da Rocha sobre Artigas, dado em entrevista para o documentário (atualmente em produção) a ser lançado por ocasião do centenário de nascimento do arquiteto. Disponível em: <http://www.vilanovaartigas.com/ centenario/artigos/artigas-por-paulo-mendes-da-rocha> acesso em 21 fev 2015 apoiados em bases sólidas. Artigas continuou revendo, atualizando, reutilizando tipos (casas pátio, tetos, palafitas, percursos, rampas, átrios, peristilos) e elementos que sempre se utilizou, mas com maestria os trouxe como novos, lustrosos e brilhantes ${ }^{53} \mathrm{com}$ a marca da novidade. É no universo desses elementos que a presente análise nos permite transitar.

"Vejo o Artigas com a força do homem primordial (...) ele era, com uma força incrivel, esse homem inaugural, se dependesse dele, tudo daria sempre certo." 54

Na segunda parte dessa dissertação, propomos uma abordagem analítica baseada em todos os elementos e preceitos teóricos apresentados até aqui e assim se inicia com uma decodificação dos projetos à partir da matéria, de vínculos e de espaços. 

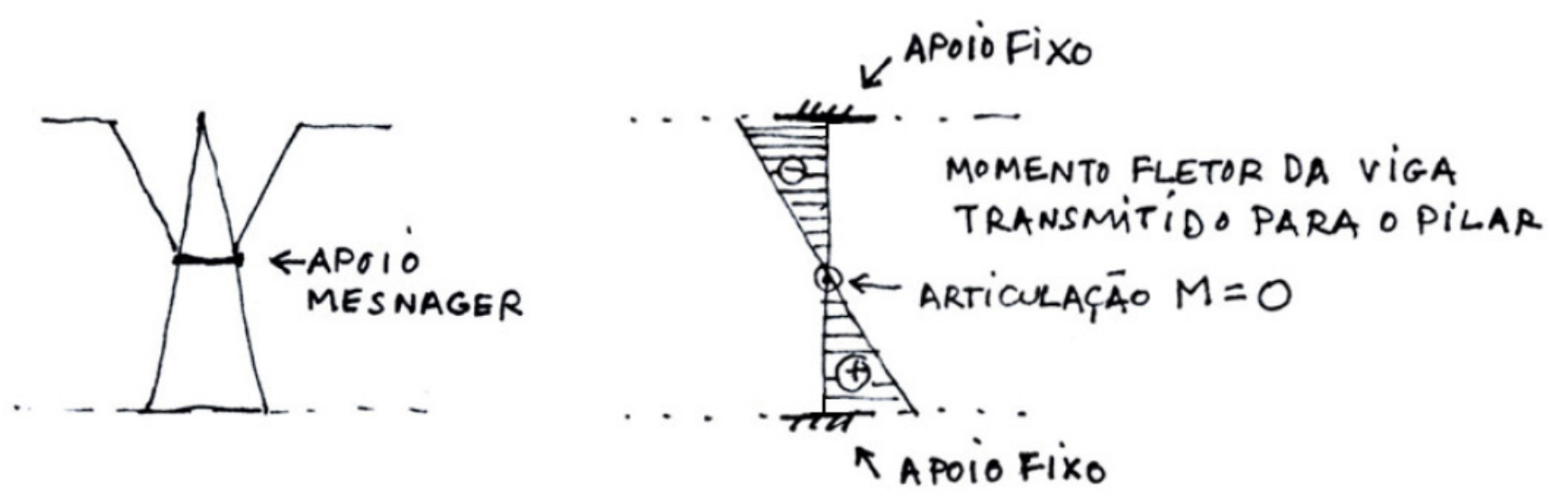

26 Pilar externo: momento fletor transmitido no sentido longitudinal ilustração e texto Ana Clara Giannecchini, sobre o pilar e os esforços, estruturais no edifício da FAUUSP in: op.cit. pg. 228
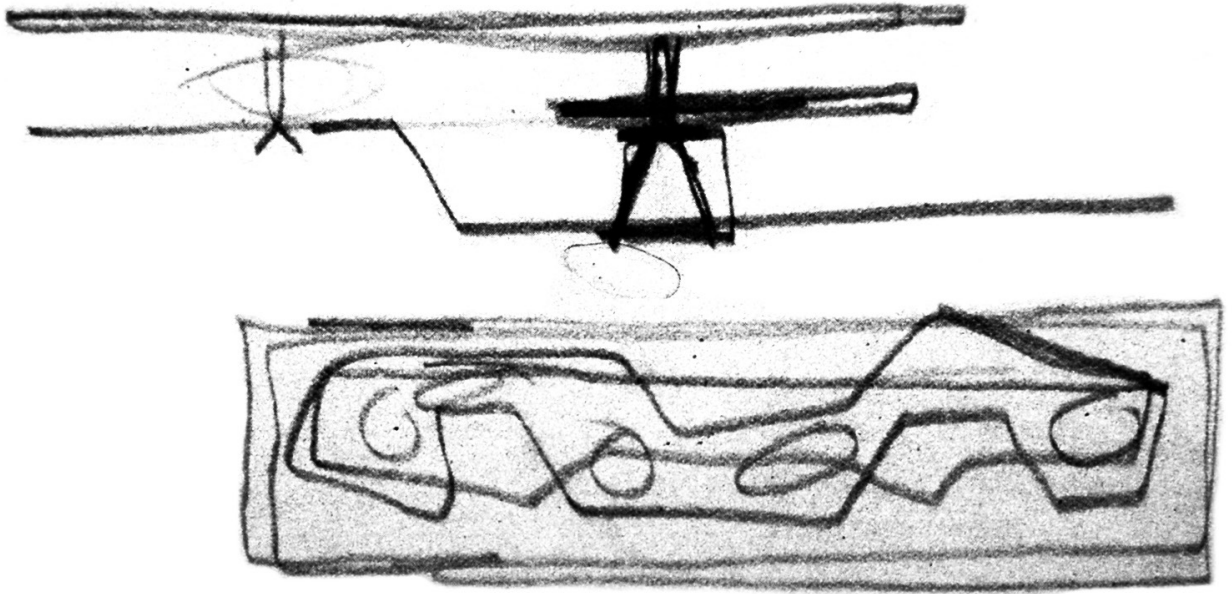

\section{Matéria}

- O terrapleno como ação primordial de projeto, corresponde ao sentimento; onde se constituirá um lugar, representa a ação fundacional da arquitetura. Nos interessará tratar do plano gerado pelo terrapleno que se desprende - elevado ou rebaixado - em relação à irregularidade do terreno natural, eleva o plano habitado em relação ao plano terrestre.

- A teto e a fachada são os formadores do limite na arquitetura, definem o dentro e o fora.

\section{Vínculos}

- O ponto de apoio surge na produção de Artigas como um elemento de celebração da técnica, do encontro entre a construção e o terreno. Das fachadas chegando ao terrapleno. 


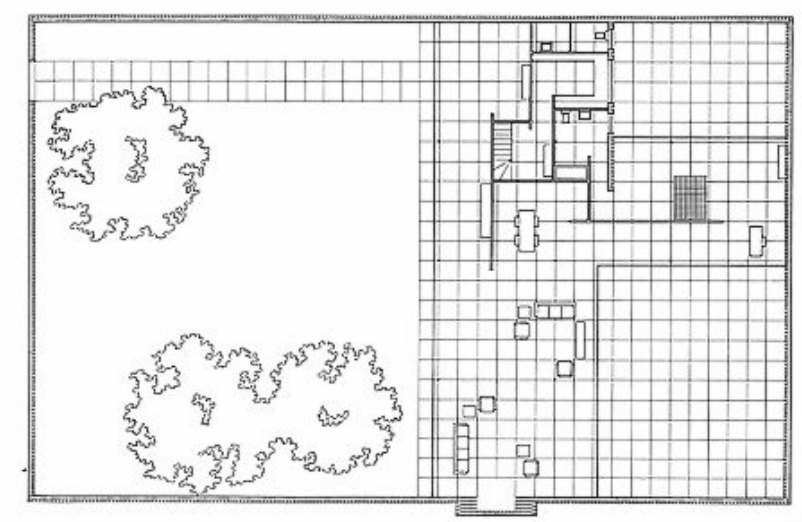

28 Casa com três patios, 1931-34, Mies van der Rohe

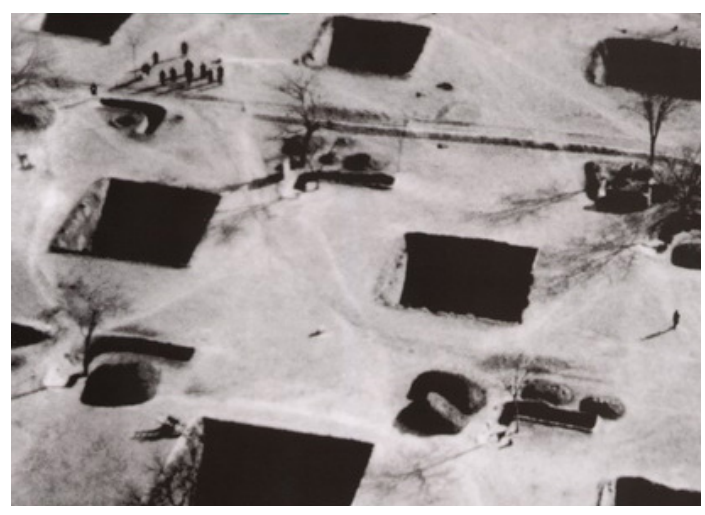

29 Revista DPA, número dedicado a casa y patio, Departament de Projetctes d'Arquitectura EtsaB, edicions UPC, 2001.
- A rampa é elemento vinculante entre a arquitetura e o sítio, assim como o ponto de apoio, mas não é apenas o ponto de contato e sim a materialização do processo de ascensão ao lugar. A rampa marca a transição gradual, incita a reflexões sobre o tempo na arquitetura, o tempo que possibilita a apreensão, é o percurso entre duas experiências espaciais dentro da mesma obra, é o silêncio que permite o reconhecimento de duas notas musicais.

\section{Espaço}

- O pátio contém a parcela de mundo controlável e a separa do universo vasto, é também lugar do fogo, ou pode ser simbolizado por ele.

\subsection{Terrapleno}

"A primeira ação que o arquiteto praticou nos terrenos vazios das casas Butantã e Millan foi a de cavar, constituindo uma nova topologia sobre a qual viria a implantar o volume das casas no lote." 55

A constatação que Catherine faz em relação aos dois projetos de Paulo Mendes da Rocha, também é válida para muitos projetos de Artigas selecionados para análise. Especialmente nas casas Baeta, Viterito, Casinha e Bitencourt II é muito evidente o terrapleno como primeira ação projetual, como apropriação do lugar.

Artigas propõe além da ação de cortar terreno a de aterrar, gerar planos horizontais elevados ou rebaixados, iniciando com essas ações a arquitetura. 
A construção foi iniciada com a abertura no terreno do espaço da fase, do escritório e dormitório, de maneira a

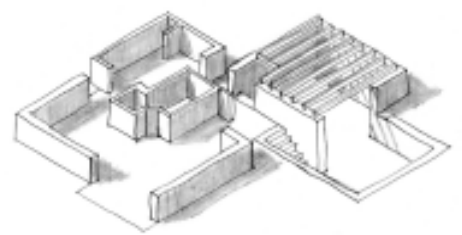

A segunda etapa foi constituída das alvenarias formando a sala, cozinha e banheiro, e sequência da anterior, tambent

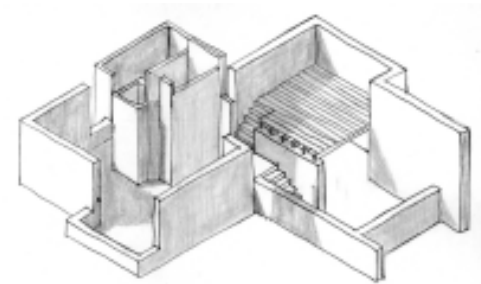

A continuação se deu até o levantamento de todas as

topografia irregular Artigas recria sobre o terreno um jogo de platôs e desníveis. Mas não é só em terrenos com topografia marcada que isso ocorre, sobre os lotes planos o arquiteto faz da movimentação de terras a primeira operação geratriz que vincula a arquitetura ao sítio, delimita determinada área de chão e para elevá-la ou rebaixá-la.

O projeto da Casinha (1942) parte da criação de um recinto, cravando as paredes no solo e esvaziando seu interior, para trazer a essa casa térrea, três níveis diferentes e assim atribuir-lhe o sentido da vertical. Cria também um pé-direito duplo que possibilita a colocação de um mezanino.
30 Processo construtivo por fases da Casinha, desenhos Marlene Yurgel.

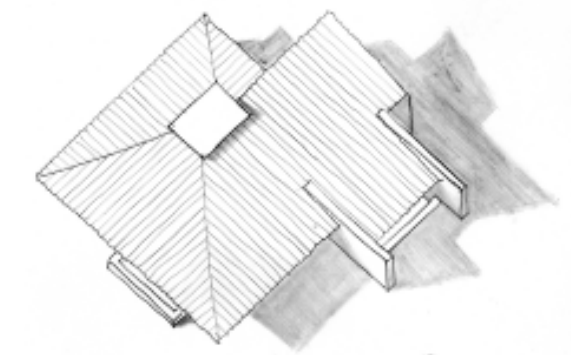

A etapa seguinte foi a construção do telhado, com espaços originais da cobertura de telha de barro 


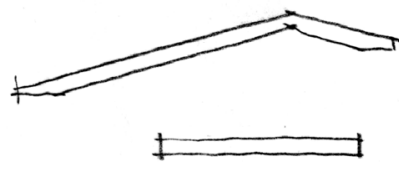

$\oplus$

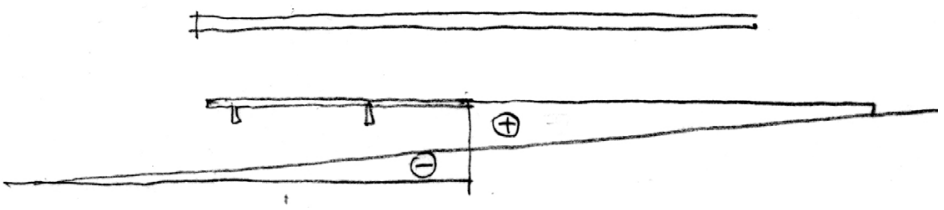

Viterito

Baeta

31 e 32 Esquemas sobre duas das casas estudadas e suas relações com o terrapleno. [croqui do autor]

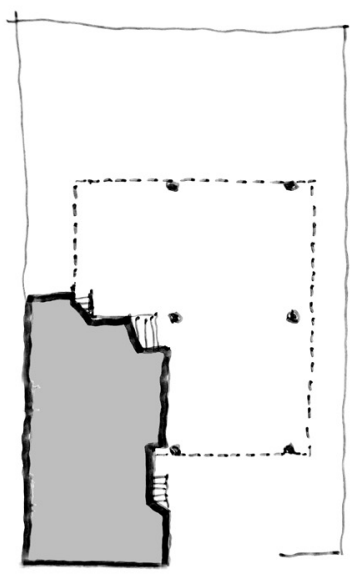

33 Casa Baeta - o terreno 'entra' debaixo da casa.
Na casa Baeta (1956) inicia pela ação oposta: no quarto esquerdo frontal do lote constrói um recinto retangular para ser preenchido de terra, forma assim o jardim elevado exterior que penetra e participa do interior em diálogo com os meios-níveis da distribuição do programa e com o patamar da escada. Na movimentação de terras surge a primeira ação construtiva, são erguidos muros que formam recintos logo preenchidos de terra; muros criados para trabalhar o terreno passam a fazer parte da topografia transformada. O prisma formado pelo platô ajardinado da casa Baeta, feito em alvenaria de pedras participa do jogo dos volumes do térreo ao se dispor sob o prisma branco de concreto, reconhecível formalmente como sendo a casa em si, portanto o terreno entra debaixo da casa.

A casa Taques Bitencourt (1959) reúne as duas operações - de corte e aterro - nessa obra Artigas repete as diretrizes compositivas da casa Olga Baeta, mas com uma mudança importante no protagonismo dos elementos. Também aqui aparece uma peça convexa, composta por muros de pedra à vista que se apresenta no alinhamento frontal. Comparado com seu análogo da casa Baeta, nesse projeto o prisma de pedras está coroado mais acima e sua parte visível passa a ter altura de um pé-direito completo,a parte invisível desde o exterior está fincada no solo, o que permite seu esvaziamento para abrigar parte do programa de serviços. Do lado externo ele faz um ajuste de terreno no sopé do muro, reduzindo virtualmente sua altura e criando um jardim inclinado.

O resultado das operações formais elencadas nessas obras e que vinculam a arquitetura ao lugar, pode abrir espaço para reflexões sobre a relação compositiva entre peça e embasamento, elevar o terreno para criar o rialzo, o pedestal, e ali pousar o objeto, nesse sentido a casa Mendes André (1966) conta com dois elementos construídos que cumprem a função compositiva de embasamento, apesar de não serem movimentos de terra em si, dois diedros feitos em alvenaria de pedra, relativamente simétricos apoiam - compositivamente - o corpo da casa ${ }^{56}$. O edifício para a garagem de barcos do Santa Paula Iate 

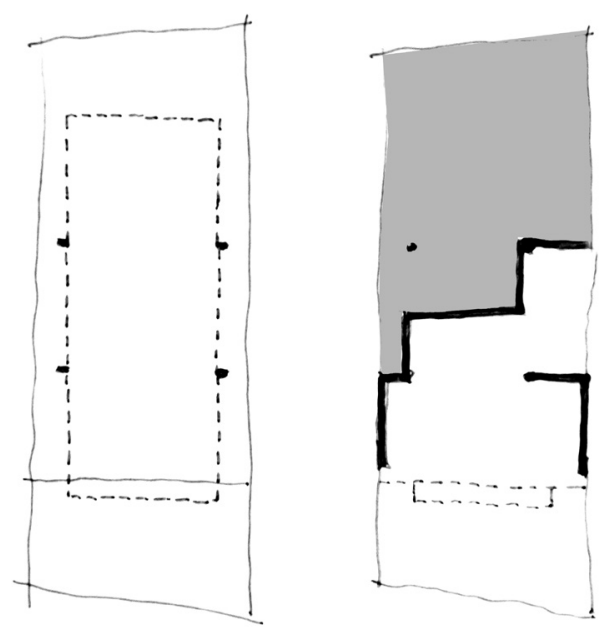

56. Esses muros são análogos ao embasamento de outras obras, mas nessa casa não têm função de arrimo, apenas de base compositiva.

57. Novamente nos deparamos com analogias, muito comuns no universo da teoria e da prática da arquitetura, que chegam praticamente a serem convenções, como ocorre ao mencionarmos as cargas como se fossem fluidos.

34 Casa Viterito - a casa 'entra' no terreno.

Clube está formado por operações compositivas análogas às da casa, também conta com duas peças como embasamento, sobre as quais se apoia - fisicamente, neste caso - o corpo principal. Nas duas obras as operações lógico-formais geratrizes dos projetos, são as mesmas.

\subsection{Ponto de apoio}

O pilar periférico é um elemento muito presente na obra de Vilanova Artigas, está diretamente associado às funções estruturais que as envolventes da construção assumem e por isso surge em diversos momentos como resposta para a questão física de fazer as cargas chegarem ao solo57. É um elemento da arquitetura trabalhado pelo arquiteto de diversas formas e assume uma ampla variedade de soluções. Artigas enfrenta o desenho do apoio como oportunidade para propor sempre um fato novo na sua arquitetura.

O pilar propriamente remetendo à imagem da coluna - seja cilíndrica ou de seção quadrada - de formas alongadas, mais alto do que largo com base e capitel definidos, acaba se tornando um elemento pouco presente nas obras mais emblemáticas, em especial se estiver situado na periferia da construção, onde é sempre trabalhado plasticamente como elemento singular. Sua posição periférica lhe dá a incumbência de se relacionar diretamente com as fachadas, fechamentos ou com a cobertura, como resultante do processo de interlocução entre estrutura portante e o solo. É com se fizesse do inevitável um motivo de celebração, as estruturas invariavelmente têm que chegar ao solo, aproximar-se da terra, e, nesse ponto de cada obra encontra o motivo para propor uma variante distinta, enriquecendo a relação plástica entre bandeja, pilar e fundações. Como se em cada obra aplicasse uma cariátide nova.

Na varanda da Casinha (1942) Artigas desenha uma única parede que é autônoma em relação à construção, um muro que corta o jardim e muda de direção duas vezes ao se aproximar da casa, para formar um 


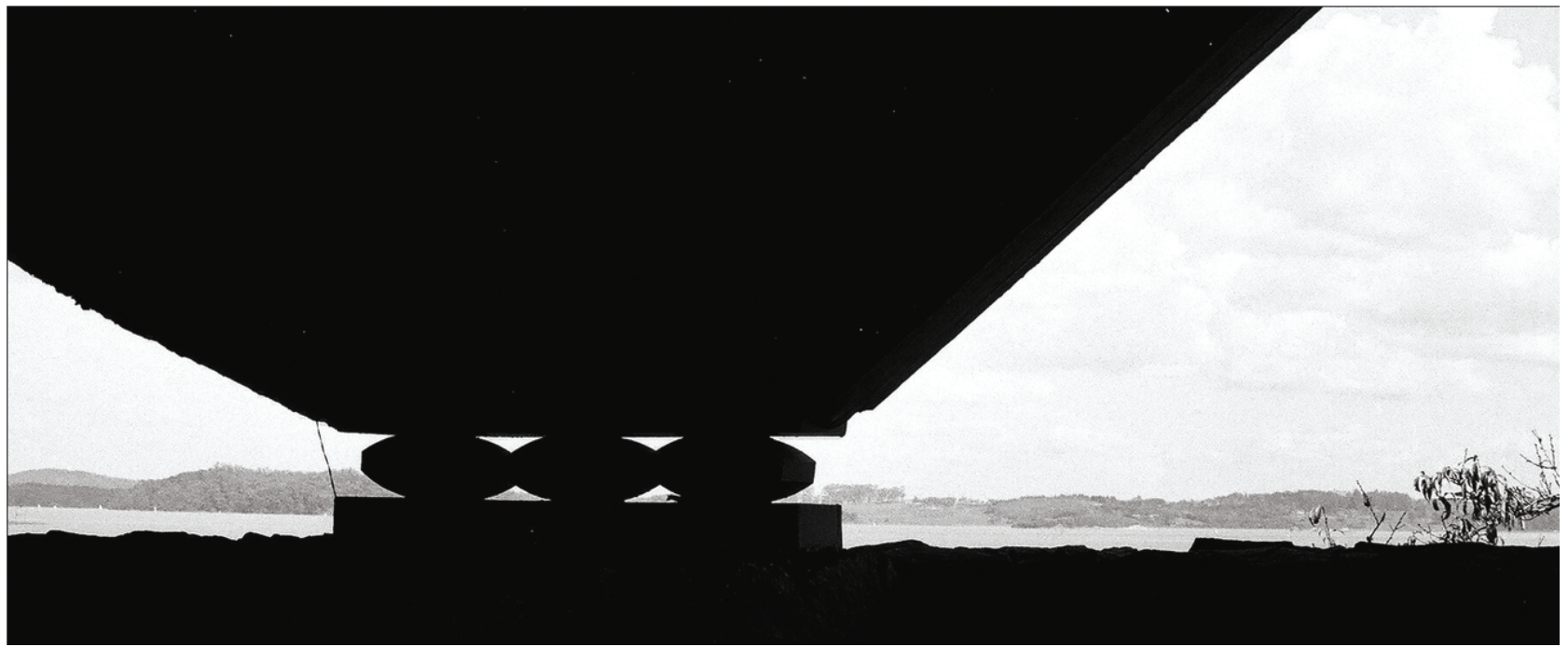

35 Garagem de barcos Santa Paula, 1970

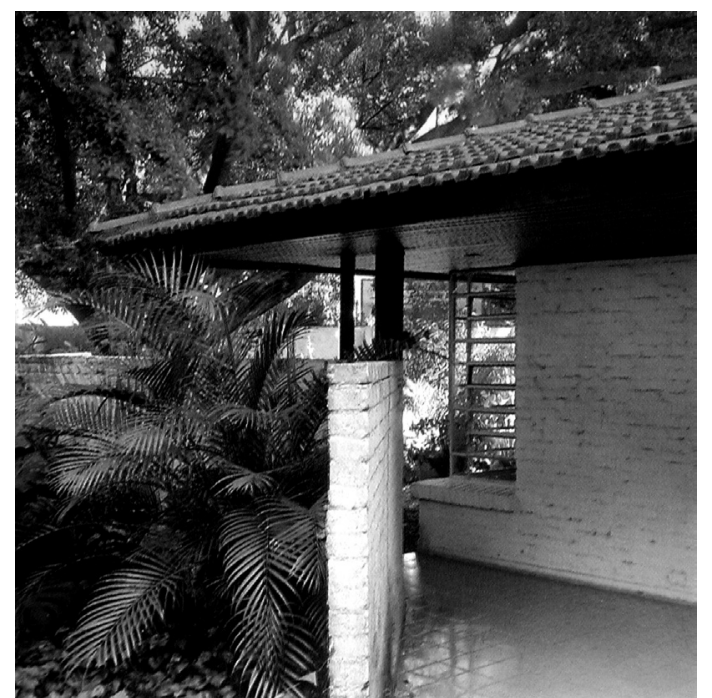

36 Casinha, 1942 diedro e apoiar um dos beirais da cobertura, aquele com o balanço mais pronunciado. Se estabelece nesse ponto uma relação pouco comum entre parede e cobertura, ainda menos usual em casas com paredes portantes. Em determinada fiada, antes de tocar o telhado, o muro para, em seu ponto de inflexão, recebendo a cobertura que, através de três pilares de madeira, repousa sobre o muro.

As paredes preservam assim sua função portante, como em toda a casa, e com as três hastes de madeira que vinculam cobertura ao muro Artigas menciona sutilmente a coluna, reduzindo-as em escala e número já que são os três únicos pilares dessa casa.

A forma de transição entre fundações e cobertura da garagem de barcos Santa Paula Iate Clube (1961) é análoga ao apoio da cobertura na varanda da Casinha; em ambos casos um elemento murário para a determinada altura para receber um apêndice da cobertura. A cobertura da garagem de barcos conta com oito pontos de apoio: os quatro voltados para a avenida apoiam-se diretamente no solo, já os quatro voltados para a represa de Guarapiranga apoiam sobre o muro de pedras faz as vezes de arrimo e resolve o terrapleno nessa obra.

Naturalmente estamos adotando aqui simplificações técnicas para facilitar a aproximação entre as duas obras. Resulta que os oito apoios da cobertura são feitos sobre roletes ou terminações metálicas, para que a longa estrutura de concreto possa dilatar e contrair sem um vínculo estrutural rígido com as fundações. Em um dos eixos da estrutura transversal, correspondente a dois dos oitos pontos de apoio, são três os roletes que fazem a intermediação entre a cobertura e o muro, coincidindo em número e posição relativa com os elementos de madeira que cumprem essa função na Casinha.

Na casa Taques Bitencourt II (1959) Artigas também faz do encontro das fachadas com o terreno um acontecimento formal e plástico interessante, por um prolongamento da empena lateral, em um dado momento em que já deve deixar de ser delgada para passar a suportar as cargas concentradas que lhe correspondem, e expande no sentido 
57. Com bastante segurança podemos afirmar que esse pilar resulta de uma questão plástica que vinha sendo trabalhada pelo arquiteto, já que as duas obras deveriam estar sobre sua prancheta mais ou menos na mesma época.

58. PONTES, Ana Paula Gonçalves, Diálogos silenciosos: arquitetura moderna brasileira e a tradição clássica, dissertação de mestrado apresentada à PUC-RJ em 2004, pg.87.

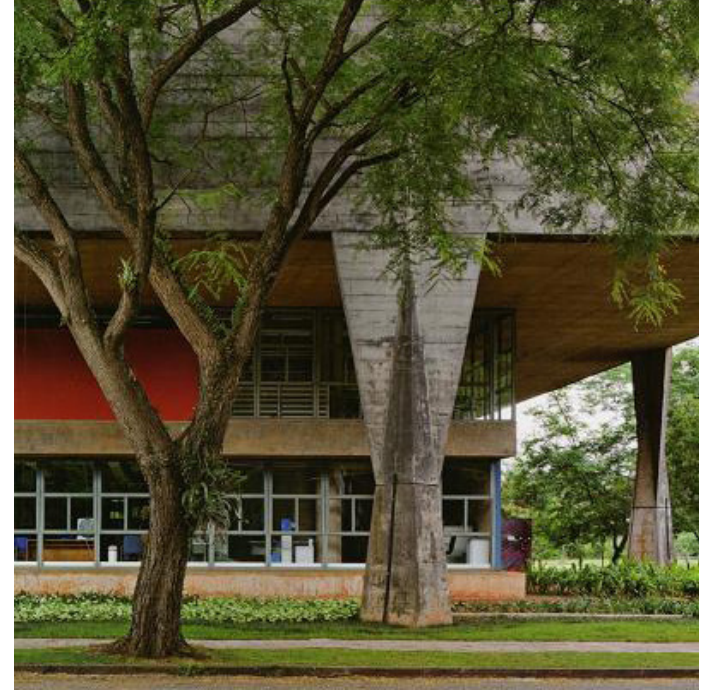

37 Faculdade de Arquitetura e Urbanismo da USP, 1961

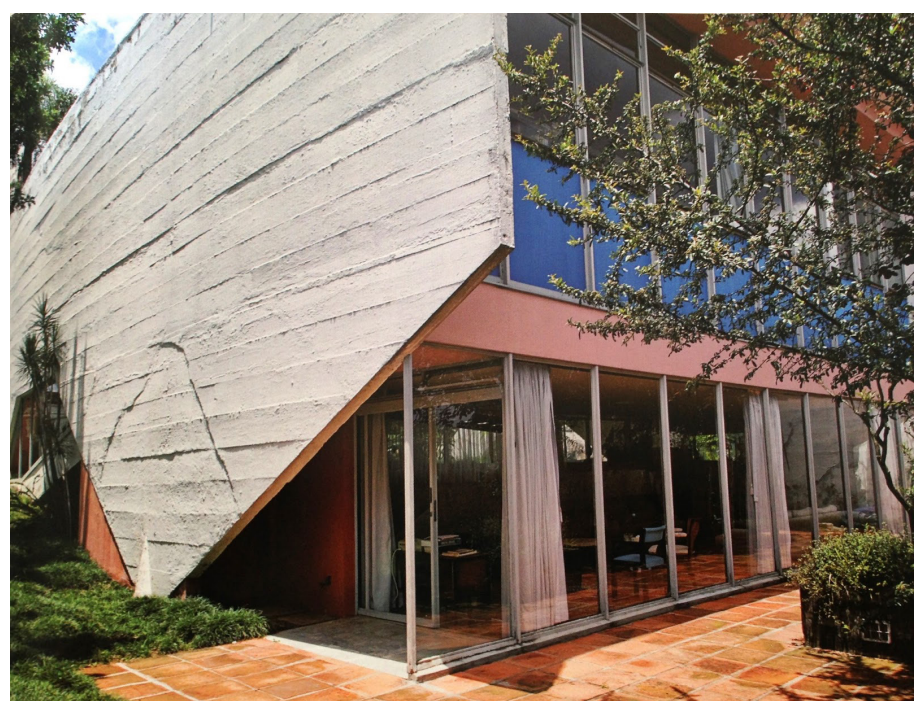

38 Casa Taques Bittencourt II transversal à sua espessura para assumir uma seção quadrada crescente na direção do solo. Foi bastante mencionada a analogia entre os quatro pontos de apoio periféricos dessa casa, de 1959, com o desenho dos pilares periféricos do edifício da FAUUSP57, construído dois anos depois.

Na composição das fachadas e pilares periféricos do edifício da FAUUSP, fica evidente a relação com a casa Taques Bitencourt II. A composição é muito semelhante, mas na FAU está distorcida pela ampliação da distância entre empena e terreno, o que obriga que as fundações subam mais para atingir a fachada, dando ao conjunto proporções mais alongadas verticalmente no edifício da Faculdade em comparação com o da casa.

A relação quase mimética entre as duas soluções construtivas citadas, não deixa de ser uma oportunidade para evidenciarmos a ideia de que Artigas estudava e aplicava hipóteses de elementos e espaços nas residências, para logo desenvolvê-los experimentando-os também nos edifícios de maior escala. Algo similar ocorre entre os pilares da casa Rubem de Mendonça e o edifício para Vestiários do São Paulo futebol Clube. É possível observar relações analíticas menos diretas e talvez mais ricas entre obras do arquiteto, inclusive diretamente relacionadas ao espaço e menos à construção. Não deixa de ser digna de menção essa semelhança sobre a qual cabe o seguinte grifo do texto de Ana Paula G. Pontes, ao se referir ao o ponto de apoio na obra de Artigas e de como essa questão surgiu na arguição quando no seu exame para professor titular da Escola, em 1984.

"A interpretação desses dois elementos (fachada e apoio) é ambígua, pois não permite decidir se é a parede suspensa que desce para buscar a base, ou se é a base que sobe para apoiar a parede." 58

Nessas quatro obras citadas até aqui, o ponto de apoio está vinculado à ideia de união pelo elemento que faz a ligação entre as fundações que afloram do terreno (ou muros) e as fachadas que descem e se transformam plasticamente para se tocarem nesse ponto singular. 


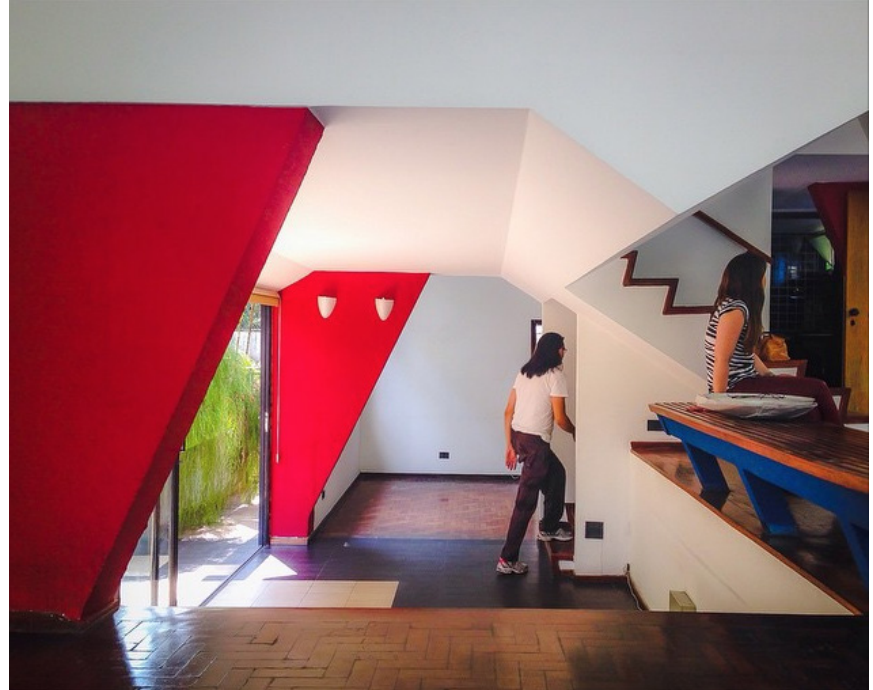

39 Casa Bubens de Mendonça, 1958

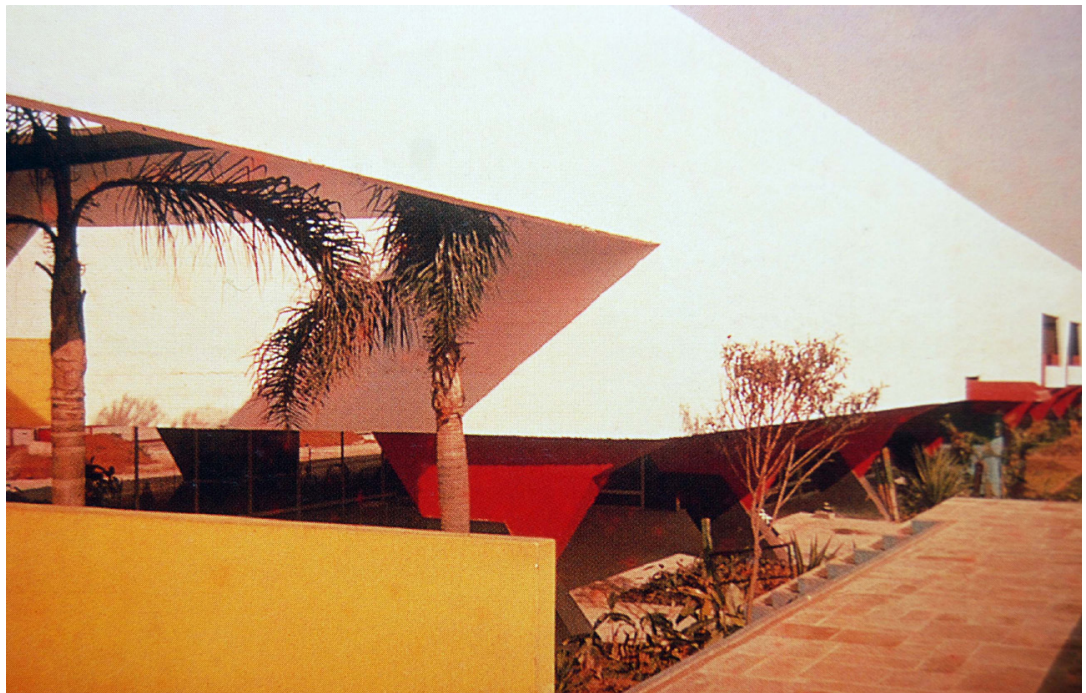

40 São Paulo Futebol Clube, Vestiários, 1959

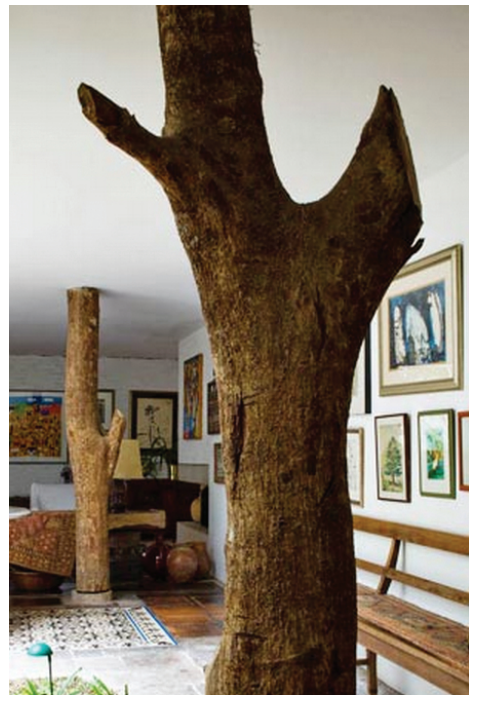

41 Casa Elza Berquó, 1965
A existência de pilares de forma mais convencional em algumas obras não supõe o abandono da ideia de celebração do ponto de apoio, mas uma via alternativa de resolver essa questão. Nas casas Mendes André (1968) e Elza Berquó (1965), o pilar está presente e é mais legível como o elemento vertical de proporções alongadas, sugerindo mais o papel de distanciador entre o elemento construído e o solo, não tanto de ligação, ao estar em contato direto com planos horizontais das lajes. Por essa razão, é um suporte afastador entre a bandeja do teto e o solo, como uma peça externa convidada a cumprir uma função estrutural. Na casa M.André, mesmo com a presença do pilar, fica sutilmente marcado o ponto de apoio pelo arquiteto, que ao fazer um rebaixo, uma ranhura horizontal que reduz ligeiramente a seção do pilar em seu topo, faz uma analogia ao capitel de uma coluna clássica. Artigas marca um friso $40 \mathrm{~cm}$ abaixo do ponto onde o pilar toca a laje, que a partir dali deixa de ter a forma de tronco de pirâmide para passar a ser um paralelepípedo regular, praticamente um cubo, portanto um capitel de ordem cúbica.
A ideia de elemento afastador entre dois planos fica evidente com os pilares - tronco colocados em torno ao pátio da casa Berquó, primeiro pela escolha do tronco para cumprir a função de pilar, por ser um elemento exótico ao vocabulário estético dessa obra e, também, pelo fato de não ser elemento construtivo que compartilha da precisão, de arestas da casa, como se os quatro pilares fossem quatro escoras que ali ficaram, como peças definitivas.

Artigas, nesse projeto, trabalha com planos de cobertura e paredes revestidos e pintados, cartesianos, e com cobertura que tem aberturas retangulares. Os únicos pontos, além do pilar, em que um elemento orgânico participa da casa surgem: ao estampar-se as tábuas da forma nas empenas de concreto que pendem do beiral, e nos pisos, muito trabalhados em suas texturas.

Na casa Baeta ocorreu um caso interessante em relação ao aparelho de apoio/afastador que foi colocado em seu pórtico central, no pé direito 

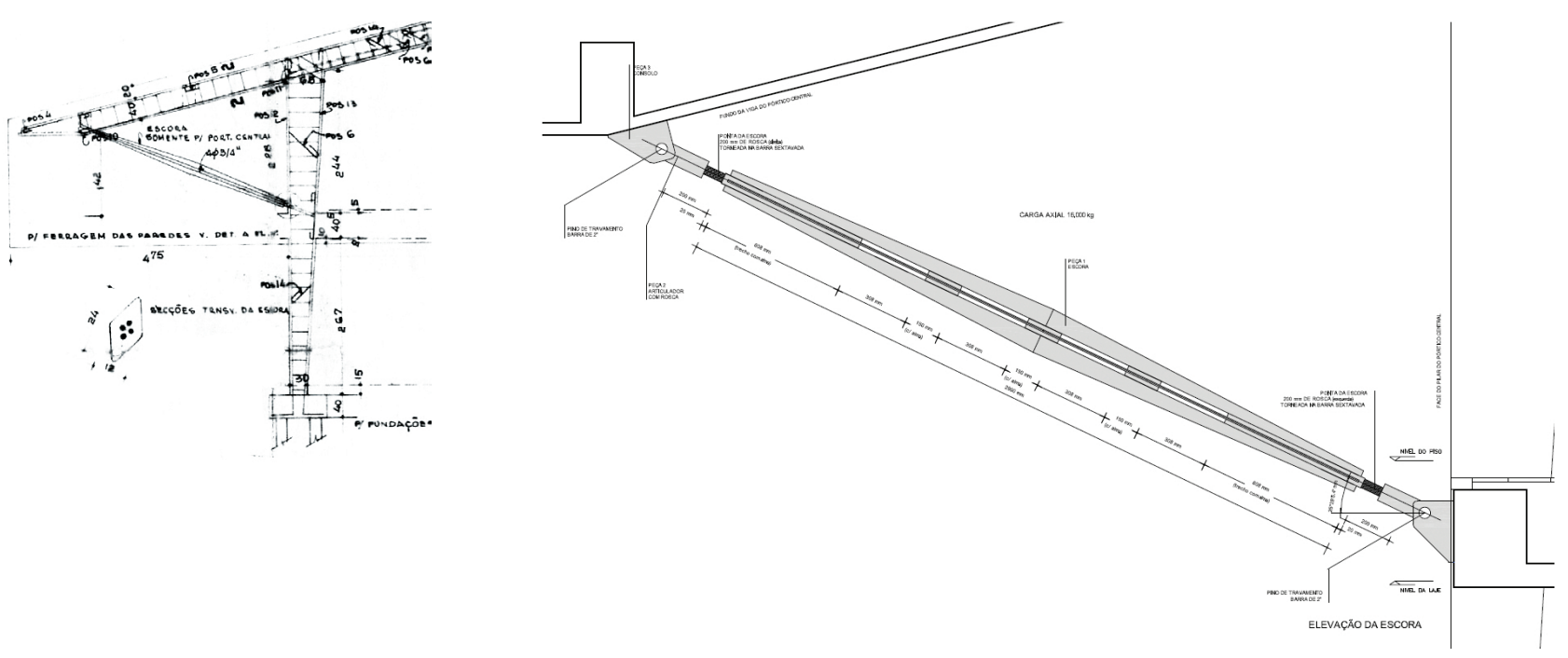

42 e 43 Residência Olga Baeta - comparação da escora original em concreto projetada por Artigas com a executada em aço projetada por Bucci

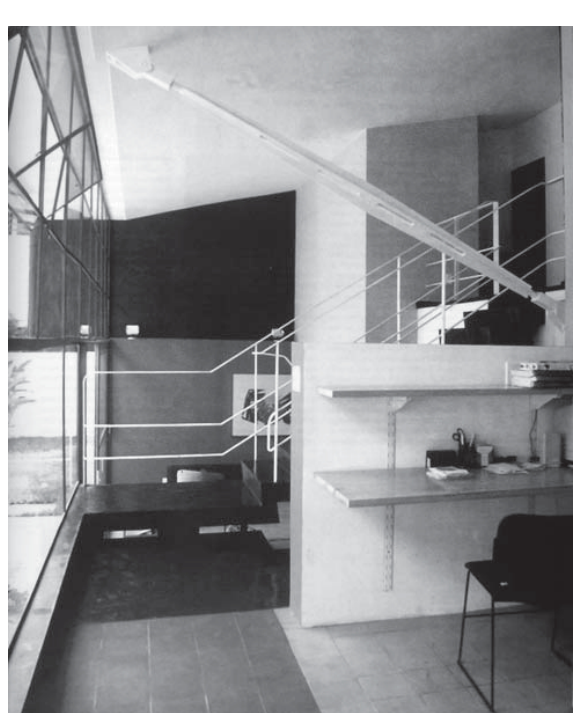

44 casa Baeta, vista interna da sala duplo da sala, quando a residência foi reformada, em 1996, por projeto de Ângelo Bucci (com MMBB arquitetos) e cálculo de estruturas do Eng. Ibsen Puleo Uvo, em busca de restituir à construção sua lógica estrutural original.

Conforme nos relata Apoena Amaral e Almeida em sua dissertação de mestrado Intervenção em patrimônio Arquitetônico Moderno - um estudo de três casas paulistas (2013).

O engenheiro, o arquiteto e suas equipes trabalharam durante a reforma em prospecções e ensaios para poderem investigar a presença prévia de uma peça estrutural inclinada, da qual se tinha notícia e supostamente cumpria a função de completar o pórtico estrutural central da casa, o único dos três que não se vale de uma empena de concreto como seu elemento estruturante. Após pesquisa documental sobre o projeto original e prospecções durante a reforma, chegou-se à conclusão de que havia sido projetada e executada, uma escora/mão francesa em diagonal unindo o ponto central da viga de fachada, que cruza a sala no sentido longitudinal passando sobre o fechamento de vidro, ao pilar mais próximo do centro da casa.

Ao se iniciar a reforma havia um pilar periférico, com aparência de não ser contemporâneo à obra e que estava alinhado ao plano de esquadrias. Os estudos confirmaram que tal pilar havia sido adicionado por conta da ruptura da escora original feita em concreto. Após a execução de diversos reforços estruturais, se decidiu pela recuperação do partido estrutural do pórtico central, de forma que o plano envidraçado de fechamento da sala ficaria livre de qualquer coluna.

A ideia de pilar como elemento afastador entre dois planos, chega a ser literal nesse caso. É muito interessante e até anedótico o relato que Bucci nos faz sobre a reforma em entrevista concedida a Amaral para sua pesquisa, por demonstrar fisicamente a consideração analítica proposta aqui. 


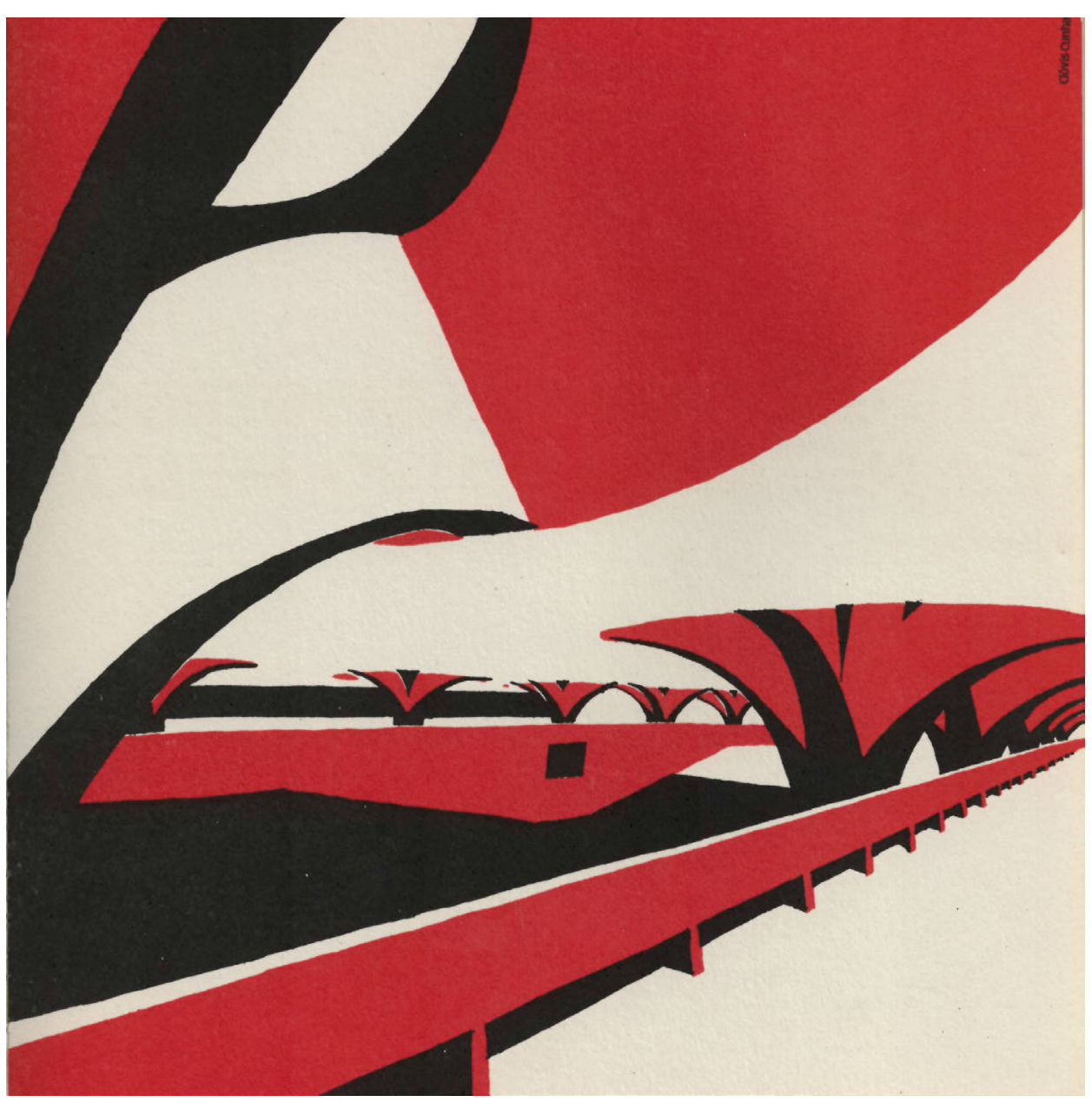

45 Rodoviária de Jaú em serigrafia de Clóvis Cunha
59. BUCCI, Ângelo, São Paulo, 02/09/2011 em entrevista concedida a Apoena Amaral e Almeida, in ALMEIDA, Apoena Amaral e, Intervenção em patrimônio Arquitetônico Moderno - um estudo de três casas paulistas, dissertação de mestrado apresentada à FAUUSP, 2013, pg. 90

"E aí a gente desenhou uma escora em aço, (...) como um macaco que, colocada na posição, você ia girando assim e ela ia carregando (...) então, parafusou a cabeça no pilar, parafusou a cabeça no teto, colocou a escora lá encima, passou o pino de travamento, (...) aí começou a girar para carregar. E isso foi um momento importante lá na obra. Toda a mão de obra, o Ibsen, eu, acompanhando isso. O pessoal girava a escora (...) e o Ibsen acompanhando...aí foi carregando e o Ibsen (...) de olho, sabe? Porque não tinha torquímetro, nada disso. (...) Mas o que foi legal é o seguinte: antes de arrochar a escora, a gente colocou em torno do pilar provisório lá fora, quatro escoras de obra, (...) bem apertadas. Aí pôs a escora do projeto, foi arrochando também, até o Ibsen dizer: Tá bom. Daí ele autorizou a cortar a coluna que estava lá fora. Ficou toda a turma encostada no muro e o cara com o maçarico veio (...) e cortou o pilar. Quando ele cortou (...) aquele escoramento (...) as quatro peças, que estavam super apertadas, soltaram, assim...Quer dizer, a laje levantou levemente. (...) tinha arrochado um pouco mais que o necessário a escora nova." 59

\subsection{Teto}

O teto é a operação seguinte ao terrapleno, podemos então passar do desenho do chão (terrapleno, tratado em capítulo precedente) para o desenho do teto ${ }^{60}$, após termos compartilhado algumas reflexões sobre o ponto de apoio, que separa - e une - esses dois elementos. 
60. Tomamos a liberdade de parafrasear Cesar Shundi Iwamizu no título dos subcapítulos de sua dissertação de mestrado,

Estação Rodoviária de Jaú e a dimensão urbana da arquitetura,

2008, onde ao tratar do tema central - a dimensão urbana da

arquitetura - subdivide no quarto capítulo em dois subcapítulos:

4.1. O desenho do Chão e 4.2. O desenho do Teto. (grifo meu).

61. ARMESTO Aira, Antonio, Op.Cit. pg. 62

62. Pavilhão aqui é um termo que pode ser entendido como

volume arquitetônico, eventualmente pode estar suspenso, e nesse caso, assume topológica e analiticamente a posição de teto.

Retomando os conceitos propostos como ferramentas de análise, teremos que o teto, o plano horizontal, ao cobrir nossas cabeças, nos tolhe a vertical e, assim, nos abre ao horizontal, ao mesmo tempo em que nos trás o horizonte e concede o abrigo. Antonio Armesto faz a seguinte colocação em relação a esse elemento:

"El pórtico es um techo sobre el suelo y determina aquello que el recinto dejó indefinido. Lo sustancial del pórtico, en este nível de la definición, es la existência del techo y no importa, por ahora, cómo éste se sustente."

"El pórtico arquitectónico impide ver el cielo o introduce un velo sobre él. A lo sumo el cielo se divisa de lejos como aquello que determina el horizonte." 61

Para ilustrar nossa postura analítica diante do teto, podemos assumir a seguinte consideração a respeito do pabellón ${ }^{62}$ - seu sinônimo, em nossa análise - feita por Carlos Martí Aris em seu artigo Pabellón y patio, elementos de la arquitectura moderna:

"El pabellón, se vincula en su origen a la tienda de campaña: una cubierta ligera que guarece de la intemperie. Al convertirse en estable, promueve la apertura lateral del espacio y la visión panorámica. El pabellón se identifica también con la edificación aislada y - referido al mundo doméstico - , con la casa que domina el paisaje, otea el horizonte (...),condiciones propias del espacio moderno que persigue la visión dilatada y la apertura hacia el horizonte."63
Artigas teve a oportunidade de trabalhar a cobertura como elemento fundacional de suas obras quer na escala da casa, quer na escala do edifício,entretanto, a condição primordial para que um partido de projeto tenha a cobertura como elemento forte é a de ter uma relação minimamente interessante com seu entorno. É preciso que o horizonte seja desejável para, com a arquitetura e fazê-lo participar do espaço interior. Existe um viés contemplativo nas casas teto: o vetor de força parte do interior e sai da obra. Nas casas pátio, o vetor muda, passa a apontar para o céu, está na vertical, conforme exploraremos nesse estudo mais adiante.

É inegável a condição de Artigas ter tido que trabalhar - na escala da casa - com um entorno urbano bastante hostil do ponto de vista da paisagem urbana que representa. Bairros jardim, muitos deles planos e de lotes murados, que seccionam a possível transição gradual entre a rua e a casa, contexto avesso à ideia de vistas interessantes.

Por conta dessa situação foi pouco freqüente entre as casas que projetou - em especial entre as onze escolhidas para esse estudo a presença daquelas com o teto como elemento diretor do projeto. Foi apenas em situações onde a topografia movimentada esteve mais presente que surgiram as casas teto emblemáticas, podemos citar como casas teto que exploram com plenitude a tipologia, apenas as casas Rio Branco Paranhos (1943) e Casa Ivo Viteriro (1962). 
As casas do arquiteto: Artigas I (Casinha) e Artigas II, (de 1942 e 1949, respectivamente) têm como elemento forte a cobertura, mas na primeira, as fachadas em muro têm também papel importante no conjunto, e fazem prevaler sua massa sobre a quantidade de aberturas sendo, portanto, uma casa do tipo aula.

A casa Artigas II tem na sua cobertura um importante elemento arquitetônico e compositivo, mas sua situação estabelece ligação muito forte com o recinto no qual está situada. Por essa razão, proponho que seja classificada como casa pátio. Há também o fato de ambas serem térreas e estarem em um contexto urbano sem a presença marcante da topografia, o que as faz perder força enquanto exemplares plenos de casa-teto, já que as vistas ao exterior não agregam força aos partidos projetuais.

Entre os edifícios de grande escala, precisamente pelo fato de manterem uma relação muito diferente com o entorno, o tipo teto está muito mais presente. Podem entrar nesse grupo: a garagem de barcos do Iate Clube Santa Paula e a Estação Rodoviária de Jaú (1961 e 1974, respectivamente). A Estação de Londrina também é um importante edifício teto e se diferencia da casa Artigas II - obras facilmente associáveis entre si por mimetismo até mesmo por contar, a estação, com o horizonte, com a vista distante.
É bastante completa a analogia possível entre a casa Rio Branco Paranhos e o edifício da Rodoviária de Jaú. Iniciando-se a análise do chão para o teto, nos dois projetos existe a consideração precisa da topografia no desenvolvimento dos patamares que relacionam diretamente a arquitetura com as várias cotas do terreno (terrapleno). É evidente em ambos a participação do percurso (promenade) que vence os desníveis nessas obras. A cobertura em si, nos dois casos, tem a peculiaridade de não obstruírem as horizontais e de não estarem ligadas a fechamentos verticais, não terem apêndices em suas extremidades que pudessem cortar a relação direta entre o dentro e o fora. Não sem razão ao analisarmos as plantas das duas obras observase a presença marcante das linhas de projeção, não há quase nenhum limite representado em planta, só o vemos graças à convenção em representação gráfica de arquitetura que nos permite diferenciar o espaço coberto do descoberto pela linha de projeção. Essa diferenciação é algo que não ocorre com tanta clareza na vivência dos espaços, em especial na estação, obra que compartilha dessa sutil confusão que a arquitetura do teto intenciona, aumentada pela operação de supressão das colunas de borda, conforme conceitua Dalva Thomas:

"Mas valeria observar que os limites interior/exterior vão se tornando mais fluidos, pelas intermediações que pouco definem o estrito âmbito de cada um. Quando se está abaixo da cobertura quase imperceptivelmente já se está dentro, embora a amplitude espacial e visual insista em dizer que se permanece fora." 64 
Pode parecer paradoxal, mas a casa e a estação só podem ser posicionadas dentro do tipo teto, nem tanto pelo fato de terem uma cobertura firme e presente, mas, principalmente, por não terem fachadas nessas condições. É a ausência de fachadas marcantes que possibilita propormos a classificação de ambas com a tipologia do teto, a presença sutil dos elementos que o suportam e lhe dão hegemonia na obra fica bem evidente nessa conceituação proposta por Antonio Armesto:

"El pórtico es la stoa, el mercado, la loggia o lonja, la parra delante de la casa, y hasta un árbol que da sombra y también un puente entre dos orillas o fronteras. En el concepto mismo está implícita la prioridad del techo respecto a los soportes que, o bien son discretos en número o espesor o, si nos es así, tienden a transmitir la noción de estar al servicio de aquello que soportan." 65

Na Estação os suportes estão recuados, distantes da beira da laje. Em uma visão externa os apoios confirmam sua condição de subordinação ${ }^{66}$ ao teto, sendo discretos em número e espessura. Já na casa, mesmo que as paredes tenham uma presença maior, até por conta das técnicas construtivas empregadas, transmitem a noção de estarem claramente à serviço daquilo que o suportam, ou seja, a cobertura com seus diversos planos e grandes beirais.

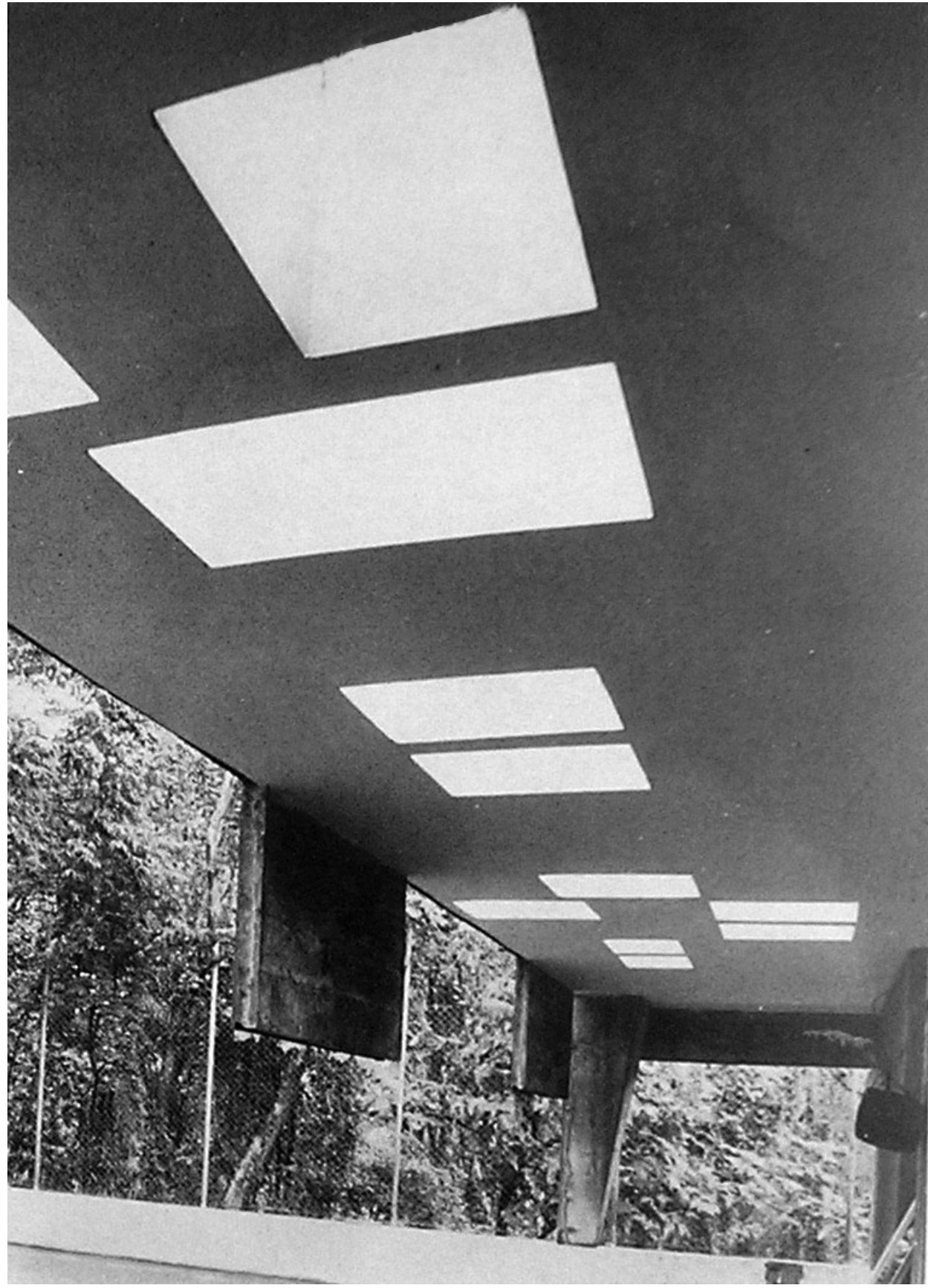

46 Varanda Casa Berquó 


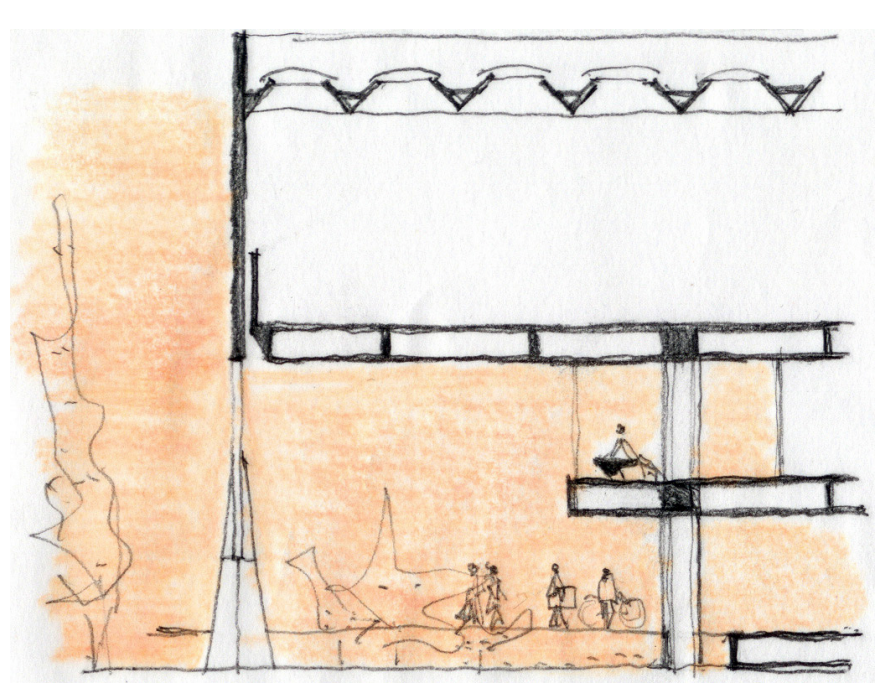

47 Pormenores de corte transversal pelo foyer do auditório (dito fosso)

Situações de correspondência (ou falta de) entre bandejas sucessivas no prédio da FAUUSP

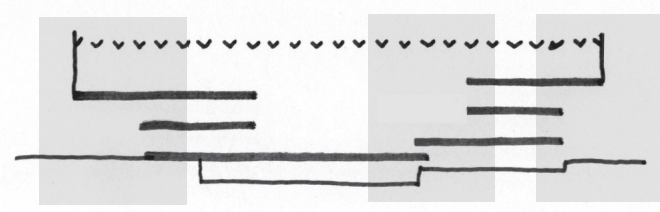

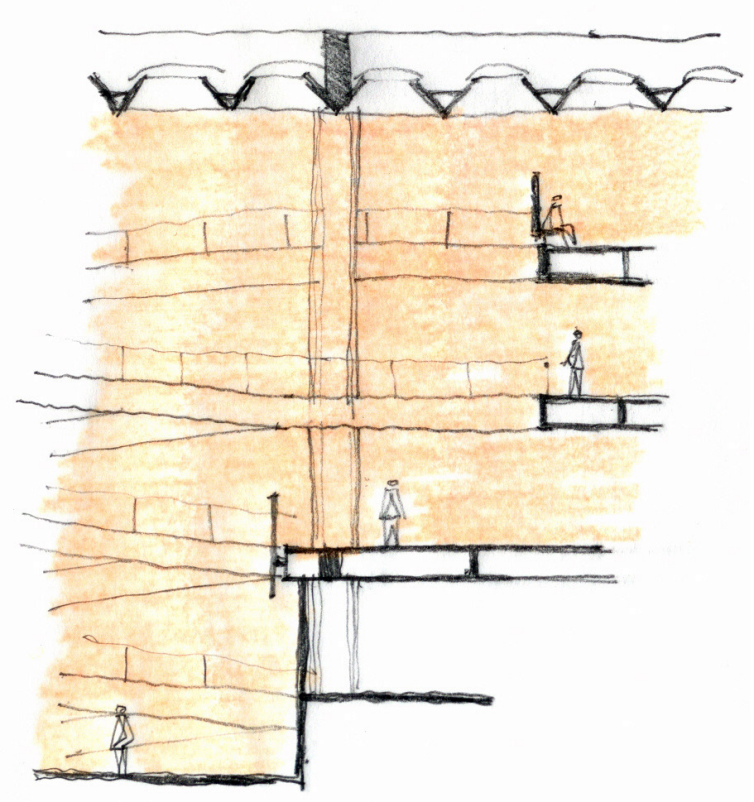

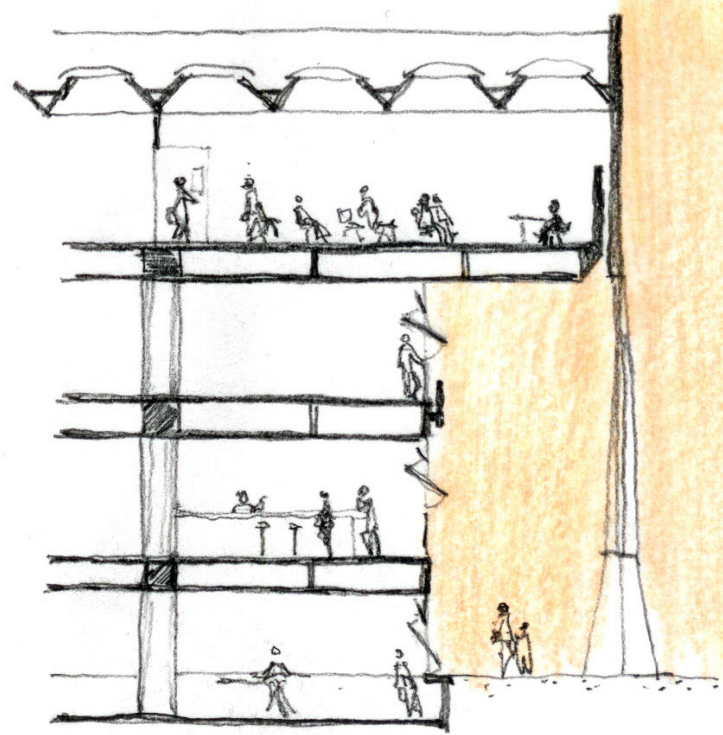

Além da abordagem do teto como elemento fundador das obras, merecem ainda destaque as intervenções plásticas propostas pelo arquiteto para o plano de cobertura, os recortes, incisões e aberturas como ações formais enriquecedoras. Essas ações compositivas são análogas àquelas possíveis a um artista diante de um material maleável e "recortável". Assim é possível entender que a cobertura participa na obra de Artigas como um elemento passível de intervenções plásticas.

Na Casa Berquó (1965), Artigas atua com grande liberdade na composição da cobertura. Produz aberturas quer no plano de cobertura quer em seu apêndice vertical. As aberturas não são em grande número e estão concentradas na varanda e posicionadas livremente, sem um padrão claro, a não ser a abertura central da casa que está perfeitamente colocada e faz às vezes do pátio, ou de uma redução sua, como desenvolveremos a seguir. 
Vilanova Artigas trabalha a do plano horizontal, não apenas o plano de cobertura - o plano do teto, a face inferior das lajes de piso.

Aqui é central a noção do teto como elemento local na obra, não ligado ao tipo global que permite classificar o edifício, mas a determinados espaços internos, onde a pureza, ou seja, a ausência visual de elementos construtivos portantes no plano do teto reconfirma a sua força. Ana Paula G. Pontes ao refletir sobre aos aspectos arquitetônicos que permitem a planta de distribuição livre nos edifícios de arquitetura moderna ressalta o seguinte:

"Um deles é a manutenção da face inferior das lajes de cobertura e pisos intermediários como superfície planas e horizontais, sem a interferência de elementos estruturais. (...)"67

O outro aspecto marcante na análise de Pontes é a separação formal entre coluna e parede. Ambos muito presentes na arquitetura de
Artigas, mas aqui nos interessa especialmente o primeiro, já que assim garantiu a presença pontual do tipo teto em determinados espaços de menor escala dentro de um edifício.

À margem de todas as reflexões possíveis sobre o teto descontínuo, trabalhada, ao propormos fixá-lo enquanto plano neutro, liso, independentemente de se tratar de uma cobertura ou um plano intermediário, ou até de dois lances de rampa sobrepostos, passam a surgir questões compositivas e arquitetônicas diferentes daquelas relativas ao plano de cobertura.

Ao se duplicar o plano de piso cria-se a condição de comparação entre um e outro. É mais freqüente na arquitetura composta pelas bandejas de concreto a ação de repetir o plano em diversas cotas mantendo seu perímetro e geometria sem mudanças. Precisamos remarcar o fato de que os edifícios habitacionais projetados por Vilanova Artigas - casas 


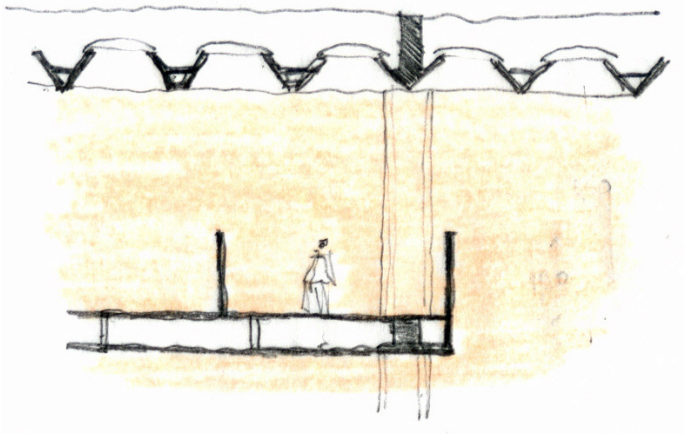

48 Pormenores de corte transversal pelo salão Caramelo. Notar a participação do peitoril e suas variedades em altura e opacidade na conformação dos espaços

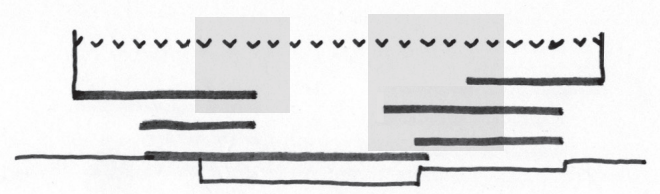

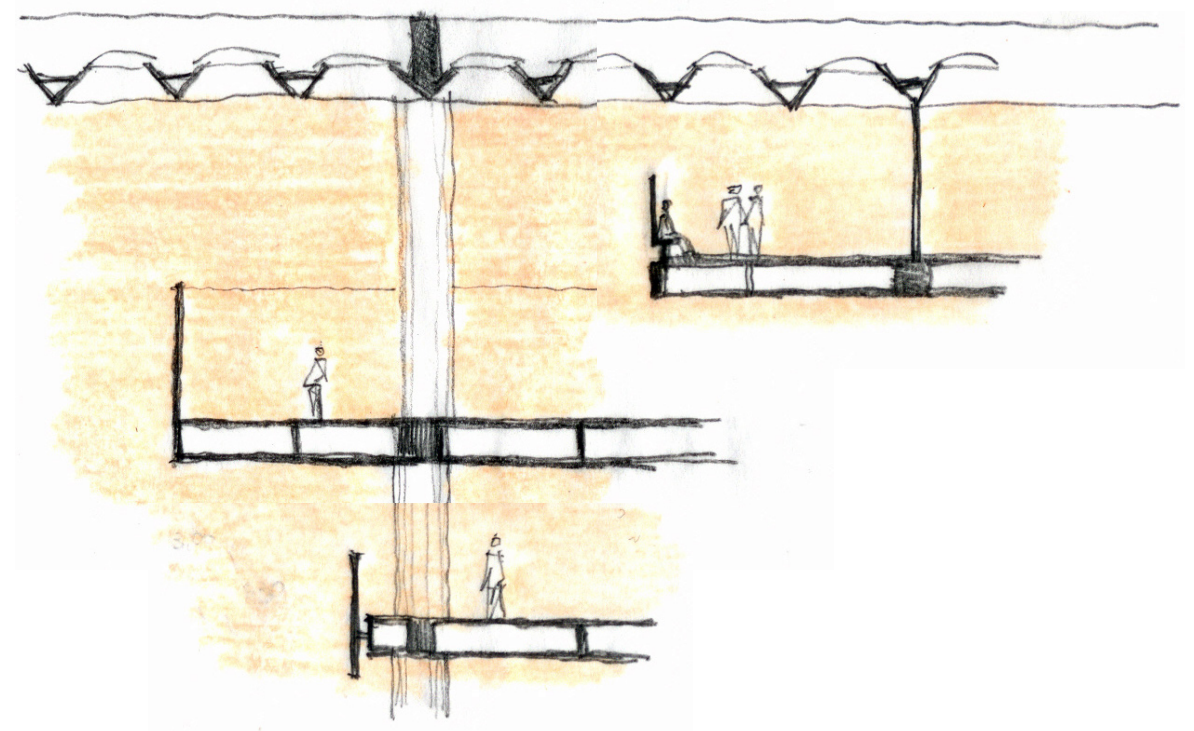

ou prédios - não representam grandes oportunidades - em termos numéricos até - para trabalhar a diferenciação de lajes sobrepostas. Nos prédios residenciais que projetou (não foram muitos) prevaleceu a lógica de multiplicação sem mudanças dos planos horizontais. Difícil especular que exista alguma razão para que isso ocorra, além da própria lógica construtiva do concreto armado e as grandes cargas na base dos pilares com muita área de laje em altura. ${ }^{68}$ Nas casas unifamiliares a oportunidade de diferenciar as lajes 'acaba' rapidamente, já que o programa se resolve com uma ou duas repetições. Portanto, foi nos edifícios públicos, destinados a "outros programas" que Artigas encontrou melhores oportunidades para explorar a diferenciação entre planos horizontais sucessivos. 
68. as fachadas dos edifícios de grande altura em concreto

armado começaram a 'perder o prumo' somente com a

arquitetura contemporânea, salvo projetos vanguardistas que

propunham o desaprumo do bloco construído já em meados do século XX, como no plano para a baía de Tokio de Kenzo Tange, não construído, obras de Le Corbusier, que exploram a empena inclinada ou os gigantes da estrutura. Podemos ainda tomar, ao azar, alguns exemplos recentes disso: as torres "porta de Europa" em Madri, de 1996 com projeto de Philip Johnson e John Burgee, ou em escala local as torres Rochaverá, de 20082010 com projeto de Aflalo \& Gasperini e Purarquitetura, ou ainda o Guggenheim de Bilbao. Esses últimos com a inovação concentrada mais na forma do que nos aspectos técnicos.

Ainda caberiam nesse assunto reflexões, sobre a arquitetura que virá, que explorará a ruptura da caixa, questionando a horizontal e a vertical constantemente, isso fica claro se tomamos como exemplo o que vem sendo produzido pelo grupo de arquitetos BIG (Bjarke Ingels Gorup) da Dinamarca, cuja produção explora as fachadas não verticais e a 'confusão' fechamento/cobertura, exploraando as potencialidades de rampa também

69. Termo que designa forro em castelhano.

O exemplo emblemático desse repertório de experiências espaciais é o edifício da FAU/USP de 1961, onde podemos encontrar todo tipo de situações: desalinhamentos entre piso e teto, correspondência entre ambos, tetos que "seguem" enquanto pisos "ficam" ou pisos que se prolongam e nos oferecem duas alturas de teto diferentes (às vezes duas texturas também). Essas três experiências básicas, combinadas com as variáveis aplicadas sobre os planos de fechamentos verticais que surgem na borda das lajes, os peitoris, ora opacos, altos ou baixos, ora inexistentes, ou transparentes. Nesse ponto, pode ser interessante a leitura desses espaços através de um conjunto de desenhos de cortes parciais do edifício. ver figuras 47 e 48

Curioso notar que o discurso marcante da arquitetura moderna - que tem tanta afinidade em demonstrar e deixar exposta a verdade dos materiais e processos construtivos - quando trata do plano horizontal do teto encontra um subterfúgio para ocultar os elementos construtivos que sempre estiveram explícitos, criando o emblemático caixão perdido para esconder vigas e nervuras, apresentando-nos na face inferior o plano ininterrupto liso e neutro, isso sim, verdadeiro em sua materialidade de cimento lixado (quase aveludado) e, por também estar constituído do material predominante, nos trazer a sensação própria do faslo-techo ${ }^{69}$, de um plano que está ali pra ocultar algo, velar uma parte da história, como uma espécie de pequeno traidor. Talvez somente assim os modernos puderam explorar a planta livre com toda a 'liberdade' - com o perdão da redundância - já que seria bem mais complicado se tivessem que andar às voltas com a dúvida de pôr ou não a parede debaixo de viga, esse malfadado efeito magnético ao módulo com o qual temos muitas vezes que lidar ao projetar. 


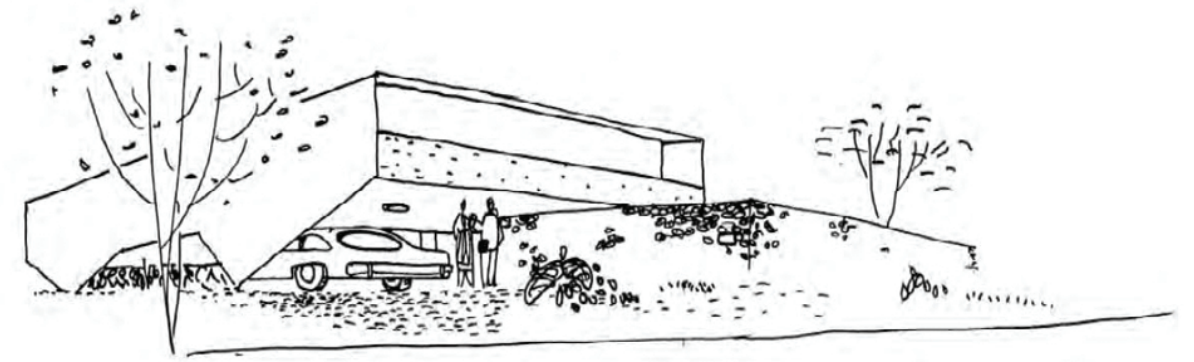

49 a 51 Relação entre fachada e terreno em três obras: Casinha-1942, Baeta-1956 e Bittencourt II-1959

\subsection{Fachada}

Concluída a explanação sobre o teto e seus desdobramentos tipológicos e plásticos, exploramos um pouco outro elemento construído, outro limita, a fachada, a partir de seus gradientes plásticos, como elemento formador da arquitetura e sua amplitude de possibilidades físicas e consequentemente arquitetônicas.

Assim como o teto, a fachada tem papel fundador, define o dentro e o fora:

"O entendimento de limite (...) torna-se mais claro ao reconhecermos na atividade arquitetônica a capacidade de definir espaços e, de certa maneira, separar o meio construído do não construído. Ao edificar o homem limita espaços, indicando fronteira, demarcando o início e o fim de sua construção." 70

Necessariamente passaremos outra vez pelo dilema de tratar de matéria ou de espaço, cheio ou vazio. Interessaremo-nos excepcionalmente - mais pelas questões ligadas ao cheio, ao paramento vertical em si e sua graduação e forma, não tanto pelas aberturas, mas ao tratar de limite se está, inevitavelmente, abordando o espaço, o limite é um dos fatores que o caracteriza.

Nas obras selecionadas e nas decorrentes dessa análise, a presença de situações em que são trabalhadas aberturas isoladas dentro de um paramento vertical é muito baixa. Artigas explorava quase gerando grandes planos envidraçados que marcam suas obras e constituem um elemento analítico carregado de ambiguidade capaz de transformar estruturalmente a arquitetura, do ponto de vista topológico e espacial.

Partindo-se de uma leitura evolutiva (cronológica) em relação ao limite vertical na obra de Artigas, no sentido de se tornar um elemento que vai paulatinamente se destacando do terreno e perdendo materialidade, a primeira mudança é a redução do vínculo do muro de cargas com o solo.

Na Casinha (1942) os muros de tijolo estão firmemente apoiados no terreno e duas das paredes principais penetram o solo tornando-se muros de contenção. Nessa obra há a ligação completa entre fachada e terreno. exclusivamente as janelas de piso a teto e as fenêtres en longueur, 


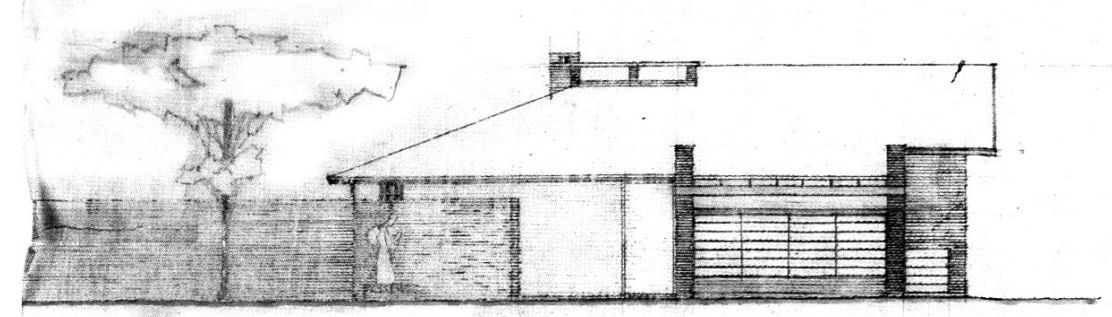

Na casa Baeta o corpo da casa passa a estar elevado do solo, ainda que com certa trampa, porque os pilotis são também habitação, o que se eleva é a zona noite da casa, suas fachadas portantes se afastam do terreno por dois pilares cada uma e o volume elevado mantém a forma dada pelas duas águas assimétricas do telhado e se abre para as laterais do lote com grandes vãos envidraçados. Nesse exemplo, Artigas busca um destaque total entre a fachada estrutural e o solo, naturalmente mediado pelos pilares.

A casa Taques Bitencourt II tem as fachadas laterais suspensas no ar, mas que se esticam em direção ao terreno para tocarem as fundações. Exemplo de fachada que toca pontualmente o solo, sem a intermediação do pilar.

Portanto temos: ligação total (Casinha) desligamento total (Baeta) e contato pontual (Bitencourt II) das fachadas com o terreno.

No projeto da Casinha (1943), Vilanova Artigas trata a fachada com bastante naturalidade, com tijolo constrói dois prismas regulares, que se interseccionam e formam o núcleo fundador da casa. As fachadas são geratrizes da forma final do edifício, as paredes estabelecem um diálogo compositivo interessante, em momentos se tocam formando

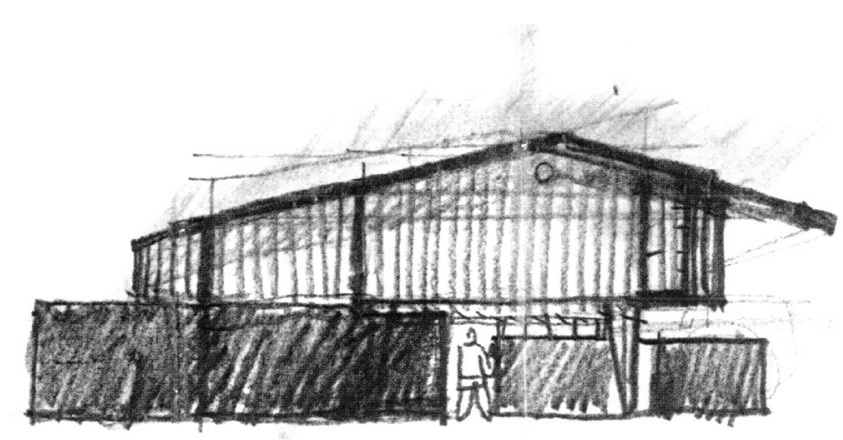

diedros côncavos ou convexos e em outros insinuam a esquina deixando frestas que formam suas aberturas e a porta de entrada.

Essas mesmas ações também participam na relação entre cobertura e muros com generosos beirais, a cobertura do maior dos volumes extrapola o plano das fachadas, as paredes se detêm e a cobertura prevalece, assim se formam os beirais e o espaço da varanda. No prisma pequeno, são as paredes que cortam o plano da cobertura, deixando o telhado contido entre elas. Nessa obra as fachadas mantêm lógica de serem elementos murários, gerados pela reprodução em altura da primeira fiada.

Na Casa Baeta, as fachadas de frente e fundo são cegas e não tocam diretamente o solo, estão elevadas por dois pilares cada uma, têm perímetros regulares, são em concreto armado, têm função estrutural e estão marcadas pela textura das formas de madeira.

Os planos das fachadas laterais não completam o prisma, na sala e escritório suprimiu uma de suas faces, formando um plano de vidro em toda a altura e largura da fachada e nos dormitórios foi recuada mas mantém a opacidade do conjunto por planos com a textura das venezianas. 


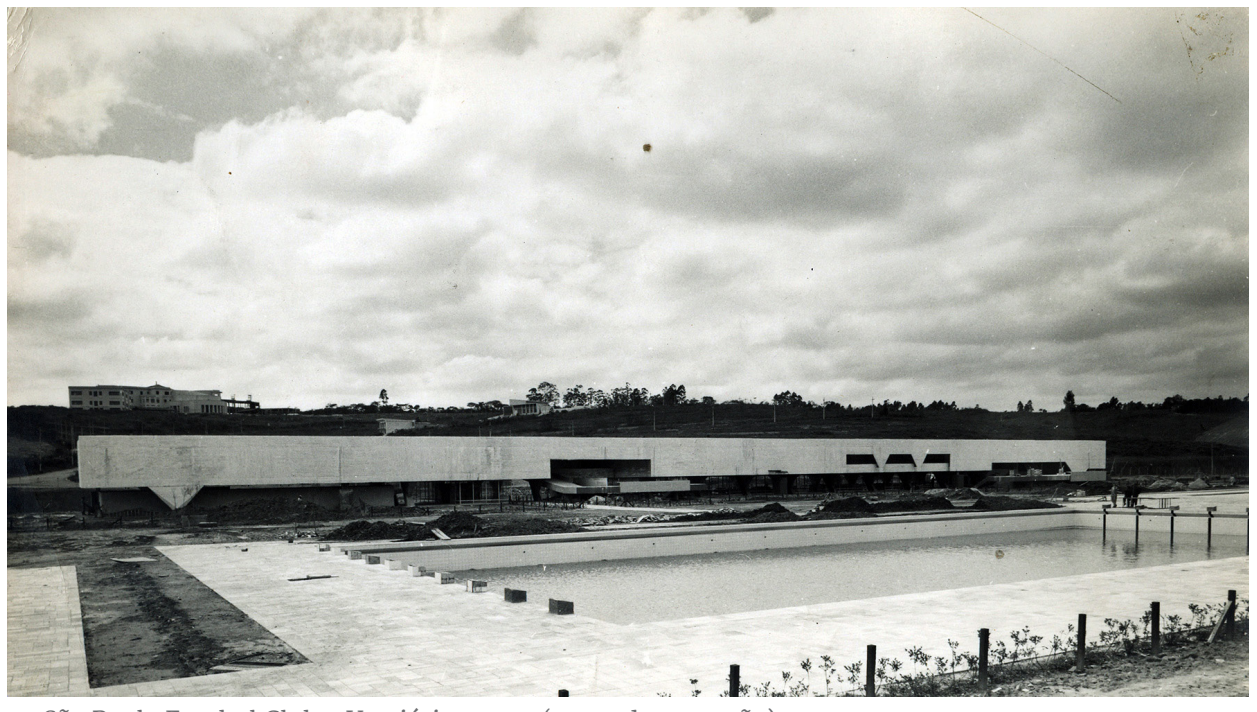

52 São Paulo Futebol Clube, Vestiários, 1959 (140m de extensão)

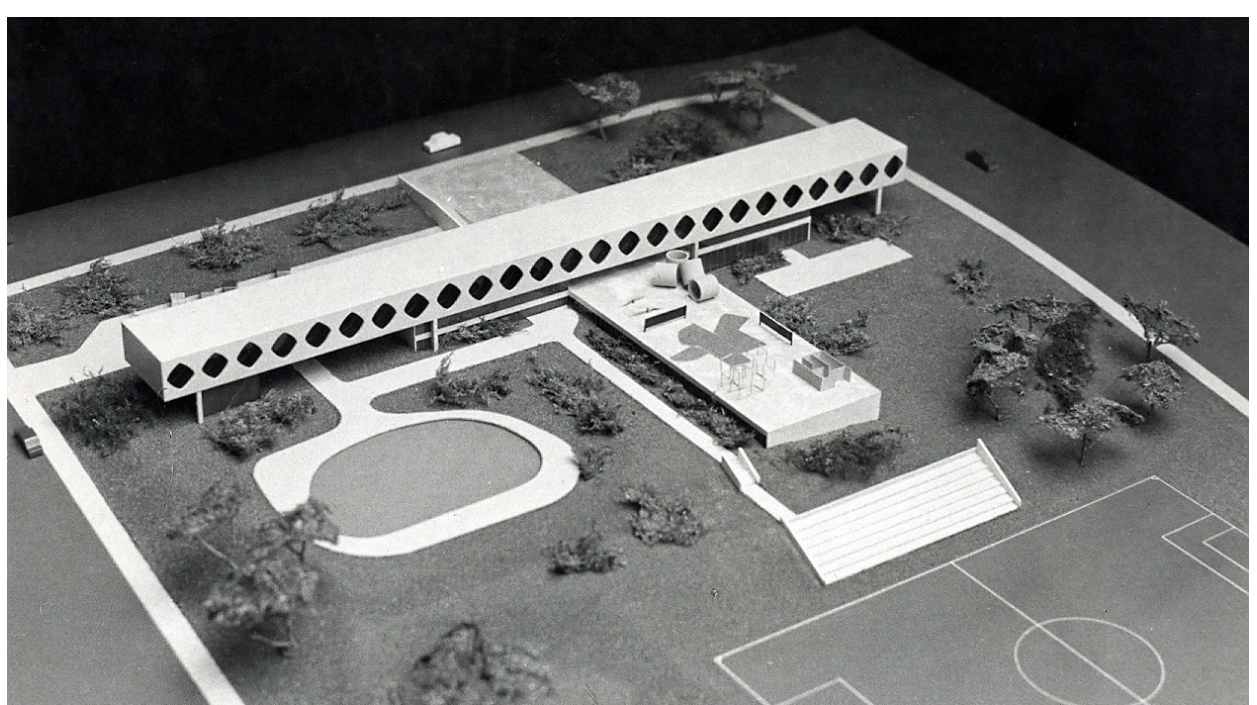

54 Centro educacional de Paranavái

Paranavái - SP - 1975

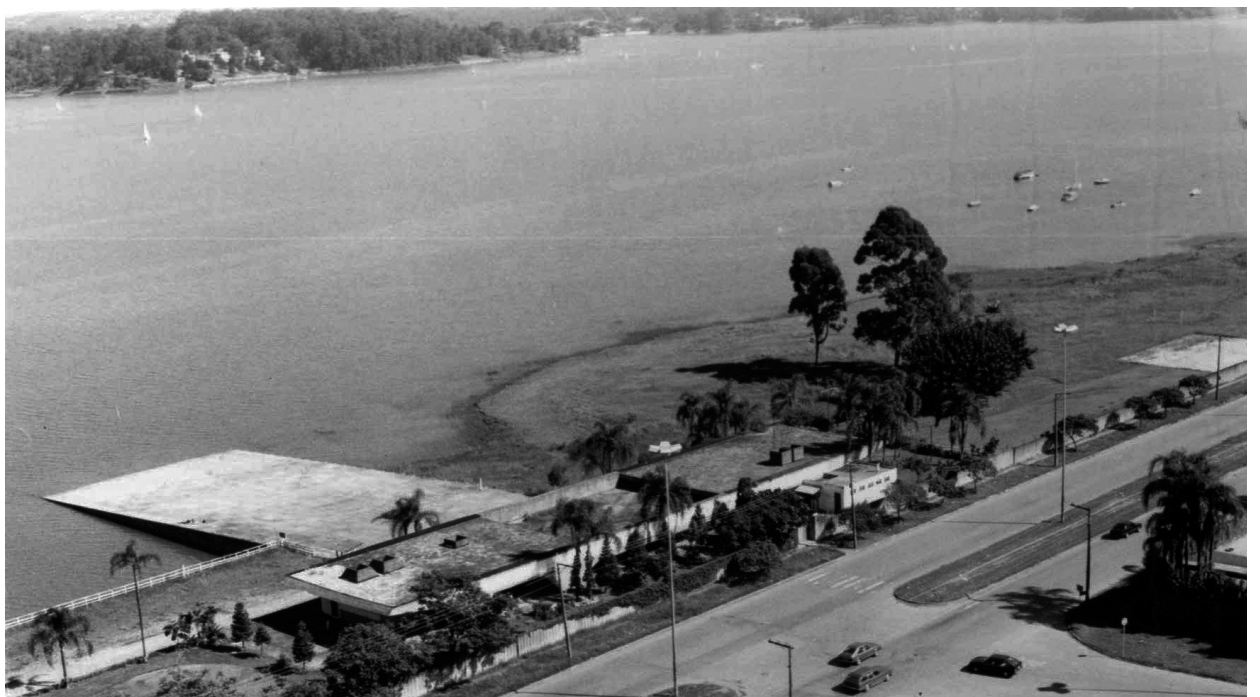

53 Garagem de barcos Santa Paula - 1961 (70m de extensão)

Na casa Taques Bitencourt II a peça volumétrica da casa está marcada pelas fachadas laterais de concreto aparente que são desdobramentos da cobertura. São planos muito esbeltos e se aproximam suavemente do terreno, não dependem de pilares para realizarem o apoio, são as fundações que afloram para receber as empenas em quatro pontos de união.

O tipo determinado pela caixa elevada com duas fachadas cegas sofre uma rotação de $90^{\circ}$ entre a casa Baeta e a Bitencourt II. As fachadas que se abrem passam a ser a de frente e a do fundo e as laterais que respondem às funções estruturais e passam a ser cegas. ver figura 69

Nos edifícios de grande escala, as fachadas assumem proporções mais longilíneas, há desde fachadas bastante longas proporcionalmente à sua altura, como ocorre nos vestiários do São Paulo Futebol Clube (1959) até outras que não são tão longas quanto essa, e, portanto, altura, assumem outras proporções. O gesto da fachada que se ajusta, estreita e afina para tocar as fundações está bastante presente entre as obras 

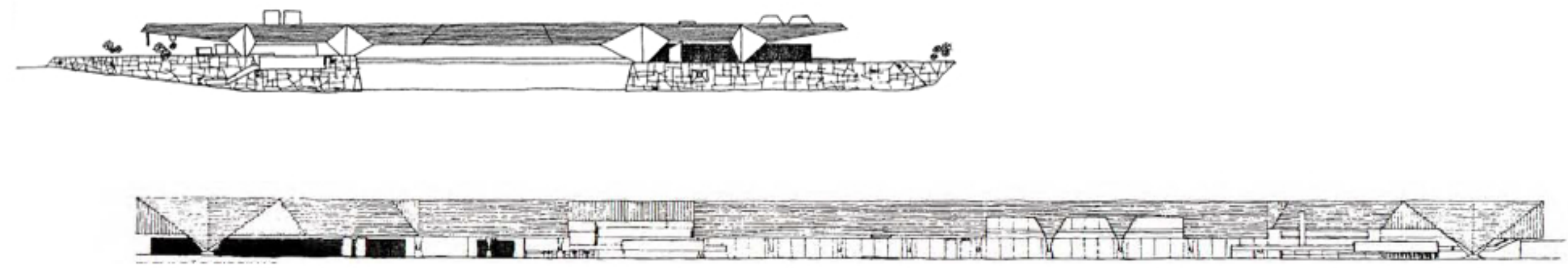

55 Garagem de barcos Santa Paula - 1961 (acima) e São Paulo Futebol Clube, Vestiários, 1959

analisadas, é assim com a Garagem de Barcos do Clube Santa Paula e com os vestiários do São Paulo Futebol Clube.

A fachada principal nas casas de Artigas sofreu um processo de reformulação gradual, passando de convexa na Casinha, mascada pelas arestas formados pelas paredes, para côncava na Bitencourt, com o avanço das empenas laterais e da cobertura, formando um nicho que contribui para sombrear a fachada aqui mais transparente.

Na casa Rubem de Mendonça, a fachada recebe uma pintura mural abstrata com formas triangulares brancas e azuis que podem simbolizar o prenúncio da ruptura do plano de fachada, que ocorreria nas obras seguintes. A pintura mural de Mario Gruber, por coincidência, remete graficamente aos diagramas de esforços estruturais aos quais as fachadas respondem, ou responderiam, caso fossem empenas estruturais propriamente, e não alvenarias apoiadas sobre vigas. É como se essa obra anunciasse uma mudança.
As formas triangulares voltam a estar presentes na fachada da casa Mendes André, mas já como resposta a uma demanda estrutural, os tirantes diagonais e os banzos da treliça são os únicos elementos que ficam da fachada após seu esvaziamento completo, ou quase completo, como se conservasse ainda a mínima matéria para poder manter sua função estrutural, surge aqui uma empena transparente.

Ao falar de materialismo construtivo, João Masao Kamita expõe:

"Deixar à vista a mecânica da construção expressa na forma dos fluxos vetoriais que a atravessam (cargas, empuxos, pesos, ventilação, movimento das águas) e as marcas do seu ciclo produtivo pela utilização franca dos materiais e pelos sinais dos processos de execução (concreto aparente) são algumas das estratégias adotadas." 71

A ideia de esvaziamento da fachada está presente também em outra escala, na relação que se estabelece se postas lado a lado as casas d’Estefani e Casinha. A fachada maciça de tijolos da Casinha, na casa 


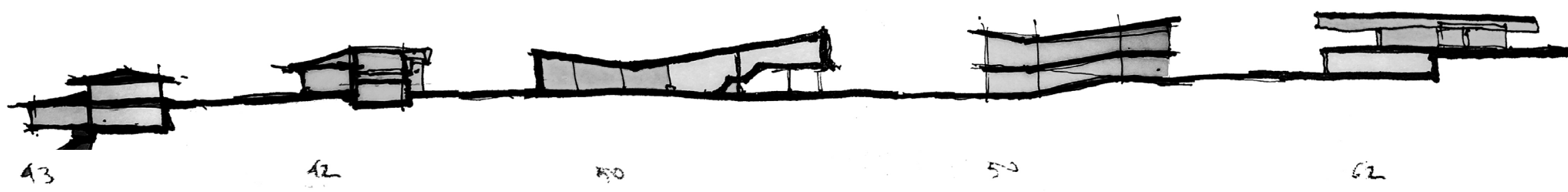

56 Elevação da casa e a aparição dos pilotis

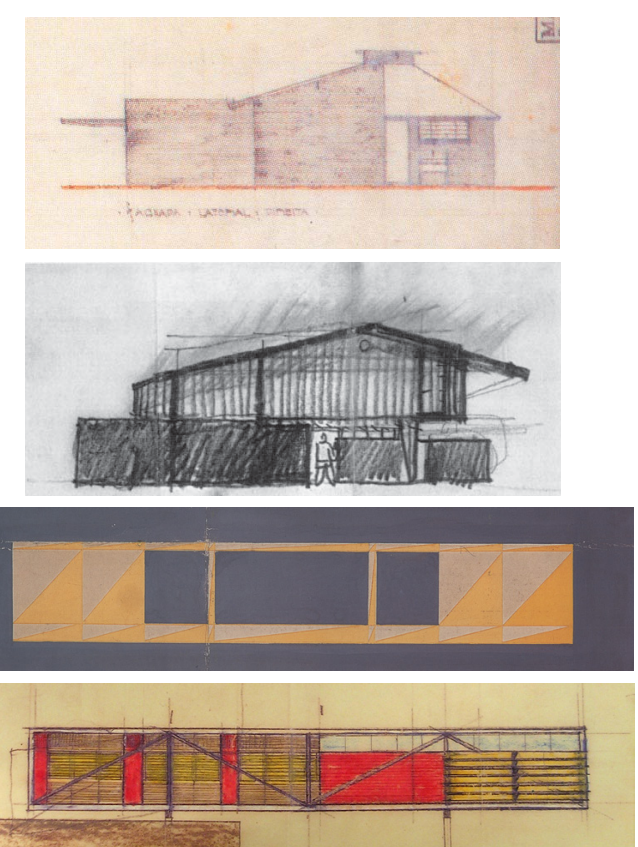

d'Estefani, ganha porosidade e permeabilidade, na forma dos pequenos vazios; continua sendo cerâmica, mas passa a ser vazada, em muxarabi.

Artigas reflete sobre a fachada:

"Marcou uma nova fase em todo o traçamento volumétrico e formal daquilo que podia chamar fachada, que é a fachada, que a fachada desapareceu daí pra frente. Desapareceu”.

Vilanova Artigas (Junho 1978) 72

\subsection{Rampa}

Carlos Martí em seu artigo Pabellón y patio, elementos de la arquitectura moderna, 2008, faz a seguinte análise ao refletir sobre as premissas projetuais de Le Corbusier (comparando-as com as de Mies van der Rohe): 


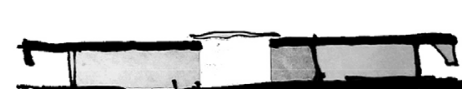

"Le Corbusier parte de otras premisas. Uno de sus axiomas es, precisamente, que la casa moderna debe estar elevada sobre pilotis y despegada del suelo, por lo que debe desarrollar sus vínculos con el mundo exterior a partir de esta separación. De este modo Le Corbusier establece, de manera inmediata, las condiciones de aislamiento que el principio del pabellón parece solicitar"73 (Martí, 2008)

Nesse trecho, Martí constata, em relação às obras de Le Corbusier, que em consequência do convicto uso dos pilotis que o arquiteto fazia, e resulta num novo posicionamento da casa em relação ao terreno, que surge então como uma caixa 74 elevada, constituída da sobreposição de duas bandejas horizontais. Ambas cumprirão a função topológica de teto, mas a uma delas lhe será atribuída também o valor de solo - ainda que elevado em relação ao terreno.

Em seu artigo Martí aborda a questão do pavilhão e do pátio nas obras emblemáticas de alguns mestres do Movimento Moderno como: Mies van der Rohe, Le Corbusier, Breuer e Jacobsen; e em escala local 75 analisa Sert, Sostres e Coderch.

O autor inicia o artigo tratando das casas pátio de Mies, de quem elenca cinco obras entre as quais há quatro casas térreas, em seguida ao falar dos princípios norteadores de Le Corbusier, surge a presença intensa dos pilotis. Seja por amostragem ou intencionalmente, o autor vincula as casas térreas à Mies e os pilotis às casas de Le Corbusier.

Ao colocarmos as casas de Artigas selecionadas para essa pesquisa em uma seqüência linear cronológica, constataremos que há tanto casas térreas quanto casas elevadas, e que as térreas são mais freqüentes nas décadas de 1940 e 1950, enquanto as elevadas entre 1950 e 1970. É possível, portanto, sugerir que Artigas também teve que lidar com questões relativas à decisão de elevar o plano habitado e afastá-lo do chão. ver figura 56 

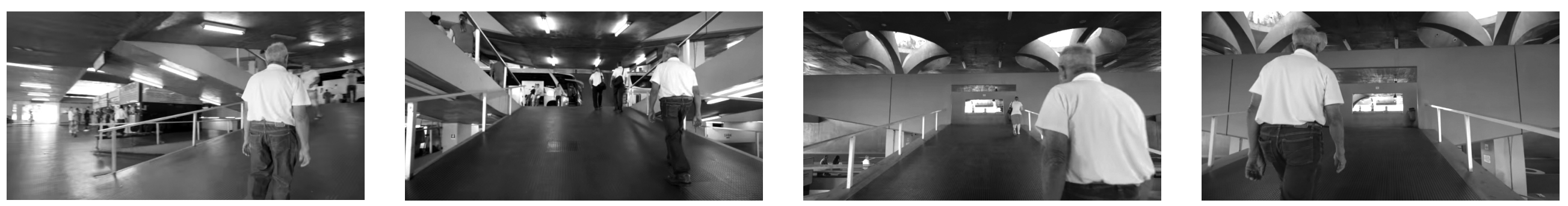

61 Promenade na estação de Jaú em companhia de Sr. Naldo (mestre de obras desse edifício) em 2014

Ainda sobre as diretrizes da arquitetura de Le Corbusier, Calors Martí segue:

"Y así como Mies concibe la casa como una rebanada de espacio horizontal, un ámbito que se dispone entre suelo y techo, con independencia del nivel en que se sitúe, Le Corbusier, en cambio, la entiende como resultado de superponer varios estratos que se van engarzando a través del tiro vertical ${ }^{76}$ del espacio. La casa, es un paseo arquitectónico (promenade architectural) que se inicia en la planta pilotis y culmina en el toit - jardin que asume la condición de patio."77

O processo ilustrado por Martí - que se inicia com a sobreposição dos planos horizontais segue com encadeamento através da 'sucção vertical' na criação do passeio arquitetônico - ilustra esse universo, muito familiar com o que nos trás a arquitetura dos edifícios e casas de Artigas, exatamente nesse ponto surge a promenade architecturale e inevitavelmente a rampa.

A rampa pode ser definida topologicamente, na arquitetura, como um plano inclinado que conecta dois níveis, sobre ela se desenvolve um
76. tiro vertical pode ser traduzido como a "capacidade de sucção de uma chaminé", intuo que Martí, ainda que aparentemente fora de contexto, faça com precisão o uso desse termo para fazer analogia à naturalidade (quase inevitável, própria da física dos fluidos) com que as arquiteturas de Corbusier te conduzem pelo passeo arquitectónico dentro das casas. Tiro vertical é grifo meu, na citação.

deslocamento combinado vertical e horizontal. Essa conexão carrega a ideia da ligação entre os planos (de diferentes cotas de nível) com uma única superfície, formando uma trajetória ininterrupta. A rampa está para a arquitetura assim como plano-contínuo ${ }^{78}$ está para o cinema, e tanto mais ricos serão se puderem nos fazer transitar entre interior e exterior, nos dois casos.

A rampa é uma das máquinas simples mais antigas que existe, sua contribuição à arquitetura extrapola muito a estrita funcionalidade. Ela nos permite, transitar, fazer deslocarmos de forma contínua por toda a arquitetura, com naturalidade e por todos os espaços de uma obra.

A rampa faz parte do promenade, quando não coincide, está contida nele. Combinada com os vazios, os pátios e as transparências nos permite a visão interna e externa ao longo de um trajeto, o reconhecimento de onde estivemos e para onde vamos. Permite também as escolhas de percurso. A rampa é arquitetura - enquanto matéria, é uma bandeja inclinada - mas é espaço e ao mesmo tempo percurso. Relaciona a arquitetura ao tempo, ao tempo necessário para a 

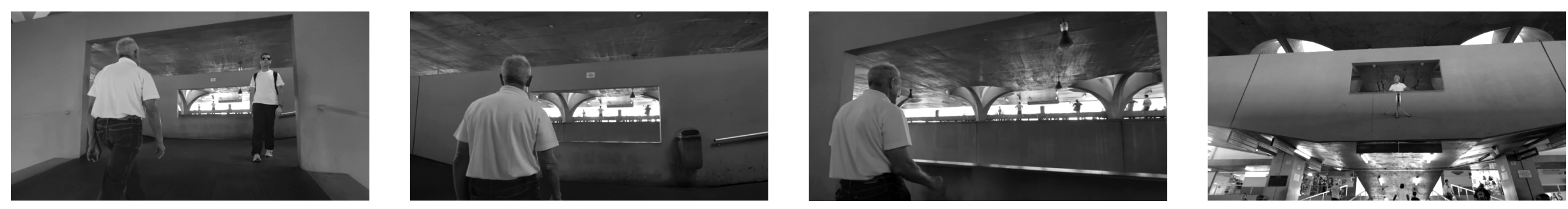

77.MARTí Aris, Carlos, Pabellón y patio, elementos de la

arquitectura moderna, 2008, in: DEARQ: Revista de Arquitectura

de la Universidad de los Andes, , $\mathrm{N}^{\circ}$. 2, maio - 2008 (Ejemplar

dedicado a: Arquitectura con A Mayuscula), pg. 20.

78. Também denominado plano-sequência no jargão cinematográfico.

apreciação, ao tempo musical, podemos entende-la como o símbolo do tempo na arquitetura.

Vilanova Artigas fez largo e bem sucedido uso da rampa, em suas obras identifica-se frequentemente uma sequência de fatos espaciais que estão presentes ao longo do trajeto da rua até o interior das casas ou dos edifícios. É um promenade architecturele, que vai além da aproximação entre homem e obra, ele não termina no umbral da porta, se prolonga, conduz o visitante até o interior da casa.

Refazendo-se o trajeto desde a entrada, nas casas, o primeiro dos fatos arquitetônicos é a presença de um plano vertical - normalmente um muro - que vem respaldar o visitante desde o limite frontal do lote. Uma vez percorrida a distância até a construção e feita a travessia do recuo frontal da parcela, entra-se debaixo de um teto, que pode ser uma marquise, ou o próprio objeto construído, a caixa elevada. O fato seguinte é a superação do umbral da porta de entrada.

Nas casas elevadas, com mais de um pavimento, é nesse ponto que se inicia a rampa ou a escada, que dão continuidade ao percurso dentro da casa. Esse roteiro pode corresponder, salvo pequenas aproximações, ao promenade das casas: Mendes André, Bittencourt II, R. Mendonça, d'Estefani e, considerando a escada como substituta da rampa, também à casa Baeta.

O promenade, em geral, tangencia um espaço representativo da casa, que pode ser um pátio ou uma variação, um pé-direito duplo, um semipátio, na maioria dos casos a rampa se abre à este espaço ou existe nesse limite um plano de vidro, separando interior exterior.

\section{A rampa e a transição entre urbano e casa.}

A sequência ritualística proposta pelo promenade pode ser entendida também como uma forma de prolongar a transição entre a cidade real e o microcosmo da casa, suavizar a passagem entre o coletivo e o nuclear, em um processo de condução de um mundo ao outro. O percurso redobra-se sobre si mesmo, assumindo o papel de labirinto, que prolonga no tempo o trajeto, por não poder contar com muito 
espaço, transforma o que seria um instante em uma seqüência de fatos de interesse. O percurso em rampa é a ferramenta qua dá ao arquiteto planas condições de velar e logo revelar os espaços da arquitetura, em uma dinâmica que possibilita percorrer toda a obra - já que permite a mudança de nível de forma natural, ininterrupta - sempre com a vivência das negações e recompensas visuais e sensoriais.

Josep Quetglas, em seu artigo Promenade Architecturale faz a seguinte reflexão:

"Sólo el trayecto en rampa permite una percepción continuada, manteniendo la mirada fija en el objeto que nos atrae, al tiempo que es función de tres variables simultáneas: la distancia, el ángulo y la altura desde la que consideramos el objeto de nuestra atención.

La rampa será, por tanto, el trayecto idóneo para considerar lo plástico. Martienssen, en su ensayo sobre la idea de espacio en la arquitectura griega, sugiere que el efecto del habitual camino en rampa quebrada hacia un templo dórico equivale a hacer girar y acercar el templo hacia el espectador, como considerándolo desde todos los puntos de vista."79

Quetgas, ao citar Martienssen, consegue colocar claramente a questão da rampa quebrada como uma ferramenta com poder de fazer variar a perspectiva e manter a atenção ininterrupta. Essa preservação da atenção dirigida ininterrupta, que existe na ascensão ao promontório na aproximação ao templo é análoga ao uso que Artigas faz da rampa, condição que vai ganhando força ao longo de sua obra.

Antoni Ubach, em citação que faz em seu livro sobre a escada no século $\mathrm{XX}$, consegue exprimir a essência do conceito de tempo na arquitetura, como sua quarta dimensão einsteniana e sua especial relação com a arquitetura moderna e o Movimento.

"Para desarrollar un movimiento se requiere un tiempo, (...) El tiempo se convierte así en la cuarta dimensión del espacio einsteniano, y de esta manera es integrado en la Idea del espacio arquitectónico de MoholyNagy: como movimiento necesario para percibir la arquitectura. A partir del Movimiento Moderno, hablar del espacio asrquitectónico es tanto considerar el tiempo, y em consecuencia, el movimiento, como parte inseparabel de él" 80

Se partirmos da hipótese de que a rampa constitui espaço e, por isso, pode corresponder a algum tipo, então se torna possível fazer algumas verificações em relação às rampas que Artigas usou e à forma com que foi aplicada em sua arquitetura.

Podemos ancorar a análise citando o projeto para o Hospital São Lucas, em Londrina, de 1945, possivelmente um dos primeiros edifícios de grande porte em que Artigas fez o uso da rampa. A lógica distributiva desse edifício é simples, mesmo se tratando de uma construção de ocupação relativamente densa. O edifício está distribuído funcionalmente em dois blocos autônomos, com quatro e dois níveis 

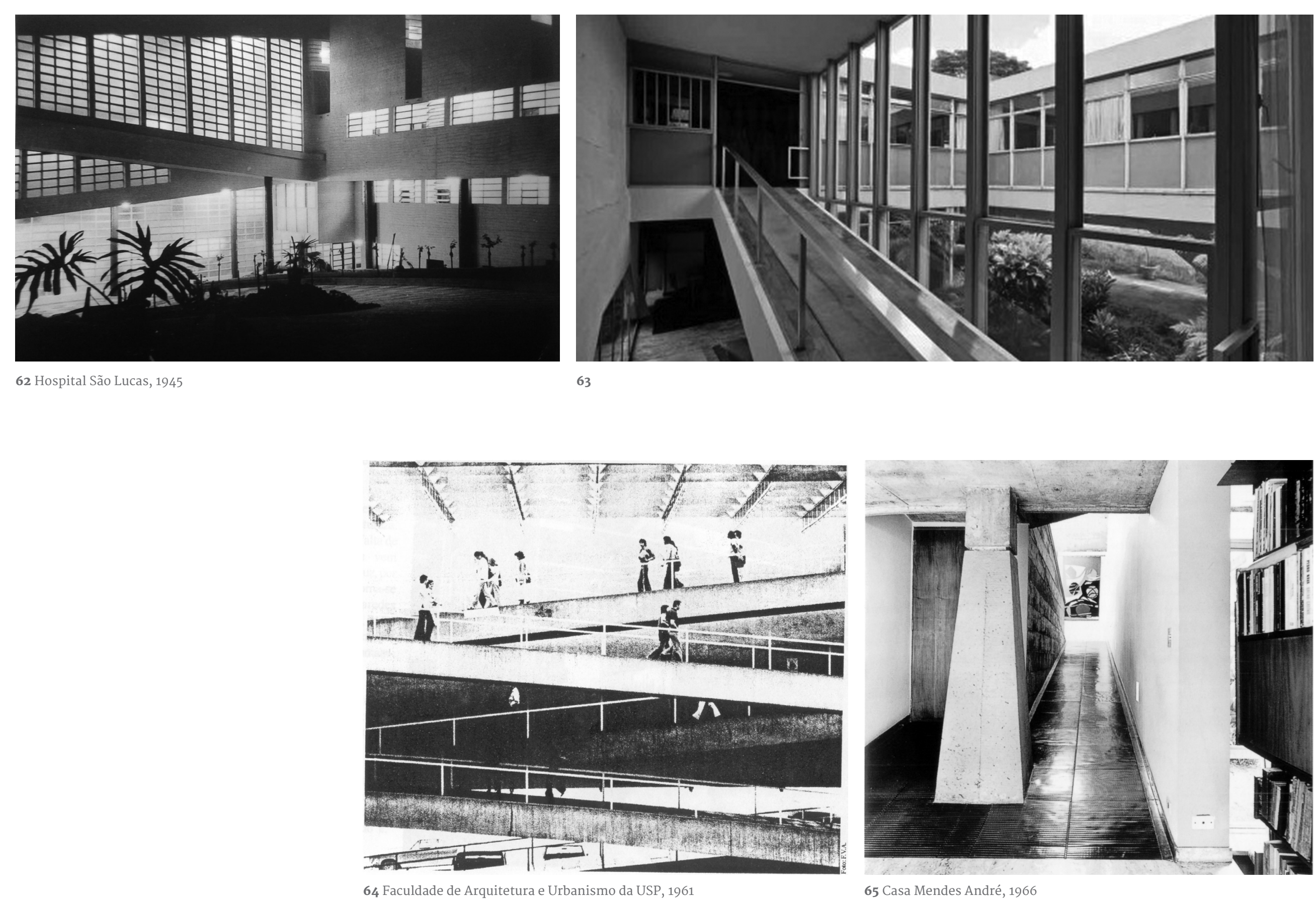


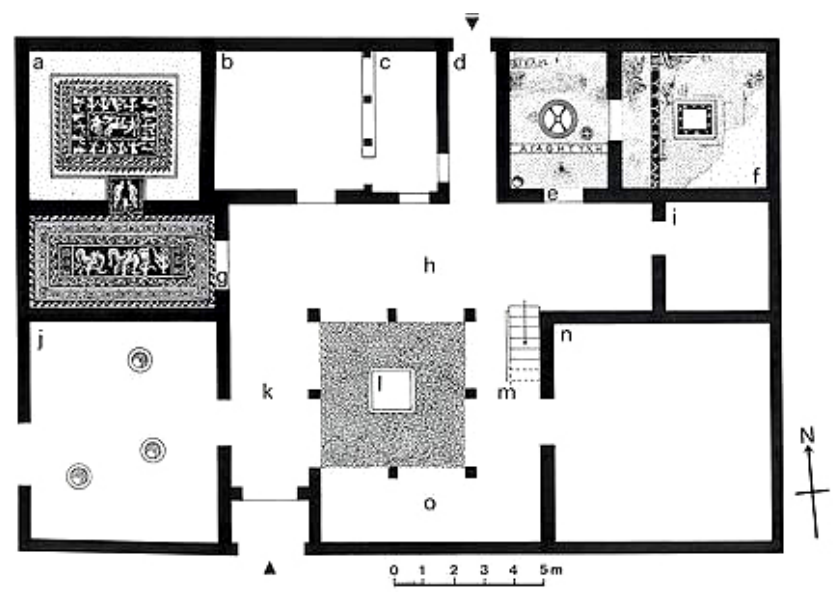

65A A casa de Olinto, séc. V a.C. (1 - aulè, h - pastás) ver nota 88.

respectivamente, que estão conectados por um conjunto de rampas. Os blocos formam entre si um espaço ajardinado que não pretende ser muito mais que um vazio para o qual parte das funções se abre. O conjunto de rampas, nessa situação, não desfruta intensamente do espaço livre, está diretamente relacionado à este ao cruzá-lo pelo ar e, também, constituir um dos seus três limites, mas não chega a abrirse planamente à ele por duas razões, a rampa está aberta somente em uma de suas laterais e o faz com pouca transparência, esquadrias muito subdivididas e vidros opacos.

Esse exemplo pode ser definido como um uso não em plenitude da rampa,incompleto talvez. Sem dúvida há um grande ganho funcional, além do fato da rampa a sustentar o partido arquitetônico, no entanto, sem explorar muitas de suas potencialidades. Dentro de uma leitura a partir do trinômio ARP, as rampas do São Lucas se enquadram na categoria de espaço aula, provido de teto e fechamento lateral, portanto introspectivas, isoladas e sem condições de potencializarem visadas cruzadas ou permitirem leitura sincrônica do espaço aos quais servem.

Duas obras com rampas em plenitude de aplicação e análogas entre si, em diversos outros aspectos, são a casa Bittencourt II e o edifício da FAUUSP, mesmo se nos ativermos aos aspectos comuns identificados entre as obras fica evidente o potencial arquitetônico da rampa ambas têm relação direta e integral com os pátios, elemento fundador tanto da casa quanto do edifício educacional. Esse fato por si só garante uma força muito maior como elemento arquitetônico do que ocorre no exemplo do hospital.

A rampa está nos dois edifícios em estado puro, ou seja, Artigas opta por reduzi-la à sua essência, construindo um plano inclinado limpo, completamente desprovido de elementos que pudessem interferir na máxima apreensão do entorno. As rampas não possuem peitoris e os guarda-corpos, quando existem, estão reduzidos à mínima matéria possível. Essa condição dá às rampas a possibilidade de enquadremse no trecho do edifício do qual participam no tipo teto, portanto sem nenhum fechamento lateral, a não ser o fechamento completamente envidraçado que existe entre a rampa e o pátio na casa Bittencourt II que, para efeitos analíticos, é um não fechamento, ou um fechamento mutável.

Entretanto, há uma nuance que ocorre tanto na casa quanto na faculdade resultante dos lances de rampa terem sim, de alguma forma, fechamentos laterais: de uma lado a proximidade com a empena, que somado ao fato de estarem entre duas bandejas, constituem nesses 
81. Para verificação de questões sobre o termo aula ou sinônimos possíveis, ver glossário em 1.2. Terminologia, em especial

para se ter registro da escolha por esse termo, pelo autor, em detrimento de outros, p.ex. sala.

82. ARMESTO Arias, Antonio. El Aula sincronica, un ensayo sobre el analisis en arquitectura, Tese de doutorado apresentada à EtsaBUPC em 1993, p.61

83. Idem, p.61

84. Ibidem, p.62

85. Iniciada no ponto 1.3. Ferramentas de análise dessa dissertação.

86. PORTOGHESI, Paolo, Dizionario Enciclopedico di Architettura e

Urbanística, Instituto Editoriale Romano, 1968, vol. I.

trechos espaços aulares, com fechamentos laterais e teto. Essa sucessão de visuais amplas - nos lances que se abrem para o vazio dos pátios - e logo contidas - junto às empenas - enriquece ainda mais o roteiro que a rampa pretende materializar.

Artigas utiliza claramente uma estratégia de negação e revelação, de restringir e recompensar, análoga ao trajeto de ascenção ao templo helênico.

\subsection{Aula}

O tipo aula ${ }^{81}$ está relacionado diretamente com alguns elementos já abordados até aqui na pesquisa; depende da existência de teto e de fechamentos para se configurar. Antonio Armesto Arias, em seu ensaio El Aula Sincronica propõe as seguintes definições topológicas para aula:

"EL AULA resultará de la suma de las constricciones topológicas o fronteras de sus componentes, determinando el espacio em $x, y, z$." 82

"También podrían caracterizarse recinto y pórtico como partes de um todo más complejo que sería el aula."83
87. prá-helênica, inserção minha. O megarón também é citado por Armesto na descrição, corresponderia, formalmente, a um átrio tetrástiloromano mas com seu impluvium coberto por um plano de teto elevado em relação ao peristilo. São notáveis os megarón da arquitetura micênica.

88. ARMESTO Arias, Antonio, op.cit. pg. 64-5, grifos do autor. Ao fazer a descrição da casa pré-helênica Armesto cita as casas de Olinto (Olynthus sec.V a.C.)

"El Aula realiza la construcción total, definiendo uma región dentro del espacio general, um recipiente capaz que contiene una porción de atmósfera, de suelo y cielo, un volumen. El aula definida como límite radical, tridimensional, no supone uma negación del espacio sino la creación de un verdadero universo, una suerte de homotecia sendible del Universo o una parte de él que de algún modo lo contiene."84

Aprofundando a reflexão sobre o termo aula ${ }^{85}$, podemos nos aproximar da sua variada origem, e da multiplicidade de significados que carrega, a partir da seguinte percurso etimológico recolhido por Armesto:

"Em el Dizionario Enciclopedico di Architettura e Urbanística" se recojen las palavras aul, aula y aulè. Aul es el termino que indica (...) el asentamiento o la acampada de yurtas de los nómadas mongoles y turcos. El sitio del campamento se deja marcado de un año para otro com uma hilera de piedras (recinto) (...) Aulè, del griego, en el mundo clássico designaba el pátio de la casa griega más antigua (pré-helênica) ${ }^{87}$ generalmente este patio estaba empedrado (...) y cerrado al norte con un pórtico (pastàs) (...) En época helenística la aulè fue sustituida por el peristilo. El término lationo aula, (...) originariamente um patio, designa, em los edifícios públicos, un ambiente de dimensiones relevantes, (...) y equipadas para recibir un cierto número de personas. ${ }^{88}$ 
89. Tomou-se a liberdade de cunhar um adjetivo que caracteriza espaços que coincidem com o tipo aula.

90. No sentido de peristilo, ver glossário em 1.2. terminologia.

91. O termo medianera é utilizado em castelhano para designar as paredes laterais das casas, construídas sobre a divisa e que frequentemente são compartilhadas por duas residências, foi dada preferência ao uso desse termo emprestado de outro idiom para concentrar em uma palavra o renque de quatro casas sem recuos laterais.

AULA RECINTOO TETO

66 Croquis ARP

Etimologicamente aula estabelece relação direta com pátio (recinto) e com teto (pórtico), que são também os dois elementos topológicos dos quais depende para se conformar.

Na obra de Artigas, o exemplar emblemático da tipologia casa-aula é a Casinha, de 1942, onde paredes e teto se combinam na formação espaços aulares ${ }^{89}$ introspectivos, rodeiam um núcleo central e têm nas aberturas e vãos uma relação dosada com o exterior. Não há excesso de transparência ou grandes vãos, o interesse pelo exterior é sutil, sem vistas incríveis que contemplar. O interior estabelece contato visual com o jardim externo sem exageros, não há portas-balcão, mesmo a varanda não estabelece forte vínculo com a casa ou com o jardim, apenas com o acesso. É um pórtico 90 mais do que varanda. Talvez por ser assim ensimesmada, essa obra nos confirme a ideia de ser do tipo que combina as paredes com o teto formando uma casa-aula autêntica.

Podemos fazer uma rápida reflexão sobre a Casa Benedito Levi, de 1944, que resultaria - analiticamente - da operação de elevar a casa-aula em relação ao solo, remetendo ao tema da casa elevada e aos pilotis, entretanto, o que ocorre nessa obra é a elevação sem a criação de pilotis a casa é suspensa sobre um muro, remetendo às ações projetuais que geraram o conjunto de casas feito para Jaime e Euzébio Porchat em 1944 em São Paulo. Trata-se de quatro casas entre medianeras ${ }^{91}$ sem recuo lateral. Compositivamente resultam da justaposição dos quatro volumes em um único renque, formando um longo pavilhão que está também elevado em relação ao solo, da mesma forma e pelo mesmo objeto que eleva a casa Benedito Levi.

Ao estudarmos a relação que as quatro casas do conjunto estabelecem com o exterior, mesmo que com grande transparência, principalmente na sala, veremos que se tratam de casas aula, "apoiadas" em cinco muros transversais ao pavilhão que formam.

Essas duas obras podem ser consideradas exemplares iniciadores de série que logo progrediu com a aparição de muitas casas elevadas sobre pilotis. Nesse capítulo nos interessam especialmente aquelas que 


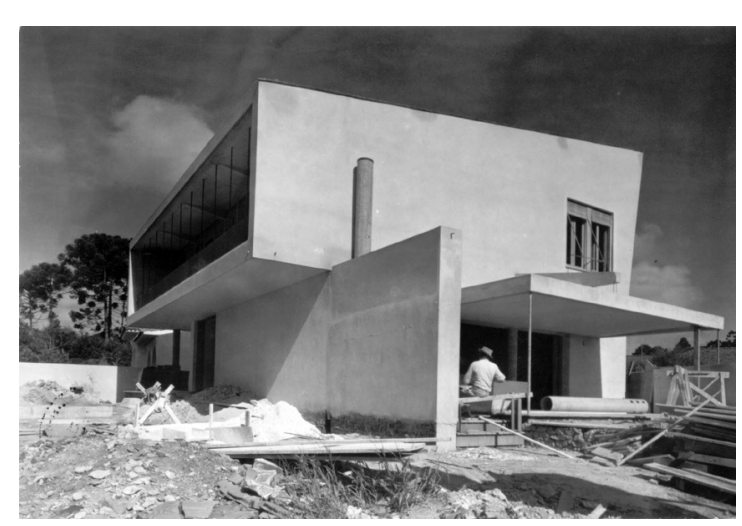

67 Casa Benedito Levi, 1944

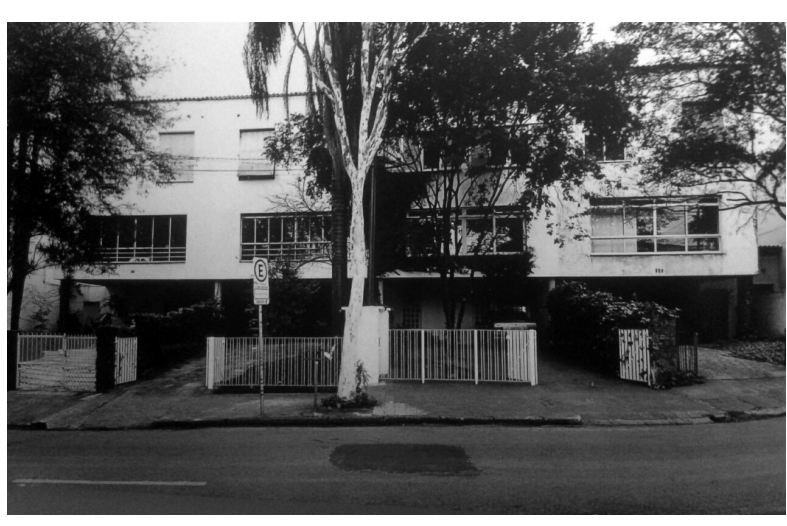

68 Casas Jaime Porchat, 1944
92. Pode haver uma relação etimológica relativamente próxima entre caixa e casa, passando por caja.

93. Janela ideal, sistema no qual o vão é fechado por dois elementos com a mesma forma e mesmo peso que se deslocam na vertical por trilhos e o peso da folha que desce serve de

contrapeso para aquela que sobe. Foi amplamente utilizado nas obras de Artigas, edifício Louveira de 1946 é outro exemplo. mantêm a introspecção característica desse tipo, podendo ser elevadas ou térreas.

A casa Rubem de Mendonça (1958) também conhecida como "casa dos triângulos", é um exemplar interessante de casa aula, apesar de ter transparência de piso a teto na sala, parte onde poderíamos considerar predominância pontual do tipo teto, a aula prevalece, na obra como um todo.

A fachada frontal e a de fundos são cegas, as fachadas laterais têm algumas aberturas, prevalecendo a superfície opaca, são trabalhados fechamentos em dois planos diferentes, o que acaba distanciando o exterior do interior.

No esquema de circulação, a solução em meios níveis e os pés-direitos altos enriquece o espaço central da casa, ao tempo em que o tornam mais complexo, sempre se tem uma laje ou mobiliário do nível imediatamente acima bloqueando a visual externa, e tornando a casa mais fechada, consolidando sua vocação introspectiva

Situada em terreno de proporções quadradas, a residência Mendes André, de 1966, também constitui uma casa classificável como casa aula. Repete a ideia da caixa elevada ${ }^{92}$ e podemos dizer que foi feito um giro de $90^{\circ}$ em relação à implantação da Mendonça. Portanto, o bloco principal se posiciona paralelamente à rua.A casa está elevada sobre apenas quatro pilares.

Artigas opta por trabalhar com pouca transparência na fachada principal e continua até o fechamento da sala com a mesma solução adotada nos dormitórios, onde há um grande vão alongado na horizontal que surge apenas com a abertura de todas as janelas ideal93 que são dotadas de folhas de vidro e também de venezianas pelo lado de fora, prevalece o espaço constituído por teto e paredes, exceção feita a um pequeno trecho de caixilhos de piso a teto existente na sala e orientado para os fundos, uma aula, que entre outros aspectos, está marcada formalmente pela virada do piso e do teto para a vertical para 


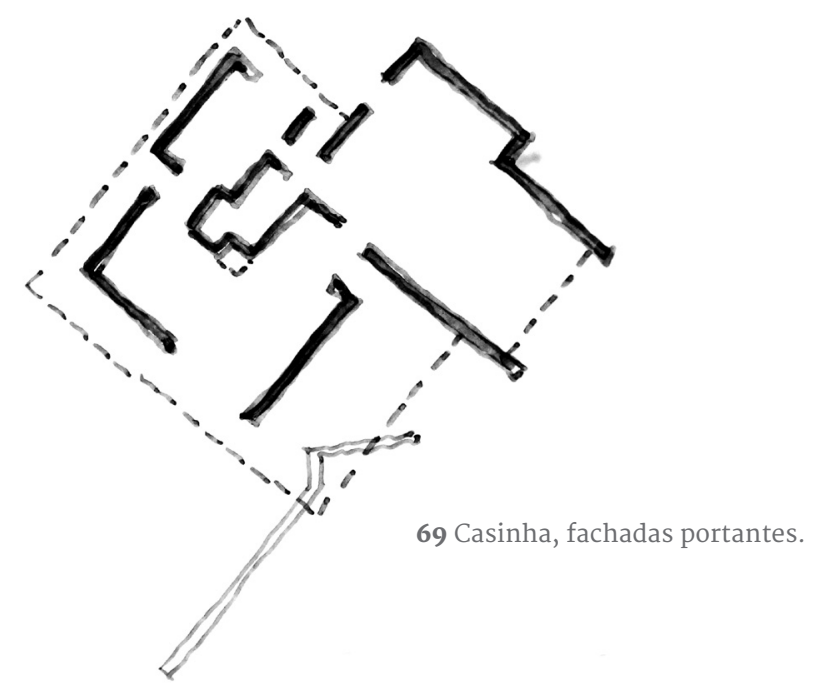

formar a empena e volta à horizontal para formar o teto. Além disso, o fechamento frontal da caixa não tem transparência total em nenhum ponto; novamente teto e piso se dobram para formar a vertical do peitoril e da verga.

A casa Mendes André reforça a ruptura entre a arquitetura exterior e interior há um grande contraste em relação ao que se esperaria para o espaço interno de uma casa de feições exteriores tão vanguardistas, e o que se encontra. Dentro dela a introspecção é forte característica , portanto, um tipo aula.

O edifício para os vestiários do São Paulo Futebol clube, de 1959, projetado sete anos antes da casa Mendes André, pode ser selecionado nesse momento para estabelecer uma relação analógica interessante com a casa. Trata-se, hipoteticamente, da extrusão da casa M. André. Poderíamos tomar o anel formado por laje de piso, cobertura e empenas laterais, supondo que fosse composto de material dúctil e pudéssemos esticá-lo, sem que houvesse perda de massa ou distorções na forma, até que se chegasse aos 140 metros de comprimento, a cada 7 metros plantaríamos um par de pilares, estaria assim, sendo formado o edifício.
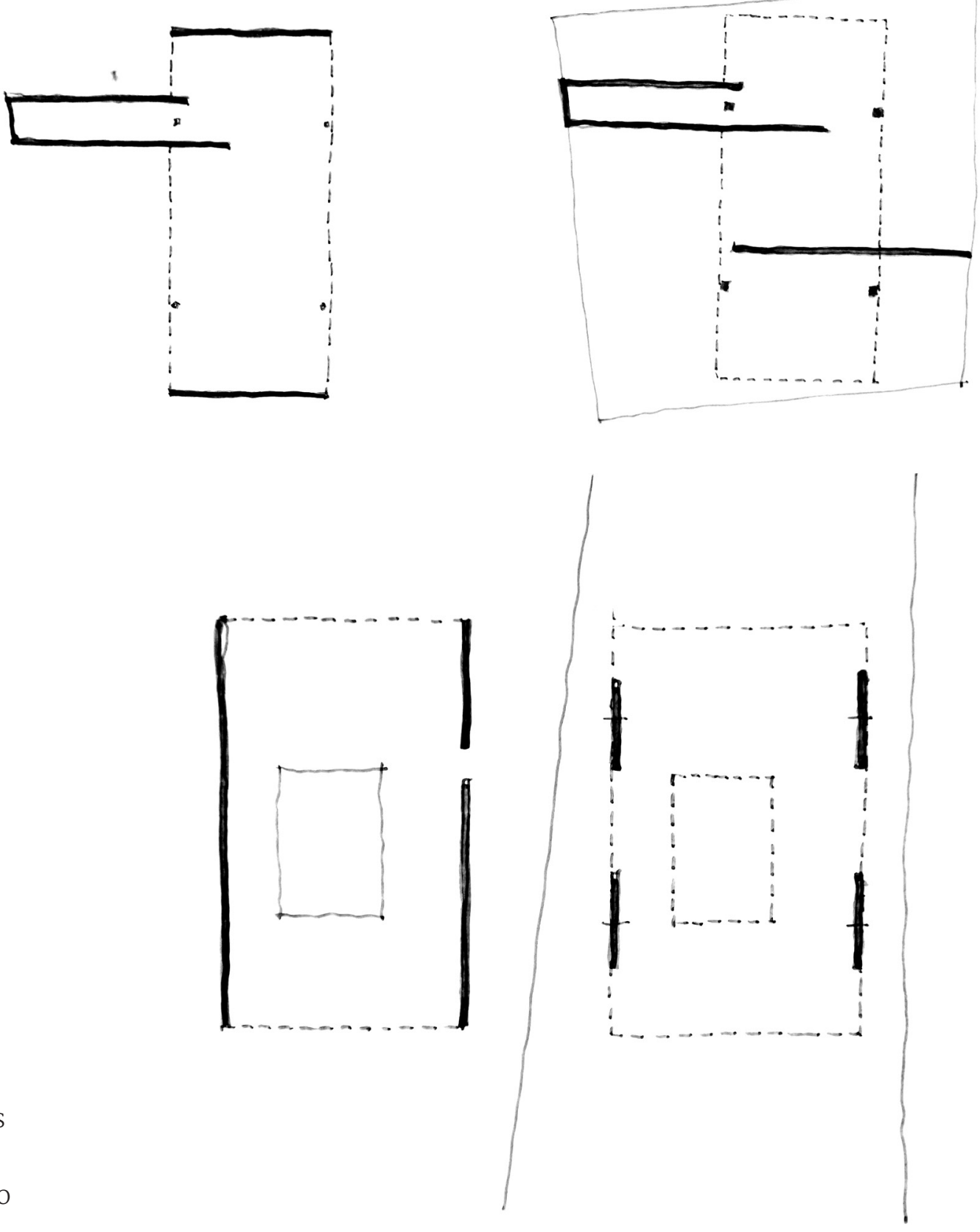

69A e B Empenas estruturais nas casas M.André (no topo) e Bittencourt II (acima), as fachadas longitudinais mantém a função estrutural, mas na casa M.André passam a ser "vazadas" 


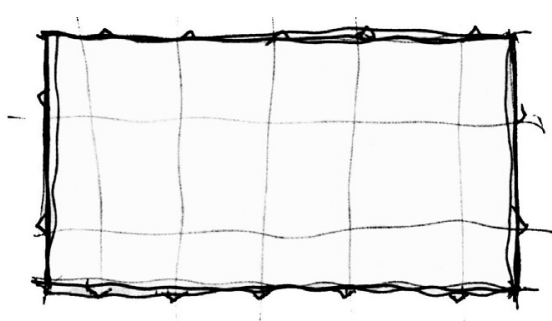

70A FAUUSP planta baixa e planta alta.

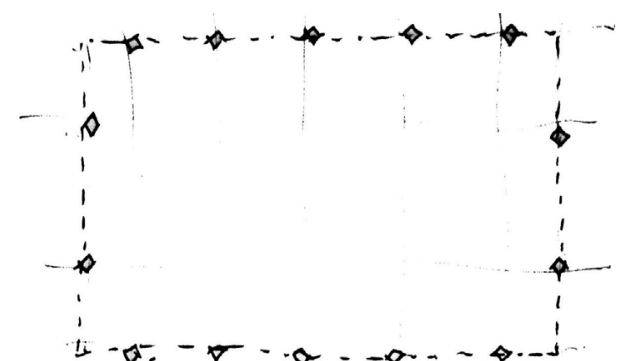

$t-\nabla,-\nabla-\infty \cdots \cdots$

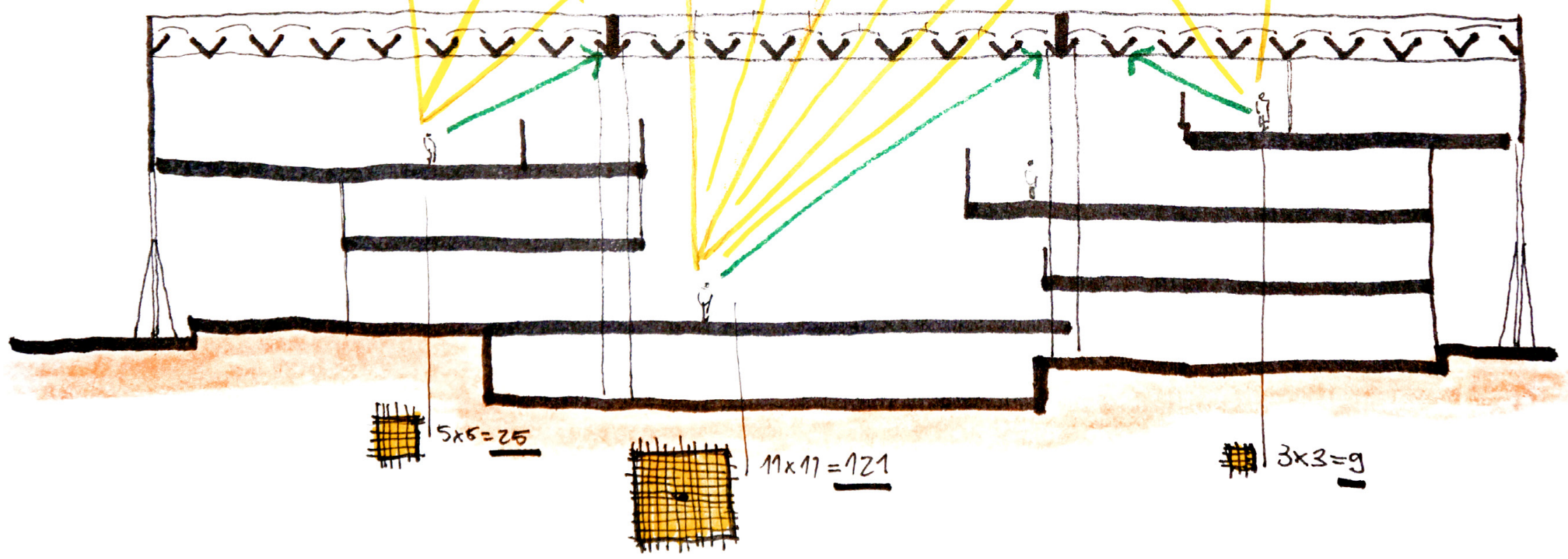




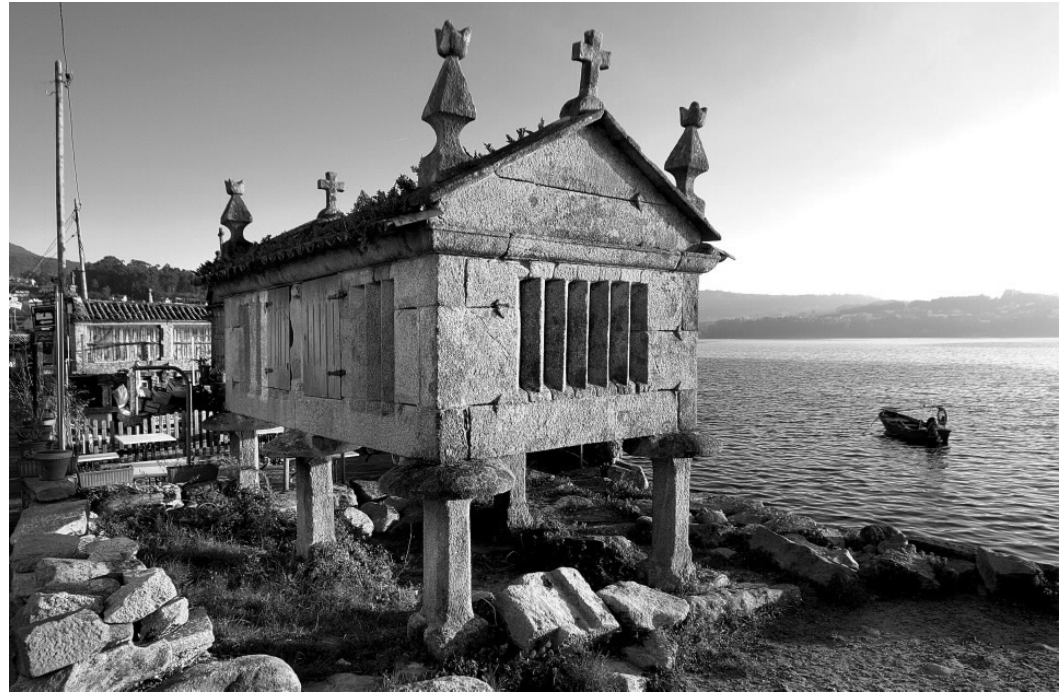

71 Hórreo em Combarro (Vigo, Galícia - Espanha)

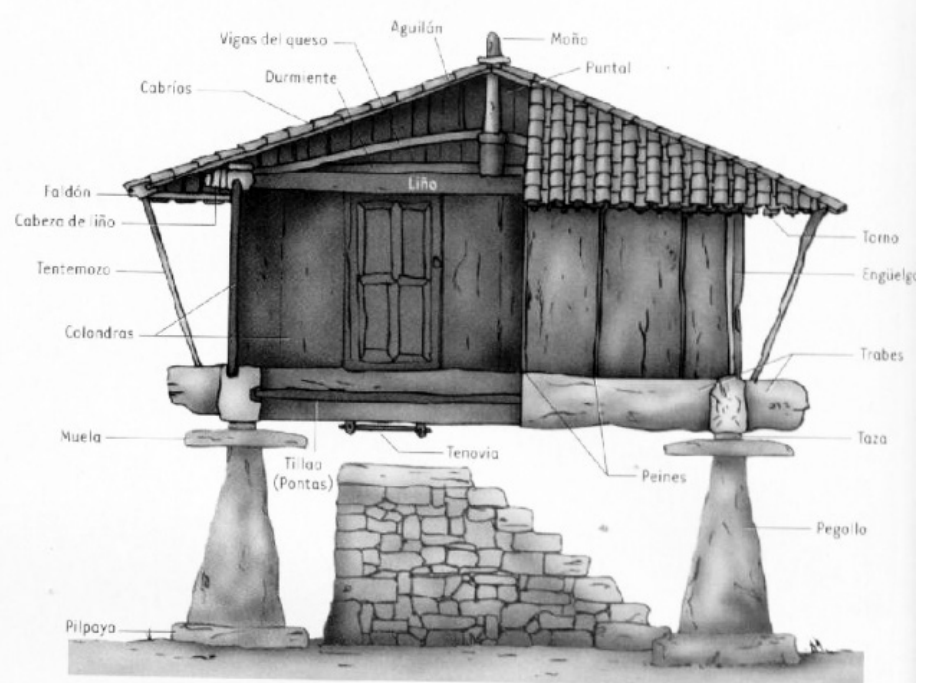

72 Hórreo típico asturiano e seus elementos
Quem sabe o mais lógico seria dizer que a casa surge do fatiamento do edifício dos vestiários.

O edifício da FAUUSP é um objeto cultural que representa rica fonte de questões para o desenvolvimento da análise, um edifício que reúne em sua arquitetura muitas das variáveis dos tipos elencados e explorados na pesquisa, basta dizer que, segundo o enfoque ou a escala do espaço que se analise, pode enquadrar-se como edifício pátio - talvez o tipo que melhor lhe define - como edifício teto e ainda como edifício aula, que nos interessa particularmente agora.

O edifício é uma grande aula. Um salão que vai se consolidando à medida que se sobe e se perde o contato visual direto com a paisagem externa, assim os limites verticais das fachadas se fazem presentes (se consolidam na vivência espacial) e o teto se solidifica, pois conforme se sobe e se aproxima do teto o numero de claraboias visível diminui, prevalecendo, sempre mais, as faces das vigas em $\mathrm{V}$ da malha de cobertura, nesse momento de proximidade máxima entre espectador e teto, ocorre que cada um passa a ter seu próprio pátio, só "verá" o céu através do domus que estiver sobre sua cabeça. O entrelaçamento entre o edifício da FAU e a tipologia do pátio vai bastante além dos domus ${ }^{94}$, esse é praticamente um símbolo de uma relação bem mais ampla.

O edifício da escola pode ser análogo a um templo, com seus peristilos e cella, mas esta não está no solo, mas suspensa pelas colunas. É como se a cella fechada do interior do templo fosse ampliada até coincidir com os limites externos, e fosse suspensa para apoiar-se na colunata. Um templo, sem a cella em seu núcleo - onde sua ausência deixa um grande vazio - as operações lógico-formais propostas nessa análise são equivalentes àquelas que originam os hórreos (cilos, graneiros) típicos do noroeste da Espanha. 


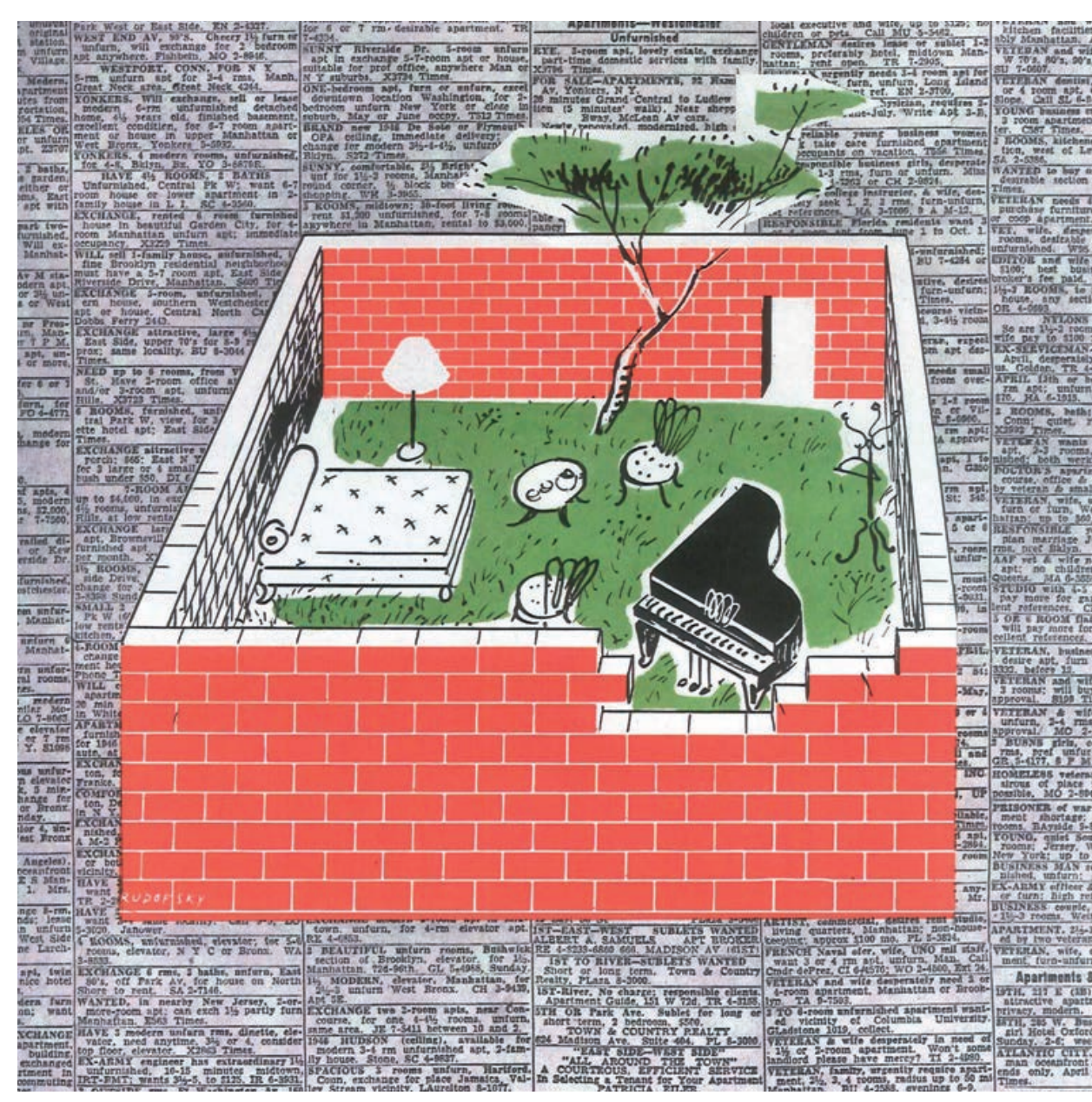

73 Ilustração para capa da revista Interiors de maio de 1946, Bernard Rudofsky.
94. domus, denominação que Artigas atribui às claraboias do edifício da FAU, explicita a relação entre a luz zenital pretendida neste edifício e a domus romana.

\subsection{Pátio}

O pano de fundo diante do qual Artigas elabora a casa urbana não é dos mais amigáveis. conceitualmente, a cidade jardim caminha no sentido de gerar um entorno mais agradável e ligado à Natureza, buscando equilíbrio na relação público-privado, um ideal representável pelas casas esparsas no jardim. Não foi com essa plenitude que os bairros jardim de São Paulo se consolidaram. Acabou ocorrendo uma compressão do modelo e a arquitetura que se consolida, geralmente, está isolada do entorno, dentro de terrenos murados, privando de urbanidade a cidade que se constitui.

Sobre a da relação casa-cidade Luiz Recamán escreve:

"A arquitetura que aí surge, a partir de ação de seu arquiteto mais inovador, Vilanova Artigas, reage prontamente à esse modelo urbano devastador

(...) a arquitetura de Artigas e de seus contemporâneos se opõe - mas considera - à realidade urbana na qual se insere. O edifício ensimesmado, 
95. RECAMÁN, Luiz, in "De volta ao Real", Folha de S.Paulo, caderno Mais!, 16 de abril de 2006, pg.6 - Luiz Recamán é

coautor de "Brazil's Modern Architecture" Phaidon (op.Cit.)

96. BAROSSI, Antonio carlos, 2010, Ensino de projeto na FAUUSP, Tese de Doutorado apresentada à FAUSP. pg.2.
97. RECASENS, Gonzalo Díaz, La tradición del pátio em la arquitectura moderna, in: DPA Documents de Projectes d'Arquitectura. Revista del Departament de Projectes Arquitectònics de la Universitat Politècnica de Catalunya (UPC), no 13, Dezembro 1997. <http://revista.dpa.upc.edu/02ARCHIVO/DPA\%2013/dpa13.html> (acessado em nov-2013)

"O pátio pode adotar infinidade de formas e papéis na arquitetura e o que podemos ver de comum a todas é a capacidade de apropriar-se de um solo e constituir lugar. É o núcleo germinal da casa, desde o pátio se vive, se respira, se recebe a luz e a água, se unifica a vida em um sistema de crenças, todos prováveis motivos de sua longevidade. Em sua origem encontra os fundamentos substanciais e permanentes do ato de assentar-se em um lugar." Tradução do autor. introvertido, recria no terreno disponível (...) uma sociabilidade distinta daquela, injusta, que desenha e destrói a cidade ao redor." 95

Esse panorama e as condicionantes com as quais Artigas teve que trabalhar nos projetos das casas lhe permitiram chegar a um repertório de soluções e composições que materializaram a expansão da casa até os limites do lote, não necessariamente com construção - já que esteve sempre presente a figura dos recuos obrigatórios - mas com vazio, com a conformação de espaços entre pavilhão e limite físico. Situação que ilustra e até justifica a preleção pelo modelo de casa pátio adotado frequentemente e destilado por Artigas.

O pátio representa o vazio, vazio como condição para a forma, complementaridade que justifica o objeto ${ }^{96}$, nessa acepção o vazio é a condição para existir a forma; o vazio é o pátio e a forma a construção.

Com a análise nos aproximaremos de algumas questões que rodeiam o valor simbólico do pátio e, principalmente, das ações arquitetônicas que o constituem.
Em relação aos valores que o pátio simboliza na arquitetura podemos citar a Gonzalo Díaz Recasens, para quem o pátio se alinha à ação fundadora do edifício, à apropriação do lugar. Também simboliza o mundo exterior e, ao mesmo tempo, cumpre o papel de trazer alguns de seus elementos para dentro da arquitetura, como a luz, a água e a vegetação.

"El patio (...) probablemente haya sido el germen de muchos edificios, adopta multitud de papeles en la arquitectura y lo que de común podríamos encontrar en todos es su capacidad de adueñarse de un suelo y constituir un lugar. Quizás, al igual que "el hogar", haya sido el núcleo germinal de la casa meridional; desde él se vivía, se respiraba, se recibía la luz y el agua, se unificaba la vida con un sistema de creencias" 97

"En este sentido, una primera interpretación trataría de presentar el patio como un mecanismo formal delimitador que encierra un lugar; la tapia, la parcela, la cerca que acota un pastizal y que etimológicamente le presta su término "patu" o "lugar de pasto comunal", pronto pasa a significar terreno sin edificar, baldío detrás o en el interior de un edificio. (...) otros elementos colaboran pero ninguno se entendería sin este primer acto de la fundación de la casa." 97 
98. WISNIK, Guilherme Teixeira, Modernidade congênita. in Arquitetura moderna brasileira. (op.cit.) pg.42.

99. ver CUNHA, Márcio Cotrim; GUERRA Abílio, Entre o

pátio e o átrio três percursos na obra de Vilanova Artigas, 2012,

disponivel em <http://www.vitruvius.com.br/revistas/read/

arquitextos/13.150/4591>, acesso em 22 fev 2015

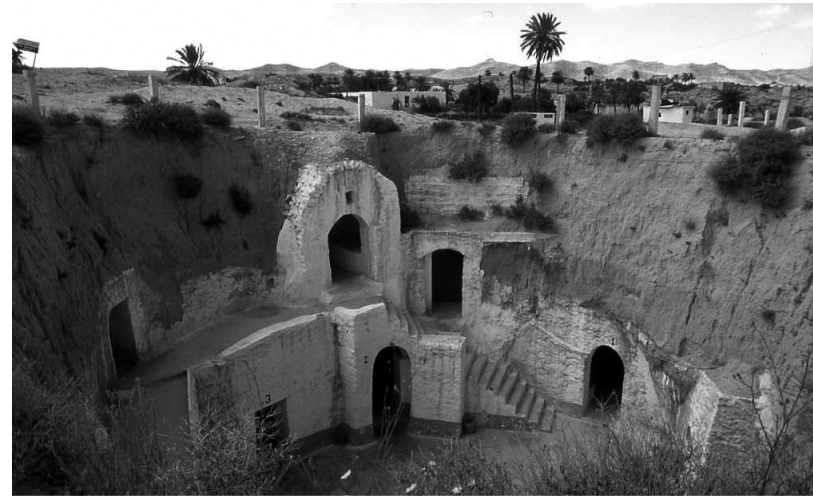

73A Matmala, Tunísia, vista de um pátio.
Recasens também reflete sobre as condições topológicas do pátio, como se constitui formalmente e a estreita relação que tem com o recinto, com a cerca que cota um trecho de território, trazendo-nos o vínculo etimológico entre pasto (patu) e pátio. O vínculo entre pátio e pasto ecoa também na ideia do pátio como um portador da Natureza dentro do mundo doméstico. Muito presente na arquitetura da escola paulista.

"Desenvolvido posteriormente à construção de Brasília, o brutalismo paulista vai internalizar uma compreensão territorial da geografia do país e do continente, tragando para dentro dos edifícios os atributos inerentes ao ambiente externo: áqua, jardins, luz solar. Essa operação se faz mediante uma poderosa integração espacial interna,nque acomoda os diversos programas do edifício sob uma cobertura única, e parece incorporar, na fluidez de suas rampas, aquela superfície contínua e anterior a qualquer diferenciação que está no horizonte desencantado de Brasília." 98

Dentro de toda a flexibilidade que lhe é própria, o pátio pode assumir um sem número de situações, escalas, valores, estados e posições relativas na arquitetura. Nesse universo, nos interessam especialmente para análise as seguintes condições: pátio externo (recinto), pátio interno (impluvium), a redução do pátio (simbologia) e o pátio como espaço ordenador (partido arquitetônico em pátio). Desses quatro tipos principais surgirão os sub-tipos: do pátio externo surge o semipátio ou pátio lateral e do interno surge o pátio ordenador, que não está simplesmente dentro, mas estabelece função estrutural no edifício, é o pátio estrturante99.

Entendemos que, a relação entre a massa construída e o recinto, pode se dar de três formas principalmente, o pátio pode: (i) estar fora, a conter a efificação, (ii) estar contido na edificação, inserido, (iii) estabelecer relações de intersecção e interferência mútuas, em igualdade de potência com a construção. Nesse capítulo pretendemos explorar as duas primeiras (interior e exterior) e a redução do pátio, já a terceira condição, em que pátio e pavilhão dialogam em igualdade de escala - por estar menos presente no conjunto de obras analisadas estará menos presente na análise.

A partir daqui é feito amplo uso do termo pavilhão, cabe, portanto esclarecer que o usaremos para nos referirmos ao volume construído. Interessa-nos especialmente esse conceito para refletir sobre a relação entre recinto e casa. Carlos Martí Aris (2008), em seu artigo Pabellón y patio, elementos de la arquitectura moderna, faz a seguinte análise sobre a relação de complementaridade entre ambos: 


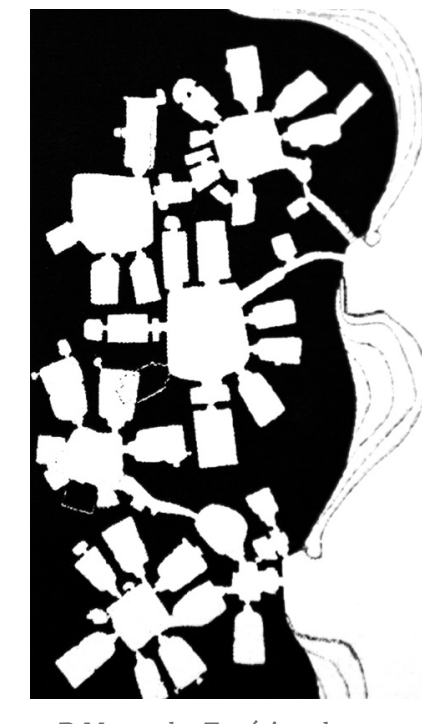

73B Matmala, Tunísia, planta.

"El patio se asocia a lo cóncavo e interiorizado, a la construcción de un recinto y a la apertura cenital; mientras que el pabellón se asocia a lo convexo, a la construcción de un techo, al carácter centrífugo y a la apertura visual hacia el horizonte. En su reducción más esencial, el patio se identifica con un muro que delimita un lugar mientras que el pabellón se asimila a un techo que protege y expande la visión lateral. El patio es una estancia sin techo. Suele ser un espacio central, nuclear, al que vierten las demás habitaciones y donde se establece la relación entre todas ellas. La casa, a través del patio, se relaciona con el exterior mediante un eje vertical que vincula la tierra y el cielo. En la arquitectura tradicional, el patio surge de horadar la masa construida."100

Martí apresenta a essência topológica do pátio: são as operações de articulação dos muros que constituirão o recinto - o côncavo - e dentro dele poderá estar contido o pavilhão, a casa ou o edifício - o convexo. Na citação é mais presente a imagem do pátio que escava a
100. MARTÍ Aris, Carlos, Pabellón y patio, elementos de la arquitectura moderna, 2008, in: DEARQ: Revista de Arquitectura de la Universidad de los Andes, , No .2 , maio - 2008, pg. 17

101. Idem, pg. 17

102. Construção isolada no lote, beirais em toda volta, passagem lateral para o carro, edícula com garagem, muitas vezes em estilo neocolonial ou eclético, esse tipo de casas esteve muito presente na fase que Artigas manteve sociedade com Duílio Marone, na construtora Marone \& Artigas, que atuou de 1938 a 1943.

103. Conforme analisado em 4.1. Terrapleno, na presente dissertação

104. CORRÊA, Maria Luiza, op.cit., pg, 83. construção para existir, reforçando a noção de que o pátio representa uma supressão de massa construída, mas o autor segue com a seguinte colocação:

"Esta idea del patio como excavación o sustracción tiende a ser sustituida, en el ámbito de la arquitectura moderna, por una operación constructiva de adición o articulación de una serie de piezas autónomas que al reunirse, según ciertas reglas, definen el espacio del patio. Lo que permanece constante es la noción del patio como concavidad y como habitación sin techo."101

Como primeira reflexão sobre o pátio, podemos entrar na imagem da casa urbana e a relação do pavilhão com a parcela de terreno, dos muros que delimitam o lote e da casa que se posiciona ali dentro. Artigas produziu por um longo período em sua carreira principalmente casas urbanas unifamiliares, acabou assim tendo frequentes oportunidades de experimentar com o domiciliar e o lote urbano. Ao longo da 


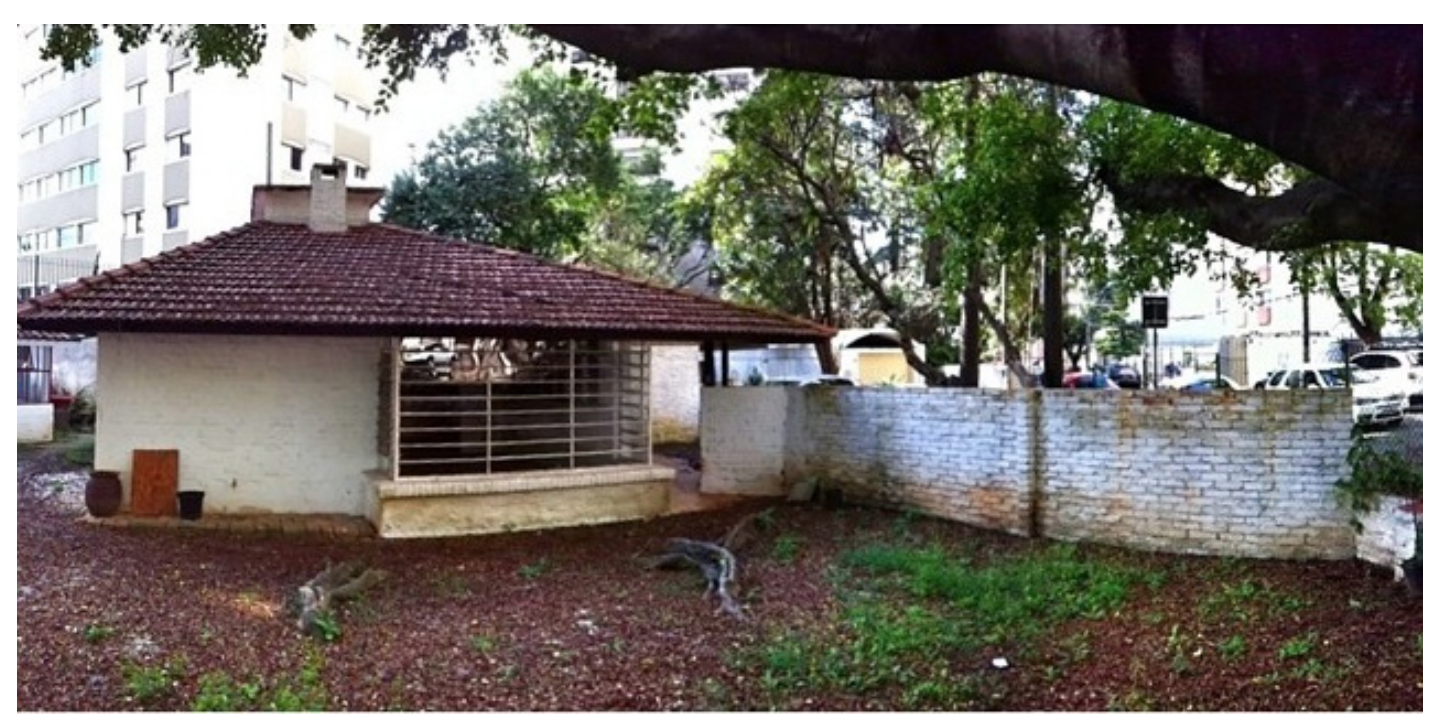

74 'Casinha' - 1942

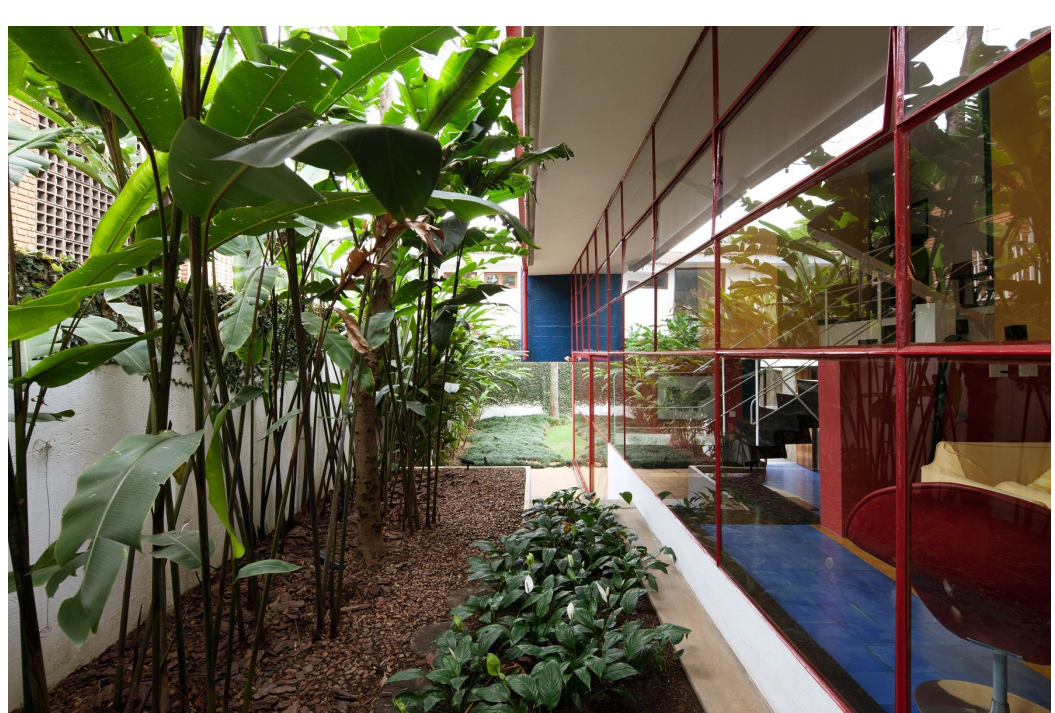

75 Casa Baeta - 1956 trajetória formada pelas casas que projetou é bastante clara a paulatina ruptura com a casa paulistana típica ${ }^{102}$, para aproximar-se da casa isolada, da casa elevada e da expandida até os limites do lote.

Se dispostas cronologicamente a Casinha, a casa Olga Baeta e casa Taques Bittencourt II, teremos uma série que pode ser análoga ao processo gradual de afastamento mencionado entre a casa e a cidade.

Na Casinha, a forma de posicionar a construção e o uso do jardim como transição entre público e privado, torna-a uma obra convexa e expectante em relação ao entorno urbano. É, portanto, uma casa sem pátio, colocada em um jardim aberto, noção reforçada pelo fato do lote não ser murado originalmente (condição preservada até hoje), e por estar situada em um terreno de esquina.

Na casa Olga Baeta cria-se um microcosmo através da manipulação da topografia e concepção dos jardins ${ }^{103}$. As áreas de longa permanência da casa se abrem para as laterais, decisão distributiva que Artigas enfatiza com o fechamento da fachada frontal. Com esta obra Artigas experimenta com o potencial dos recuos laterais. Começam a se fazer evidentes as intenções do arquiteto de sublimar os limites do lote urbano, fazendo com que o espaço habitável se prolongue até os muros de divisa.

Sobre a figura dos recuos, Maria Luiza Corrêa faz a seguinte constatação:

"Toda a estrutura está dizendo que o recuo não é recuo. Se trocássemos o nome recuo para espaço externo, concluiríamos que ela diz que o espaço externo é interno"104

Em um rápido alinhamento analítico entre três das casas em foco, encontramos elementos para refletirmos sobre a relação da moradia com o território e a cidade.

Surge aqui o tema da casa dentro do pátio e da composição de pátio efetivo a partir da reinvenção do espaço tradicionalmente residual, 


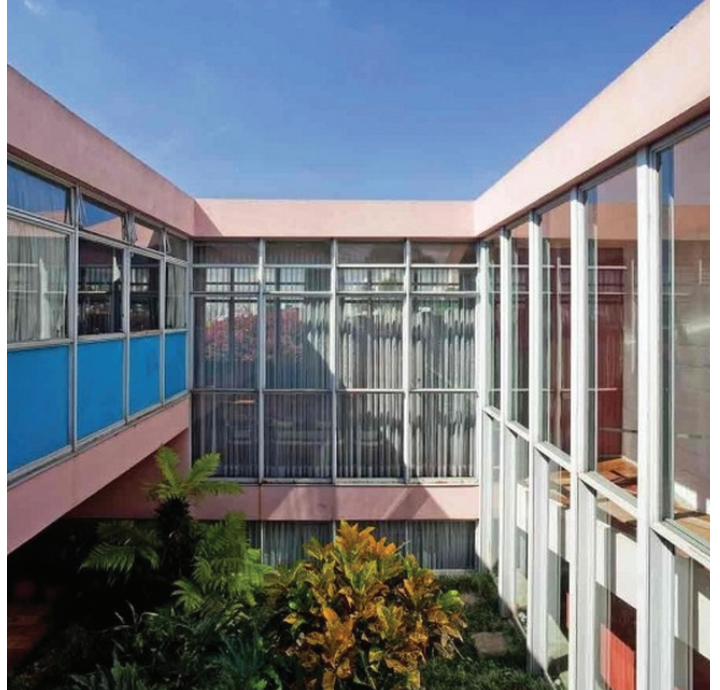

76 Casa Taques Bittencourt II - 1959

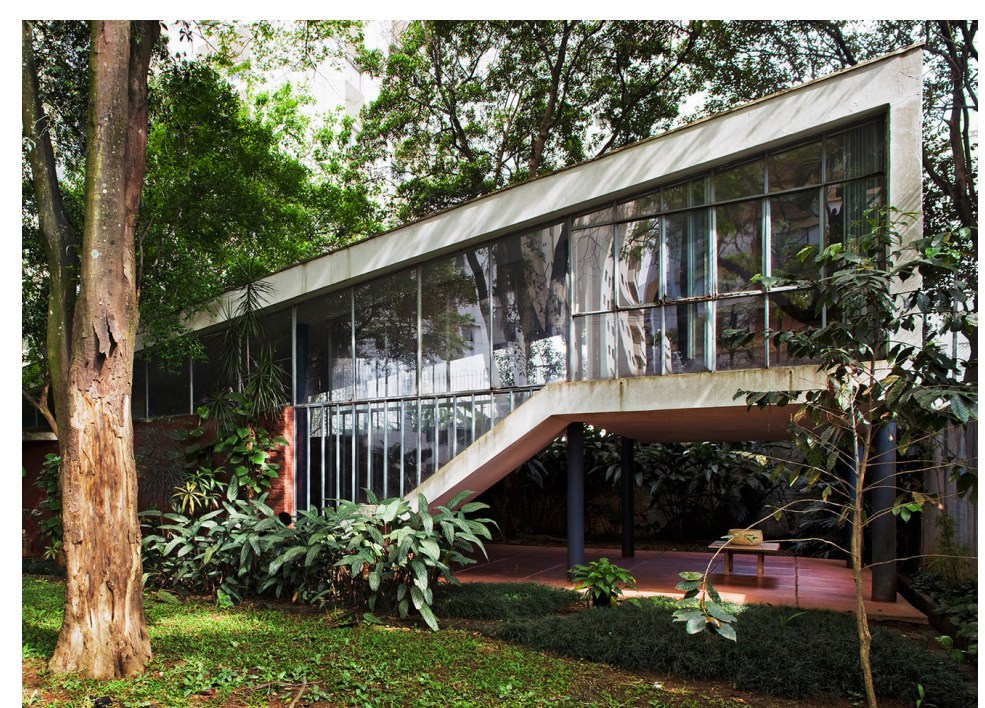

77 Casa Artigas II - 1950
105. MARTÍ Aris, Carlos, Pabellón y patio, elementos de la arquitectura moderna, 2008 in: DEARQ: Revista de Arquitectura de la Universidad de los Andes, , No. 2, maio - 2008, pg.18. (isoladamente)- complemento meu. a sobra obrigada de terreno, que é o recuo. A casa Baeta é um exemplar de casa com pátio lateral.

Nessa ambiguidade identificada por Corrêa que reside o grande interesse pelo pátio, nessa condição de confundir interno/externo que lhe é própria e na capacidade que Artigas teve de fazer do espaço do recuo o pátio.

Na casa Taques Bitencourt II o arquiteto esgota a ocupação normativa do terreno, expande a casa até tocar os limites e cria um pátio jardim que plasma no interior da obra a representação da natureza, marcando a mudança, com essa obra, para um enfrentamento menos otimista em relação ao entorno urbano. Essa casa é um exemplar de pátio interno

O vazio, a ausência de construção que surge quando o pátio está contido na casa, também está presente entre a casa e os limites, quando é a casa que está contida no pátio. Esse vazio que rodeia a casa na forma dos recuos, de projeto em projeto vai deixando de ser um espaço residual para ser protagonista, para se tornar um autêntico pátio: um pátio externo, que contém o pavilhão de forma mais ou menos centralizada, ou um pátio tangencial, que cota - reserva - um determinado espaço em torno da casa para que o interior se relacione com o exterior.

\subsubsection{Pátio externo - delimitador}

Sobre a relação pavilhão e pátio, Carlos Martí (2008) trás a seguinte passagem que reforça a condição de interdependência que estabelecem entre si:

"Ambos principios (pabellón y patio) se solicitan el uno al otro en la medida que no se dan las condiciones para desarrollar hasta el límite las propriedades espaciales de cada uno de ellos." (isoladamente) ${ }^{105}$

Podem ser compreendidas como casas de pátio externo, ou contidas no pátio, as seguintes obras: casa Artigas II, casa Baeta e casa Viterito, sendo essas últimas marcadas pela ideia de serem tangentes ao pátio, não tanto contidas nele, como veremos à seguir. 


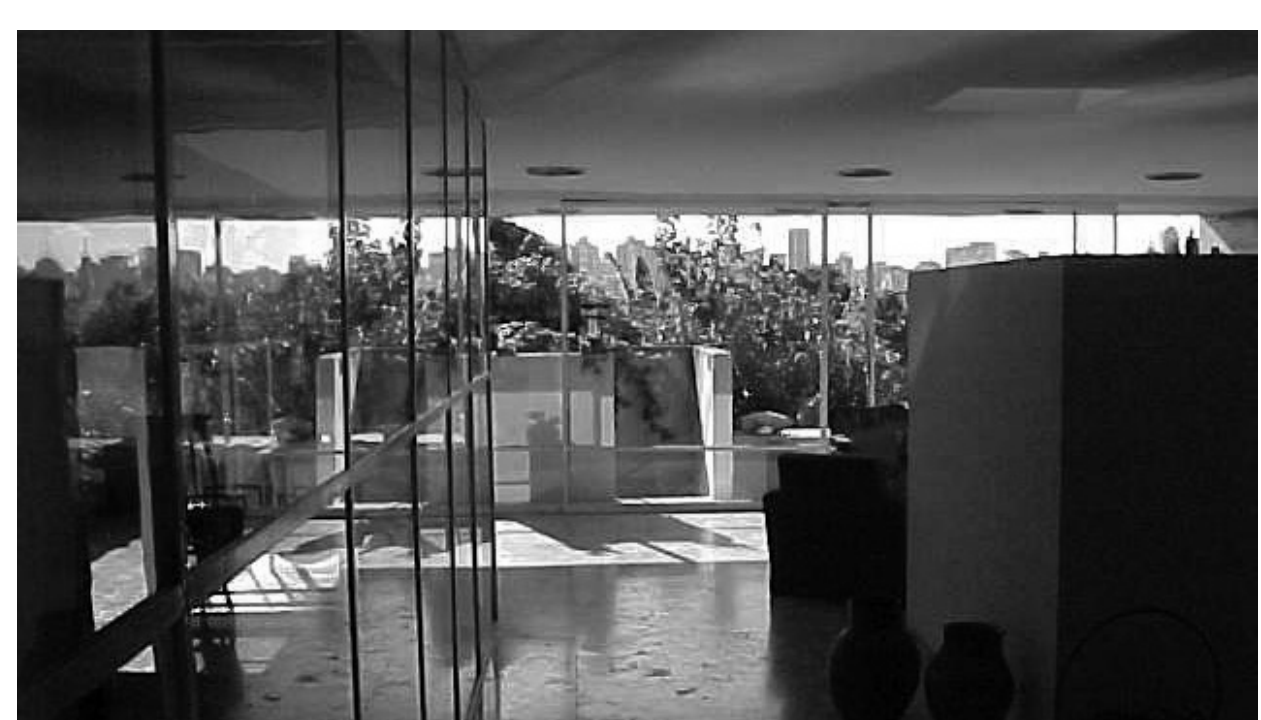

78 Casa Viterito, vistas ao entorno

A casa Artigas II é constituída por um pavilhão que organiza a residência a partir da linearidade e reserva em torno a si o espaço livre entre as fachadas e os limites, o jardim que expande a área habitada ao exterior, conformando uma casa no pátio, recintada.

Nessa casa, Artigas propõe um gesto de elevação pontual no manuseio do pavilhão que transforma a relação entre cheio e vazio; suspende a casa para que o pátio passe por debaixo dela. Ação análoga ao que logo faria com a casa toda ao trabalhar a caixa elevada sobre pilotis. Nas casas Baeta e Viterirto há também o gesto de elevação da casa - mas não como ocorre na casa Artigas, em que se cria um pilotis que tem relação direta com o pátio externo - sem contar com o térreo livre, ambas se posicionam no centro do terreno, e não logram manter plenamente a condição de casa no recinto, já que nos dois casos o espaço que rodeia a casa acaba sendo subdividido pela própria condição de centralidade assumida pela contrução e porque Artigas opta, nessas duas casas, por manipular os níveis do terreno para concentrar o espaço

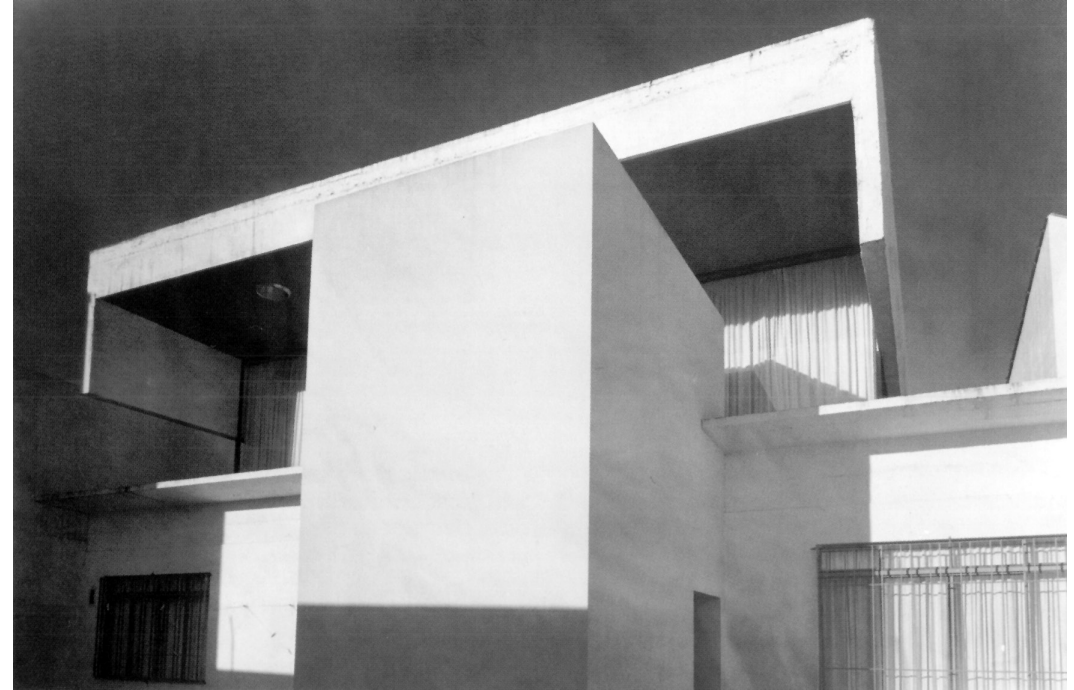

79 Casa Viterito, vista à partir do pátio

do pátio e destaca-lo do corredor formado pelo recuo

A forma como são trabalhadas as cotas do terreno na casa Viterito lhe garante uma condição especial, ao estar implantada em terreno em declive, e com vistas interessantes ao entorno, Artigas optou por concentrar o programa de longa permanência no nível da rua, junto ao acesso, portanto essa é uma casa teto autêntica, no pavimento superior. Entretanto, fazendo uso da declividade e talvez por não poder abrigar satisfatoriamente todas as funções domésticas sob o grande teto, posiciona os dormitórios no piso inferior, e ali então faz a operação clássica de abrir os quartos - cubicula - para o pátio - atrium - formado pela fachada da casa e pelos três muros. A casa Viterito é um exemplo de hibridação de dois tipos, que resulta da sobreposição de uma casa teto - pavilhão - com uma casa pátio. Não deixa de ser uma casa contida em um recinto - casa no pátio - e um teto sobre o promontório - casa teto. 


\subsubsection{Pátio tangencial / semipátio}

Na casa Baeta, há a construção de um novo nível no terreno, elevado-o à cota do patamar da escada, esse platô, pelo desnível que cria, subdivide o espaço do maior recuo em dois e ao mesmo tempo reforça a presença do pátio no térreo, concentrando-o na área que é nivelada com a sala. Seus limites físicos são o muro de divisa, o plano envidraçado e as empenas laterais que se insinuam, em balanço, como a fechar os lados curtos do pátio. Nessa casa há um pátio ao lado do pavilhão, talvez o que poderíamos chamar de pátio tangencial, ou semipátio

O pátio criado na casa d'Estefani representa a dualidade entre a casa binucleada e a casa de corpo único. Tradicionalmente a ocupação dos lotes em São Paulo sempre esteve marcada pela construção do corpo principal com recuo em um dos lados, além do frontal e dos fundos, e a construção da edícula no fundo do terreno. Nesse projeto Artigas dialoga com a ocupação tradicional do lote, por uma relação de oposição, como se construísse o negativo da mancha edificada típica, criando dois corpos onde normalmente estão os espaços vazios de edificação, conectados por um conjunto de rampas que vencem os desníveis e ocupam a área que corresponderia ao recuo lateral.
A classificação para o pátio da casa d'Estefani é um pouco ambígua: é um pátio contido na edificação, portanto interno, mas por diversos motivos não realiza plenamente sua condição de pátio central, e por isso é análogo ao pátio do Hospital São Lucas, onde também está relegado à condição de lateral. Uma lateralidade até em importância, condição que acaba vinculando as duas obras.

A reflexão sobre o pátio lateral nos suscita uma questão interessante em relação ao contexto em que a obra se insere. Se admitimos que todos os pátios laterais se valem do muro de divisa como um dos seus limites, portanto se completam a partir da existência de uma barreira relativamente débil, que caso não existisse abriria um dos lados do pátio e assim subverteria sua condição de recinto.

“...la visión panorámica que la terraza propone es justamente lo opuesto al hueco cenital del atrio romano. El patio de la cultura tradicional mira el cielo y en él encuentra la explicación de la existéncia humana. La terraza, en cambio mira la tierra, el medio fisico cuya observación habrá de permitir el avance de la ciéncia y el progreso de la razón." 107

Esse enunciado de Recasens permite fazermos - com bastante liberdade - o exercício analítico de imaginar que um pátio romano, com seu átrio e impluvium centrais, portanto pleno em sua verticalidade e conexão com os céus, pudesse ser cortado ao meio. Instantaneamente 


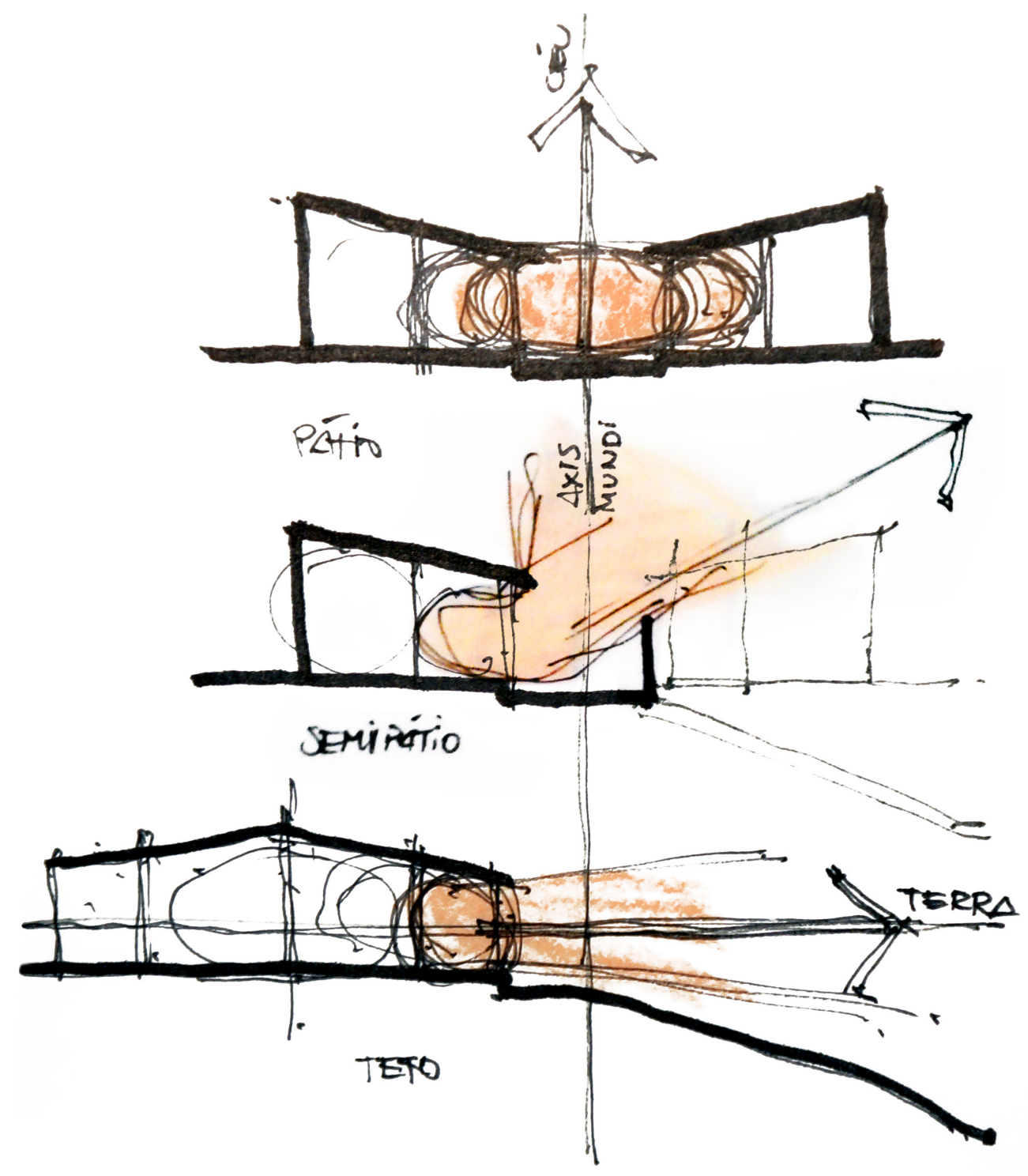


seu peristilo se tornaria uma varanda, portanto o teto; e o pátio se perderia no horizonte, devolvendo ao mundo os elementos que coletou. Então todas as questões que rodeiam esses dois tipos - o pátio e o teto, portanto a vertical e a horizontal, os céus e a terra, o sagrado e o civil estariam invertidas, transformadas, antagonizadas.

Essa reflexão serve para reforçar a condição fundadora dos pátios de duas casas de Artigas, o pátio lateral, ou o semipátio das casas Baeta e Viterito.

Do pátio tangencial da casa Baeta tratamos no início do capítulo, para introduzir o tema, já na casa Viterito o pátio é formado por uma depressão do terreno - é o ponto em que o terreno mantém sua cota natural - que resulta estar abaixo da cota do térreo. Nesse 'afundamento' se produz o jardim, que incorpora a área correspondente ao recuo lateral e se expande até a divisa, parcialmente sob a cobertura, criando uma galeria envidraçada voltada para o pátio e intermediada pelo peristilo representado pelo balanço da cobertura. É um pátio tangencial, um semipátio, conformado de um lado pelo pavilhão e de outro completado pelo recinto constituído pelo muro lateral.

Podemos fazer a operação inversa à de cortar o pátio central e, ao invés disso, duplicarmos as casas com semipátio, fazendo um rebatimento usando o alinhamento da divisa como plano de simetria, criando um pátio completo entre as duas construções, casas geminadas pelo pátio. A garagem de barcos do Santa Paula Iate Clube, com certa liberdade de leitura, também pode ser vista como uma construção dotada de um semipátio, coberto e aberto - a varanda é formada pela grande cobertura e seu limite oposto se dilui no lago da represa, ou seja, não existe.

Essa situação é análoga à hipotética retirada da casa Viterito de seu contexto urbano, onde deixaria de ter o limite lateral como barreira formadora do pátio.

Mas nos interessa assumir a Garagem de Barcos como objeto para repetir, em outra escala, o exercício analítico. Como se pudéssemos duplicar a construção na direção do lago, fazendo um rebatimento em função da linha da orla, teríamos assim um pátio, a conter todos os elementos que lhe são próprios, o céu, a natureza, o verde e a lâmina d'água, balizado por dois pórticos, duas longas stoas em concreto armado e sutilmente apoiadas no terreno. Essa imagem remete ao pátio linear, um pátio formado por duas construções longas, postas em paralelo e cujos finais se perdem na perspectiva. 

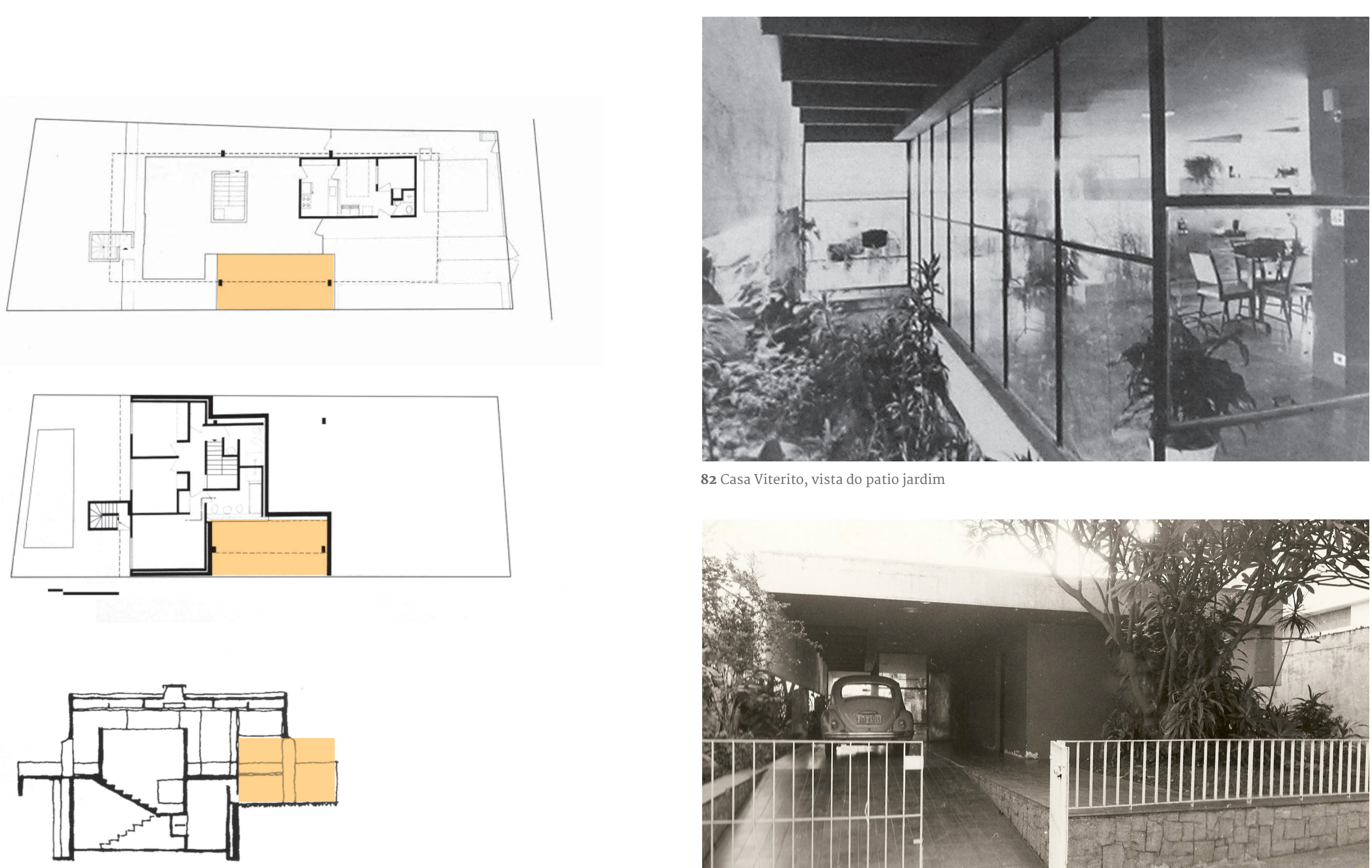

82 Casa Viterito, vista do patio jardim

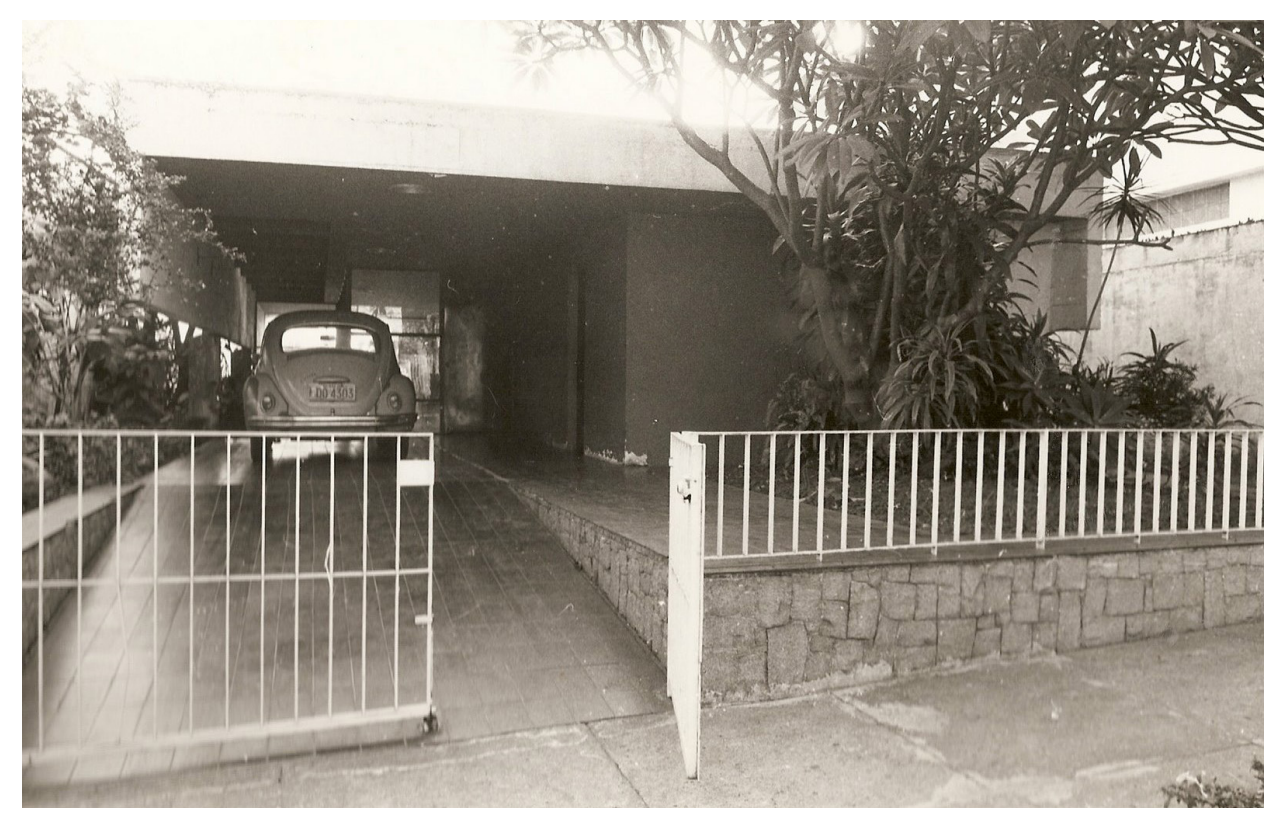




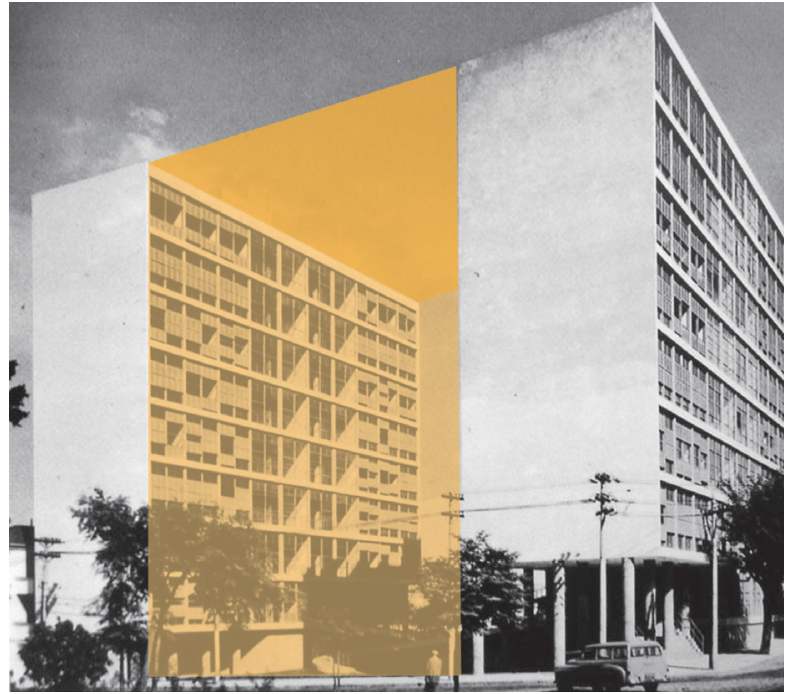

84 e 85 Edifício Louveira, pátio jardim, pátio em cubo.

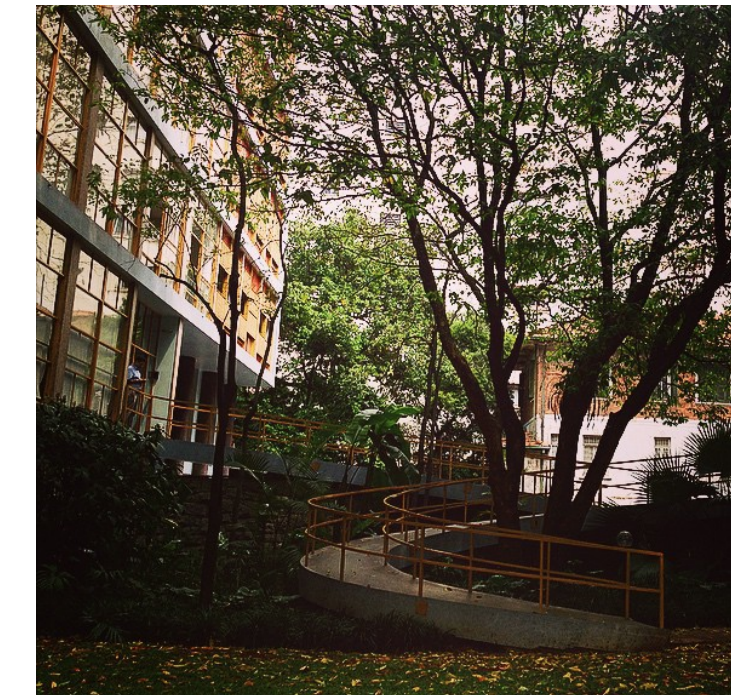

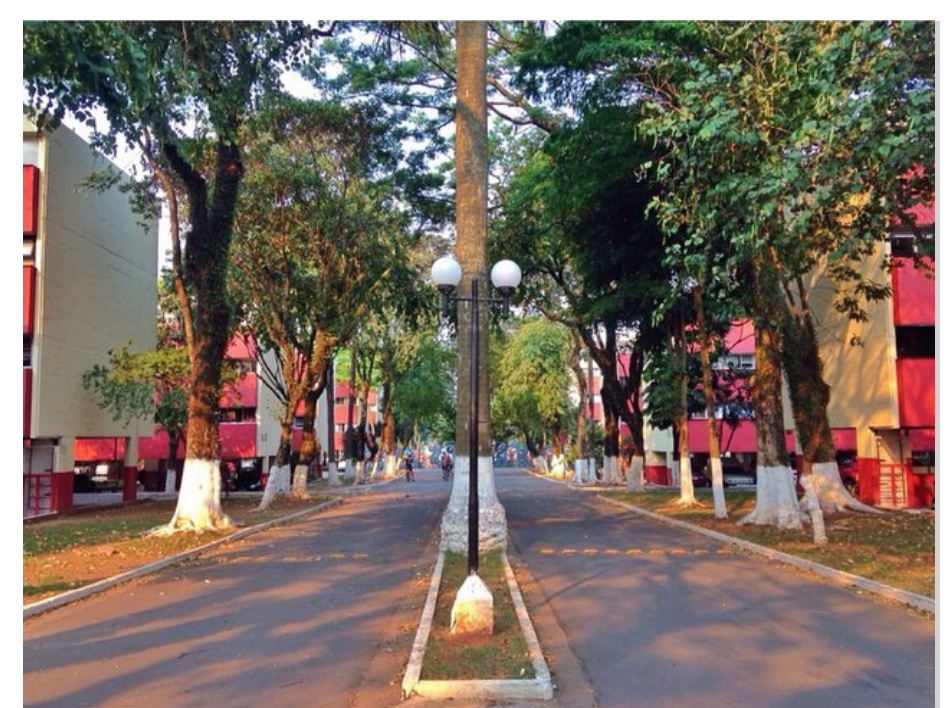

86 Conjunto CECAP “Zezinho Magalães Prado” - 1967, pátio linear.

\subsubsection{Pátio linear - a rua}

A partir da imagem anterior, da duplicação do edifício da Garagem de Barcos em função da linha da orla, podemos propor agora sua multiplicação na vertical, para formar assim um par de elementos construídos resultantes da sobreposição de bandejas, portanto dois edifícios. Esse pátio linear ladeado por dois blocos em lâmina corresponde à imagem do pátio "interno" do edifício Louveira de 1946, desenhado por Artigas como um jardim, formando um grande cubo.

Esse jardim estabelece com a praça Vilaboim uma analogia direta, com sutil diferença de escala, representando um núcleo menor autônomo (o jardim), separado de outro maior (a praça), ambos constituem pátios, um é um pátio urbano, de miolo de quadra, mas que estabelece contato direto e continuidade com um outro pátio urbano, na escala da praça.

O conjunto Cecap - Zezinho Magalhães prado (1967)108 tem como ação geratriz inicial a repetição das bandejas, já que trata-se de um edifício em altura, mas é com a segunda ação, a repetição no eixo longitudinal, com o sequenciamento de seus blocos ao longo do trajeto, que o pátio linear passa a poder ser chamado de rua, um recinto com apenas dois lados de extensão virtualmente infinita.

\subsubsection{Pátio interno - centralizado}

"Suele ser un espacio central, (...) En la arquitectura tradicional, el patio surge de horadar la masa construida. (...)109

A ação de perfurar e esvaziar parcialmente a construção - extraindo-lhe também o teto - é a que define o pátio interno; o vazio rodeado totalmente de aulas ou tetos, estabelece uma relação ativa com a arquitetura. Em contraponto com a conformação do pátio externo, marcada pela presença do recinto com o pavilhão dentro, no pátio interno toda a casa se relaciona com o exterior através do pátio, depende dele para se constituir. 
108. Zezinho de Magalhães Prado, 1967, conjunto residencial no parque CECAP é projeto de João Vilanova Artigas, Fábio Penteado e Paulo Mendes da Rocha

109. MARTÍ Aris, Carlos, Pabellón y patio, elementos de la

arquitectura moderna, 2008, in: DEARO: Revista de Arquitectura

de la Universidad de los Andes, , No. 2, maio - 2008, pg.19.

horadar, perfurar, grifo meu

Entre as casas recortadas para análise, há duas classificáveis dentro do tipo casa-pátio: casa d'Estefani e casa Bittencourt II: a primeira delas já abordada nesse texto e, conforme dissemos, apesar de estar classificada nessa tipologia, acaba relegando ao pátio certa lateralidade, nos centraremos, portanto na segunda, que parece ter mais plenitude em sua correspondência com o tipo.

A casa Bitencourt II, onde o pátio é um elemento presente logo na entrada - que ocorre pela passagem sob o volume suspenso tangenciado pela sequencia de rampas que fazem do ato de circundar o impluvium - o jardim nesse caso - deixar de ser uma trajetória plana um circuito fechado, para passar a ser uma helicoidal em torno do pátio, remarcando sua verticalidade.

O conjunto Zezinho de M. Prado (1967) apresenta um elemento que remarca a vertical dentro de seu pátio interno, nas unidades construídas com a escada de três lances (não as de lance reto, mais novas) foi criado um shaft de planta quadrada que se posiciona no

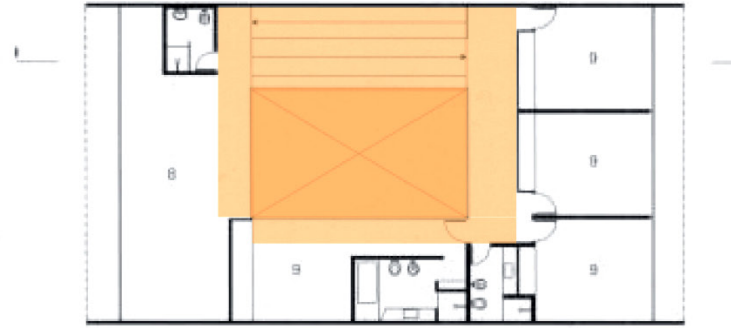

PLANTA PAVIMENTO SUPEHIOA

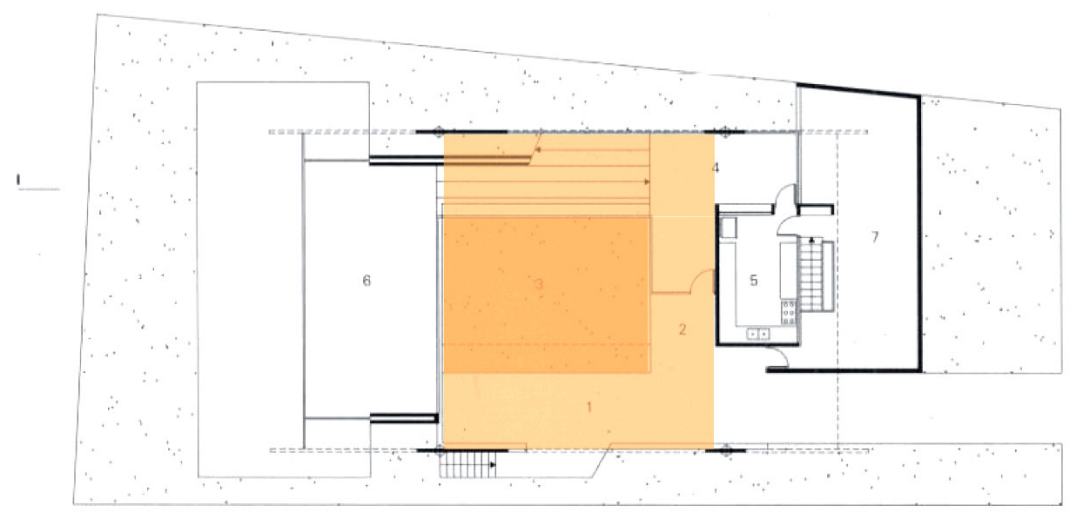

PLANTA TÉRREO

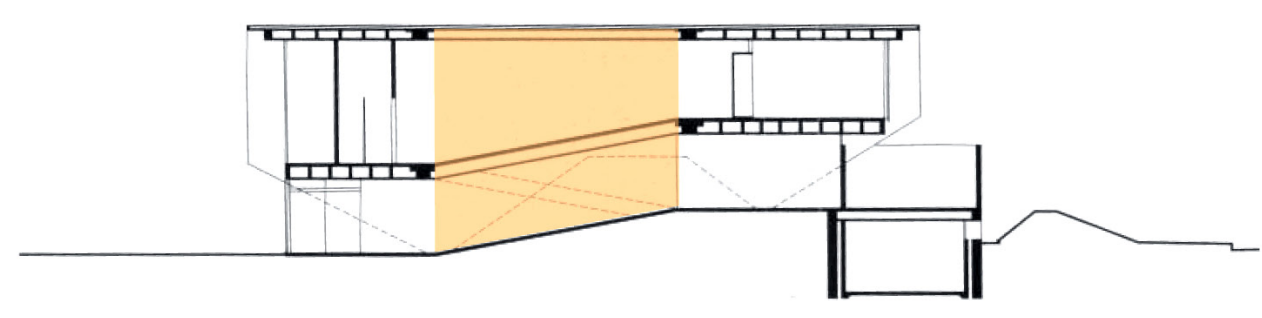

CORTE LONGITUDINAL 


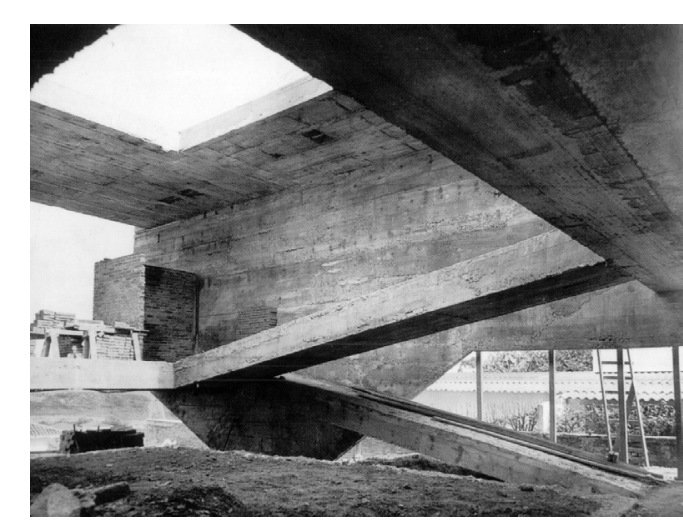

88 Casa Taques Bittencourt II - 1959, em obras

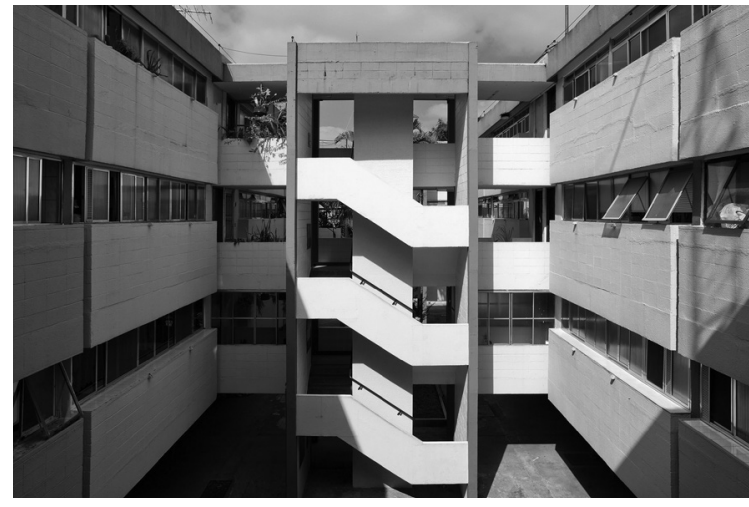

89 Conjunto CECAP "Zezinho Magalães Prado" - 1967, pátio com elemento vertical
110. Essas peças chegam a ser literalmente aquedutos, já que as águas pluviais são coletadas em uma calha em seu topo.

111. A figura do pátio coberto, frequentemente mencionado dessa forma no jargão da arquitetura escolar, pode soar como um grande contrassenso se admitirmos a aplicação dos tipos e estruturas propostos nessa análise, segundo esse discurso, para que o pátio se constitua, é mandatário que não tenha teto. Na escola Conceiçãozinha se trata realmente do pátio, pois os muros em arcos seguem ao longo de toda a fachada interna, cruzado por debaixo de uma cobertura transversal, que ao cobrir parte do pátio, o torna, portanto, um pátio coberto, literalmente.

Na designação pátio coberto podemos entender que pátio tem relação com a função do espaço, pátio como área de recreio, que quando provista de teto, mantém a função mas passa a ser coberto. miolo da escada (em planta) e, junto com a grande altura das empenas que flanqueiam a circulação vertical, formam três elementos que 'contrariam' os anéis de massa construída correspondentes aos peitoris das unidades elementos que ao se repetirem em diferentes alturas também estabelecem, no gesto, uma noção de verticalidade.

O projeto de Artigas para a escola Coceiçãozinha, no Guarujá - SP, de 1976, tem no pátio a sua estrutura, mas desperta a dúvida entre ser obra com pátio central ou linear, está organizado em torno do pátio, tratase de uma construção térrea composta por dois pavilhões alongados paralelos, que a modo de stoa organizam a circulação longitudinal junto ao pátio para dar acesso às salas (de aula) voltadas pra fora. As analogias com a arquitetura clássica, nessa escola, extrapolam o universo da estrutura e do tipo, são sublinhadas pelas formas construtivas e materiais empregados, Artigas utiliza tijolos maciços e coberturas de telhas cerâmicas com estrutura de madeira. Os planos que separam o pátio das circulações são formados por uma sequência de arcos romanos, de forma que a perspectiva que se tem ao longo do pátio pode ser análoga à visão de dois aquedutos correndo paralelos ${ }^{110}$, para logo serem interceptados pelo grande telhado de duas águas do pátio coberto. ${ }^{111}$

\subsubsection{Redução do pátio}

Gottfried Semper (1803 - 1879) em seu texto Die vier Elemente der Baukunst (Os quatro elementos da arquitetura) de 1851 enumera: terrapleno, fogo, teto e cerca ${ }^{112}$ como sendo os elementos 
112. São bastante controversas as traduções encontradas sobre o texto de G.Semper citado: em : Gottfried Semper and the Vier Elemente der Baukunst: em texto da Aarhus School of

architecture, da Dinamarca, de autoria desconhecida, Acessado 14 Fev $2015<$ http://rum1.aarch.dk/uploads/media/Intro_

forelaesning_v._Niels_Park_Nygaard.pdf $>$, opta-se por listar

os seguintes como sendo os quatro elementos Semperianos:

"The earthwork - The hearth - The framework - The enclosing

membrane" portanto o terrapleno, core, carpintaria e tapeçaria

(em tradução tendenciosa do autor)

Já em tradução de texto de Semper, Igor Fracalossi opta por dique ao invés de terrapleno:

"Assim, pois, das mais imediatas necessidades surgem quatro elementos da edificação primitiva: o teto, o dique, a cerca e, como centro espiritual do conjunto, o fogo social."

Igor Fracalossi, trad. "Os elementos básicos da arquitetura / Gottfried Semper” 13 Fev. 2014. ArchDaily Brasil. Acessado 14 Fev 2015. <http://www.archdaily.com.br/174291/os-elementosbasicos-da-arquitetura-gottfried-semper

representantes das ações fundadoras da relação do homem com o meio. O terrapleno é análogo à escolha do lugar, à decisão por um determinado sítio, o seguinte ato é o de se fazer o fogo, assentar-se em torno a ele, os dois elementos que seguem são o teto e a cerca - foram os que surgiram com maior frequência na análise até aqui, além de todas as combinações que formam.

Retomando o fogo como elemento fundador de toda arquitetura e tomando-o não de forma literal, mas essencialmente simbólica, veremos que guarda uma relação muito próxima com o pátio. O fogo não pode ser totalmente coberto pelo teto, pode ser cercado pela construção, seja pelo recinto ou pelas paredes de uma lareira, mas precisa manter de alguma forma seu contato com o céu, sua vertical ascendente. Na shabono (a oca yanomami) o fogo está posicionado sob o
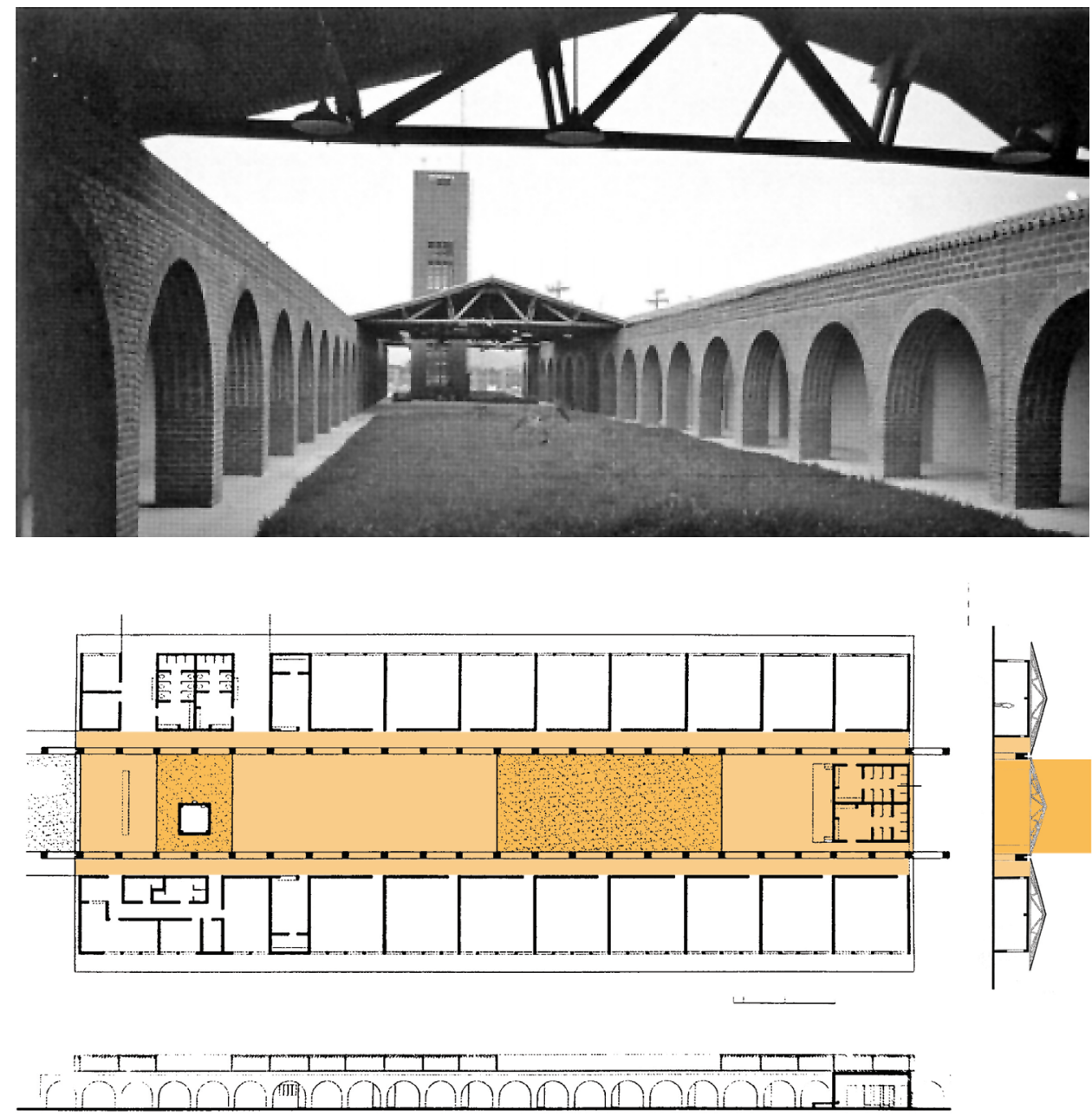

90 e 91 Escola conceiçãozinha, Guarujá, SP - 1976 


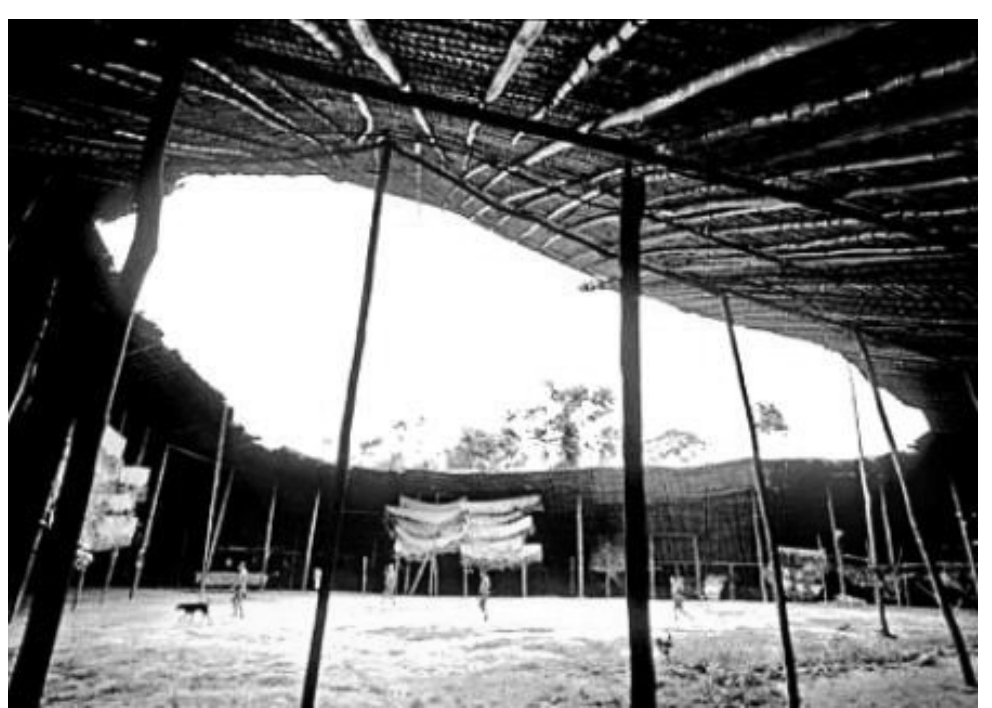

92 Shabono Yanomami

óculo zenital que é deixado livre em seu teto, como uma grande cúpula sem seu lanternim, análoga ao panteão romano em sua forma final.

A confirmação da estreita relação entre o fogo e a casa pode ser ilustrada pelas relações etimológicas encontradas, por exemplo, no compartilhamento da raiz entre lar e lareira, ou seus equivalentes em castelhano: hogar e hogera, lar e fogueira respectivamente, é interessante verificar que fogo compartilha raiz com foco (fuoco).

Sem estabelecer analogias diretas com o fogo como elemento fundador da arquitetura - mesmo porque seriam difíceis nas obras elencadas ${ }^{113}$ - podemos passar a refletir sobre o foco, no caso do pátio seu centro focal, é frequentemente marcado por algum elemento vertical, uma fonte ou uma figura (estátua) podem cumprir essa função na escala do pátio doméstico, um obelisco o faz na escala do pátio urbano, da praça, e de forma mais dispersa, em diversos focos, os ciprestes no pátiojardim.
113. A única obra analisada onde é possível encontrar relação direta com o fogo e seu core (heart - ver nota anterior) é a

Casinha onde o elemento fundante está no fogo. A composição da planta ocorre em espiral e tem sua origem no sólido formado pela lareira e pelo fogão. Essa constatação talvez venha do fato de ser uma obra da fase Wrightiana de Artigas e F.L.Wright ser reconhecidamente semperiano na composição de suas plantas em torno da lareira.

114. "Por definición, un patio es um espacio cerrado al exterior (...) y abierto al cielo en la totalidad del perímetro (...) la ausencia de una techumbre lo pone en relación con el cielo.

Si incorporamos un árbol a este patio, además, se enfatiza su carácter vertical, puesto que éste, generalmente, apunta hacia el cenit" DEVESA i Devesa, Ricardo, DEVESA, Ricardo Devesa. La casa y el árbol, Aportes teóricos al proyecto de arquitectura. tese doutoral apresentada à EtsaB-UPC em junho de 2012, pg.213-14.
Nas obras de Artigas, possivelmente o único pátio que tem marcado seu foco e faz clara alusão ao sentido vertical seja o conjunto de clarabóia e pilar desenhados para a estação de Jaú.

A clarabóia redonda posicionada no mesmo eixo que o pilar da estrutura, geram um conjunto que funde os dois elementos em um único, o pilar faz a ligação da vertical com o plano horizontal e difuso do teto, o faz precisamente no centro da clarabóia, em seu foco.

Esse exemplo trata de uma redução do pátio, ou uma concentração em espaço reduzido dos elementos que o definem. Não há diferenciação entre interno e externo, não se entra ou se sai desse pátio, a água da chuva não chega no chão, o exterior participa do interior exclusivamente pela luz zenital, que se projeta sobre o 'obelisco' do pilar ou do tronco e sobre a ramagem baixa da grande árvore cuja copa está fora do pátio, acima do teto. ${ }^{114}$ 
115. Na obra da ermida de San Baudélio é curioso notar que são aplicados arcos plenos (romanos) mas que são

trabalhados esteticamente como arcos mouriscos, talvez até

complementados com o revestimento para se tornarem mais mouros.

As ações geratrizes que conformam o "pátio com árvore" da estação de Jaú, encontram correspondência plena com a as ações formadoras da Ermida de San Baudélio de Berlanga, uma obra moçárabe situada na província de Sória na Espanha, construída em finais do século XI. Composta de um nave única com pilar central e pequeno corpo de planta retangular anexo. Sua operação geratriz principal é a revolução de um arco pleno ${ }^{115}$ tomando como eixo a vertical do pilar e resultando num total de oito arcos a formar um espaço aular, com proporções predominantemente verticais.

A diferença da estação de Jaú onde a revolução do meio arco (ou da viga-pilar) resulta em quatro unidades que se dispersam dentro do plano liso do teto e se tornam nervuras ocultas dentro da cobertura, em San Baudélio as nervuras dos arcos estão aparentes, destacadas do plano da 'cúpula' e voltam a concordar com a vertical ao descarregarem nas paredes externas. A grande diferença entre os dois objetos nessa analogia é a presença/ausência da luz zenital, da clarabóia presente em

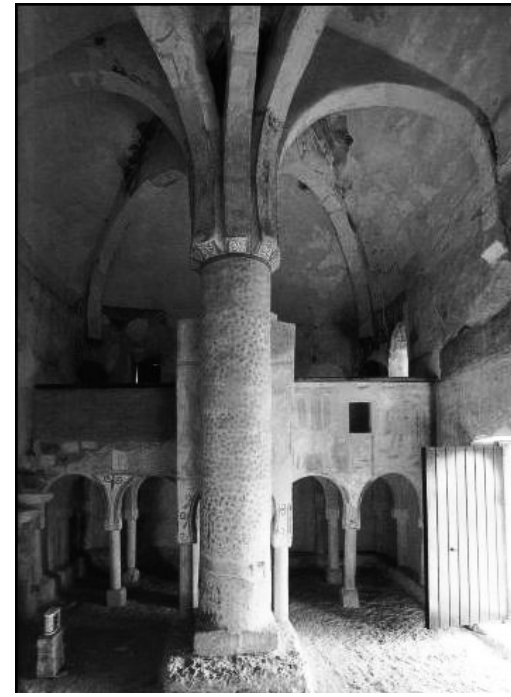

93 Ermida de San Baudélio de Berlanga, província de Sória na Espanha, século X

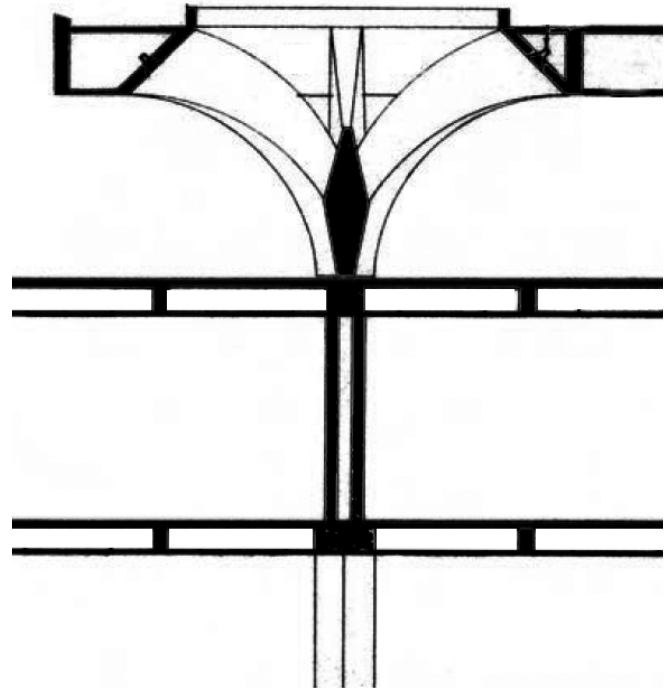

94 Estação de Jaú, corte pelo pilar - 1973

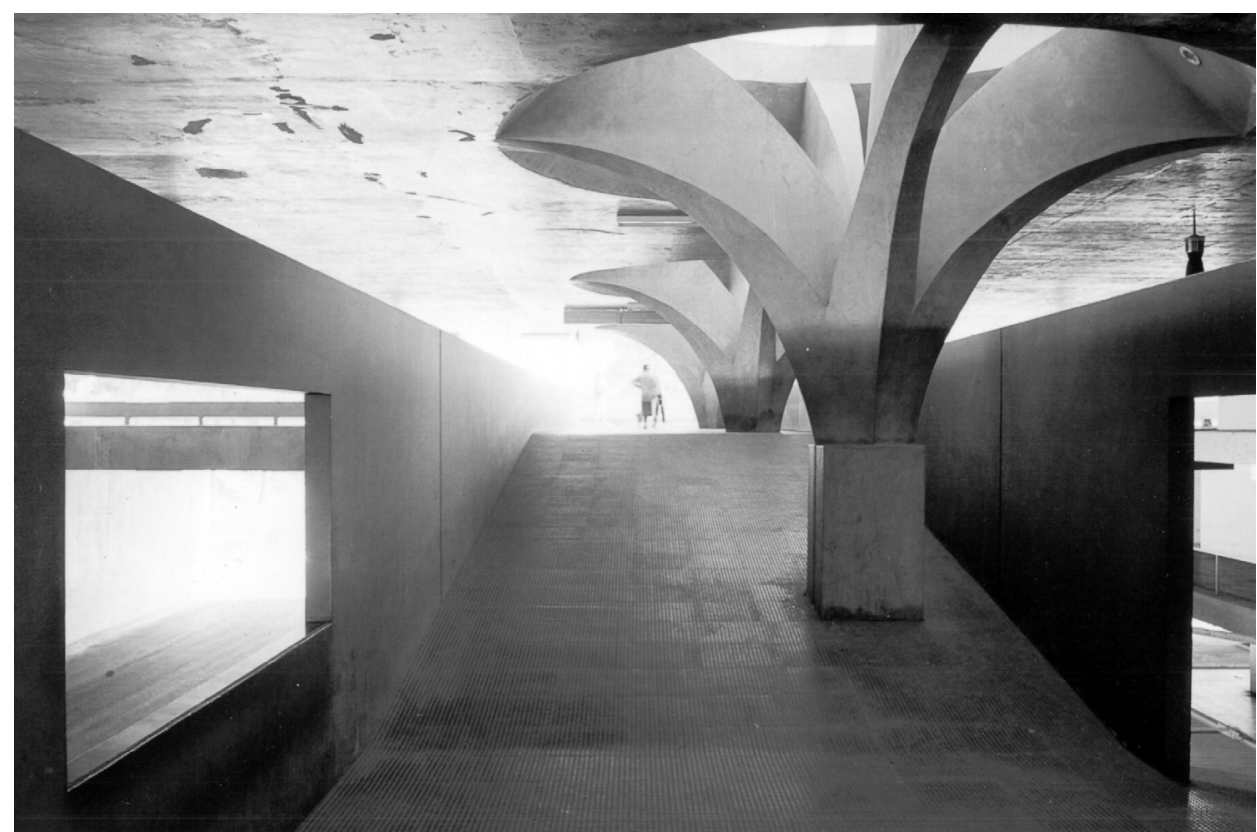

95 Estação de Jaú, vista interna 

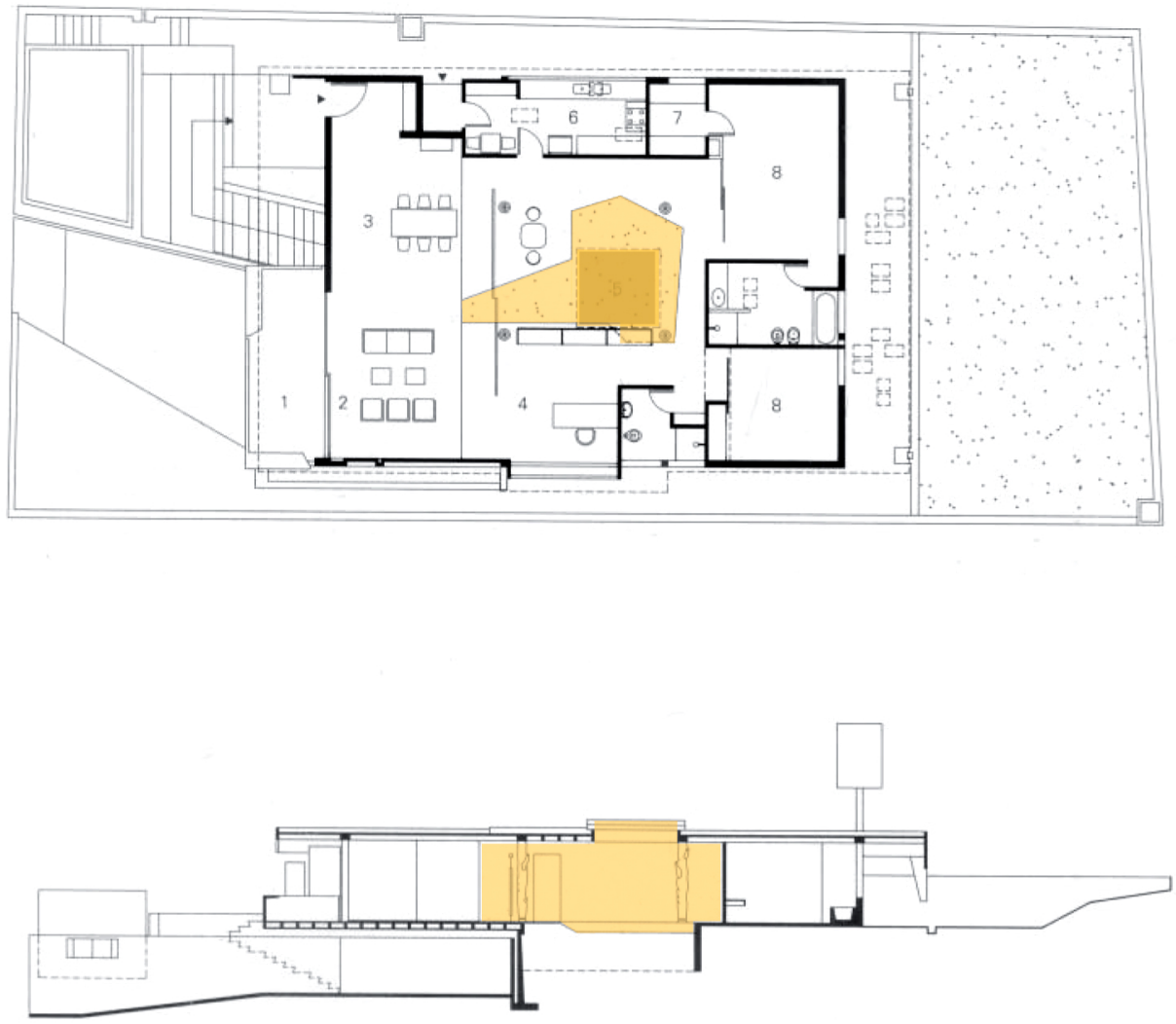

96 Casa Berquó - 1966
116. ARTIGAS, João Batista Vilanova, apud ZEIN, Ruth Verde, Artigas pop-cult: considerações sobre a cabana primitiva, a casa pátio e quatro colunas de madeira. 2013. pg.12<https://bibliodarq.files. wordpress.com/2012/10/zein-r-v-artigas-pop-cult.pdf>, acesso em 14 Fev 2015, grifo meu.

117. Idem, pg.7.

Jaú, que poderia surgir na ermida se cortássemos - analiticamente - a meia altura sua calota de cobertura.

Dentro do universo da redução - ou condensação, concentração - dos pátios na arquitetura de Artigas temos a figura do pátio projetado para a casa de Elza Berquó que condensa em suas escassas dimensões muitos elementos naturais em poucos metros quadrados, a luz zenital, o jardim e os pilares-tronco e a chuva.

A relação que esta obra estabelece com a Estação Rodoviária de Jaú não é da ordem de operações lógico-formais mas sim semântica e dela participam pilar e pátio. Na casa, o pátio produzido por um vazio na cobertura está rodeado por quatro troncos de madeira, formando um atrium tetrástilo, que materializa - de forma literal - a analogia existente entre tronco e pilar. Na estação de Jaú o pátio está presente na luz zenital dada pela clarabóia e o jardim é simbolizado pela forma do pilar de concreto - pilar árvore - também 'de madeira' em sua forma. 


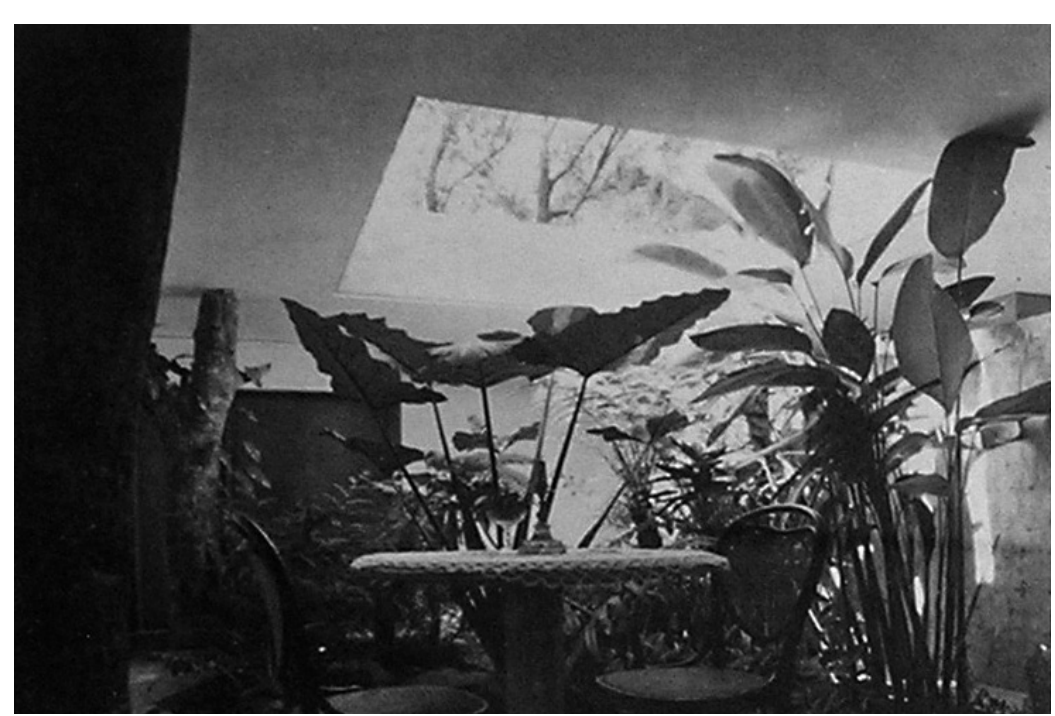

97 Casa Berquó - 1966

Sem deixar de lado a referência ibérica citada na análise entre Jaú e San Baudélio, podemos verificar a relação com o pátio ibérico ou mouro no discurso de Artigas em relação ao projeto da casa Berquó, diz:

"a casa tem o piso com toda sorte de materiais diferentes e é inspirada num modelo espanhol, que tem um pátio no meio"116

Ao citar o piso, nessa passagem, o arquiteto acaba aludindo ao mosaico, elemento presente em toda arquitetura mediterrânea, ibérica, itálica e moura, universo que permanece no discurso do:

"A distribuição da planta desta casa é de inspiração mediterrânea. Os recintos em torno de um 'pátio', que no caso é um jardim coberto com uma clarabóia de vidro que se abre, de maneira que nos dias próprios tudo fica meio 'ao ar livre' [sic]. Esta idéia é reforçada com o apoio da laje de cobertura no pátio, sobre quatro troncos de árvore, ao invés de colunas de concreto armado. 0 colorido da fachada, em duas cores, como faixas, marca a intenção de ajeitar os volumes com o inesperado da arquitetura popular tradicional." "117

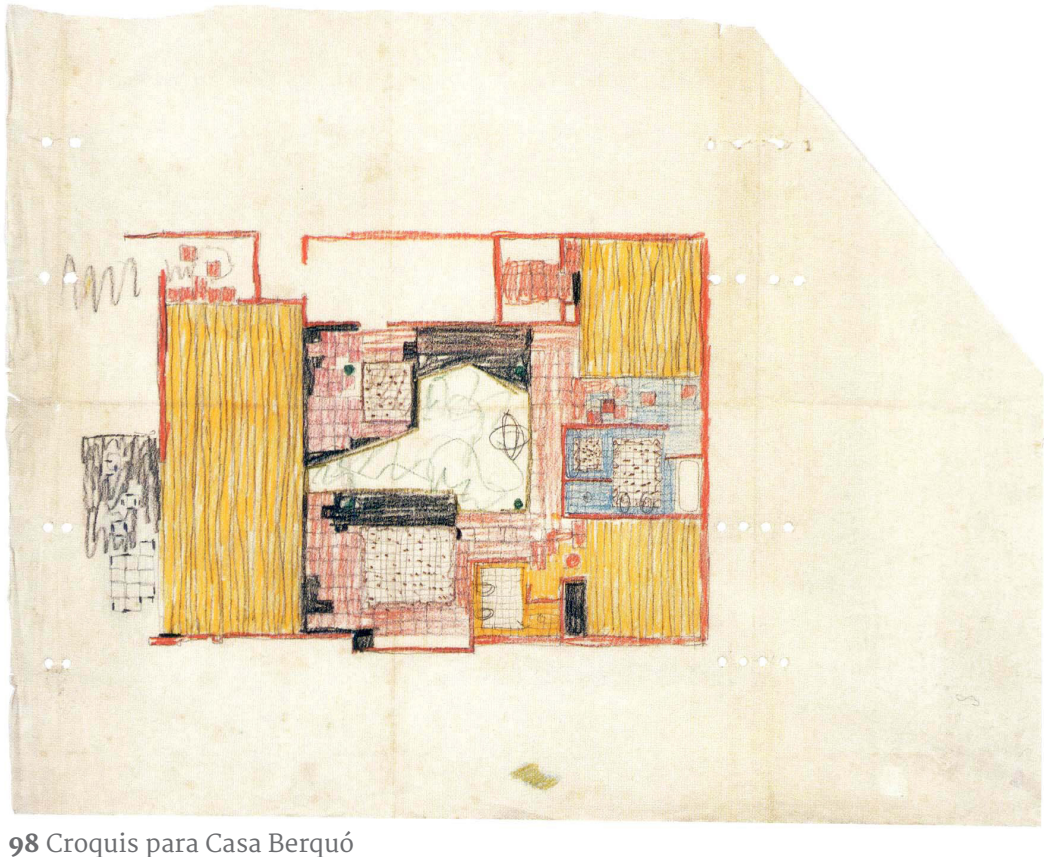




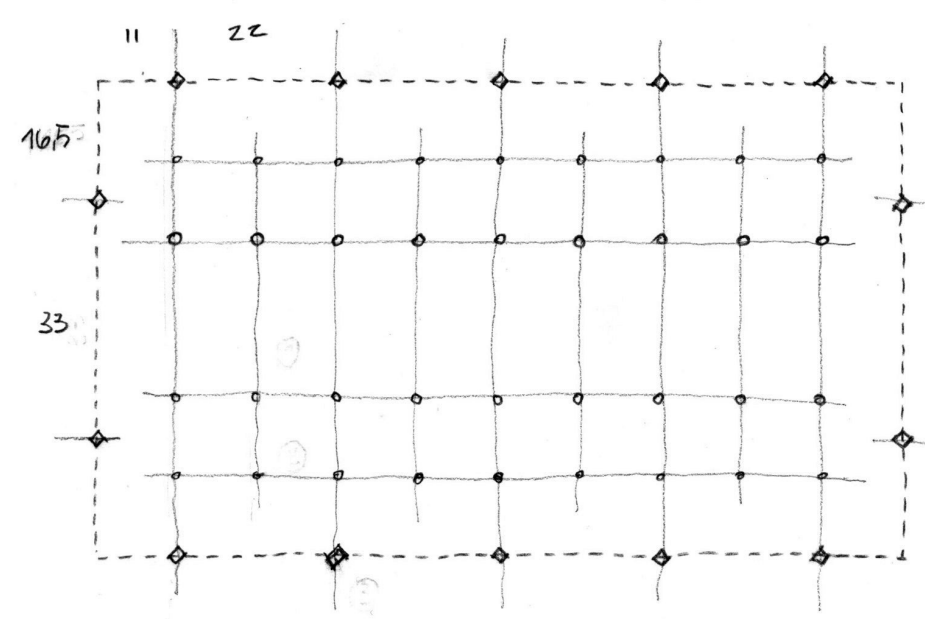

99 Métrica do edifício da FAU

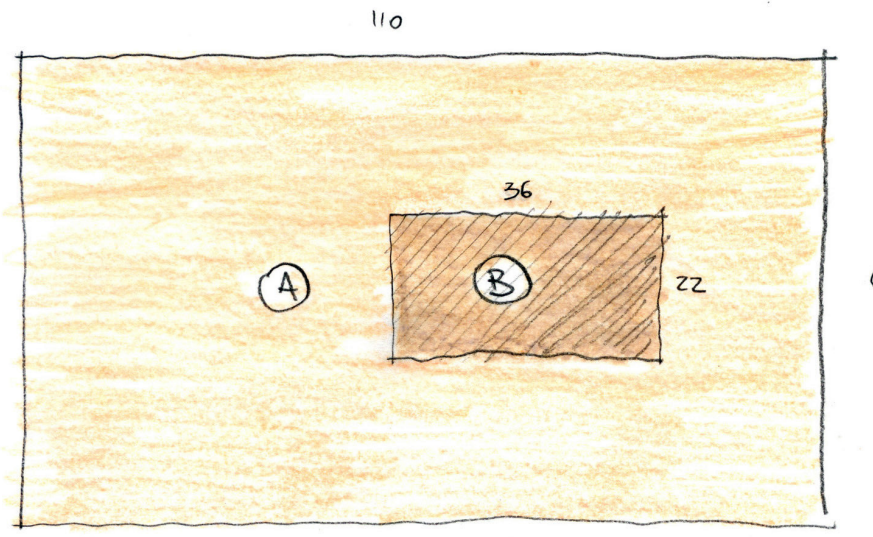

PropDRCIÓN $\frac{5}{3}=\frac{110}{66}=\frac{36}{22}$
SUPERTICIE $B=\frac{A}{10}$

100 Proporções do edifício da FAU
Apesar de termos optado por posicionar a casa Berquó dentro do capítulo dedicado ao pátio, entendemos que a casa é um exemplo de hibridação entre tipos, que combina o pátio com a aula, literalmente, com a movimentação de sua clarabóia corrediça pode se transformar em pátio ou em aula. A casa é dotada portanto de um pátio interior,que se revela no desenho do teto e no desenho do chão e junto com os pilares primordiais abarcam todos os elementos externos, jardim, luz e água.

\subsubsection{Pátio ordenador}

"Muchas obras de arquitectura pueden ser explicadas como el resultado de aplicar determinadas operaciones de transformación a una o várias estructuras elementales. Estas operaciones revisten diversas modalidades: yuxtaposición, combinación, superposición, inversión, variación, etc. Todas ellas constituyen herrameintas básicas para el proyecto. Así, em la arquitectura, como em cualquier actividad humana, sólo la elementalidad de los ingredientes logra dar razón de la complejidad del resultado.”118
O edifício da FAU resulta de muitas das operações citadas por Martí, se iniciamos sua análise na tentativa de enquadrá-lo em um tipo único, ou identificarmos uma estrutura que responda por um tipo predominante, talvez não tenhamos êxito, por se tratar de um edifício 'bastante misto', característica que compartilharia com a Casa del Fascio (1936) de G.Terragni, segundo Martí:

"...edificio de apariencia simple pero, en realidad, bastante mixto, es decir, compuesto por diferentes ideas tipológicas que en él se superponen y armonizan." "119

É nessa harmonização e nessa ambiguidade que reside o interesse que o prédio da FAU desperta enquanto arquitetura e objeto cultural. Podemos debater longamente sobre qual tipo clássico ou ancestral melhor receberia sua arquitetura, mas nunca há consenso, seria análogo à um templo grego, mas logo seu interior não é construído e fechado como a cella clássica, então poderíamos atribuir-lhe o tipo romano, até chegarmos ao pátio ibérico ou mouro, a partir de certos 
119. Idem, pg. 128

120. QUETGLAS, Josep, Federación de textos de distinta longitud,

hostiles a la "esencia vacia del arte moderno", Barcelona,

Universitat Politécnica de Catalunya. Departament de

Composició Arquitectónica. ETSAB, s/ data, p. 30. Apud VILLAC,

Maria Isabel, Mendes da Rocha, Lisboa, Blau, 1996, pg. 13.

121. Nome dado ao grande espaço vazio de pé direito múltiplo

que constitui o centro do edifício da Escola (FAUUSP).

elementos, ou ainda defender sua analogia com a basílica ou com o fórum.

É fato que se trata de um edifício singular, talvez um exemplar atípico, ou "politípico" que nos demonstra, na sua aparente bruteza, que a estética pode estar justamente nessas operações projetuais de diversas modalidades e não no adorno, no ornamento delituoso de Loos, fazendo dele um exemplar moderno em essência, moderno no sentido defendido por Josep Quetglas:

"En la experiencia moderna, es en el dispositivo obra-espectador donde se produce el discurso"

"Lo moderno no esta en la obra sino en la relación que establece com el espectador, la obra te permite compreender cosas exteriores a ella. El contenido de la obra moderna aparece en esa relación, de forma que el espectador participa de la obra. El moderno no se deja mirar y a la vez se impone, no representa, se presenta, y allí es donde surge el lenguaje." 120
Moderno, que se faz a todo momento como único, que existe de uma maneira diferente para cada um dos que o vivem.

Não há consenso sobre o que os espaços despertam ou provocam nas pessoas, não é um edifício facilmente 'tipificável', ao não pretender figurar nada, nos trás arquitetura em estado puro, construído, naturalmente com deve ser a arquitetura, mas que não tem a construção em seu discurso. A FAU nos permite fazer análise em arquitetura apenas, tratando dos espaços, dos tipos e estruturas, sem deixarmos o discurso ser conduzido pelos encantos da técnica.

Um dos poucos elementos do edifício da FAU que parece gerar algum consenso é o grande vazio central, muito bem apreendido na descrição feita do Caramelo ${ }^{121}$ por Ana Paula G. Pontes: 


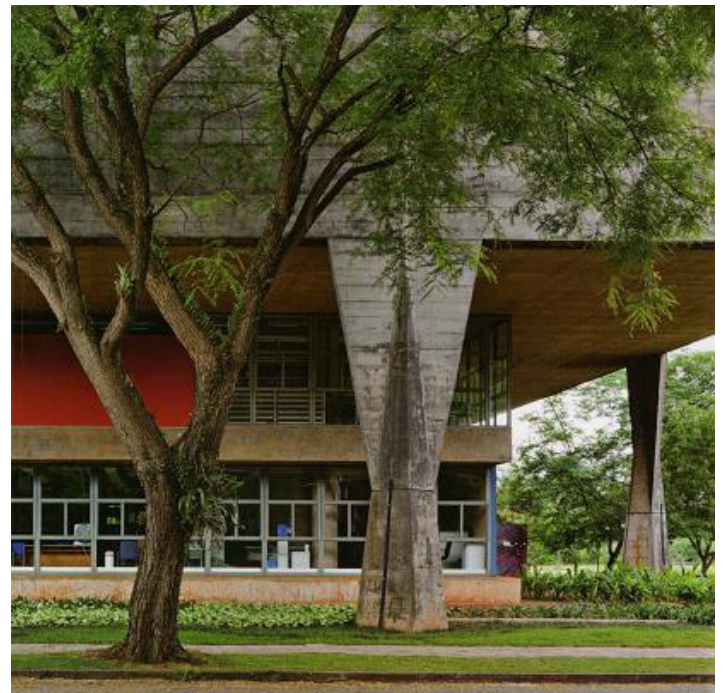

102 Edifício Vilanova Artigas

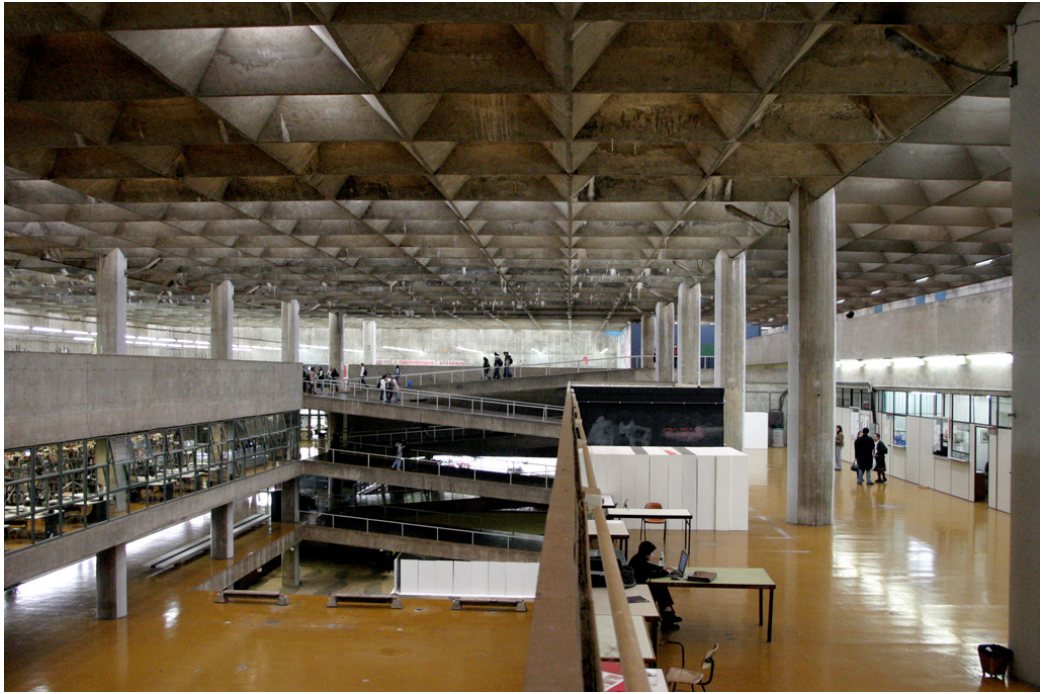

103 Edifício Vilanova Artigas
"É o "vazio" do chamado Salão Caramelo que permite que o olhar perceba a todo momento a dimensão total do edifício, tanto na horizontal quanto na vertical, e que provoca a sensação de unidade interior que o caracteriza. A espacialidade interiorizada da FAU/USP, girando em torno de um pátio central, é a principal pista para pensar sua eventual relação com o passado, tomando como referência a arquitetura romana - marcada pela delimitação precisa de lugares cercados por paredes - em oposição à arquitetura grega, caracterizada pela exterioridade."122

O vazio do Caramelo não é resultado de uma operação de esvaziamento, de perfuração - como ocorre no pátio interno - mas é um vazio estrutural, estruturador do tipo, composto por diversas operações:

“...por una operación constructiva de adición o articulación de una serie de piezas autónomas que al reunirse, según ciertas reglas, definen el espacio del patio." 123
Surge assim, entre as obras analisadas, a figura do pátio ordenador, que é próprio dos edifícios de grande escala, o pátio ao redor do qual todo o edifício se estrutura, lhe atribui escala e se torna indissociável da obra.

Ana Paula Pontes, ao discorrer sobre o edifício da FAUUSP no quarto capítulo - O templo-escola de Vilanova Artigas ${ }^{124}$ - de sua dissertação de mestrado, propõe um trajeto analítico muito interessante e também pertinente para esse texto. Se inicia no exterior da obra, para logo entrar, ensaiando sempre sobre as possibilidades de associação do edifício aos tipos ancestrais, em um processo de análise que parte da leitura da forma arquitetônica para avançar no campo dos significados que a escola representa.

Desde a visão externa encontra similitudes com o templo grego, por conta da experiência do peristilo e da relação entre colunas e entablamento válida na leitura de ambos - templo e escola - logo ao entrar, surge a figura do vazio, contrária à do templo, que é construído, 
123. MARTÍ Aris, Carlos, Pabellón y patio, elementos de la arquitectura moderna, 2008, in: DEARQ: Revista de Arquitectura de la Universidad de los Andes, , Nº. 2, maio - 2008, pg.20.

124. PONTES, Ana Paula Gonçalves, Diálogos silenciosos: arquitetura moderna brasileira e a tradição clássica, dissertação de mestrado apresentada à PUC-RJ em 2004, pgs.86-123.

125. Idem, pg. 94.
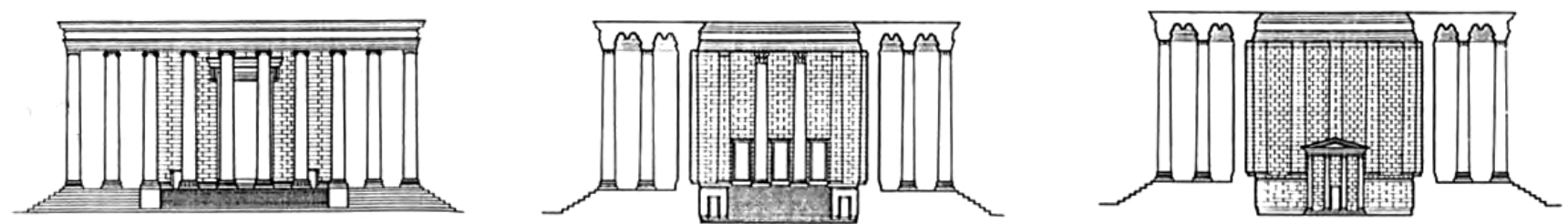

104 Templo jônico de Dídyma, exemplar de cella aberta, séc. 3 a.C. circa. cujo interior é ocupado pela cella, encontra assim, no vazio, analogia com a espacialidade romana, centralizada no pátio. A associação mais direta é com o a estrutura do tipo basilical, não tanto com a casa romana, por conta da escala.

"Se a configuração tipológica da basílica tem semelhanças com o salão da FAU/USP, não se pode dizer o mesmo das características estáticas de seu espaço interno, dada tanto pela rígida simetria axial quanto pelo peso das massas murais. Essa espacialidade definida por contornos construídos encontra seu equivalente urbano no fórum - praça pública onde funcionava o mercado - cujas configurações não possuem a mesma rigidez espacial, sendo mais complexas e dinâmicas que as da basílica. o fórum é, portanto, a referência romana mais interessante para a escola de Artigas, pois tratava-se de um "vazio" urbano qualificado por edifícios circundantes, que desempenhava um papel vital na vida da cidade."125

Com a identificação do forum como tipo válido para compreensão da escola, Pontes exterioriza o pátio, vinculando-o à praça urbana e à

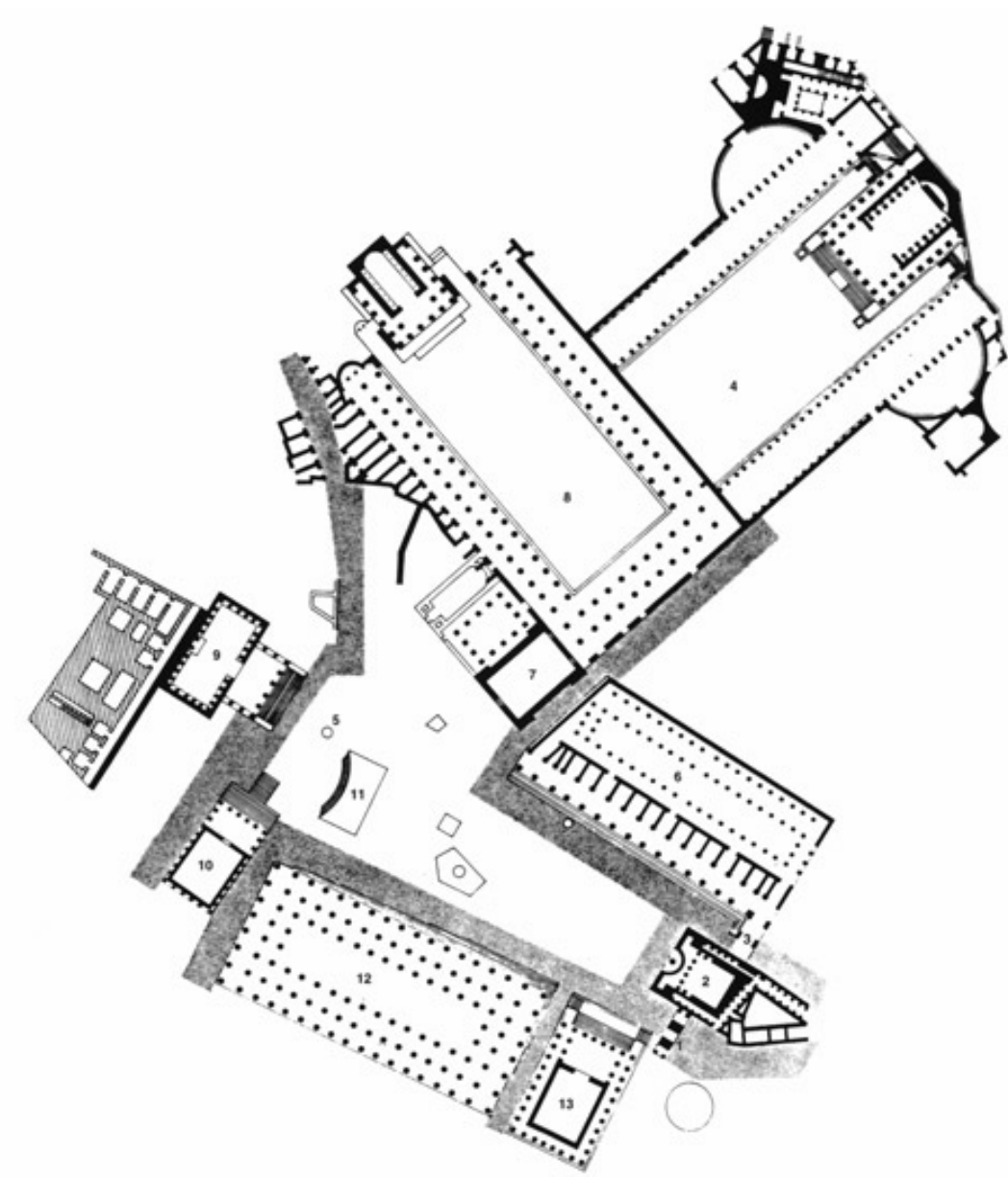

$\mathbf{1 0 5}$ Fori Imperiali - Roma, ano 40 a.C. 


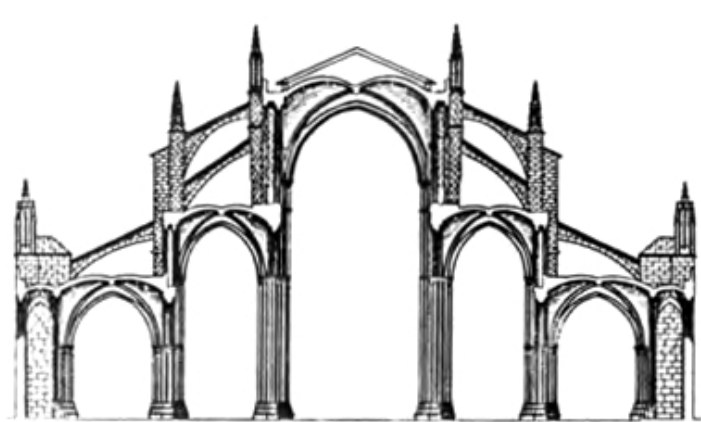

106 Corte Basilica de Toledo, séc XIII

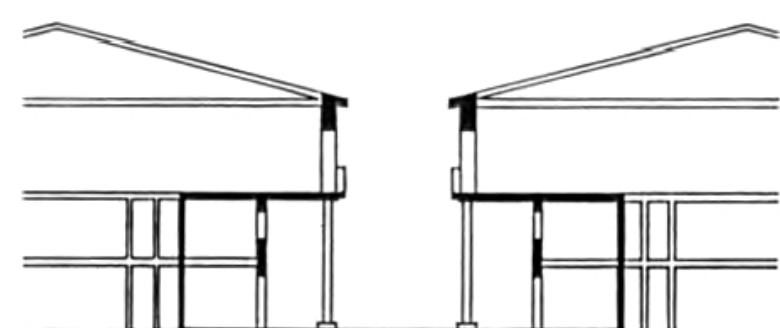

107 Rua porticada mediaval - Salvatierra, Navarra, Espanha
126. De acordo com o plano diretor da CUASO (Cidade Universitária Armando de Salles Oliveira) os edifícios a ocupar o corredor das humanas seriam os dos cursos de história, geografia, filosofia, letras, ciências geológicas, arquitetura e urbanismo e matemática. Por força do mesmo plano (ou por alguma diretriz assumida entre os arquitetos que desenvolveram os anteprojetos das unidades), todos deveriam considerar um fluxo/eixo de passagem de alunos no nível térreo para que se formasse uma grande rua de pedestres interligando as sete unidades, o que se efetivou apenas parcialmente, com o edifício para os cursos de história e geografia (que foram combinados em uma construção única, da autoria do Arq. Eduardo Corona) e com a Faculdade de Arquitetura ambos de 1961.

Os projetos produzidos nessa oficina internacional ETH/FAU podem ser apreciado no seguinte link:

< http://projetofau2009.jimdo.com/oficina-eth-fau/> acessado em 13 jan 2015.

Nota: ETH Zurich é a sigla para Eidgenössische Technische Hochschule Zürich - Faculdade Técnica Federal de Zurique. dinâmica que os edifícios que a formam lhe conferem, numa leitura muito feliz do espaço central da escola, inclusive coincidente com o discurso de Artigas, que via no caramelo um espaço de trocas e um salão cívico, como de fato é.

Mas aqui nos interessa aproveitar certa ambiguidade presente na análise da autora, no vínculo entre praça urbana, forum, e o espaço da FAU, as aproximações analíticas feitas por Pontes estão na diferença de escala e na questão topológica da conformação do espaço. A analogia com o fórum é completa na coincidência das estruturas da forma, na linearidade e na presença das stoas em ambos lados, mas o forum tem escala territorial além de ser externo, descoberto, ambas características não compartilhadas pela escola. Não há limites para a praça urbana em relação à sua escala, da mesma forma que não para o fórum, mas a linearidade do espaço do salão caramelo, que poderia aproximá-lo do forum e portanto reforçar a relação analógica, foi completamente esfacelada ao longo do tempo, o que nos leva a uma leitura equivocada do espaço, mais próxima do nuclear e que acabou reforçando sua conotação vertical.

O espaço do caramelo, no projeto original do edifício se abria diretamente ao exterior, no térreo por um de seus lados menores, oposto ao conjunto de rampas, estabelecendo também nesse ponto relação com o exterior similar à que encontramos no acesso principal do edifício, um pórtico. Não é isso que a história nos legou, por uma ação simples, mas devastadora, que foi a de ocupar - como área disponível para escritórios administrativos - a faixa externa de 'varanda' que a FAU tinha, perdeu-se assim um espaço que se vinculava aos edifícios que constituiriam o corredor das humanidades da USP, espaço que tinha (teria) a função clara de receber o eixo de circulação de alunos que percorreria todos os edifícios ${ }^{126}$ para gerar nesse fluxo um vórtice ${ }^{127}$, exatamente no salão caramelo e 'entregar' 
127. A imagem do vórtice pode ser reforçada pela presença das rampas.

128. Em proposta equivalente à do exercício proposto em oficina de projeto promovida pela FAUUSP e pela ETH Zurich entre 24/ago e 04/set de 2009, em São Paulo, com participação de alunos e professores de ambas instituições e que teve como tema central a readequação funcional de todos os usos da FAUUSP dispersos em diversos espaços e edifícios. Em muitas das propostas surgiu a imagem da rua que cruza ou tangencia o edifício, em casos no nível térreo e em outros no subsolo.

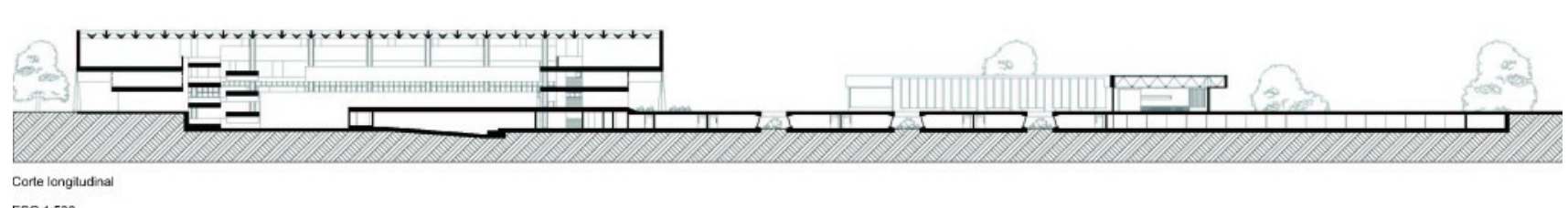
Corte longiludina
ESC 1.500

ESC 1:50

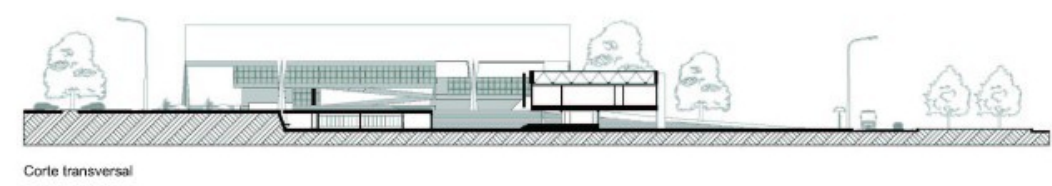

Corte transversal

108 Corte longitudinal da FAUUSP, proposta de projeto da oficina ETH/FAU agozoog os usuários na fachada oposta à que teve sua abertura tolhida, já na direção do Instituto de Matemática, e vice-versa, recebe-los ali e leválos ao "corredor, ou rua, das humanas".

Para progredir na análise, propomos então um exercício de abstração, de estabelecimento de vínculos do edifício da FAU com um entorno diferente da que lá está, numa realidade que poderia ter sido, em especial na relação que estabeleceria com o entorno imediato, como um exercício de projeto ${ }^{128}$, que considera o corredor de humanidades consolidado e o salão caramelo, talvez nesse contexto hipotético, mais fiel à sua concepção original.

Com todas essas condições analíticas estabelecidas, surge rapidamente a imagem da rua, espaço de livre trânsito, dinâmico, com edifícios que se assomam, ora desalinhados, transversais ao percurso, com alturas diferentes, balcões e fachadas diversas, envidraçadas, cegas, simples bandejas, planas ou inclinadas.

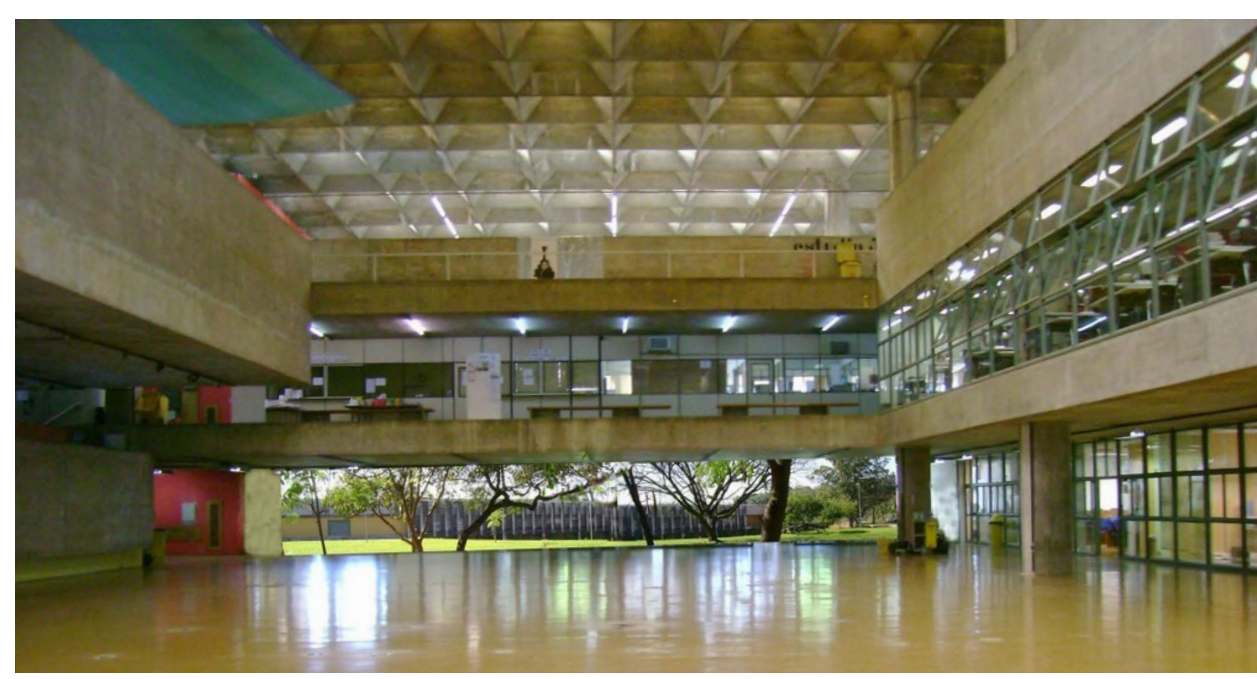

109 Caramelo aberto ao exterior (proposta original do projeto), fotomontagem, oficina ETH/FAU ago2oo9 


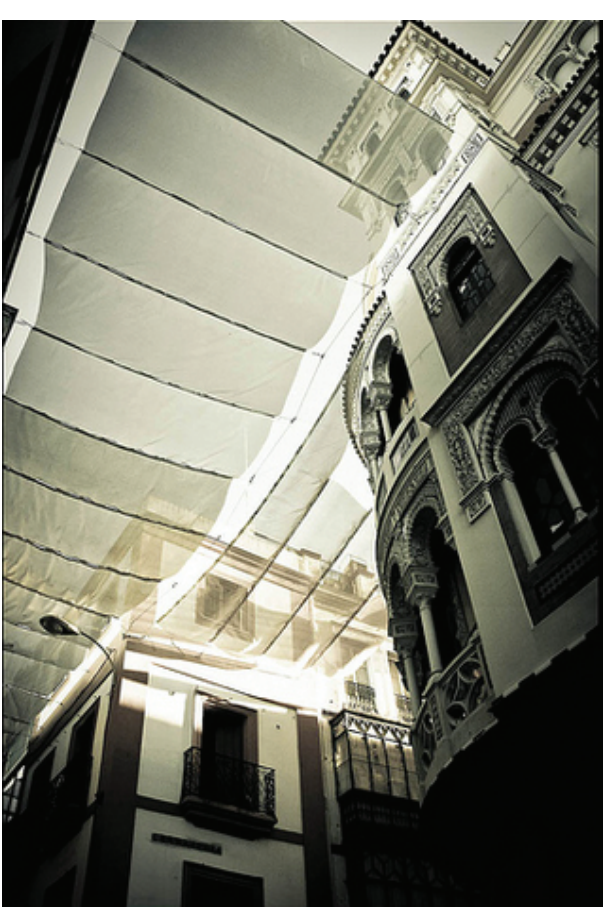

110 Calle Cuna, Sevilla, España

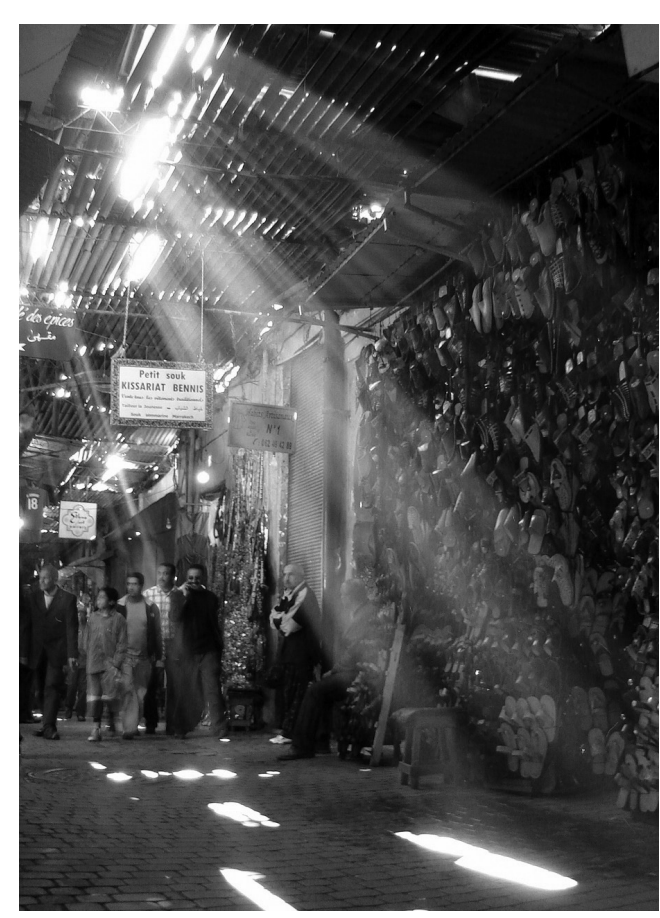

111 Souk Marrocain
129. VALENTİN, Fabio Rago, op.cit., pgs.217-18.

130. ARMESTO Aira, Antonio, Op.Cit. pg. 65, nota 13.

131. Zoco, do espanhol: Zoco. (Cf. azogue). 1. m. En Marruecos, mercado. 2. m. Lugar en que se celebra este. $3 . \mathrm{m}$. ant. Plaza de una población. in Diccionário de la Real Academia Española (DRAE) disponível em:

< http://lema.rae.es/drae/?val=zoco> acesso em 18/02/2015.

Souk, do inglês: Souk. from Arabic sq. (also suk, sukh, or suq): noum 1. An Arab market or marketplace; a bazaar. in Oxford Dictionaries disponível em: <https://www.oxforddictionaries. com/definition/english/souk> acesso em 18/2/2015

132. Tectônica na acepção da atividade desenvolvida pelo tecelão, a tessitura, tectum, teto. Tekton () do grego, constructor o carpinteiro.

133. Azotea, Del ár. hisp. *assuáya, dim. de sá, y este del ár. clás. sa: planicie, terraza. 1. f. Cubierta más o menos llana de un edificio, dispuesta para distintos fines, in Diccionário de la Real Academia Española (DRAE) disponível em:

$<$ http://lema.rae.es/drae/?val=azotea> acesso em 18/02/2015. “...pontuação cromática das poucas alvenarias (pintadas nas cores vermelho, azul e amarelo), a textura das tábuas impressas no concreto, (...) lâminas e blocos (...) parecem estar em suspensão, mesclados com paredes de vidro, paredes coloridas, pilares com desenhos distintos, varandas internas, um conjunto de rampas (...) percebe-se a riqueza da sucessão de transparências, opacidades, frestas, vistas que recortam ora o andar, ora todo o prédio..."129

O edifício Vilanova Artigas resulta de um sem-número de operações lógico formais que é próprio da cidade e das casas.

Em relação à imagem da rua e de sua multiplicidade e variabilidade de tipos, Antonio Armesto Arias faz a seguinte colocação:
"Pensemos en los toldos que se añaden a las calles de Sevilla o los techos de cañas en un zoco marroquí: la calle que era un recinto poco antes se convierte en una habitación, en un interior. En Sevilla la calle con toldo y las casas patio a ambos lados crean una arquitectura, un edificio que funde en una sola realidad arquitectónica la casa y la calle. Igual passa en una calle porticada medieval: si se cubriera obtendríamos la sección de una basílica en la que por las ventanas del claristório, en lugar de la luz se assomarían las dependencias del piso superior de las casas."130

Ajustamos, de acordo com nossa conveniência, a descrição de Armesto da rua medieval ou sevilhana, para aproximá-la do edifício da FAU, imaginemos que essa rua porticada coberta tem em seu teto um elemento híbrido, meio têxtil meio construído em caniços (como o teto do zoco ${ }^{131}$ 


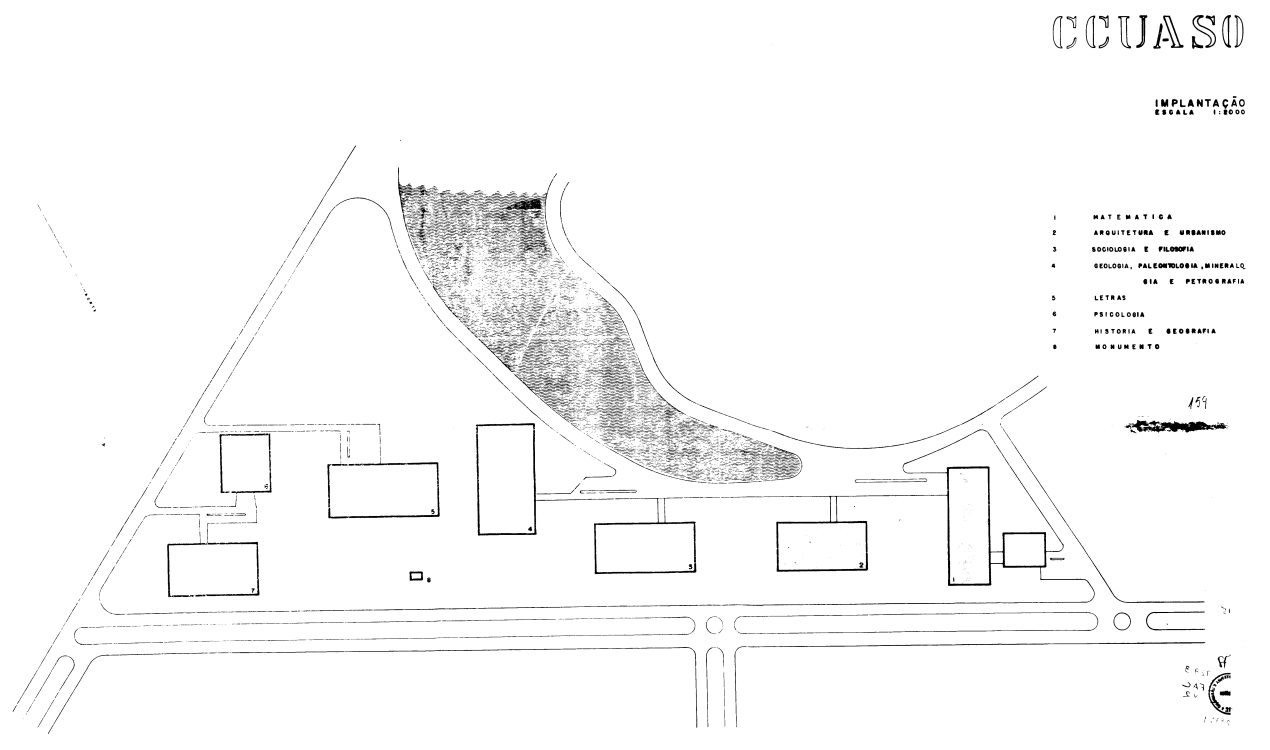

$\mathbf{1 1 2}$ corredor das humanidades

marroquino) - para não abrirmos mão de nenhuma das três imagens - formando uma trama que nos deixa entrever o exterior, deixa passar o sol, difundindo sua luz, nos permite saber o que está acontecendo no céu, lá fora. Essa cobertura tectônica ${ }^{132}$ não pende das fachadas da rua ou dos balcões das casas mas está atada às fachadas de seus áticos e assim abrigam também as atividades que ocorrem nas terraças, criando uma arquitetura que funde em uma só realidade os pórticos, as casas e as azoteas ${ }^{133}$ sob um teto único um edifício-rua, local das trocas, do mercado, definitivamente urbano, mas que não está restrito às atividades no térreo, estão também nos terrados e nos intermediários. ${ }^{134}$
134. A ideia de que as atividades do forum (mercado) se expandirem para as adjacências está refletida nesse trecho de Giulio Carlo Argan: "organismos abertos como os fóruns (mercados) podem ser considerados como verdadeiros e autênticos organismos arquitetônicos ou tipos de edifícios: quase sempre a função dominante dos edifícios que delimitam sua área é a de abrigar atividades complementares às do forum, e definir sua forma arquitetônica" grifo meu.

ARGAN, Giulio Carlo, História da arte italiana: da Antiguidade a Dcuccio - vol.I. São Paulo: Cosac \& Naify, 2003. P. 180. Apud PONTES, Ana Paula Gonçalves, op.cit.

135. MARTí Arís, Carlos, Las variaciones de la identidad - Ensayo sobre el tipo en arquitetcura. Barcelona, Ed. del Serbal, 1993. pg.128. tradução do autor.

\subsection{Hibridações e justaposições}

Todas as obras, como vimos, acabam sendo 'bastante mistas', ou seja, compostas por diferentes ideias tipológicas que, na obra, se sobrepõe e harmonizam ${ }^{135}$ mas nos deparamos, ao analisá-las, que um tipo acaba prevalecendo sobre os demais, entre as obras de Artigas selecionadas há situações em que os tipos permanecem legíveis e não se deixam sobrepor. O exemplo emblemático de obra mista é o edifício da FAUUSP ao qual podemos atribuir o adjetivo de 'politípico', ou 'tritípico' (aula-teto-pátio) porque oferece condições plenas ser observado em consonância com qualquer um dos três tipos, dependendo da escala do espaço que se analisa e da amplitude espacial da análise. Além do prédio da FAU - que poderia ser considerado um importante exemplar híbrido - surgem outros dois, que a presente análise alcançou. 

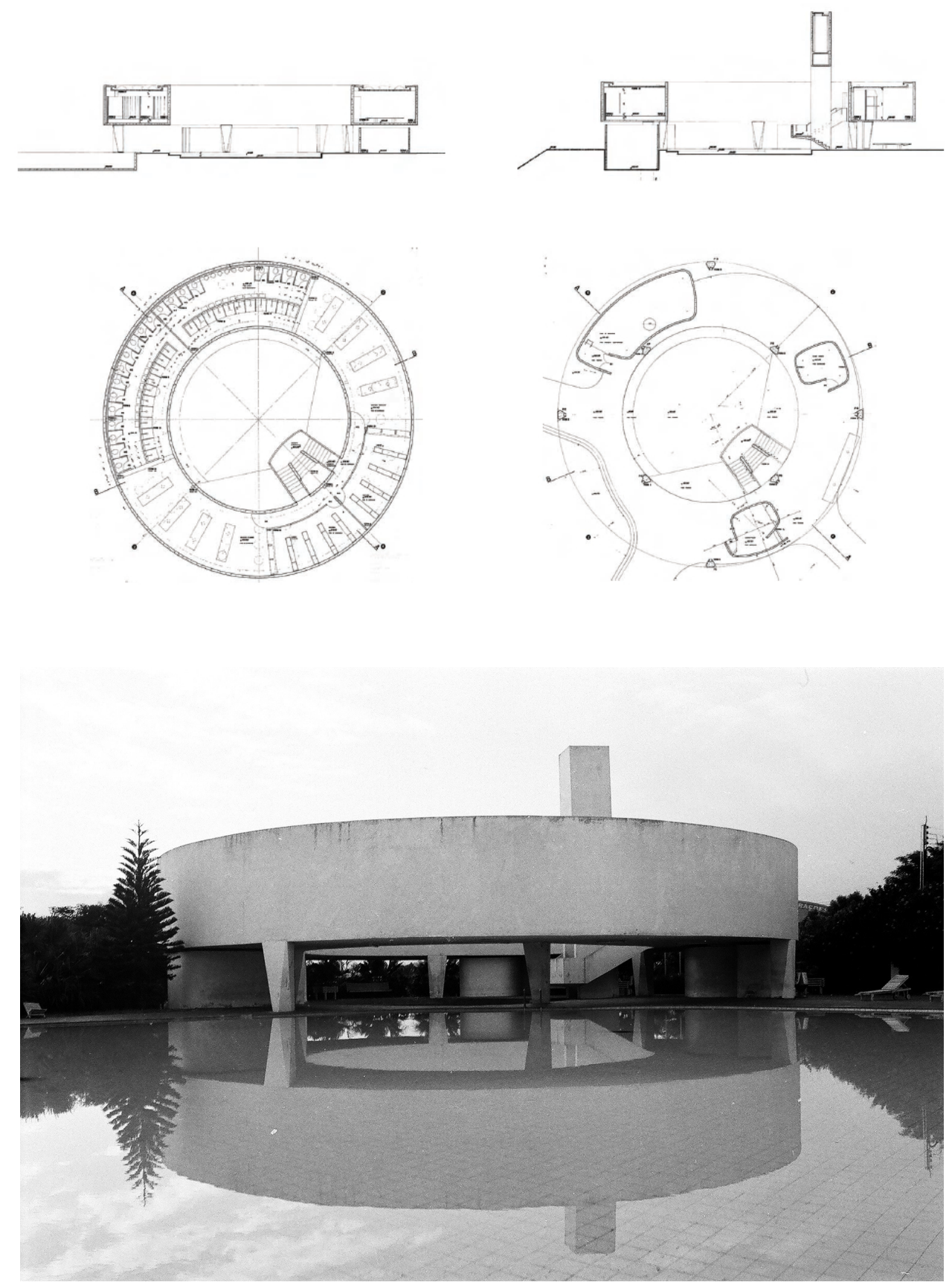

113 e 114 Balneário de Jaú, 1975
136. Hoje denominado Balneário Aristides Coló.

137. Interessante notar que no concurso internacional para o masterplan do Setor Federal de Instituições Jurídicas de Madri - Espanha (Campus de la Justicia) promovido em 2005, na proposta vencedora, desenhada pelo escritório local Frechilla López-Peláez flpsl arquitectos, todos os edifícios do Campus tem a forma cilíndrica, naturalmente em outra escala em comparação com o Balneário Aristides Coló de Jaú, mas um masterplan com uma proposta tão singular levou deiversos escritórios de arquitetura a terem que experimentar a inserção dos programas em um cilindro, muitos trabalharam o pátio. 30 anos separam as duas empreitadas. Conferir: <http://www.flparquitectos.com/ ImagenAmpliada. aspx?id=124> e <http://es. wikipedia.org/wiki/ Campus_de_la_Justicia_de_Madrid\#Concurso_de_ideas_para_ el_anteproyecto>
Artigas parece ter experimentado não apenas com a casa, exercitou também com o edifício de grande escala, independentemente de estar gerando modelos. O projeto para o balneário de Jaú136 de 1975 é um edifício singular e aparentemente não se tornou modelo ${ }^{137}$, mas é inegável que o projeto foi abordado com basante liberdade - em especial se o mantemos no contexto da construção civil e da arquitetura de sua época - o cenário era favorável, havia abundância de terreno e liberdade de posicionamento da construção, Artigas não estava obrigado a assumir ações projetuais condicionadas pelos limites da parcela. O programa a se construir representa pouca área frente à escala do terreno, aliado ao fato de se tratar de um balneário, com piscinas ao ar livre e áreas de solarium e ajardinadas.

A operação lógico-formal principal nessa obra é a de criação de um pátio, bastante singular em sua froma, um pátio resultante de um sólido de revolução - análogo ao toro - que surge da revolução de um retângulo - não uma circunferência - o perímetro de uma aula vista 
escada posicionada lateralmente no pátio. Toda a ventilação e

iluminação naturais do programa são feitas zenitalmente, o que

permitiu que as fachadas fossem lisas interna e externamente.

139. Torre d'água, denominação para caixa d'água encontrada em croquis e memorial de Artigas para a escola Conceiçãozinha no Guarujá, interessante que o nome atribuido denota a vertical.

140. No Campus da Justiça de Madri (ver nota 137) no edifício da Audiencia Provincial, com projeto de autoria do escritório londrino Foster and Partners, assim como Artigas em Jaú,

também criou recintos dispostos livremente sob o grande teto dos pilotis. Conferir:

$<$ http://www.fosterandpartners.com/projects/high-court-ofjustice-and-supreme-court-city-of-justice/>

141. Denominação nos anos 1970: Centro Integrado Piloto de Vila Alpina, denominação atual: EMEIEF Prof ${ }^{a}$ Therezinha M.Barros Nosé, rua João Fernandes, s/n, Santo André-SP.

em corte, com piso, teto e fechamentos laterais, elevado em relação ao terreno e revolucionado em torno a um eixo vertical afastado 7,om da lateral do objeto, assim chegaremos a um tipo aula-pátio, pois resulta da hibridação entre aula, que forma o sólido elevado dos vestiários, e pátio, resultante da conformação desse sólido opaco ${ }^{138}$. A distribuição dos vestiários dentro do sólido elevado, do anel, é feita de tal forma que existe apenas uma abertura em fachadas verticais, é por ela que se acessa aos vestiários, com o auxílio de uma escada de três lances, simétrica, posicionada lateralmente no pátio e que tem sobre si uma torre d'água ${ }^{139}$ de $10 \mathrm{~m}$ de altura, reforçando a vertical do pátio. Toda a ventilação e iluminação naturais do programa são feitas zenitalmente, o que permite que as fachadas sejam lisas, sem aberturas, interna e externamente.

O grande volume, ao estar elevado, cria ainda um espaço de teto, um pilotis sob o anel elevado, espaço onde se situam três pequenos recintos de formas arredondadas que não tocam a cobertura ${ }^{140}$. Nesse edifício hibrido, também há a participação do elemento teto, além de aula e pátio.

A escola projetada por Vilanova Artigas no bairro da Vila Alpina ${ }^{141} \mathrm{em}$ São André-SP, de 1970 é um edifício que responde a várias tipologias, é um híbrido difícil de definir completamente. Esse projeto pôde ser abordado com liberdade pelo arquiteto, não apresentando reflexo de nenhum dos limites territoriais na forma final, responde a um programa de necessidades experimental, enxuto e bastante livre. Situase em terreno de topografia suave e muito amplo, uma parte grande das atividades infantis ocorre ao ar livre.

O elemento físico predominante é o teto, uma grande marquise, térrea, com forma irregular e curvilínea acolhe todas as funções que precisam de recintos fechados - as três salas, galpão coberto, administração e serviços - esse grande teto é fomado por uma bandeja de concreto suspensa do solo por sete pilares e pelo corpo correspondente aos sanitários. 
Sobre a laje se desenvolve um grande terraço, uma praça elevada que se liga ao terreno em três pontos (nas suas três pontas) uma delas acessa em nível a cota elevada do terreno onde se sitúa a quadra esportiva, por uma 'ponte' sob a qual se posiciona o programa administrativo, o segundo ponto de ligação ocorre com a área da piscina, que está em cota intermediária entre o térreo e a cobertura. No terceiro ponto de união entra as duas cotas, ocorre uma situação interessante, a bandeja se estreita suavemente, faz uma curva para a direita e deriva em uma ampla escada de dois lances que forma em torno de si um 'recinto' em forma de um J, e nesse ponto reúne o tipo teto com o pátio.

Sem muita dúvida o tipo que prevalece nesse edifício é o teto, que dialoga de uma forma interessante com o terreno, gerando grande diversidade de percursos entre edifício, praça elevada e terreno, em um universo tipológico que retoma os valores arquitetônicos logrados pelas casas projetadas por Artigas, onde a participação do terrapleno, da bandeja e das ligações nos percursos gera uma relação de 'continuidade ininterrupta' com o espaço, dando uma condição ao promenade, não mais labiríntica e concentrada em um pequeno lote - como havia de ocorrer nas casas - mas renovada, onde a sucessão de eventos é suave, longilínea e tem a favor de si a amplitude do território sobre o qual se desenvolver, consolidadno uma relação moebiana ${ }^{142}$ entre espectador e obra; entre sob e sobre; entre interior e exterior; entre teto e pátio, fazendo de todas essas dualidades sua maior riqueza. 


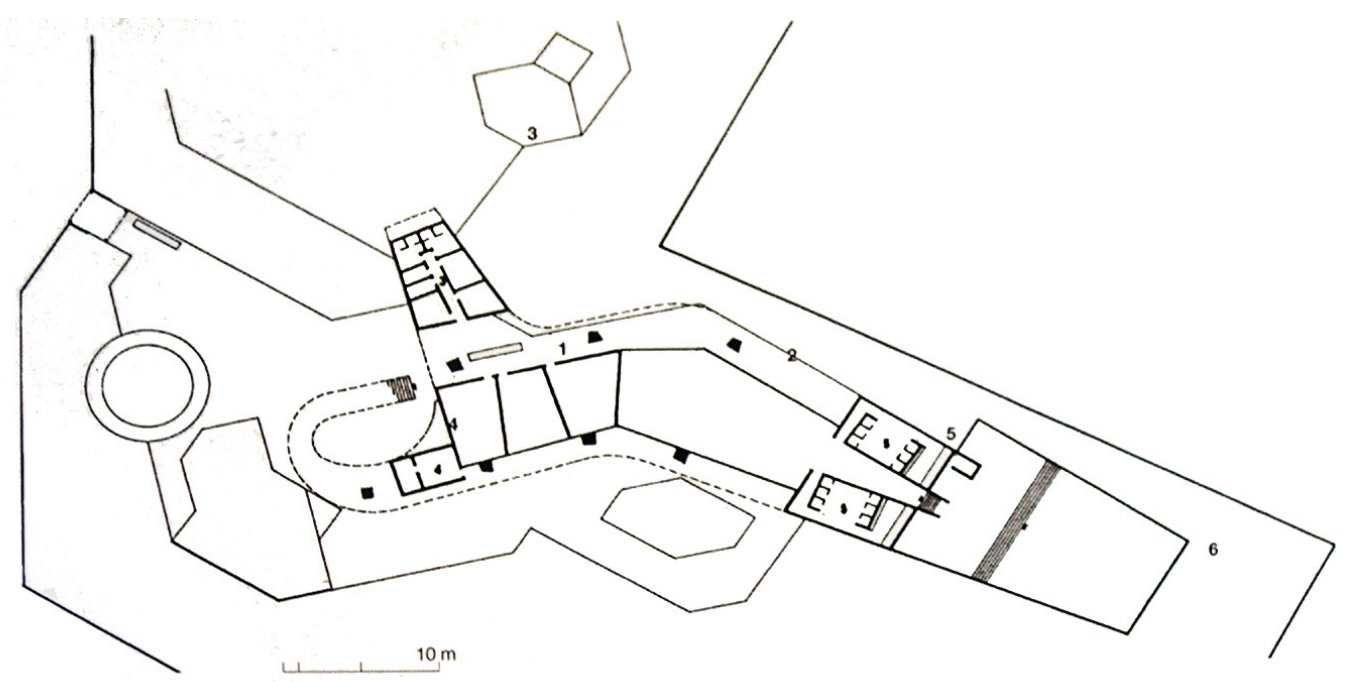

115 Escola Vila Alpina, Santo André, SP - 1970
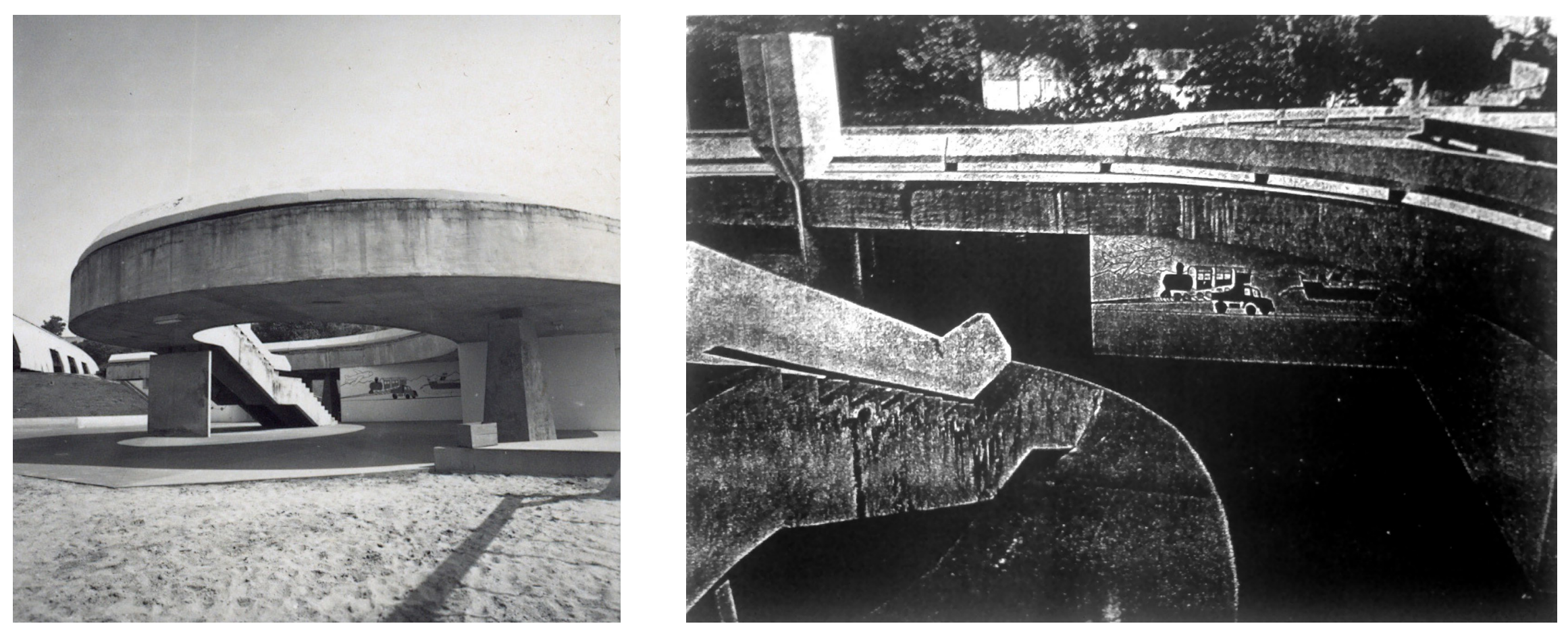

116 e 117 Escola Vila Alpina, Santo André, SP - 1970 

5. DESENHOS ANALITIICOS 

vista

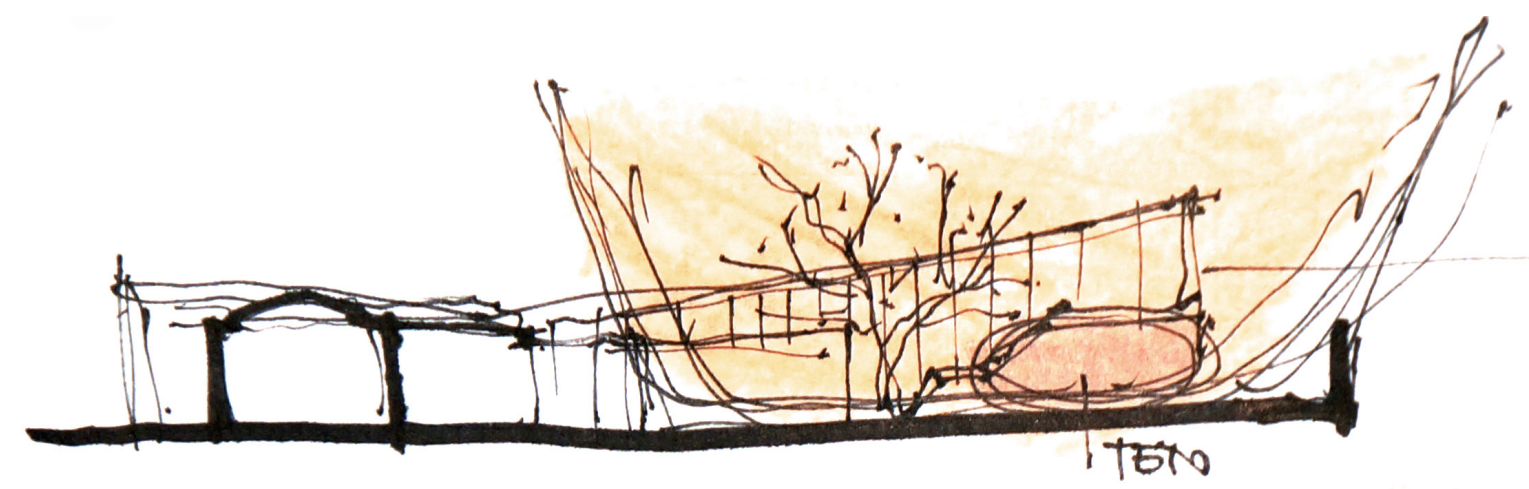

- Pátio
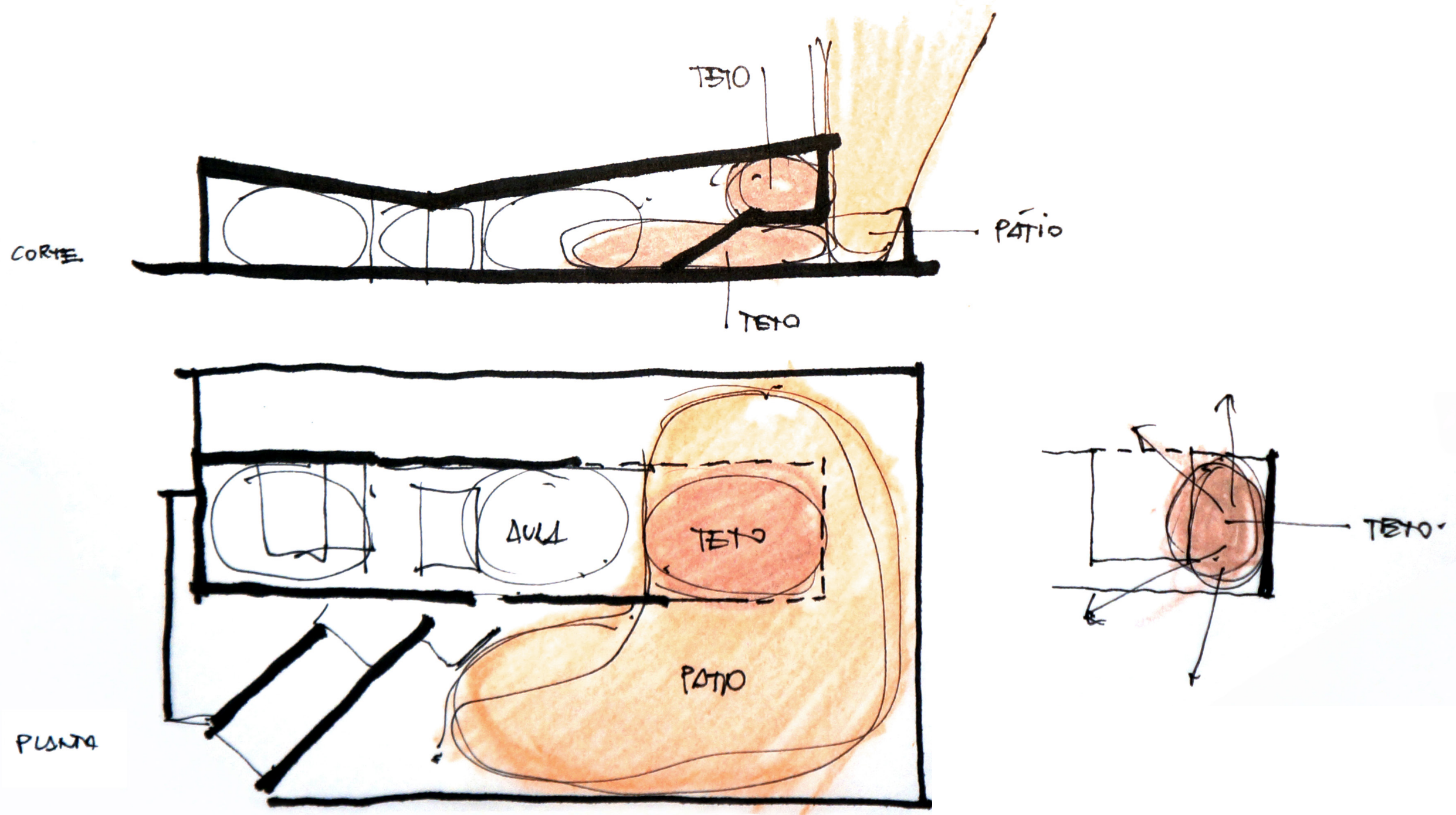


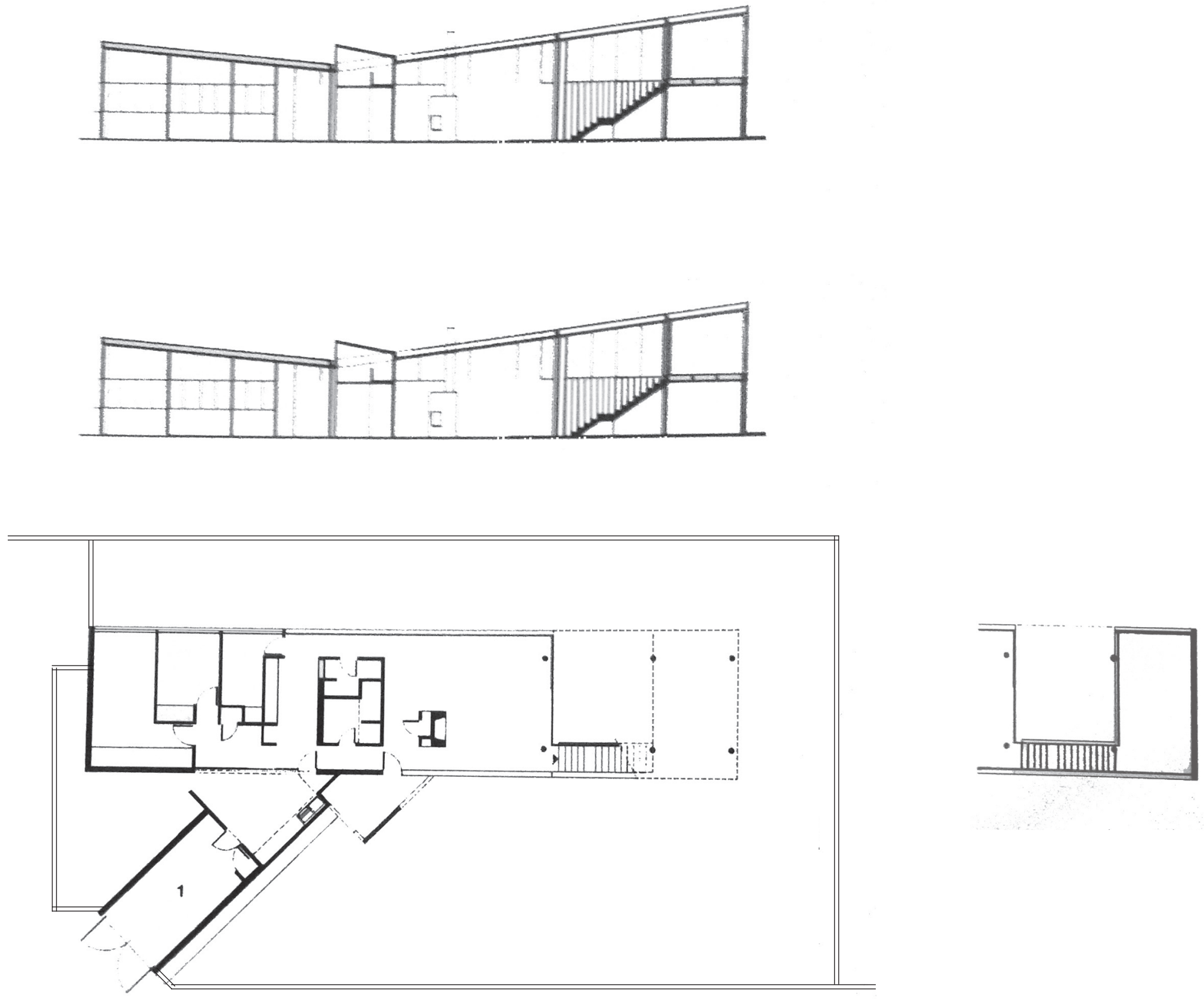


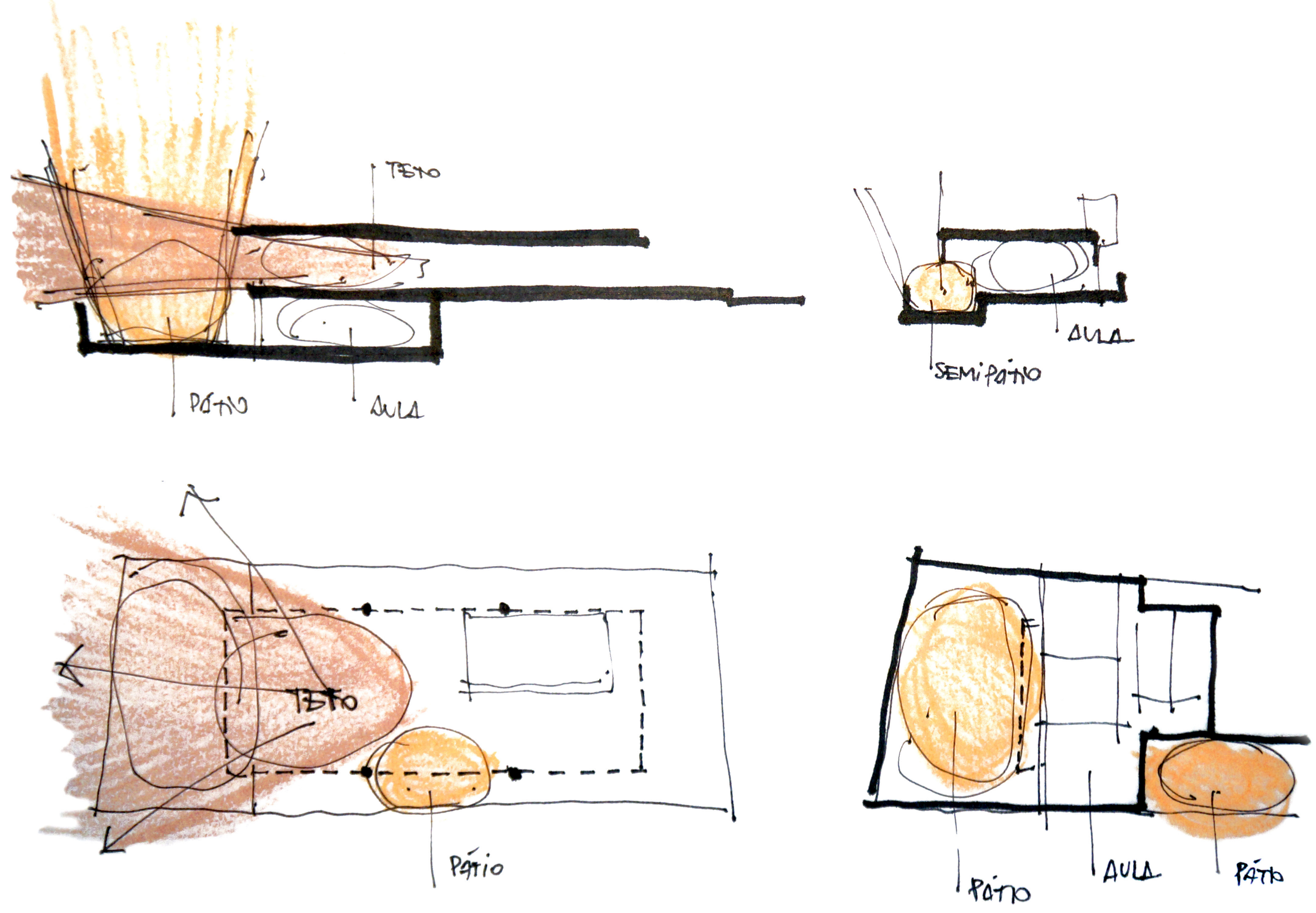


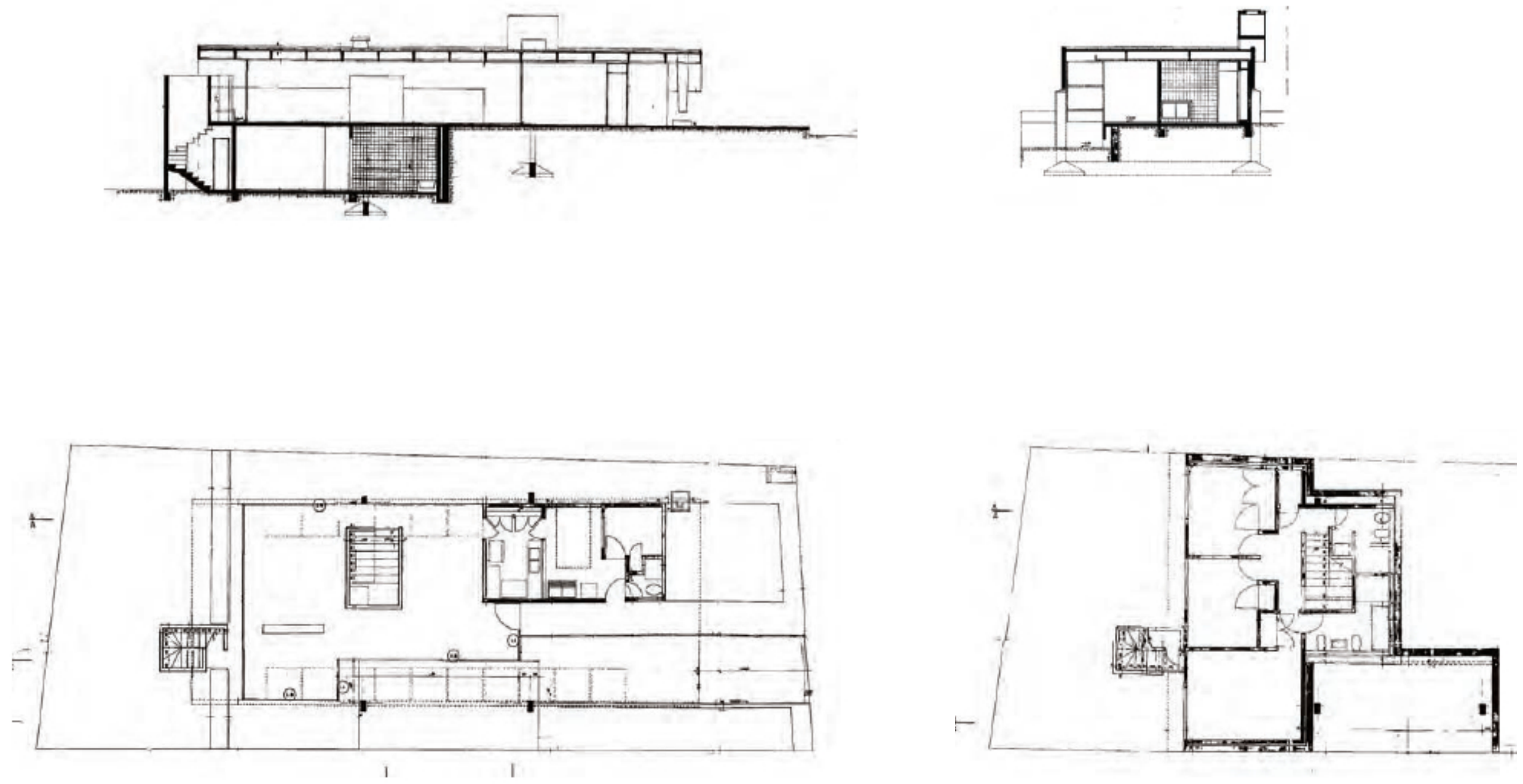


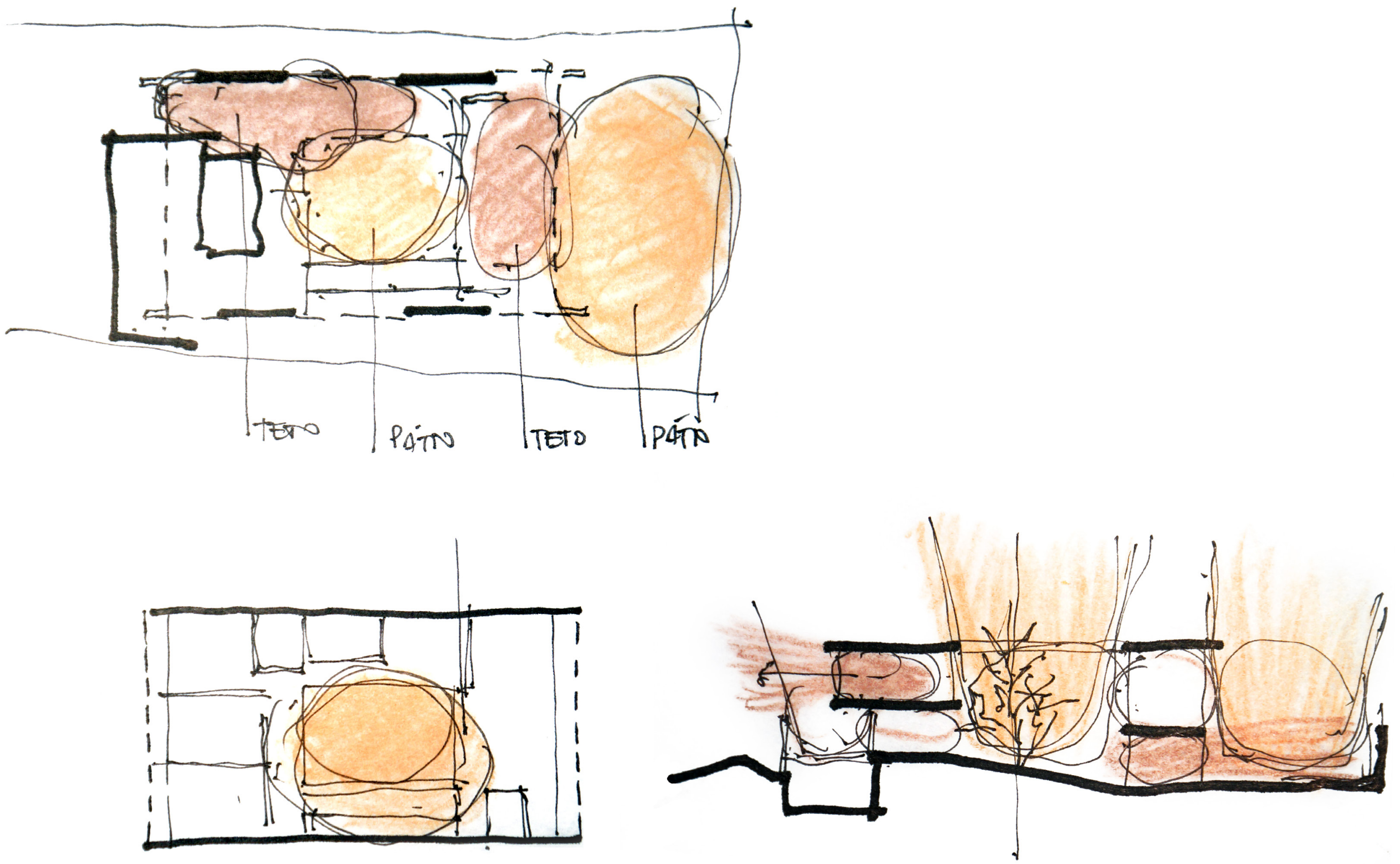


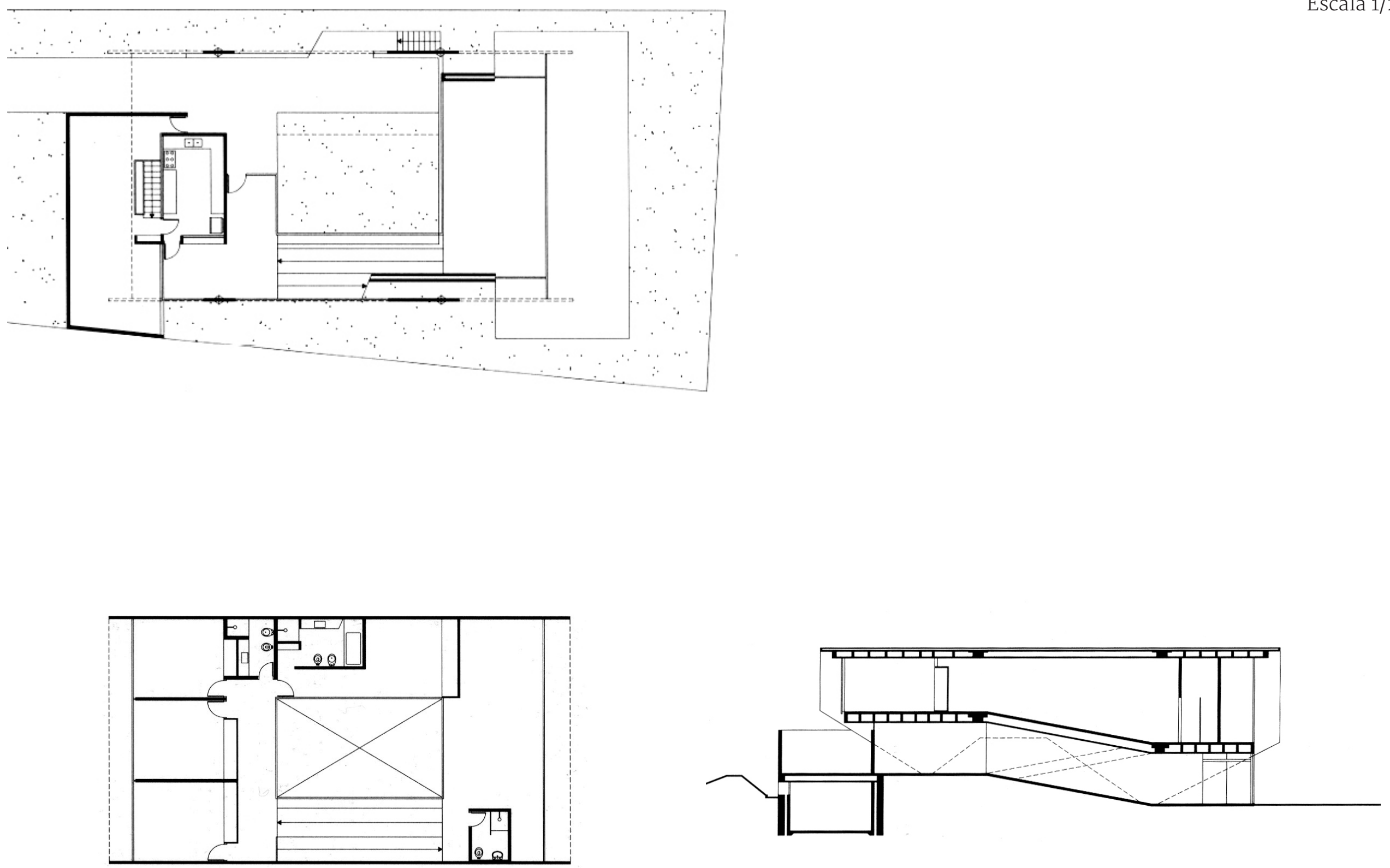



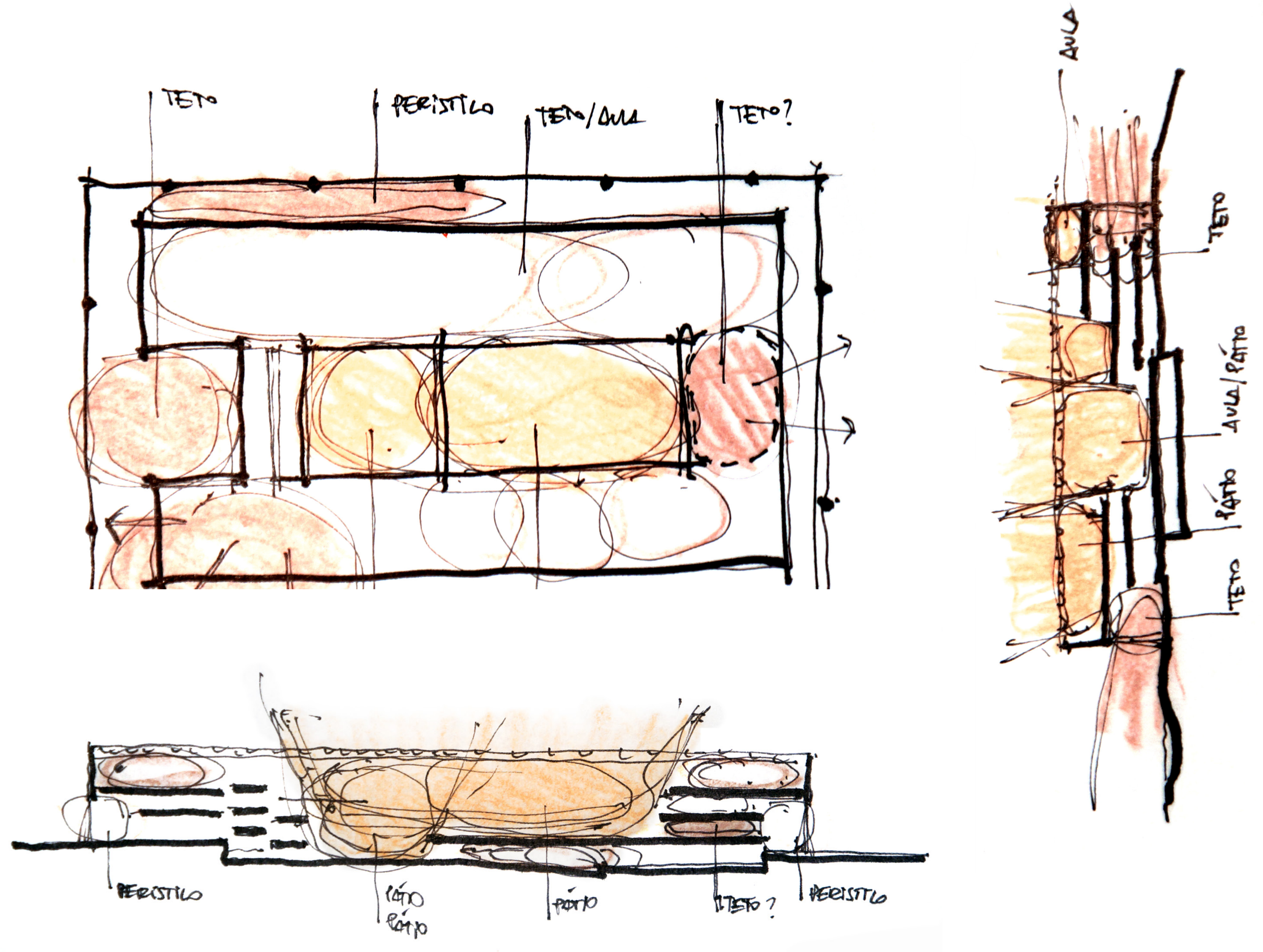




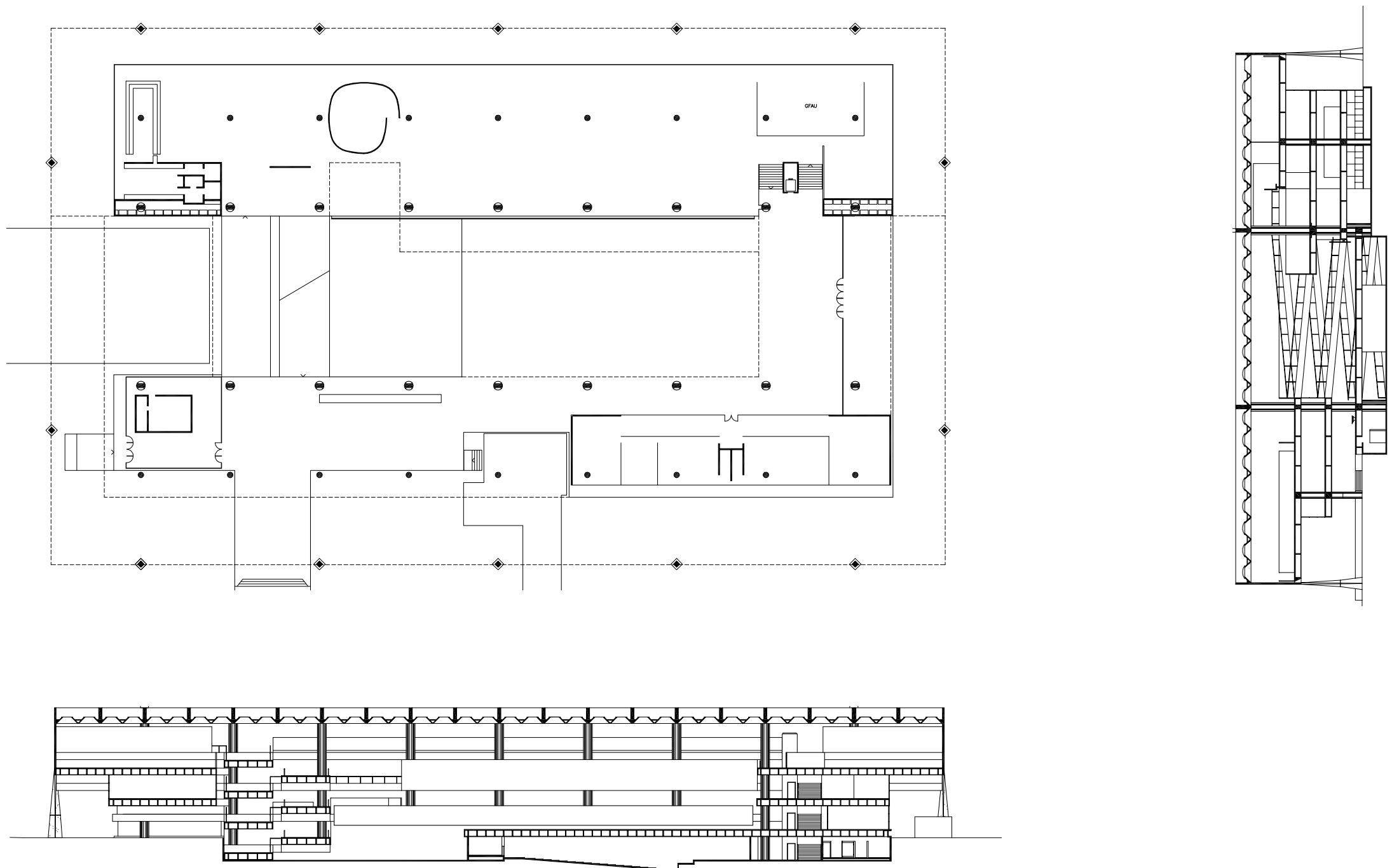



\section{CONSIDERAÇÕES FINAIS}

"Hemos dicho que el aula se puede construir superponiendo un techo o un pórtico a un recinto. Pero si hablamos ahora de la combinación de los tres elementos tomados de dos em dos las relaciones posibles se hacen más numerosas. Es posible construir un pórtico dentro de un aula, un aula bajo un pórtico y un aula sobre un pórtico. 0 un aula dentro de un recinto y un recinto dentro de un aula. Un pórtico o más dentro de un recinto y también por fuera de él, etc. La arquitectura, como un juego, donde el aspecto sintáctico es lo más relevante, se nos presenta así como una ars inventia o ars combinatoria. Las relaciones topológicas se multiplican como en un caleidoscopio al combinar los elementos." 143
Antonio Armesto Aria faz a análise combinatória dos elementos analíticos Aula Recnito e Pórtico - que formam o sistema analítico ARP que propõe - tomando-os dois a dois e inserindo as variáveis de estarem contidos/conterem ou sob/sobre uns aos outros. Seu discurso caminha na direção de elaborar uma matriz onde seria possível indicar todas as possibilidades de combinações para quaisquer dois dos três elementos-espaço.

Uma consideração possível sobre essa dissertação é a seguinte: partindo de uma fração da obra arquitetônica de João B. Vilanova Artigas talvez tenhamos podido preencher muitos dos quadros da matriz hipotética formada pelas combinações de elementos sugeridas. Chega a ser admirável o fato de termos nos deparado com um repertório em arquitetura tão amplo, variado e cheio de experimentações em composição, em escala e hierarquia, Artigas levou a arte inventiva e combinatória da arquitetura a sua condição mais plena, explorando, majestuosamente, muitas das infinitas possibilidades que nos dá o caleidoscópio. 
145. CERDÀ i Sunyer, Ildefons, Teoría general de la urbanización, Imprenta Española, Madri, 1867." op.cit., pg.509.

A dissertação poderia ter materializado essa matriz combinatória, expandindo o uso das tabelas analíticas propostas, poderia se buscar maior número de referências fora da obra de Artigas, o que abriria sem dúvida um horizonte interessante; ou aprofundado estudos sobre as arquiteturas clássica, romana, moura, ibérica ou ancestral. Poderia ainda ter sido feita de forma mais centrada na palavra, que pudesse prescindir de parte das imagens e desnhos, explorando melhor a prosa, por exemplo. Mas o que se buscou foi um caminho central, equilibrando um pouco das duas vertentes, equilibrando os memoriais e os desenhos, sem estabelecer nenhuma prevalência entre eles, a não ser a complementareidade.

Essas hipóteses ficam então ilustradas como caminhos possíveis de serem traçados, com um método similar ou complementar (ou outro método), aplicado na obra de outro(a) arquiteto(a) ou em um conjunto de obras de múltipla autoria ou autoria coletiva, enfim, essa dissertação se inclui no conjunto de inúmeros estudos já realizados sobre a produção arquitetônica de João Batista Vilanova Artigas aportando de forma singela mais um degrau na consolidação de seu importante legado.

Retomo o discurso de Idelfons Cerdà em sua empenhada busca pela raiz etimológica do urbano. O engenheiro urbanista traça - não tão expedita e resumidamente quanto procuro transmitir aqui, mas de forma precisa e até sedutora - um percurso histórico e filológico convincente, ao longo do qual parte de urbe, passa por uri/uria (cidade) para chegar a ur (casa, côncavo, cavidade), todas raízes celtas ${ }^{144}$ que além de estarem em urbe também compartilham raiz com urbum, que o autor prova ser 


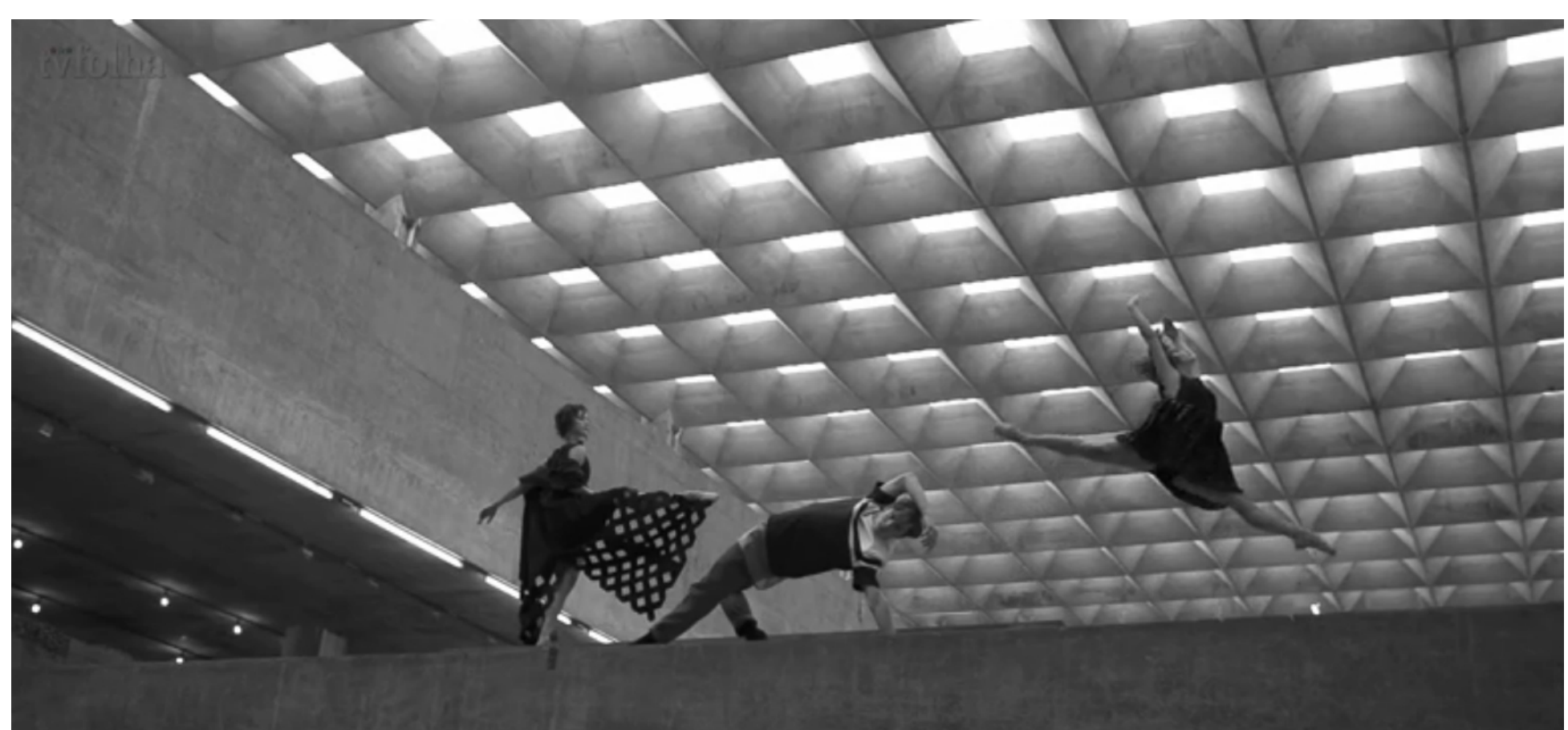

118 frame de "São Paulo Cia. de Dança - "Ensaio em marcos arquitetônicos de SP" - 2'17"

http://tvuol.uol.com.br/video/sao-paulo-cia-de-danca-estrela-ensaio-em-marcos-arquitetonicos-de-sp-04024D183162D4995326, acessado em 24 jan 2015

análogo ao arar, hurgar, então nos conta efusivamente:

"Hermosa, hermosísima es la consecuencia (...) de este (...) importantísimo descubrimiento (...) La misma palabra que indica el primer esfuerzo hecho para cultivar la tierra, es la que nos expresa también (...) el primer esfuerzo hecho para dar á la humanidade albergue. (...) lo mismo significa abrir la tierra para cultivarla, que abrirla para habitarla.” 145

\section{Para concluir}

"En una palabra, urbanizar significa arar, cultivar, y cultivar es el origen y la cusa mas fecunda de civilización."

Concluo convencido de que o trajeto proposto para a dissertação - que partiu das casas, passou por seus tipos e modelos, por sua mudança de escala e relação com a cidade - foi uma maneira de arar, cultivar a casa e todo o universo que a rodeia, confirmando assim o estreito vínculo entre a casa e a cultura. 

7. FICHAS DAS OBRAS 



\section{VILANOVA ARTIGAS.}

CASAS 1942-1968 


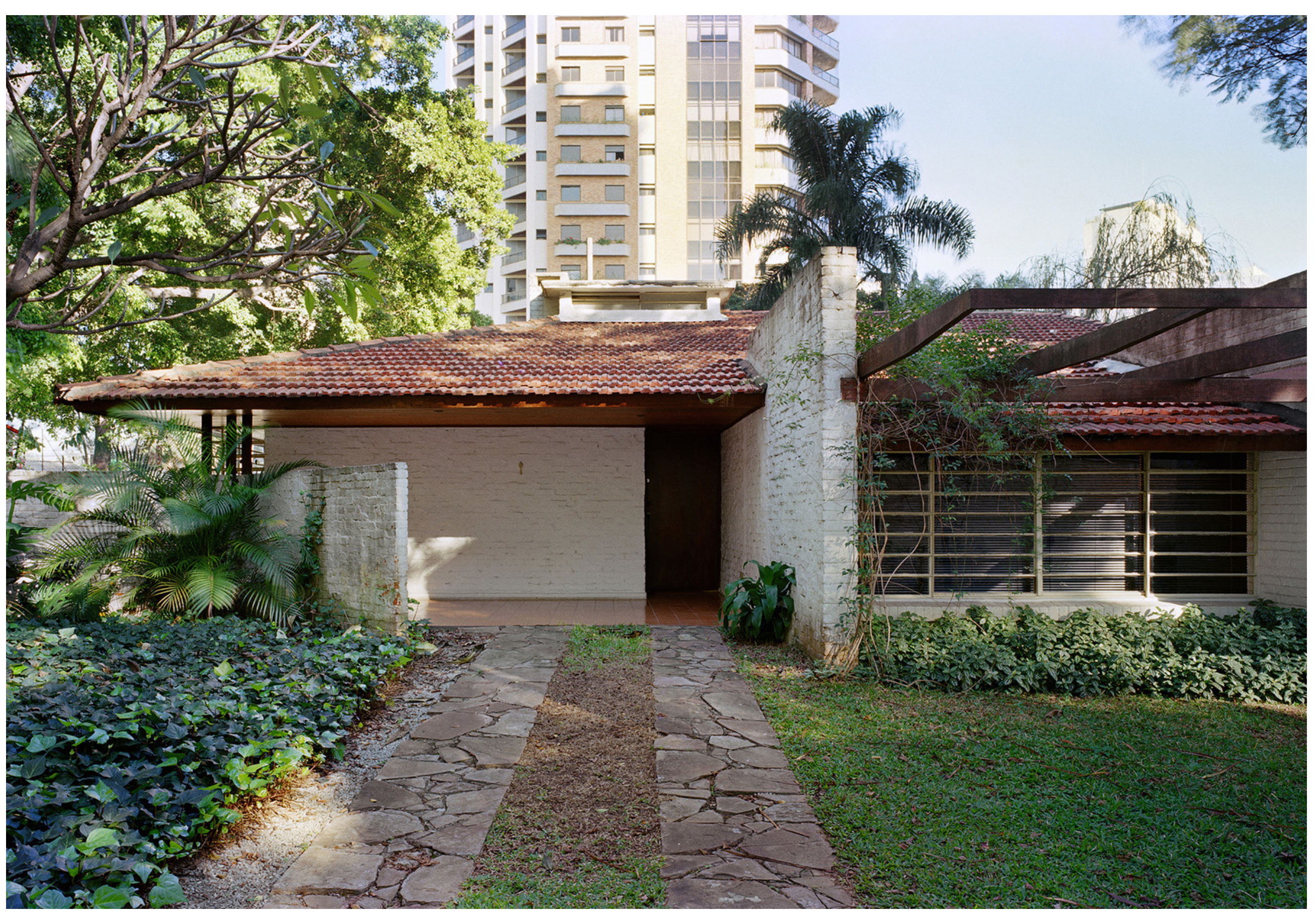




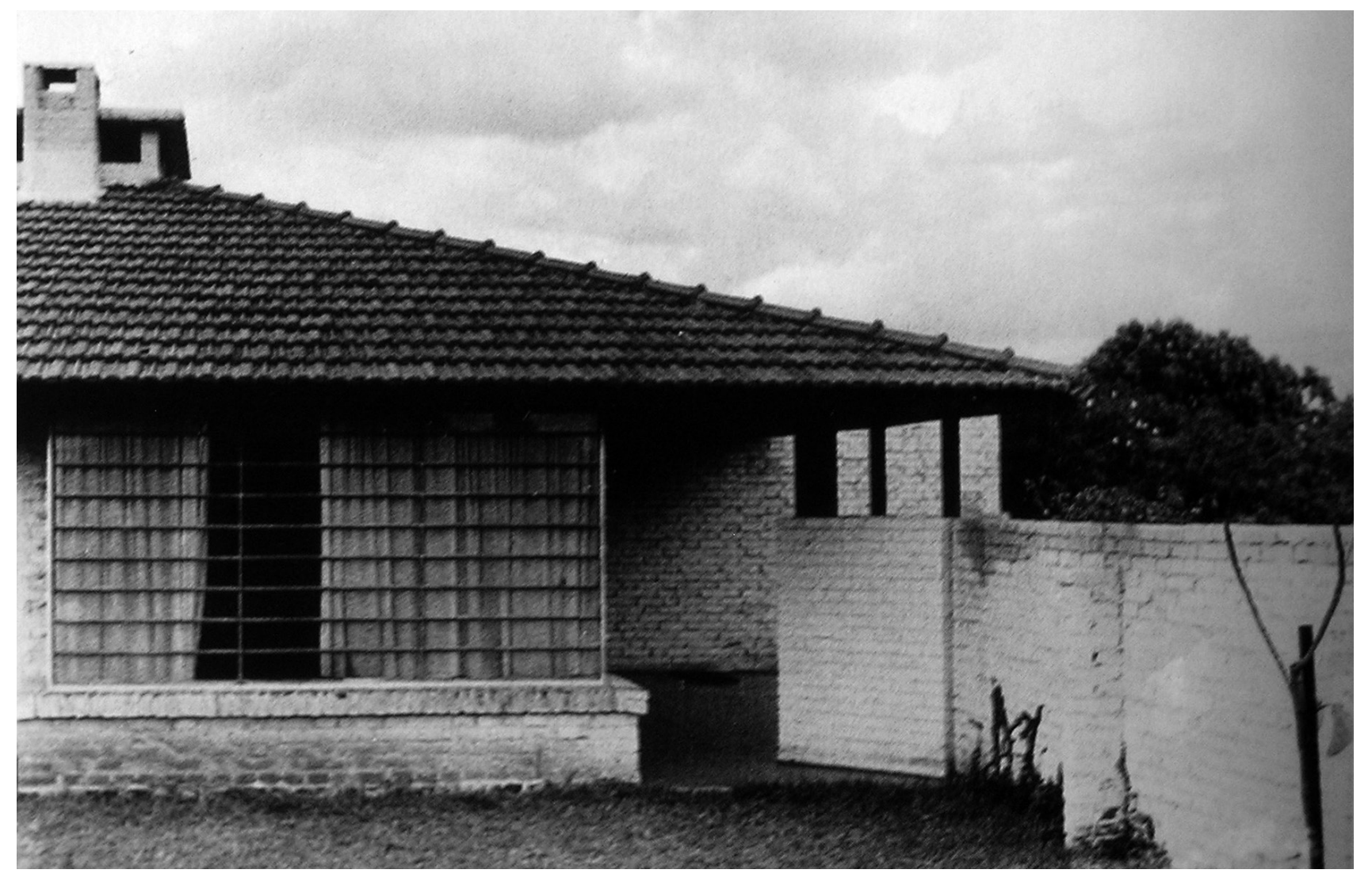

'Casinha' 1942

endereço

Rua Barão Jaceguai, 1149 esquina com a Rua de João Souza Dias São Paulo - SP

projeto Vilanova Artigas

cliente o próprio arquiteto

características casa térrea

técnicas e materiais alvenaria de tijolos pintada cobertura em telha cerâmica estrutura do telhado em madeira
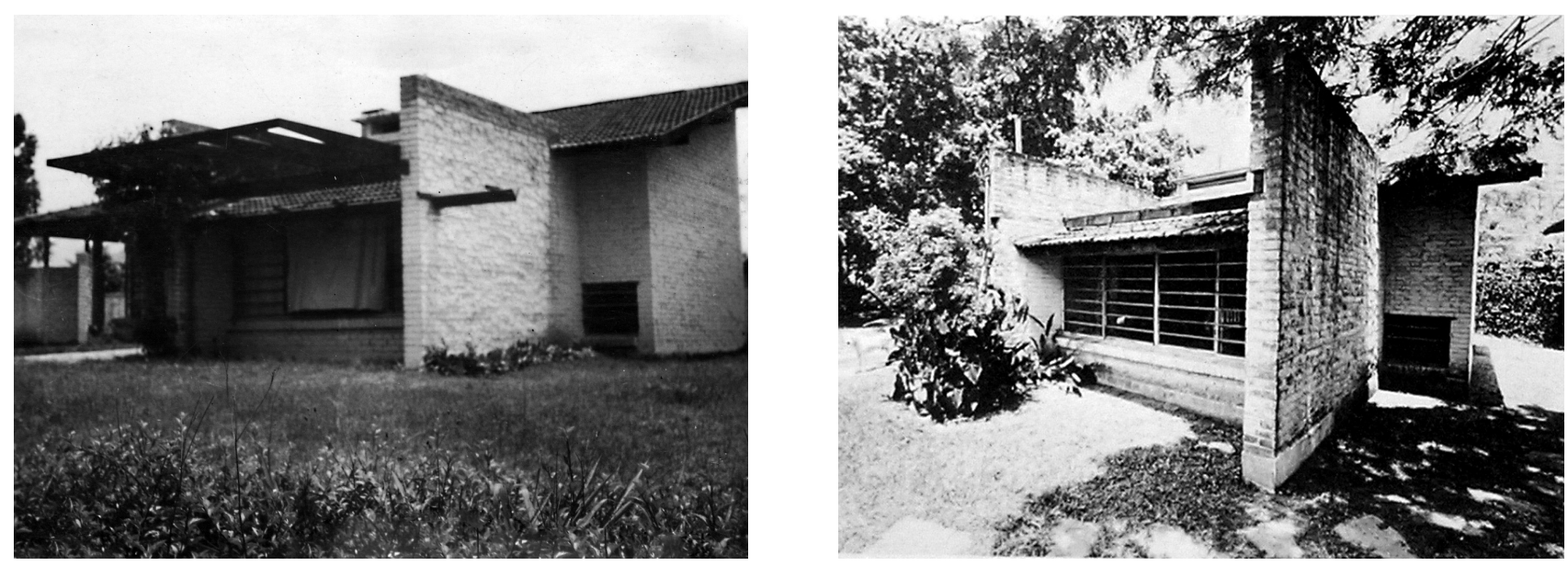

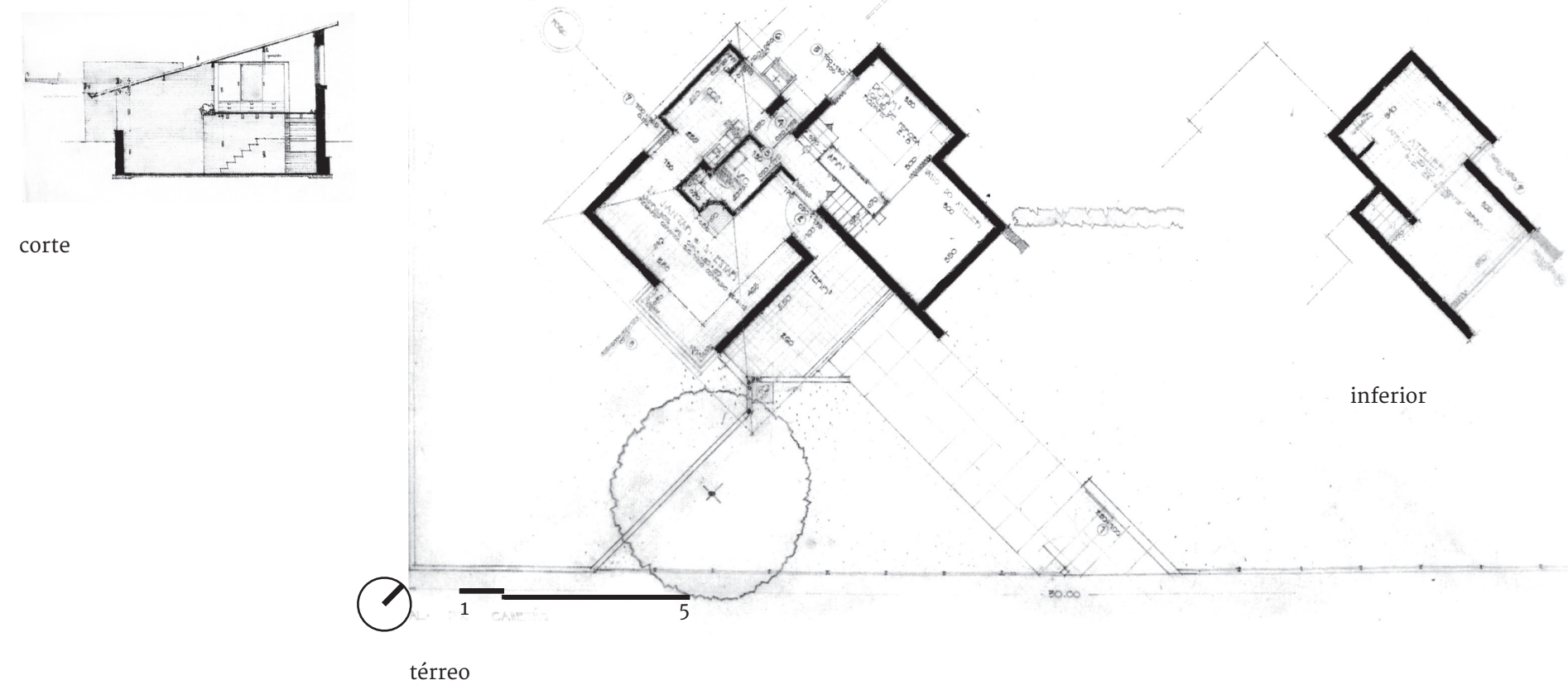

inferior

térreo
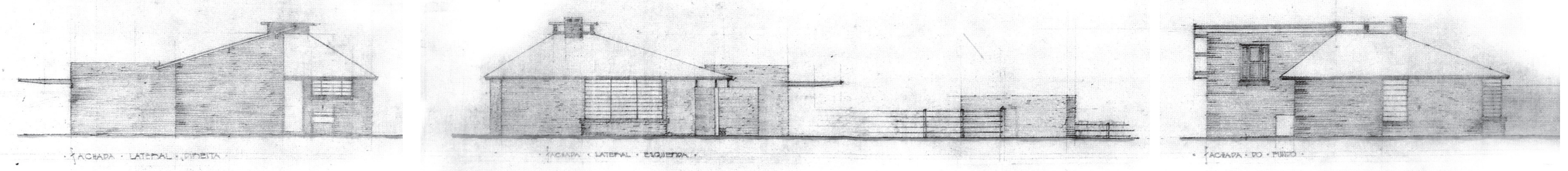

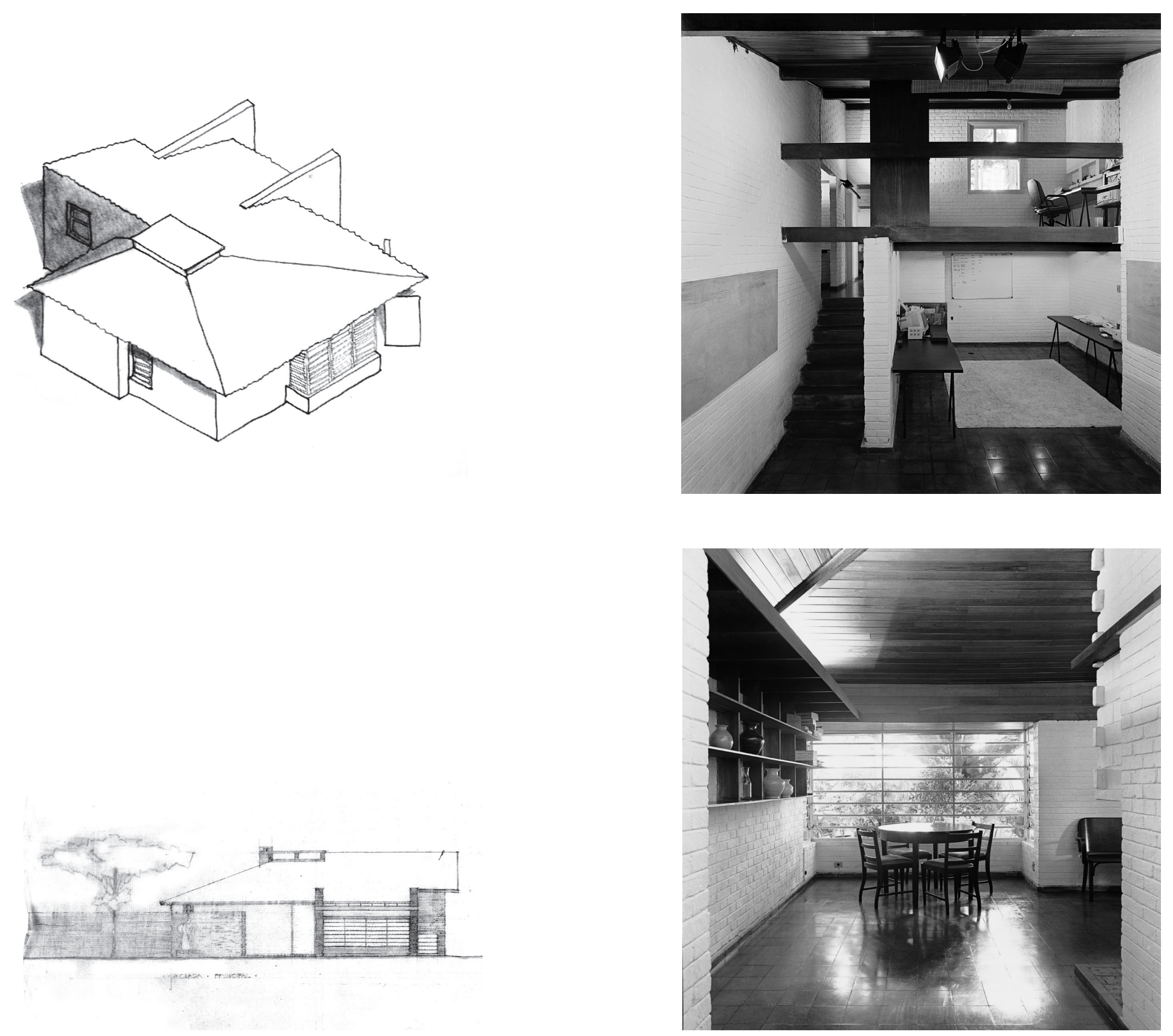

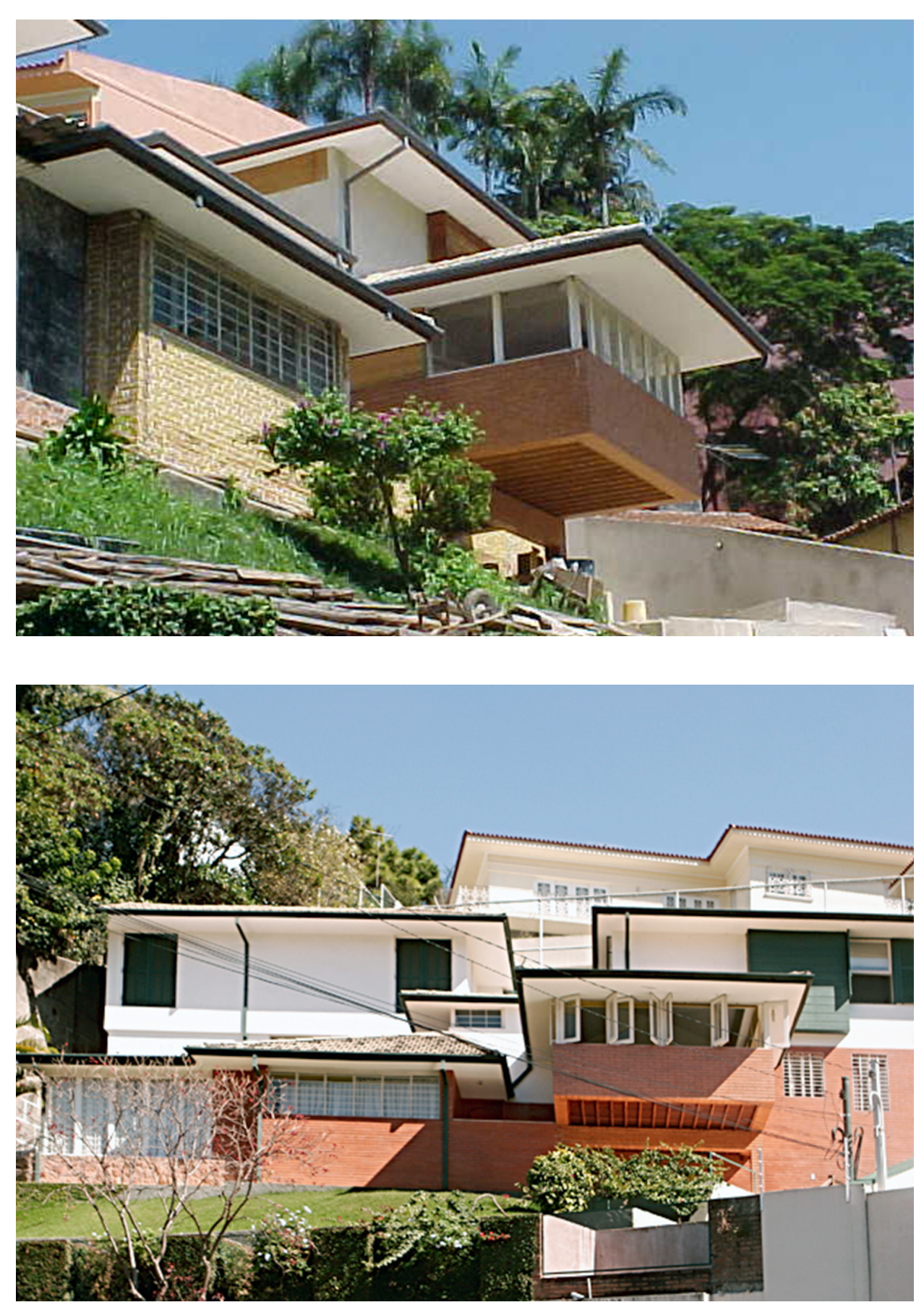


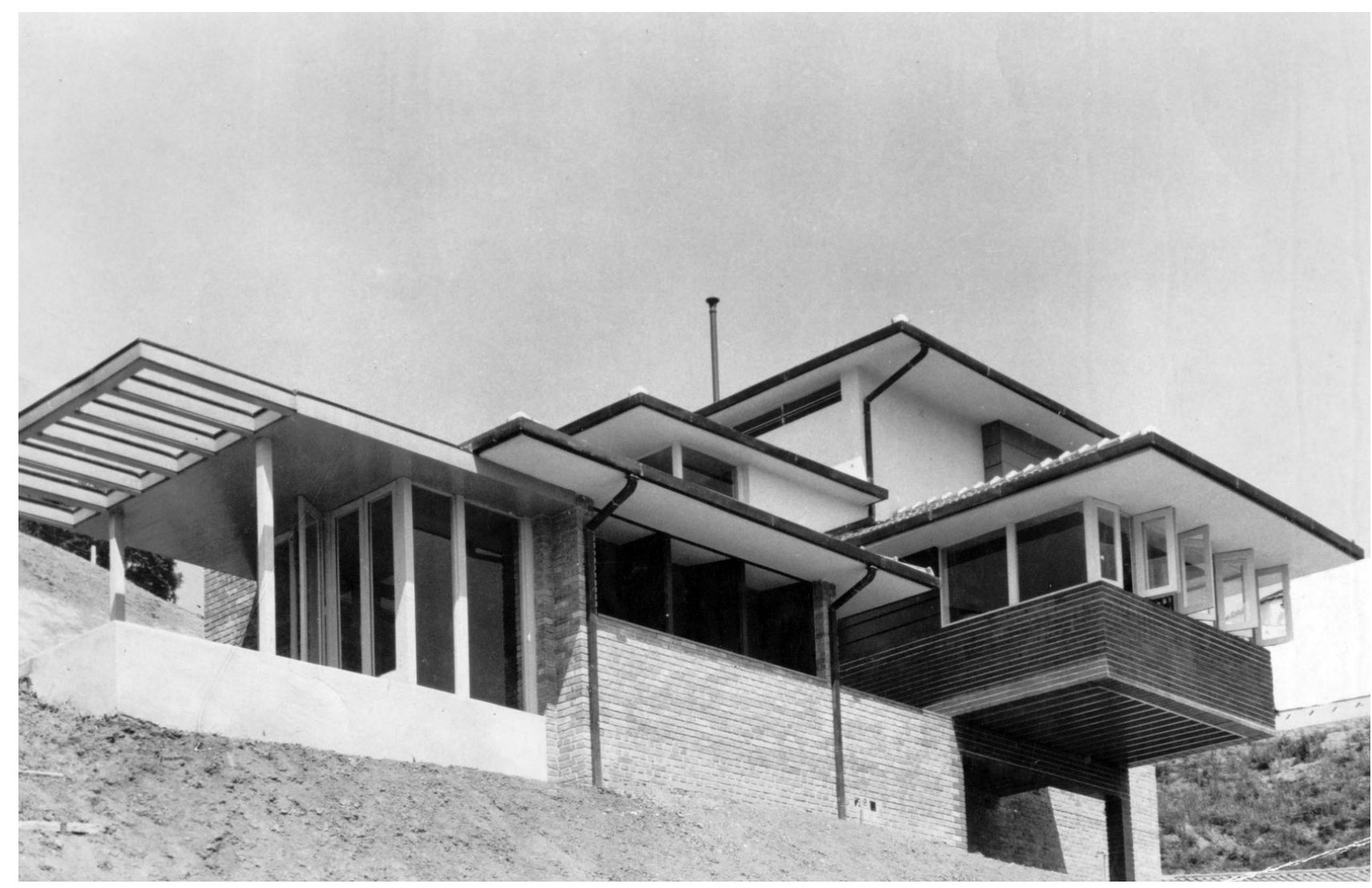

Rio Branco

endereço

Rua Heitor de Morais, 120

Pacaembú, São Paulo - SP

projeto

Vilanova Artigas

cliente

Rio Branco Paranhos

caractrísticas casa em meios níveis

técnicas e materiais estrutura portante em concreto estrutura do telhado em madeira
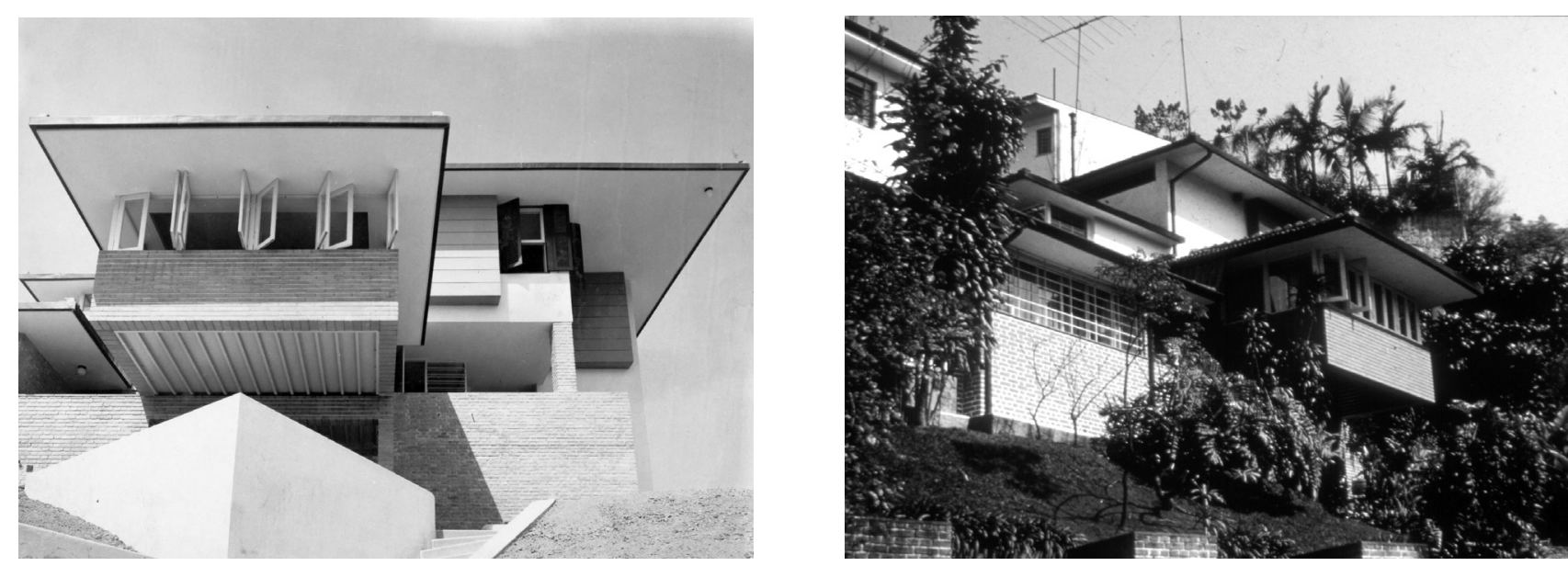

$241 \mathrm{~m}^{2}$ 

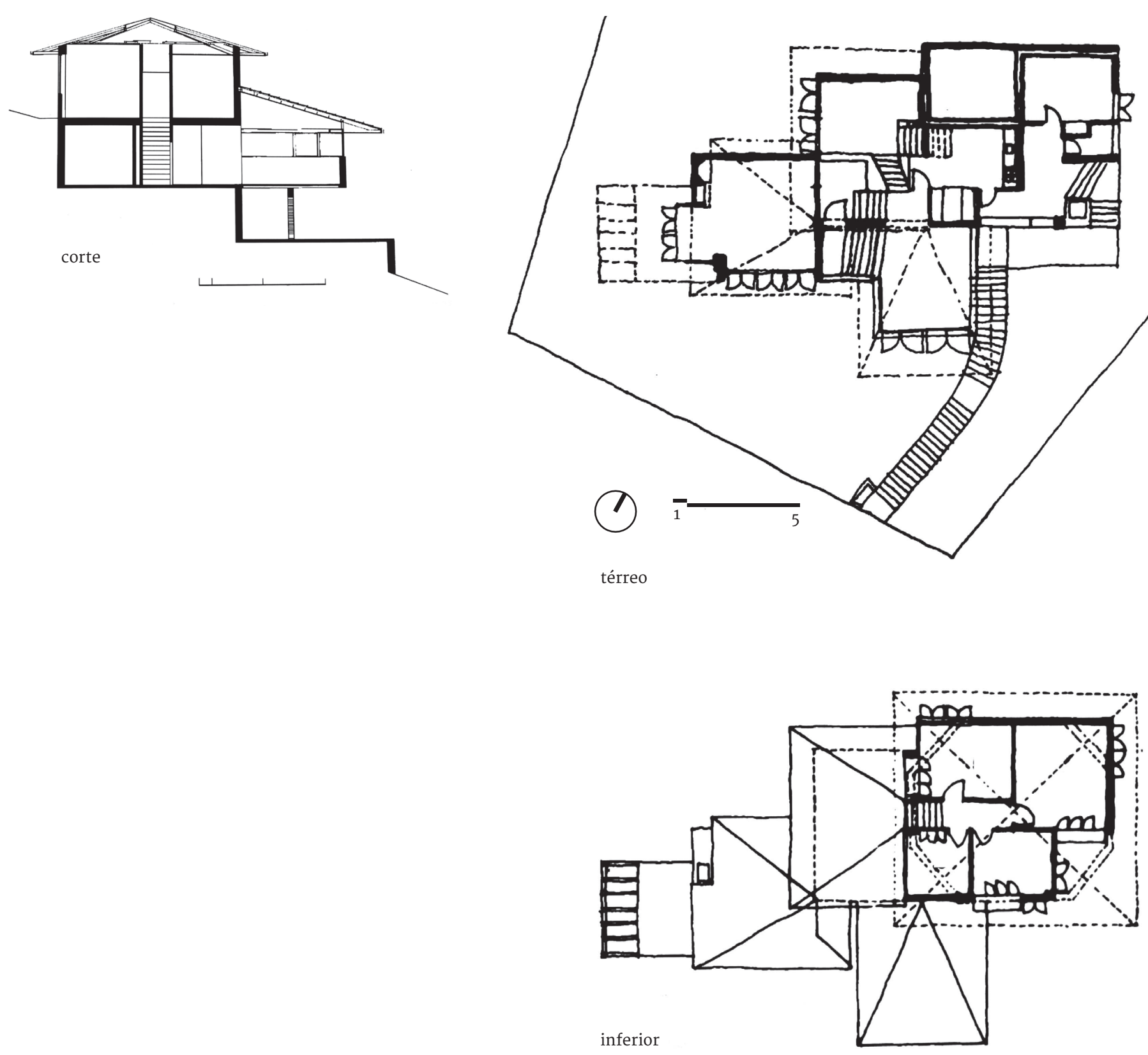


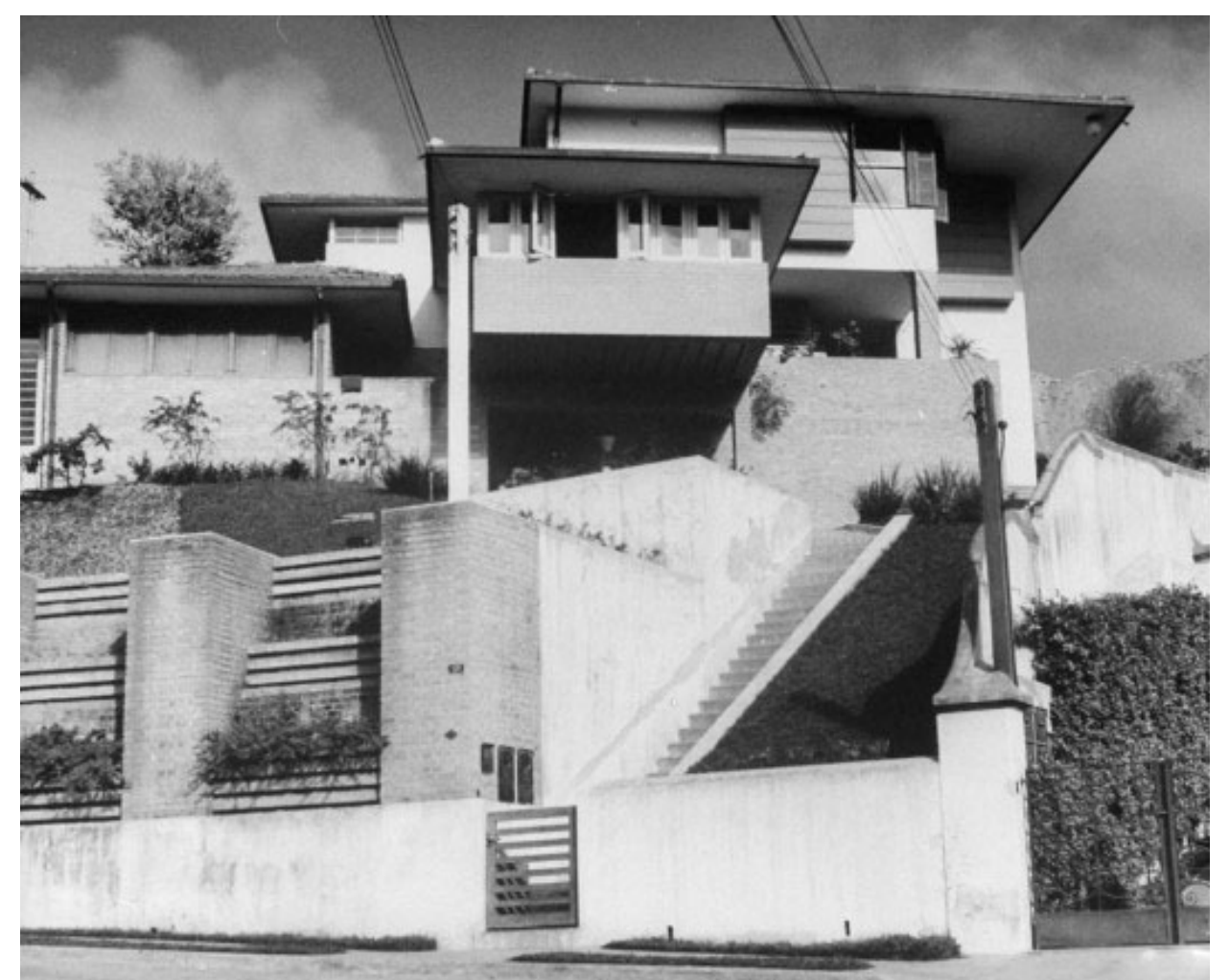




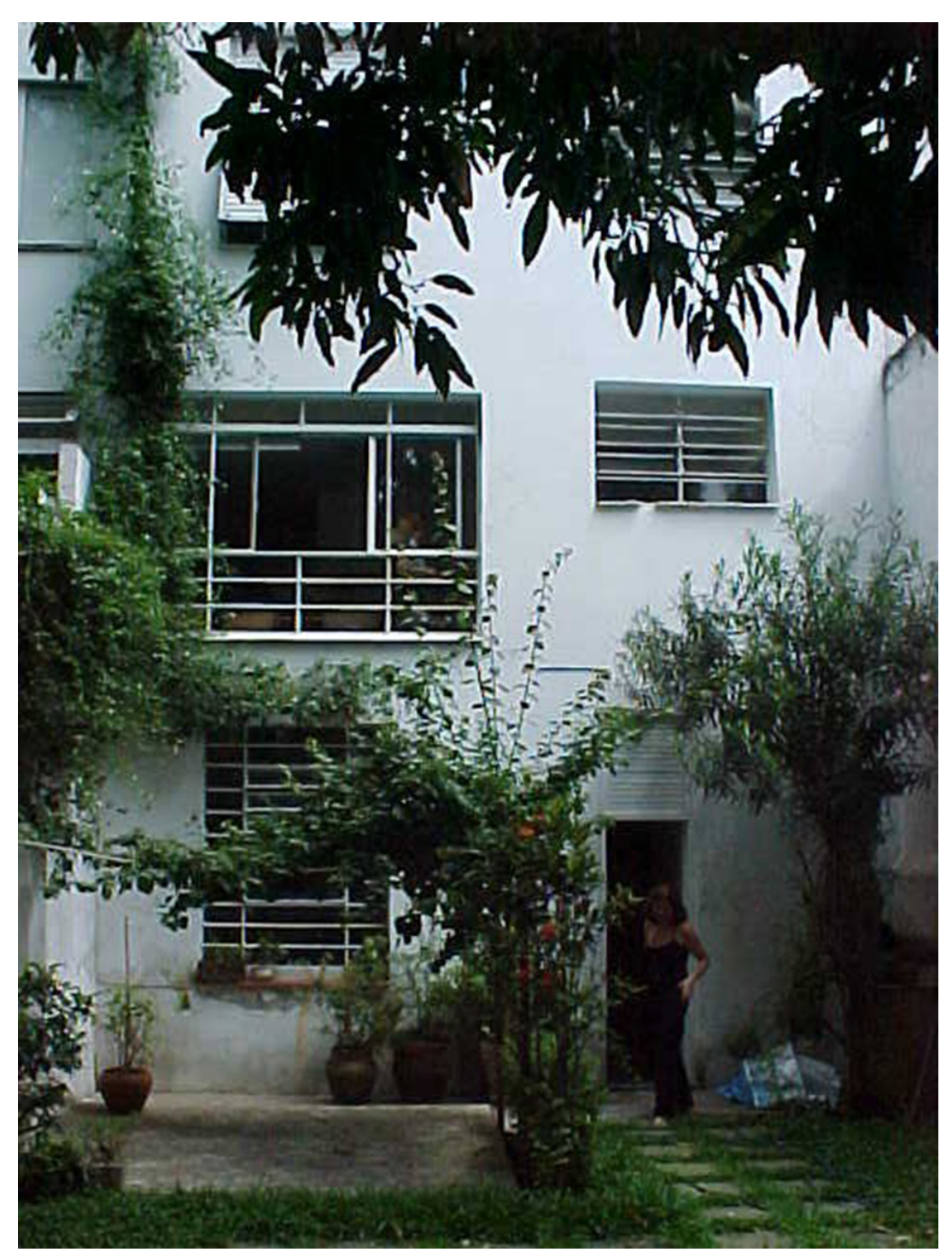




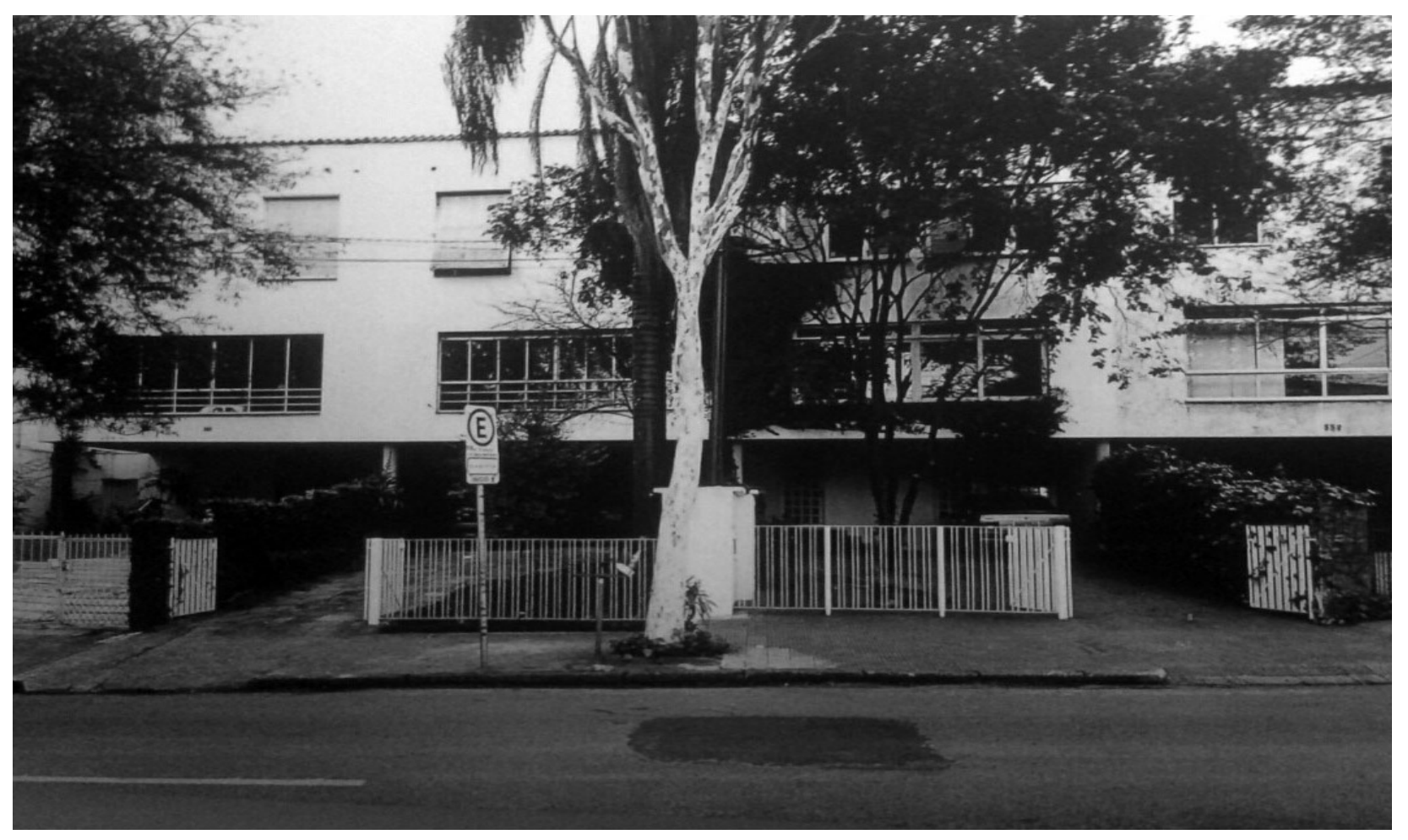

4 Casas Jaime Porchat 1944

endereço

Rua Sampaio Vidal, 558-570 Jardim Paulistano, São Paulo-SP

projeto

Vilanova Artigas

cliente

Jaime Porchat Queiroz Mattoso

caractrísticas

quatro sobrados emparelhados

técnicas e materiais

estrutura em concreto armado

vedos em alvenaria revestida
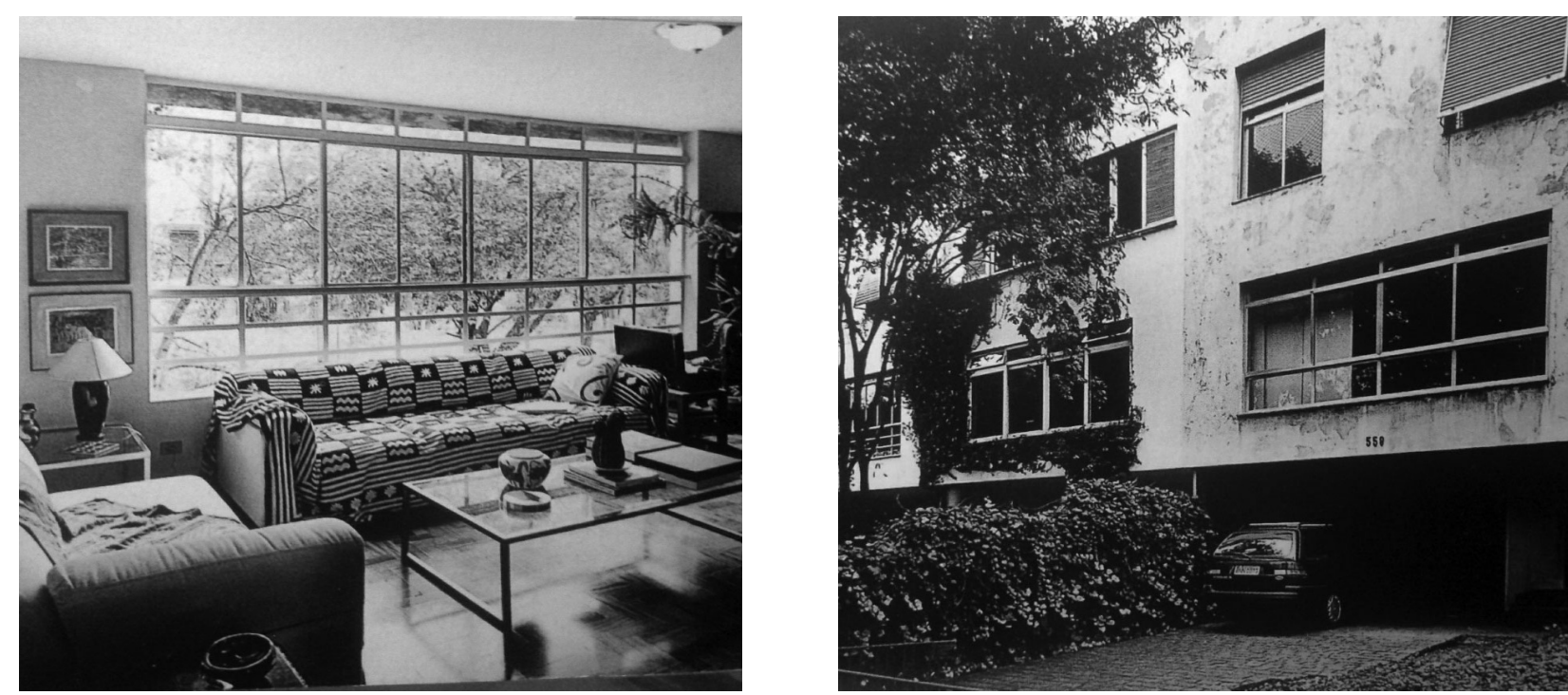

cobertura em telhas de fibro-cimento

área

por unidade $156 \mathrm{~m}^{2}$ total $624 \mathrm{~m}^{2}$ 


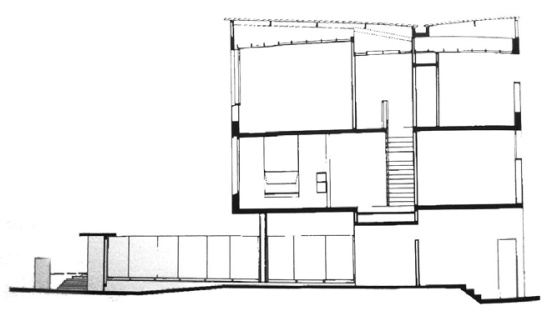

corte

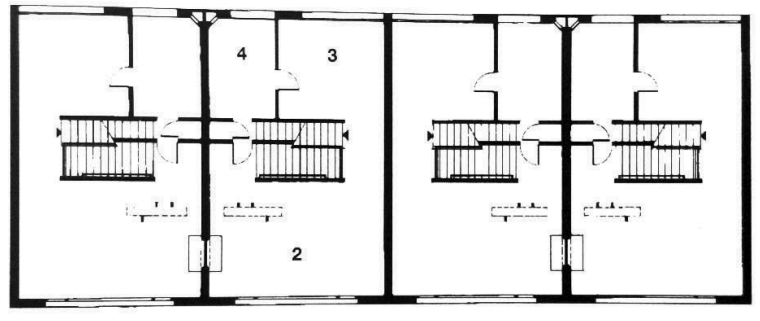

superior

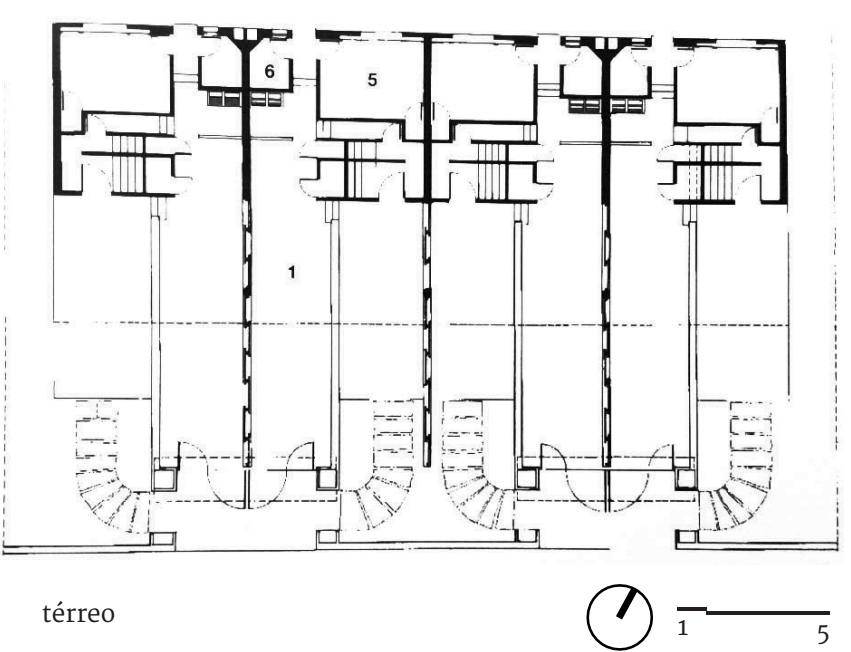



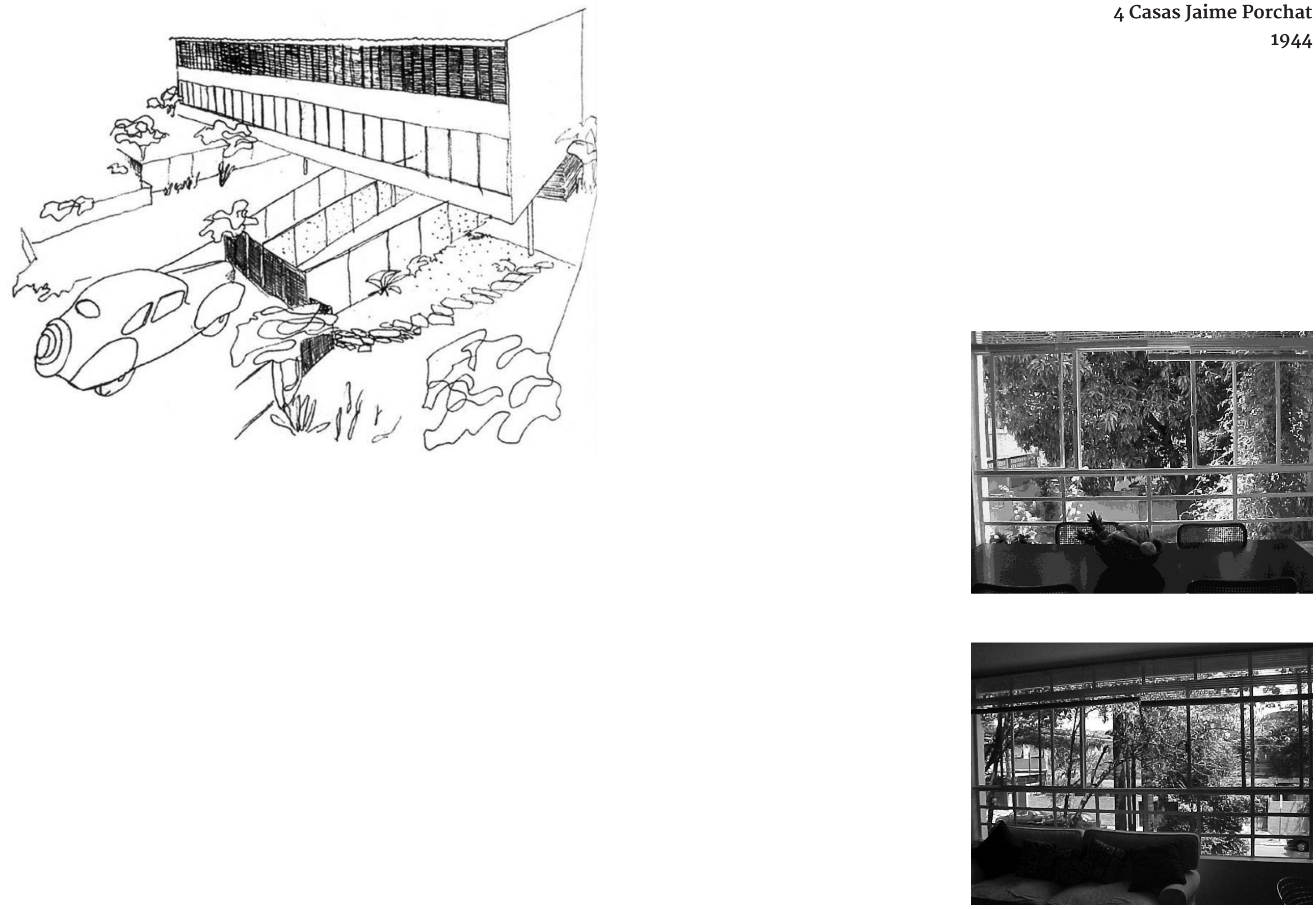
Casa d'Estefani

1950

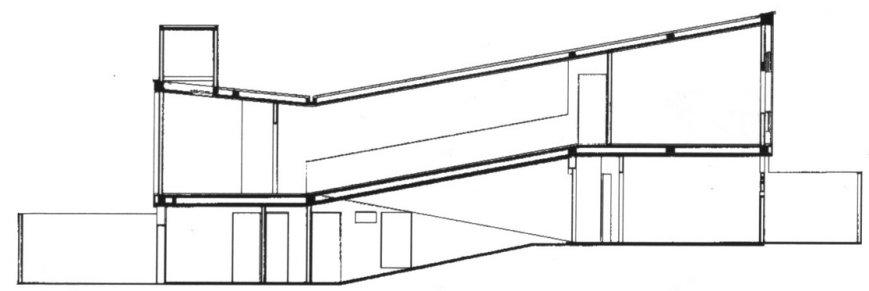

corte
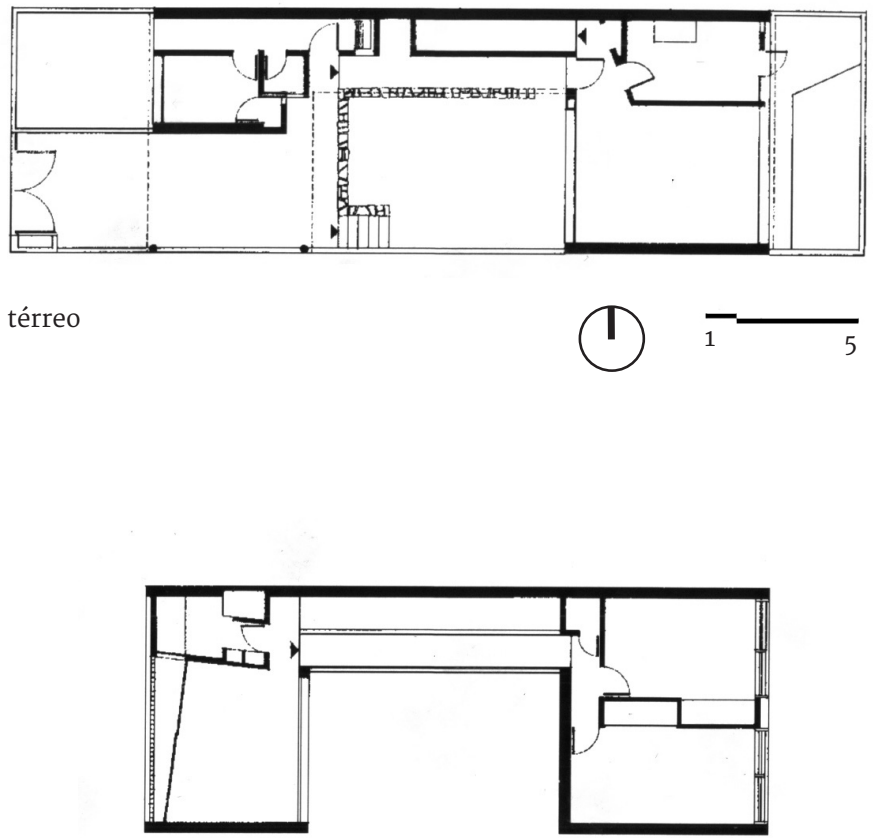

inferior 


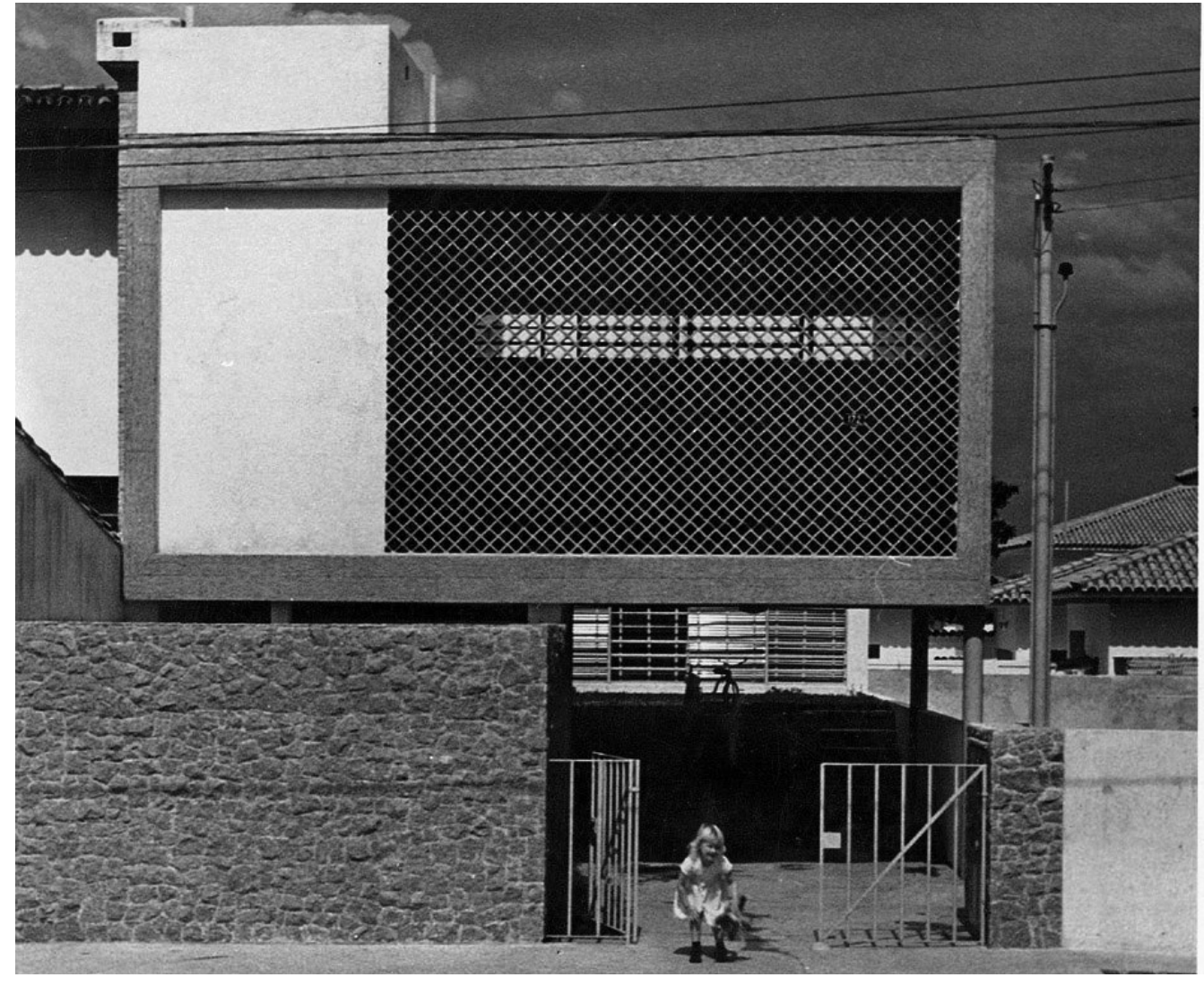

Casa d'Estefani 1950

endereço

Rua José de Magalhães, 176

Vila Clementino, São Paulo-SP

projeto

Vilanova Artigas

cliente

Geraldo De Stefani

caractrísticas

casa em quaro meios-níveis

técnicas e materiais

estrutura em concreto armado

vedos em alvenaria revestida

cobertura em telhas de fibro-cimento

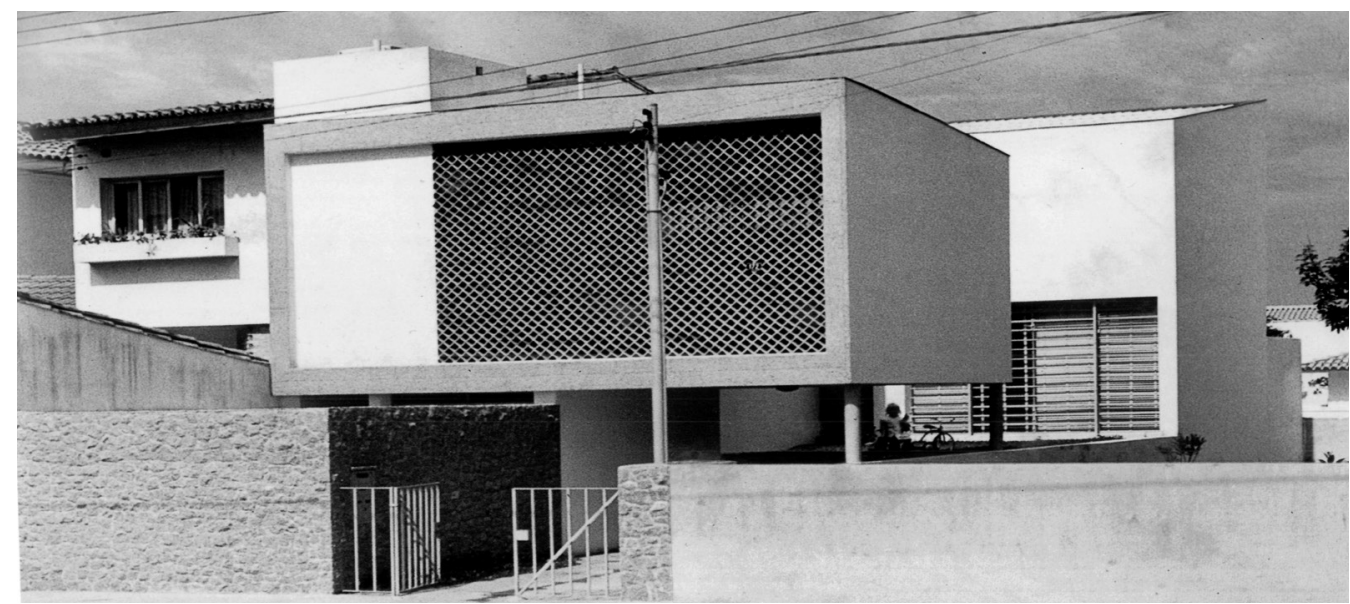




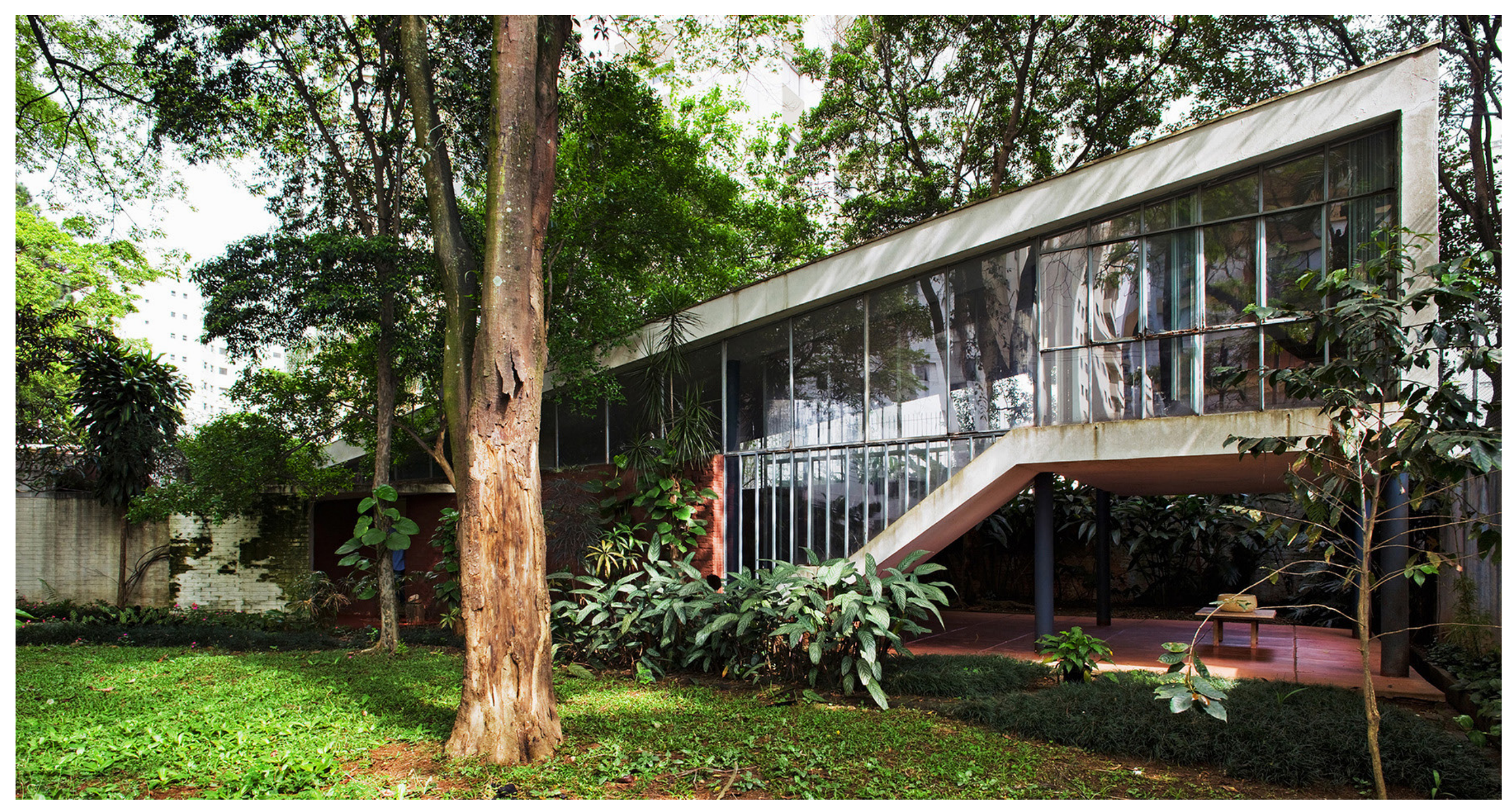




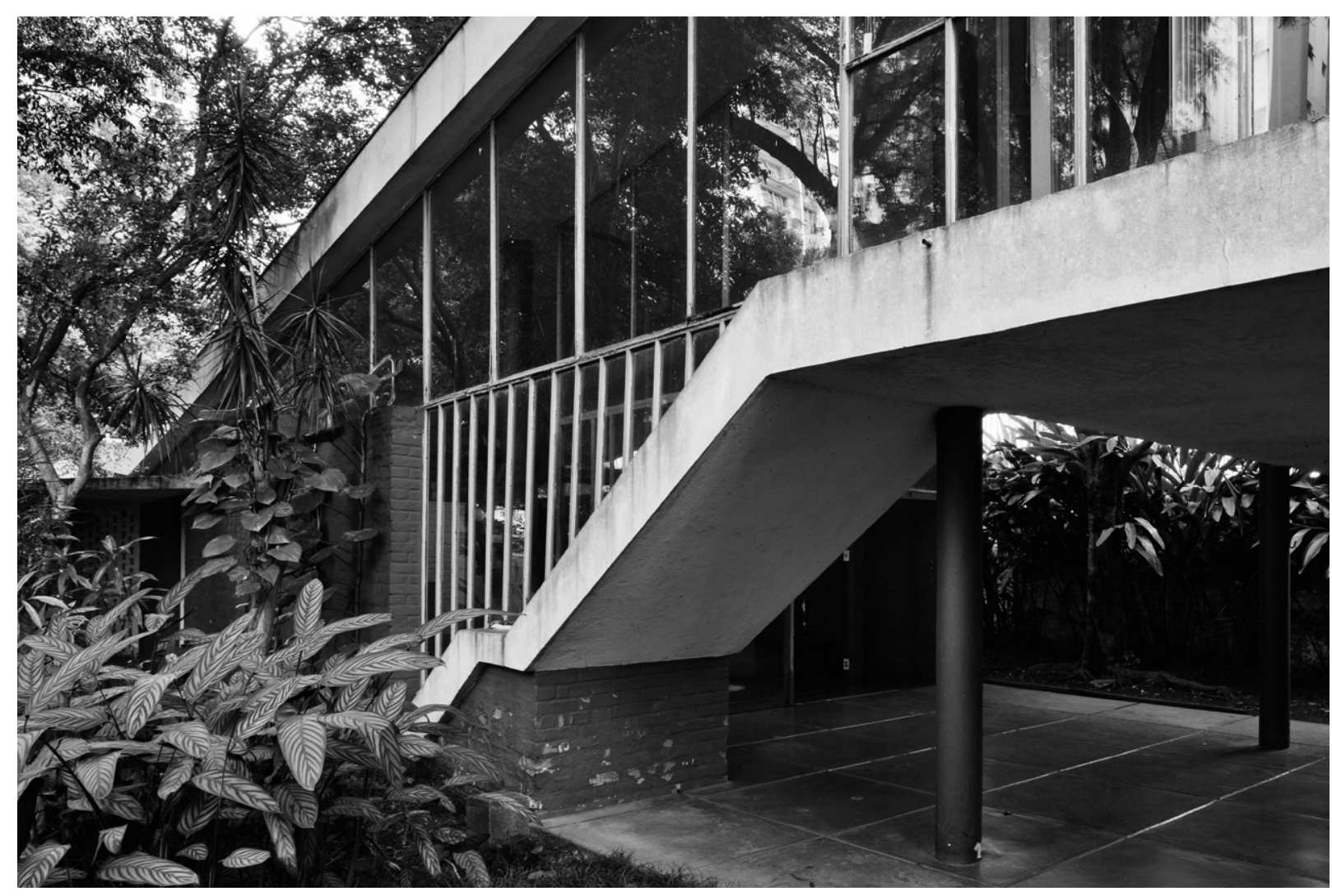

Casa do Arquiteto 1950

endereço

Rua Barão Jaceguai, 1151

Campo Belo, São Paulo - SP

projeto

Vilanova Artigas

cliente

o próprio arquiteto

caractrísticas

casa térrea com biblioteca elevada

técnicas e materiais

cobertura em laje de concreto armado fecahmentos em vidro

área
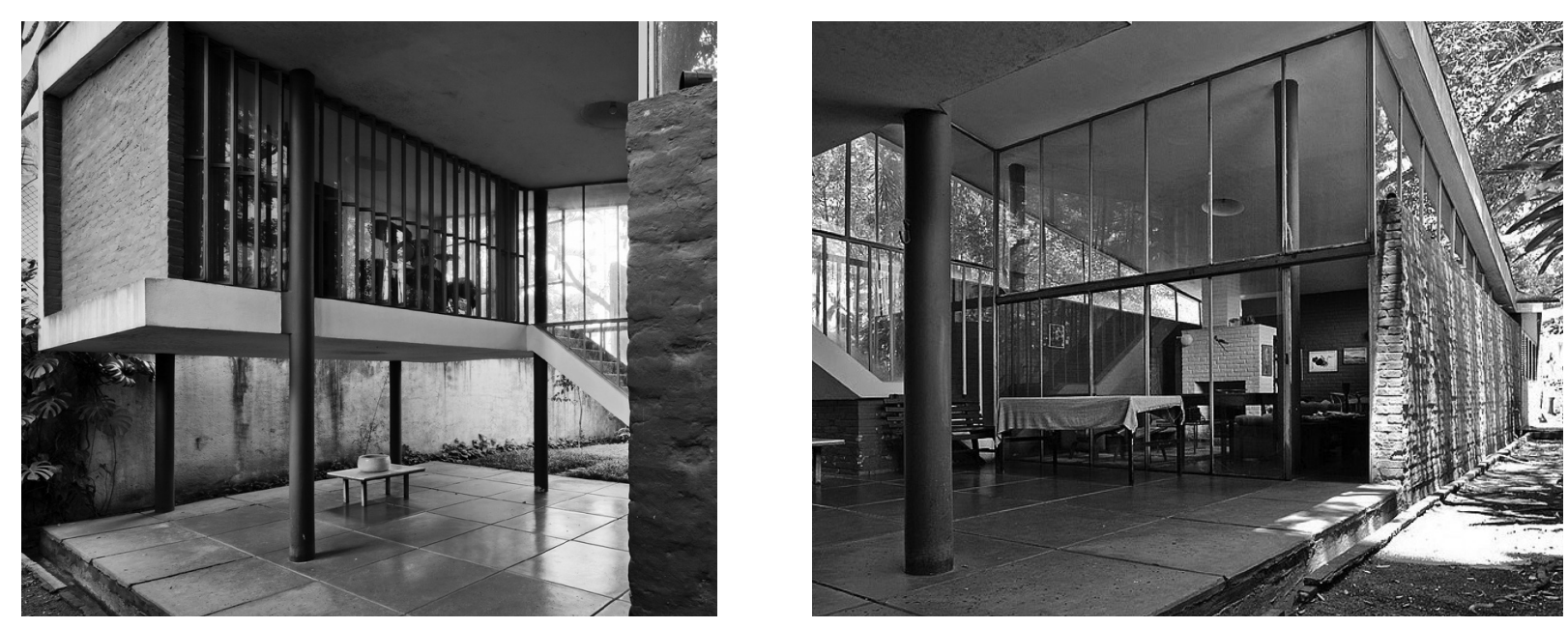

$223 \mathrm{~m}^{2}$ 

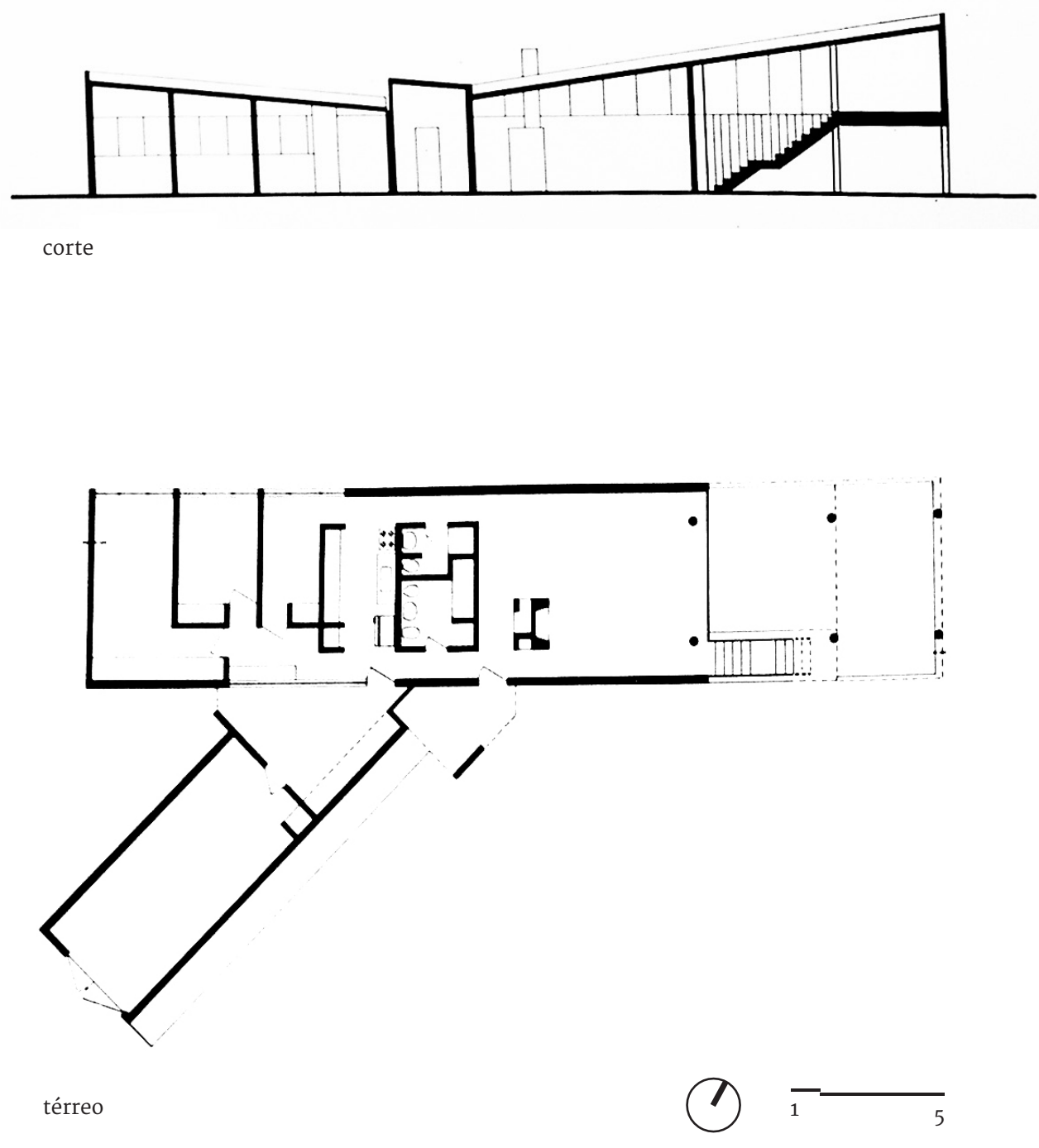

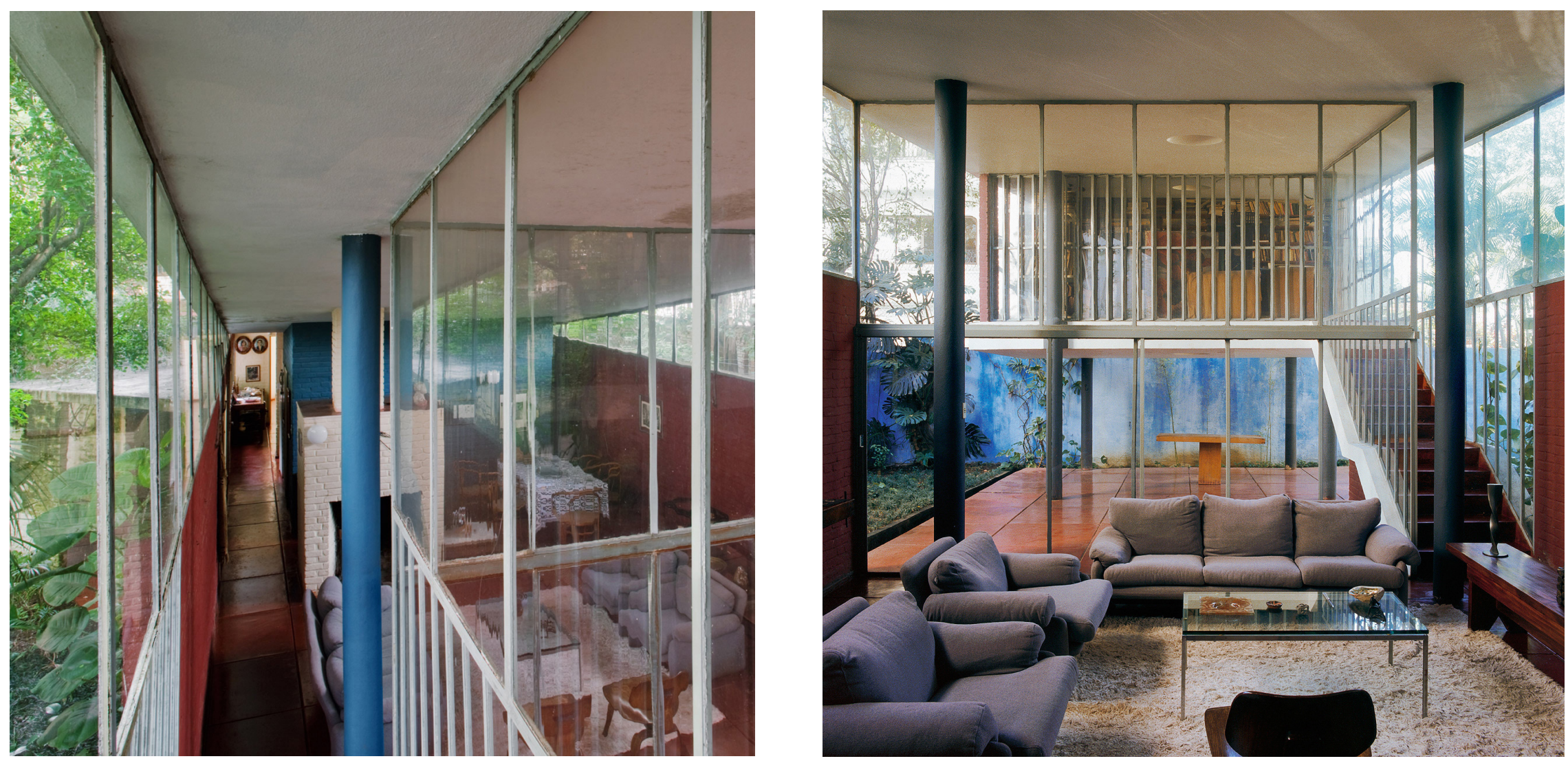


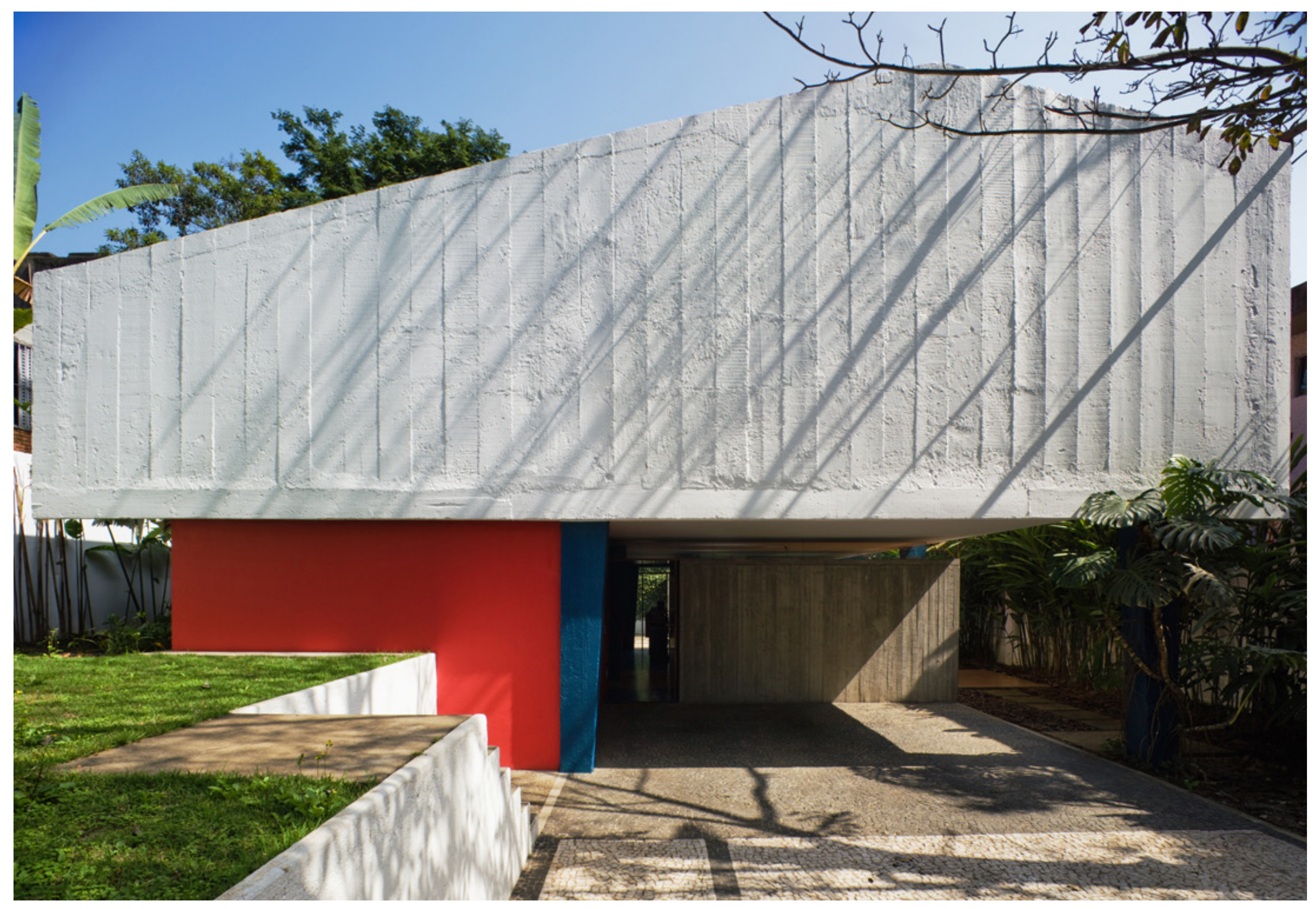




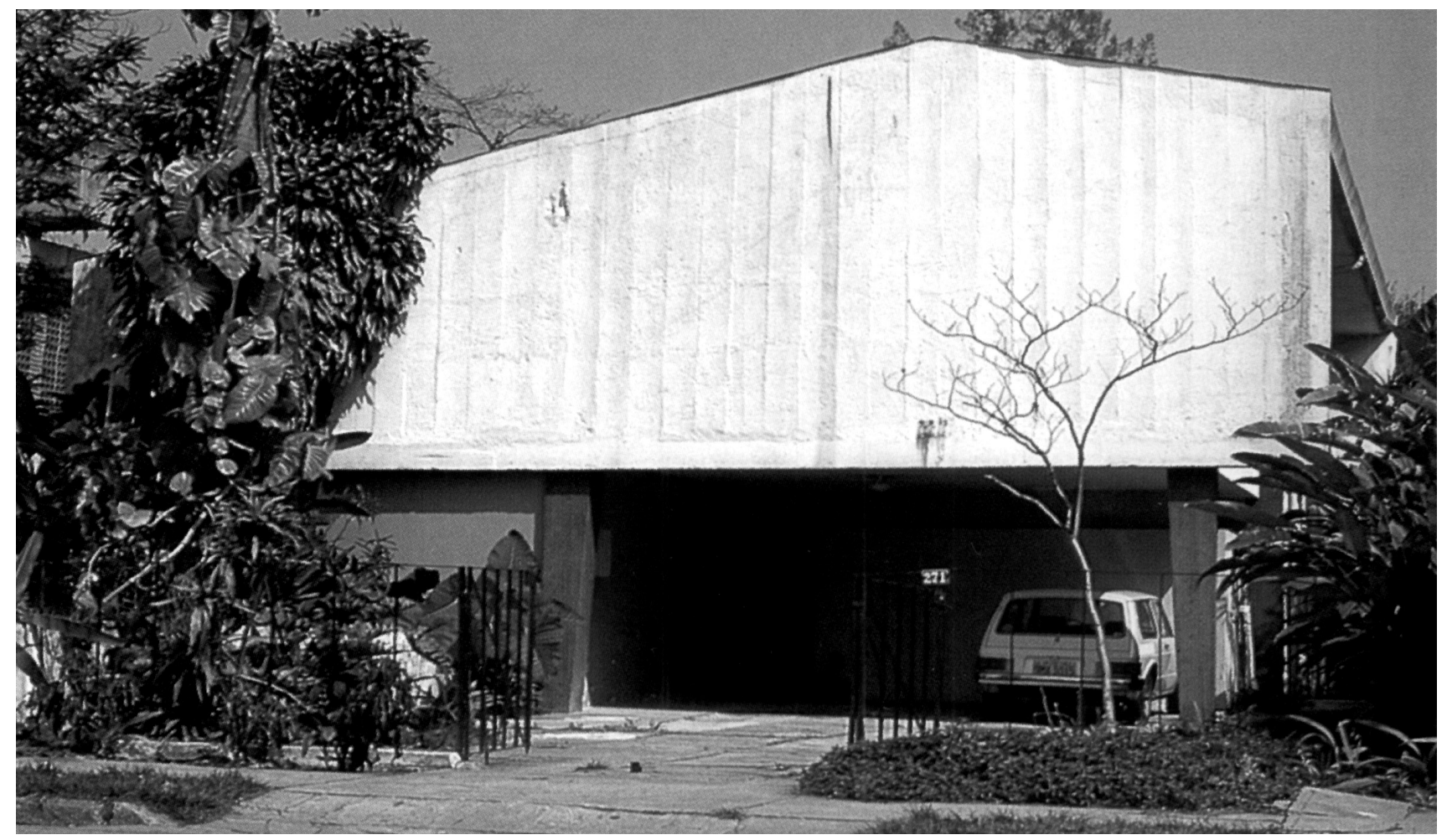

Casa Baeta
1956

endereço

Rua Gaspar Moreira, 271

Butantã, São Paulo - SP

projeto

Vilanova Artigas e Carlos Cascaldi Ângelo Bucci (MMBB) reforma 1996

cliente

Sebastião Baeta Henriques

caractrísticas casa em dois níveis

técnicas e materiais
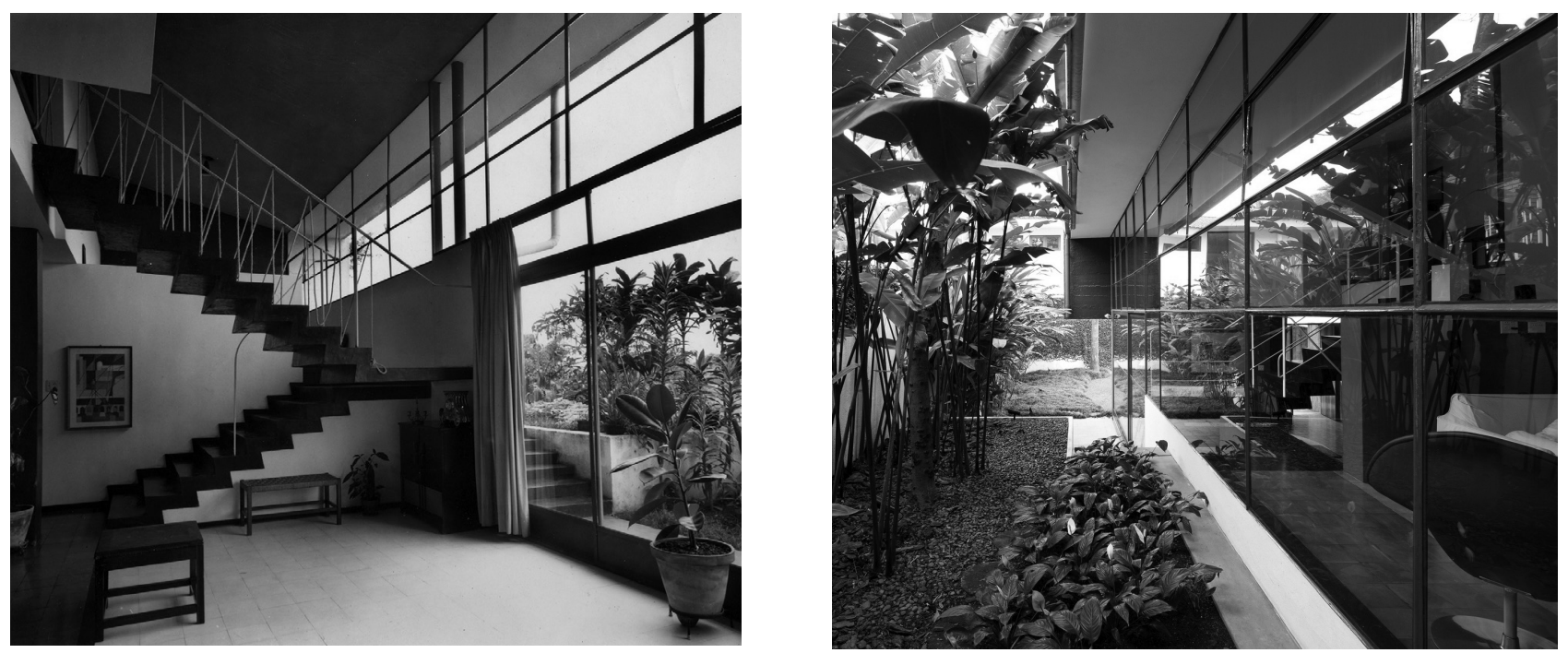

estrutura em concreto armado cobertura em telha cerâmica 


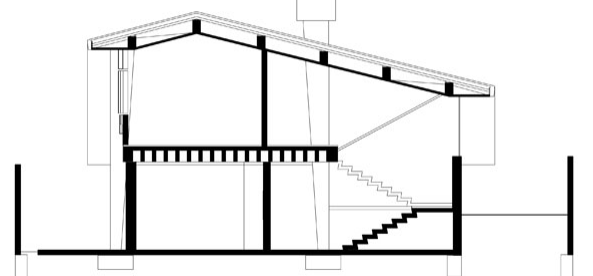

corte
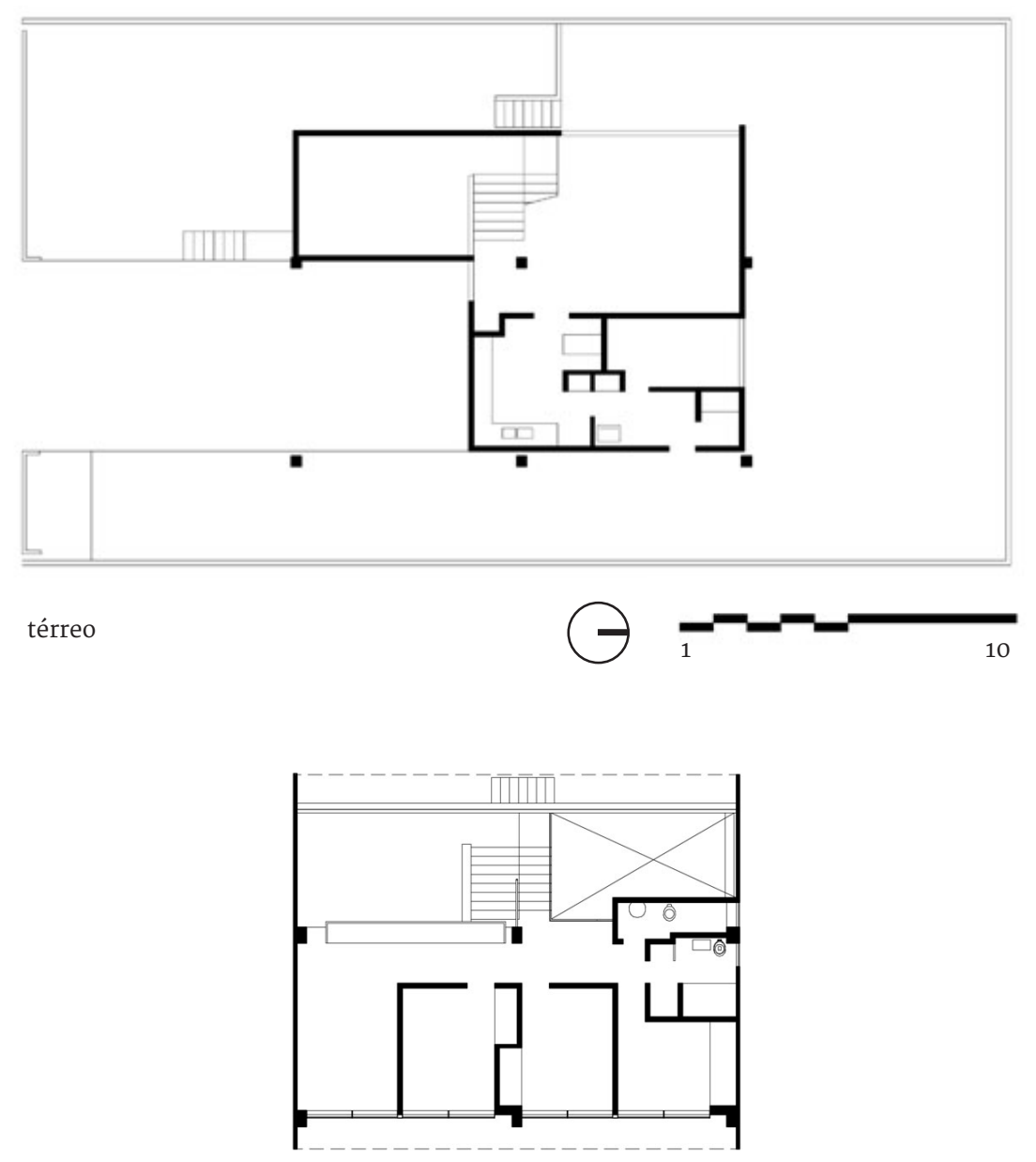

superior 

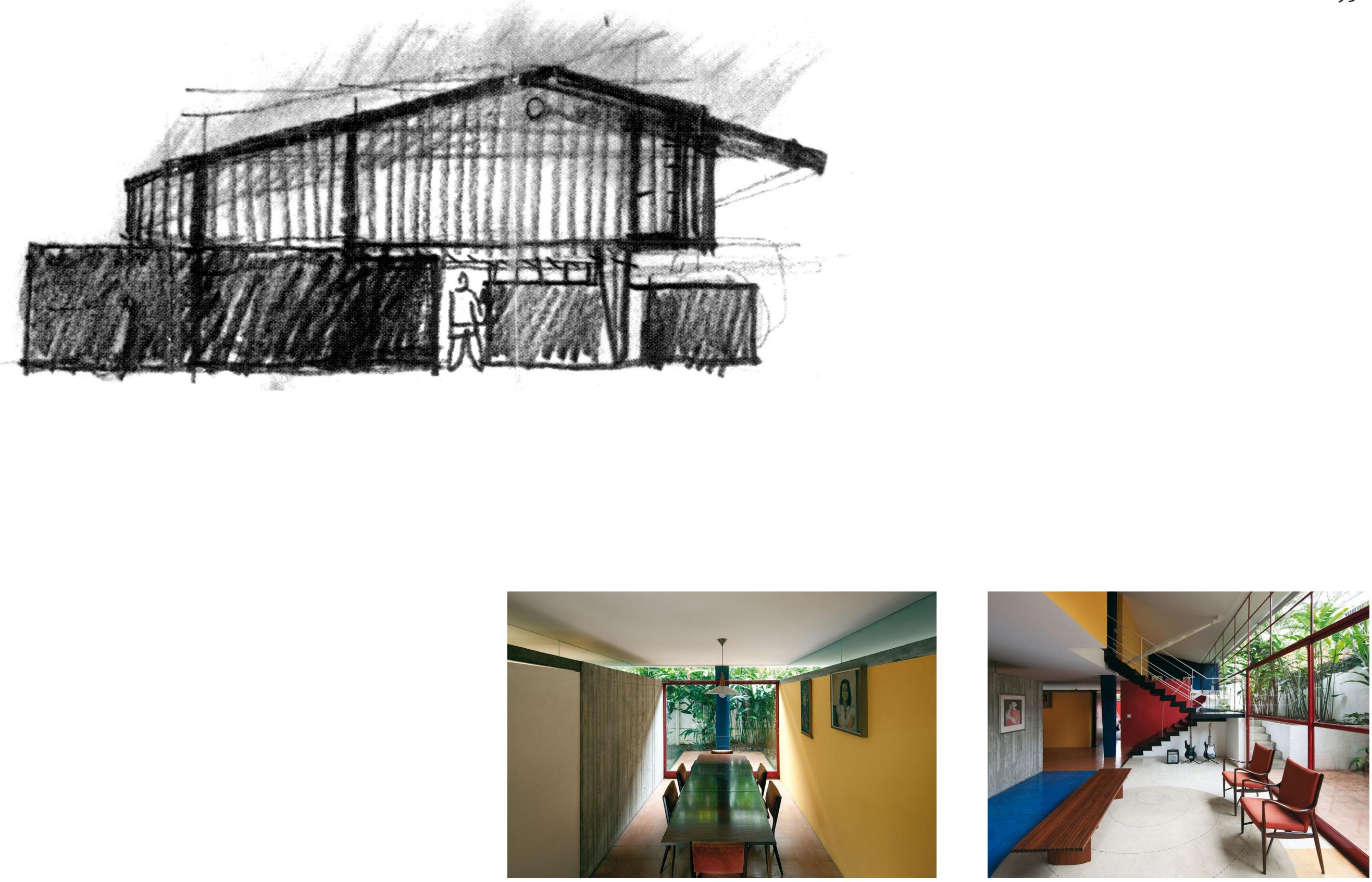


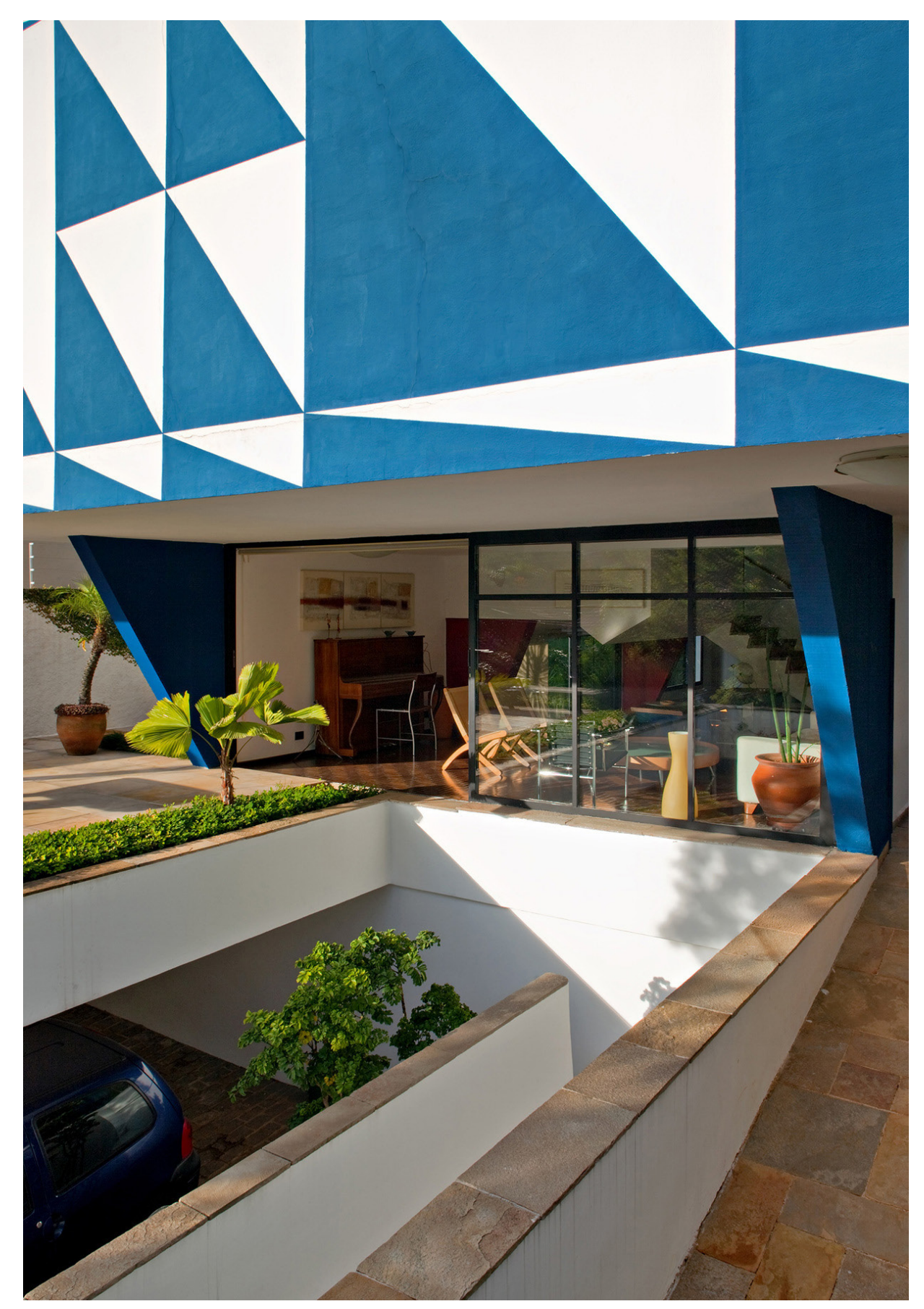




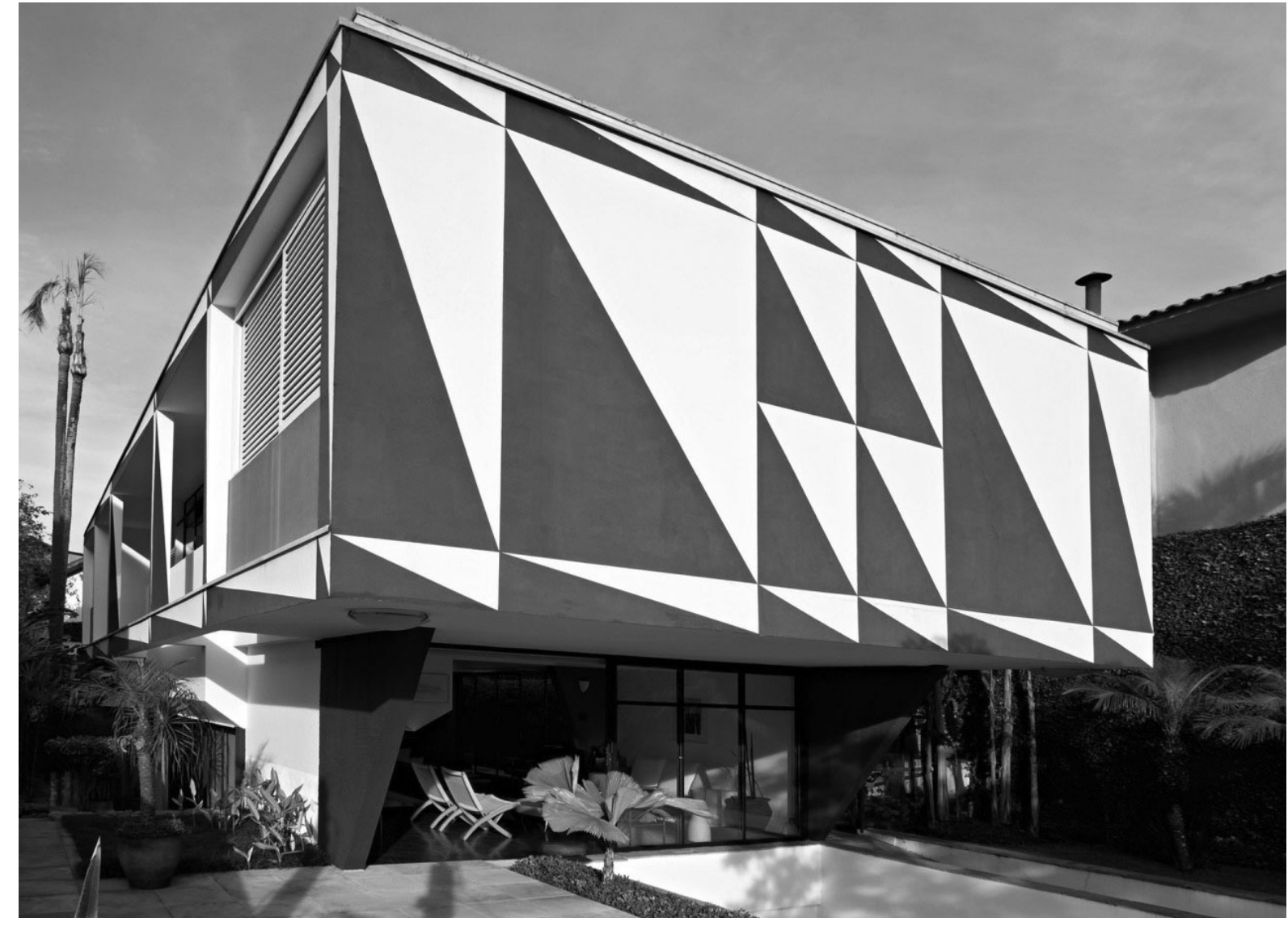

Casa Rubem de Mendonça 1958

endereço

Rua Guaçú, 176

Sumaré, São Paulo - SP

projeto

Vilanova Artigas e Carlos Cascaldi

cliente

Rubem de Mendonça

caractrísticas casa em dois níveis

técnicas e materiais estrutura em concreto armado vedos em alvenaria revestida
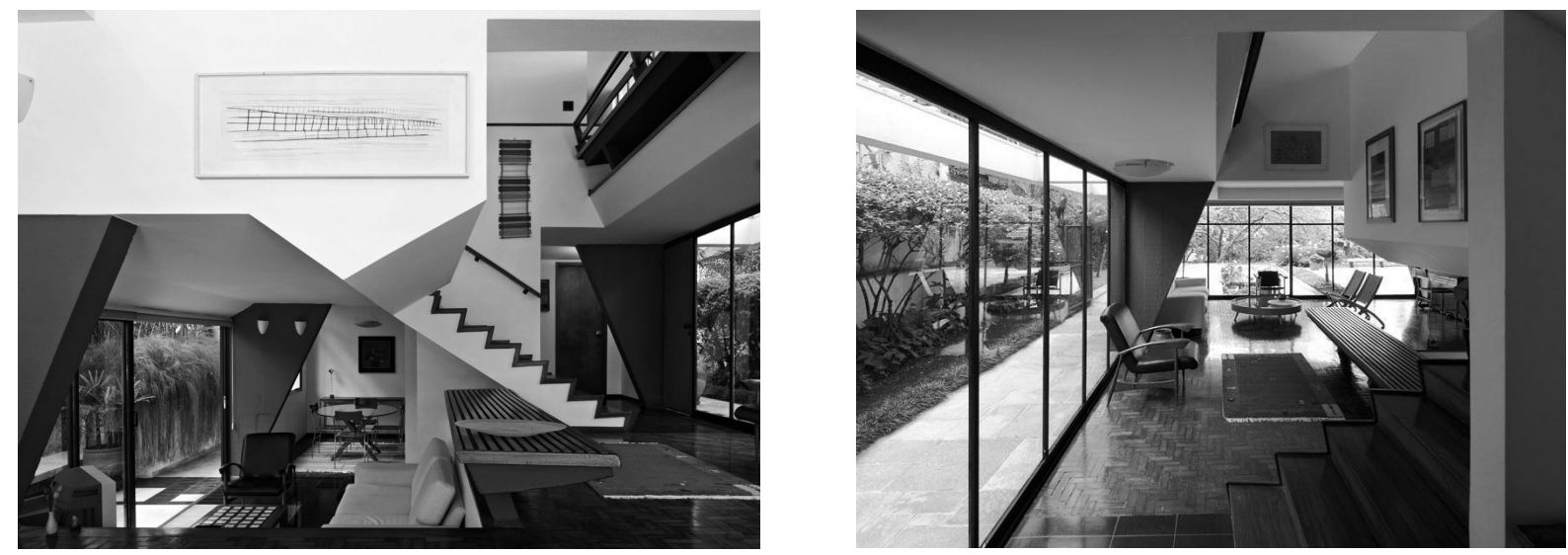

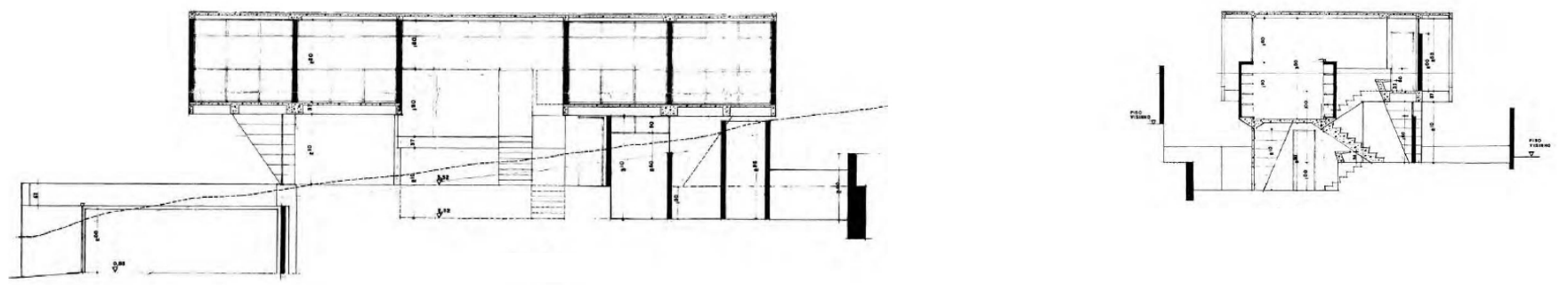

cortes
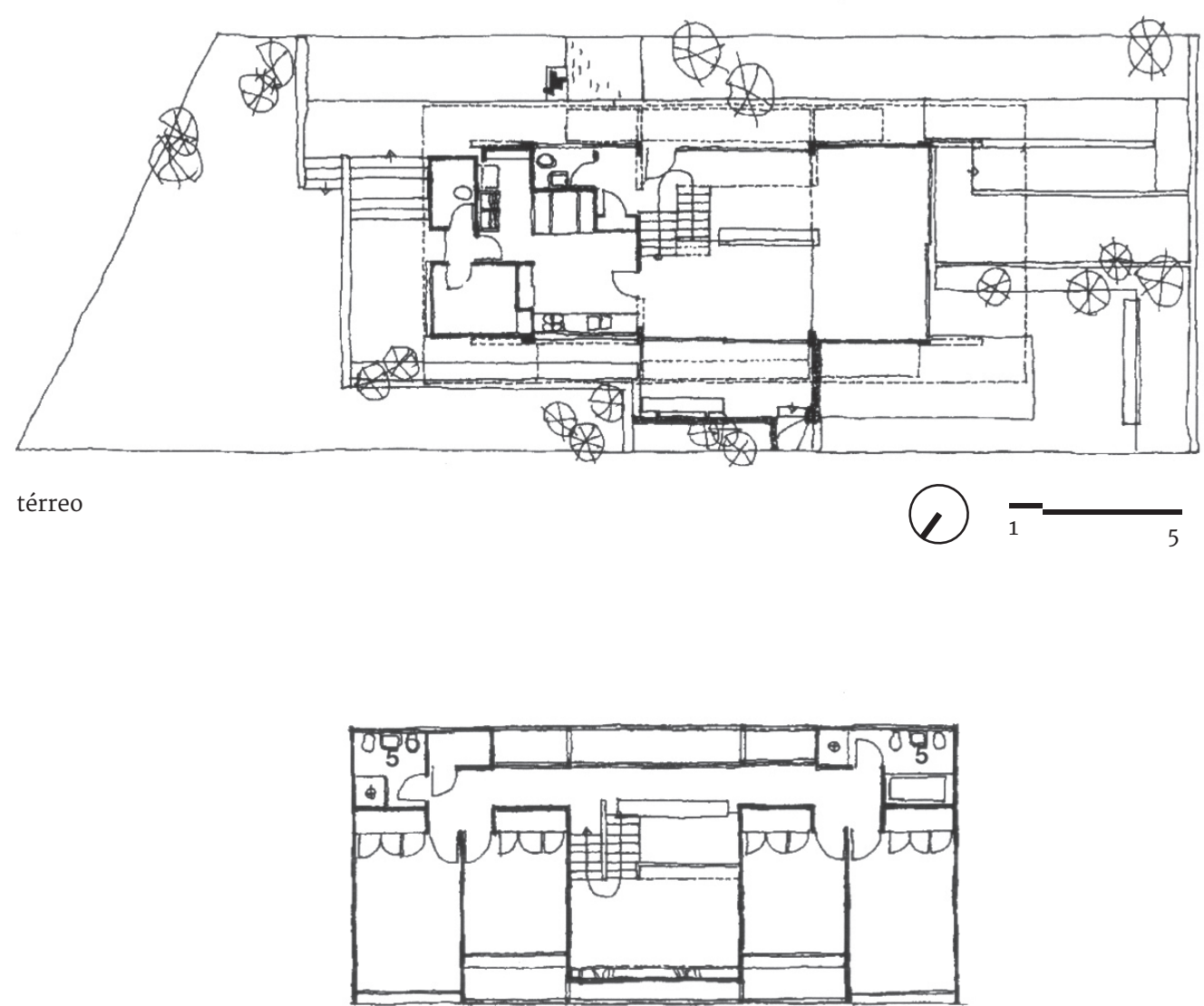


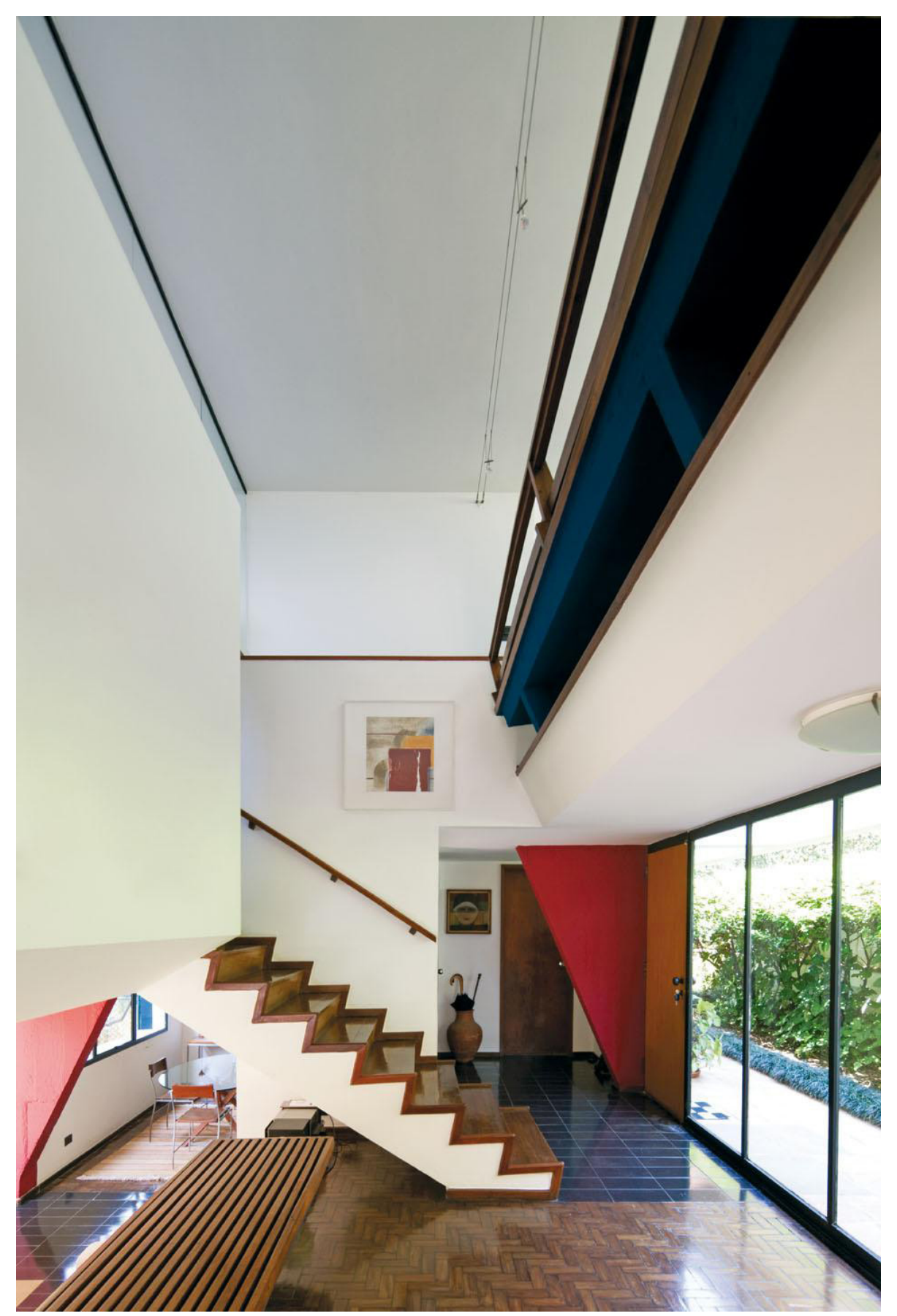




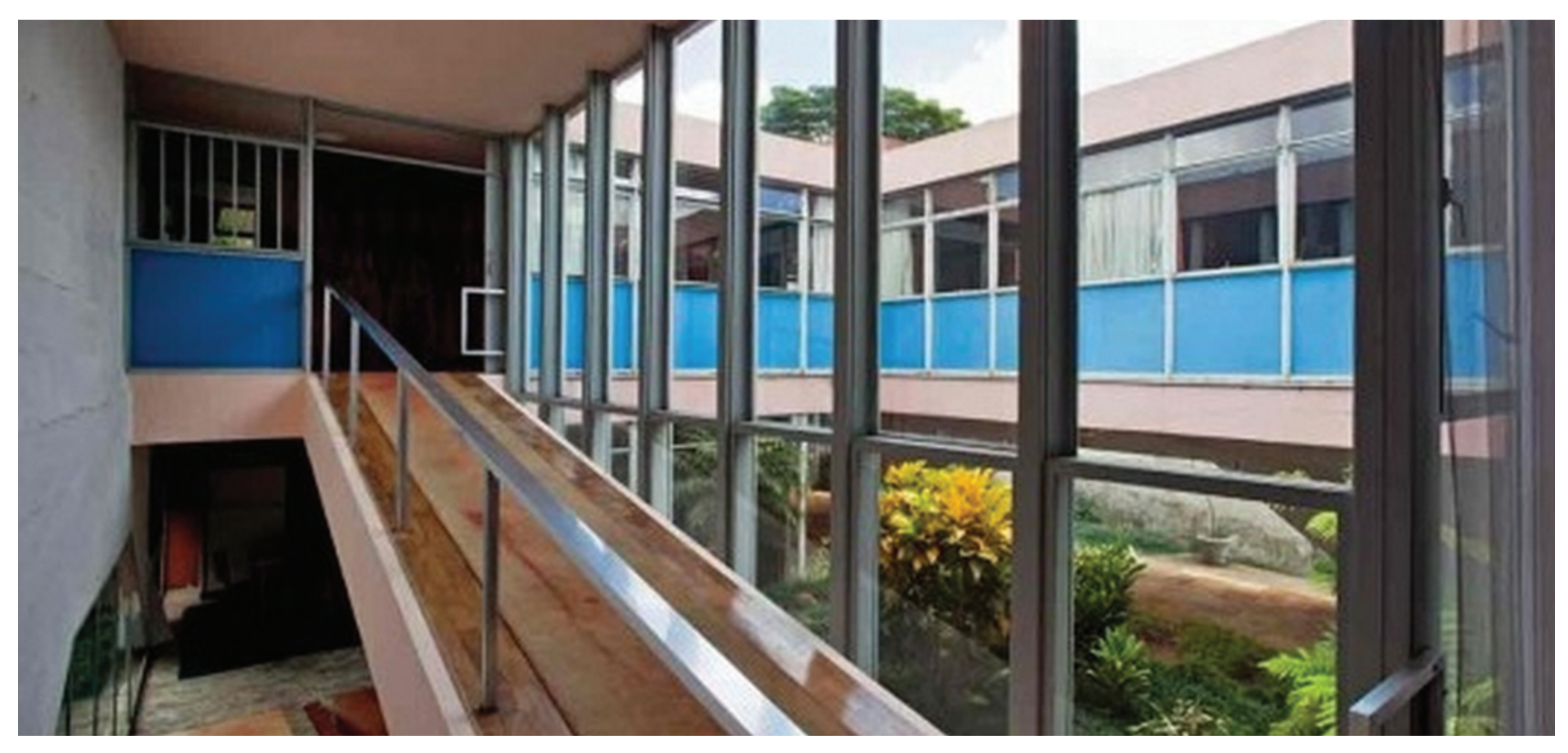



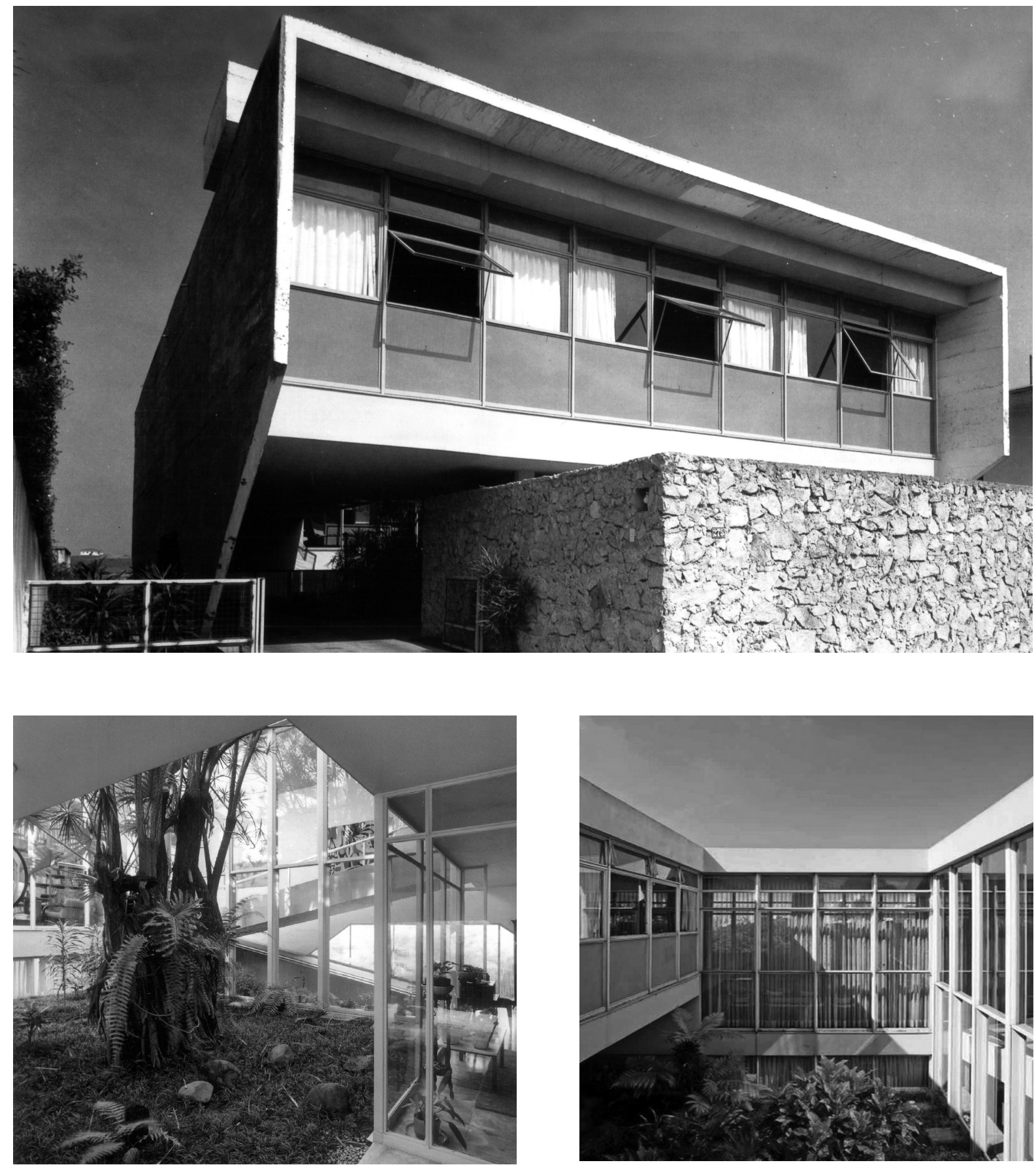

Casa Taques Bittencourt II 1959

endereço

Rua Votuporanga, 275 Sumaré, São Paulo - SP

projeto

Vilanova Artigas e Carlos Cascaldi

cliente José Taques Bittencourt

caractrísticas casa em dois níveis

técnicas e materiais estrutura em concreto armado fechamentos em leves em esauqdrias de alumínio e vidro 

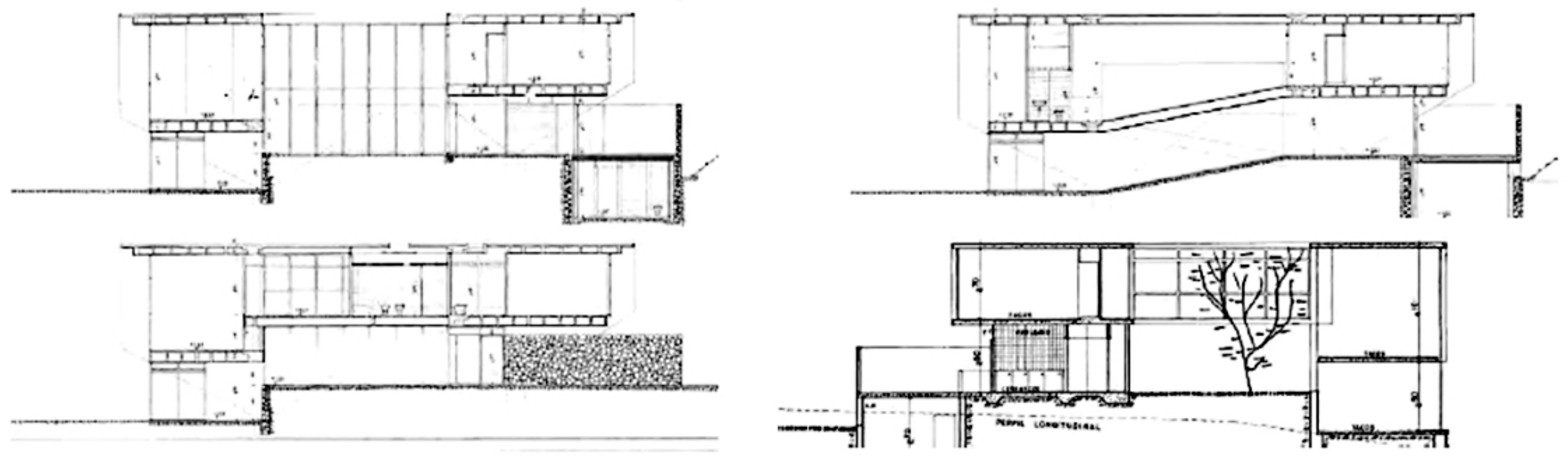

cortes
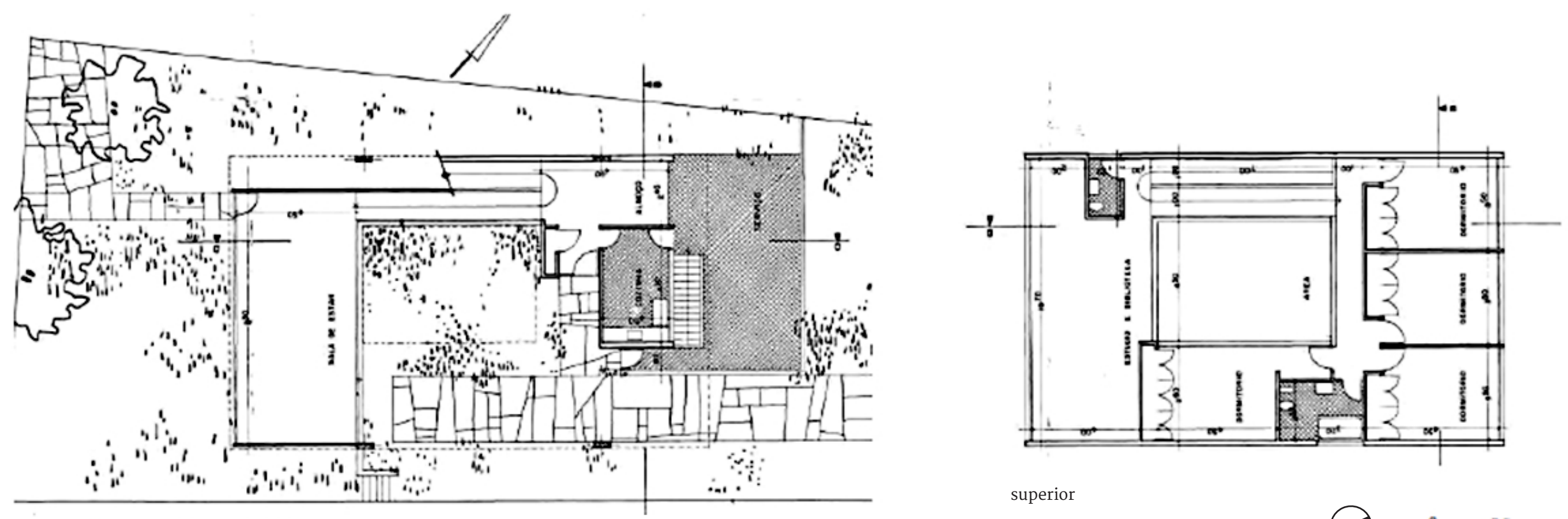

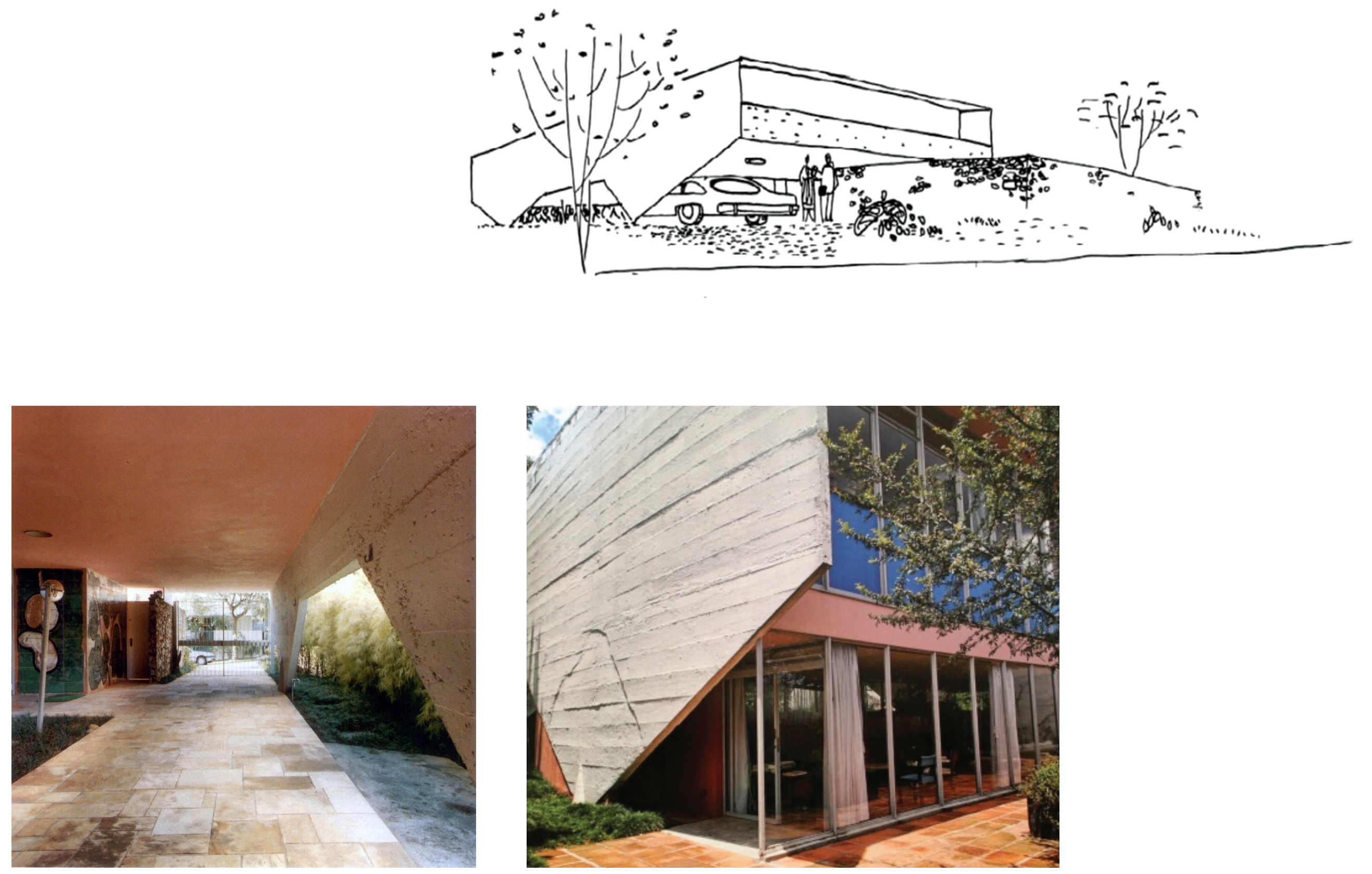


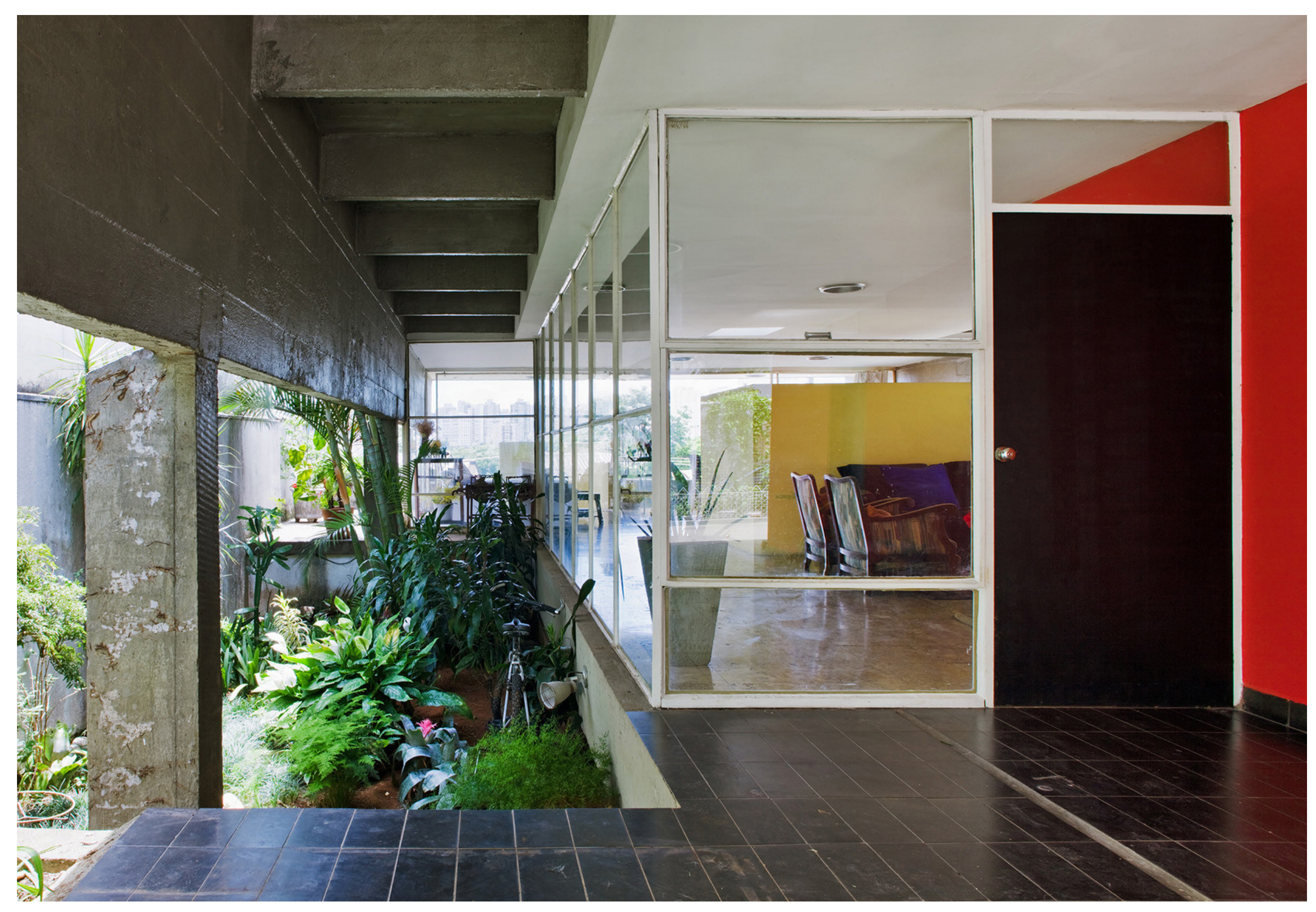




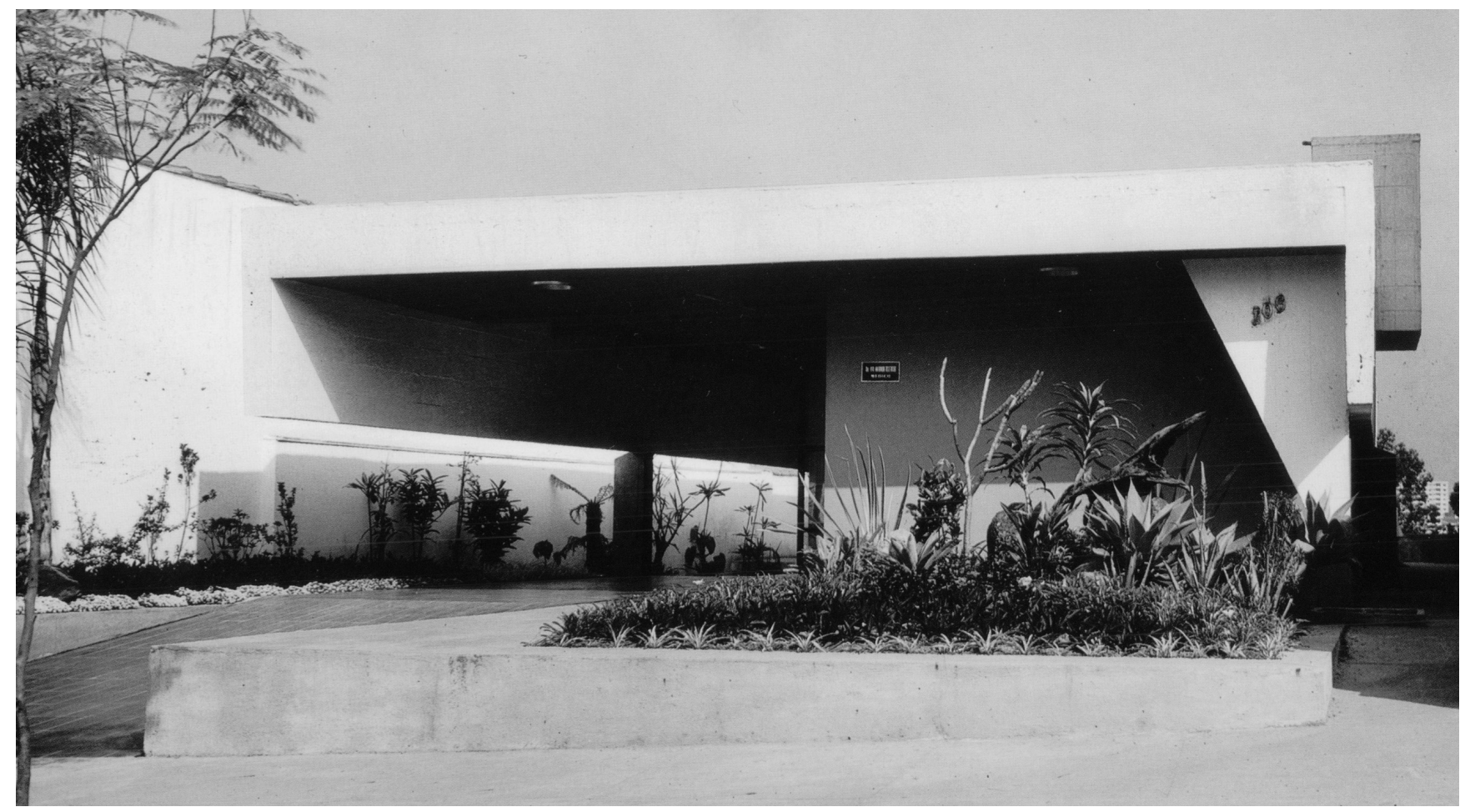

Casa Viterito 1962

endereço Rua José Comparato, 106 Aclimação, São Paulo - SP

projeto

Vilanova Artigas e Carlos Cascaldi

cliente

Ivo e Marisa Viterito

caractrísticas casa em dois niveis

técnicas e materiais

estrutura em concreto armado vedos em alvenaria revestida
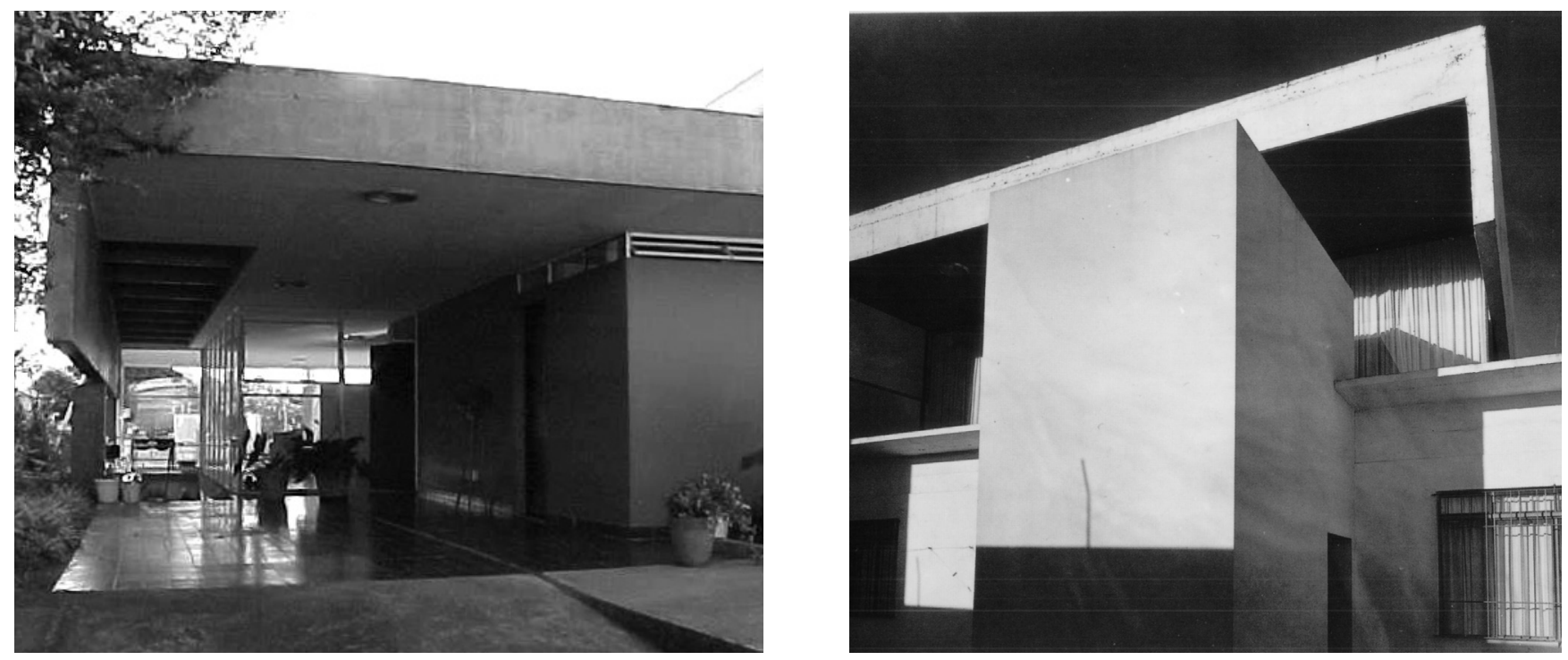

área

$260 \mathrm{~m}^{2}$ 

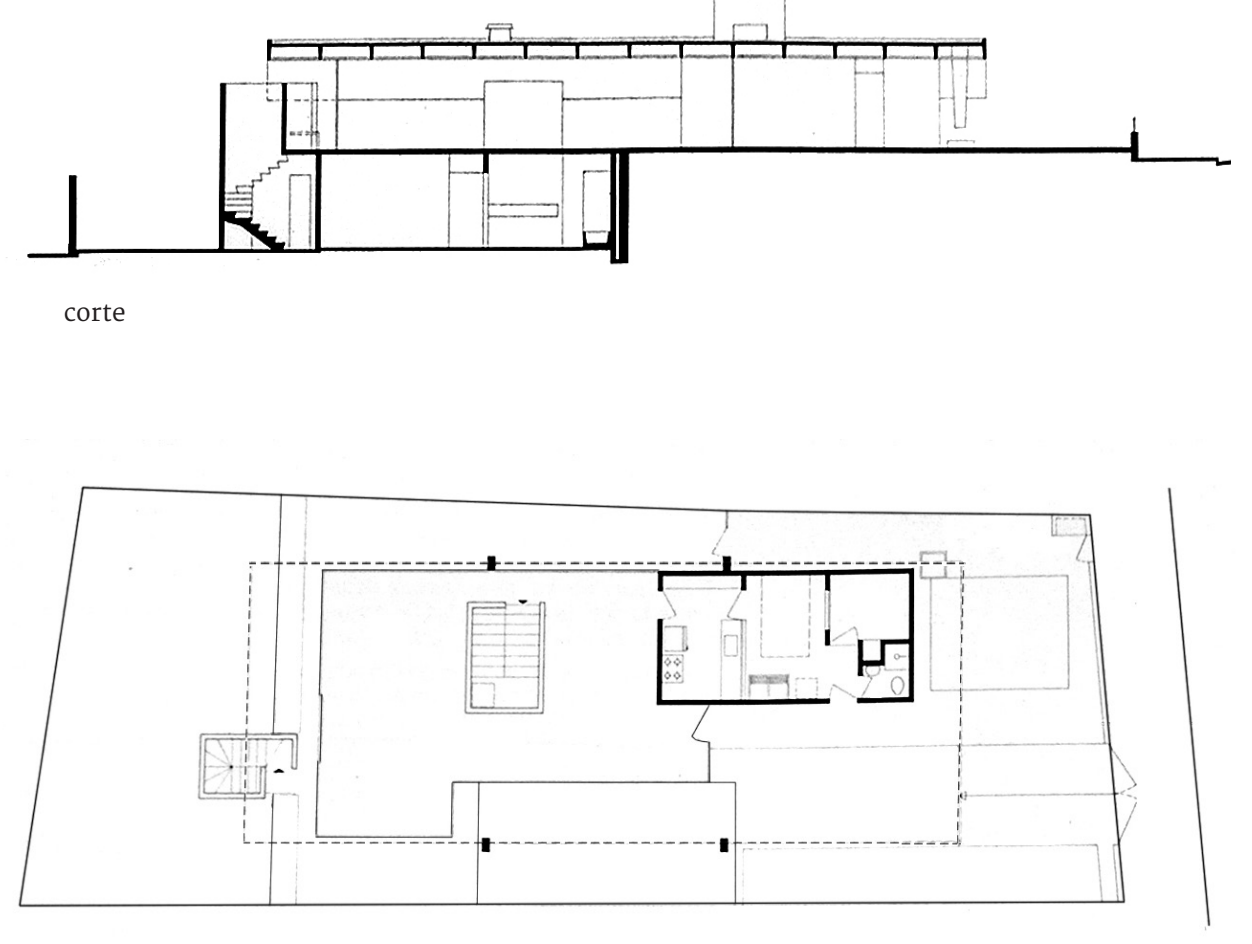

térreo

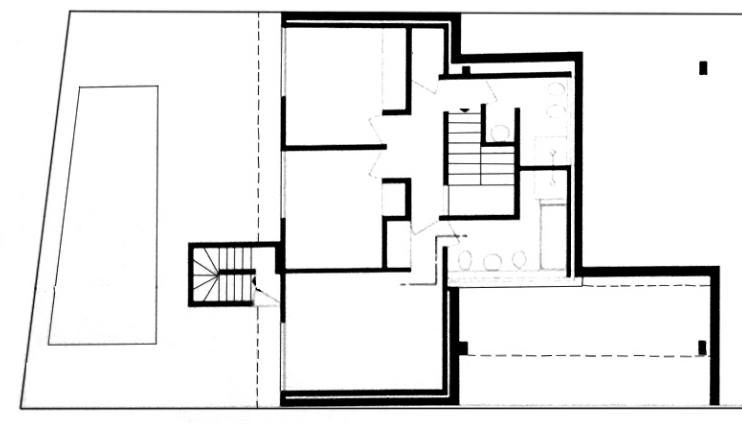

superior

(1) $-\frac{}{5}$ 

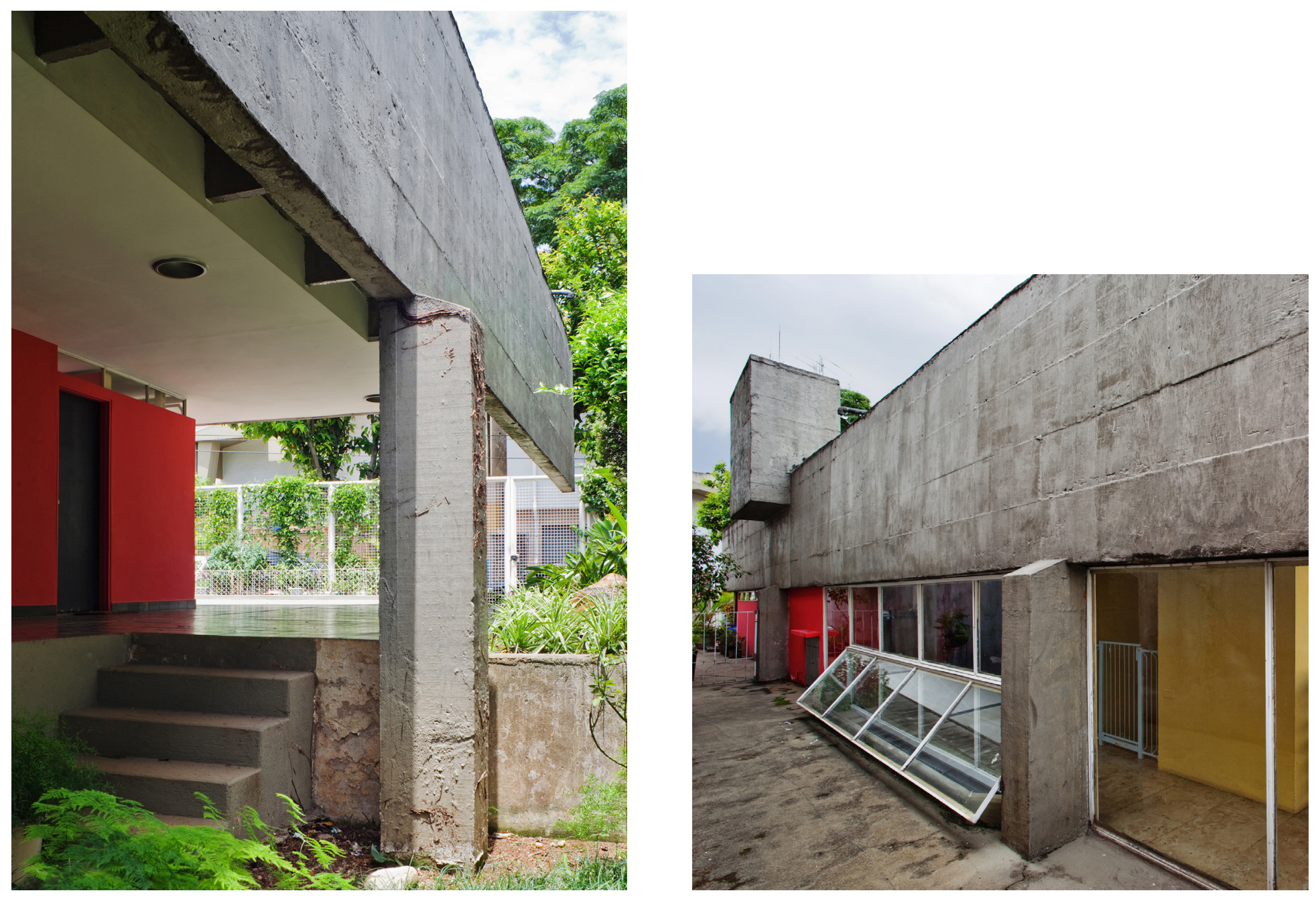


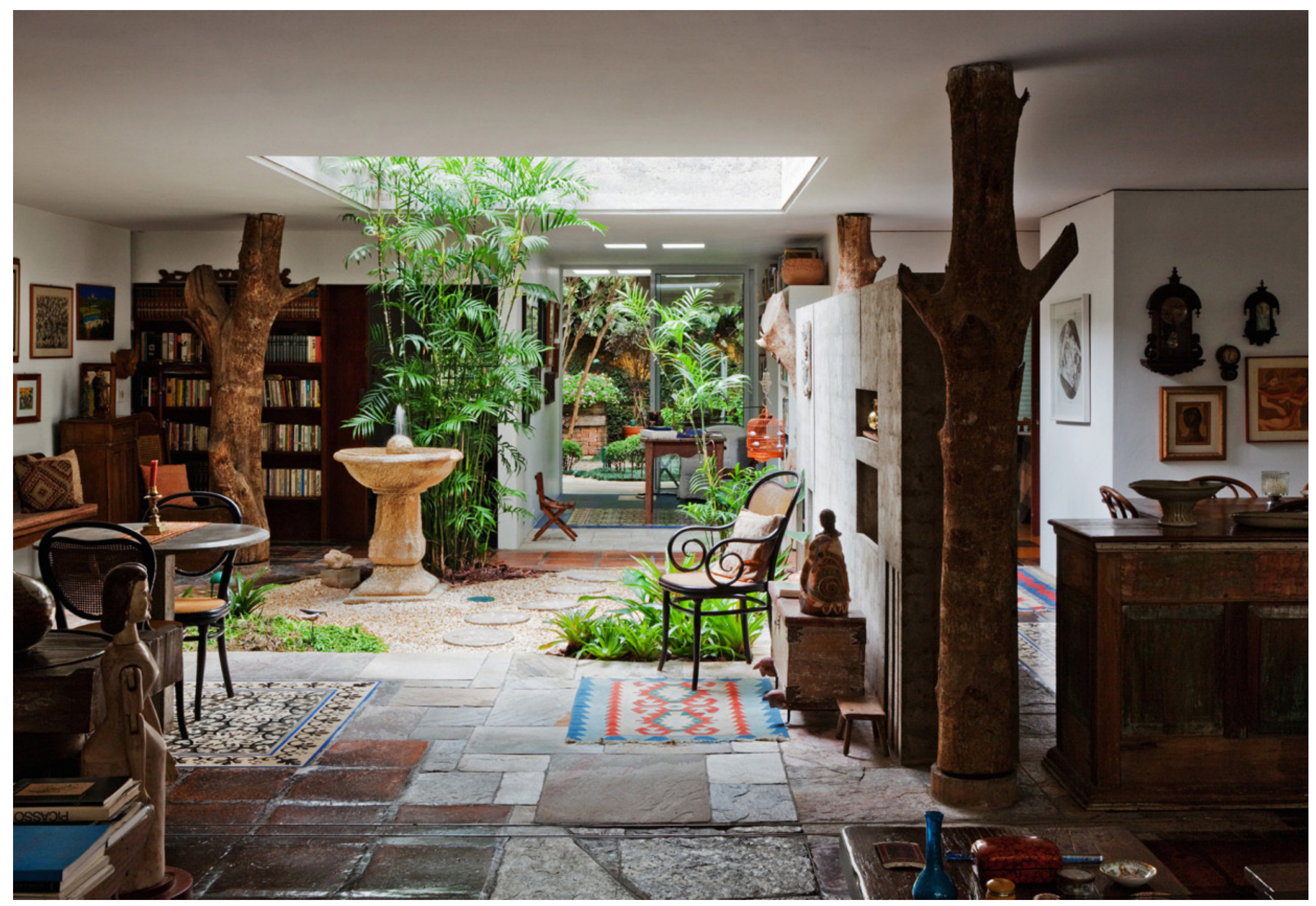



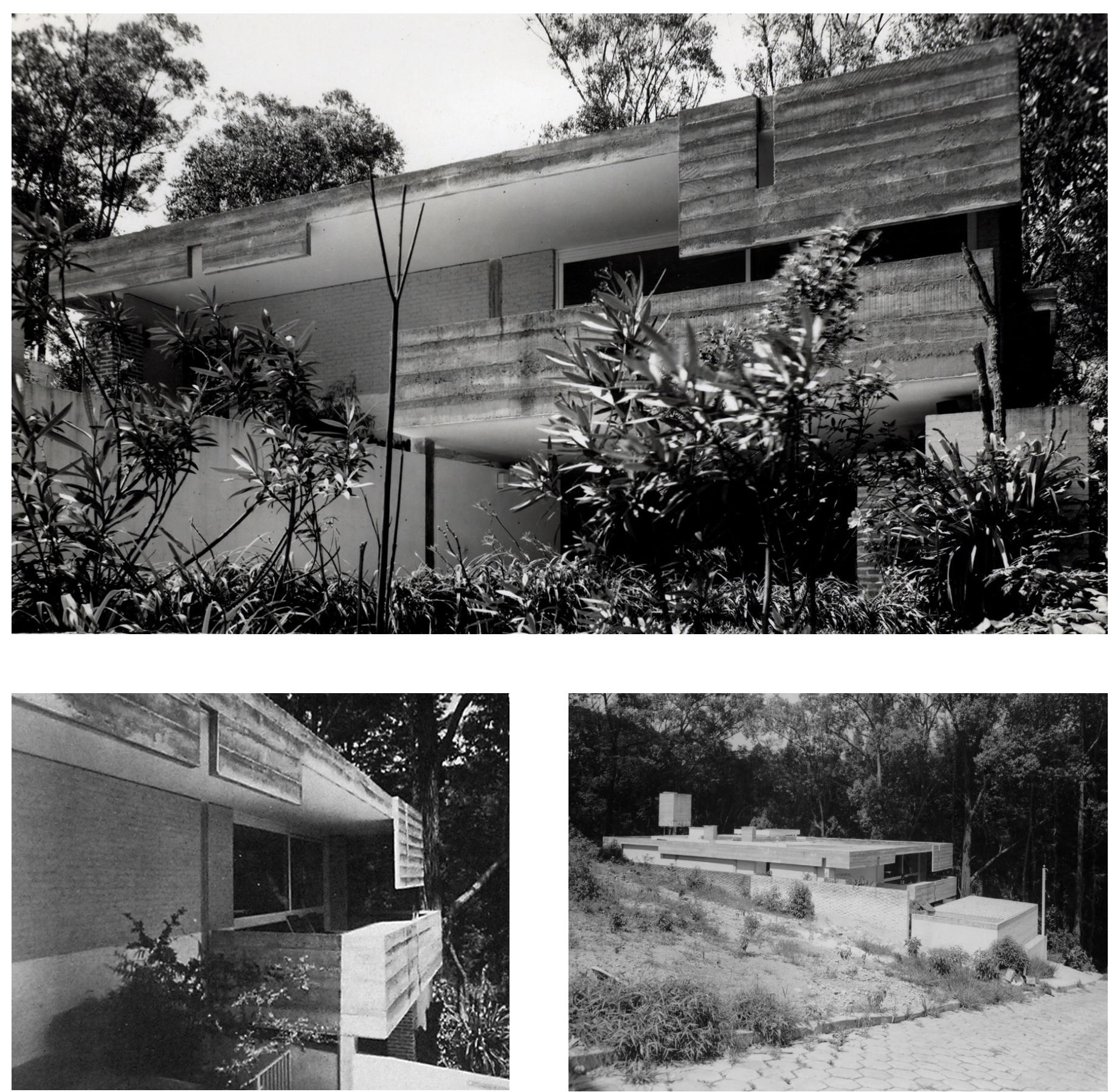

Casa Berquó 1965

endereço

Rua Paulo Roberto Paes de Almeida, 51 Chácara Monte Alegre, São Paulo - SP

projeto

Vilanova Artigas

cliente Elza Berquó

caractrísticas casa térrea

técnicas e materiais estrutura em concreto armado com elementos estruturais em madeira

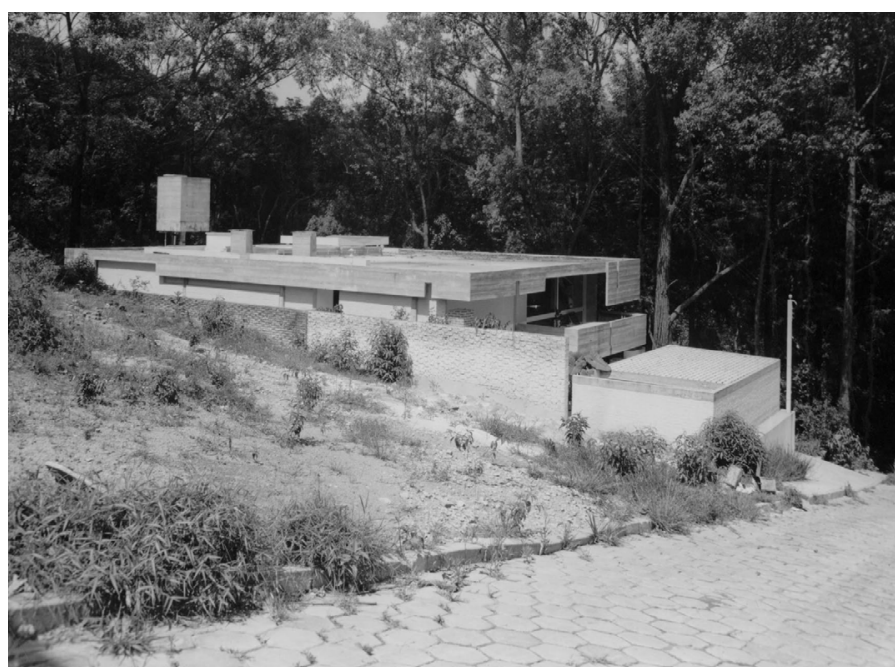




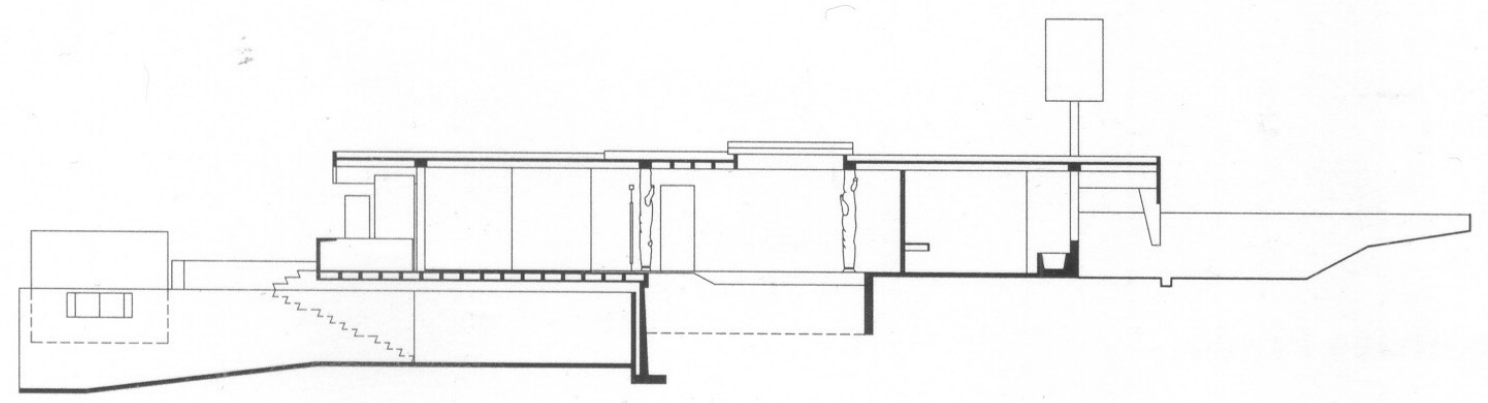

corte

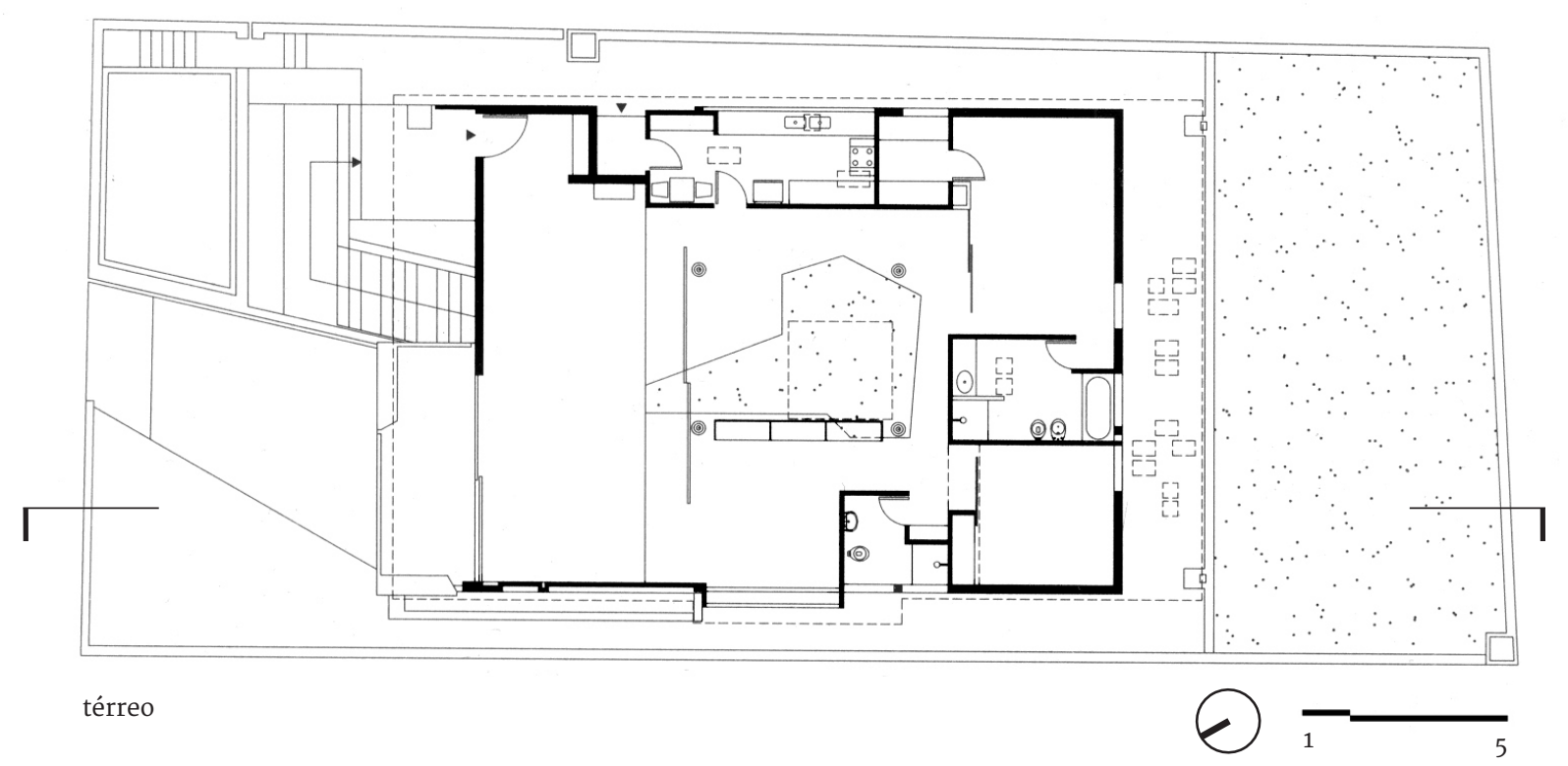



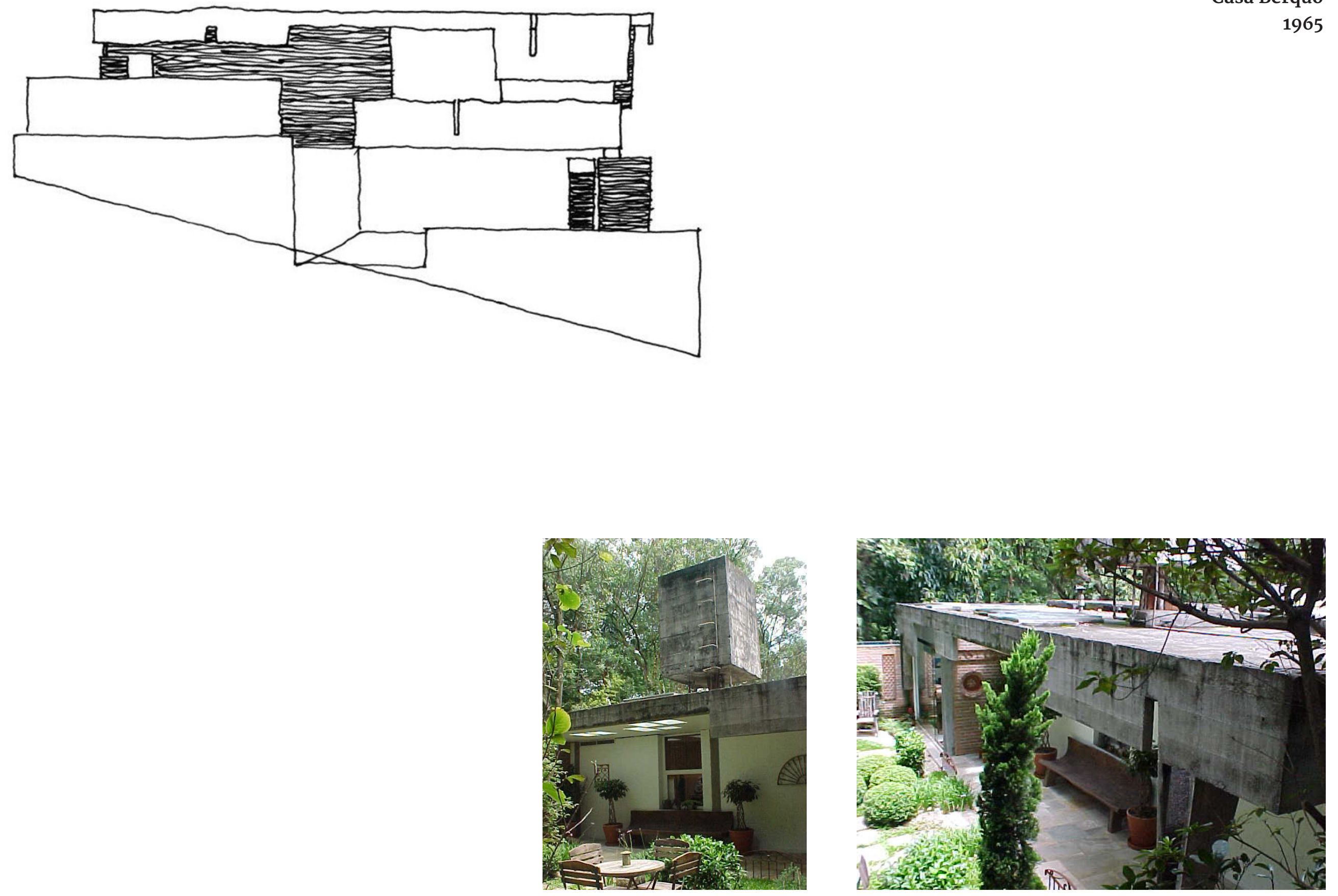


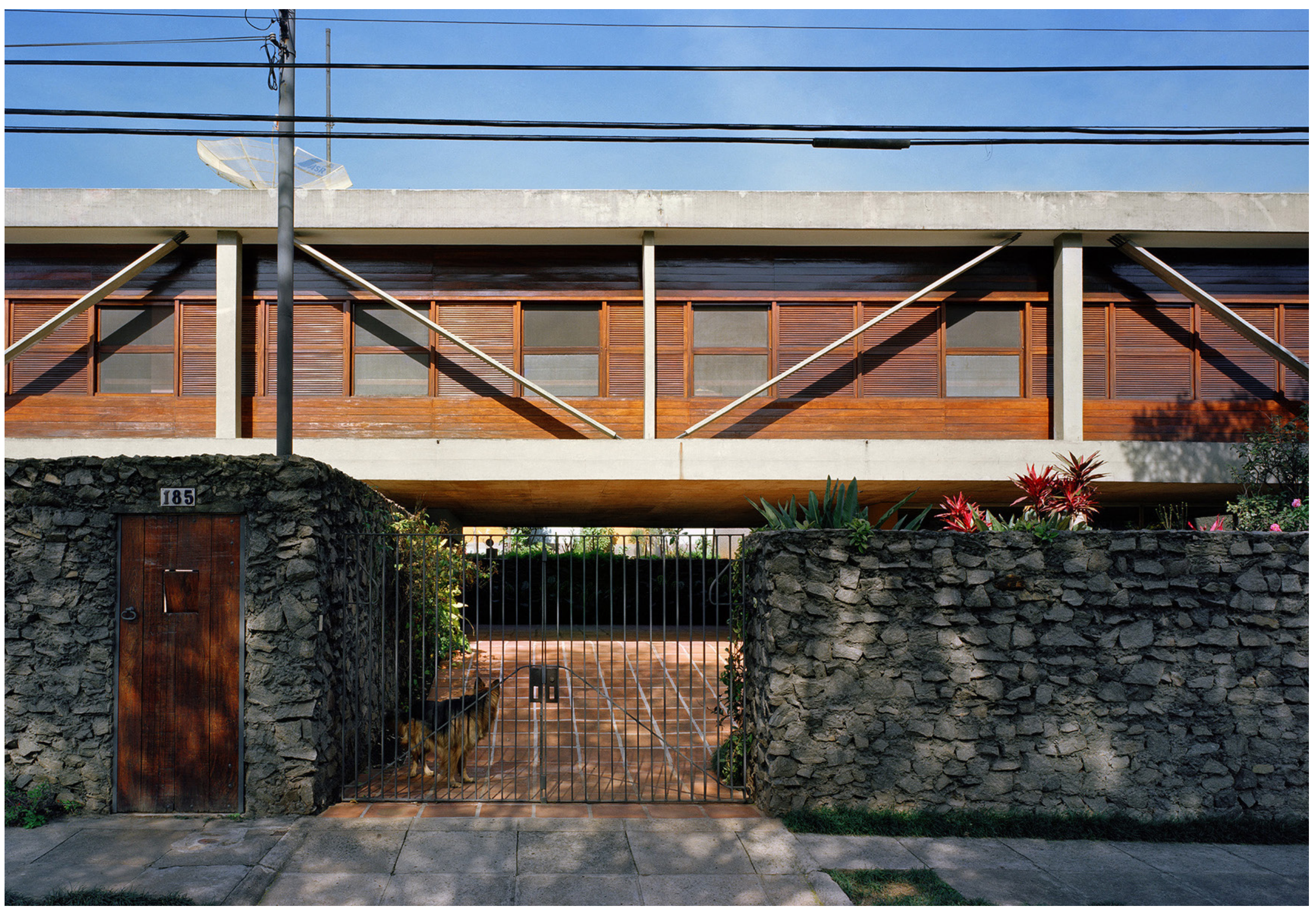




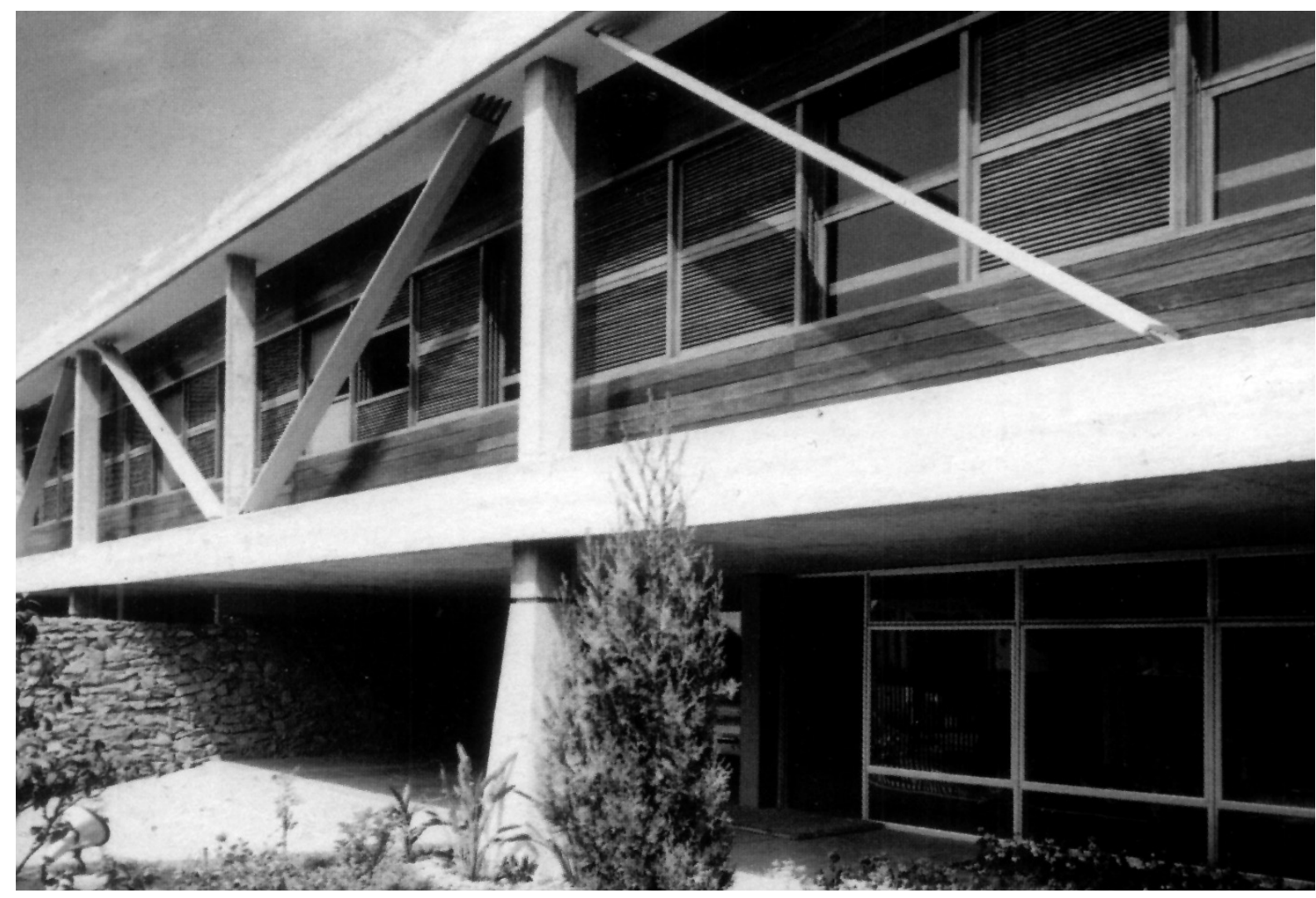

Casa Mendes André 1968

endereço

Rua Cel. Artur de Godó, 185

Vila Mariana, São Paulo - SP

projeto

Vilanova Artigas

cliente

Manuel Mendes André

caractrísticas casa em dois niveis

técnicas e materiais estrutura em concreto protendido vedos leves em madeira
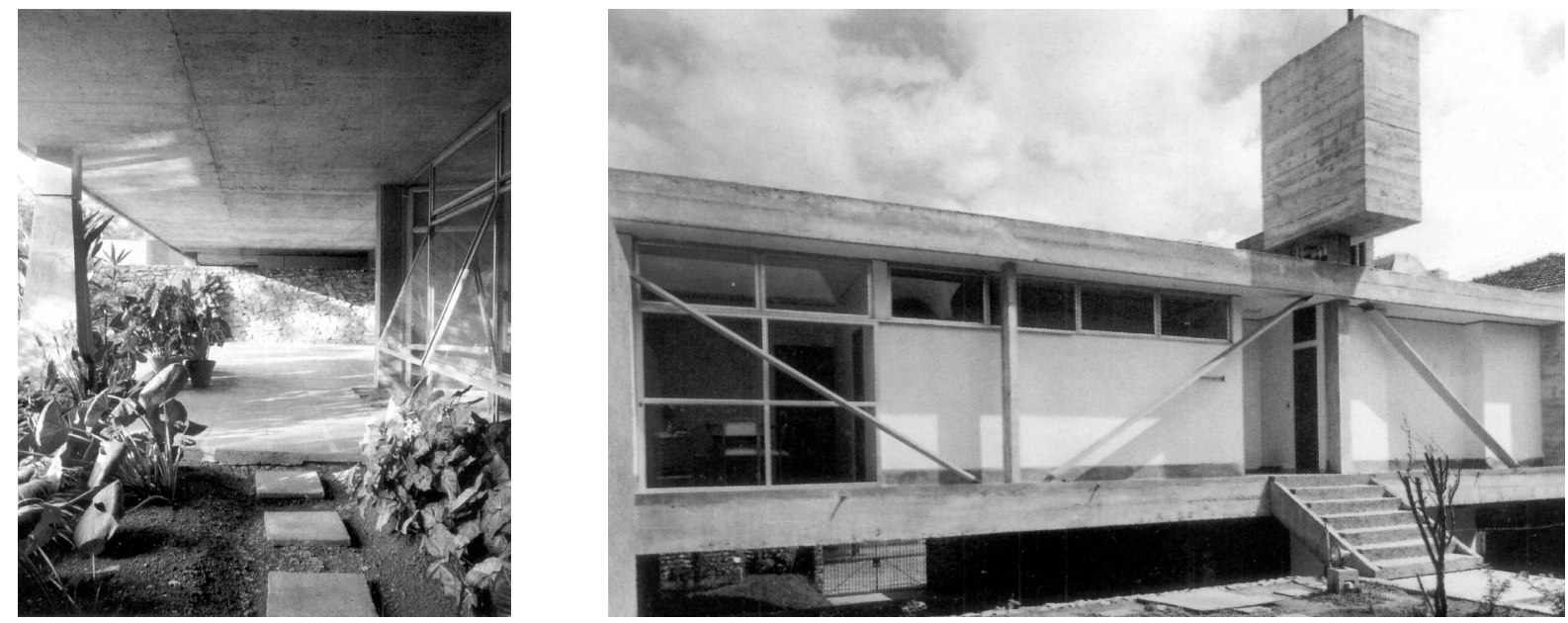


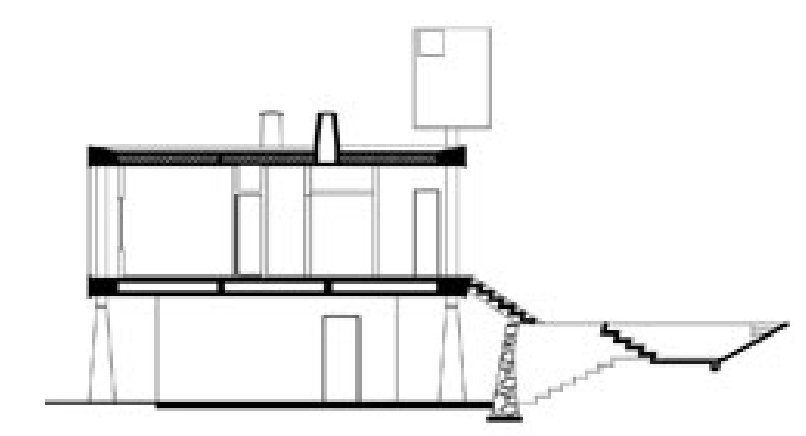

cortes

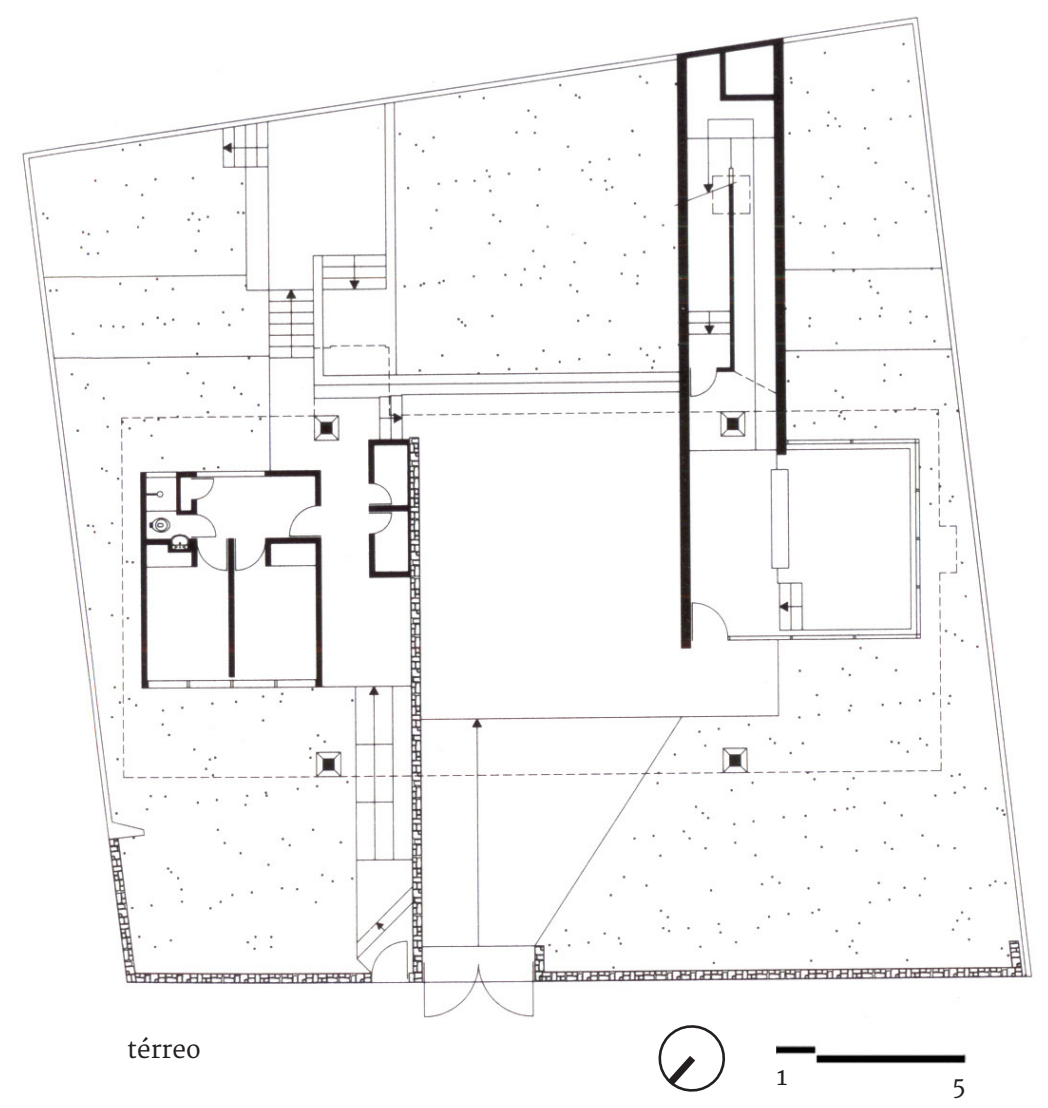

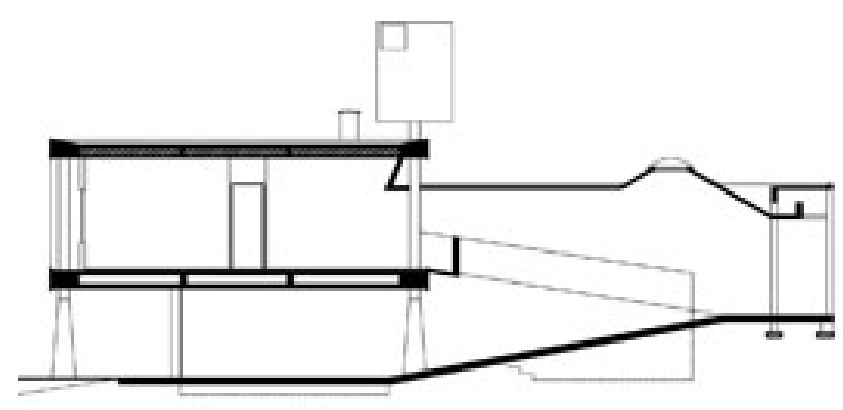

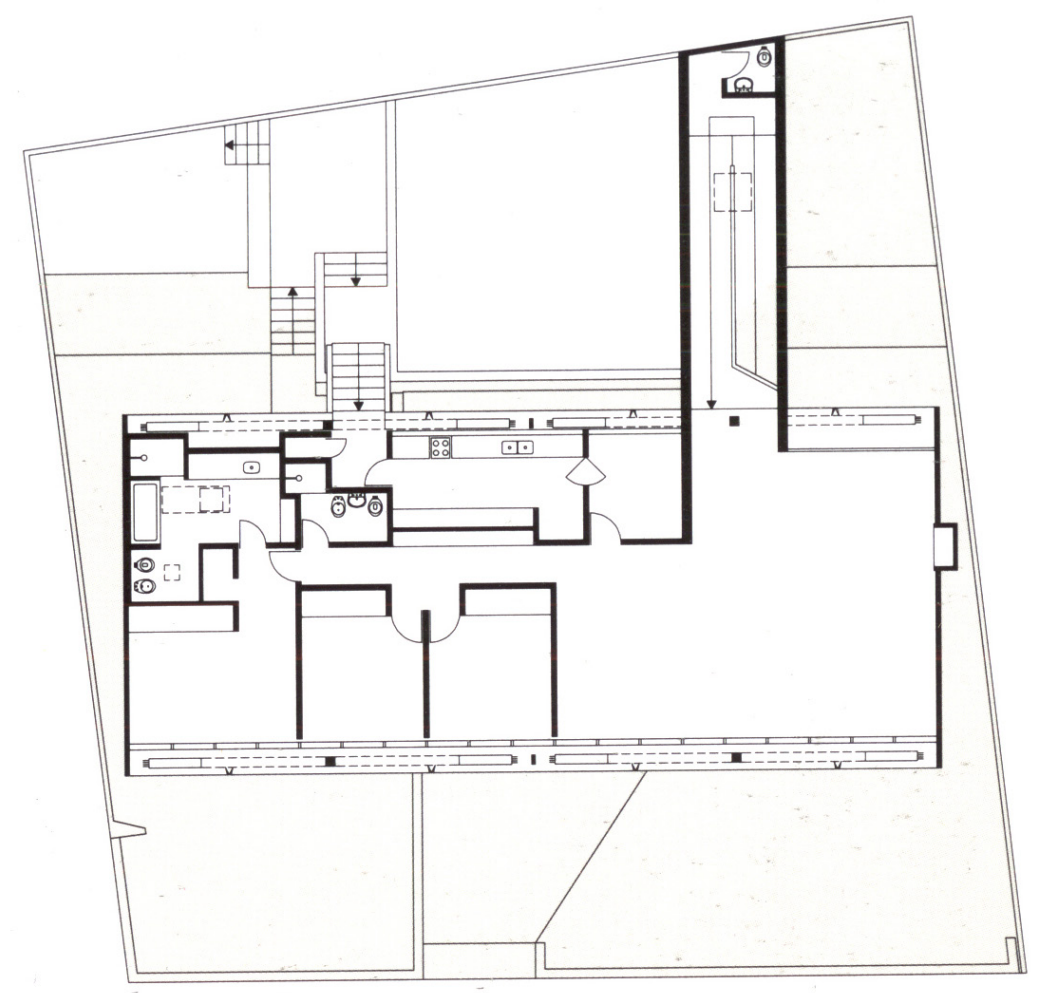

superior 

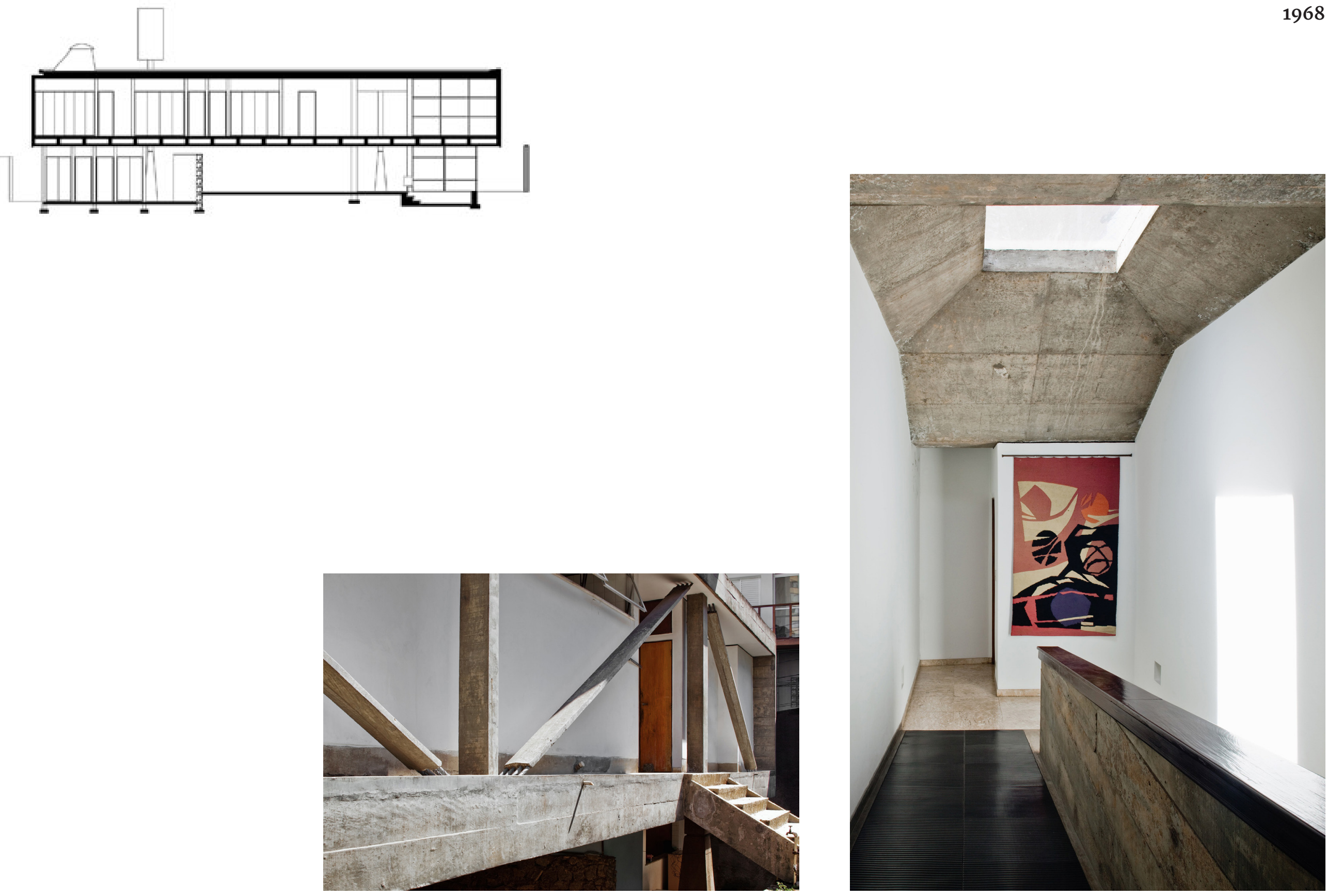


\section{VILANOVA ARTIGAS.}

EDIFÍCIOS PÚBLICOS 1945-1973 


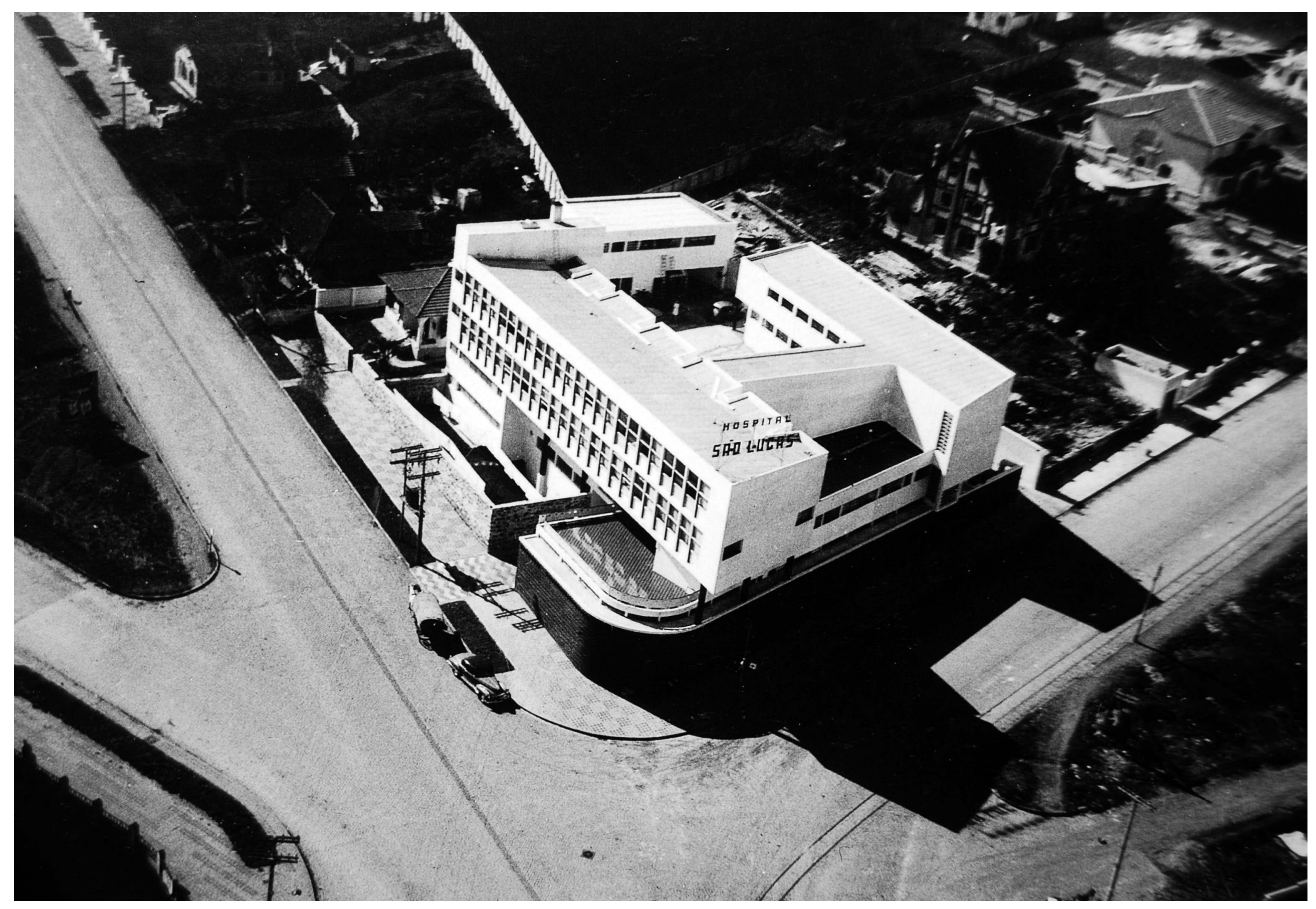




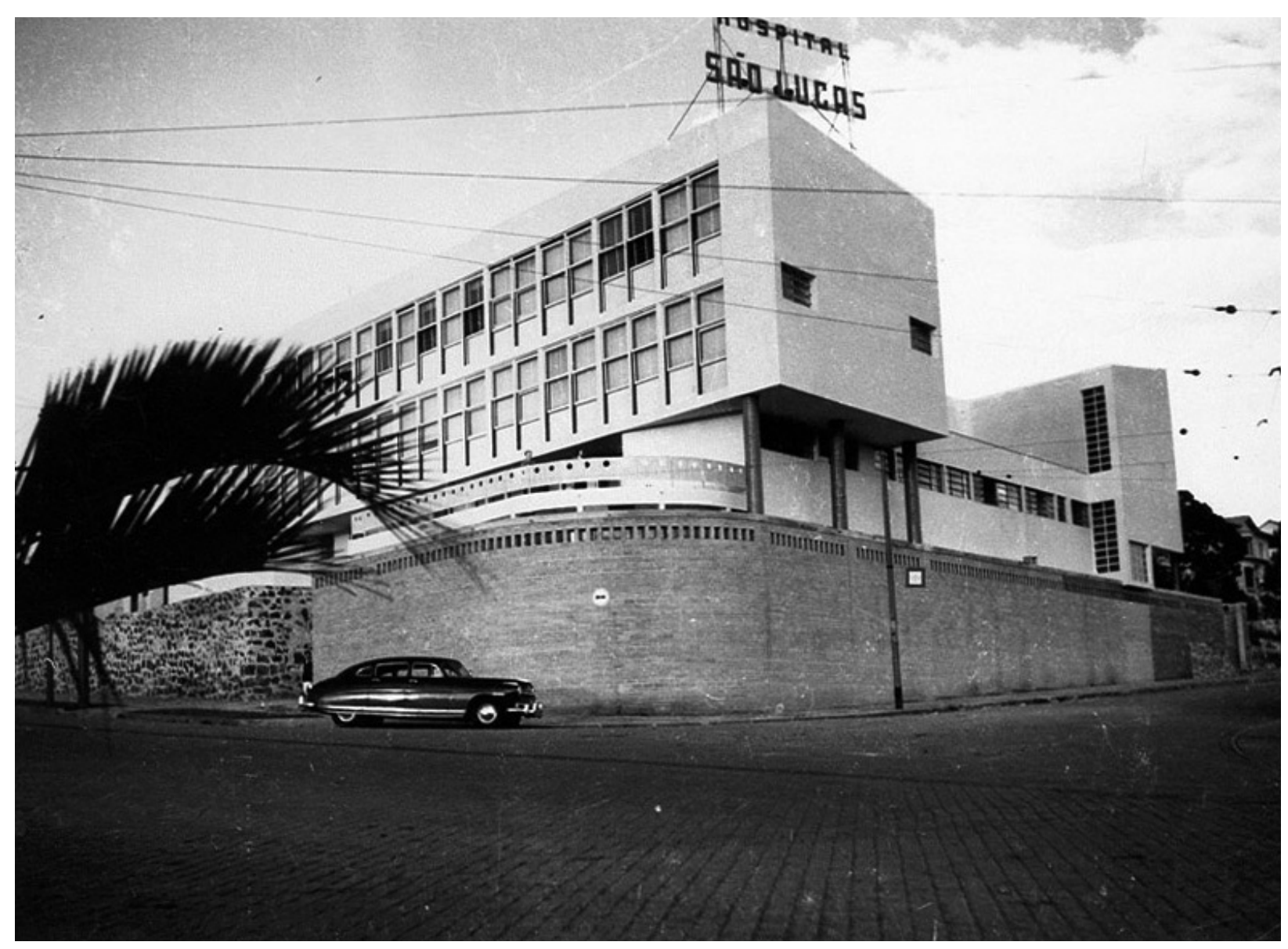
Hospital São Lucas
1945

endereço

Centro, Londrina - PR

projeto

Vilanova Artigas

saúde

cliente

Prefeitura de Londrina

caractrísticas

construção em dois blocos a meios-níveis, unidos por rampas.

técnicas e materiais estrutura em concreto armado vedos em alvenaria
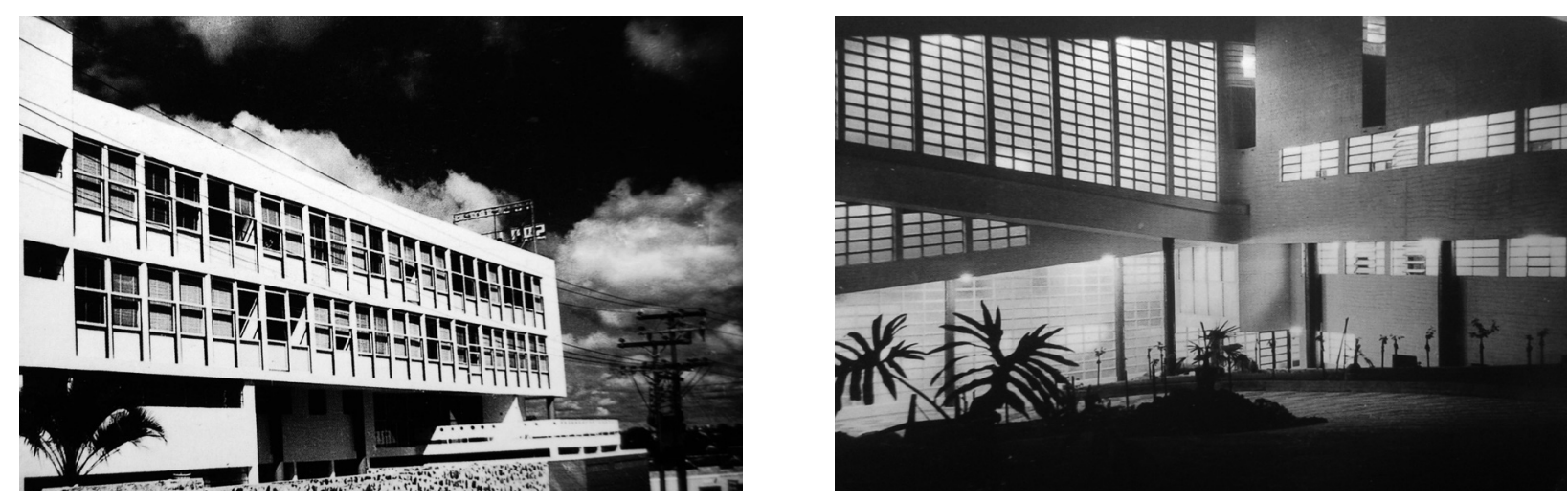

área 


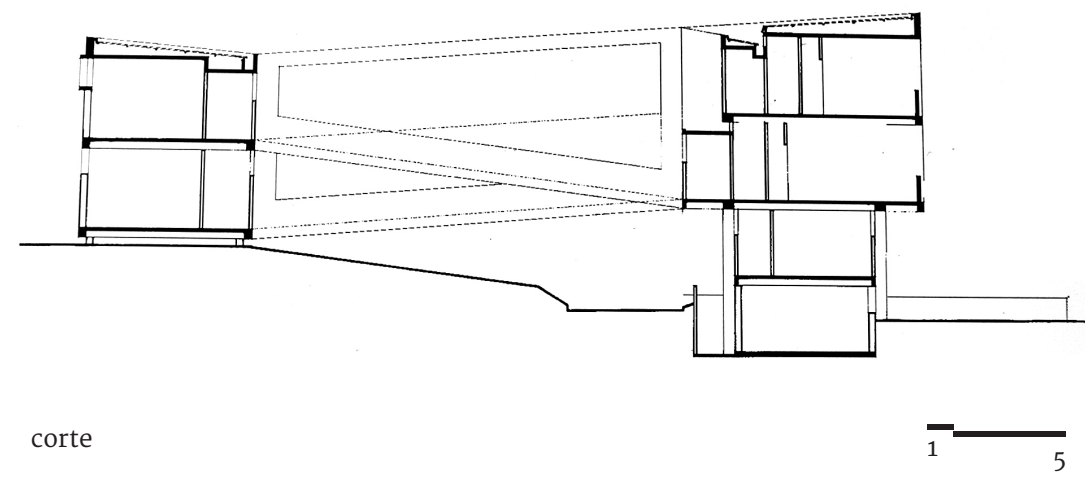



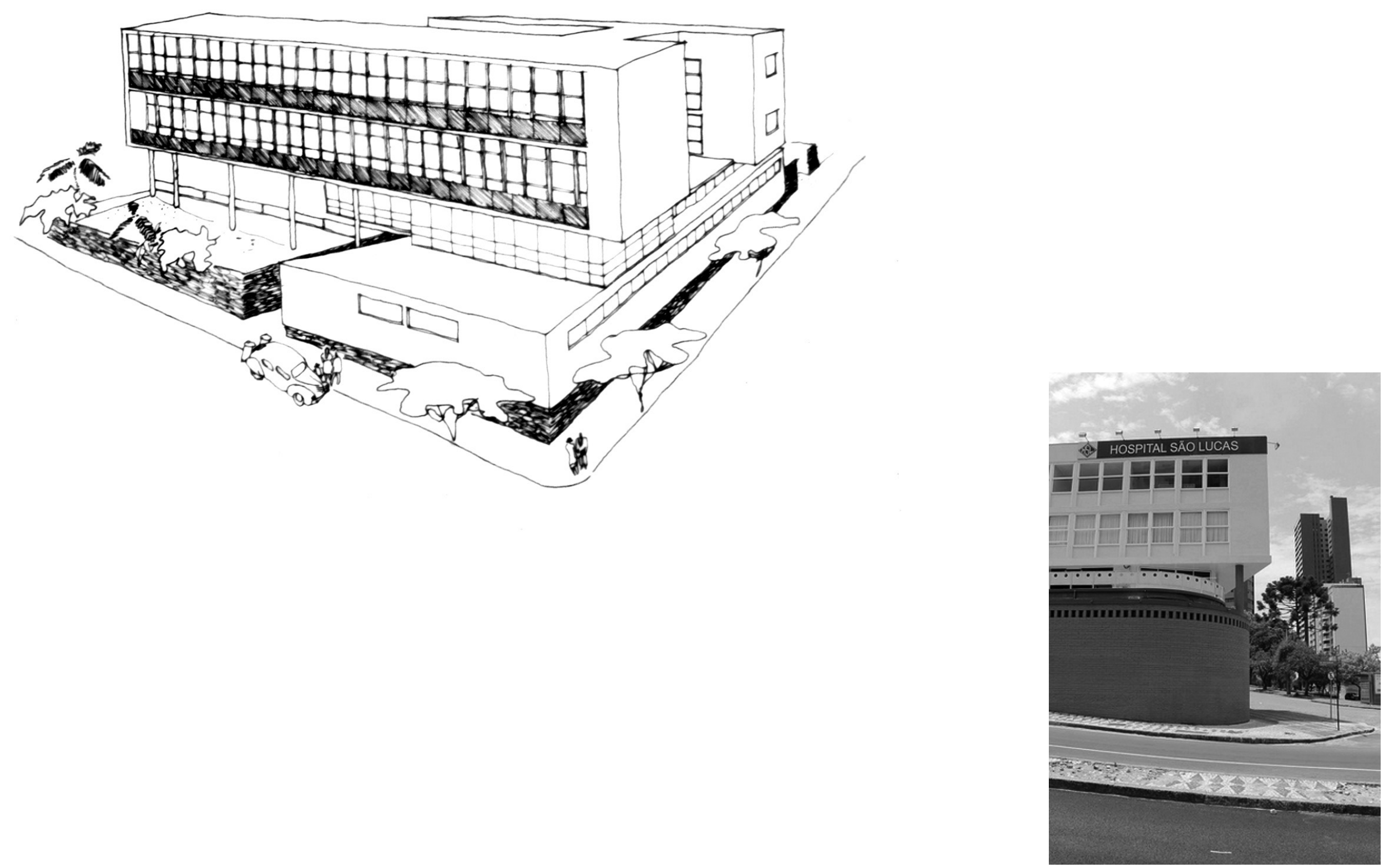


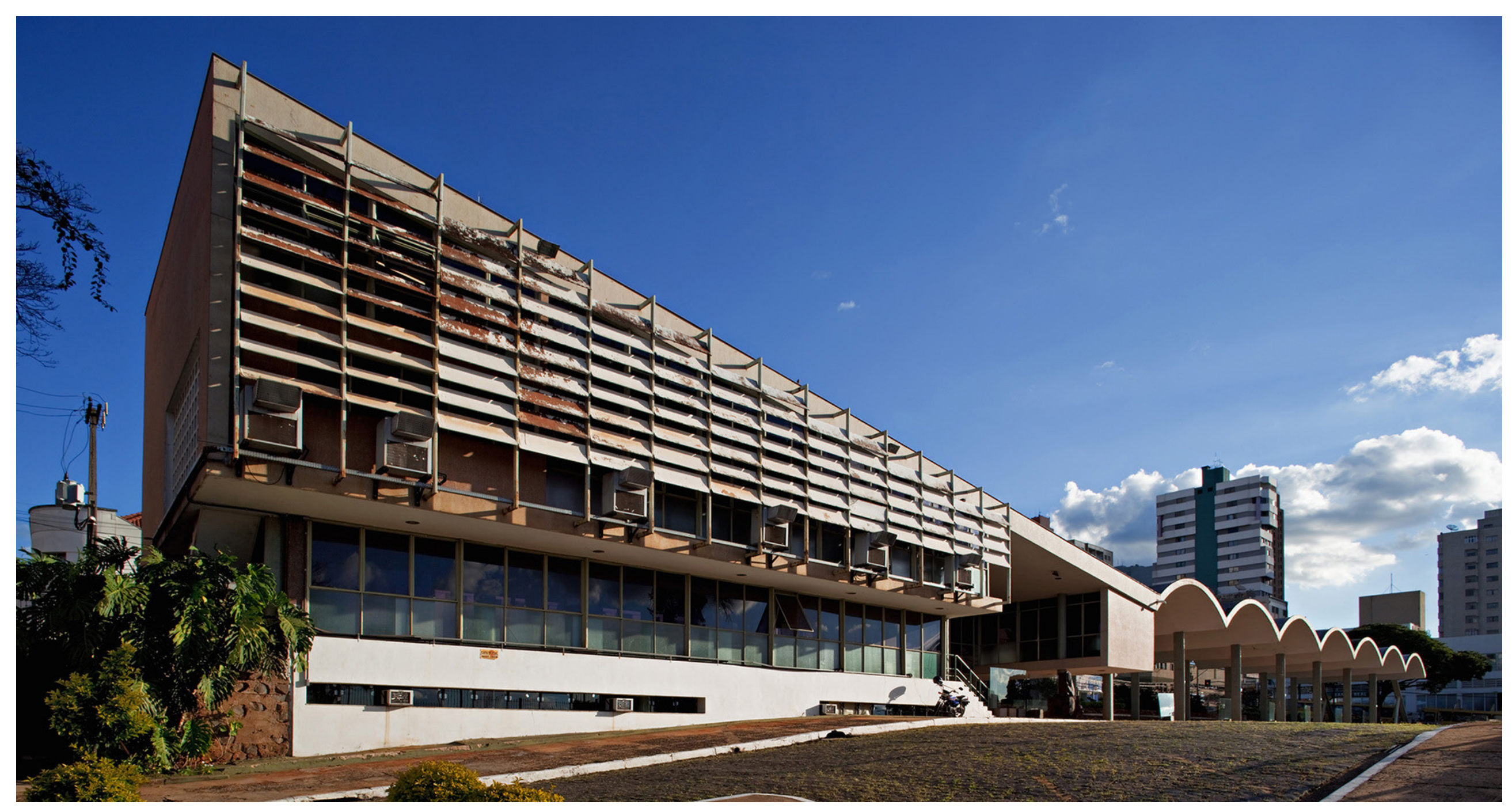




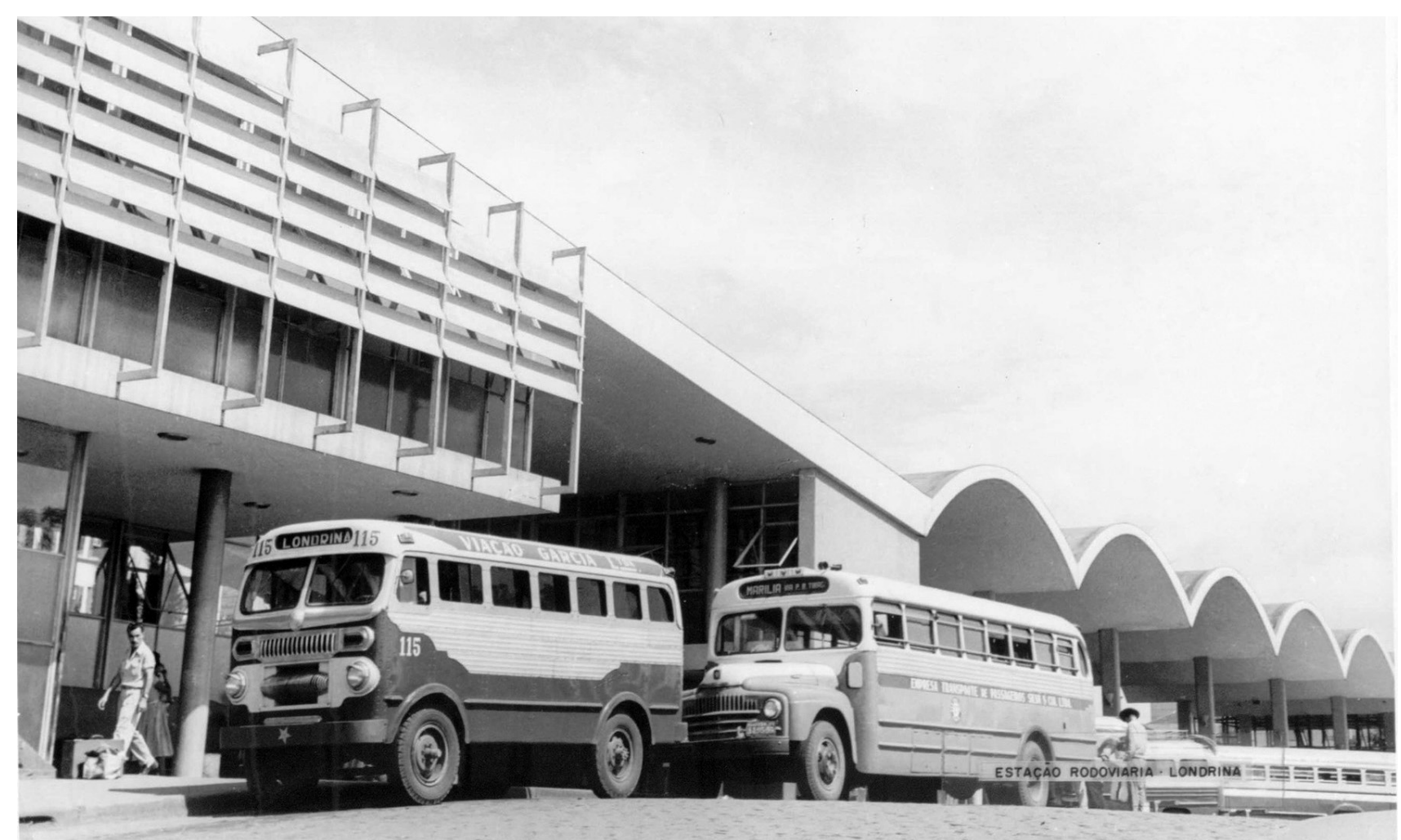

Rodoviária de Londrina
1950

endereço

rua Sergipe, 640

Centro, Londrina - PR

projeto

Vilanova Artigas

uso original/atual transporte /museu

cliente

Prefeitura de Londrina

caractrísticas

bloco de apoio aos passageiros plataformas de embarque cobertas
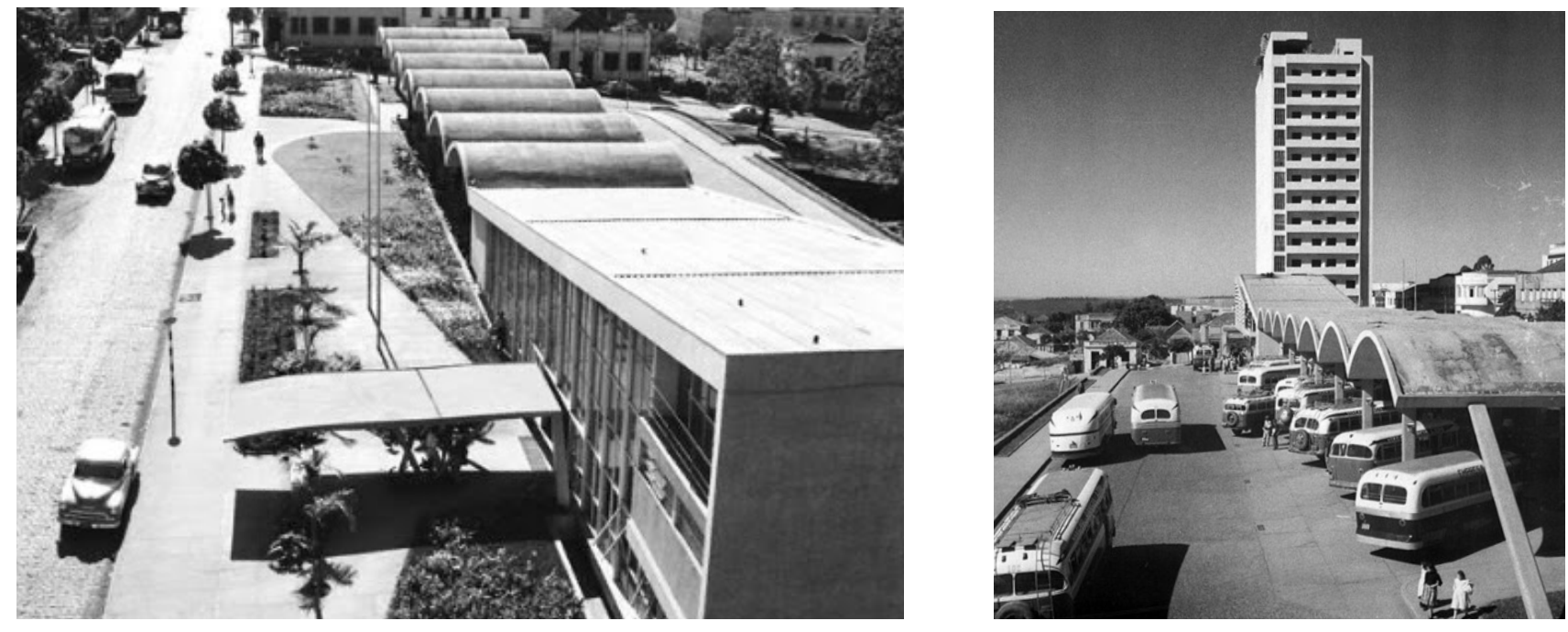

técnicas e materiais cobertura lajes em concreto armado fecahmentos em vidro 

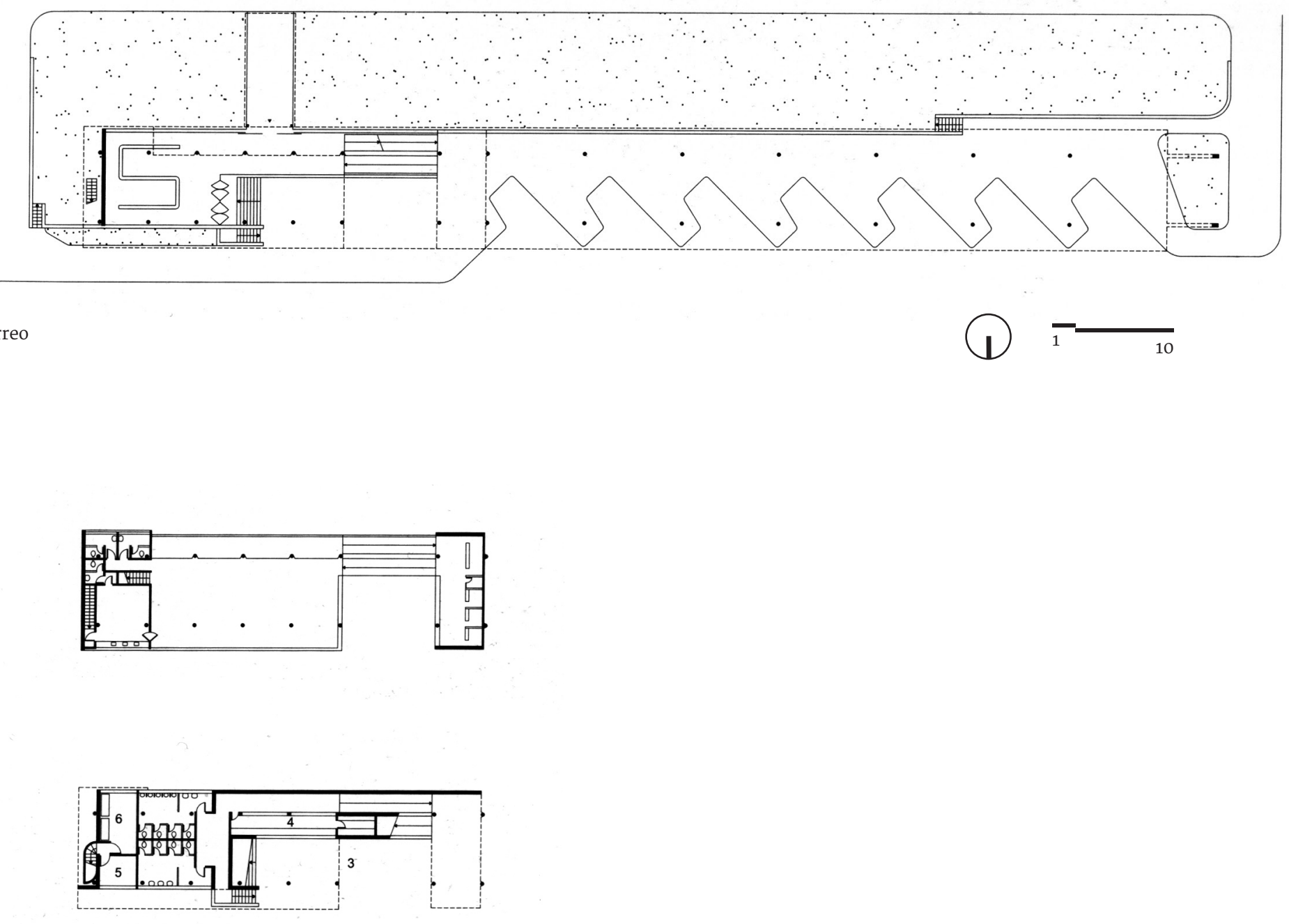

superior 

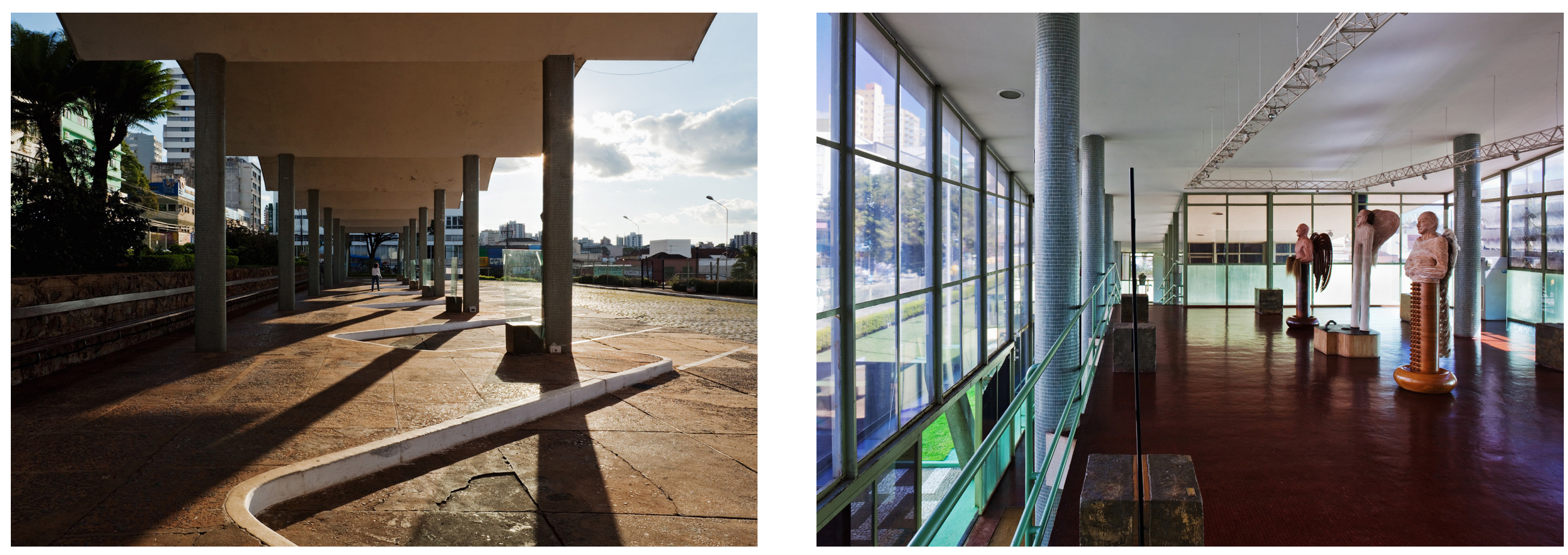


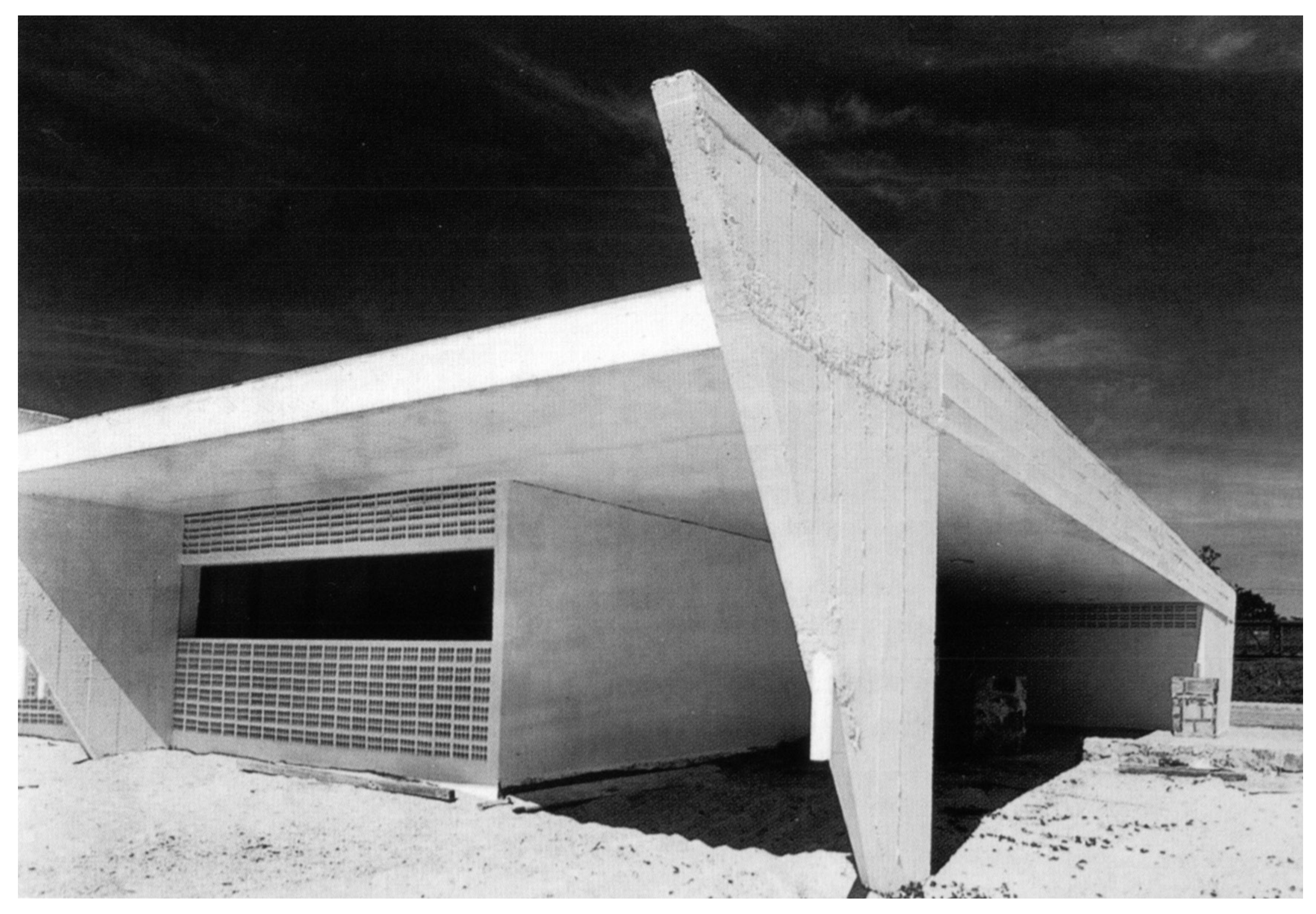




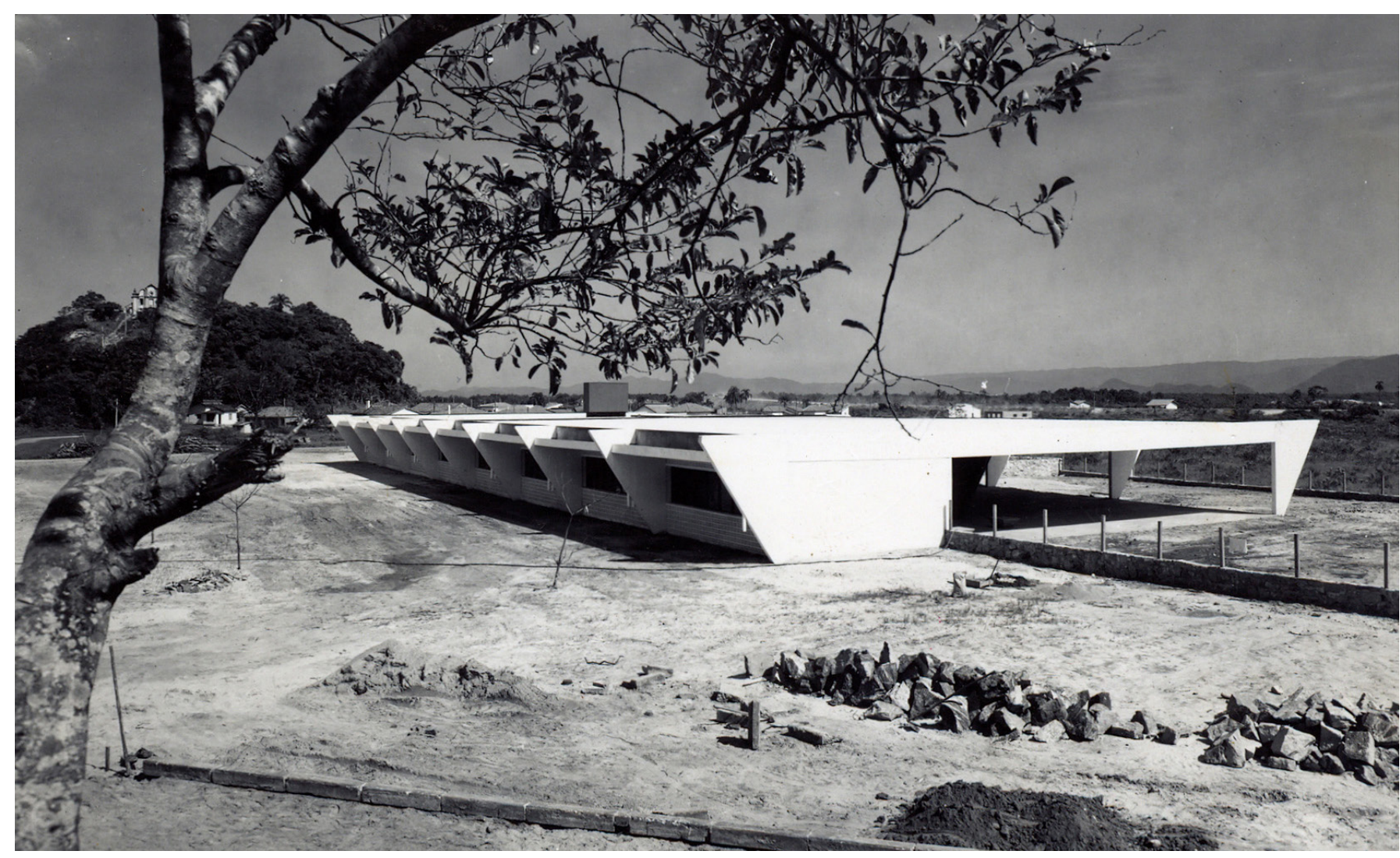
Escola em Itanhaém
1959

endereço Av Tiradentes Centro, Itanhaém - SP

projeto

Vilanova Artigas e Carlos Cascaldi

usO

ensino

cliente

Conesp

caractrísticas construção térrea

técnicas e materiais cobertura em concreto armado vedos em alvenaria
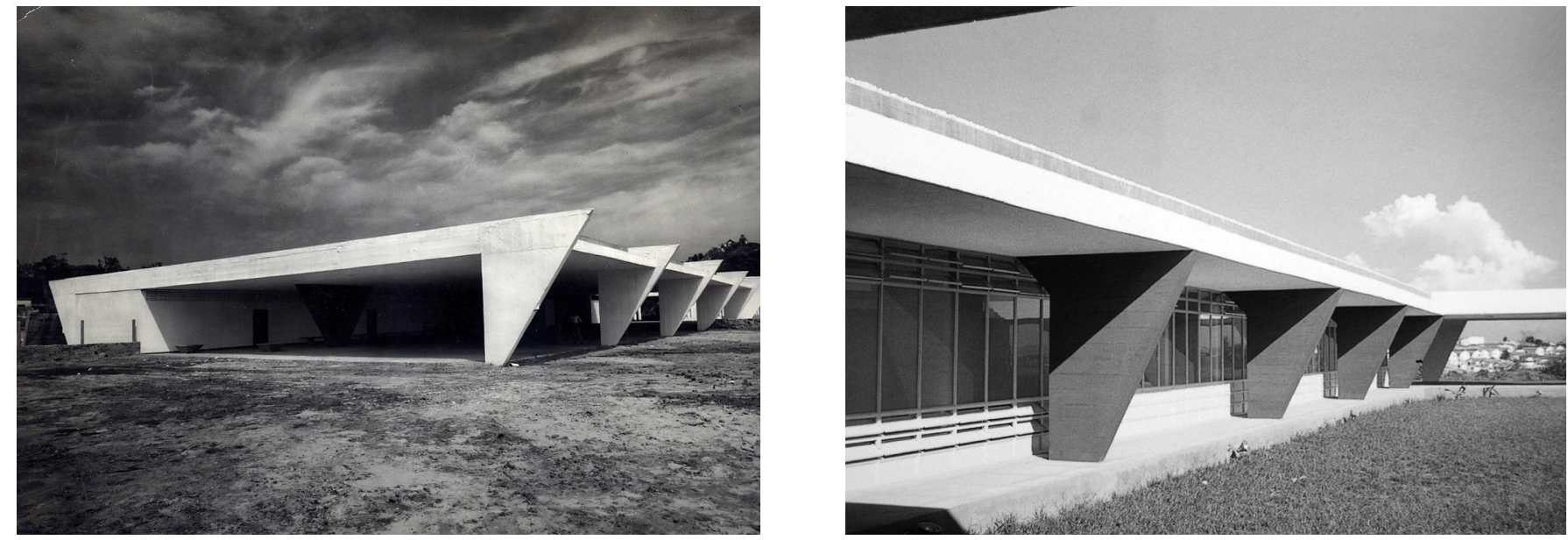

área

$1.400 \mathrm{~m}^{2}$ 

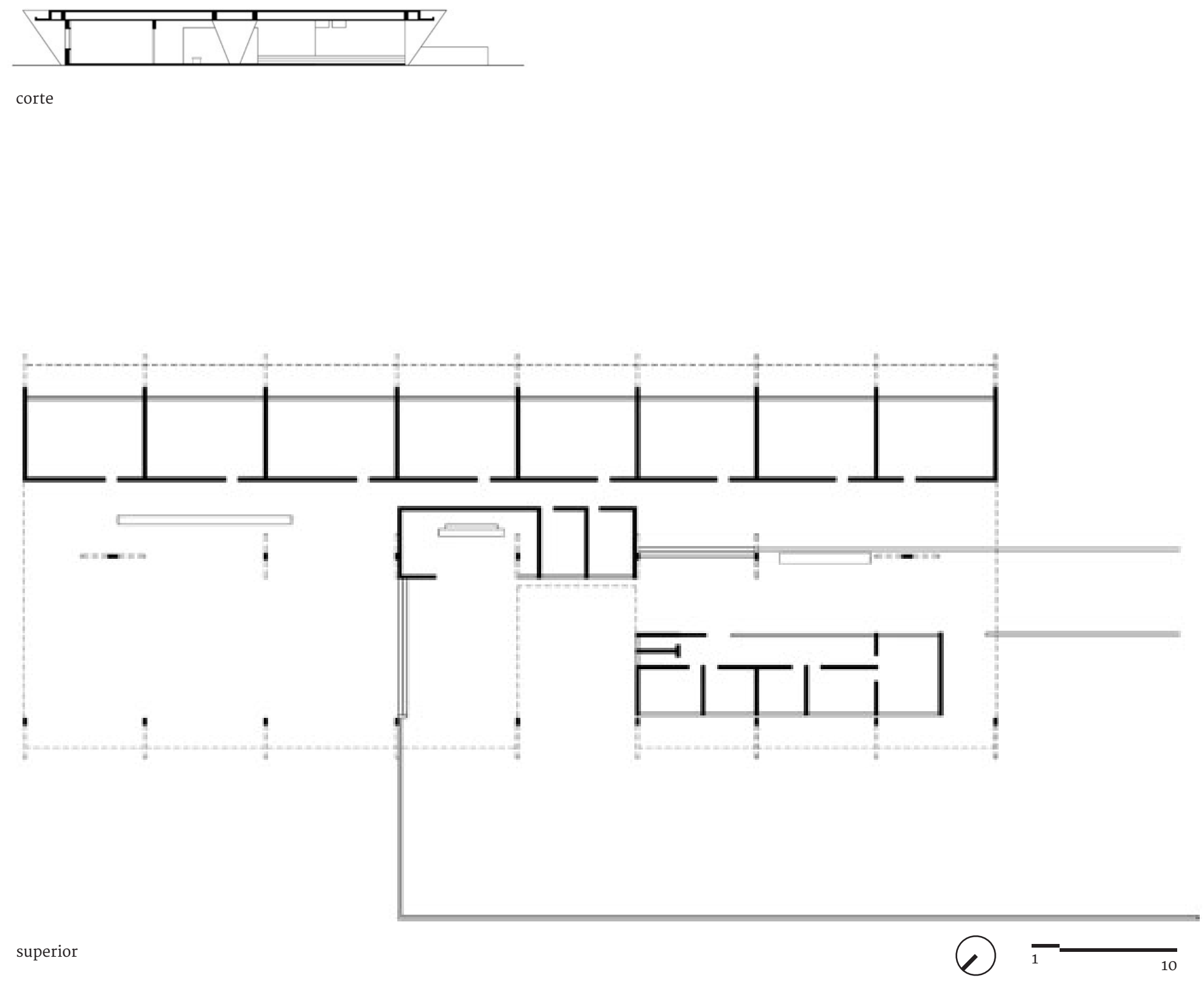

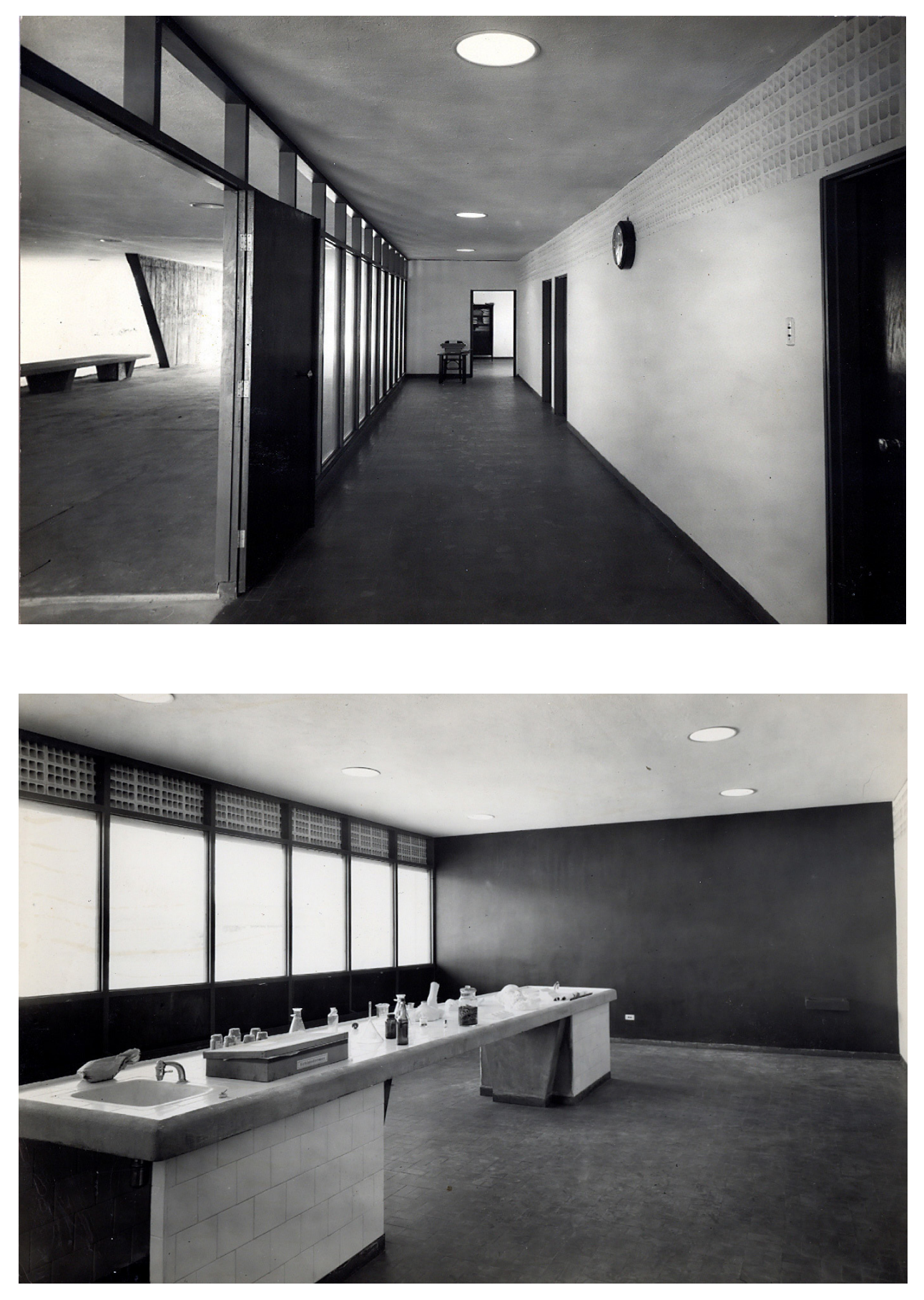


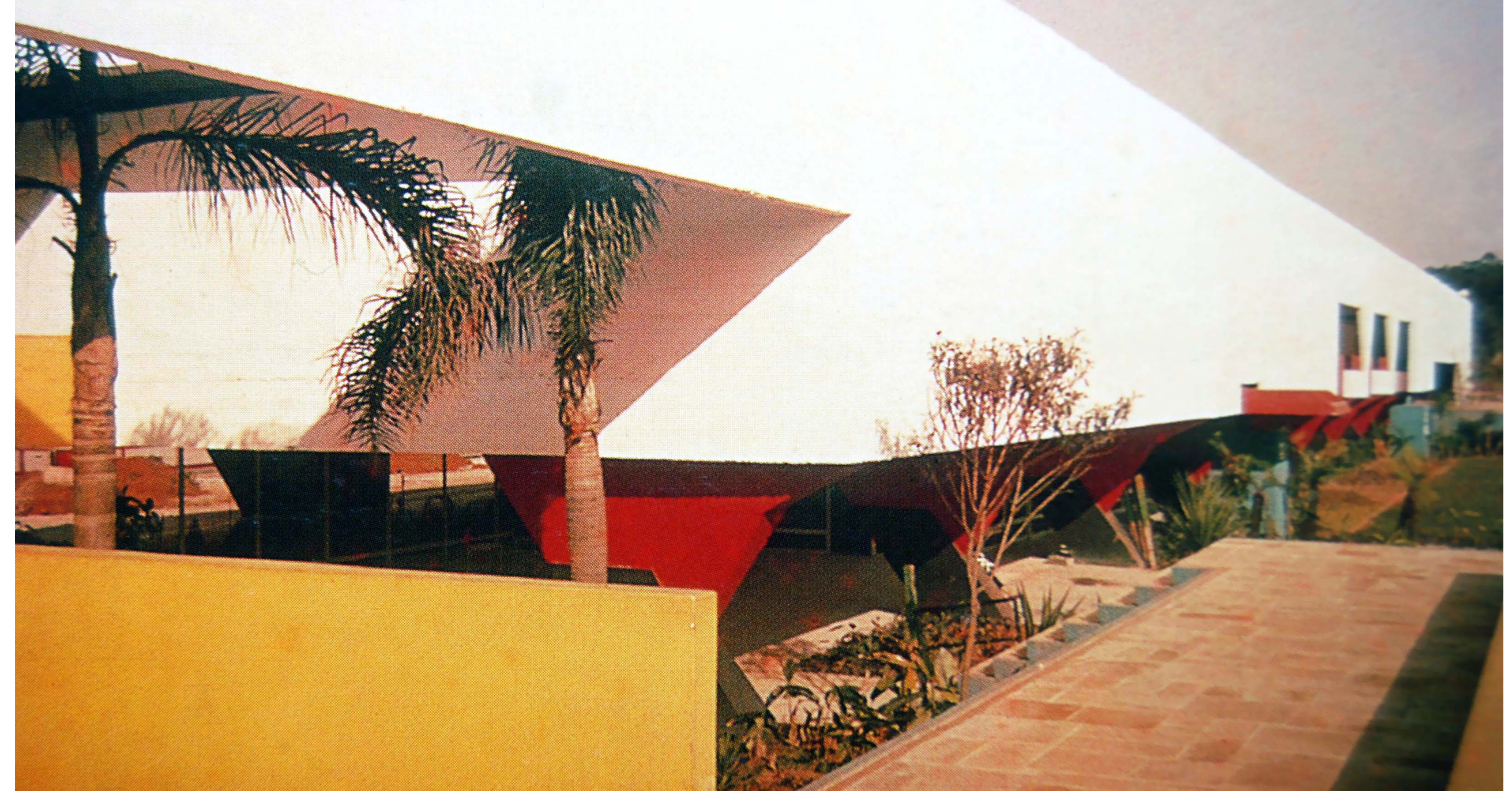




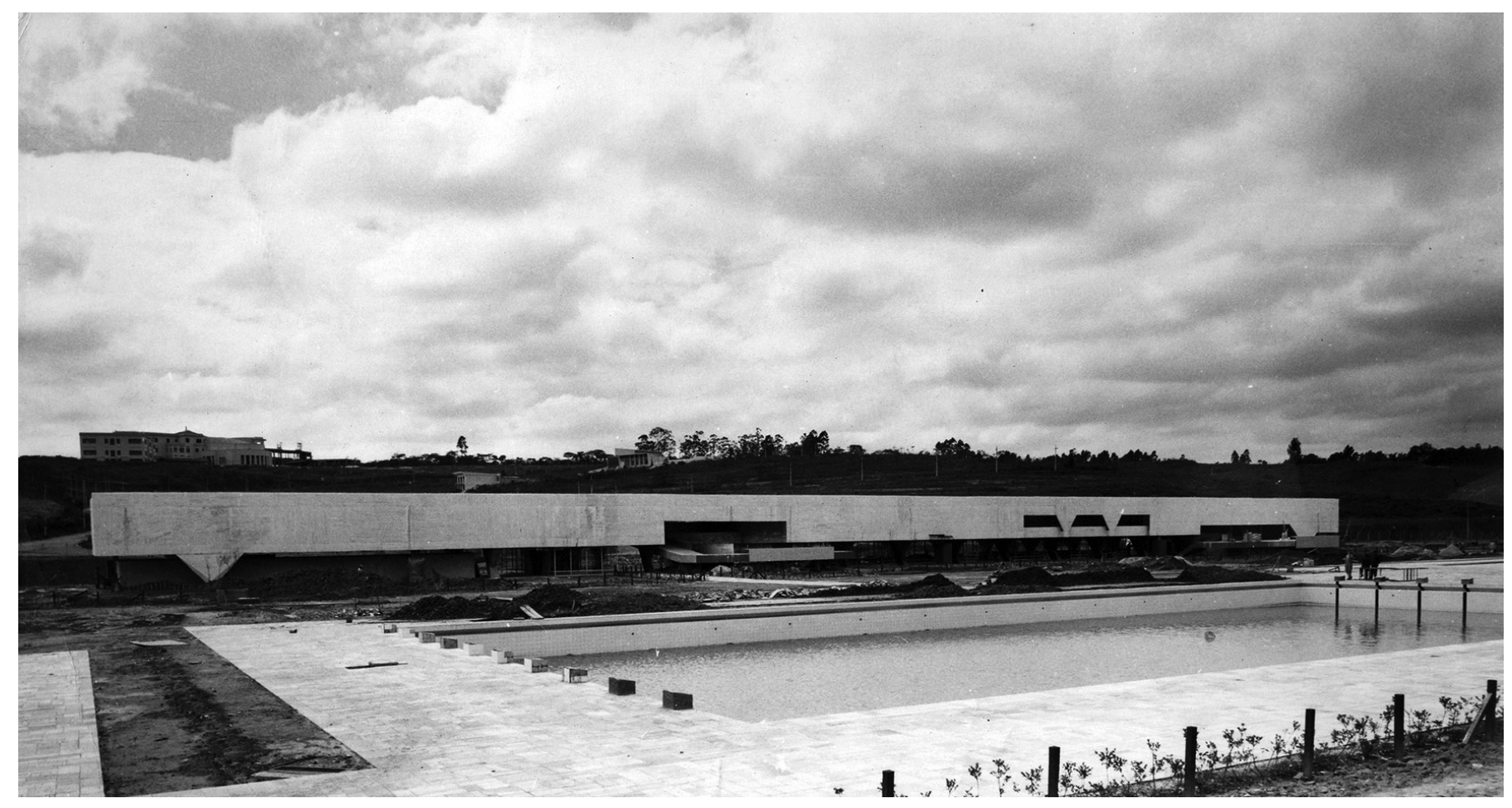

\section{Vestiários São Paulo Futebol Clube 1959}

endereço Av. Jules Rimet Morumbi, São Paulo - SP

projeto

Vilanova Artigas e Carlos Cascaldi

uso

esportivo

cliente São Paulo Futebol Clube

caractrísticas
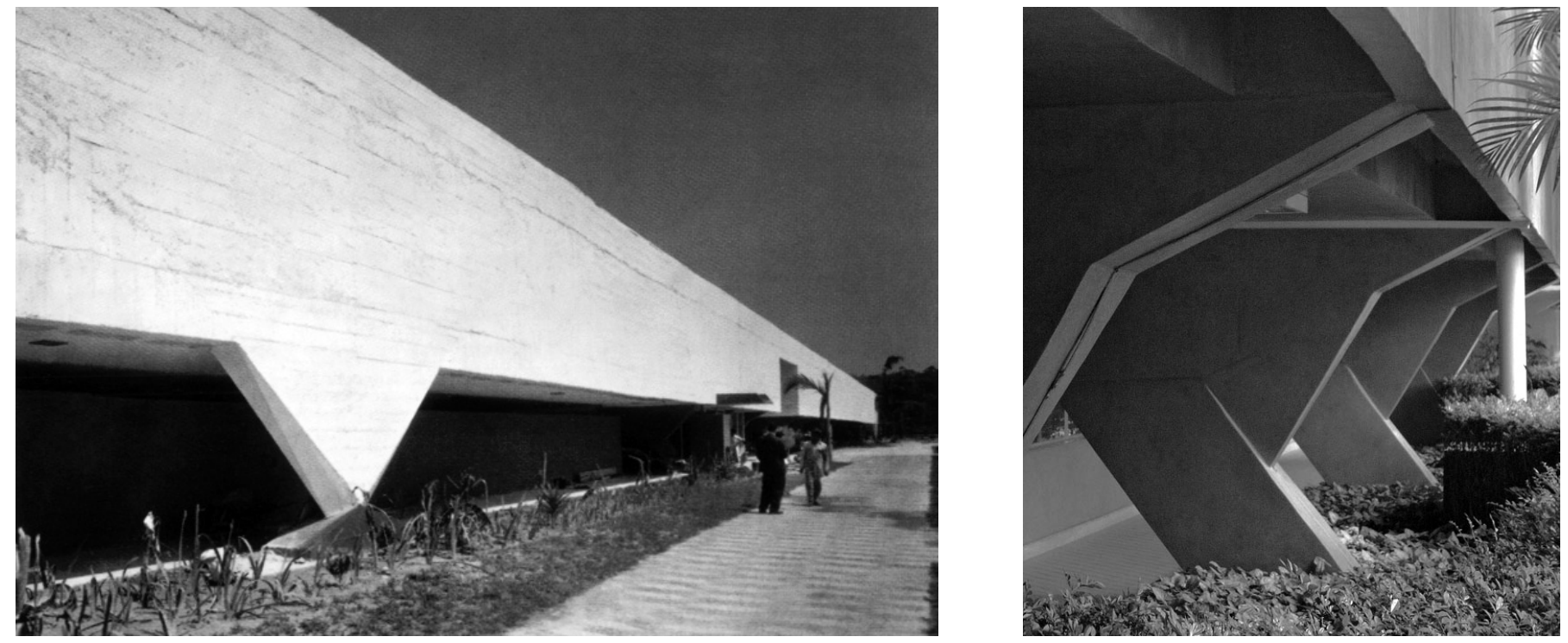

bloco elevado sobre pilotis

técnicas e materiais cobertura lajes em concreto armado 

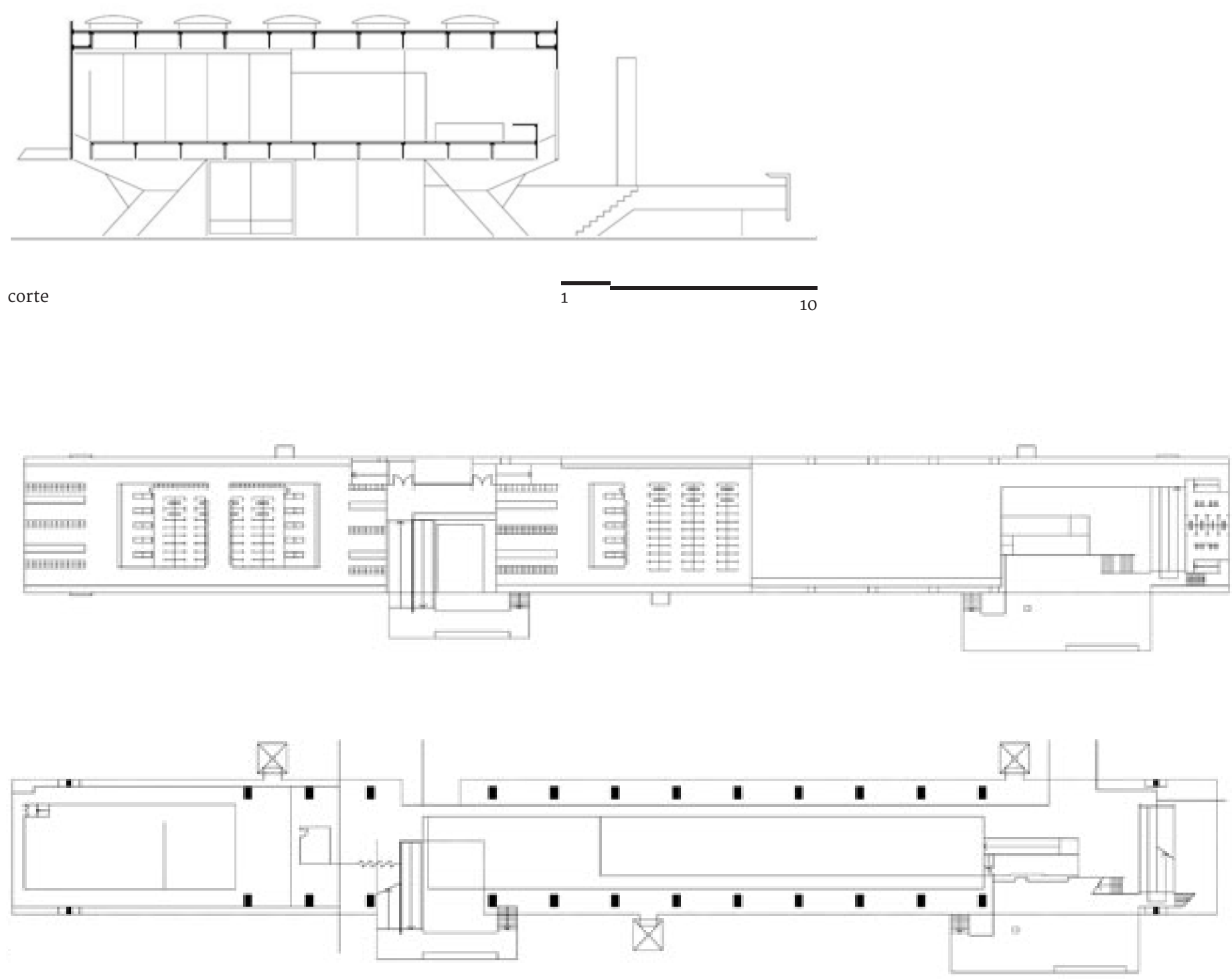

$\bigcirc \frac{-10}{1}$ 

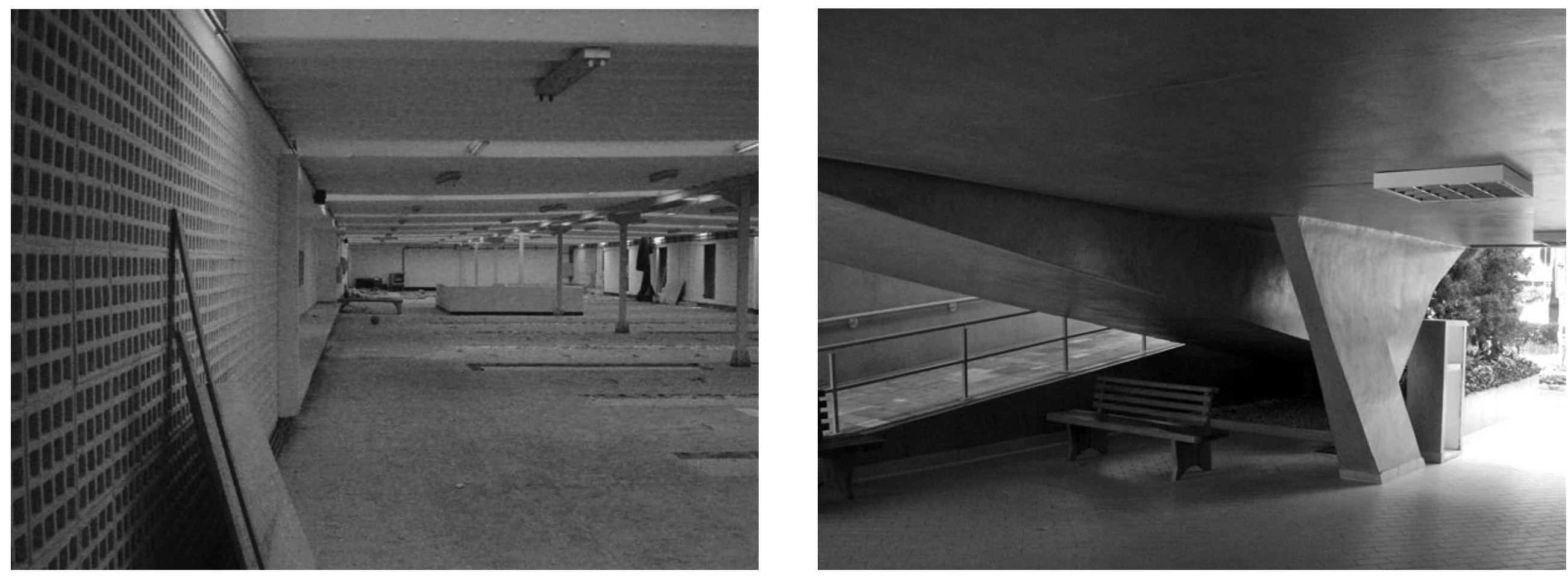


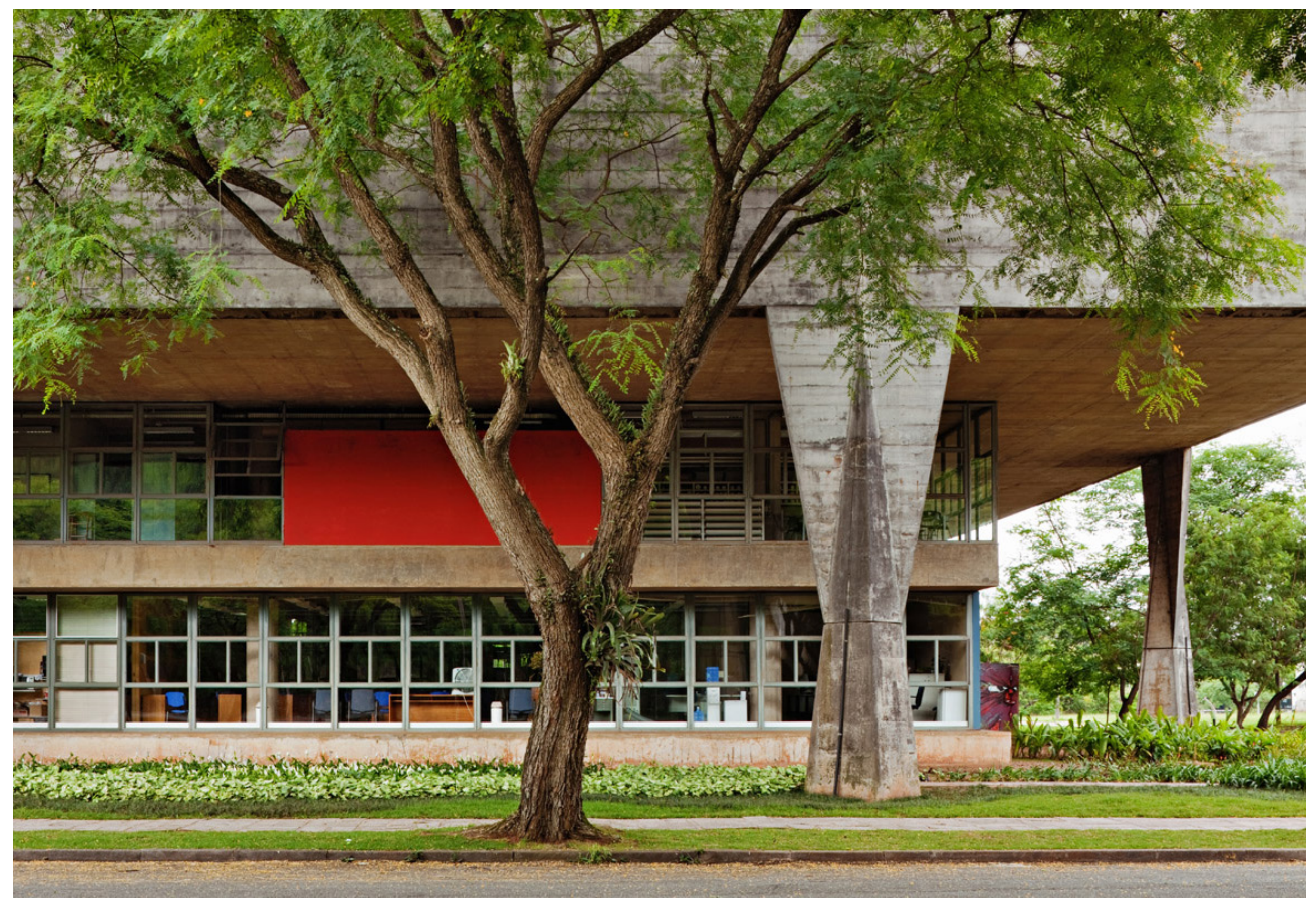




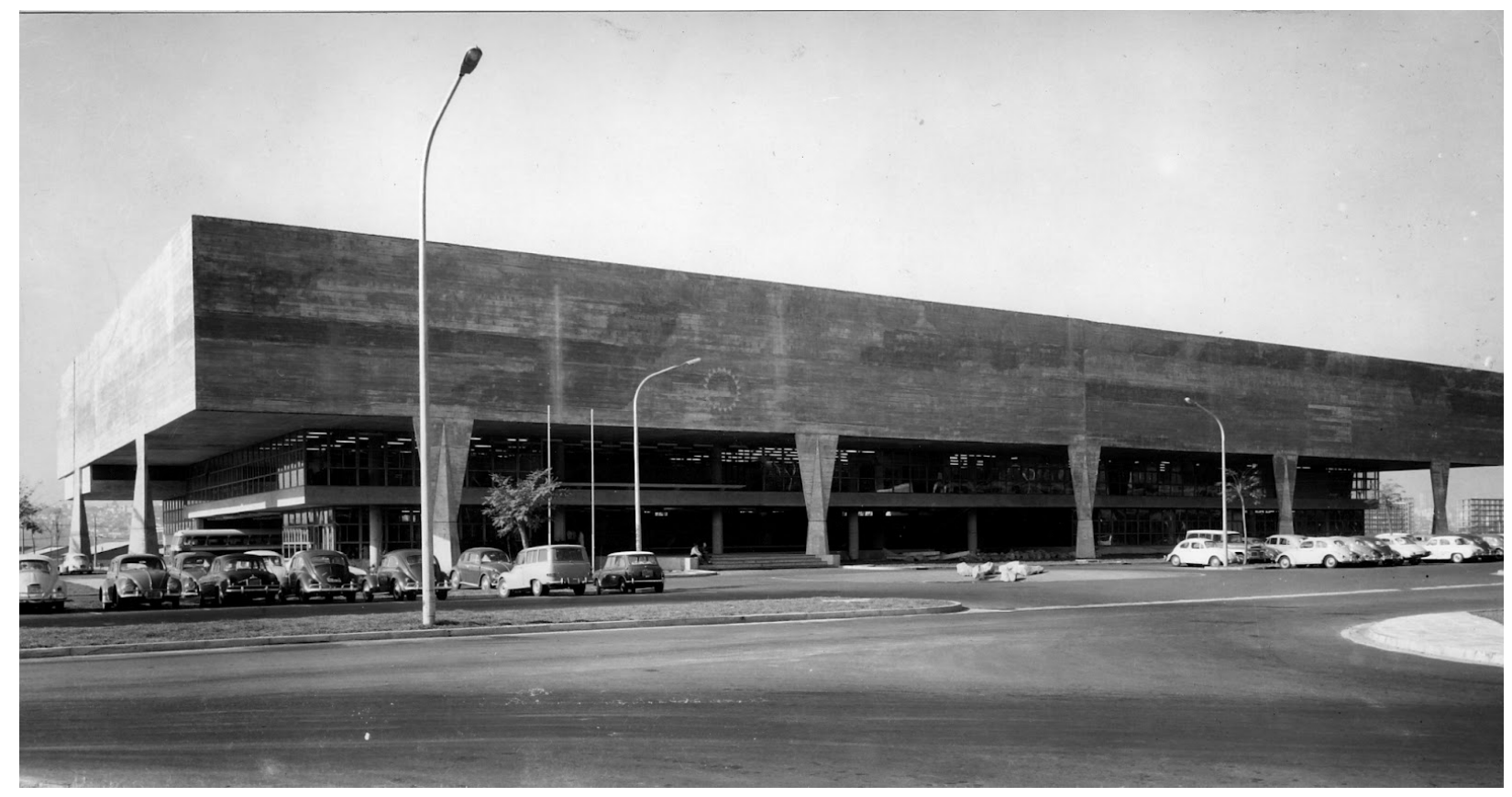

Faculdade de Arquitetura e Urbanismo - USP 1961

endereço

Rua do Lago, 876

CUASO - Cidade Universitária Armando de Sales Oliveira

São Paulo - SP

projeto

Vilanova Artigas e Carlos Cascaldi

institucional/didá

uso

cliente

Universidade de São Paulo

caractrísticas
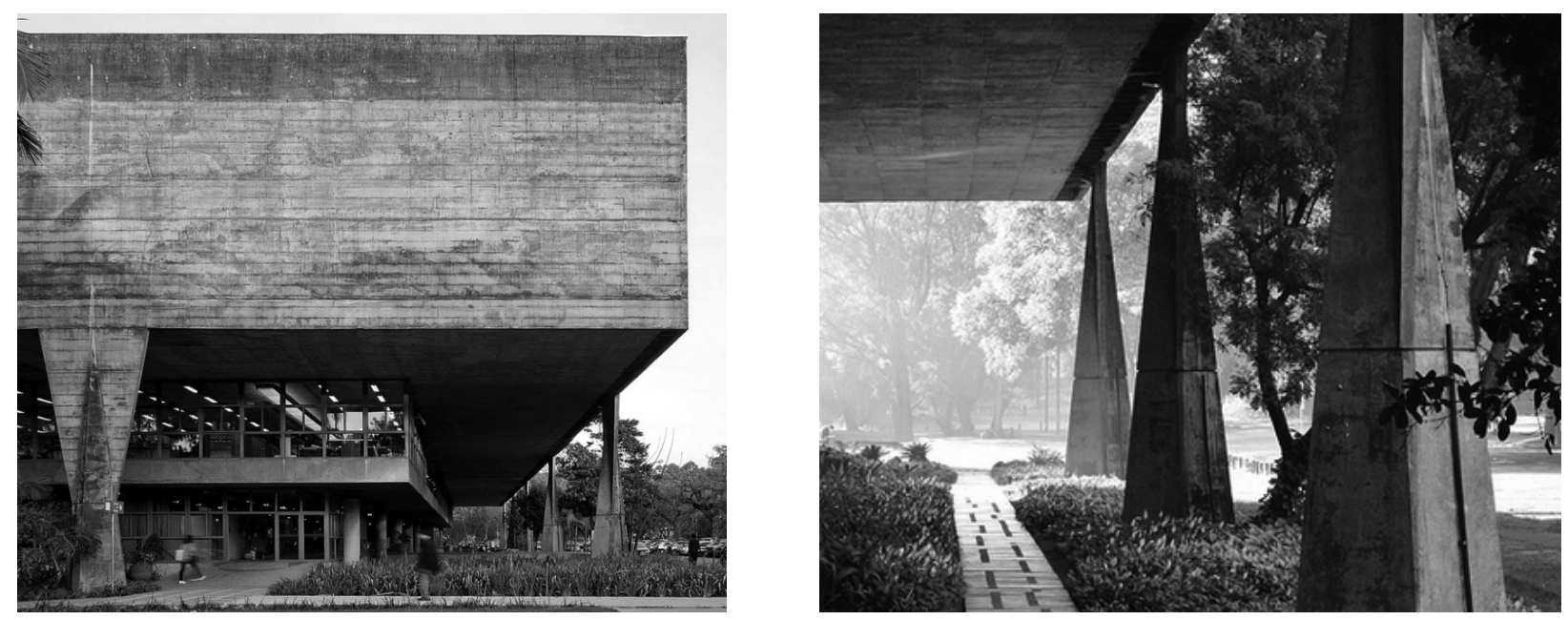

edifício em 9 pavimentos dispostos em meios-níveis

técnicas e materiais estrutura em concreto armado cobertura em grelha de concreto e elementos translúcidos grandes panos envidraçados

área $18.600 \mathrm{~m}^{2}$ 


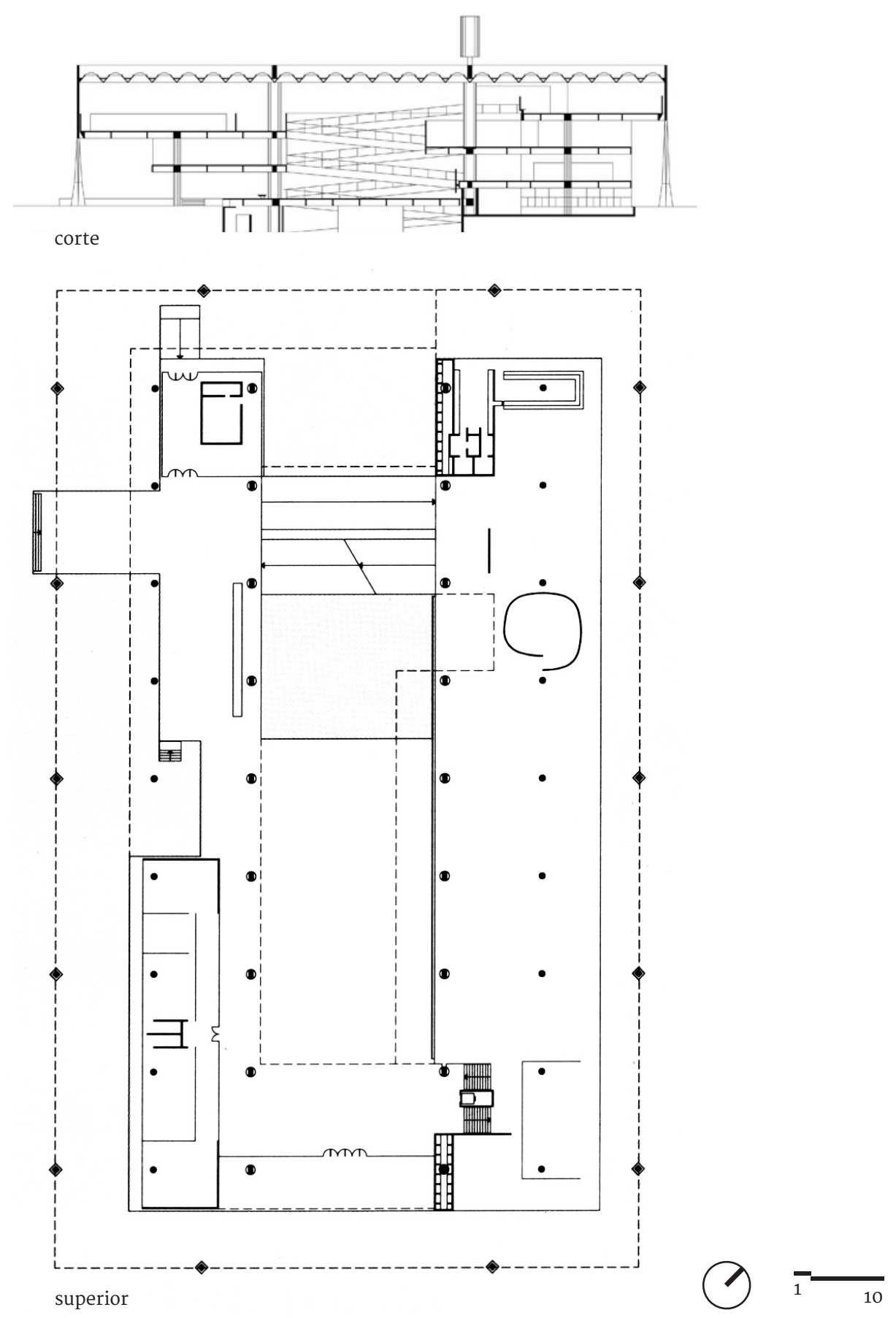



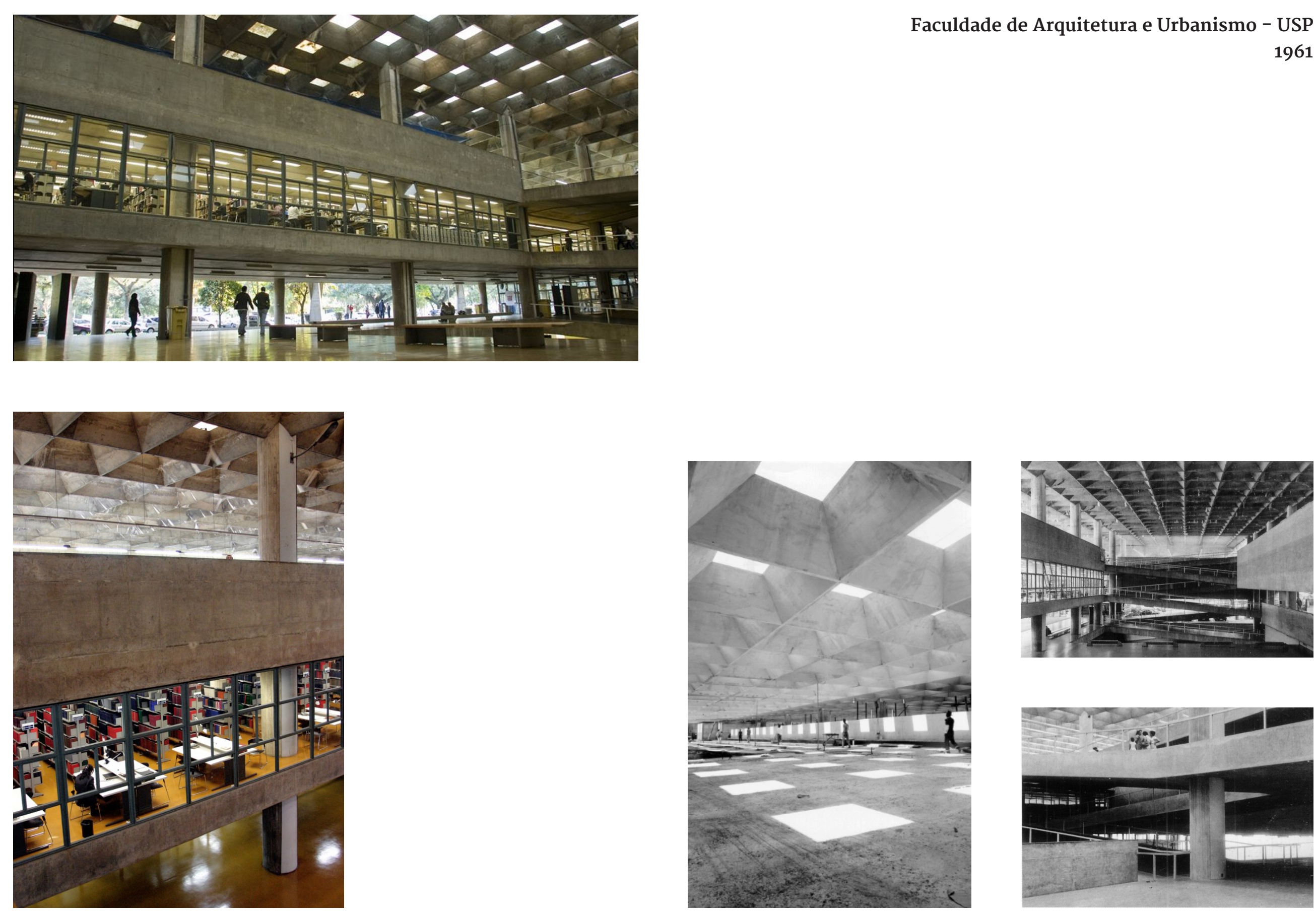


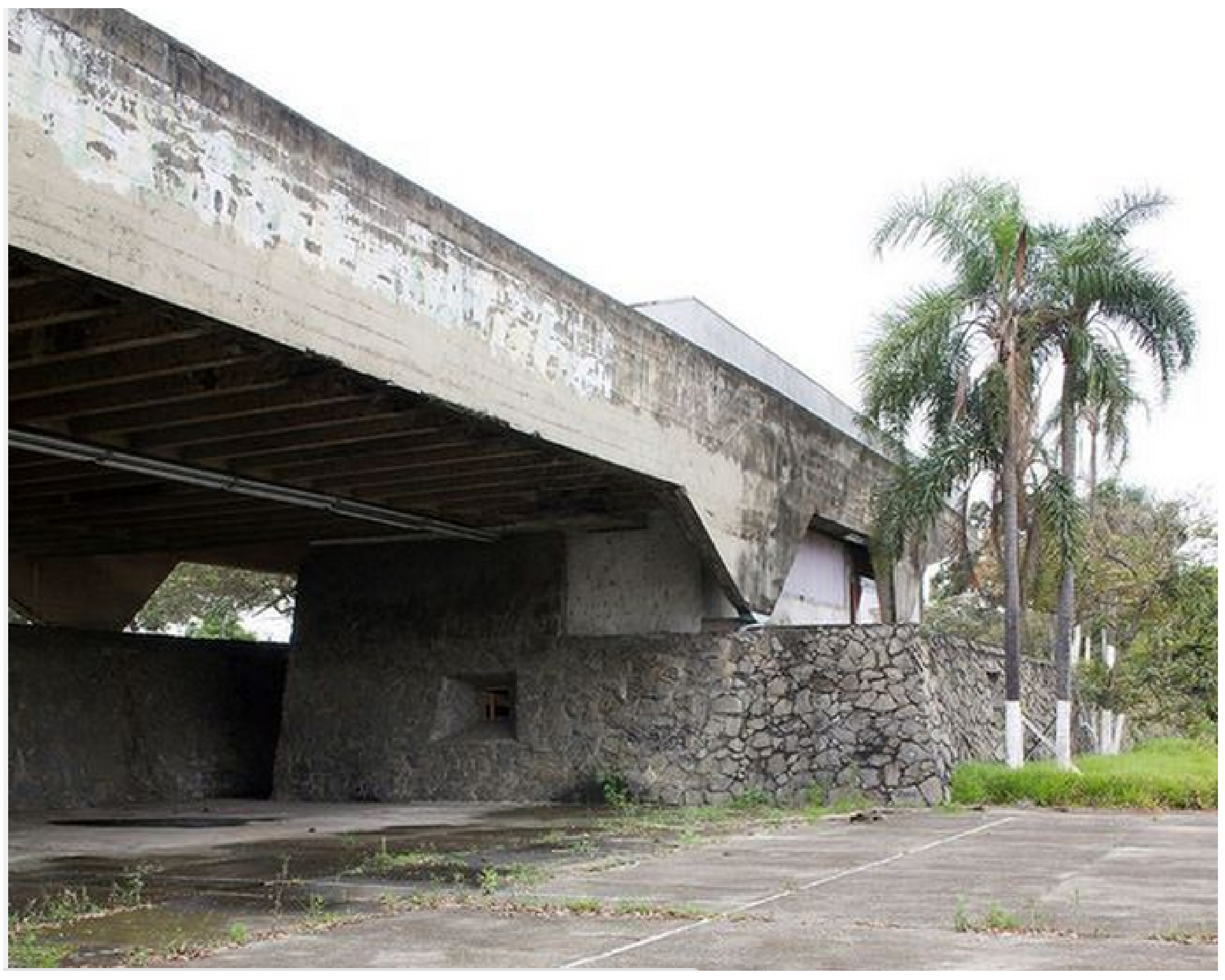




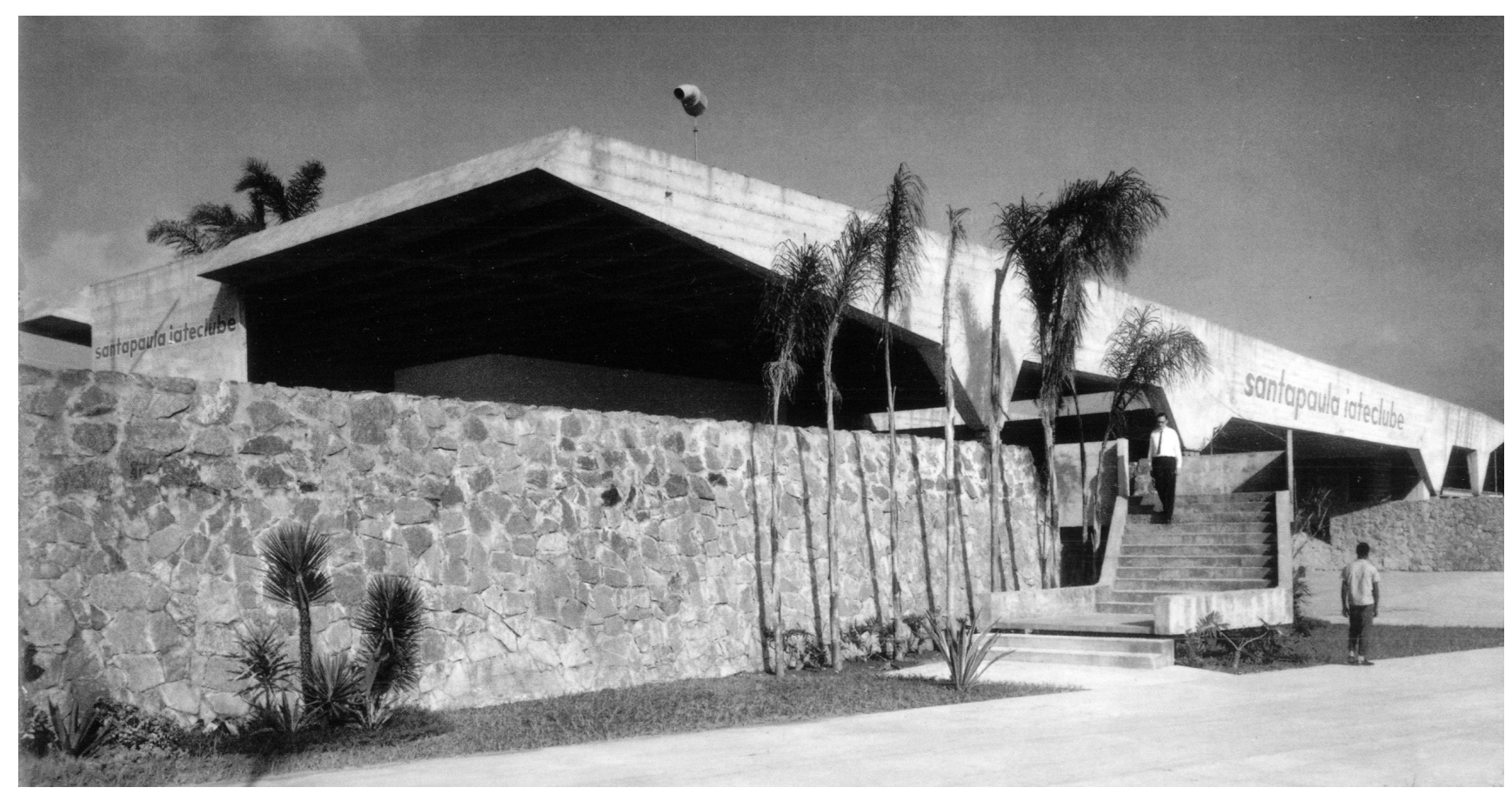

Garagem de Barcos Santa Paula Iate Clube 1961

endereço Av. Robert Kennedy, 4901 Interlagos, São Paulo - SP

projeto

Vilanova Artigas e Carlos Cascaldi

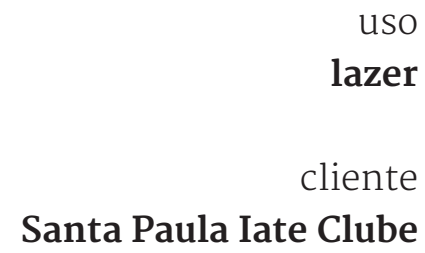

Santa Paula Iate Clube

caractrísticas
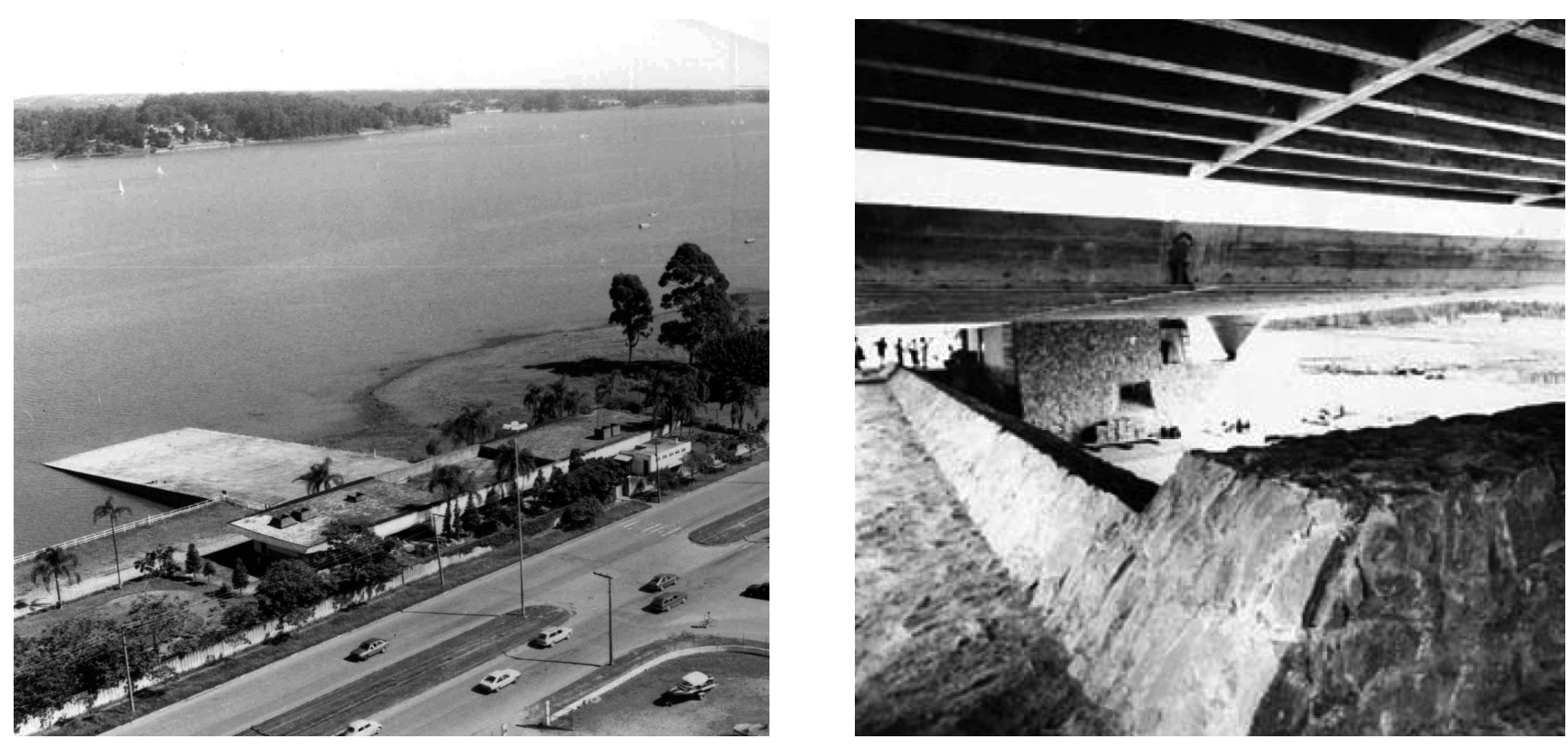

técnicas e materiais

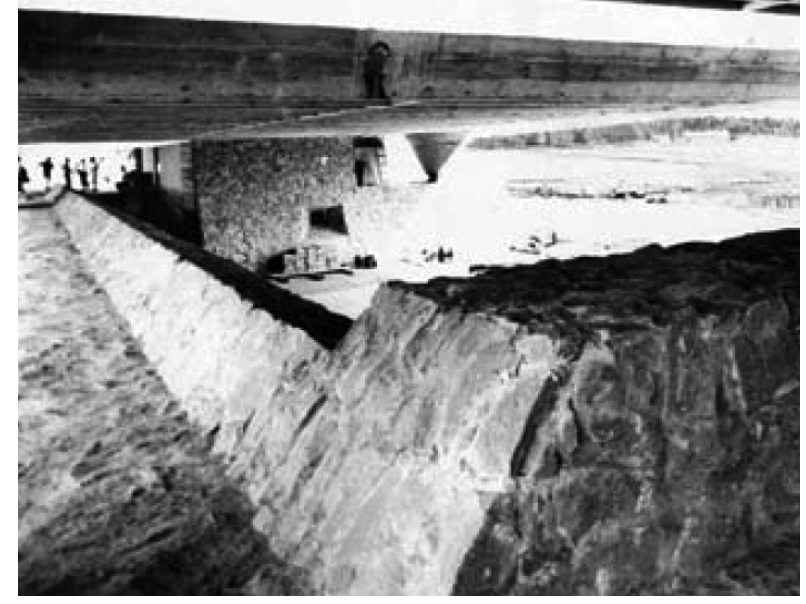

pórtico de cobertura em concreto alvenaria de pedra

área

$1.580 \mathrm{~m}^{2}$ 


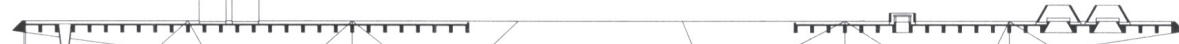

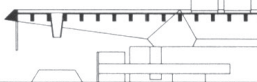

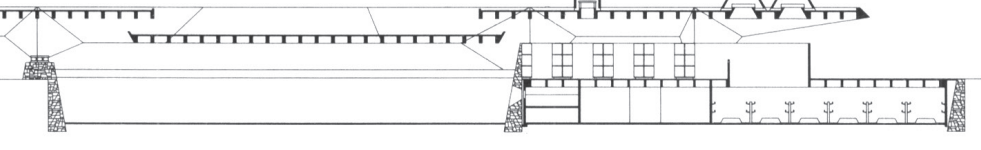

$$
\text { त का }
$$

corte
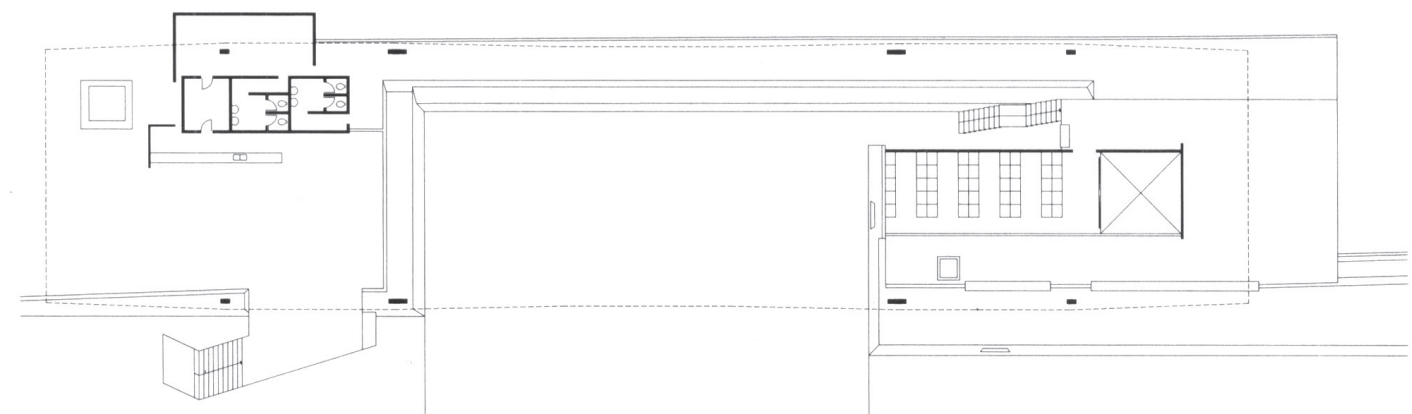

superior

()

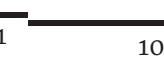



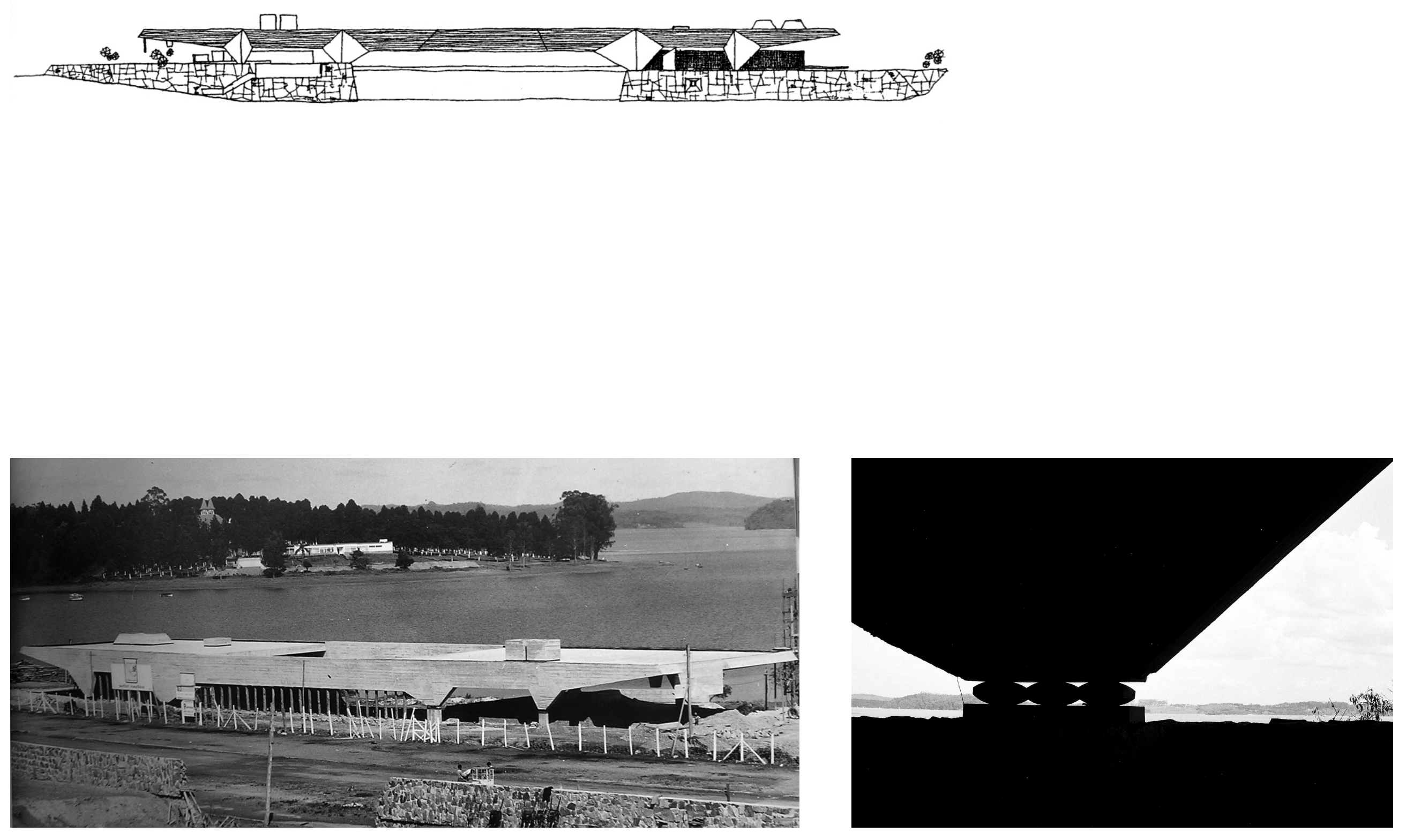


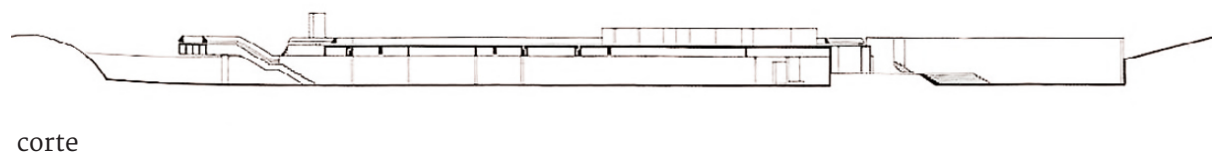

corte

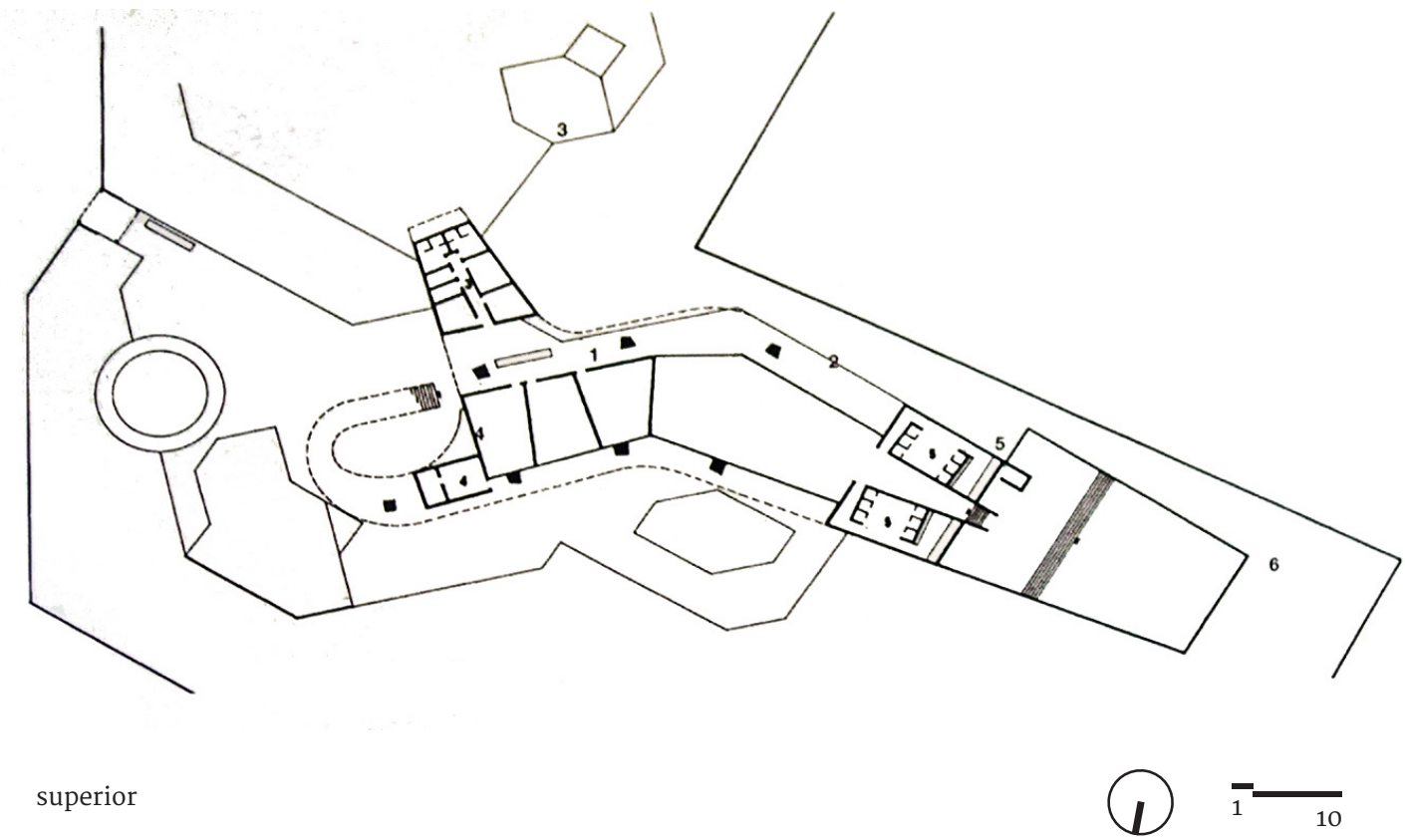




\section{Escola Vila Alpina \\ 1970}

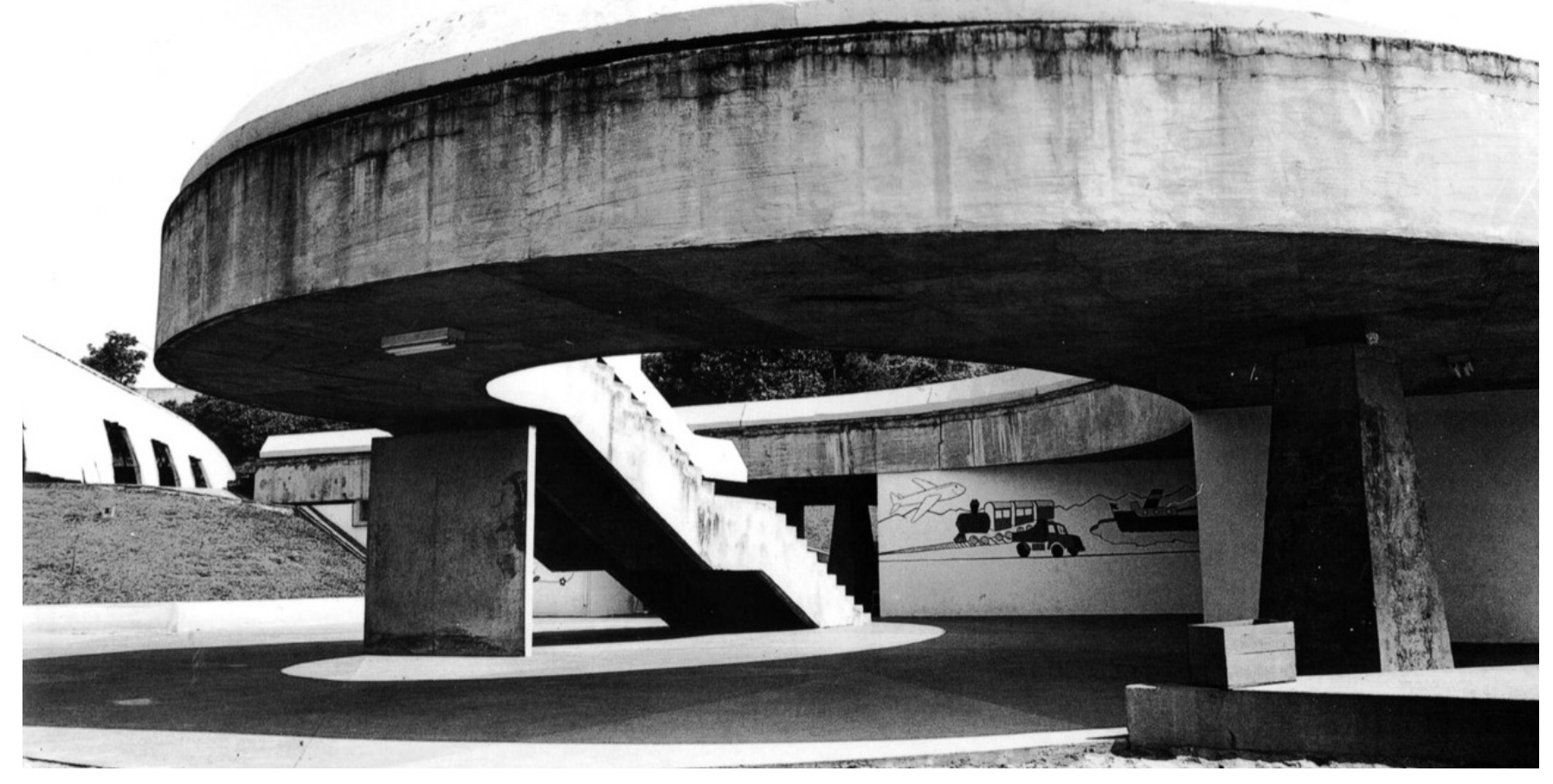

endereço Rua João Fernandes, s/n Santo André-SP

projeto Vilanova Artigas

uso educacional

cliente

Prefeitura de Santo André

caractrísticas

Escola infantil experimental
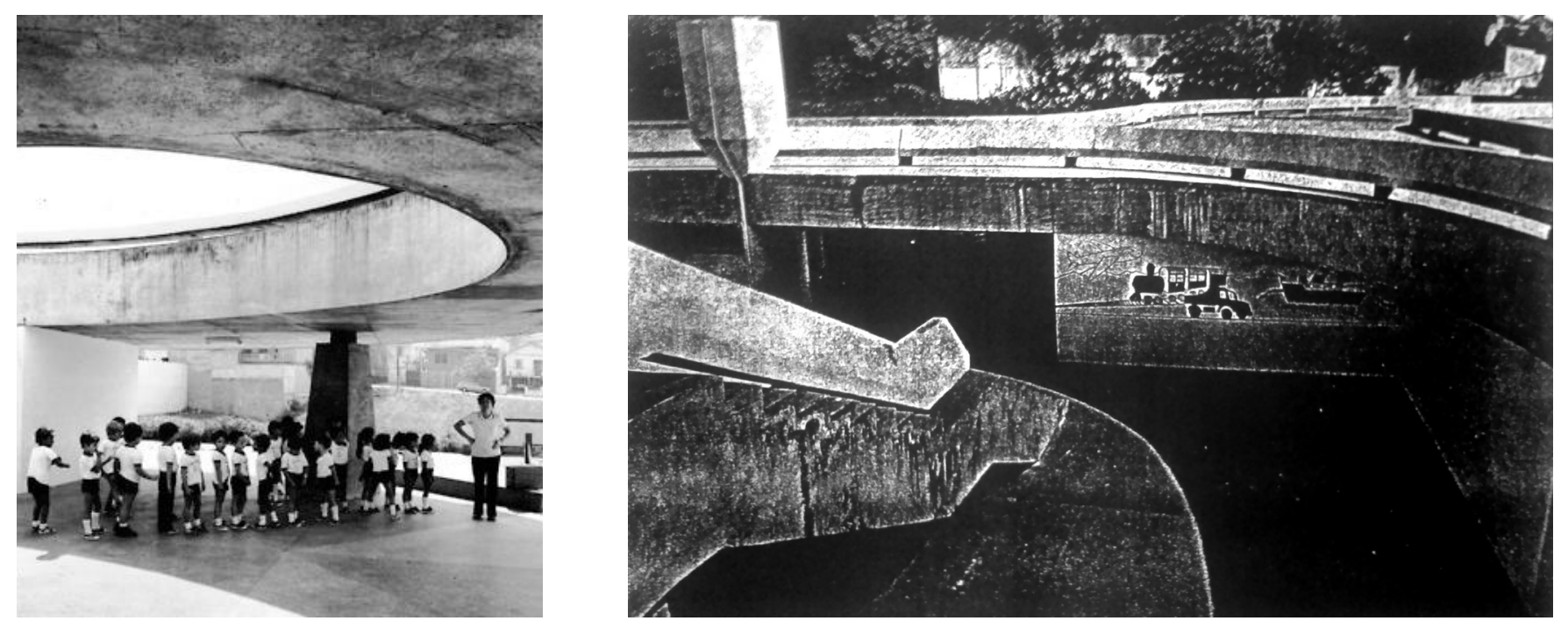

técnicas e materiais cobertura lajes em concreto armado alvenaria revestida

área $1.230 \mathrm{~m}^{2}$ 


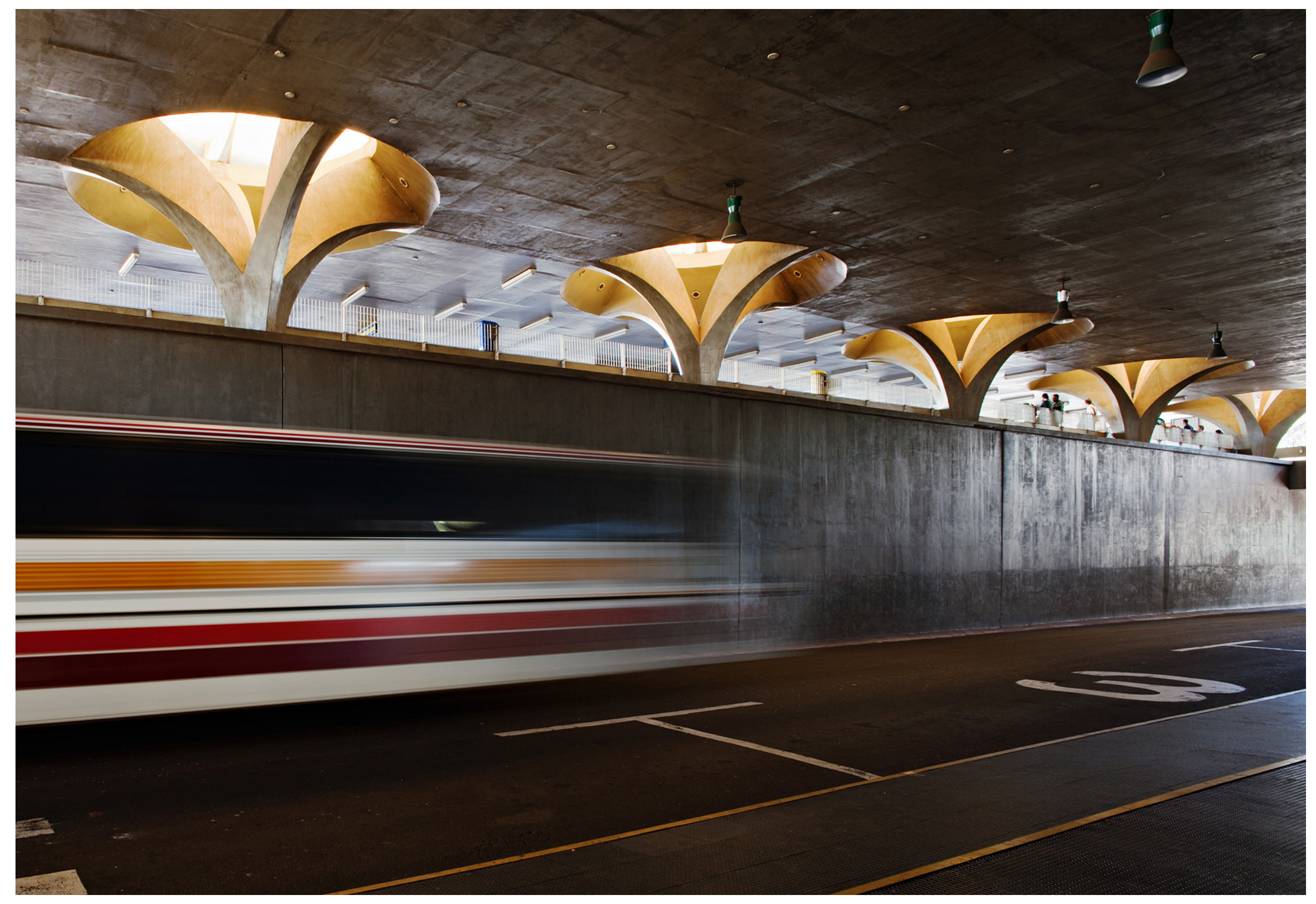




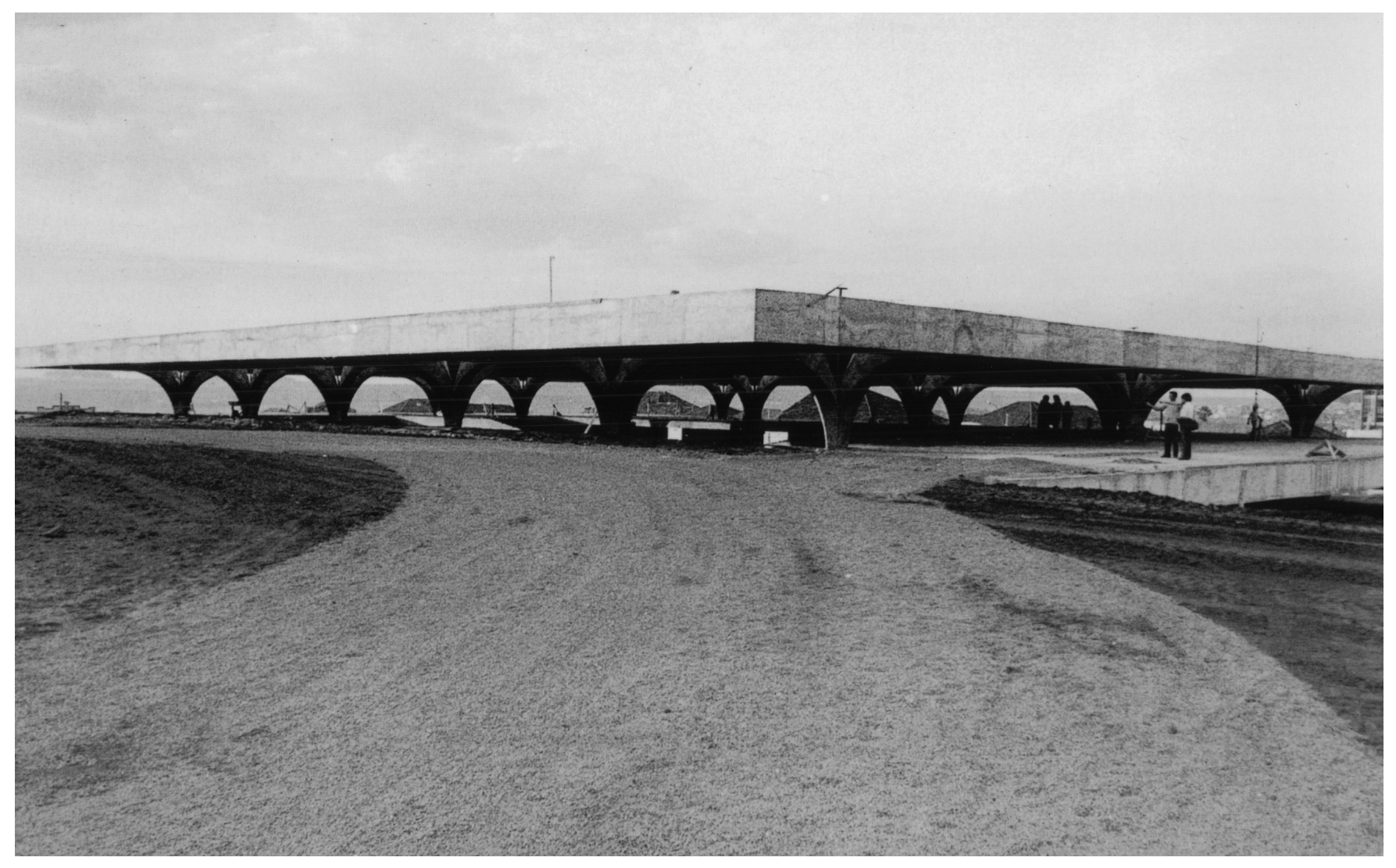

\section{Rodoviária de Jaú} 1973

endereço R Humaitá, 499 Centro, Jaú - SP

projeto

Vilanova Artigas e Carlos Cascaldi

USO

transporte

cliente

Prefeitura de Jaú

caractrísticas

centro náutico e restaurante

técnicas e materiais
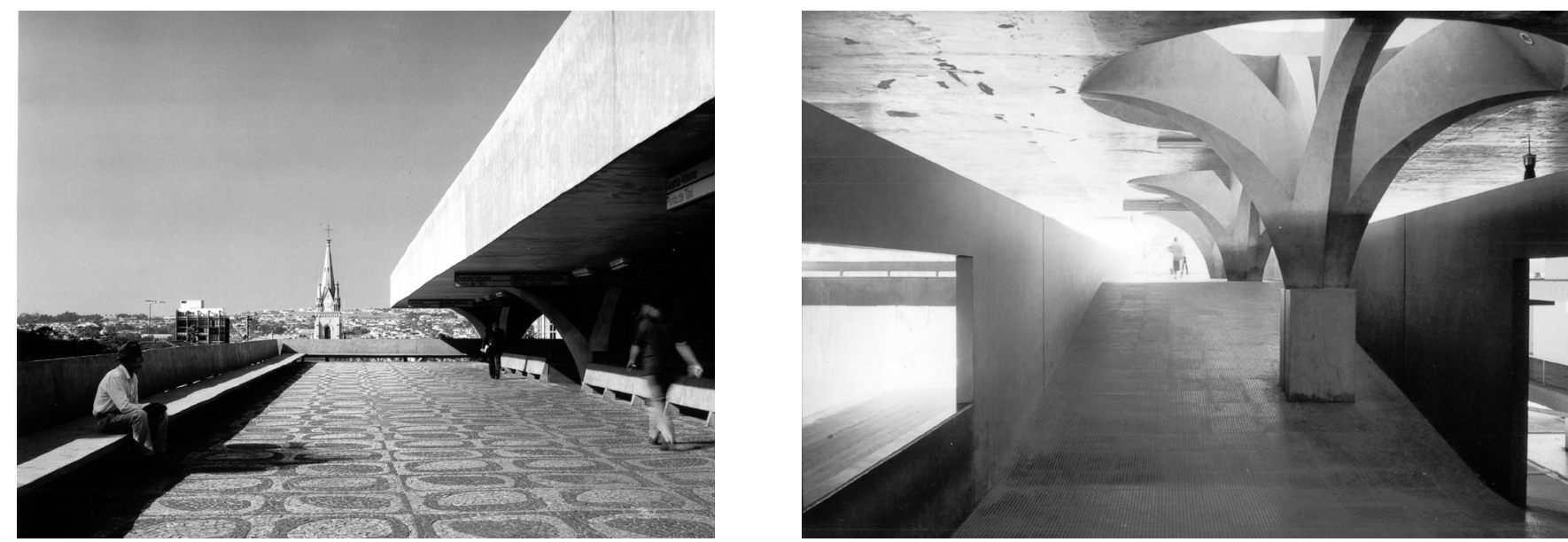

cobertura lajes em concreto armado alvenaria revestida

área $9.300 \mathrm{~m}^{2}$ 

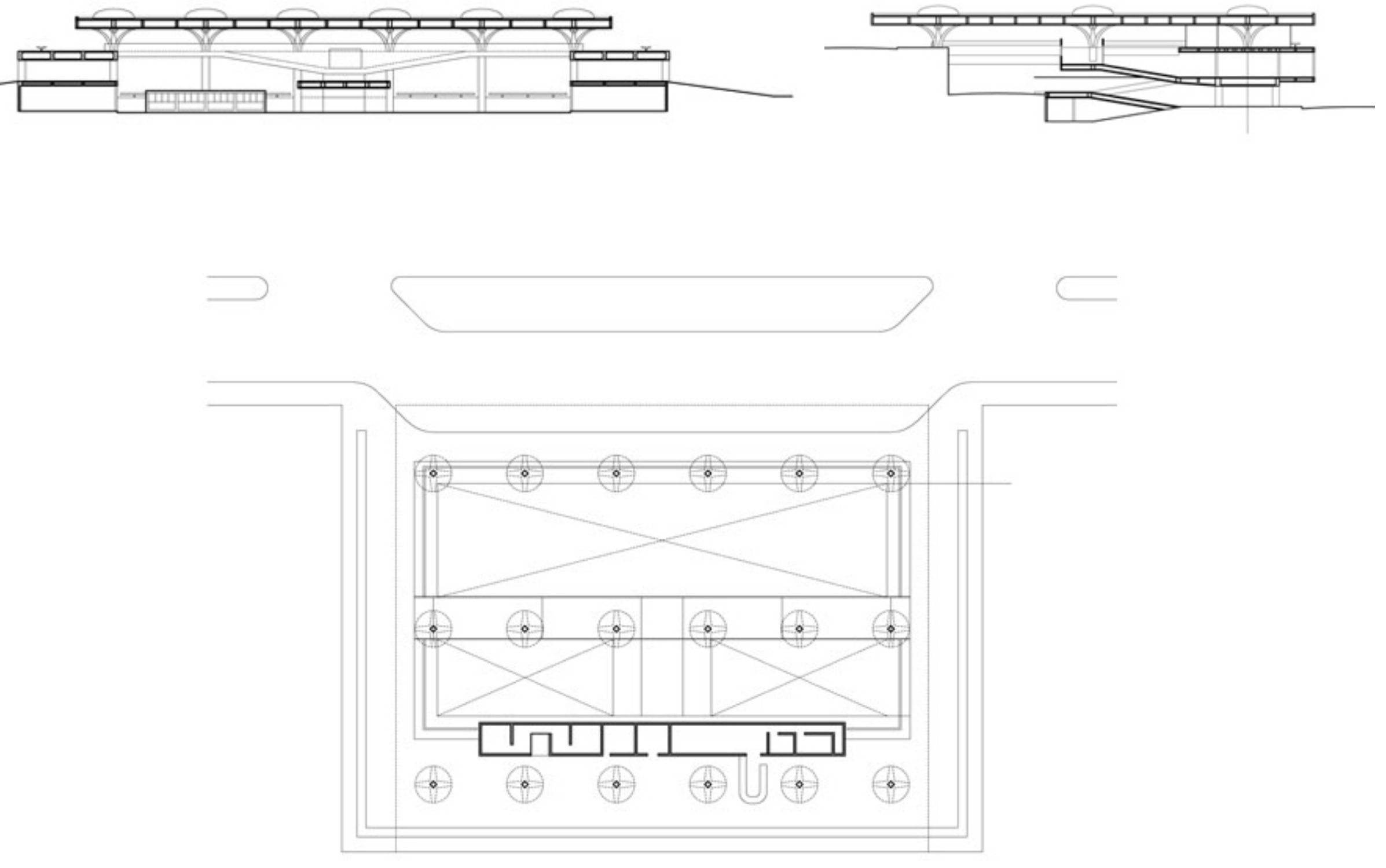

Q -5 

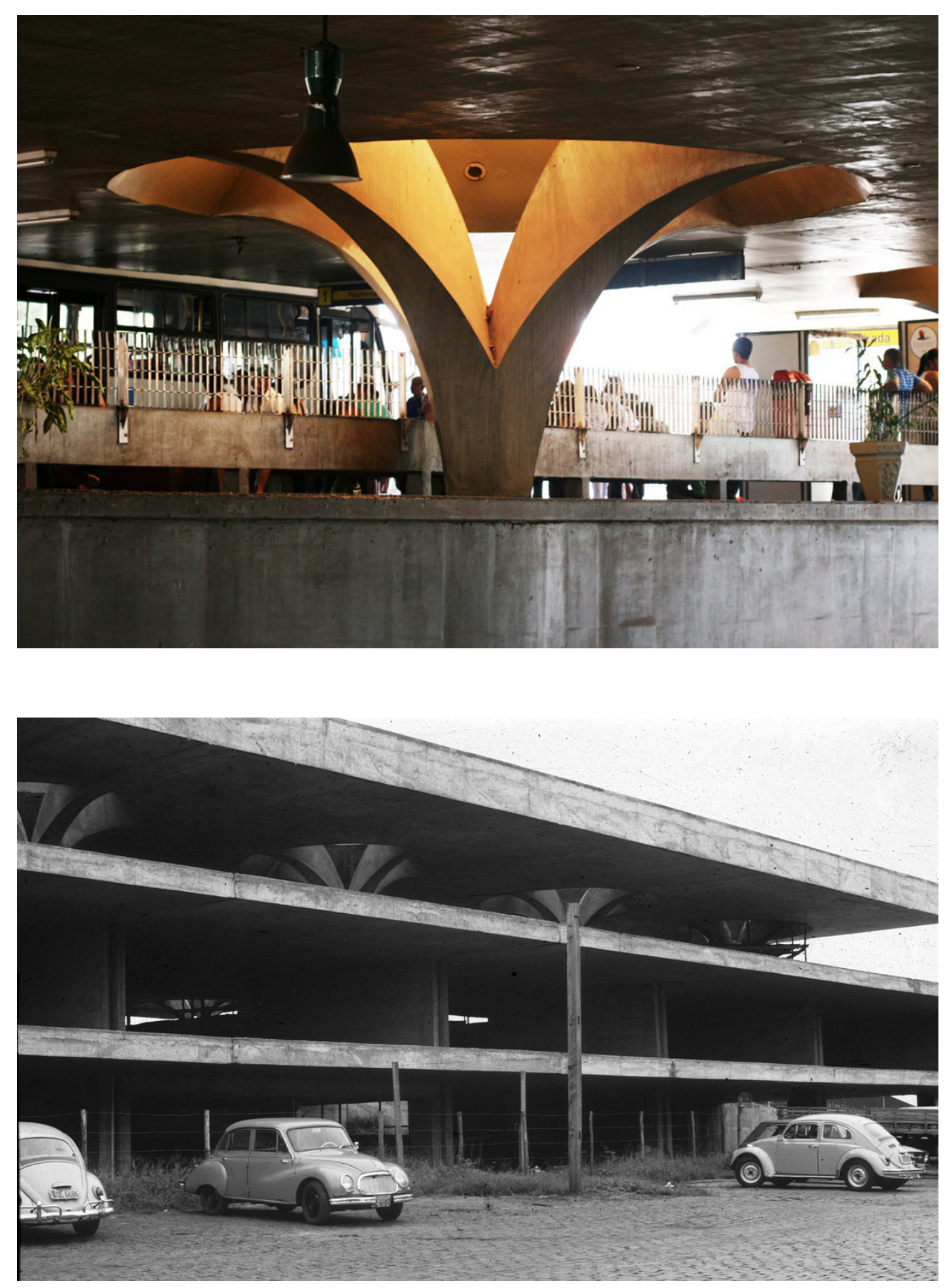


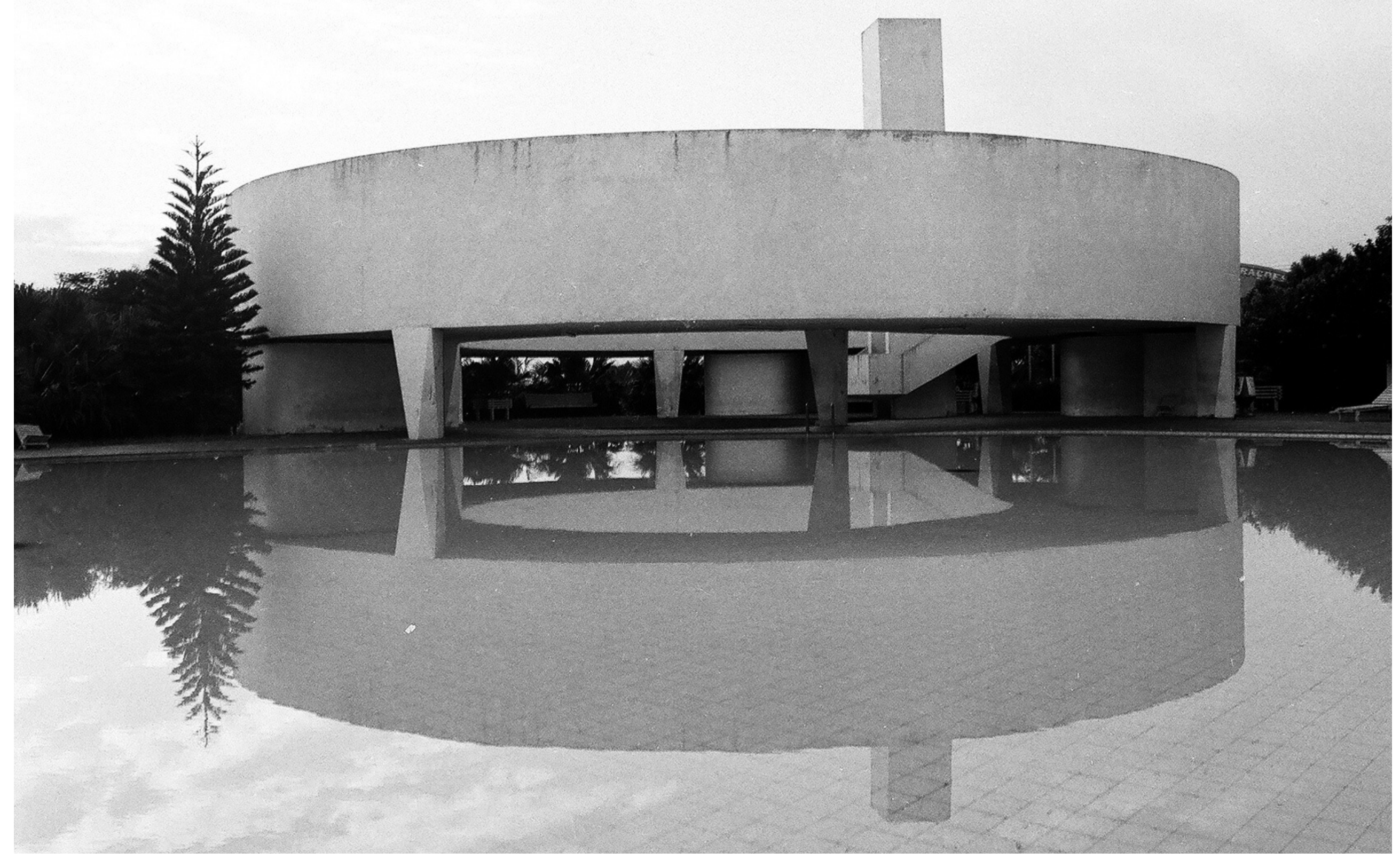




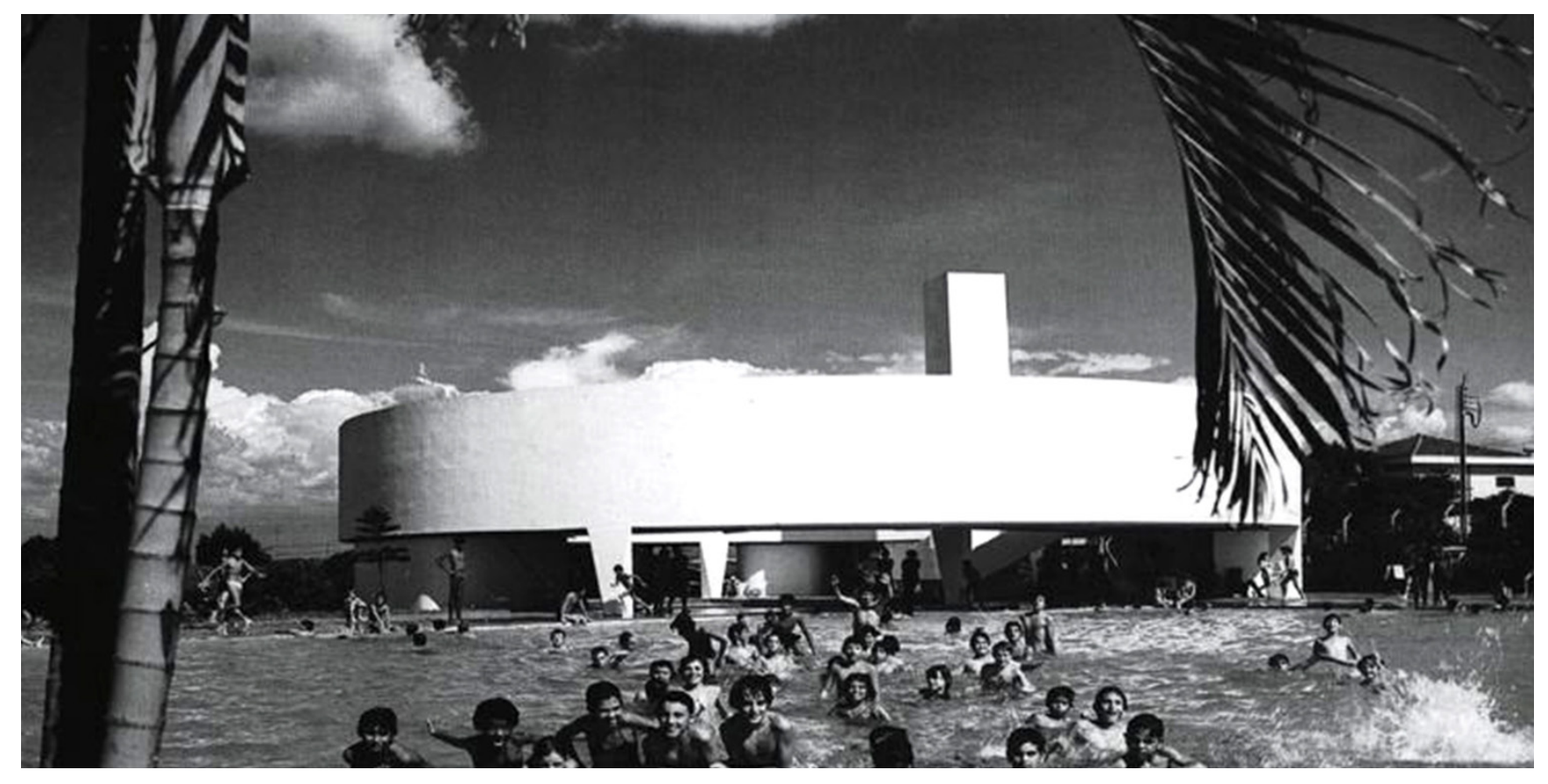

\section{Balneário de Jaú 1974}

endereço

Rua Vinte e Quatro de Maio, 1965 Vila Nova Jaú, Jaú - SP

projeto Vilanova Artigas

uso lazer Prefeitura de Jaú

caractrísticas balneário
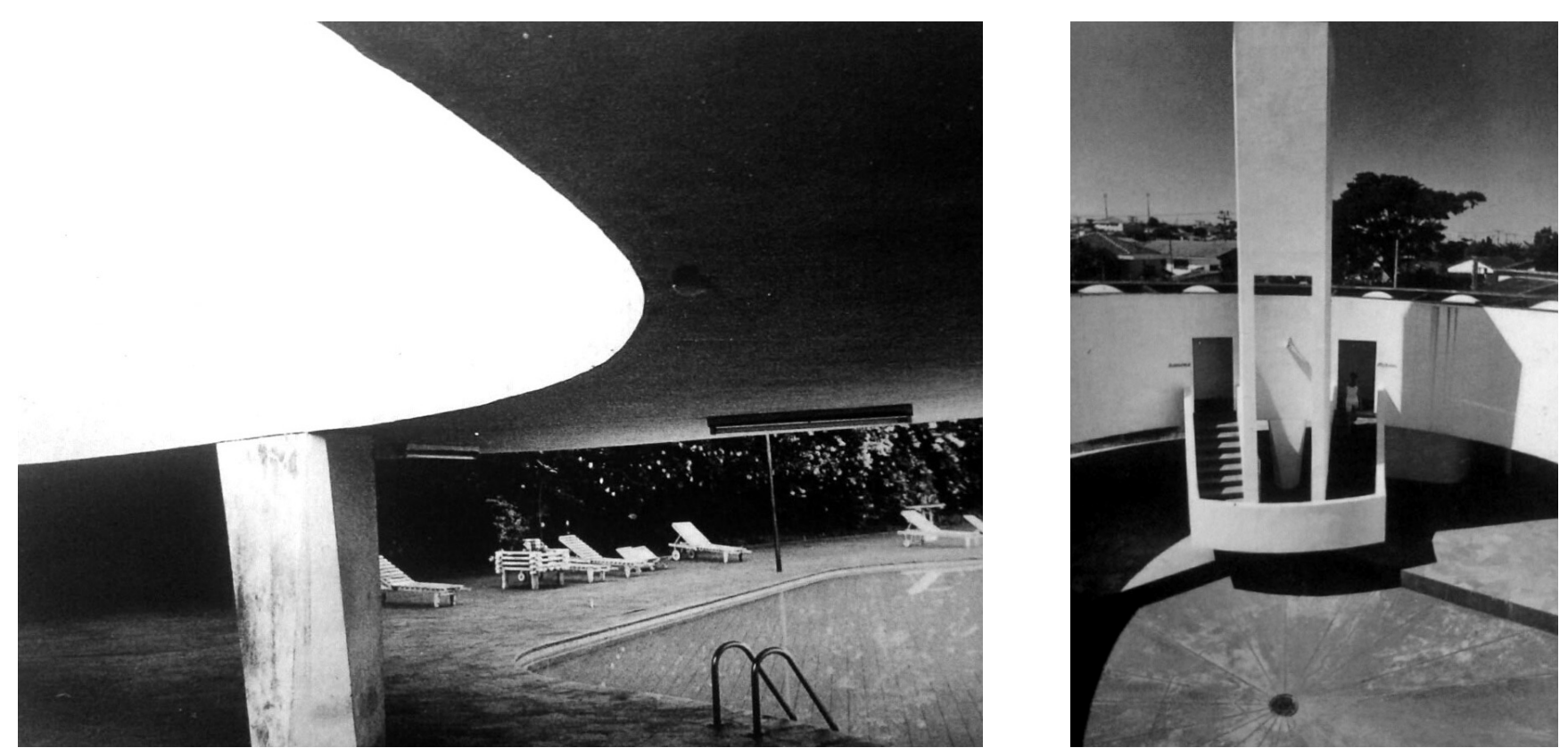


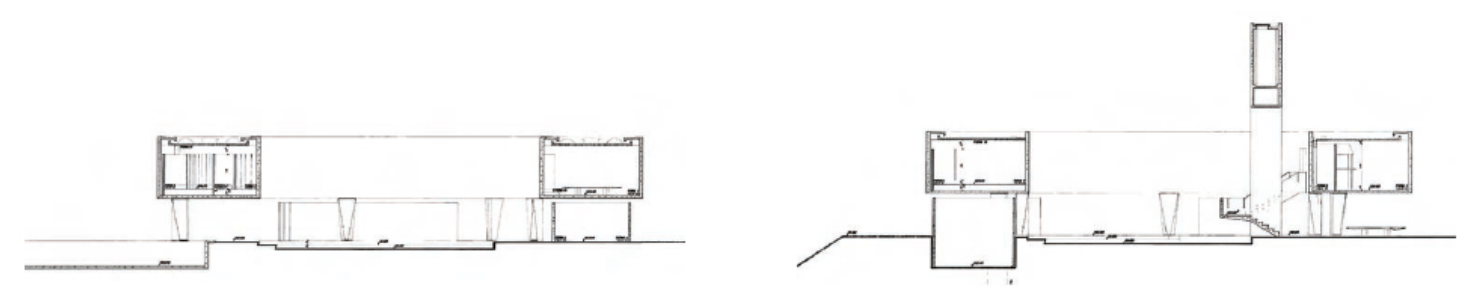

corte

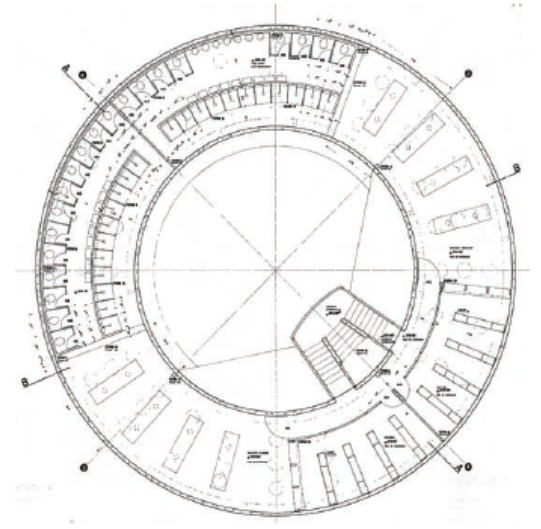

superior

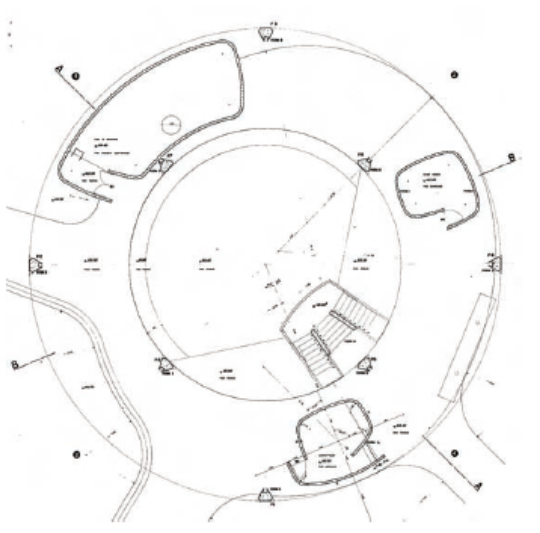

térreo

$0 \div-10$ 

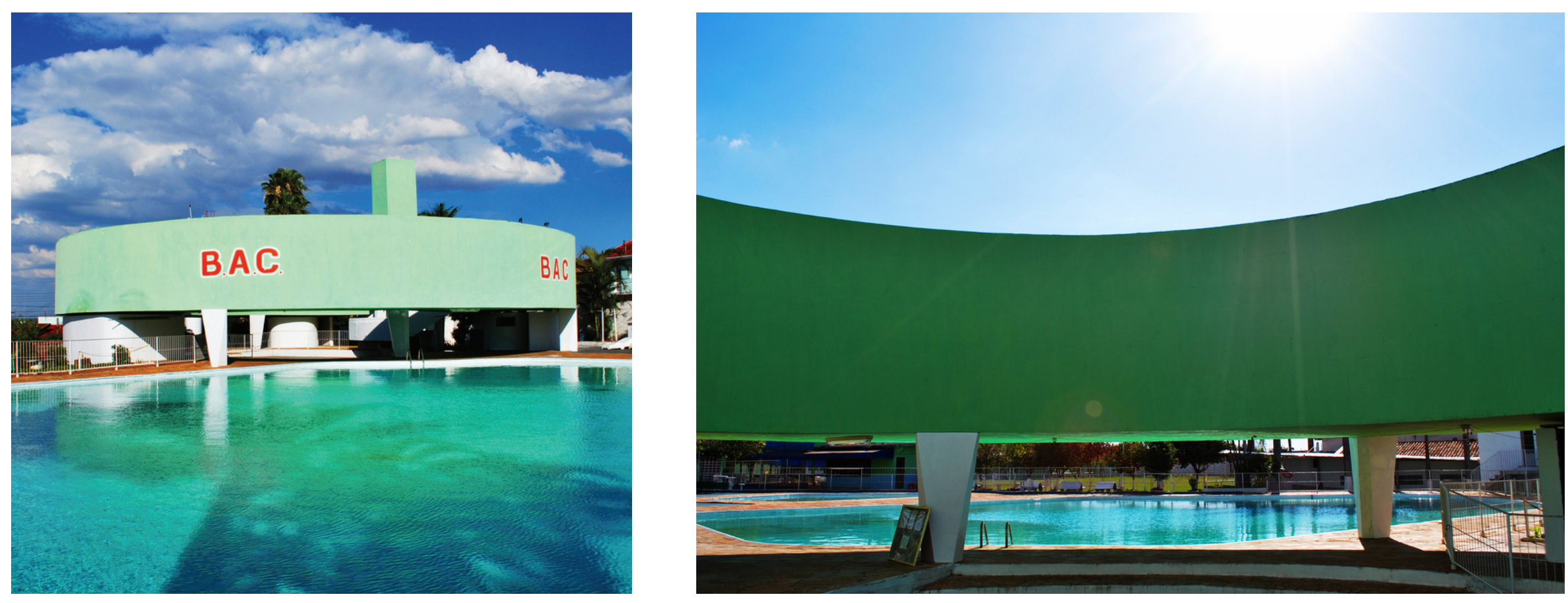

8. tabela analítica e de tIPOS 


\subsection{Cronologia}

Professor titular por concurso público depois de 5 anos como auxiliar de ensino

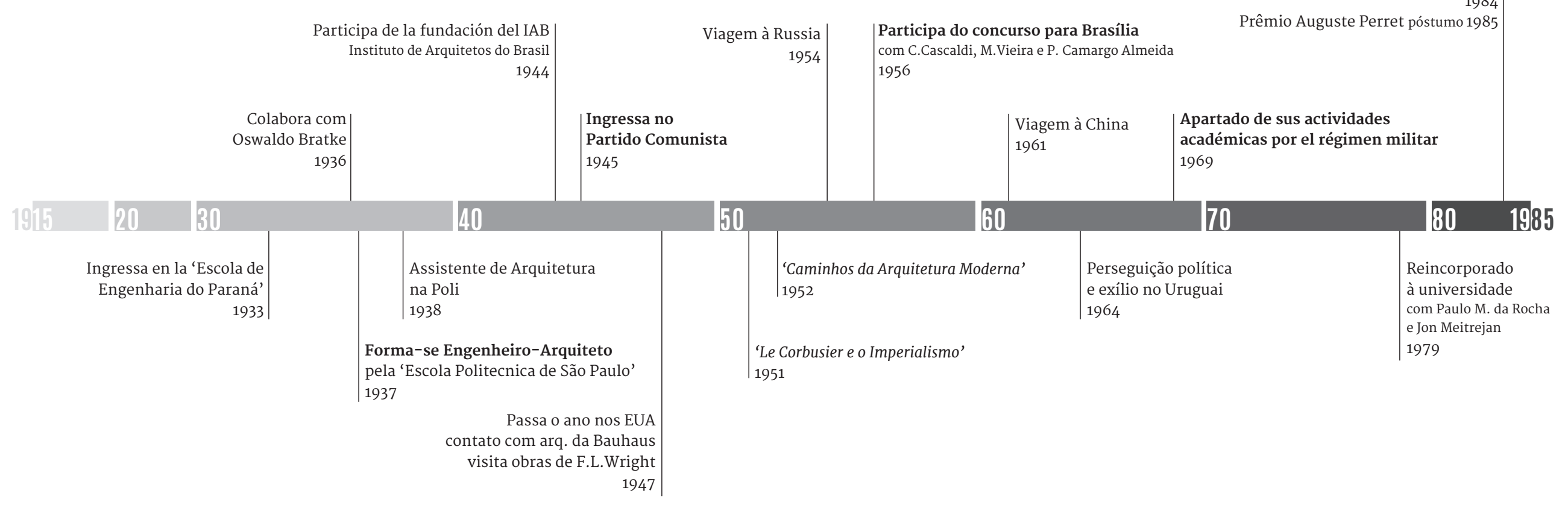



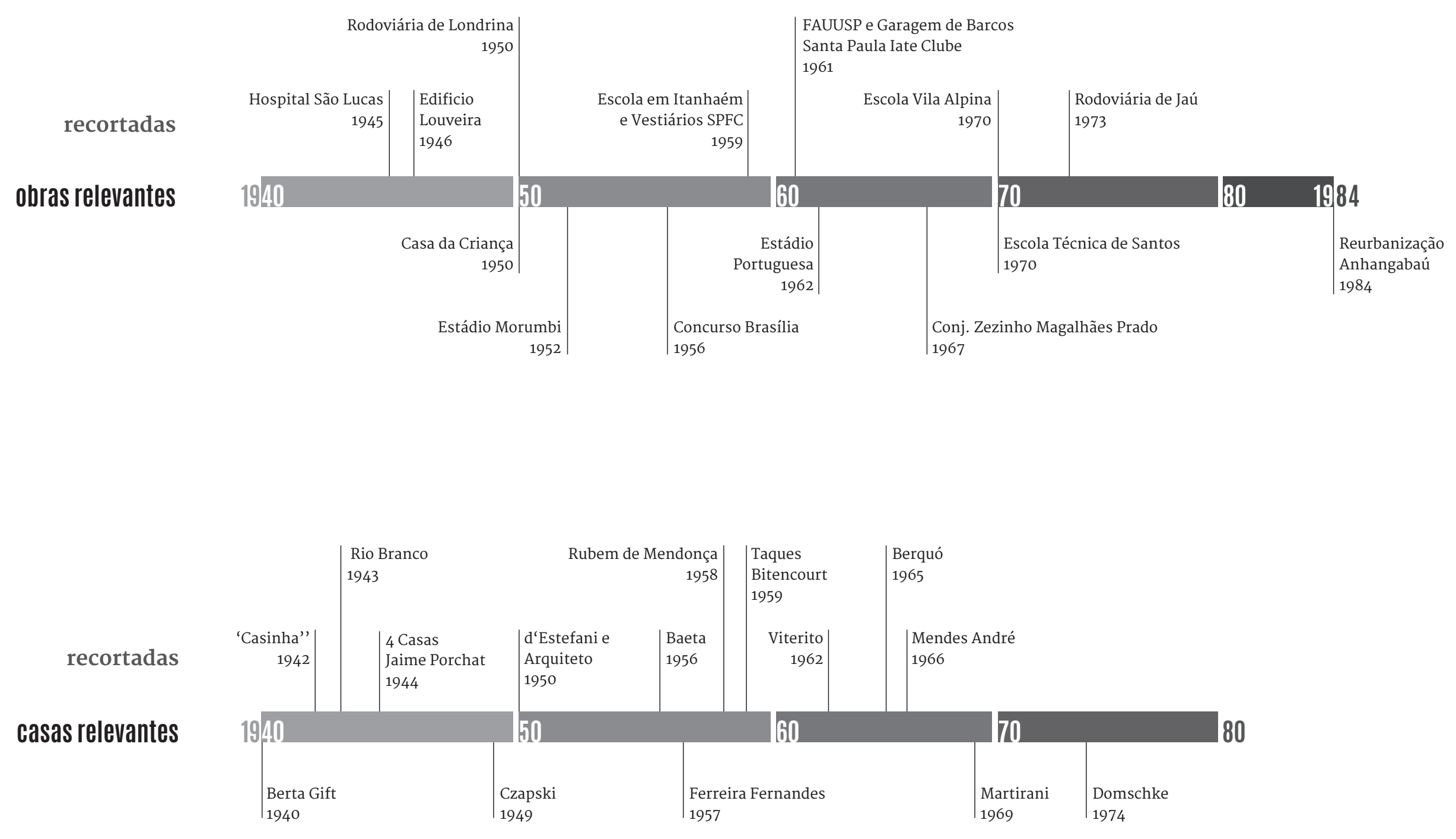



\section{TABELA ANALIITICA}

A leitura eficiente da tabela organizada aqui depende de um elevado grau de conhecimento de cada uma das obras citadas

nos eixos da peça gráfica, já que as imagens que aparecem representando os edifícios são simples menções visuais.

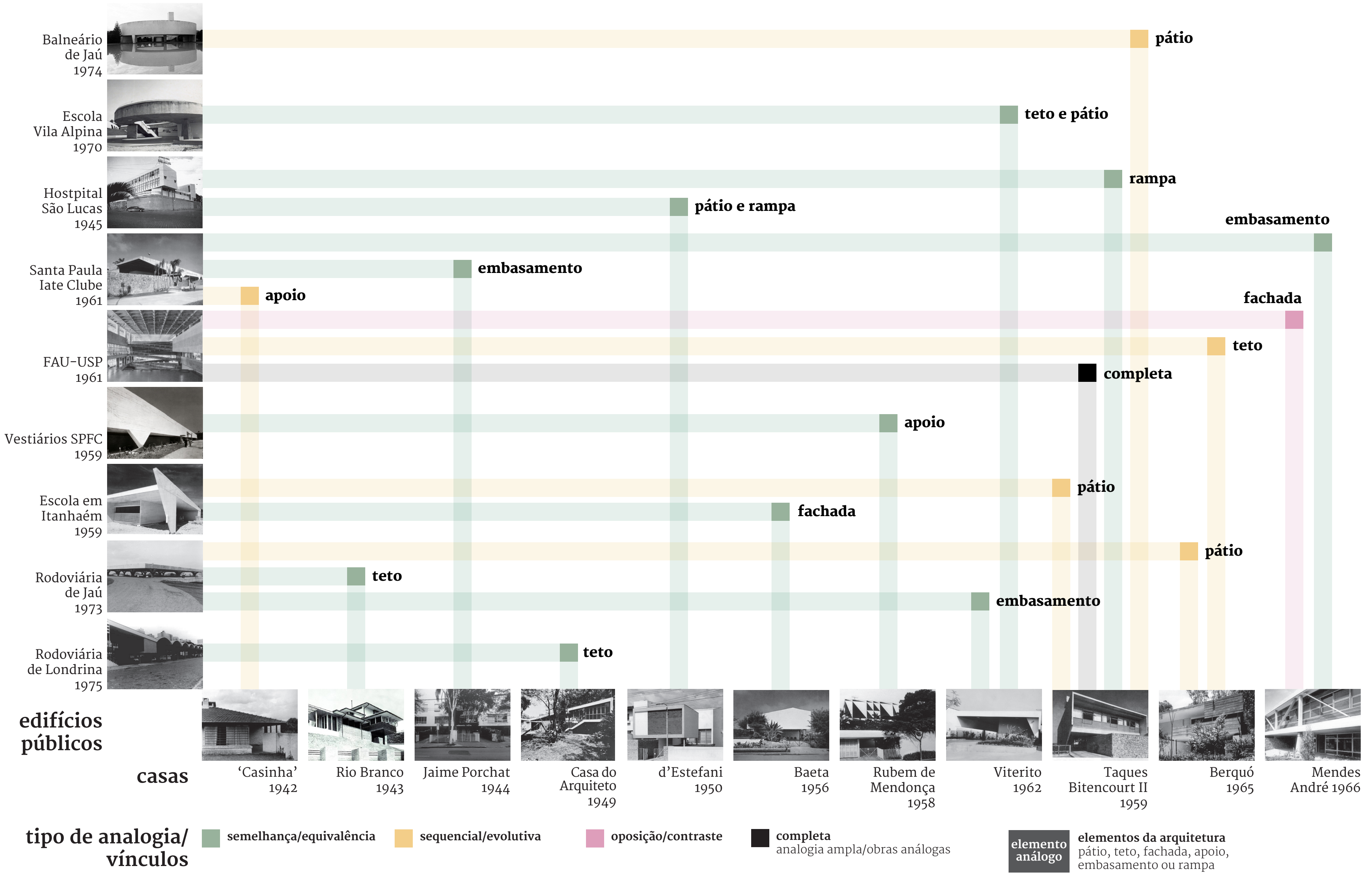




\section{casas}

as casas em função do tipo

arquitetônico dos qualis se

As obras que tem origem em mais

áreas hibridas.

Escala $1 / 400$

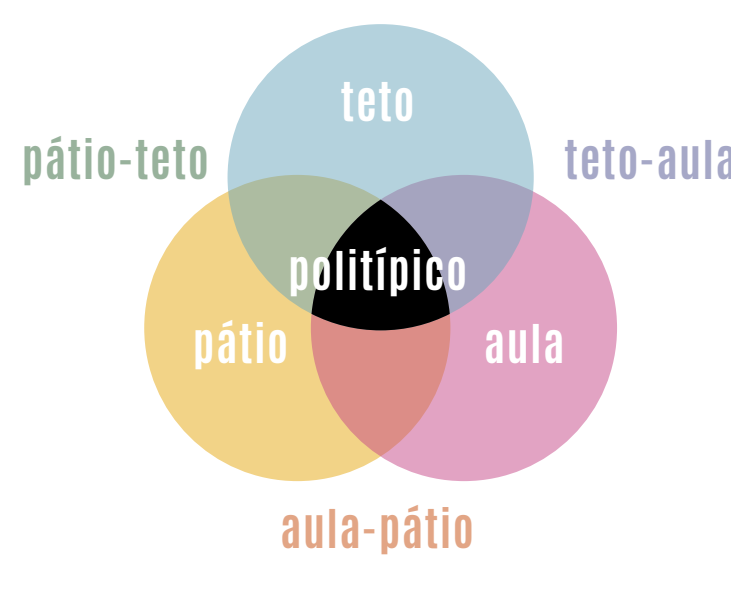

Casa do Arguiteto

Rio Branco

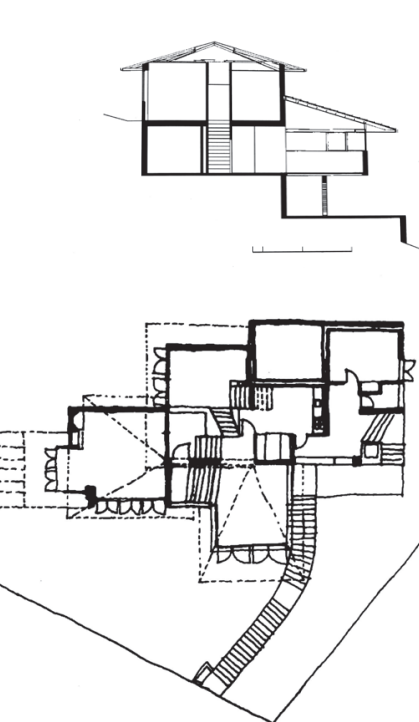

自然
Fy

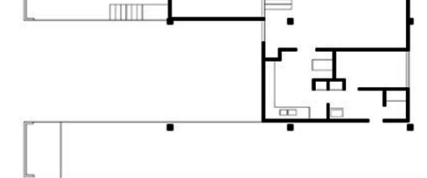

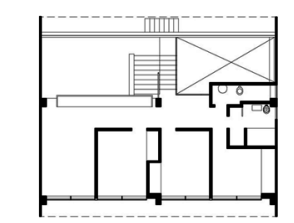

4 Casas Jaime Porchat

$\begin{array}{r}710 \\ \hline\end{array}$

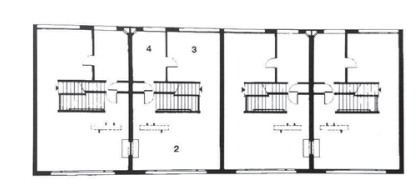

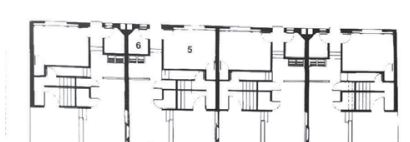

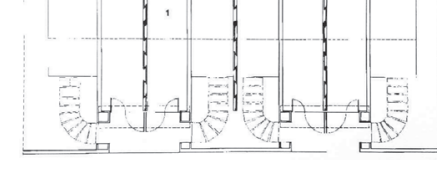

(casinge

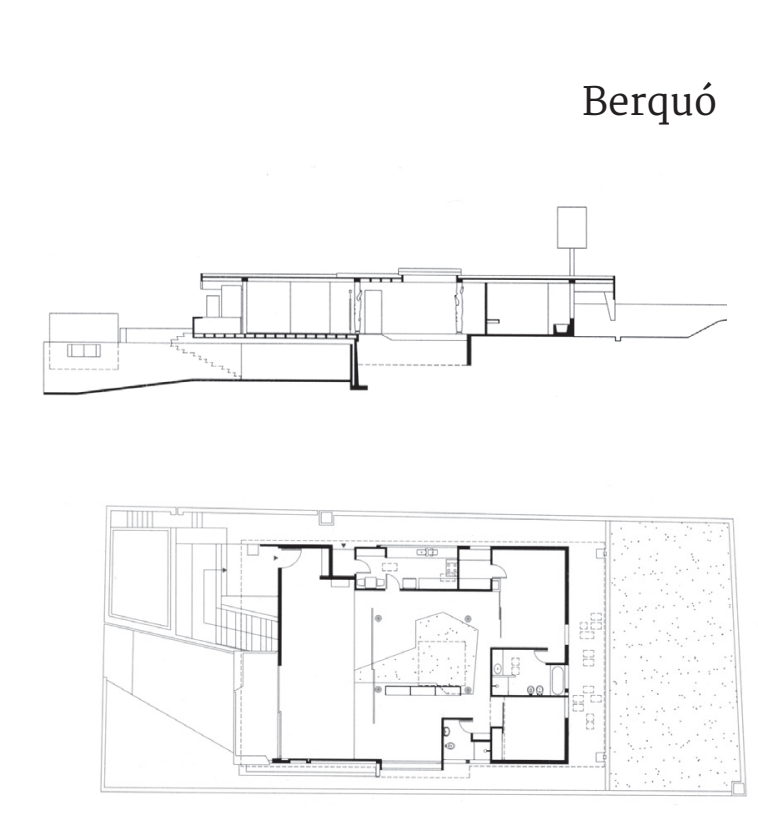

tin

(n)

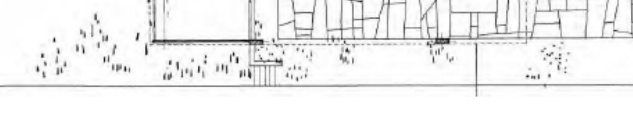

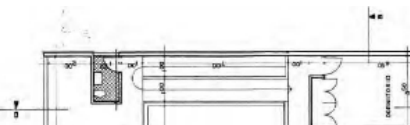

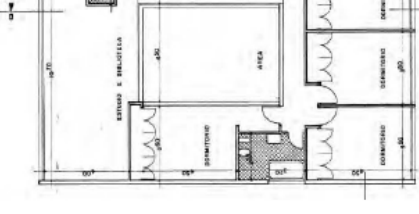

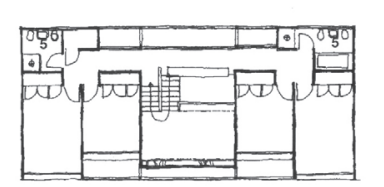

Mendes André

d'Estefani

IIIII

Eg

$\square \square$

$\perp \sqrt{n=4}$

$\sqrt{\square+}$

咆 
TABELA DE TIPOS

teto

edifícios públicos

A tabela por tipos apresenta os

tipo arquitetônico dos quais se

As obras que tem origem em mais
de um tipo estão posicionadas nas

áreas hibridas.

Escala 1/1000

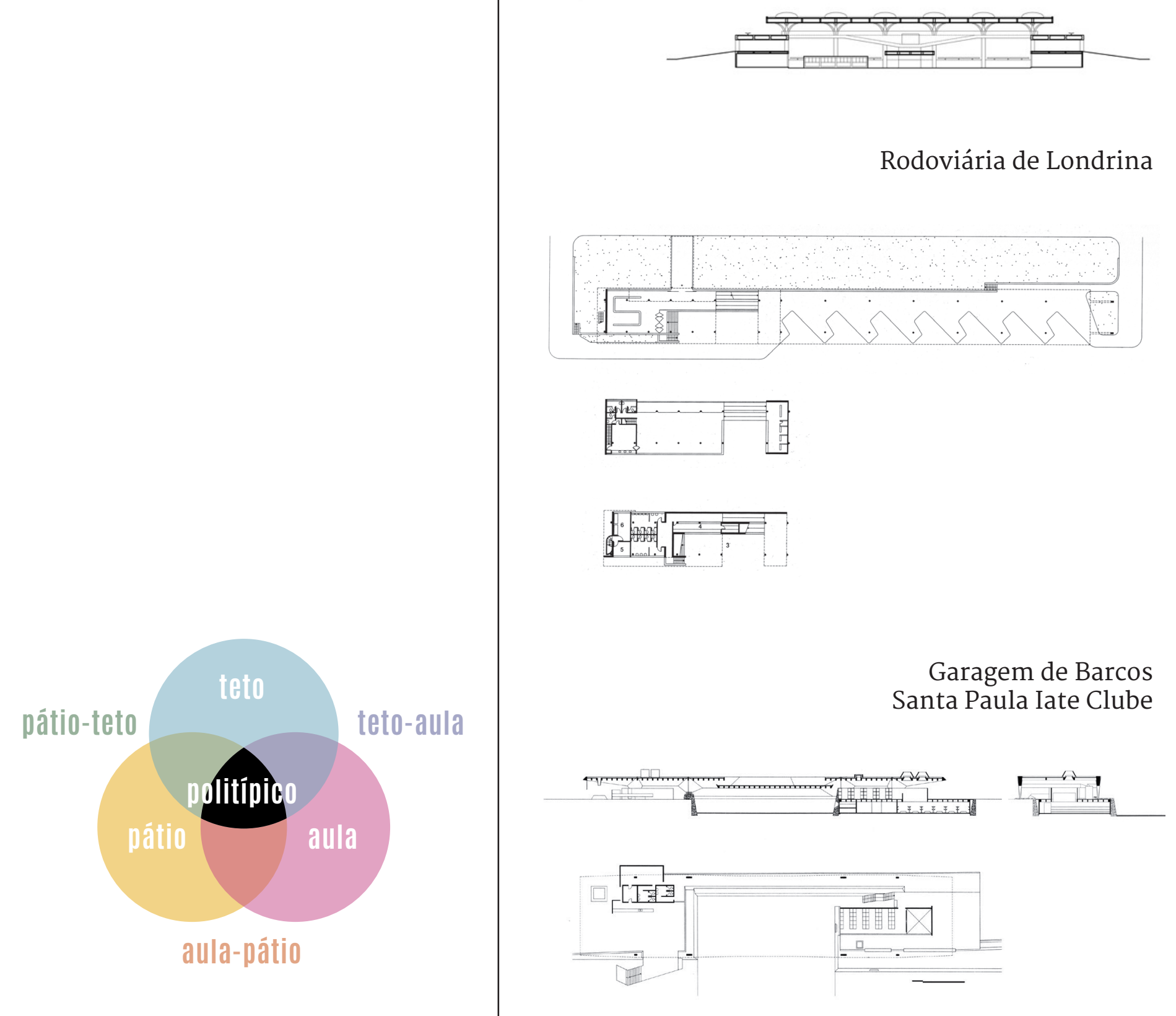

teto-aula

aula

Rodoviária de Jaú

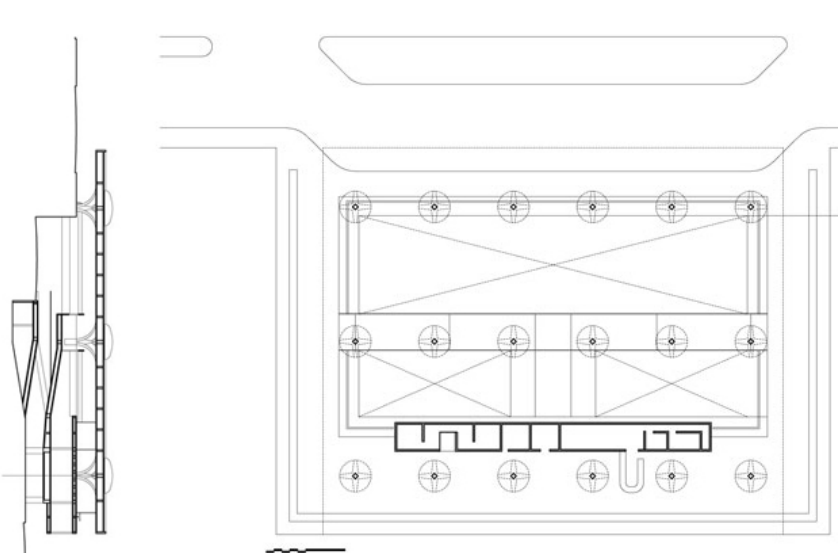

L(क)

$\longrightarrow$

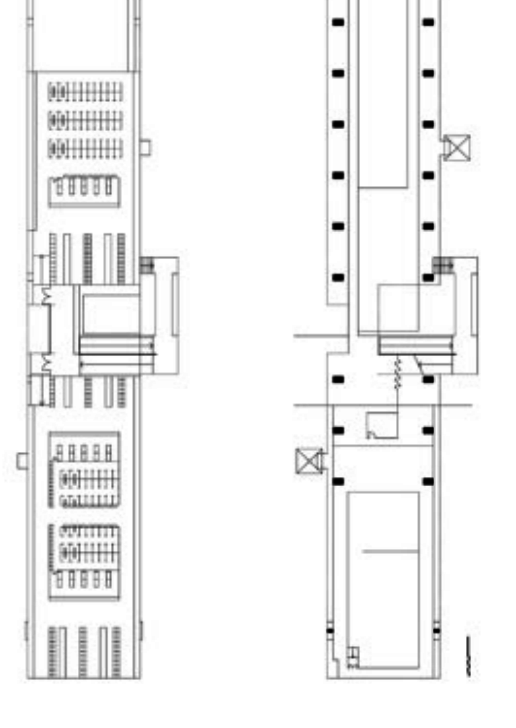

aula-pấtio pấtio

pátio-toto

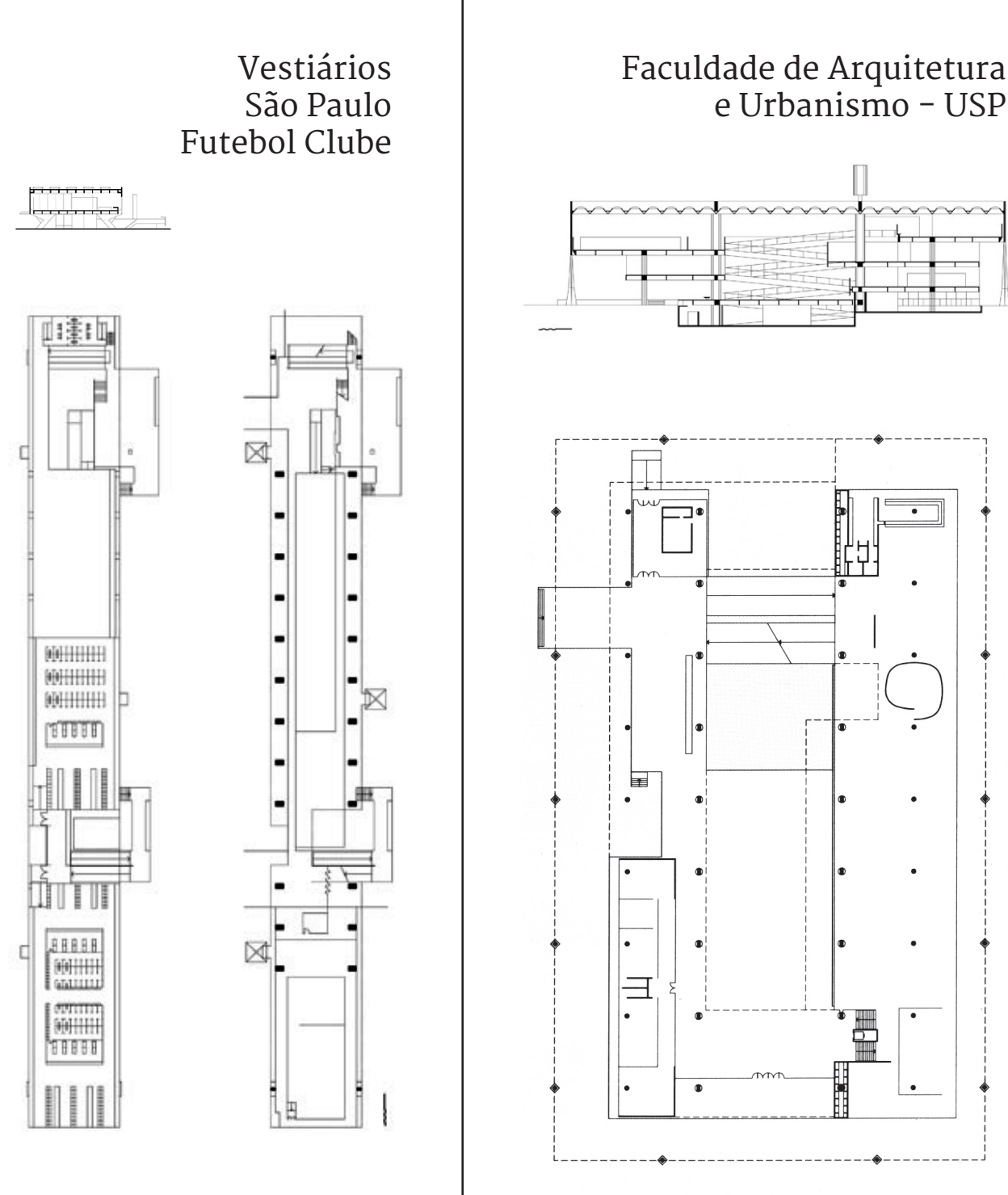

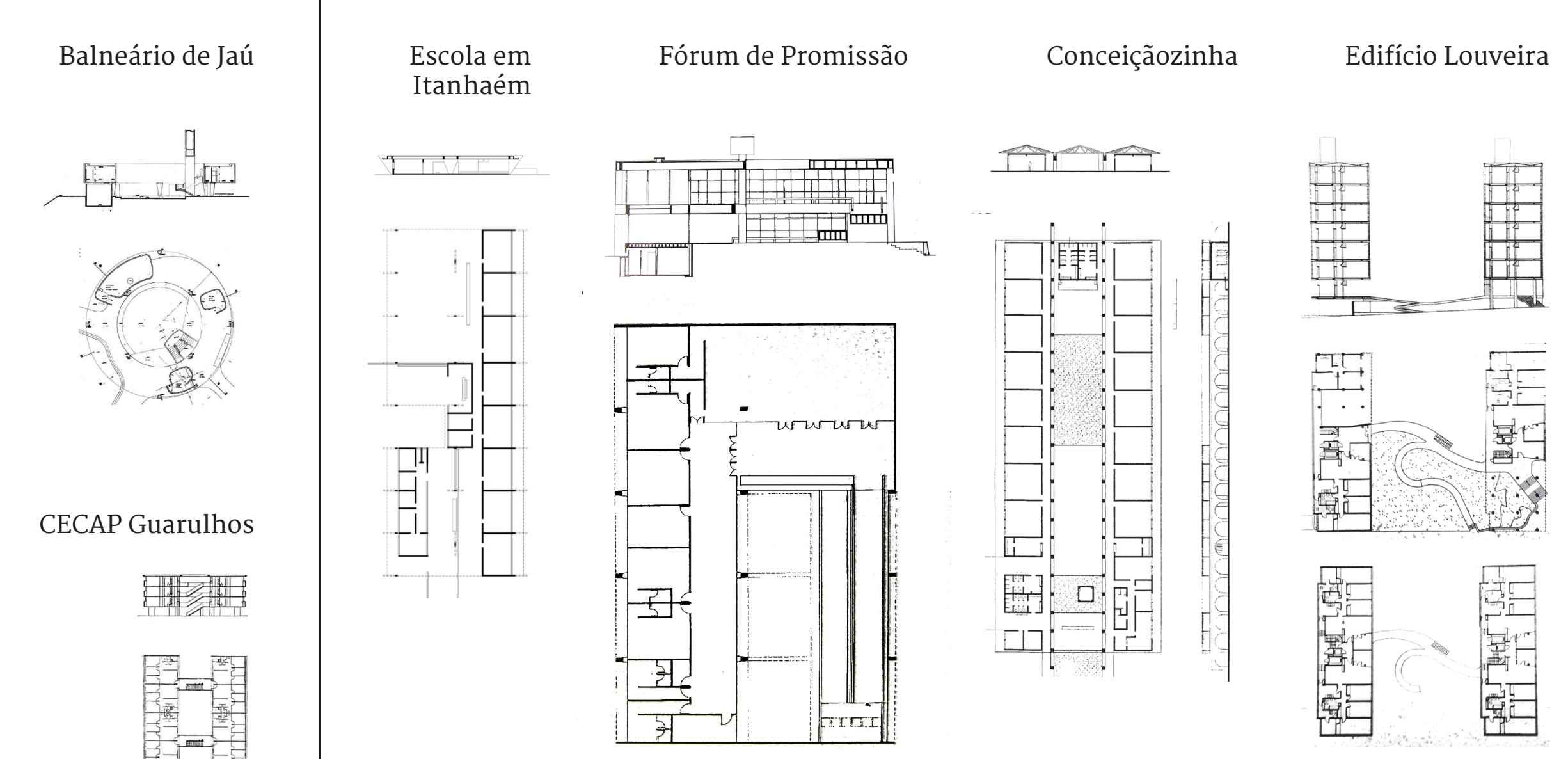

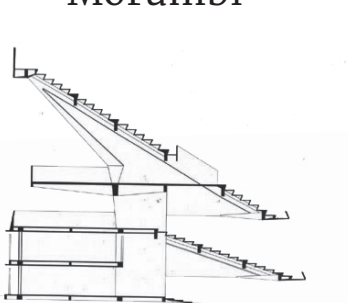

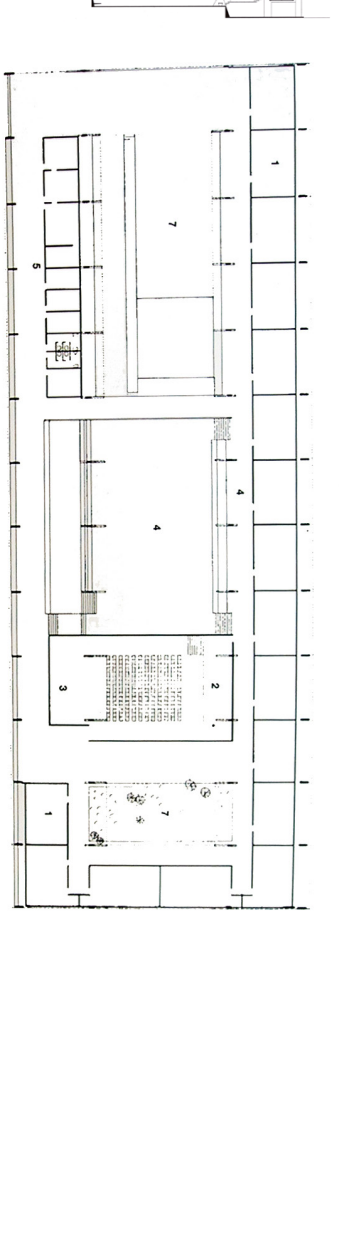





\section{REFERÊNCIAS BIBLIOGRÁFICAS E FONTES}

ACAYABA, Marlene Milan. Residências em São Paulo: 1947-1975, Ed. Projeto, 1986, São Paulo.

ANDREOLI, Elisabetta / FORTY, Adrian. Brazil's modern architecture, Phaidon, London, 2004.

ARGAN, Giulio Carlo, História da arte italiana: da Antiguidade a Dcuccio vol.I. São Paulo: Cosac \& Naify, 2003.

ARMESTO Arias, Antonio. El Aula sincronica, un ensayo sobre el analisis en arquitectura, Tese de doutorado apresentada à EtsaB-UPC em 1993.

ARTIGAS, João B. Vilanova. Caminhos da Arquitetura, Cosac e Naif, São Paulo, 1999.

Caderno dos riscos originais: projeto do edifício da FAUUSP na Cidade Universitária, São Paulo, FAUUSP dez. 1998. Portugal Albuquerque, Roberto (coord.).

Vilanova. Vilanova Artigas. São Paulo, Instituto Lina Bo e P. M. Bardi/Fundação Vilanova Artigas, Coord. Editorial: FERRAZ, Marcelo C., 1997.

BAROSSI, Antonio Carlos, Ensino de projeto na FAUUSP, Tese de Doutorado apresentada à FAUSP, 2010.
BUZZAR, Miguel Antonio. João Batista Vilanova Artigas, Elementos para a compreenção de um Caminho da Arquitetura Brasileira 1938-1967. Dissertação de mestrado apresentada a FAUUSP. São Paulo, 1996.

CALIA, Cynthia Ceravolo. La rampa en la arquitectura, projeto de qualificação para tese doutoral, apresentado à Etsab-UPC em maio de 2006. Barcelona.

CARVALHO, Jorge Pessoa, A Tipologia dos edifícios de apartamentos e sua relação com o tecido urbano da cidade, Dissertação de mestrado apresentada à FAUSP, 2008.

CORRÊA, Maria Luiza. Artigas: Da idéia ao Desenho. Dissertação de mestrado apresentada a FAUUSP. São Paulo, 1998.

COSTA, Lúcio. Razões da nova arquitetura, 1934; Documentação necessária, 1938 in: Registro de uma vivência, Empresa das Artes, São Paulo, 1995.

CUNHA, Gabriel Rodrigues da. Uma análise da produção de Vilanova Artigas entre os anos de 1967 e 1976, dissertação de mestrado apresentada à Escola de Engenharia de São Carlos - USP em junho de 2009.

CUNHA, Marcio Cotrim. João Batista Vilanova Artigas: Doze casas paulistas, 1942 a 1969. Dissertação de mestrado apresentada à EtsaB-UPC, 2002 
CUNHA Mahfuz, Edson, Transparência e sombra: o plano horizontal na arquitetura paulista. Arquitextos, Vitruvius, dezembro 2006.

CERDÀ i Sunyer, Ildefons, Teoría general de la urbanización, Imprenta Española, Madri, 1867.

DA CUNHA, A.G. Dicionário etimológico Nova Froneteira da língua portuguesa, Rio de Janeiro; Ed. Nova Fronetiera, 1999.

DEVESA, Ricardo Devesa. La casa y el árbol, Aportes teóricos al proyecto de arquitectura. Tese doutoral apresentada à EtsaB-UPC em junho de 2012

FAGGIN, Marina Masetti, Os limites na arquitetura, aspectos perenes mediados pela construção, São Paulo, 2012. Trabalho Final de Graduação apresentado à FAUUSP em 11/2012.

FIORINI, Juliana, A casa do arquiteto: residências de arquitetos como paradigmas da arquitetura moderna 1927-1964, dissertação de mestrado apresentada à FAUUSP em maio 2014

FRAMPTON, kenneth. História crítica da arquitetura moderna, São Paulo, Martins Fontes, 1997. Trad. CAMARGO, Jefferson Luiz.

GIANNECCHINI, Ana Clara. Técnica e estética no concreto armado: um estudo sobre os edifícios do MASP e da FAUUSP. Dissertação de Mestrado apresentada à FAUUSP em 2009.
GIEDION, Sigfried. Architecture in the 1960`s: Hopes ans fears, in Zodiac $\mathrm{n}^{\mathrm{0}} 11$

IRIGOYEN, Adriana. Wright e Artigas: duas viagens. São Paulo, Ateliê Editorial, 2002

IWAMIZU, Cesar Shundi, Estação Rodoviária de Jaú e a dimensão urbana da Arquitetura, dissertação de mestrado apresentada à FAUUSP em maio de 2008.

KAMITA, João Massao. Vilanova Artigas. São Paulo, Cosac \& Naif, 2000.

MARTÍ ARÍS, Carlos, Las variaciones de la identidad - Ensayo sobre el tipo en arquitetcura. Barcelona, Ed. del Serbal, 1993.

La cimbra y el arco, Fund. Caja de Arquitectos, 2005.

MIGUEL, Jorge Marão Carnielo. A Casa. Londrina, Eduel, 2003.

MONEO, Rafael, Inquietação teórica e estratégia projetual, São Paulo, Cosac \& Naif, 2008, trad. CODDOU, Flávio.

PALLADIO, Andrea, Os quatro livros de Arquitetura, São Paulo: Hucitec, 2009.

PETROSINO, Mauricio Miguel. João Batista Vilanova Artigas - residências unifamiliares: a produção arquitetônica de 1937 a 1981, dissertação de mestrado apresentada à FAUUSP em 2009. 
PONTES, Ana Paula Gonçalves, Diálogos silenciosos: arquitetura moderna brasileira e a tradição clássica, dissertação de mestrado apresentada à PUC-RJ em 2004.

RECASÉNS, Gonzalo Díaz. Recurrencia y herencia del patio en el movimiento moderno, Consejería de Obras Públicas y Transportes, Sevilla, 1992.

ROZESTRATEN, Artur Simões, Estudo sobre a história dos modelos arquitetônicos na antiguidade: origens e características das primeiras maquetes de arquiteto. São Paulo: S.n., 2003

RUDOFSKY, Bernard, Architecture without architects : a short introduction to non-pedigreed architecture, Albuquerque: University of New Mexico Press, 1987, c1964.

Constructores prodigiosos - apuntes sobre una historia natural de la arquitectura, Ed. Concepto, México, 1984.

RYKWERT, Joseph. A Casa de Adão no Paraíso, a idéia da cabana primitiva na história da arquitetura. Ed. Perspectiva, São Paulo, 2003.

The Dancing column: an order in architecture, Cambridge: The MIT Press, cop. 1996
SEMPER, Gotfried. The Four Elements of Architecture and Other Writings', Cambridge University Press, 1989.

SUMMERSON, John. A linguagem clássica da arquitetura. $1^{\mathrm{a} e d}$. São Paulo: Ed. Martins Fontes, 1982

SUZUKI, Juliana Harumi. Artigas e Cascaldi - arquitetura em Londrina. São Paulo, Ateliê Editorial, 2003.

TAGLIARI, Ana. Os Projetos Residenciais não Construídos de Vilanova Artigas em São Paulo, São Paulo, FAUUSP, 2013

THOMAZ, Dalva Elias. Um olhar sobre Vilanova Artigas e sua contribuição à Arquitetura Brasileira. Tese de mestrado FAUUSP. São Paulo, 1997.

Uma escola, uma síntese arquitetônica. Jornal dos Arquitetos n. 201, Lisboa, Ordem dos Arquitetos, 2001.

VALENTín, Fabio Rago. A casa do ensino, escolas de Vilanova Artigas. Dissertação de mestrado apresentada a FAUUSP. São Paulo, 2004.

VILLAC, Maria Isabel. La Construcción de la mirada, naturaleza, ciudady discurso en la arquitetura de Paulo Archias Mendes da Rocha, orientador: Josep Quetglas Universitat Politècnica de Catalunya. UPC, Escola Tècnica Superior d'Arquitetura de Barcelona, 2000. 
XAVIER, Alberto, (org.), Depoimentos de uma geração - arquitetura moderna brasileira, Cosac e Naify, São Paulo, 2002.

WISNIK, Guilherme Teixeira. Vilanova Artigas y la dialéctica de los esfuerzos. in: 2G Rev.int. de Arquitectura, edição nº 54. João Vilanova Artigas. Barcelona: Gustavo Gilli, 2010

YURGEL, Marlene. As aventuras de um arquiteto no reino da fantasia da geometria. Tese. São Paulo, 1999.

Projetos digitalizados de João Batista Vilanova Artigas. Monografia/ livro, São Paulo: FAUUSP, 2010.

Introduzindo Einstein e Vilanova Artigas na Arquitetura Brasileira. Artigo de periódico, São Paulo, 2005.

ZEIN, Ruth Verde. A Arquitetura da Escola Paulista Brutalista 1953-1973, Tese de doutorado, PROPAR-UFRS, Porto Alegre, apresentada em 2005.

Artigas pop-cult: considerações sobre a cabana primitiva, a casa pátio e quatro colunas de madeira. 2013. pg.14<https://bibliodarq.files. wordpress.com/2012/10/zein-r-v-artigas-pop-cult.pdf>, acesso em 14 Fev 2015.

\section{Revistas}

CARAMELO, revista, n 3, GFAU - Grêmio da Faculdade de Arquitetura e Urbanismo (USP), outubro, 1991.

n 2, GFAU - Grêmio da Faculdade de Arquitetura e Urbanismo (USP), junho, 1991.

DPA Documents de Projectes d'Arquitectura. Revista del Departament de Projectes Arquitectònics de la Universitat Politècnica de Catalunya (UPC), Patio y casa, nº 13, Dezembro 1997.

Cota cero, $n^{\circ} 21$, junho 2005

MÓDULO, revista. Número Especial Vilanova Artigas, Rio de Janeiro, 1985.

PÓS, revista do programa de pós-graduação em arquitetura e urbanismo da FAUUSP - nº 18 Especial Vilanova Artigas, Dezembro 2005. Disponível em: <http://www.revistas.usp.br/posfau/article/ view/43415/47037>. Acesso em: 21 Fev. 2015 


\section{0. ÍNDICE DE IMAGENS}

No Descrição

Desenho.

Diagrama do eixo paradigmático

Desenhos analíticos

Tabela tipológica basilical

Diagrama por Alfred Kroeber...

Planta de Djemila

Planta de Timgad

Casa de pilato sevilha

Catedral de sevilha

Tabela analítica.

Vista da ponte de Blackfriars em obras, Londres

Eixample de Barcelona - plano Cerdà 1867

Modelo minóico

Catedrais goticas francesas

Cubo, diedro, elevado, etc

Aula Recinto, Pórtico e Platô

Planta, corte e detalhes

da Igreja de San Cataldo, Palermo

Haus mit einer Mauer, a casa de um muro só

Maison domino

Fair Store building

Garagem de Barcos Santa Paula Iate Clube

Estação Rodoviária de Jaú.

a tree is a leaf.......

Tabela analítica

Peristilo de entrada da FAUUSP

Pilar externo da FAUUSP.....

Croquis para projeto não identificado

Casa com três patios, 1931-34, Mies van der Rohe

Comunidade rural da China

Processo construtivo por fases da Casinha

Terrapleno Baeta.

Terrapleno Viterito

Planta Baeta

Planta Viterito ......

Garagem de Barcos Santa Paula Iate Clube

Casinha, 1942

FAUUSP....

Casa Taques Bittencourt II

Casa Bubens de Mendonça, 1958

\section{Autor}

ARTIGAS, J.B. Vilanova

FAGGIN, Caio Luis Mattei ....

FAGGIN, Caio Luis Mattei

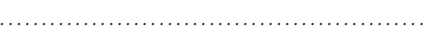

-

Jean-Nicolas-Louis Durand

Giovanni Battista Piranesi, 1766

Idefons Cerdà i Sunyer

Matthew Frederick

FAGGIN, Caio Luis Mattei ....

FAGGIN, Caio Luis Mattei

LOOS, Adolf .

JEANNERET, Pierre (Le Corbusier)

William Le Baron Jenney

- .

VAN EYCK, Aldo "a tree is a leaf"

Jean-Nicolas-Louis Durand

FAGGIN, Caio Luis Mattei

Ana Clara Giannecchini.

ARTIGAS, J B. Vilanova

Mies van der Rohe

RUDOFSKY, Bernard

Marlene Yurgel

FAGGIN, Caio Luis Mattei

idem

idem

idem

$-$

KON, Nelson

KON, Nelson

\section{Fonte}

ARTIGAS, João B. Vilanova, Vilanova Artigas, op.cit. Pg. 128

croquis do autor

croquis do autor

MARTİ Aris, Carlos, Las Variaciones de la identidad, op.cit. Pg 10

idem, pg. 53

idem, Pg 99

idem, Pg 98

http://miguelcuervoarango.blogspot.com.br/2011/09/casa-de-pilatos.html

https://www.flickr.com/photos/8449304@No4/2058743583/

ESTEVE, Manuel Bailo, Catalizadors de la Urbanitat,tese doutoral apresentada à EtsaB-UPC em 2008. http://aphelis.net/bridge-invisible-cities-italo-calvino-1972/

http://www.artehistoria.com/v2/obras/23285.htm

ROZESTRATEN, Artur Simões, 2003, op.cit.

MARTİ Aris, Carlos, Las Variaciones de la identidad, op.cit.

FREDERICK, Matthew, 101 Things I learned in Architecture School, MIT Press, 2007, pg .5

croquis do autor

croquis do auto

http://eng.archinform.net/projekte/3407.htm

http://maquinademorar.blogspot.com.br/

MARTİ Aris, Carlos, Las Variaciones de la identidad, op.cit.

Acervo Biblioteca FAU-USP, via Arquigrafia

Acervo Biblioteca FAU-USP, via Arquigrafia

ESTEVE, Manuel Bailo, Catalizadors de la Urbanitat, tese doutoral apresentada à EtsaB-UPC em 2008.

SITTE, Camilo, Plantas a SITTE, C., Construcción de ciudades según principios artísticos, Ed. Gustau Gili, Barcelona, 1980 croquis do autor

GIANNECCHINI, Ana Clara, op.cit

ARTIGAS, João B. Vilanova, Caderno de Riscos Originais, op.cit.

DPA, revista, Casa y patio, 2001, op.cit.

The Prodigious Builders

YURGEL, Marlene, Introduzindo Einstein e Artigas... op.cit. in: Revista PÓS, núm. 18, FAUUSP, 2005 croquis do autor

idem

idem

idem

Acervo da Biblioteca da FAUUSP

Acervo da Biblioteca da FAUUSP

2G, revista, n.54 Vilanova Artigas (foto Nelson Kon) Ed. G Gili, setembro 2010

comover-arq.blogspot.com.br

'@vilanovaartigas, <http://ink361.com/app/users/ig-1112951813/photos> 


\section{No Descrição}

Idem

"Elevação Casi

Pátio .......
São Paulo Futebol Clube, Vestiários, 1959

Casa Elza Berquó, 1965

Residencia Olga Baeta - comparação da escora

original em concreto com a nova em em aço

Casa Baeta, vista interna da sala

e Clóvis Cunha

aranda Casa Berquó .................................................

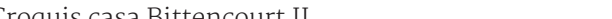

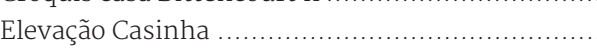

Croquis casa Baeta.

Vestiários do São Paulo Futebol Clube ...

ARTIGAS, J.B. Vilanova

KON, Nelson

Acervo Angelo Bucci

KON, Nelson

CUNHA, Clóvis .

FAGGIN, Caio Luis Mattei

ARTIGAS, J B Vilanova

ARTIGAS, J B Vilanova

ARTIGAS, J.B. Vilanova

Garagem de Barcos Santa Paula Iate Club

Vestiários SPFC

Sequencia de cortes encadeados

"elevação da casa e aparição dos pilotis"

Croquis casa Baeta.

Estudo para pintura mural para casa Mendonça ...

Elevação casa Mendes André

Promenade na estação de Jaú em companhia de

Sr. Naldo (mestre de obras desse edifício) em 2014

Hospital São Lucas, 1945

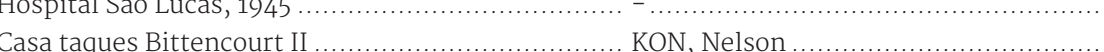

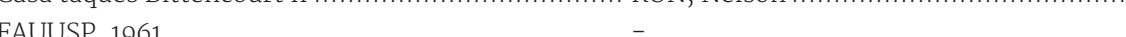

Casa Mendes André, 1966.

Casa de Olintos

Aula Recinto e Teto m.n.........

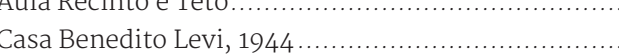

Casas Jaime Porchat

Casas Baeta e Mendes André

Croqui gradientes do teto da FAU.

antas baixa e alta da FAU

Hórreo em Combarro (Vigo, Galícia - Espanha)

Hórreo típico asturiano e seus elementos

Pátio de Matmala Tunísia.

Pátio de Matmala, Tunísia... no

Casinha' -1942 ......

Casa Taques Bittencourt II - 1959 idem

http://vilanovaartigas.com/centenario/artigos/rodoviaria-de-jau-1973

ARTIGAS, João B. Vilanova, Vilanova Artigas, op.cit., pg.50.

arquitextos, nov. 2012 <http://www.vitruvius.com.br/revistas/read/arquitextos/13.150/4591>

Acervo da Biblioteca da FAUUSP

.

FAGGIN, Caio Luis Mattei ............................. croquis do autor

.............................................. vilanovaartigas.com.br

Acervo da Biblioteca da FAUUSP

croquis do autor

AGGIN, Caio Luis Mattei ...................... idem

idem .............................................. idem

idem

-

RUDOFSKY, Bernard ............................ Interiors, revista, maio de 1946

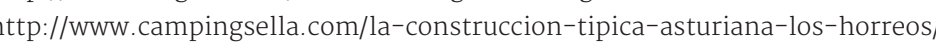

http//blogdebanderas com/2014/04/21/un-recorrido-por-o-ciudades-o-parte-de-ellas-bajo-tierra/

DPA, revista, casa y patio, 2001, op.cit

Acervo da Biblioteca da FAUUSP

Acervo Nelson Kon

idem 


\section{No Descrição}

Casa Artigas II - 1950
Casa Viterito, vista do

Diagrama impluvium cortado ao meio....

Casa Viterito , pátio lateral.

Edifício Louveira, pátio jardim.

Autor

Idem

m...........

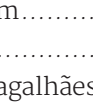

Casa Taques Bittencourt

. ........

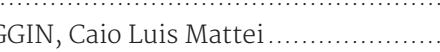

89 Conjunto CECAP “Zezinho Magalhães Prado" - 1967,

pátio com elemento vertical ................................. -

Escola Conceiçãozinha, Guarujá, SP - 1976

.

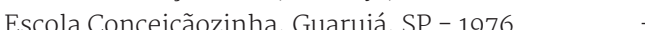

Shabono Yanomami $\quad$ STEWART, Catrina

Ermida de San Baudélio de Berlanga

província de Sória na Espanha, século XI................

Estação de Jaú, corte pelo pilar ...................................

Estação de Jaú, visata intern

.

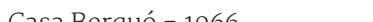

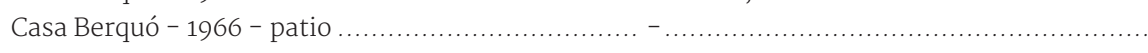

Croquis para Casa Berquó

ARTIGAS, J.B. Vilanova

idem

Edifício Vilanova Artigas ................................. KON, Nelson .................................. Acervo Nelson Kon

Edifício Vilanova Artigas ..............

Templo jônico de Dídyma

exemplar de cella aberta, séc. 3 a.C. circa................ - -..................................................

05 Fori Imperiali - Roma, ano 40 a.C. ........................ - . .

106 Corte Basilica de Toledo, séc XIII ....

107 Rua porticada mediaval - Salvatierra,

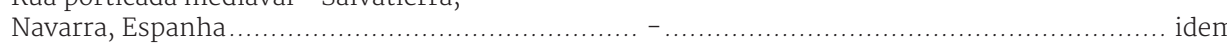

108 Corte longitudinal da FAUUSP, proposta de

projeto da oficina ETH/FAU ago2009 .................

109 Caramelo

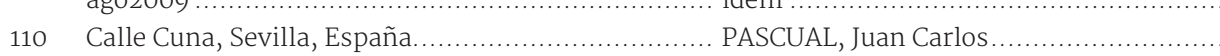

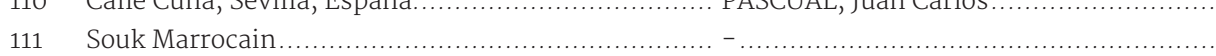

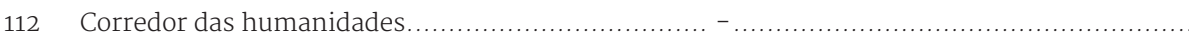

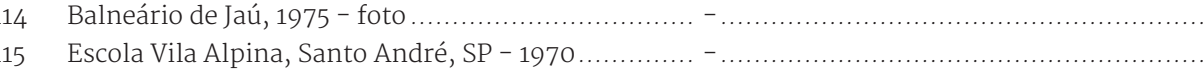

16 Idem

117 Idem

"lem

Frame de "São Paulo Cia. de Dança

"Ensaio em marcos arquitetônicos de SP" - 2'17" ... Cia. São Paulo de Dança...

\section{Fonte}

ovaartigas.com.br

Acervo pessoal

Vilanova, Vilanova Artigas, op cit.,pg.124

croquis do autor

aplicação de cor sobre desenho técnico

aplicação de cor sobre foto

Lilanovaartigas, <http://ink361.com/app/users/ig-1112951813/photos>

cem

plicação de cor sobre desenho técnico

AilGAS, João B. Vilanova, Vilanova Artigas, op.cit., pg.82

RTIGAS, João B. Vilanova, Vilanova Artigas, op.cit., pg.149

ARTIGAS, João B. Vilanova, Vilanova Artigas, op.cit., pg.201

em, pg. 200

http://www.celtiberia. net/verlugar.asp?id=596

Acervo Biblioteca FAU-USP

Acervo Biblioteca FAU-USP

plicação de cor sobre desenho técnico

ARTIGAS, João B. Vilanova, Vilanova Artigas op.cit., pg.141

RTIGAS, João B. Vilanova, Vilanova Artigas, op.cit., pg.138

croquis do autor

<http.//www archdaily.com.br/br/627179/ranking-de-faculdades-de-arquitetura-brasileiras>

ARMESTO Arias, Antonio. El Aula sincronica, op.cit., pg. 81

http://www.uark.edu/campus-resources/cicero/urbs/urbs_fora.html

n Armesto, op.cit. Pg.81-II

http://projetofau2009.jimdo.com/oficina-eth-fau/

Jaun Carlos Pascual <https://www.flickr.com/photos/arquijcarlos/5960063679/in/set-72157627114644281>

www. fuckyouverymuch.dk

Acervo Biblioteca FAU-USP

Acervo Biblioteca FAU-USP

Acervo Biblioteca FAU-USP

acervo biblioteca FAUUSP

vilanovaartigas.com

VALENTİN, Fabio Rago, op cit, pg.209.

http://tvuol.uol.com.br/video/

sao-paulo-cia-de-danca-estrela-ensaio-em-marcos-arquitetonicos-de-sp-04024D183162D 4995326 